
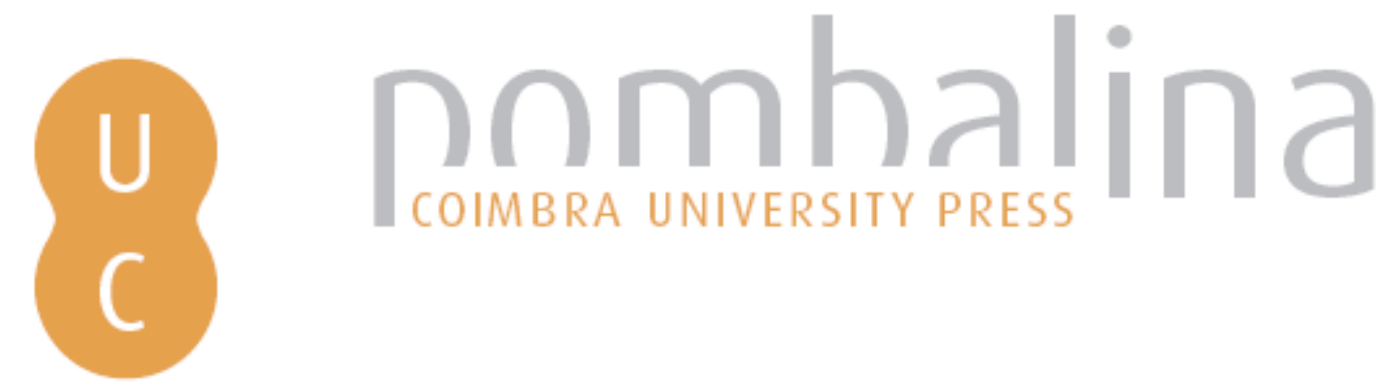

\title{
A política externa russa no espaço euro-atlântico: dinâmicas de cooperação e competição num espaço alargado
}

Autor(es): Daehnhardt, Patrícia; Freire, Maria Raquel

Publicado por: Imprensa da Universidade de Coimbra

URL

persistente: URI:http://hdl.handle.net/10316.2/31894

DOI: $\quad$ DOI:http://dx.doi.org/10.14195/978-989-26-0712-2

Accessed : $\quad$ 19-May-2017 18:11:14

A navegação consulta e descarregamento dos títulos inseridos nas Bibliotecas Digitais UC Digitalis, UC Pombalina e UC Impactum, pressupõem a aceitação plena e sem reservas dos Termos e Condições de Uso destas Bibliotecas Digitais, disponíveis em https://digitalis.uc.pt/pt-pt/termos.

Conforme exposto nos referidos Termos e Condições de Uso, o descarregamento de títulos de acesso restrito requer uma licença válida de autorização devendo o utilizador aceder ao(s) documento(s) a partir de um endereço de IP da instituição detentora da supramencionada licença.

Ao utilizador é apenas permitido o descarregamento para uso pessoal, pelo que o emprego do(s) título(s) descarregado(s) para outro fim, designadamente comercial, carece de autorização do respetivo autor ou editor da obra.

Na medida em que todas as obras da UC Digitalis se encontram protegidas pelo Código do Direito de Autor e Direitos Conexos e demais legislação aplicável, toda a cópia, parcial ou total, deste documento, nos casos em que é legalmente admitida, deverá conter ou fazer-se acompanhar por este aviso.

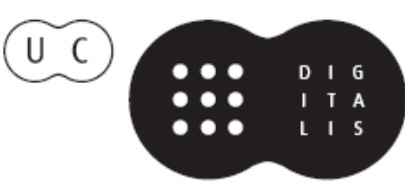


IMPRENSA DA

UNIVERSIDADE

DE COIMBRA

COIMBRA

UNIVERSITY

PRESS

\section{A POLÍTICA EXTERNA \\ RUSSA NO ESPAÇO \\ EURO-ATLÂNTICO}

$\therefore:$

\section{Dinâmicas de cooperaçấo e}

competiçẫo num espaço alargado

PÁTRICIA DAEHNHARDT

MARIA RAQUEL FREIRE

Coordenadoras 
(Página deixada propositadamente em branco) 
竞

$\frac{1}{T}$ 
EDIÇÃo

Imprensa da Universidade de Coimbra

Email: imprensa@uc.pt

URL: http//www.uc.pt/imprensa_uc

Vendas online: http://livrariadaimprensa.uc.pt

COORDENAÇÃO EDITORIAL

Imprensa da Universidade de Coimbra

CONCEÇÃO GRÁFICA

António Barros

IMAGEM DA CAPA

By NASA Earth Observatory (Earth Observatory)

[Public domain], via Wikimedia Commons

PRÉ-IMPRESSÃo

Mickael Silva

REVISÃo

Lúcia Queirós

EXECUÇÃO GRÁFICA

Gráfica de Coimbra

ISBN

978-989-26-0711-5

ISBN DIGITAL

978-989-26-0712-2

DOI

http://dx.doi.org/10.14195/978-989-26-0712-2

DEPÓSITO LEGAI

$373091 / 14$ 
IMPRENSA DA

UNIVERSIDADE

DE COIMBRA

COIMBRA

UNIVERSITY

PRESS

\section{A POLÍTICA EXTERNA}

RUSSA NO ESPAÇO

EURO-ATLÂNTICO

Dinâmicas de cooperação e competição num espaço alargado 
(Página deixada propositadamente em branco) 


\section{S U M Á R I O}

Lista de acrónimos

Prefácio

Novas dinâmicas da política externa russa

Carlos Gaspar. 9

Introdução

A Rússia e o espaço Euro-Atlântico

Patrícia Daehnhardt e Maria Raquel Freire 11

\section{Capítulo 1}

A evolução da política externa da Rússia

Maria Raquel Freire.

\section{Capítulo 2}

As relações da Rússia com a Ucrânia, Bielorrússia e Moldova: poder, dependências e assimetrias no espaço pós-soviético

Vanda Amaro Dias.

Capítulo 3

A Rússia e o Cáucaso do Sul: das relações neocoloniais à realpolitik no 'estrangeiro próximo'

Maria Raquel Freire e Licínia Simão 85

Capítulo 4

A Rússia e a Ásia Central: globalização e competição hegemónica 


\section{Capítulo 5}

A Rússia e a Alemanha: uma relação sui generis em mudança

Patrícia Daehnhardt

Capítulo 6

As relações entre a Polónia e a Rússia: 1980-2011

Madalena Meyer Resende

Capítulo 7

Rússia e União Europeia: dois gigantes e um continente

Sandra Dias Fernandes

Capítulo 8

Washington e Moscovo: em busca de um modus vivendi

Bernardo Pires de Lima

Capítulo 9

Relações Rússia-Turquia: da rivalidade à parceria estratégica

André Barrinha

Capítulo 10

A política externa russa em relação ao Norte: a dimensão setentrional e o Ártico Alena Vysotskaya Guedes Vieira

Capítulo 11

A quarta vaga de democratização e a sua influência na Rússia. O início da transição? Alberto Priego Moreno. 301

Conclusão

A política externa russa no espaço Euro-Atlântico

Maria Raquel Freire e Patrícia Daehnhardt

Bibliografia 331

Notas biográficas .357

Index. .363 


\section{LISTA DE ACRÓNIMOS}

APC - Acordo de Parceria e Cooperação

BEAC - Conselho Euro-Ártico de Barents

BEAR - Região Euro-Ártica de Barents

CEdE - Comunidade Económica da Eurásia

CEI - Comunidade de Estados Independentes

CSNU - Conselho de Segurança das Nações Unidas

ESN - Estratégia de Segurança Nacional

EUA - Estados Unidos da América

FMI - Fundo Monetário Internacional

MIU - Movimento Islâmico do Uzbequistão

NEI - Northern European Initiative

OCX - Organização de Cooperação de Xangai

OMC - Organização Mundial do Comércio

OPEP - Organização dos Países Exploradores de Petróleo

OSCE - Organização para a Segurança e Cooperação na Europa

OTAN - Organização do Tratado do Atlântico Norte

OTSC - Organização do Tratado de Segurança Coletiva

PECC - Plataforma de Estabilidade e Cooperação para o Cáucaso

PEV - Política Europeia de Vizinhança

PKK - Partido dos Trabalhadores do Curdistão

PpP - Parceria para a Paz

SSBN - Ship Submersible Ballistic Nuclear

TSC - Tratado de Segurança Coletiva

UE - União Europeia

URSS - União das Repúblicas Socialistas Soviéticas 
(Página deixada propositadamente em branco) 


\section{P R E F Á C I O}

\section{NOVAS DINÂMICAS DA POLÍTICA EXTERNA RUSSA}

Este livro começou em Obidos, quando o Instituto Português de Relações Internacionais decidiu revisitar, vinte anos depois, as três crises que marcaram o fim da Guerra Fria. Foi esse o tema de três edições sucessivas da sua Escola de Verão, entre 2009 e 2011, que reuniram especialistas, diplomatas e personalidades portuguesas, polacas, alemãs, ucranianas e russas no Museu municipal, para analisar, sob o olhar dos santos e dos mártires renascentistas, os suaves milagres que tornaram possível o fim pacífico da divisão de Berlim, da Alemanha e da Europa.

Raquel Freire e Patrícia Daehnhardt, respectivamente a melhor especialista portuguesa sobre a Rússia pós-soviética e a melhor especialista portuguesa sobre a Alemanha pós-unificação, decidiram, por sua vez, fazer uma versão própria e abençoada da aliança russo-alemã e pegaram no legado das Escolas de Verão para organizar este magnífico volume que estuda as políticas externas da Rússia, desde o fim da União Soviética até à Primavera Árabe, incluindo capítulos específicos sobre as suas relações com os Estados Unidos, a Alemanha, a Polónia e a Turquia e com o seu "estrangeiro próximo" nas três marcas eslava, caucasiana e asiática.

O livro tem três qualidades dignas de nota. A primeira é a escolha e o tratamento do tema. Contra a tendência dominante, que privilegia temas esotéricos e irrelevantes ou análises impressionistas da conjuntura, Raquel Freire e Patrícia Daehnhardt escolheram um tema crucial da política internacional do pós-Guerra Fria e procuraram estudar as políticas externas russas num período significativo, ao longo dos últimos vinte anos, e de forma sistemática, valorizando todas as dimensões mais relevantes 
para as relações entre a Rússia, os Estados Unidos e a Europa Ocidental. A segunda é a qualidade dos textos, que podiam ser publicados em qualquer edição internacional de estudos sobre a Rússia e que rompem com a tradição paroquial que prevalece ainda numa parte dos estudos portugueses de política internacional, reféns das velhas ilusões autárcicas e isolacionistas do nacionalismo universitário. De facto, a maior parte dos autores deste volume obteve os seus graus académicos em universidades estrangeiras, onde os estudos de relações internacionais não são uma extensão dos estudos coloniais, e publica, regularmente, em publicações internacionais. A terceira é a demonstração de que é possível reunir um conjunto de especialistas portugueses competentes em domínios críticos da investigação e da política internacional.

A combinação dessas qualidades, reforçada pelo facto saliente das investigadoras serem uma clara maioria, obriga todos os responsáveis a reconhecer que, no domínio da ciência política e das relações internacionais, tal como no domínio das "ciências duras", há uma nova geração de cientistas portugueses de classe internacional. São eles (elas) que estão a construir uma escola portuguesa moderna de relações internacionais para o novo século, para lá crise. 


\section{N T R O D U Ç Ã O}

\section{A RÚSSIA E O ESPAÇO EURO-ATLÂNTICO}

Patrícia Daehnhardt e Maria Raquel Freire

A Rússia é uma das potências centrais no espaço euro-atlântico que se tem vindo a afirmar, desde o fim da Guerra Fria como um ator estratégico unitário, e que na condução da sua política externa tem optado por reafirmar o seu estatuto de grande potência perdido, com implicações para o futuro quadro de segurança regional europeia e transatlântica.

O processo do início do fim da União Soviética decorre num contexto de acelerada dinâmica dentro do espaço euro-atlântico, onde Moscovo é simultaneamente sujeito catalisador das mudanças fundamentais que ocorrem desde meados da década de 1980 e objeto, ultrapassado pela rapidez dos acontecimentos e pela incapacidade dos seus decisores políticos em assumir a liderança desse processo e impedir a implosão do Estado. A última fase da Guerra Fria (Sarotte, 2009), que se inicia com a queda do Muro de Berlim, em 9 de novembro de 1989 e que culmina com a implosão da União Soviética, em 25 de dezembro de 1991, acelerou o processo de integração europeia, ao promover a assinatura do Tratado de Maastricht e despoletou o alargamento institucional da Aliança Atlântica. Neste sentido, a Rússia, que viria a emergir da defunta União Soviética constituiu-se num contexto de triangularidade entre a unificação alemã, o fim da União Soviética e o aprofundamento da integração europeia e alargamentos da União Europeia (UE) e da Organização do Tratado do Atlântico Norte (OTAN) que têm que ser articulados em conjunto.

O percurso percorrido pela Rússia nos últimos vinte e dois anos tem sido marcado tanto por dinâmicas de cooperação como por dinâmicas 
de competição e mesmo confrontação com os seus vizinhos, num registo misto de incerteza, instabilidade e cooperação que da perspetiva russa é condicionado por um princípio definidor da sua diplomacia: a rápida recuperação do estatuto de poder do país e a consolidação desse estatuto. Este processo dá-se num mundo de mudança global, deslocamento e emergência de novos pólos de poder que desafiam a centralidade do espaço euro-atlântico onde a Rússia, por condicionalismos históricos, geográficos e geopolíticos, tem preferencialmente atuado. Este trajeto de recuperação do estatuto de grande potência no período do pós-Guerra Fria tem sido acompanhado pela redefinição das relações bi e multilaterais com vários Estados e instituições, conduzido pela Rússia com várias regiões, com especial incidência no espaço euro-atlântico.

O conceito de espaço euro-atlântico é compreendido aqui na sua dimensão política e estratégica, pressupondo na sua concetualização dois pontos fundamentais. Primeiro, a existência de fronteiras, tanto num registo territorial como político, entre quem está incluído e quem está excluído desse espaço, ou seja, entre 'nós' e ‘eles' (Neumann, 1995). Durante a Guerra Fria, a URSS, como potência adversária dos Estados Unidos e da Europa ocidental (Gaddis, 2006), era a parte excluída. A sua existência para lá da fronteira política, enquanto regime de natureza marxista-leninista, fortaleceu a entidade estratégica do ocidente onde ocorria uma interação política, económica, militar e cultural entre os seus atores. Segundo, a criação de instituições que servissem de catalisador para criar uma identidade própria ao espaço euro-atlântico. Este passou a ser entendido como integrando grandes potências assim como as instituições do pós-guerra que se foram criando, através da partilha de objetivos institucionalmente definidos na Aliança Atlântica e nas Comunidades Económicas Europeias.

As relações de poder e competição que se desenvolveram entre as potências ocidentais eram assim atenuadas pelo objetivo comum de contenção do comunismo (comonalidade negativa), bem como fortalecidas por um sentimento de pertença a uma "comunidade de segurança" (Deutsch, 1957) composta por "grupos sociais que interagem através de um processo de comunicação política, mecanismos de cumprimento de regras e hábitos públicos de respeito por essas regras" (comonalidade 
positiva). A comunidade transatlântica desenvolveu-se a partir destes pressupostos e da convergência de valores, com base na tradição judaico-cristã, respeito pelos direitos humanos, liberdade individual, e vigência do direito, fortalecendo uma ordem internacional que G. John Ikenberry definiu de "ordem liberal constitucional" (Ikenberry, 2001) sustentada por instituições internacionais limitadoras do poder dos Estados. ${ }^{1}$

O fim da Guerra Fria e as alterações estruturais que isso teve para a política internacional desafiou os limites do espaço euro-atlântico, tanto na sua dimensão territorial como política. O modo como a Rússia pós-soviética se tem posicionado perante o espaço euro-atlântico, ele próprio em mutação desde 1991, ilustra da forma mais marcante as alterações em curso. Muitas das questões ainda por resolver entre a Rússia, a Europa e os EUA prendem-se com o entendimento de como se define o espaço euro-atlântico. Como afirma Patrícia Daehnhardt neste volume, "se no final da Guerra Fria o percurso da URSS fora de retraimento do poder de Moscovo, de fora para dentro, perdendo influência na zona mais longínqua, passando pela Europa de leste e finalmente perdendo o poder sobre as antigas repúblicas da URSS, a partir de 2000 o percurso de recuperação de poder seguia a lógica inversa, de gradual recuperação de poder junto das capitais dos novos Estados soberanos da antiga URSS, onde Moscovo apoiava regimes simpatizantes e tentava frustrar apoios europeus à democratização nesses países, como aconteceu na Geórgia, Ucrânia ou Bielorrússia.”

O alargamento da União Europeia a oito países da Europa de leste, em maio de 2004, correspondeu ao alargamento da fronteira entre a UE e a Rússia, e os vários alargamentos institucionais da OTAN desde 1999, foram contestados pela Rússia por significarem o avanço da instituição até às suas fronteiras. Estes alargamentos dificultaram as relações com o ocidente ao ponto de permanecer a desconfiança e incerteza mútuas, por

\footnotetext{
${ }^{1}$ Ikenberry, a partir de uma conceção liberal institucionalista definiu uma ordem constitucional como sendo uma "ordem política organizada em torno de instituições legais e políticas que funcionam para atribuir direitos e limitar o exercício do poder... Os riscos nas lutas políticas são reduzidos pela criação de processos institucionalizados de participação e de tomada de decisão que especificam regras, direitos e limites para os detentores do poder." (2001, p. 29)
} 
Moscovo considerar o alargamento uma potencial ameaça à sua segurança. ${ }^{2}$ A discussão sobre a possibilidade da Rússia se vir a tornar membro de pleno direito da Aliança Atlântica chegou a estar em cima da mesa, mas não passou de retórica política com vista quer a desafiar pressupostos competitivos na base do seu relacionamento com os restantes países da OTAN, quer como uma forma de procurar colmatar dinâmicas associadas a exclusão na redefinição de uma ordem euro-atlântica de segurança, com uma componente europeia muito forte.

Qual é o papel que a Rússia deve desempenhar nesta ordem de segurança euro-atlântica? Da perspetiva da OTAN e da UE a cooperação com a Rússia é necessária em questões como a segurança energética ou o controlo de armamento, incluindo princípios de não proliferação nuclear, a resolução de conflitos étnicos no Kosovo ou na Transnístria, por exemplo, ou a estabilização do Afeganistão, principalmente após a saída da OTAN depois de 2014. Mas a cooperação foi muitas vezes acompanhada de momentos de tensão, como revelaram as posições divergentes sobre os alargamentos da OTAN, as revoluções coloridas na Geórgia, Ucrânia e Quirguistão, as guerras no Afeganistão, no Iraque e na Geórgia, as questões nucleares do Irão e da Coreia do Norte, assim como reações divergentes à Primavera Árabe e às guerras civis na Líbia e na Síria, ou, por último, o projeto de defesa antimíssil norte-americano. Da perspetiva de Moscovo, os seus líderes políticos sabem que a Rússia goza de duas mais valias: por um lado, a posse de importantes recursos energéticos, dos quais a Europa depende; por outro, um importante potencial de alavancagem devido ao seu direito de veto como membro permanente do Conselho de Segurança das Nações Unidas (CSNU). Sem o apoio ou aval da Rússia, o ocidente dificilmente conseguirá ser eficaz na dissuasão do Irão nas suas pretensões de se tornar uma potência nuclear, ou na resolução pacífica do conflito sírio, uma vez que a Rússia tem nestas matérias não só voz, como poder de influência e capacidade de atuação.

\footnotetext{
2 Em 1999, a Polónia, a Hungria e a República Checa aderiram à OTAN, seguidos, em 2004, por sete países da Europa do norte e do leste europeu: Bulgária, Eslovénia, Eslováquia, Estónia, Letónia, Lituânia e Roménia. Em 2009, a Albânia e a Croácia foram os últimos dois países a tornarem-se membros da Aliança Atlântica.
} 
Politicamente, a Rússia integra o espaço euro-atlântico de uma forma incompleta: tem acordos de parceria e de cooperação com a OTAN e a UE, mas não integra a comunidade de segurança no sentido restrito do termo e continua a manter uma posição sui generis: não totalmente excluída nem totalmente integrada. É isto que torna a temática deste volume tão premente e é esta incerteza que está subjacente às relações que a Rússia desenvolve com os seus parceiros europeus e transatlânticos e que continua, embora de uma forma diferente da Guerra Fria, a afetar a segurança europeia e euro-atlântica, num espaço alargado onde o Médio Oriente, desde a Primavera Árabe, ganha uma nova relevância, passando por reajustamentos no posicionamento da Turquia até à crescente importância do Ártico como nova zona de competição na triangularidade Rússia, UE e EUA.

A política externa da Rússia pós-soviética é definida a partir de cinco linhas de continuidade. Primeiro, a questão da identidade russa: situada entre a ambiguidade identitária e uma ansiedade existencial (Gaspar, 2005) na definição da sua identidade internacional. De facto, a Rússia sente-se constrangida em afirmar uma identidade assertiva e consolidada face à indecisão em se definir e atuar como potência europeia ou asiática. Esta indefinição identitária afeta inevitavelmente a condução da política externa, o que tem levado a Rússia a optar por políticas europeias e asiáticas nem sempre conciliáveis. Como argumentou Ilya Prizel, existe uma ligação direta entre a identidade nacional e a política externa da Rússia (Prizel, 1998). A identidade internacional de um país define-se sempre contra 'um outro', ou seja, é “relacional” (Neumann, 2006). Por outro lado, 'o outro' também surge como elemento definidor da identidade. Margot Light et al. (2000) definiram a Rússia como um "Estado excluído" ao confrontar-se desde o fim da Guerra Fria com os alargamentos institucionais da OTAN e da UE e com a clara perceção de que a Rússia ficaria excluída destes clubes, sentindo-se isolada e marginalizada. O alargamento da OTAN, para junto do antigo território da União Soviética teve repercussões sobre a capacidade de influência dos decisores políticos liberais no Kremlin, que se viram fragilizados na linha de argumentação de proximidade com o ocidente. Isto veio a reforçar uma identidade internacional russa mais 
pragmática e nacionalista e a primazia de defesa do interesse nacional, sob a presidência de Vladimir Putin, a partir de 2000.

A linha de continuidade, nesta lógica identitária, reside assim na permanência da incerteza e ambiguidade quanto à inserção numa instituição onde a Rússia se sinta incluída e autoconfiante, assente numa estrutura de aliança fragilizada ou inexistente. Para resolver esta indefinição identitária alguns autores sugerem que a Rússia deveria optar por voltar-se para o ocidente, integrando as suas estruturas institucionais (Trenin, 2002). A relação entre a Rússia e a China, não abordada neste volume por se pretender contextualizar apenas as dinâmicas do espaço euro-atlântico, não reflete uma relação de aliança, sendo caracterizada como um "eixo de conveniência" (Lo, 2008) onde apesar de uma convergência de interesses baseada no comércio energético, na cooperação militar e na competição com os Estados Unidos, a desconfiança persiste quanto às intenções um do outro no domínio securitário. No entanto, o facto de a Rússia se afirmar enquanto ator estratégico unitário concede-lhe ao mesmo tempo maior autonomia para se aliar com outros países, europeus ou asiáticos, e deixar assim os seus rivais e/ou competidores na incerteza de que alinhamento a Rússia irá escolher em determinada circunstância.

Em segundo lugar, a posição geográfica da Rússia, entre o ocidente e o oriente, continua a condicionar a sua atuação externa: a vastidão do território assim como a história têm durante séculos condicionado os decisores russos, impondo à própria Rússia o estatuto de grande potência (Legvold, 2007). Na dificuldade de definição de opções estratégicas esta optou por um percurso que desde então posicionou o país numa procura constante de inserção na centralidade da política europeia, desde o século XVIII. O envolvimento em guerra europeias, assim como a resolução negociada dos conflitos passou pela ligação da Rússia às potências vencedoras e definidoras da nova ordem. Esta centralidade da Europa também explica, em parte, a contínua aversão russa quanto ao envolvimento norte-americano no continente europeu, historicamente recente, sempre visto como sendo feito em detrimento da Rússia e excluindo-a.

Em terceiro lugar, apesar da constituição de um novo Estado, perdura a centralização do poder político, que na Rússia pós-soviética tem vindo 
a acentuar uma forte personalização do poder (Shevtsova, 2007) mas que é um elemento constante vindo do império czarista, da União Soviética e da Rússia atual. Essa centralização de poder, que dificulta a democratização das estruturas políticas russas e a consolidação de um verdadeiro regime plural, mantém-se até à atualidade, sendo confirmada pela eleição de Vladimir Putin, para um terceiro mandato presidencial, em março de 2012.

Em quarto lugar, o impulso hegemónico da Rússia levou-a a estabelecer a Comunidade de Estados Independentes (CEI), em 1991, onde Moscovo cedo se evidencia como o protagonista de uma nova ordem regional, dentro do chamado 'estrangeiro próximo' e onde a Rússia advoga para si um direito de first among equals e de ingerência. Como afirma Maria Raquel Freire neste volume, a guerra na Geórgia, em agosto de 2008 exemplifica essa política de projeção de poder russo na área pós-soviética, tendo "Moscovo aproveit[ado] a oportunidade para demarcar linhas de influência e interferência, enfraquecendo a Geórgia, sinalizando a sua política assertiva no espaço CEI, reforçando a sua estratégia de contenção dos Estados Unidos na Eurásia, e sublinhando o reconhecimento de estatuto que tem prosseguido no sistema internacional."

Por último, a Rússia permanece fiel ao princípio realista das relações internacionais. A narrativa russa assenta num instinto realista e é diferente da narrativa de muitos países membros da UE. A Rússia sempre seguiu uma leitura realista das relações internacionais segundo a qual os interesses russos definem a orientação da política externa e a conceção da soberania política como moderna e vestefaliana. Daí que prossegue uma visão geopolítica com o intuito de garantir um estatuto de grande potência e de projetar a sua influência no espaço territorial que lhe é mais próximo, o espaço pós-soviético. Consequentemente, os instrumentos de que dispõe para alcançar os referidos objetivos não são sujeitos aos constrangimentos normativos ocidentais, deixando aos decisores russos uma margem de manobra mais ampla. Como afirma André Barrinha neste volume, "a Rússia e a Turquia procuram expandir as suas zonas de influência, ao mesmo tempo que privilegiam a cooperação de curto prazo em matérias de interesse mútuo, num discurso pautado pelo interesse nacional e esvaziado de alusões normativas." 
Quando Moscovo recorre à força militar tende a fazê-lo dentro do seu 'estrangeiro próximo' onde sente interesses seus a serem ameaçados e onde se atribui um droit de regard. O recurso ao uso do hard power encontra-se, assim, confinado a uma leitura russa do mesmo, e não está enquadrado no entendimento da comunidade internacional quando esta decide, nas Nações Unidas, a utilização da força militar por razões humanitárias, e onde a Rússia, por regra, se recusa a aprovar as resoluções conducentes à intervenção militar. Como os casos recentes das guerras civis na Líbia e na Síria demonstram, a Rússia demonstra grande hesitação no uso conjunto da força militar, por constrangimentos financeiros, por prudência, ou por não subscrever o princípio da ingerência humanitária nos assuntos internos, em grande parte por receio que esse princípio possa vir a ser aplicado contra ela. O facto de se ter abstido na votação sobre a aplicação de uma zona de exclusão aérea sobre a Líbia, em 17 de março de 2011, no CSNU, viabilizando o mandato da intervenção militar internacional da OTAN, foi como que uma exceção à regra que o veto aplicado a tentativas de resolução sobre a Síria, durante 2012, comprova. Para a Rússia, o emprego da força militar continua a fazer parte das prerrogativas exclusivas do Estado russo, com pouca recetividade aos princípios pós-soberanistas de ingerência humanitária e da "responsabilidade de proteger".

Estes elementos de continuidade contrastam com linhas de rutura que se verificaram na política externa da Rússia, desde 1991, em quatro domínios. A primeira linha de rutura foi a forma como terminou o império soviético, cuja liderança se viu confrontada com um recuo estratégico forçado, derivado à sobreextensão imperial (Kennedy, 1989). Após um recuo político e militar do exterior longínquo, como Nicarágua, Angola e Vietname, para o exterior europeu, como os países da Europa de leste, e o fim do Pacto de Varsóvia, finalmente para o interior da própria URSS, o poder centralizador sob a liderança de Mikhail Gorbachov foi incapaz de evitar a implosão das próprias estruturas políticas da federação soviética e o fim da URSS enquanto Estado soberano.

Para além desse momento trágico para o projeto comunista, a perda do estatuto de grande potência internacional e a perda do poder ideacional que ele acarretou representa uma segunda linha de rutura que marca 
a constituição da Rússia pós-soviética. A década de 1990 sinaliza uma década de procura de redefinição das prioridades da sua política externa, dificultada pelos problemas económicos internos e pela contestação ao poder centralizador de Moscovo, o que se evidenciou nas duas guerras na Chechénia, em território russo. Na primeira década, entre 1991 e 1996, afirma-se a tendência de ocidentalização conduzida pelo presidente Boris Ieltsin e pelo ministro dos negócios estrangeiros, Andrei Kozyrev que opta pela aproximação aos Estados Unidos e à Europa ocidental ao sugerir a adesão às instituições ocidentais para contrariar tendências de isolamento e de desclassificação do estatuto para potência periférica. Mas à exceção do espaço composto pelas antigas repúblicas soviéticas, agora soberanas, onde a Rússia ainda reivindica um estatuto de preponderância, a classificação do status de grande potência não é facilmente recuperado, e continua a não reunir consenso junto dos analistas.

Ligado a este receio e para amortecer o percurso de recuperação do estatuto de poder, os decisores russos, advogam, principalmente com o ministro dos negócios estrangeiros, Evgeny Primakov, a partir de 1996, a multipolaridade em termos de distribuição de poder entre as grandes potências, numa altura em que o sistema internacional se caracterizava por uma unipolaridade americana durante a década de 1990 (Brooks e Wohlforth, 2002; Wohlforth, 1999). A opção pela multipolaridade constitui uma terceira linha de rutura com o passado soviético, e explica-se pela incapacidade de a Rússia se vir a afirmar a curto prazo como a potência hegemónica, na Europa e no mundo, contrapondo-se aos EUA e tentando procurar alternativas em alianças com a Índia ou a China. Contudo, estas não se concretizaram como verdadeiras alternativas capazes de redefinir a orientação estratégica da Rússia que permanece, assim, um ator estratégico unitário.

Uma quarta linha de rutura em comparação à Guerra Fria é a natureza mutável das relações entre a Rússia e os Estados Unidos, potência que representou a unipolaridade momentânea da década de 1990 e com a qual Moscovo desenvolveu uma aliança tática assente numa perceção comum das novas ameaças, como aconteceu na determinação de em conjunto combater o terrorismo internacional, na sequência do 11 de setembro de 
2001. Quase pela mesma altura contrariou os EUA nas decisões sobre o uso da força militar, em 2003, quando Moscovo, juntamente com Berlim e Paris se opôs à intervenção norte-americana no Iraque, impedindo que a operação fosse legitimada com um mandato do Conselho de Segurança. Há duas leituras possíveis quanto à reação russa. Primeiro, pode ser entendida como a confirmação de um sentimento de impotência e de uma noção de cerco crescente durante a crise transatlântica de 2003. Como afirma Bernardo Pires de Lima neste volume, "um ano antes da guerra do Iraque, sete países da 'nova Europa' tornaram-se membros da Aliança Atlântica e um ano depois dessa intervenção militar, a União Europeia recebeu-os de braços abertos. Este quadro geopolítico que interligava uma decisão unilateral da superpotência, os alargamentos das instituições ocidentais, e a fragilidade do alcance do eixo alternativo composto por Paris, Berlim e Moscovo, dotou o Kremlin de um sentimento de impotência e de uma noção de cerco crescente."

Uma segunda leitura sugere que o episódio refletiu a estratégia que a Rússia segue na escolha de alianças: uma preferência por alianças flexíveis que não lhe condicionem a margem de manobra e que permitam a Moscovo optar por um ou vários aliados (temporários) em função dos interesses russos em causa, o que pode ser resultado da falta de opção de Moscovo, ou de uma convição estratégica de que a Rússia deve manter-se à margem de compromissos de aliança demasiadamente comprometedores.

Os capítulos que integram este volume analisam as dinâmicas de cooperação e de competição no espaço euro-atlântico alargado: as relações da Rússia com os seus vizinhos, tanto na zona que fazia parte da antiga União Soviética como com dois países membros da UE, a Alemanha e a Polónia, assim como com a própria União Europeia; as relações com os Estados Unidos da América, que se mantiveram centrais na política russa desde o final da Guerra Fria, ora numa lógica cooperativa ora numa lógica de contenção; as relações com a Turquia, que, com a recente reorientação da política externa desta e a sua emergência como um ator com importante estatuto regional transformaram as relações com Ancara num eixo adicional para a diplomacia de Moscovo; e o posicionamento da Rússia face ao Ártico, uma zona de crescente relevância internacional 
pela riqueza dos seus recursos energéticos abundantes e a potencialidade de novas rotas de transporte marítimo. De um modo inclusivo esta análise visa clarificar os alinhamentos de política externa russa, e perante as mudanças profundas que se verificaram no continente europeu nas últimas duas décadas, traçar o caminho de transformação, tanto na política externa como interna que a Rússia tem percorrido, e a forma como as relações com outras potências se têm vindo a alterar a partir daí.

Com base na análise das políticas interna e externa russas, pretende-se identificar as dimensões europeia e transatlântica do caminho da Rússia na recuperação do seu estatuto de grande potência internacional. Para tal, este volume reúne um conjunto de contributos de especialistas nesta área de estudo, partindo da contextualização da evolução das políticas russas e dos principais alinhamentos atuais das mesmas, para depois analisar relações multilaterais e num quadro bilateral centrais à compreensão do posicionamento e das políticas russas no espaço euro-atlântico.

Um primeiro capítulo, de Maria Raquel Freire contextualiza a posição internacional da Rússia a partir de uma revisão atualizada da bibliografia e o state of the art sobre a evolução da política externa russa. Maria Raquel Freire traça a evolução da política externa russa de um contexto de rivalidade bipolar para um novo quadro pós-Guerra Fria, identificando elementos de continuidade e mudança nos processos que lhe estão associados na formulação de política externa no período do pós-Guerra Fria que se desenvolve numa vertente mais pragmática e multivetorial. Analisando as presidências de Ieltsin, Putin e Medvedev a autora sugere a consolidação de tendências que se apresentam como estruturais ao processo de tomada de decisão e implementação em matéria de política externa na Federação Russa. Assim, o processo de transição na Rússia acabou por revelar-se uma transição incompleta, por se ter "materializado num modelo de governação com traços autoritários e de centralização de poder, a par de uma política de abertura ao exterior e modernização interna".

A sequência dos capítulos que se seguem foi organizada partindo de uma lógica inside-out, ou seja, analisando, primeiro, o espaço pós-soviético, definido nos principais documentos de política externa russa como área vital de atuação e influência, ou seja, as relações de Moscovo com as 
novas repúblicas da antiga União Soviética, como a Ucrânia, a Moldova e a Bielorrússia, analisadas por Vanda Amaro Dias. Esta é uma área de importância acrescida pela sua localização entre a Federação Russa e a União Europeia, bem como pelo facto de estas três repúblicas pertencerem à CEI, descrita pelas autoridades russas como espaço preferencial de atuação e influência da Rússia nos seus alinhamentos de política externa. Contudo, deve ser notado o grande diferencial entre estes três Estados, acentuado no seu curso pós-soviético, e que exige a Moscovo políticas talhadas em termos políticos, económicos e de segurança, de modo a que correspondam quer a objetivos traçados em comum quer aos desafios que são colocados a estas relações com base nas diferenças existentes. Vanda Amaro Dias define a estratégia russa para esta região como sendo de exploração de dependências com vista à afirmação do seu poder em quadros relacionais assimétricos onde as relações entre os países permanecem tensas. Vanda Amaro Dias conclui que "esta região [que engloba a Bielorrússia, Moldova e Ucrânia] continuará, muito provavelmente, a ser palco de dinâmicas de poder complexas, que exploram dependências múltiplas para perpetuar relacionamentos assimétricos que privilegiam a prossecução e satisfação dos interesses de Moscovo.”

Ainda dentro da área que a Rússia identifica como o seu 'estrangeiro próximo' mas com interesses diferenciados, as relações da Federação Russa com as três repúblicas do Cáucaso do Sul, nomeadamente a Arménia, Azerbaijão e Geórgia, são analisadas por Maria Raquel Freire e Licínia Simão, estudando as mudanças nas relações bilaterais e na sua 'dimensão regional' desde o final da Guerra Fria aos dias de hoje. Neste relacionamento destacaram-se alguns conflitos armados, entre os quais a 'guerra dos cinco dias' entre a Rússia e a Geórgia, em agosto de 2008, e as relações de maior ou menor cooperação que caracterizam a diplomacia russa nesta região.

Vizinha do Cáucaso do Sul e ainda integrando a zona do 'estrangeiro próximo' onde a Rússia requer especial influência, a Ásia Central e a sua relevância na definição das prioridades externas russas é estudada por Licínia Simão. A autora demonstra que à medida que a política externa russa abandonou o ocidente como sua prioridade central e se concentrou na afirmação de uma esfera de influência no seu 'estrangeiro próximo' 
com enfâse na CEI, as relações com a Ásia Central voltaram a ser uma parte fundamental dos interesses russos. A Rússia encontra-se numa fase de consolidação da sua presença militar, económica e política na região, embora num plano de longo prazo esta consolidação vá continuar a ser desafiada, quer pelos atores regionais, quer pelas outras potências hegemónicas a atuar na região, com especial destaque para os EUA. Licínia Simão afirma que a "capacidade política e operacional limitada da Rússia em atuar como garante da segurança regional ficou bem visível no caso dos conflitos no Quirguistão em 2010, e no Tajiquistão, em agosto de 2012", concluindo que a "crescente complexidade da competição hegemónica em curso na Ásia Central representa um risco real de instabilidade e conflito na região."

Fora da vizinhança imediata da Rússia, e dentro do contexto da União Europeia, a Alemanha e a Polónia surgem como atores importantes para Moscovo. O capítulo de Patrícia Daehnhardt analisa as relações bilaterais entre a Rússia e a Alemanha de uma perspetiva de convergência quanto à procura da redefinição das respectivas identidades internacionais no pós-Guerra Fria, e de divergência quanto à inserção em contextos institucionais diferenciados e aos parâmetros definidores das respectivas políticas externas. Num cenário pós-11 de setembro, de convulsões sócio-políticas no Médio Oriente e de novos desafios energéticos e enquadramentos geopolíticos, a análise centra-se nas políticas bilaterais no domínio da cooperação económica, de segurança energética e do relacionamento securitário, três dimensões que sugerem uma relação sui generis entre Berlim e Moscovo, com implicações para a União Europeia e a Aliança Atlântica. Patrícia Daehnhardt conclui que "enquanto que a Rússia prossegue uma estratégia de revisão dos contornos da ordem europeia do pós-Guerra Fria, a Alemanha é defensora do status quo sem aceitar que para manter essa ordem terá de assumir um papel de liderança. O paradoxo daí resultante é que a Rússia quer ser a grande potência europeia do espaço euro-atlântico mas não consegue ao passo que a Alemanha exerce influência e ganhou auto-confiança mas permanece cautelosa e hesitante em afirmar-se enquanto grande potência europeia. Enquanto a primeira quer mais do que as capacidades lhe permitem, a segunda, apesar das expetativas 
de alguns parceiros e da potência económica evidente abstém-se de exercer, de forma assertiva, a liderança na Europa."

O capítulo de Madalena Meyer Resende analisa as relações da Rússia com a Polónia, um Estado da UE que esteve na esfera de influência soviética durante o período de Guerra Fria, num quadro de transição onde as mudanças nas dinâmicas de relacionamento têm sido marcadas por momentos de rutura e outros de maior proximidade. O processo de integração da Polónia na UE e as alterações internas nas políticas polacas e na Rússia marcam este estudo. Ilustrando a importância que as relações triangulares podem ter, Madalena Meyer Resende afirma que "a Polónia conseguiu realizar o programa inicial da sua política externa democrática, assente na reconciliação com a Alemanha e na integração europeia e ocidental como condição prévia para uma reconciliação com a Rússia." De facto, a autora demonstra como através de uma "aliança privilegiada com a Alemanha e [d]a integração nas instituições euro-atlânticas (...) a Polónia [assumiu] um papel de pivot na relação da UE com a Rússia."

Desta análise de relacionamentos bilaterais parte-se para a análise da UE como ator internacional na sua tentativa de estabelecer um relacionamento estratégico com a Rússia. Sandra Fernandes analisa o percurso que a UE e a Rússia têm desenvolvido num quadro institucional de cooperação único. Do Acordo de Parceria e Cooperação (APC) em 1997, passa-se para uma nova metodologia de cooperação, em 2003, acionada pelas alterações significativas que alargaram e aprofundaram as suas relações num conjunto ampliado de domínios, na tentativa de consolidar uma visão estratégica através do acordo sobre os Quatro Espaços Comuns. Daí evoluiu-se para uma "Parceria para a Modernização”, em 2009. Paradoxalmente, afirma Sandra Fermandes, o resultado é "uma relação difícil” porque apesar do avanço dos métodos e domínios de cooperação, a qualidade da relação Rússia-UE deteriorou-se, em parte devido a posições e políticas divergentes entre os diferentes atores face às relações com a Rússia o que dificulta até hoje a formulação de uma verdadeira parceria estratégica. Mais decisivamente, a guerra da Geórgia de 2008 foi igualmente marcante de um esfriamento de relações. 
As dificuldades afirmam-se também na relação entre a Rússia e os Estados Unidos. Bernardo Pires de Lima analisa a relação transatlântica numa lógica de mudanças profundas desde o final da Guerra Fria e o posicionamento da Rússia na redefinição da sua relação de segurança com os Estados Unidos. Os momentos chave na definição das relações Rússia-Estados Unidos, como o 11 de setembro de 2001 ou a redefinição do novo enquadramento estratégico da Aliança Atlântica, refletem a constante oscilação entre a cooperação e a rivalidade e como os alinhamentos entre ambos afetam o contexto euro-atlântico mais alargado.

A Turquia é um ator cada vez mais importante no espaço euro-atlântico. Como argumenta André Barrinha, o relacionamento entre a Rússia e a Turquia foi sempre marcado por uma grande ambiguidade. Pelo facto de percorrerem um percurso simultâneo de ascensão no sistema internacional e serem os dois maiores vizinhos da UE no espaço euro-atlântico alargado, constituem-se como atores fulcrais no sucesso das políticas europeias relativamente à sua vizinhança, tanto a norte como a leste. $\mathrm{O}$ autor identifica padrões de comportamento que marcam as relações entre a Rússia e a Turquia para compreender o estado do relacionamento entre estes dois países, bem como as eventuais tendências de evolução desse mesmo relacionamento.

O posicionamento da Rússia face à exploração do Ártico, região com crescente preponderância na agenda russa, pelos recursos naturais inexplorados e pela redefinição das rotas de trânsito, encerra a análise das relações da Rússia com os Estados vizinhos que integram o espaço euro-atlântico. Alena Vieira analisa as dinâmicas associadas ao Ártico como região de crescente relevância nas agendas internacionais, pelas suas riquezas e novas rotas de trânsito marítimo. O interesse russo na área, e a confrontação com interesses estratégicos e económicos de outras potências, que sugerem um novo potencial de rivalidade, são objeto de análise. Como Alena Vieira sublinha, "a nova navegabilidade do Ártico, tal como a exploração petrolífera, apresenta custos, nomeadamente o aumento dos riscos securitários da região. O incremento do trânsito marítimo suscita a necessidade de reforçar o seu controlo, que exige reforço da frota de quebra-gelos, investimentos nos sistemas 
de navegação e também uma presença militar ou policial reforçada. Esta última medida prende-se com o possível aumento do terrorismo e crime organizado. Por último, o Ártico levanta uma importante questão sobre o desenho da governação e o modo de cooperação entre os atores desta região."

Por último, o capítulo de Alberto Priego interroga-se sobre a solidez do regime russo após o regresso de Vladimir Putin à presidência, em março de 2012. O autor conclui que "a Rússia está em transição, no entanto isso não implica que no dia de amanhã será uma democracia. Se, no final, a Rússia se democratizar, um dos aspetos que mais seria afetado seria a sua política externa que, sem dúvida, seria menos agressiva, tanto no estrangeiro próximo como nas suas relações com o ocidente." Em última instância, uma transição democrática consolidada representaria, como afirma Alberto Priego, "a concretização última do final da Guerra Fria".

Por enquanto, contudo, as eleições legislativas para a Duma, em dezembro de 2011 e as eleições presidenciais, em março de 2012 ocorreram num clima de acentuado distanciamento, senão esfriamento das relações da Rússia com os restantes países do espaço euro-atlântico. Em primeiro lugar, os líderes ocidentais não apoiaram a pretensão de Putin em se recandidatar à presidência da Rússia, e a alteração constitucional que fora necessária para que Putin pudesse ser reeleito para um terceiro mandato. Em segundo lugar, na sequência da participação do presidente Medvedev na cimeira da OTAN em Lisboa, em novembro de 2010 e do prenúncio de uma maior cooperação entre o Conselho OTAN-Rússia, as relações deterioraram-se durante 2011, muito devido ao projeto de defesa anti-míssil proposto pelos EUA, para defesa da Europa contra uma eventual agressão do Irão, mas que nos atuais moldes é rejeitado pela Rússia por razões de acesso à informação, partilha do sistema de comando e localização geográfica do sistema, i.e. perto das suas fronteiras. A política do reset das relações entre os EUA e a Rússia, definida pela administração Obama em 2009, não alcançou os seus objetivos, e em finais de 2011 o presidente Medvedev chegou mesmo a ameaçar a colocação de mísseis de médio alcance em Kaliningrado, como forma de pressionar os EUA e os seus aliados a alterar a sua estratégia. 
Num contexto mais alargado é possível constatar-se que tem existido um esfriamento nas relações e que, de 2007 até 2012, houve mesmo um endurecimento das políticas de Moscovo face ao ocidente. Neste sentido, a cimeira OTAN em Lisboa em dezembro de 2010 parece agora um interlúdio numa relação multilateral de crescente mal-estar, interrompido por algumas ocasiões de cooperação esporádica. A política do reset parece já distante e a questão da necessidade de um novo reset nestas relações não se revelou uma prioridade nem para o presidente russo nem para o presidente Obama, reeleito em novembro de 2012 . A recusa do presidente Putin de participar na cimeira do G8, em Camp David, em maio de 2012 e na cimeira da OTAN em Chicago, dois dias depois, foram interpretados no ocidente como mais um sinal não apenas da deterioração das relações como da pouca vontade do líder russo em demonstrar uma atitude cooperativa. Além do mais, a persistência de incompatibilidades em questões centrais ao debate internacional, como a crise na Síria ou a questão nuclear, parecem não tender a uma aproximação do discurso e das ações entre a Rússia e os seus pares no espaço euro-atlântico.

Todas estas questões são analisadas de forma detalhada nos capítulos que se seguem, permitindo uma compreensão aprofundada das dinâmicas associadas à diversidade de relações que a Rússia vem desenvolvendo no espaço euro-atlântico, pautadas por linhas de convergência e divergência, caracterizadas por grandes assimetrias, e pautadas por uma necessidade constante de afirmação e reafirmação de políticas e práticas, não só por parte da Rússia, como também por todos os outros atores e intervenientes no espaço central a este estudo, o espaço euro-atlântico.

\section{Bibliografia}

BROOKS, Stephen G., e WOHLFORTH, William C. - American primacy in perspective. Foreign Affairs. Vol. 81, N. ${ }^{\circ} 4$ (2002), p. 20-33.

DEUTSCH, Karl W.; BURRELL, Sidney A.; KANN, Robert A. e LEE, Maurice Jr. - Political Community and the North Atlantic Area. Princeton: Princeton University Press, 1957.

GADDIS, John Lewis - The Cold War: A New History. London: Penguin Books, 2006. 
GASPAR, Carlos - A Rússia e a segurança europeia. Nação e Defesa. N. ${ }^{\circ} 110$, 3. ${ }^{a}$ Série (2005), p. $45-57$.

IKENBERRY, G. John - After Victory: Institutions, Strategic Restraint and the Rebuilding of Order after Major Wars. Princeton: Princeton University Press, 2001.

KENNEDY, Paul - The Rise and Fall of the Great Powers: Economic Change and Military Conflict From 1500 to 2000. New York: Vintage Books, 1989.

LEGVOLD, Robert - Russian Foreign Policy in the Twenty-First Century and the Shadow of the Past. Columbia: Columbia University Press, 2007.

LIGHT, Margot, WHITE, Stephen e LOWENHARDT, John - A wider Europe: the view from Moscow and Kyiv. International Affairs. Vol. 76, N. ${ }^{\circ} .1$ (2000), p. 77-88.

LO, Bobo - Axis of Convenience. Washington D.C.: Brookings Institution Press, 2008.

NEUMANN, Iver - Russia and the Idea of Europe: Identity and International Relations. London: Routledge, 1995.

NEUMANN, Iver - European Identity and its changing Others. Norwegian Institute of International Affairs, N. ${ }^{\circ} 710$ (2006). [Acedido a 22 de julho de 2012]. Disponível na Internet: http://english.nupi.no/content/download/613/13779/version/8/file/710.pdf.

PRIZEL, Ilya - National Identity and Foreign Policy: Nationalism and Leadership in Poland, Russia and Ukraine. Cambridge: Cambridge University Press, 1998.

SAROTTE, Mary-Elise - 1989: The Struggle to create Post-Cold War Europe. Princeton and Oxford: Princeton University Press, 2009.

SHEVTSOVA, Lilia - Russia lost in translation: The Yeltsin and Putin Legacies. Washington D.C.: Carnegie Endowment for International Peace, 2007.

TRENIN, Dmitri - The End of Eurasia: Russia on the Border between Geopolitics and Globalization. Washington D.C.: Carnegie Endowment for International Peace, 2002.

WOHLFORTH, William - The stability of a unipolar world. International Security. Vol. 24, N. ${ }^{\circ} 1$ (1999), p. 5-41. 


\section{CA P ÍTULO 1}

\section{A EVOLUÇÃO DA POLÍTICA EXTERNA DA RÚSSIA}

Maria Raquel Freire

O final da Guerra Fria e a desagregação da União das Repúblicas Socialistas Soviéticas (URSS) em 1991 constitui um marco histórico fundamental, com consequências a vários níveis. A nível político representa o fim do grande bloco de leste que marcou a rivalidade bipolar no confronto com o bloco ocidental. Após décadas de bipolaridade a redefinição da ordem internacional implicada nestes acontecimentos constitui um desafio a longo prazo. O lugar da Federação Russa no sistema internacional, após assumir responsabilidades fundamentais da antiga URSS, como, por exemplo, o assento permanente no Conselho de Segurança das Nações Unidas (CSNU), assume relevância no entendimento de possíveis configurações desta nova ordem. A questão do ajuste necessário entre a extinta superpotência URSS e a sua sucessora fragilizada, destaca-se na agenda internacional.

O fim do bloco soviético representou também o falhanço de um modelo de governação assente na ideologia marxista-leninista, cuja experimentação desvirtuou os pressupostos de base, gerando disparidade, iniquidade, e por vezes tendendo ao conformismo acrítico perante um conjunto de princípios e procedimentos definidos pela elite dirigente do Partido Comunista. Em termos sociais, esta experimentação revelou constrangimentos vários ao nível da expressão de liberdades individuais, apontando o caminho da coletivização como o caminho para o desenvolvimento e crescimento. A centralização do poder político e o sistema fechado em que a política se fazia não permitia uma relação de proximidade entre 
os dirigentes e a população em geral. A nível económico, as políticas de coletivização, os planos de desenvolvimento e produtividade centrados na indústria pesada, num contexto de Guerra Fria, criaram obstáculos variados à promoção de um desenvolvimento horizontal, com investimento em setores diferenciados da economia e que acabou por se refletir nas outras dimensões de atividade, nomeadamente política e social.

O processo de transição que se inicia com o fim da União Soviética, para além de significar uma reestruturação profunda de um sistema centralizado de orientação comunista, para um novo quadro político, económico e social, significou ainda o redimensionamento da Rússia, num novo mapa geográfico onde a antiga União Soviética deu lugar a 15 novos Estados, incluindo a Federação Russa. O impacto desta alteração geopolítica é significativo, apesar de a Rússia ter mantido os lugares de representação nas principais organizações internacionais, incluindo um lugar permanente no CSNU, bem como capacidade nuclear. Neste contexto, este capítulo analisa a política externa russa em transição, desde o final da Guerra Fria e da União Soviética até aos nossos dias, visando compreender as dinâmicas de reformulação de políticas e práticas que vem sendo operacionalizada num contexto diferenciado.

O capítulo começa com a contextualização do processo de transição, sublinhando o modelo de governação interno e o reajustamento político que a Rússia vai prosseguir. A análise da experiência democrática na Rússia pós-soviética será objeto de atenção, bem como as implicações associadas à transição política e social, e o regresso ao centralismo. Além do mais, as relações que a Rússia desenvolve na sua área de vizinhança, e como a sua política se molda aos desenvolvimentos que aí têm lugar, serão ainda analisadas. O texto prossegue com o enquadramento da transição russa no contexto internacional em que esta tem lugar. Em particular serão analisadas aqui as relações a ocidente, incluindo os Estados Unidos da América (EUA) e a União Europeia (UE), e na sua dimensão oriental, a China. Sem pretender desenvolver uma análise exaustiva, o capítulo procura ilustrar a evolução da política externa russa, nas suas linhas de continuidade e mudança e nos vários palcos em que esta se desenvolve. 


\section{Transição do modelo soviético: a experiência democrática}

A Rússia dos czares e a União Soviética representam séculos de governação centralizada onde as linhas definidoras de democracia, num entendimento amplo do conceito, incluindo não só a participação popular em atos eleitorais, mas também questões de representatividade, direitos e liberdades individuais, nunca estiveram presentes. Deste modo, o final da União Soviética gerou um breve período onde na transição para um novo desenho político, o processo de democratização foi equacionado mas nunca verdadeiramente implementado, com a política de abertura iniciada por Mikhail Gorbachov rapidamente a dar lugar a tendências de centralização e controlo, pouco após Boris Ieltsin assumir a presidência. Vários factores contribuíram para este desenvolvimento, incluindo a falta de experiência democrática e a instabilidade que as medidas a serem implementadas acabaram por gerar. De facto, as reformas promovidas tiveram um impacto muito claro na vivência quotidiana das populações, que se viram privadas de um conjunto de bens anteriormente assegurados pelo Estado, como por exemplo transportes públicos ou eletricidade gratuita. No contexto de transição capitalista estes pressupostos são suprimidos em favor de princípios de iniciativa privada, numa sociedade que não os reconhecia. Daí o surgimento de uma nova classe social - os oligarcas -, como analisado adiante, que reflete um número restrito de pessoas que passam a deter bens fundamentais anteriormente propriedade do Estado, em processos de privatização pouco transparentes.

A adicionar à parca clareza das dinâmicas em curso, a organização de processos eleitorais ditos democráticos é também ela exterior à realidade vivida ao longo de várias décadas. Os processos democráticos implicam não só mudanças profundas de procedimentos e mentalidades, como também tempo para que a sua solidez se possa concretizar e manifestar no quotidiano político e socioeconómico. Neste quadro, e dadas as dificuldades associadas ao processo de transição na Rússia, que se acabou por revelar uma transição incompleta, é uma interpretação minimalista de democracia, centrada na realização de eleições (independentemente da qualidade dos processos eleitorais) a que perdura até aos dias de 
hoje. Uma transição que está por acabar, e que se tem materializado num modelo de governação com traços autoritários e de centralização de poder, a par de uma política de abertura ao exterior e modernização interna - factores que não são facilmente conciliáveis.

A política externa russa tem evoluído de acordo com ajustes internos resultantes do próprio processo de transição, e com o contexto internacional em que se tem desenvolvido. É aqui assumido que as dinâmicas de política externa não podem ser dissociadas da componente funcional interna ao Estado, onde os processos de formulação, decisão e implementação de políticas têm lugar, associados a variáveis concretas em termos de objetivos e meios para a sua prossecução. Vários autores têm avançado com tipologias caracterizadoras da evolução da política externa russa, que ajudam o leitor a situar dinâmicas e atores. Neste trabalho seguiremos a proposta de Richard Sakwa (2012), que propõe quatro fases na análise da evolução da política externa russa: internacionalismo liberal, competitividade pragmática, novo realismo e neo-revisionismo. Segundo este autor, a primeira fase que se situa no período pós-independência onde se começam a desenhar objetivos contraditórios de integração em estruturas ocidentais, enquanto prosseguindo o estatuto de grande potência com uma vertente centralizadora clara, denomina-se de 'internacionalismo liberal'. Este período ficou marcado pela viragem e abertura a ocidente da política russa assente no discurso promovido por Gorbachov sobre a 'casa comum Europeia' e prosseguido por Ieltsin e o ministro dos negócios estrangeiros Andrei Kozyrev.

Nesta fase a Rússia reforça relações com as Comunidades Europeias, adere à Parceria para a Paz no âmbito da Organização do Tratado do Atlântico Norte (OTAN) e solicita a sua adesão ao Conselho da Europa. No entanto, os benefícios esperados do apoio ocidental e as políticas de condicionalidade associadas à pertença a estas instituições não correspondem às necessidades do processo de transição russo, especialmente em termos económicos, o que acaba por levar à formulação de críticas severas dentro do sistema, especialmente dos grupos mais conservadores. A resposta a esta surge na adoção de uma visão mais estratégica em termos de uma atuação mais ativa na vizinhança próxima, que havia 
sido de algum modo descurada no processo em curso, em detrimento da política de aproximação ao ocidente.

No entanto, a alteração no discurso não foi suficiente para evitar uma alteração neste alinhamento pró-ocidental. Apesar da relevância que a Comunidade de Estados Independentes (CEI) assume na agenda de política externa, o desequilíbrio associado à dimensão ocidental necessitava de ser corrigido. A pressão para a mudança de orientação da política externa russa vai resultar no início de uma nova fase, identificada como de 'competitividade pragmática' e associada à chegada ao Ministério dos Negócios Estrangeiros de Evgeny Primakov, em janeiro de 1996. Com uma visão mais crítica do ocidente, embora assumindo uma postura de cooperação, adiciona à política externa russa a necessidade de desenvolvimento de relações com a China, a Índia e o Médio Oriente. Desta forma, Primakov pretendia maior equilíbrio na política externa russa, o que lhe permitia maior margem de manobra em termos negociais nestas várias dimensões de atuação. Além do mais, este reajuste possibilitava reafirmar uma questão que foi desde o início do processo de transição fundamental para as políticas da Federação Russa - uma ordem internacional multipolar. Primakov assume uma política pragmática, mas também competitiva, no sentido em que se define em 'competição' com o ocidente, não num sentido tradicional militar de Guerra Fria, mas em termos do reconhecimento do estatuto da Federação Russa como ator privilegiado no sistema internacional. Igor Ivanov, a partir de 1999 na pasta dos Negócios Estrangeiros, dá continuidade ao pragmatismo do seu antecessor, mantendo na sua essência os alinhamentos da política externa russa.

O ano 2000 constitui um ano de viragem, após a retirada anunciada de Ieltsin e a chegada ao poder de Vladimir Putin. Eleito presidente da Rússia na primavera desse ano, Putin incute um 'novo realismo' à política externa russa, que o ministro dos negócios estrangeiros Igor Ivanov acompanha. Este traduz-se na combinação de uma visão tradicional realista de interesse nacional e de prossecução do mesmo no sistema internacional, com a procura de equilíbrios e vantagens competitivas para a Rússia, com particular ênfase para as estruturas ocidentais e as Nações Unidas. Este duplo processo de socialização e adaptação 
enquanto mantendo uma política externa independente procurava dar resposta às ambivalências que as anteriores políticas haviam produzido, especialmente visíveis na tensão permanente entre a escolha de uma aproximação ao ocidente que a ala europeísta defendia, de um maior diálogo a oriente promovido pelos orientalistas, ou de concentração no espaço vital, com base em pressupostos nacionalistas. Estas tensões não desapareceram, mas Putin através das suas políticas, assentes num pressuposto de multivetorialidade bem delineado, consegue introduzir uma maior coerência na política externa russa. É importante sublinhar que a política multivetorial não foi uma novidade introduzida por Putin, antes refletia a consolidação de um processo que havia sido iniciado ainda na presidência de Ieltsin, como analisado, e que se sintetiza na priorização geoestratégica no que são denominados vetores de política externa: a CEI como área de atuação prioritária, seguida dos vetores ocidental e oriental. Contudo, o contexto era então de grande instabilidade no espaço pós-soviético, e as contradições inerentes aos processos de desenvolvimento de 'parcerias estratégicas' com os EUA e a UE não permitiram que as contradições sugeridas por este posicionamento fossem facilmente ultrapassadas.

A adicionar às dinâmicas internas, o contexto internacional revelou-se difícil para o prosseguimento das políticas de reafirmação russas, com a guerra no Iraque em 2003 a constituir um elemento de tensão incontornável. A somar a outros desenvolvimentos entendidos como desfavoráveis às políticas russas, as relações a ocidente tornaram-se difíceis. O discurso de Putin na Conferência sobre Segurança de Munique em 2007 (Munich Security Conference, 2007) foi revelador do descontentamento que se desenvolveu face a decisões norte-americanas e também europeias entendidas na Rússia como contrárias aos seus interesses (por exemplo, o projeto de defesa antimíssil norte-americano ou a questão do Kosovo). Este novo período, denominado de 'neo-revisionismo' demonstra uma maior afirmação da Federação Russa no contexto internacional, ora como resultado do desenvolvimento económico e crescimento de que a Rússia beneficiou nesta década, em particular resultante da exploração de recursos energéticos, ora 
como forma de sinalizar os seus interesses e postura afirmativa no sistema internacional. ${ }^{3}$

Dmitri Medvedev mantém os alinhamentos fundamentais de Putin em matéria de política externa, combinando o crescimento que resulta do uso de recursos energéticos com um novo vetor de política externa assente no princípio de modernização, que visa várias vertentes desde investigação em áreas científicas de ponta até formação pessoal. Esta postura reflete o reconhecimento de que a política monosetorial, traduzida na dependência russa em termos económicos da exploração de recursos energéticos, e por isso também vulnerável a alterações de preços, necessita de ser revertida através do desenvolvimento de uma política de diversificação económica. Partindo do entendimento de que a política externa é condicionada por factores internos, um posicionamento doméstico sólido e de crescimento é essencial para sustentar uma política externa ativa e de reconhecimento do estatuto da Rússia no quadro internacional.

Os quatro anos da presidência de Medvedev (2008-2012) ficaram marcados pela tentativa de afirmação de políticas mais liberais não só na dimensão económica, mas também em termos de políticas sociais. Contudo, Medvedev nega publicamente essa intencionalidade e a sua caracterização como 'progressista' quando afirma que muitas vezes comentam "É um liberal. Ao que responde: Posso dizer francamente, nunca tive convicções liberais" (Barry, 2012). A sua postura política nos anos em que assumiu a presidência russa contribuiu decisivamente para o desfecho do seu primeiro mandato como colocando um ponto final na possibilidade de recandidatura. $\mathrm{O}$ anúncio antecipado da recandidatura de Vladimir Putin à presidência a 24 de setembro de 2011 demonstra claramente a necessidade sentida de reposicionamento de alinhamentos e de re-centralização de poder, face a fissuras cada vez mais evidentes no seio do Kremlin, especialmente entre as alas mais conservadoras e as alas mais liberais.

De facto, no plano externo, Medvedev conseguiu promover um desanuviamento nas relações, apesar da guerra na Geórgia já ter tido lugar sob a

\footnotetext{
3 Esta secção sobre a tipologia relativa à evolução da política externa é essencialmente informada pelo trabalho de Richard Sakwa (2012), como referenciado acima.
} 
sua presidência, mas sendo o culminar de um conjunto de desenvolvimentos entendidos na Rússia como adversos aos seus objetivos de política externa, em particular no espaço pós-soviético. O retomar de relações diplomáticas a nível multilateral e o reforço de relações bilaterais no contexto pós-Geórgia devem ser sublinhados, a par da postura de maior abertura do presidente que em grande medida contribuiu para este desanuviamento nas relações da Rússia com os seus parceiros ocidentais. Internamente, as políticas de modernização foram bem acolhidas, mas não tiveram tempo suficiente para germinar. Além do mais, permitiram maior mobilização social, o que ampliou o espaço para vozes de descontentamento e maiores reivindicações em termos de reformas políticas - um desenvolvimento que a elite no poder, especialmente centrada em Vladimir Putin, tinha que conter. O regresso de Putin à presidência russa na primavera de 2012 significa o retorno a políticas centralizadas, a contenção da voz popular, e o reforço do poder através do afastamento de elementos mais progressistas e liberais. O novo governo que se forma em resultado das legislativas de dezembro de 2011, liderado pelo anterior presidente Medvedev, visa prosseguir um curso de modernização, contudo, num ambiente pautado por linhas dirigistas e onde a autoridade centralizada é reconhecida como estrutura basilar de atuação e desenvolvimento de políticas.

As próximas secções ilustram esta evolução na política externa russa em diferentes dimensões desta, incluindo relações com a sua área de vizinhança, o ocidente (EUA e UE), e o oriente (China), demonstrando linhas de continuidade e mudança numa política que tem vindo a assumir-se, crescentemente, como assertiva num contexto internacional em mudança.

\section{A Federação Russa e a vizinhança próxima: uma assertividade crescente}

A desagregação da União Soviética implicou, como analisado, um redesenhar do espaço pós-soviético com o estabelecimento de vários novos Estados. A criação da Comunidade de Estados Independentes (CEI) em dezembro de 1991 procurou responder a um processo de desmantelamento de uma 
antiga unidade territorial, mantendo ligações fundamentais e procurando perpetuar unidade numa estrutura institucional que agregasse as novas repúblicas, à exceção dos Estados do Báltico (CIS, s.d.). A CEI, iniciativa conjunta da Rússia, Bielorrússia e Ucrânia tornou-se um instrumento central aos interesses russos na sua vizinhança próxima, entendida como referido como área privilegiada de atuação.

De facto, não é difícil perceber a relevância do espaço CEI na política externa russa. Primeiro, devido a um passado histórico partilhado e à localização geográfica desta área que lhe confere importância estratégica entre este e oeste. Segundo, dadas as ligações económicas e comerciais que uniam estes Estados no período soviético e que permanecem importantes nos dias de hoje, em particular relativamente a mercados e rotas de trânsito, com a energia a constituir um elemento central. Terceiro, devido a questões de segurança, com Moscovo a assumir um posicionamento de que instabilidade na sua área de vizinhança tem implicações diretas na sua segurança e estabilidade, bem como nesta área regional alargada (Freire, 2012b).

As relações da Federação Russa com o espaço CEI são desde o final da União Soviética matéria fundamental na agenda de Moscovo. Apesar de na fase inicial denominada de 'internacionalismo liberal' ser notória uma política de abertura e grande autonomização destes Estados face a Moscovo, as pressões domésticas face a desenvolvimentos entendidos como contrários aos interesses russos, como analisado na secção anterior, conduziram a uma alteração nas políticas para a área. Estas irão concentrar-se de forma clara no espaço CEI, assumindo mesmo um cariz de afirmação da influência que a Rússia pretende manter na área. No entanto, duas anotações são aqui importantes: primeiro, o espaço CEI não é um espaço homogéneo, e segundo, a Rússia não usufrui de poder ilimitado sobre estes Estados.

De facto, a heterogeneidade da CEI acentuou-se ao longo das últimas duas décadas, com a consolidação nestes Estados de orientações diferenciadas em termos políticos, económicos, sociais e de segurança. A evolução política face a Moscovo corresponde a opções de aproximação, distanciamento e de procura de equilíbrios, gerindo relações com outros atores na área de modo a contornar situações de grande dependência da Rússia. Exemplos concretos incluem a Arménia, país que 
mantém uma política de forte dependência de Moscovo a nível político, económico e militar; a Geórgia que reorientou a sua política a ocidente e incompatibilizou-se com Moscovo, como demonstrado na guerra do verão de 2008, analisada mais à frente; e o Azerbaijão que vai gerindo boas relações com Moscovo, mas mantendo uma postura de grande autonomia e independência, prosseguindo uma política multivetorial ancorada em opções diversificadas especialmente ao nível de relações políticas e económicas a oriente e ocidente.

Neste quadro diverso, tem sido visível a preocupação russa face a mudanças políticas nestas repúblicas procurando, por um lado, evitar desenvolvimentos contrários aos seus interesses, nomeadamente o estabelecimento de regimes de orientação pró-ocidental, como no caso da Geórgia, e a quebra de lealdades políticas e económicas fundamentais à manutenção da influência de Moscovo; e por outro, o controlo do envolvimento ativo de atores externos, em particular a UE, os EUA e a China, procurando minimizar a sua presença e influência sobre estes governos.

Relativamente ao primeiro ponto, as revoluções coloridas no espaço pós-soviético merecem especial destaque. A revolução das rosas na Geórgia (2003), a revolução laranja na Ucrânia (2004), e a revolução das túlipas no Quirguistão (2005), constituíram uma onda de mudança e contestação social e política que marcaram a política russa, espelhando o receio em Moscovo de perda de influência nestes espaços. A leitura feita dos acontecimentos sublinhava os apoios ocidentais como forma de minar a exclusividade russa neste espaço. Moscovo reiterou e caracterizou estes acontecimentos como "tentativas ocidentais de imposição de democracias em países da antiga União Soviética, com a prática de financiamento de ONGs na Rússia e em Estados vizinhos, e em usar informação como 'arma numa batalha competitiva global'" (Thorun, 2009, pp. 31-32). No entanto, os efeitos adversos destas contestações foram minimizados, à exceção do caso georgiano. De facto, o Quirguistão mantém um curso político claramente na órbita russa, tendência confirmada pela eleição de Almazbek Atambayev como presidente a 30 de outubro de 2011, e a Ucrânia assumiu um curso pró-russo após a eleição de Viktor Yanukovitch para a presidência do país em fevereiro de 2010. 
O caso da Geórgia é paradigmático do desenvolvimento de relações e do posicionamento russo no espaço CEI. A guerra na Geórgia no verão quente de 2008 corresponde a uma política de reafirmação russa na área pós-soviética. A violência nos cinco dias de confrontos armados revelou a força russa face a uma Geórgia fragilizada e sem apoios militares diretos ocidentais, em particular da Organização do Tratado do Atlântico Norte (OTAN). O não-envolvimento da Aliança Atlântica numa guerra com a Federação Russa era previsível, bem como uma rápida derrota do exército da Geórgia (muito menor em número e capacidade militar). A Federação Russa aproveitou o momento e face ao contexto mais alargado das relações russas com o ocidente, num quadro de grande instabilidade e dificuldades marcadas pelas discussões relativas ao alargamento da OTAN, ao projeto do escudo de defesa antimíssil e ao Tratado sobre Forças Convencionais na Europa, entre outros, marcou a sua posição. E fê-lo em relação ao ocidente, bem como à sua área de vizinhança, demonstrando que se necessário recorreria à força para garantir a sua posição de primazia no espaço pós-soviético. Em suma, Moscovo aproveitou a oportunidade para demarcar linhas de influência e interferência, enfraquecendo a Geórgia, sinalizando a sua política afirmativa no espaço CEI, reforçando a sua estratégia de contenção dos Estados Unidos na Eurásia, e sublinhando o reconhecimento de estatuto que tem prosseguido no sistema internacional.

Como analisado, a CEI assume desde cedo relevância no discurso da Federação Russa. Logo com Ieltsin, no documento de política externa de 1993 (Foreign Policy Concept, 1993) as referências ao "estrangeiro próximo" são evidenciadas. Na altura a área era mencionada como parte dos "interesses vitais" da Rússia, constituindo uma "prioridade máxima" e sendo de "importância fundamental". O reforço deste posicionamento é claro em 2000, quando a CEI é definida como "área prioritária” onde é dada primazia ao "desenvolvimento de boas relações de vizinhança e parceria(s) estratégica(s)" (Russian Foreign Policy Document, 2000) com os Estados CEI ('parceiros tradicionais' da Rússia. Num Estudo sobre Política Externa da Federação Russa conduzido pelo Ministério dos Negócios Estrangeiros (Survey of Russian Federation Foreign Policy, 2007) a CEI é referida como prioridade essencialmente devido a factores económicos e de segurança. 
O documento indica que a Rússia pretende vizinhos na sua periferia que sejam amigáveis, prossigam políticas de desenvolvimento, uma orientação democrática e premeiem a estabilidade. O Conceito de Política Externa de 2008 (Foreign Policy Concept, 2008) reitera o significado do espaço CEI, sublinha a relevância da cooperação dentro da CEI e especialmente no quadro da Organização do Tratado de Segurança Coletiva, definido como "um instrumento fundamental para a manutenção de estabilidade e segurança na área da CEI" que se deve tornar "uma instituição central para garantir segurança na sua área de responsabilidade”, em diversos âmbitos, desde a atividade comercial e a proteção de minorias, até à luta contra o terrorismo (ver também Medvedev, 2008b). O documento inclui ainda uma referência interessante às "parcerias e alianças estratégicas [que] são desenvolvidas com os Estados que demonstrarem vontade em fazê-1o" (Foreign Policy Concept, 2008), evidenciando o reconhecimento da crescente diversidade que a CEI representa.

As políticas de Putin e Medvedev para a CEI têm sido desenvolvidas numa linha de reafirmação da influência russa na área e do prosseguimento de reconhecimento do seu estatuto a nível internacional como grande potência. A diversidade existente neste espaço, em particular ao nível das riquezas energéticas e da capacidade de independência política face à Rússia, constitui um desafio e tem exigido políticas de reajustamento e de atração da parte da Federação Russa. É de realçar, que num quadro nem sempre favorável, como analisado, a Rússia tem recuperado influência e poder na sua vizinhança próxima, através da combinação de políticas mais interventivas a nível militar e económico, bem como da promoção de programas de cariz educativo ou cultural, que têm também desempenhado um importante papel na aproximação a alguns destes Estados (com especial relevância nesta dimensão para as relações da Rússia com as repúblicas da Ásia Central (Freire, 2009). A formulação dos sucessivos conceitos de política externa e a forma como estes consagram a CEI como área prioritária tem servido como guia de ação da Rússia para este espaço, não significando no entanto a definição de uma estratégia clara para a área. Esta indefinição é visível em políticas reativas, muitas vezes decorrentes da presença de atores 
externos e/ou do aumento de influência e autonomia dos países nesta área de importância vital.

O acordo relativo a uma área de comércio livre alcançado dia 19 de outubro de 2011, na Cimeira da CEI entre a Rússia, Ucrânia, Bielorrússia, Cazaquistão, Arménia, Quirguistão, Moldova, e Tajiquistão, visa facilitar as trocas comerciais reduzindo tarifas para um número alargado de produtos. Do acordo, que entrou em vigor em janeiro de 2012, apenas ficaram fora o Azerbaijão, o Uzbequistão e o Turquemenistão. Esta proposta liderada pela Rússia, a par do anúncio do primeiro ministro Putin em finais de 2011 do objetivo de estabelecimento de uma União Euroasiática, com integração política e económica na linha da experiência da União Europeia, demonstra a vontade da Rússia de incutir novo dinamismo no contexto da CEI. Em fevereiro de 2012, a criação da Comissão Económica Euroasiática constituiu um passo importante na consolidação deste projeto, que é esperado possa ser concretizado numa união económica em 2015.

A Rússia tem prosseguido uma política de renovação do quadro CEI enquanto fórum multilateral, e a concretização da área de comércio livre, a par da projeção da possibilidade de avançar para uma união económica, reforça a presença russa e o objetivo de integração desta área. Os desenvolvimentos no espaço CEI não têm sido completamente favoráveis às políticas russas, como o caso da Geórgia bem ilustra e que culminou na sua retirada da Comunidade, contudo, e apesar de não ter poder ilimitado na área, a Rússia tem procurado reforçar laços, não só através de iniciativas de cariz económico, como também do reforço de proximidade cultural, e em alguns casos, de maior cooperação no âmbito militar. Os exercícios miliares no âmbito da Organização do Tratado de Segurança Coletiva na Arménia em setembro de 2012 são reveladores do posicionamento que a Rússia pretende que lhe seja reconhecido, sublinhando que não será mera observadora da instabilidade que vem aumentando nas relações entre a Arménia e o Azerbaijão. Estas ações revelam uma estratégia que Moscovo tem promovido no sentido de agilizar a sua capacidade de ação no espaço pós-soviético, aumentando a sua margem de manobra face a políticas mais autónomas e independentes de muitos destes Estados, e minimizando o envolvimento e atuação de atores externos, como analisado em seguida. 


\section{As relações com os EUA e a UE no contexto da transição russa}

As relações da Federação Russa com o ocidente percorreram um caminho sinuoso desde o final da União Soviética aos nossos dias. O período do 'internacionalismo liberal' que marcou o início dos anos 1990 foi caracterizado por uma aproximação e abertura a ocidente, com a inclusão da Federação Russa em vários fóruns institucionais que se mantém ainda, embora com contornos diferenciados. Esta fase nas relações a ocidente é marcada pelo discurso da 'casa comum europeia' e da desconstrução da rivalidade bipolar que marcou toda a Guerra Fria. Numa lógica de desanuviamento, permitiu que o reajustamento internacional ao novo ordenamento se fizesse com base num espírito cooperativo. Contudo, condicionantes internas na Rússia, nomeadamente a pressão de grupos mais nacionalistas e comunistas, e externas, incluindo uma resposta ocidental de apoio aquém das expetativas, além de um alargamento da influência ocidental no espaço pós-soviético, conduziram a uma nova fase nas relações - a 'competitividade pragmática'.

A Federação Russa assume um posicionamento mais autónomo face ao ocidente e mais assertivo face ao espaço CEI, como analisado. A chegada de Evgeny Primakov ao Ministério dos Negócios Estrangeiros, o diplomata conhecido como o Eurasianista, traz novas linhas de orientação à política externa, onde um maior equilíbrio deve ser dado às relações a ocidente e a oriente. Ou seja, a política externa russa deve assumir-se como multivetorial, e deve gerir os benefícios que os equilíbrios resultantes desta postura permitem. Assim tem sido desde então, embora a gestão de princípios e pressupostos diferenciados implique dificuldades no ajustamento de políticas.

As relações com a União Europeia consolidaram-se com a assinatura do Acordo de Parceria e Cooperação (APC) em dezembro de 1997, por um período de dez anos, e que estabelecia as bases legais da relação. Amplo nos princípios que engloba, desde relações políticas, culturais, económicas e comerciais, assume como pressupostos de base o diálogo, a partilha de valores e princípios de cooperação. No entanto, é importante sublinhar que a Federação Russa e a UE são dois atores desiguais, em 
vários aspetos, mas especialmente nesta parceria pelo facto da primeira ser um Estado e a segunda uma organização internacional. Este aspeto é importante ao nível da negociação e implementação de acordos, que se tem revelado por vezes morosa e muitas vezes ineficaz.

Além do mais, a partilha de princípios e a base de diálogo firmadas têm enfrentado entendimentos diferenciados de 'democracia', 'respeito por direitos humanos', 'estado de direito', entre outros. As linhas definidoras da relação são, pela diversidade de entendimentos e pela diferenciação entre os atores, mais linhas orientadoras do que a base de uma parceria consolidada entre ambos. Revelador destas dificuldades é a não renovação do APC volvidos mais de dez anos após a sua assinatura, e num quadro internacional mudado. Apesar da sua renovação anual automática, como previsto na letra do texto, é muito relevante a incapacidade em renegociar um novo texto refundador da relação legal. Desde 2007 assim tem sido, e as conversações têm-se arrastado, sendo que a admissão da Rússia na Organização Mundial do Comércio, um desejo de longa data concretizado em dezembro de 2011, poderá significar novos avanços nesta matéria, oferecendo possibilidades de cooperação diferenciadas (De Gucht, 2012).

Em 2005 foi assinado o Acordo sobre os Quatro Espaços Comuns em São Petersburgo, consolidado em 2005 com a aprovação do roadmap para a sua implementação. E este tem sido o documento de referência no desenvolvimento das relações bilaterais, mantendo o carácter abrangente em termos de áreas de atuação (Espaço económico comum; Espaço comum de liberdade, segurança e justiça; Espaço comum de cooperação no âmbito da segurança externa; e Espaço comum de investigação, educação e cultura), e segue os pressupostos de diálogo e cooperação do acordo inicial. A parceria estratégica definida inclui como linha fundamental a estabilização e desenvolvimento da área de vizinhança partilhada. Esta é objeto de leituras diferentes na Rússia e na UE. Como analisado, para a Rússia assume uma importância vital sendo considerada área primária de atuação da sua política externa; para a UE representa um vasto mercado e grande potencialidade em particular em matéria energética. 
O desenvolvimento da Política Europeia de Vizinhança (PEV) ${ }^{4}$ resultado do alargamento da União de 2004, com enfoque mais especializado no espaço pós-soviético através da Parceria a Leste criada em maio de 2009 (que inclui os três países do Cáucaso do Sul, a Bielorrússia, a Moldova e a Ucrânia), é entendido por Moscovo como ingerência no seu espaço preferencial de atuação e tem gerado algum descontentamento, com implicações na relação bilateral. As acusações de Moscovo relativas ao apoio da UE às revoluções coloridas, constituem disso um exemplo. Demonstram ainda como o conceito de "vizinhança partilhada" é um conceito que sugere divergências e com o qual a Rússia se sente desconfortável face a um espaço que entende como de influência vital para os seus interesses e objetivos de política externa.

É interessante notar que apesar das relações Rússia-UE serem genericamente mais estáveis do que as relações Rússia-EUA, as primeiras refletem muitas vezes os desentendimentos nas segundas. A tensão nas relações em 2007 e 2008 resultante das políticas de alargamento da Aliança Atlântica, do projeto dos EUA de escudo de defesa anti-míssil, e do que era entendido em Moscovo como ingerência alargada no espaço pós-soviético, entre outros, implicaram diretamente a UE. E, claramente, um dos momentos mais difíceis na relação bilateral prendeu-se com a Guerra na Geórgia em agosto de 2008. Pouco antes, em junho de 2008 na Cimeira UE-Rússia de Kanti-Mansiisk haviam sido finalmente lançadas oficialmente as negociações para um novo acordo APC, que são imediatamente suspensas face aos acontecimentos na Geórgia. No entanto, cedo é retomado o diálogo após a mediação da UE, e em novembro na Cimeira de Nice é confirmado o retorno às negociações para um novo acordo, ainda não alcançado. Uma demonstração de que ambos reconhecem a relevância da parceria e do diálogo num contexto de grande interdependência. No entanto, o novo quadro 'neo-revisionista' russo traça um novo mapeamento para estas relações, exigindo maior paridade no âmbito da denominada parceria estratégica.

\footnotetext{
${ }^{4}$ Os países PEV incluem na sua dimensão sul a Argélia, Egito, Israel, Jordânia, Líbano, Líbia, Autoridade Palestiniana, Síria, e Tunísia; e na dimensão leste a Arménia, Azerbaijão, Bielorrússia, Geórgia, Moldova, Marrocos, e Ucrânia.
} 
O regresso de Vladimir Putin à presidência tem aqui implicações claras pelas medidas centralizadoras e mais restritivas em termos de atuação nas políticas interna e externa. O retrocesso nos princípios de mobilização social, de limitação de diálogo, de intolerância face a visões distintas, visível por exemplo no cerco à oposição e no encerramento de missões políticas estrangeiras na Rússia, veio marcar o novo cenário político no país. Catherine Ashton, a Alta Representante da UE para os Negócios Estrangeiros e a Política de Segurança deixou já clara a preocupação em Bruxelas por estes desenvolvimentos que claramente implicam um passo atrás nas políticas de abertura de Medvedev e que fazem regressar às agendas políticas discursos críticos e de preocupação face a uma Rússia assumidamente revisionista (Ashton, 2012a e 2012b).

No que concerne as relações com os EUA estas seguem maior sinuosidade. Do apoio imediato e solidariedade russa na altura dos ataques terroristas de 11 de setembro de 2001 nos Estados Unidos até às acusações de criação de linhas divisórias e de procura de hegemonia perniciosa no sistema internacional, na Conferência sobre Segurança de Munique em 2007 (Munich Security Conference, 2007), as relações bilaterais têm sido objeto de cooperação e rivalidade, sublinhando o 'novo realismo' que caracterizou a presidência de Vladimir Putin, e o período de 'neo-revisionismo' que se inicia nesta altura com uma postura mais assertiva da Rússia.

Os temas de desacordo entre os Estados Unidos e a Rússia, nesta leitura alargada de uma relação com contornos múltiplos, são vários e têm implicações muito concretas ao nível do diálogo e em termos de implementação de políticas. Sem pretender elaborar uma lista exaustiva, são de realçar: (i) a questão sempre difícil do alargamento da OTAN com uma aproximação às fronteiras russas (com o recuo norte-americano no seu apoio à aprovação dos Planos de Adesão da Ucrânia e Geórgia, na Cimeira de Bucareste da Aliança Atlântica, na primavera de 2008, entendido na Rússia como uma vitória diplomática); (ii) a retirada unilateral dos Estados Unidos do Tratado sobre Mísseis Anti-Balísticos (Tratado ABM), em 2001, apesar da assinatura de um novo Tratado em maio de 2002 relativo à redução de armas nucleares de longo alcance - o Tratado de Redução [de Armas] Ofensivas Estratégicas, mas de alcance bastante mais limitado; (iii) o 
projeto do presidente George W. Bush de desenvolvimento de um escudo de defesa antimíssil e de instalação de equipamentos relacionados com este em território europeu, nomeadamente na Polónia e República Checa; (iv) a postura norte-americana no Iraque, que levou a críticas duras da parte da Rússia; (v) o reconhecimento da independência do Kosovo fora do quadro do Conselho de Segurança das Nações Unidas; (vi) o envolvimento alargado no espaço pós-soviético, nomeadamente através de uma presença militar na Ásia Central consentida pela Rússia, mas que se prolongava no tempo, e o que foi considerado como apoio direto às revoluções coloridas na Geórgia, Ucrânia e mais tarde Quirguistão, fomentando políticas anti-russas nestas repúblicas; e (vii) o posicionamento diferenciado face à questão da violência prolongada na Síria. Estes são aspetos concretos da agenda de dissensão que contribuíram para uma deterioração gradual, mas clara, das relações entre os Estados Unidos e a Rússia.

A retirada unilateral russa do Tratado sobre Forças Convencionais na Europa (Tratado CFE), a não-renovação do Acordo de Parceria e Cooperação com a UE, o aprofundamento da cooperação no âmbito da Organização de Cooperação de Xangai, com especial relevância para a China (analisada na próxima secção), incluindo a realização de vários exercícios militares, e o discurso duro proferido por Putin em Munique em 2007, são demonstrativos do nível de tensão a que as relações foram votadas. Em Munique, o presidente russo afirmava que os Estados Unidos "ultrapassaram as suas fronteiras nacionais por todos os meios. Isto é visível nas políticas económicas, culturais e educativas que impõe a outras nações”, e adicionava ainda que a Rússia é um Estado diferente, disposto a interagir com "parceiros responsáveis e independentes com quem possa trabalhar conjuntamente na construção de uma ordem mundial justa e democrática que seja capaz de assegurar segurança e prosperidade não apenas de alguns selecionados, mas de todos". Neste período surgem mesmo um conjunto de publicações que cunham de 'uma nova Guerra Fria' a dificuldade de relacionamento bilateral, o que refletiu um exagero terminológico dado o carácter de interdependência e as bases de diálogo existentes entre as partes, mesmo no período mais difícil aquando dos confrontos armados na Geórgia. 
O pós-Geórgia constitui o momento de reajustamento concretizado na reset policy promovida pela administração norte-americana de Barack Obama, e que tomou forma a partir da primavera de 2009, numa declaração conjunta dos presidentes norte-americano e russo em Londres. Esta afirmava que estamos "prontos para avançar para além das mentalidades da Guerra Fria e esboçar um novo recomeço nas relações entre os dois países" (Joint Statement, 2009), princípio reforçado aquando da visita de Obama a Moscovo em julho de 2009, tendo em vista um discurso e uma prática mais moderada que anteriormente. A criação da Comissão Presidencial Bilateral Estados Unidos-Rússia, ${ }^{5}$ com 16 áreas de intervenção desde contra terrorismo e controlo de armamento até agricultura e cooperação espacial, sinaliza a nova postura.

Nesta linha de promoção de confiança, Sergei Ryabkov afirma que apesar dos temas de divergência não desaparecerem de forma mágica, há condições para "formar visões estratégicas comuns e abordagens táticas em várias áreas (...), contudo, encontrar soluções consensuais exige trabalho árduo bem como forte compromisso. Só é possível se confiarmos mutuamente e se todos cumprirmos as nossas obrigações" (Ryabkov, 2010, p. 208).

O objetivo é a construção de diálogo efetivo e o desenvolvimento de cooperação em áreas consideradas fundamentais, como no quadro da redução ou limitação de armamentos, não proliferação, e estabilização de áreas de interesse estratégico, nomeadamente o Afeganistão. Neste quadro, a ratificação do Tratado START, sobre redução de armas estratégicas, em janeiro de 2011 é exemplar. Em conjunto, Estados Unidos e Rússia detêm cerca de $90 \%$ do arsenal nuclear a nível mundial, pelo que a ratificação de um acordo que visa redução de arsenais, inspeções conjuntas e troca de informações numa lógica de transparência e consolidação de confiança, é um passo assumidamente positivo na consolidação da parceria estratégica.

Neste quadro de aproximação, a administração Obama redefiniu o projeto de defesa antimíssil propondo uma alternativa faseada e com envolvimento (ainda a clarificar) russo, ou seja, com contornos bem

\footnotetext{
5 Mais informação disponível em http://www.state.gov/p/eur/ci/rs/usrussiabilat/index.htm.
} 
diferenciados da proposta original. Contudo, persistem dificuldades e "é preciso novo software" na base deste relacionamento (Antonenko, 2009, p. 228), que terá que passar pela definição de uma linguagem comum e de ação também ela partilhada.

A questão síria que tem ensombrado o relacionamento bilateral merece ainda destaque. A campanha presidencial nos EUA, durante o ano de 2012 afiou, como usual, a retórica e o discurso político cada vez mais crítico de uma Rússia distante que não se rege pelos mesmos princípios ordenadores. Mas para além da retórica política, parece claro no seio das elites governativas nos Estados Unidos que o regresso de Vladimir Putin pôs termo a três anos em que claramente foram registados avanços no relacionamento bilateral. O caso da Síria e a postura de força russa no seu apoio à autoridade instituída tem contribuído claramente para o aumento de fricção, a par de outras medidas provocadoras, como por exemplo o encerramento das representações da USAID no país, resultante de uma nova lei publicada em julho de 2012 e que exige o registo de todas as organizações não governamentais financiadas externamente como agentes estrangeiros, à qual várias ONGs reagiram negativamente. Além do mais, as autoridades russas acusam a USAID de imiscuição em questões políticas sensíveis à segurança nacional, como o seu envolvimento com rebeldes islâmicos no Cáucaso do Norte, e de por isso mesmo, esta decisão de encerramento resultar do entendimento russo de que a ONG está a agir para lá dos contornos do seu mandato (RFE/RL, 2012). Dificuldades acrescidas e que no novo registo político de Putin na presidência parecem sublinhar o regresso de um clima gélido às relações bilaterais.

A participação russa na Cimeira da OTAN em novembro de $2010 \mathrm{em}$ Lisboa marcou de forma vincada a melhoria nas relações bilaterais, pela representação ao mais alto nível da Rússia na cimeira, na pessoa do presidente, e pelas conversações relativas aos princípios definidores da possível cooperação russa no projeto antimíssil, revelando uma abertura cuja sinalização foi muito positiva. Apesar de áreas de desentendimento, momentos de tensão, expetativas frustradas, a possibilidade de cooperação na diferença constituiu um novo registo na redefinição desta relação bilateral, que deve ser relembrado. O 'espírito de Lisboa' como foi cunhado informalmente por 
diplomatas russos sinalizava este mesmo entendimento, o de que a diferença não tem que ser um obstáculo inviabilizador de maior cooperação. Contudo, após este período de maior abertura, as relações entre ambos voltaram em inícios de 2012 a contrair, e medidas numa linha de dureza política, como o caso da expulsão da representação da USAID, apenas vêm adensar sombras que se vão formando em torno do relacionamento bilateral e que parecem apontar para a criação de dificuldades adicionais nos vários setores de cooperação bilateral, bem como no âmbito de quadros multilaterais onde se refletem este tipo de problemas, nomeadamente a Aliança Atlântica.

\section{Relações com a China: entre contenção e cooperação}

As relações da Federação Russa com a República Popular da China seguiram um curso diferenciado das relações com o ocidente. A 'competitividade pragmática' alternando cooperação e competição tem sido a linha marcante neste relacionamento bilateral. De qualquer modo, é importante notar que a leitura das relações Rússia-China não se deve fazer sem o enquadramento mais lato das relações da Rússia num quadro multivetorial. Aliás, algumas dinâmicas no quadro da Organização de Cooperação de Xangai são reflexo de procura de equilíbrios não só em relação à própria China, mas também em relação a outros atores, em particular os EUA. Contudo, deve ser notado que a evolução deste relacionamento bilateral ao longo dos últimos anos tem sido prosseguida em contraciclo face às relações a ocidente onde tem sido visível maior tensão. O regresso de Vladimir Putin à presidência russa, em maio de 2012 enquanto sugerindo dificuldades acrescidas no relacionamento com os EUA, como analisado, parece possibilitar o estreitar de cooperação com a China.

A base de pragmatismo nesta relação não esconde as diferenças existentes nos entendimentos de identidade no sistema internacional e de integração em projetos multilaterais. ${ }^{6}$ Por exemplo, a procura de

\footnotetext{
${ }^{6}$ O desenvolvimento de conteúdos desta secção é informado por trabalho desenvolvido anteriormente. Ver Freire e Mendes (2009).
} 
apoio da Rússia para o reconhecimento das independências da Abcázia e Ossétia do Sul no rescaldo da guerra na Geórgia em 2008, não encontrou sustentação. Na Cimeira de Dushanbe em agosto de 2008 a Rússia foi mesmo criticada pelos seus parceiros pelo facto de ter violado um pressuposto fundamental da organização, entendido como o não apoio a movimentos separatistas, abrindo um precedente que poderia ter consequências imprevistas em vários Estados desta região alargada. A Declaração Final acabou por conter apenas uma referência de preocupação face aos acontecimentos e de que "as partes relevantes devem resolver os problemas existentes de forma pacífica e através de diálogo, desenvolver esforços de reconciliação e facilitar negociações (Declaração de Dushanbe, 2008). Este exemplo ilustra a inexistência de solidariedade entre os membros em termos de princípios, bem como o facto de a Rússia não assumir um papel de primazia no seio da mesma, face à China. Como afirma Stephen Blank (2008), a parceria sino-russa não corresponde de forma alguma a uma aliança.

As relações entre a China e a Rússia foram reforçadas com a assinatura em julho de 2001 do Tratado de Boa Vizinhança e Cooperação Amigável (Treaty of Good-Neighborliness, 2001), que consolida a ideia de parceria estratégica, embora no seu conteúdo se revele um documento regulador, especialmente em matéria de venda de armamento, e questões energéticas com uma Rússia produtora e uma China consumidora. Assim, o documento revela-se limitado em termos da definição e operacionalização de uma relação estratégica entre estes dois atores. Os acontecimentos pós-11 de setembro e a postura dos EUA de maior assertividade contribuíram, no entanto, para uma aproximação entre a Rússia e a China, num quadro internacional entendido como desfavorável. A defesa da multipolaridade tem estado presente nos discursos russos e chineses (China Elections and Governance, 2007 e Putin, 2006), e o entendimento das políticas norte-americanas como afirmação de hegemonia choca diretamente com os interesses chineses e russos. Assim, esta tem sido essencialmente uma parceria estratégica construída pela negativa, ou seja, por oposição a uma posição de afirmação dos EUA (Freire e Mendes, 2009). Mesmo em termos de conteúdo a relação tem incidido essencialmente em temas económicos. 
A nível bilateral e com contornos regionais, a preocupação com minorias e separatismo, com os casos da Chechénia na Rússia e Xinjiang na China, por exemplo, e o aumento do radicalismo islâmico têm oferecido espaço de cooperação. O discurso do princípio da inviolabilidade da integridade territorial do Estado é, sem surpresa, partilhado. A par deste, a não ingerência em assuntos internos com particular enfoque em questões de direitos humanos e liberdades fundamentais é também sublinhada. A cooperação no combate ao terrorismo e criminalidade organizada faz também parte da agenda. Em termos militares, a realização de vários exercícios conjuntos de natureza bilateral e no contexto da Organização de Cooperação de Xangai reforça a dimensão securitária desta relação. Por exemplo, a Peace Mission 2005 foi o primeiro exercício bilateral conjunto envolvendo forças aéreas, terrestres e marítimas. No quadro da Organização de Cooperação de Xangai, o primeiro exercício militar teve lugar em 2003, e vários outros lhe têm sucedido. O não direcionamento destas ações contra qualquer país terceiro tem sido reforçado, sendo estas ações justificadas com base no aumento da segurança da vasta área da Ásia Pacífico, e deste modo numa lógica de cooperação intra-organizacional e não de contenção de terceiros.

Apesar da forte dimensão económica implícita nesta relação não há uma integração económica densa entre a China e a Rússia. Os índices de integração comercial, por exemplo, são baixos, de acordo com dados estatísticos oficiais de ambos os países. ${ }^{7}$ Em termos de comércio de armamento tem havido uma política de retraimento de Moscovo acautelando o poder emergente da China e uma eventual paridade a este nível.

7 Ver, por exemplo, Federal State Statistics Service, Russian Federation: "Foreign Trade of the Russian Federation with Far Abroad Countries", http://www.gks.ru/free_doc/2007/ b07_12/25-05.htm; "Distribution of Export and Import of the Russian Federation by some Foreign Countries",

http://www.gks.ru/free_doc/2006/rus06e/25-07.htm. Ministry of Commerce of the People's Republic of China: "Imports and Exports between China and European Countries (2007/1-5)", Table 1, Department of European Affairs, 12 June 2007,

http://english.mofcom.gov.cn/aarticle/statistic/chinaeuropeancountry/200707/20070704880231. html; "Imports and Exports between China and European Countries (2007/1-5)", Table 2,

Department of European Affairs, 12 June 2007,

http://english.mofcom.gov.cn/aarticle/statistic/chinaeuropeancountry/200707/20070704880390. html. Ver ainda Freire e Mendes, 2009. 
Questões de migração e problemas fronteiriços têm estado na agenda, e apesar dos acordos que têm sido negociados estes foram problemas que colocaram pressão na relação.

Assim, a relação sino-russa apresenta contornos pragmáticos de dupla contenção (entre os dois principais parceiros no quadro da Organização de Xangai, Rússia e China) e para com os EUA. Mas esta contenção não significa hostilidade para com os Estados Unidos. Da análise fica claro que as relações entre a Rússia e os EUA flutuam entre tensão e cooperação e o mesmo se passa em relação à China. A importância geopolítica dos EUA é reconhecida, bem como a relevância da manutenção de diálogo. As linhas de pragmatismo que têm sublinhado esta relação parecem manter-se, incorporando elementos de maior cooperação e factores de alguma tensão, mas numa lógica onde um espírito cooperativo tem prevalecido. E este tem-se traduzido em alguns avanços que merecem destaque, nomeadamente a resolução dos problemas fronteiriços, que constituía uma questão de grande delicadeza diplomática, e o redesenho dos contornos da relação na denominada parceria estratégica coordenada alargada, que visa o reconhecimento de posições conjuntas próximas face a grandes temas da atualidade internacional. Além do mais, a definição de objetivos de crescimento económico conjuntos, onde o aumento do comércio bilateral já se faz notar, a par de iniciativas culturais que procuram aproximar comunidades, demonstram os objetivos de coordenação que as lideranças russa e chinesa têm desenvolvido. Seja numa lógica positiva de cooperação ou numa lógica negativa de competição face a atores externos, ou ambas, está em curso a consolidação de relações de proximidade, que Putin pretende adensar (Xinhuanet, 2012).

\section{Conclusão}

A evolução da política externa russa desde o final da União Soviética aos nossos dias tem-se revelado um processo complexo com diversas variáveis. A inter-relação entre a transição a nível doméstico, como analisado, e a transição no sistema internacional, é evidente e marca o 
percurso seguido pela Federação Russa nos últimos vinte anos. De uma postura de 'internacionalismo liberal' muito apoiada na aproximação ao ocidente, a política russa evoluiu para uma posição de 'competitividade pragmática' onde a multivetorialidade da sua política externa se assume com preponderância. Na prossecução dos seus objetivos de reafirmação no contexto internacional e de procura de reconhecimento de estatuto pelos seus pares como grande potência - num quadro lido como multipolar - a Rússia adota o 'novo realismo' com um discurso mais inflamado face ao que entende como políticas e práticas promovidas especialmente pelos parceiros ocidentais, como contrários aos seus interesses. Como ilustrado no texto, o 'neo-revisionismo' que resulta do quadro de tensão que culmina na guerra da Geórgia em 2008, mantém-se como alinhamento fundamental nos dias de hoje, e ao longo da presidência de Medvedev. Uma política que deverá ser mantida e prosseguida pela Rússia de Vladimir Putin nos próximos anos.

\section{Bibliografia}

ANTONENKO, Oksana - Mr. Obama goes to Moscow. Survival. Vol. 51, N. 5 (2009), p. 227-231.

ASHTON, Catherine (2012a) "Statement by EU High Representative Catherine Ashton in the European Parliament on the political use of justice in Russia", Strasbourg, 11 setembro, A 403/12. [Acedido a 14 de set. de 2012]. Disponível na Internet: http://www.consilium.europa.eu/uedocs/cms_Data/docs/pressdata/EN/foraff/132370. pdf.

ASHTON, Catherine (2012b) "Statement by High Representative Catherine Ashton on the wave of violent attacks against diplomatic missions", Brussels, 14 setembro, A 410/12. [Acedido a 14 de set. de 2012]. Disponível na Internet: http://www.consilium.europa. eu/uedocs/cms_Data/docs/pressdata/EN/foraff/132457.pdf.

BARRY, Ellen - Leaving the Presidency in Russia, Medvedev Fights for Relevance. The New York Times, 3 maio 2012. [Acedido a 4 de jun. de 2012]. Disponível na Internet: http:// www.nytimes.com/2012/05/04/world/europe/leaving-presidency-russias-medvedevfights-for-relevance.html?_r=0.

BLANK, Stephen - The Shanghai Cooperation Organization and the Georgian Crisis. China Brief. Vol. 8, N. ${ }^{\circ} 17$ (2008). [Acedido a 9 de jan. de 2012]. Disponível na Internet: http://www.jamestown.org/single/?no_cache=1\&tx_ttnews\%5Btt_news\%5D=5134.

China Elections and Governance - China, Russia sign joint communiqué, pledging to broaden strategic co-op. China Elections and Governance, 7 novembro 2007. [Acedido a 9 de jan. de 2012]. Disponível na Internet: http://en.chinaelections.org/newsinfo. asp? newsid=12598. 
CIS (s.d.) Commonwealth of Independent States official webpage. [Acedido a 9 de jan. de 2012]. Disponível na Internet: http://www.cisstat.com/eng/cis.htm.

Constitution of the Russian Federation (1993) The Constitution of the Russian Federation, Adopted at the December 12, 1993 referendum. [Acedido a 9 de jun. de 2012]. Disponível na Internet: http://www.mid.ru/ns-osndoc.nsf/1e5f0de28fe 77 fdcc32575d900298676/ d0bd6a5ba542c949c32575dd004009ee?OpenDocument.

DE GUCHT, Karel - Karel De Gucht European Commissioner for Trade Seizing the Opportunity: EU-Russia Relations beyond the WTO Seminar on EU-Russia Trade and Economic Relations, Helsinki, Finland 7 September 2012. SPEECH/12/590, 7 setembro. [Acedido a 14 de set. de 2012]. Disponível na Internet: http://europa.eu/rapid/pressReleasesAction. do? reference $=$ SPEECH/12/590\& format $=$ HTML\&aged $=0 \&$ language $=E N \&$ guiLanguage $=e n$.

Declaração de Dushanbe - Dushanbe Declaration of Heads of SCO Member States. Agosto 2008. [Acedido a 9 de jan. de 2012]. Disponível na Internet: http://en.sco2009.ru/ docs/documents/index.html.

Foreign Policy Concept (1993) Russian Federation. Janeiro.

Foreign Policy Concept (2000) Russian Federation. Approved by the President of the Russian Federation V. Putin, 28 junho. [Acedido a 2 de mar. de 2011]. Disponível na Internet: http://www.fas.org/nuke/guide/russia/doctrine/econcept.htm.

Foreign Policy Concept (2008) Russian Federation. Approved by Dmitry A. Medvedev, President of the Russian Federation, 12 julho. [Acedido a 30 de mar. de 2011]. Disponível na Internet: http://www.mid.ru/ns-osndoc.nsf/1e5f0de28fe 77 fdcc32575d900298676/8 69c9d2b87ad8014c32575d9002b1c38?OpenDocument.

Foreign Policy Concept (2013) Russian Federation. Approved by President of the Russian Federation V. Putin, 12 fevereiro. [Acedido a 10 de jan. de 2013]. Disponível na Internet: http://www.mid.ru/brp_4.nsf/0/76389FEC168189ED44257B2E0039B16D.

FREIRE, Maria Raquel - Russia's Energy Policies in Eurasia: Empowerment or Entrapment?. In Kanet, Roger E. e Freire, Maria Raquel (org.), Russia and Its Near Neighbours: Identity, Interests and Foreign Policy. Basingstoke: Palgrave Macmillan, 2012.

FREIRE, Maria Raquel - Russian Foreign Policy towards its Neighbourhood: A Complex Mosaic of Relations. In Kanet, Roger E. e Freire, Maria Raquel (org.), Competing for Influence: The EU and Russia in Post-Soviet Eurasia. Dordrecht: Republic of Letters Publishing, 2012.

FREIRE, Maria Raquel - USSR/Russian Federation Major Power Status Inconsistencies. In Volgy, Thomas; Corbetta, Renato; Grant, Keith e Baird, Ryan (org.), Major Powers and the Quest for Status in International Politics: Global and Regional Perspectives. Basingstoke: Palgrave Macmillan, 2011.

FREIRE, Maria Raquel - Russian Politics toward Central Asia: Supporting, Balancing, Coercing or Imposing?. Asian Perspective. Vol. 33, N. ${ }^{\circ} 2$ (2009), p. 125-149.

FREIRE, Maria Raquel e MENDES, Carmen Amado - Realpolitik Dynamics and Image Construction in the Russia-China Relationship: Forging a Strategic Partnership?. Journal of Current Chinese Affairs. N. ${ }^{\circ} 2$ (2009), p. 27-52.

Joint Statement - Joint Statement by President Barack Obama and President Dmitry A. Medvedev of Russia. Administration of Barack H. Obama, Compilation of Presidential Documents, 1 abril 2009, DCPD Nr: DCPD200900208. [Acedido a 9 de jan. de 2012]. Disponível na Internet: http://www.gpo.gov/fdsys/pkg/DCPD-200900208/pdf/DCPD-200900208.pdf.

MEDVEDEV, Dmitry - Speech at the Meeting with Russian Ambassadors and Permanent Representatives to International Organisations. Statements on Major Issues, Russian Foreign Ministry, Moscovo, 15 julho 2008. [Acedido a 2 de mar. de 2011]. Disponível na Internet: : http://www.norway.mid.ru/old/news_fp/news_fp_81_eng.html. 
Munich Security Conference - Discurso do presidente da Federação Russa Vladimir Putin, 10 fevereiro 2007. [Acedido a 9 de jan. de 2012]. Disponível na Internet: http://www. securityconference.de/Putin-s-speech.381+M52087573ab0.0.html.

PUTIN, Vladimir - Written Interview given by President Vladimir Putin to Chinese News Agency Xinhua. Russian Presidency, 20 março 2006. [Acedido a 9 de jan. de 2012]. Disponível na Internet: http://www.kremlin.ru/eng/text/speeches/2006/03/20/1117_ type82916_103264.shtml.

RFE/RL - Russia Shut Downs USAID Activities. 19 setembro 2012. [Acedido a 19 de set. de 2012]. Disponível na Internet: http://www.rferl.org/content/moscow-shuts-downusaid-activities-in-russia/24712579.html.

RYABKOV, Sergei - An Interview with Sergey Ryabkov. Journal of International Affairs. Vol. 63, N. ${ }^{\circ} 2$ (2010), p. 207-216.

Survey of Russian Federation Foreign Policy - Ministry of Foreign Affairs of the Russian Federation, Department of Information and Press, 2007. [Acedido a 11 de mar. de 2011]. Disponível na Internet: http://www.mid.ru/brp_4.nsf/e78a48070f128a7b43256 999005bcbb3/89a30b3a6b65b4f2c32572d700292f74? OpenDocument.

THORUN, Christian - Explaining Change in Russian Foreign Policy: The Role of Ideas in Post-Soviet Russia's Conduct Towards the West. Basingstoke: Palgrave Macmillan, 2009.

Treaty of Good-Neighborliness - Treaty of Good-Neighborliness and Friendly Cooperation Between the People's Republic of China and the Russian Federation, 24 julho 2001. [Acedido a 9 de jan. de 2012]. Disponível na Internet: http://www.fmprc.gov.cn/eng/ wjdt/2649/t15771.htm.

Xinhuanet - Russia-China relations at 'unprecedented high': Russian FM, 3 junho 2012. [Acedido a 14 de jun. de 2012]. Disponível na Internet: http://news.xinhuanet.com/ english/china/2012-06/03/c_131628116.htm. 
(Página deixada propositadamente em branco) 
CAPÍTULO 2

\author{
AS RELAÇÕ ES DA RÚSSIA COMA UCRÂNiA, \\ B I LLORRÚSSIA E MOLDOVA: PODER, DEPENDENCIAS \\ E ASSIMETRIAS NO ESPAÇO PÓS-SOVIÉTICO
}

Vanda Amaro Dias

\title{
Introdução
}

O fim da Guerra Fria e o colapso da União Soviética tiveram amplas repercussões na cena internacional. Desde logo, estes fenómenos influenciaram a forma como a Federação Russa passaria a atuar e a projetar o seu poder nos planos regional e global. Após um breve período romântico que privilegiava a integração nas instituições ocidentais, a Rússia passou a conceber o espaço pós-soviético como zona de interesses privilegiados e condição sine qua non para a sua segurança e prosperidade. Para além disso, a manutenção deste espaço na esfera de influência de Moscovo é vista como um elemento chave na sua estratégia para recuperar o estatuto de grande potência e contestar o que critica como unilateralismo norte-americano.

Consequentemente, o Kremlin tem recorrido a mecanismos políticos, económicos e de segurança para manter os países da sua vizinhança na sua órbita de influência e garantir a harmonização com as opções de política externa russa. Nesta equação, a atual vizinhança partilhada com a União Europeia (UE) - Ucrânia, Bielorrússia e Moldova - assume uma posição estratégica de destaque. Barry Buzan e Ole Waever (2003, p. 416) defendem que é nesta sub-região do espaço pós-soviético 
que as dinâmicas políticas e securitárias são mais intensas, uma vez que esta constitui o último reduto entre a Rússia e o mundo ocidental e, em particular, a Organização do Tratado do Atlântico Norte (OTAN) percecionada por Moscovo como um projeto expansionista que visa disseminar o poderio norte-americano na sua zona de interesses privilegiados. ${ }^{8}$

O relacionamento da Rússia com cada um destes países tem um cariz assimétrico, uma vez que a interdependência que marcara as suas relações durante a União Soviética deu lugar, com o colapso desta, a uma forte dependência política e económica. Na persecução da sua visão regional, o Kremlin não se coíbe de utilizar as vulnerabilidades da sua periferia para satisfazer os seus interesses. No entanto, a Ucrânia, a Bielorrússia e a Moldova procuram escapar a uma total submissão perante os ditames de Moscovo, tentando contrabalançar o seu poder sempre que thes é possível. Para tal, recorrem às vantagens que advêm da sua posição geoestratégica entre a Rússia e o ocidente para obter mais valias no relacionamento com as autoridades russas e refrear as suas tentativas de dominar os destinos políticos e económicos da região.

São justamente estas dinâmicas complexas que emergem do relacionamento da Rússia com a vizinhança partilhada com a UE que nos propomos analisar. O objetivo será desvendar as dependências, assimetrias e relações de poder que daqui emanam e permitir um maior entendimento sobre as mesmas. Para tal abordaremos, numa primeira parte, a formulação de uma orientação de política externa na Federação Russa, após o colapso da União Soviética, e a construção do seu relacionamento com o espaço pós-soviético. As três secções seguintes analisam a relação da Rússia com a Ucrânia, a Bielorrússia e a Moldova, enfatizando as suas dimensões económica, política e de segurança e destacando a forma como Moscovo explora as dependências destes países para manter um padrão de relacionamento assimétrico e afirmar o seu poder na região.

\footnotetext{
${ }^{8}$ As demais regiões do espaço pós-soviético identificadas pelos autores são o Cáucaso, Ásia Central e os Estados bálticos (Buzan e Waever, 2003, p. 397).
} 


\section{A política externa russa no pós-Guerra Fria e o relacionamento com o espaço pós-soviético}

Os acontecimentos que culminaram no desmembramento da União Soviética tiveram consideráveis implicações internacionais. Para lidar com os novos desafios com que se deparava, a Federação Russa foi confrontada com a necessidade de redefinir a sua estratégia de política externa. Numa primeira fase, esta passaria por uma aproximação às instituições internacionais, contempladas como uma oportunidade para promover a cooperação económica e política com as principais potências ocidentais (Lynch, 2002, p. 164). Contudo, este período 'romântico', acompanhado por uma política de não ingerência no espaço pós-soviético, seria rapidamente abandonado, perante a incapacidade da Rússia se projetar como um parceiro igual nos fóruns internacionais (Freire, 2009, p. 83), não se prolongando para além de 1993 (Donaldson e Nogee, 2005, p. 127).

Nesse mesmo ano, o documento relativo ao conceito de política externa consagrava um novo entendimento daquele que devia ser o papel da Rússia no mundo e, em particular, no espaço pós-soviético. Neste sentido, define a vizinhança próxima como área prioritária da agenda russa, representando um interesse vital para a sua segurança (Igumnova, 2011, p. 257). Os três grandes objetivos da política externa russa na região - manutenção da sua presença militar, proteção dos russos étnicos e obtenção de vantagens económicas - constituem os alicerces de uma atuação pragmática que privilegia a satisfação dos interesses políticos e económicos de Moscovo (Tsygankov, 2006a, p. 109). Esta estratégia seria reafirmada por documentos chave como os renovados Foreign Policy Concept(s) de 2008 e 2013 que comprometem Moscovo com a afirmação de um papel mais relevante na sua vizinhança e a contestação à hegemonia norte-americana. ${ }^{9}$

\footnotetext{
9 "The Foreign Policy Concept of the Russian Federation". Disponível em: http://archive. kremlin.ru/eng/text/docs/2008/07/204750.shtml. Consultado em 4 janeiro 2012. "Concept of the Foreign Policy of the Russian Federation - Approved by President of the Russian Federation V. Putin on 12 February 2013". Disponível em: http://www.mid.ru/bdomp/brp_4.nsf/ e78a48070f128a7b43256999005bcbb3/76389fec168189ed44257b2e0039b16d!OpenDocument. Consultado em 30 agosto 2013.
} 
Com a eleição de Vladimir Putin para a Presidência da Federação Russa em 2000, esta visão estratégica ganha uma nova dimensão e visibilidade. Numa lógica pragmática e beneficiando dos lucros provenientes do setor energético, Putin restaura o poder do Estado e desenha um modelo assertivo que passa a definir a atuação da Rússia no espaço pós-soviético. Este modelo, continuado pelo presidente Medvedev desde 2008 (Mankoff, 2009, p. 2), visa afirmar a excecionalidade da posição geoestratégica russa como condição sine qua non para a sua grandeza internacional, utilizando recursos económicos, políticos e militares na prossecução dos interesses regionais de Moscovo (Isakova, 2005, pp. 17-18). Como afirma Dmitri Trenin:

A política externa russa voltou a tornar-se assertiva. [...] Ela fala sobre o que a Rússia quer e não sobre quaisquer interesses abstratos da comunidade internacional ou da paz mundial. [...] Moscovo usa sanções económicas para reforçar a sua mensagem de "não se metam connosco" sempre que outras formas de persuasão não funcionam. (Trenin, 2007c, p. 198)

A guerra entre a Rússia e a Geórgia em agosto de 2008 veio reforçar este modelo de afirmação na vizinhança de Moscovo e a disponibilidade para usar todos os meios para assegurar que os países do espaço pós-soviético se mantêm na sua esfera de influência. Daqui resultou uma mensagem clara, não só para os países da região, mas para a comunidade internacional, refreando o alargamento das instituições euro-atlânticas para um espaço onde Moscovo tem interesses privilegiados. Neste sentido, a Rússia ganhou vantagens sobre a região ao conseguir que a adesão da Ucrânia e da Geórgia à OTAN fosse descartada pela administração norte-americana e que a UE, desgastada pela crise interna, visse diminuídas as probabilidades de prosseguir uma política coerente e pró-ativa na região (Larrabee, 2010).

Ao assumir em maio de 2012 a presidência da Federação Russa pela terceira vez, Vladimir Putin mostra uma tendência de continuidade da assertividade que caracteriza a política externa do país e do reforço da sua influência no espaço pós-soviético. A proposta de uma União Eurasiática, cuja definição permanece vaga mas que Putin considera que 
deve servir o propósito de unir a Federação Russa aos seus vizinhos numa comunidade de Estados capaz de se projetar como um dos grandes polos de poder mundial - a par dos EUA, UE e da China - é sintomática desta tendência de continuidade (Zagorski, 2012).

Assim, a Rússia tem visado aumentar a sua atratividade para estes países, seja pela exploração das suas dependências económicas, pela sua projeção como mercado preferencial para os seus produtos ou pelo acolhimento da sua força laboral no estrangeiro, cujas divisas alimentam a economia dos países de origem (Popescu e Wilson, 2009, p. 3). Da mesma forma, tem promovido a sua integração económica por meio de arranjos bi e multilaterais, que vão desde a ocupação de posições estratégicas nos principais setores económicos da região à tentativa de edificação de um Espaço Económico Comum entre a Rússia, a Bielorrússia, a Ucrânia e o Cazaquistão (Tsygankov, 2006a, pp. 147-148).

Neste panorama, a dimensão energética é incontornável, uma vez que a forte dependência da Moldova, Bielorrússia e Ucrânia dos recursos energéticos russos tem constituído uma vantagem política para o Kremlin, permitindo-lhe explorar esta vulnerabilidade em seu proveito (Denisov e Grivach, 2008, p. 96). Ainda que Moscovo evoque uma racionalidade económica para as querelas energéticas com o espaço pós-soviético, a sua coincidência com episódios políticos que contrariam os seus interesses, a diferenciação nos preços aplicados e a falta de transparência nas negociações (Makarychev, 2008, p. 54) sugerem que estas não podem ser reduzidas a uma dimensão comercial. Para além disso, o facto do presidente russo surgir, frequentemente, como principal interlocutor, oferecendo uma saída política aos países envolvidos, contribui para reforçar a imagem que a Gazprom (empresa detentora do monopólio da produção e transporte de gás natural) é um instrumento ao serviço do Kremlin (Trenin, 2007c, p. 205). O que aqui se evidencia é que o controlo do fornecimento energético confere uma enorme influência sobre estes países e, não obstante a sua dimensão económica, pode ser usado como arma política para os punir sempre que tomem medidas contrárias aos interesses russos. Todavia, e uma vez que não se trata de um processo unidirecional, a condição de países de trânsito energético constitui uma 
mais valia negocial para a vizinhança partilhada, permitindo-lhe contrabalançar o poder da Rússia e moderar a sua capacidade de condicionar os rumos políticos e económicos da região (Heinrich, 2006, p. 3). ${ }^{10}$

Paralelamente, Moscovo tem procurado combinar as vantagens decorrentes do legado soviético, como a proximidade histórica, linguística e cultural, com uma estratégia política pró-ativa que visa controlar o que sucede neste espaço (Igumnova, 2011, p. 266). Nesta lógica, tem promovido uma série de iniciativas regionais para preservar a sua influência na região, como a Comunidade de Estados Independentes ${ }^{11}$ (CEI) ou a Organização do Tratado de Segurança Coletiva ${ }^{12}$ (OTSC), entre outras. Da mesma forma, tem apoiado os partidos pró-russos na sua vizinhança, que se oponham à integração em instituições ocidentais como a OTAN e a UE, cujos alargamentos são percecionados por Moscovo como parte de um cerco estratégico que visa enfraquecer a sua posição internacional (Stent, 2007, p. 12). Como tal, a Rússia tem desenvolvido uma tradição de ingerência nos principais processos eleitorais do espaço pós-soviético, com predominância nos países da vizinhança partilhada e da Ásia Central, através do apoio político, económico e mediático a determinados candidatos ou da avaliação da legitimidade dos atos eleitorais, por meio da Organização de Monitorização de Eleições da CEI, promotora dos interesses russos na região (Tolstrup, 2009, pp. 932-933). Da mesma forma, apoia organizações não governamentais e outros movimentos cívicos, de modo a ampliar a sua influência regional (Popescu e Wilson, 2009, p. 29).

De não somenos importância nesta estratégia surge a forte presença militar que a Federação Russa mantém no espaço pós-soviético, refletindo a perceção de que este território constitui uma área sensível para a sua

${ }^{10}$ As tarifas de trânsito energético e a suspensão do trânsito de gás russo para o mercado europeu constituem os principais mecanismos que permitem a estes países ganhar vantagens negociais e influenciar as decisões do Kremlin (Gromadzki e Kononckuz, 2007, p. 22).

11 Organização criada em dezembro de 1991 que incluía originalmente a Rússia, a Ucrânia, a Bielorrússia, a Moldova, o Cazaquistão, o Quirguistão, o Uzbequistão, o Turquemenistão, o Tajiquistão, a Arménia e o Azerbaijão. Os seus objetivos prendiam-se, essencialmente, com a harmonização das políticas externas dos seus membros, e a criação de espaços militares e económicos comuns.

12 Organização subordinada à CEI, fundada em 2002 após a ratificação pelos presidentes da Arménia, Bielorrússia, Cazaquistão, Rússia, Quirguistão e Tajiquistão. 
segurança. Concomitantemente, Moscovo tem procurado reforçar a sua posição militar através de acordos bilaterais com os países da sua vizinhança, nos domínios defensivo e militar, que lhe permitiram estabelecer bases na Arménia, Azerbaijão, ${ }^{13}$ Bielorrússia, Geórgia (Abcázia e Ossétia do Sul), Cazaquistão, Quirguistão, Moldova (Transnístria), Tajiquistão e Ucrânia (Igumnova, 2011, pp. 258-259). Alegando a manutenção da segurança regional, as forças militares russas são promovidas como um mecanismo de peacekeeping cujo mote é a mediação e resolução de conflitos (Morozova, 2009, p. 671). Este poderio torna-se um importante instrumento persuasivo quando o Kremlin apoia movimentos separatistas nos territórios onde tem um considerável aparato militar, como sucede no caso da Moldova (Mankoff, 2009, p. 245). Na prática, a presença militar russa na região constituiu um limite à soberania dos seus Estados vizinhos, negando-lhes o completo controlo do seu território e limitando, indiretamente, as suas opções políticas (Trenin, 2011, p. 11).

Desta forma, vemos que o relacionamento da Rússia com o espaço pós-soviético esconde uma série de dinâmicas complexas que resultam da importância estratégica desta zona. Para manter a sua influência na região, Moscovo tem promovido um relacionamento assimétrico com a sua periferia, aproveitando o facto de muitos destes Estados serem politicamente fracos e economicamente dependentes, o que os torna vulneráveis às suas pressões políticas, económicas e militares. Combinadas, as estratégias que prossegue permitem-lhe aumentar a sua influência política no espaço pós-soviético, salvaguardando os seus interesses, ao mesmo tempo que dissuade a interferência de outros atores na região (Baev, 2007, p. 454). Confrontados com tal cenário, estes países procuram obter um padrão de relacionamento mais igualitário, fazendo uso da sua condição geoestratégica para ganhar alguma vantagem negocial perante Moscovo (Gromadzki e Kononczuk, 2007, p. 13). Seguidamente analisamos as dinâmicas que emergem neste palco de manobras geopolíticas singulares e complexas, em particular as

13 Após o fracasso das negociações entre Moscovo e Baku com respeito ao futuro da estação de radar de Gabala, as autoridades russas decidiram retirar as suas forças do terreno no final de 2012 . 
que caracterizam o relacionamento da Rússia com a Ucrânia, a Bielorrússia e a Moldova - a vizinhança partilhada com a UE.

\section{Relações Rússia-Ucrânia}

Dos três casos analisados, o relacionamento da Rússia com a Ucrânia é aquele que tem sofrido maiores oscilações, variando entre momentos

de aproximação e episódios de conflitualidade. Em parte, isso decorre do facto de Kiev constituir uma peça central na estratégia regional russa. Para além dos fortes laços históricos e culturais que tem com Moscovo (Donaldson e Nogee, 2005, pp. 180-81), a Ucrânia representa um vasto mercado, com muitas oportunidades de investimento, e constitui o principal país de trânsito de gás da Rússia para a Europa, com 80\% da quota de mercado (Closson, 2008, p. 97). Porém, se esta realidade aumenta a sua importância geoestratégica, também a torna mais vulnerável perante o Kremlin, que perceciona a sua aproximação às instituições ocidentais, como uma ameaça à sua segurança, pelo que a Rússia tem procurado manter o país na sua esfera de influência (Baek, 2009, p. 469).

Durante a década de 1990, as relações da Rússia com a Ucrânia foram marcadas por negociações turbulentas em torno de questões relativas às competências da CEI, o arsenal nuclear que permanecera em solo ucraniano e os termos a serem definidos para o transporte energético com destino ao mercado europeu (Trenin, 2007c, p. 199). Muito embora a resolução de alguns destes problemas tenha dado alguma estabilidade a este relacionamento, continuariam a existir pontos de tensão, como o controlo da frota russa estacionada na Crimeia ou a aproximação ucraniana às instituições ocidentais.

A primeira questão ficaria parcialmente resolvida em 1997, quando Kiev consentiu a permanência da frota russa na região, em troca do reconhecimento da Crimeia como parte integrante do seu território e do perdão de grande parte da sua dívida energética (Donaldson e Nogee, 2005, pp. 188-9). Porém, o cariz estratégico da base de Sebastopol levou a que o assunto fosse retomado em situações de maior tensão entre os dois países 
vizinhos. Nestes casos, Moscovo utilizava a elevada percentagem de russos na região (cerca de 60\%) para promover sentimentos anti-Ucrânia e, assim, exercer pressão política sobre o governo em Kiev, condicionando as suas opções políticas por temer retaliações que comprometam a sua estabilidade (Makarychev, 2009a, p. 63). Desta forma, Moscovo age como um ator que refreia a consolidação do Estado ucraniano e, através da projeção de um cenário de instabilidade latente, compromete a sua aproximação ao ocidente (Popescu e Wilson, 2009, p. 16).

Nesta fase, a estratégia de política externa de Kiev passava por um equilíbrio entre a Rússia e o ocidente procurando obter o melhor dos dois relacionamentos. Por um lado, procurava uma aproximação à UE e à OTAN, por forma a obter vantagens que lhe permitissem levar a cabo a sua transição política e económica com sucesso. Por outro lado, tentava não alienar o Kremlin, do qual dependia económica e energeticamente, mantendo contactos bilaterais e participando nas suas iniciativas regionais (Härtel, 2010, p. 2). Todavia, em 1999, o presidente Leonid Kuchma abandonou esta política de equilíbrio, para promover uma maior aproximação a Moscovo. Em troca de apoio político, cooperação militar e económica e a garantia de preços reduzidos pelo fornecimento de gás, a Rússia assegurava a manutenção de Kiev na sua órbita de influência (Dimitrova e Dragneva, 2009, p. 858).

Os acontecimentos que culminaram na revolução laranja, em 2004, implicaram um novo reajuste no relacionamento entre a Rússia e a Ucrânia. Para Moscovo, este episódio não foi percecionado como um produto interno da sociedade ucraniana, mas como uma ingerência dos poderes ocidentais que visavam estender a sua influência na região, ameaçando não só a integridade territorial russa ${ }^{14}$ como toda a sua estratégia de reafirmação enquanto grande potência (Mankoff, 2009, p. 250). Como tal, o apoio político, financeiro e mediático ao candidato pró-russo Viktor Yanukovitch, surge como uma reação para prevenir que a Ucrânia fosse

${ }^{14} \mathrm{O}$ Kremlin percecionou este movimento como uma ameaça à sua integridade territorial, por temer que os princípios liberais ocidentais penetrassem as suas instituições políticas e colocassem em causa a sobrevivência da liderança russa (Wilson, 2010, p. 21). 
absorvida pelas estruturas ocidentais (Wilson, 2010, p. 29). Porém, o Kremlin ignorou o poder da sociedade civil e a popularidade do candidato Viktor Yushchenko (Stent, 2008, p. 1100), que viria a ser eleito presidente, imprimindo uma orientação pró-europeia à política externa de Kiev (Härtel, 2010, p. 3).

Este redirecionamento político implicou que a crise energética de 2006, em torno do aumento de preços pelo fornecimento de gás, fosse interpretada como uma retaliação pelas opções políticas de Kiev (Gromadzki e Konunckuz, 2007, p. 22). Ainda que esta não constituísse a primeira querela energética entre a Rússia e a Ucrânia, foi aquela que teve maior dimensão e visibilidade internacional até à data, incorporando a estratégia pragmática e assertiva russa no espaço pós-soviético (Sherr, 2008, p. 7). Não obstante, a condição de país de trânsito permitiu à Ucrânia alguma vantagem negocial ao utilizar o aumento nas tarifas de trânsito energético para chegar a um compromisso com Moscovo (Tsygankov, 2006b, p. 1088).

A par desta aparente instrumentalização política do fornecimento de gás, Moscovo tem tentado aumentar a sua participação no setor energético ucraniano. Consciente da vulnerabilidade que daqui pode advir, o parlamento ucraniano tem procurado obstaculizar o processo de privatização do sistema de gás. Ainda assim, em virtude das negociações que se seguiram à crise de 2006, a Rússia conseguiu controlar a distribuição de gás no mercado doméstico ucraniano, o que lhe dá uma vantagem considerável nos planos económico e político, acentuando a dependência de Kiev e tornando a Ucrânia mais suscetível à sua influência (Gromadzki e Konunckuz, 2007, p. 28). Paralelamente, Moscovo tem aumentado a sua participação noutros setores da economia ucraniana, com destaque para as atividades financeiras (Popescu e Wilson, 2009, p. 33).

A tendência negativa que as relações entre a Rússia e a Ucrânia revelavam desde a revolução laranja, seria agravada pelo facto de Kiev deixar em aberto o futuro da frota russa estacionada na Crimeia numa altura em que se colocava a questão da renovação do contrato assinado em 1997. Aliada à recusa em apoiar a intervenção russa na Geórgia, em 2008, esta situação levou o presidente russo Dmitri Medvedev a acusar 
o seu homólogo ucraniano de seguir uma política externa anti-russa (Härtel, 2010, p. 2).

Adicionalmente, a realização da Cimeira UE-Ucrânia, em setembro de 2008, que consagra a intensificação da sua cooperação económica e energética (EU-Ukraine Summit, 2008), bem como a celebração, em dezembro, de uma parceria estratégica com os EUA $^{15}$, em domínios defensivos e securitários, que choca com a estratégia regional russa, agravaram as relações entre Kiev e Moscovo. O resultado foi a eclosão de uma nova crise energética em 2009, que girava em torno dos preços a serem cobrados pelo fornecimento de gás, a dívida da Ucrânia e as tarifas de trânsito energético aplicadas à Gazprom, constantes no diálogo energético entre os dois países (Malygina, 2010, p. 8).

Este relacionamento só se voltaria a estabilizar, em 2010, após a eleição do pró-russo Viktor Yanukovitch para a presidência ucraniana, que manifestara a vontade em prosseguir uma política externa mais pragmática e próxima de Moscovo (Härtel, 2010). A consagração, pelos acordos de Karkiv, de preços preferenciais na importação de gás, em troca de extensão da permanência da frota russa na Crimeia até 2042, e a extinção da comissão governamental que preparava a adesão da Ucrânia à OTAN ${ }^{16}$, confirmam um momento positivo neste relacionamento, para além de evidenciar a tendência para Moscovo premiar os regimes que lhe são favoráveis e punir os que se afastam da sua esfera de influência (Vahabov, 2010). Concomitantemente, este episódio parece comprovar que a política energética russa na sua vizinhança não obedece somente a uma lógica de mercado, passando antes por uma cuidada ponderação entre interesses económicos e políticos na sua zona vital de segurança.

Ainda que em termos gerais as relações entre a Rússia e a Ucrânia tenham melhorado durante a presidência de Yanukovitch ${ }^{17}$, seria novamente

15 "United States - Ukraine Charter on Strategic Partnership". Disponível em: http:// merln.ndu.edu/archivepdf/EUR/State/113366.pdf. Consultado em: 7 janeiro 2012.

${ }^{16}$ Esta medida foi acompanhada da retirada da adesão à OTAN como um dos objetivos estratégicos da agenda política e de segurança de Kiev (Weir, 2010).

17 Em julho de 2012, na primeira visita oficial de Putin à Ucrânia após as eleições presidenciais russas, os dois países assinaram a Declaração da Parceria Estratégica entre a Rússia e a Ucrânia que prevê o aprofundamento da cooperação entre as partes e estabelece os pontos prioritários desta cooperação. 
uma questão energética a estar no cerne de mais uma desestabilização nas relações entre os dois países. O objeto desta contenda gira em torno da revisão dos preços de gás estabelecidos pelos acordos de 2009 assinados pelo primeiro ministro russo Vladimir Putin e a sua homóloga ucraniana Yulia Timoshenko. Porém, a Rússia recusa-se a rever o contrato a menos que a Ucrânia ceda à Gazprom o controlo do seu sistema de trânsito energético ou integre uma União Aduaneira liderada por Moscovo (RFE/ RL, 2012a). Kiev considera ambas as hipóteses difíceis de aceitar, por um lado, porque reconhece o cariz estratégico dos gasodutos que atravessam o seu território e a fonte de riqueza que representam para as oligarquias do país; por outro lado, há muito que negoceia um acordo de livre comércio com a UE que seria colocado em causa pela sua participação numa União Aduaneira com a Rússia, para além de considerar que daí resultaria uma concessão de prerrogativas comerciais e económicas a Moscovo que se traduziriam numa perda de controlo político sobre o país. A tensão em torno desta questão agravou-se quando, após a detenção da ex-primeiro ministro Yulia Timoshenko e a sua condenação a sete anos de prisão por abuso de poder na negociação dos acordos do gás de 2009, Kiev considerou estes mesmos acordos ilegais e ameaçou levar a Gazprom ao Instituto de Arbitragem da Câmara de Comércio de Estocolmo (Shumylo-Tapiola, 2012), num julgamento que Moscovo vê como sendo parcial, anti russo e politicamente motivado (RiaNovosti, 2012). Uma vez que a Ucrânia não está disposta a fazer as concessões almejadas pela Rússia, e que esta não se mostra favorável a rever os acordos em questão na ausência destas mesmas concessões, é previsível que a tensão entre os dois países se arraste durante algum tempo.

Desta forma vemos que as relações Rússia-Ucrânia têm oscilado entre momentos de cooperação e conflitualidade. Se a posição estratégica de Kiev lhe permite alternar a sua estratégia de política externa entre os vetores europeu e russo, a sua vulnerabilidade política, militar e económica constitui uma vantagem a favor do Kremlin que consegue preservar um relacionamento assimétrico. O intuito é manter a Ucrânia na sua esfera de influência e impedir a sua integração nas estruturas ocidentais. Como veremos, ainda que em dimensões diferentes, esta é uma tónica constante 
no relacionamento com o espaço pós-soviético, em particular nos casos da Bielorrússia e Moldova que analisamos em seguida.

\section{Relações Rússia-Bielorrússia}

A Bielorrússia é frequentemente percecionada como sendo o Estado politicamente mais próximo da Federação Russa. Isso sucede porque a eleição presidencial de Aleksandr Lukashenko, em 1994, não só comprometeu o país com um regime autoritário, como implicou uma política externa que fazia depender a segurança de Minsk de uma relação simbiótica com Moscovo (Donaldson e Nogee, 2005, p. 218).

Para o Kremlin, a Bielorrússia tem uma importância geoestratégica incontornável, representando um escudo de proteção que separa a Rússia do ocidente, para além de permitir o acesso ao enclave de Kaliningrado. Da mesma forma, ocupa uma posição favorável à defesa aérea russa, o que tem levado Moscovo a favorecer a integração dos seus sistemas de defesa (Buzan e Waever, 2003, p. 416). A cooperação no seio da União entre a Rússia e a Bielorrússia, estabelecida em 1997, realça a primordialidade das questões militares e defensivas neste relacionamento. Ainda que, nos seus termos iniciais, esta União privilegiasse a integração política, económica e militar entre Moscovo e Minsk, a verdade é que apenas a cooperação nos domínios da defesa e segurança tem conseguido passar do plano virtual (Deyermond, 2004, p. 1191). O resultado desta integração é visível na criação de estruturas de defesa comuns e na presença de forças russas em solo bielorrusso, que corroboram a importância estratégica do país para a defesa de Moscovo (Martinsen, 2002, p. 404).

Consequentemente, Minsk tornou-se defensiva e militarmente dependente de Moscovo, o que representa um constrangimento à sua soberania, para além de constituir uma ameaça latente no caso de um afastamento da esfera de influência russa (Tolstrup, 2009, p. 935). No entanto, este processo sempre teve a conivência de Lukashenko, que aproveitou a sua posição estratégica entre a Rússia e o ocidente para obter benefícios económicos, que têm permitido a sobrevivência do seu regime (Oldberg, 1997, p. 114). 
Contudo, se a integração no plano militar e defensivo tem sido bem sucedida, a cooperação no plano económico tem-se revelado mais complicada. Apesar de a Rússia ter assinado com a Bielorrússia, a Ucrânia e o Cazaquistão, em 2003, um acordo para a criação de um Espaço Económico Comum, a falta de avanços concretos na integração económica tem levado Minsk a mostrar-se descrente face ao potencial deste projeto (Allison et al., 2005, p. 496). Com efeito, ele constitui mais um instrumento geopolítico que, através de mecanismos económicos, visa cimentar a influência de Moscovo no espaço pós-soviético (Sushko, 2004, p. 128). Não obstante, a integração neste fórum tem permitido a Minsk beneficiar da conclusão de uma série de acordos políticos, da abertura do mercado russo aos seus produtos e de preços vantajosos pelo abastecimento energético (Leshchenko, 2008, p. 1427).

Apesar destas mais valias, a dependência energética de Minsk e a forte politização do setor energético constituem uma clara vulnerabilidade, pelo que qualquer distúrbio na relação com Moscovo pode acarretar graves consequências económicas e políticas (Gromadzki e Kononckuk, 2004, pp. 14-15). Consciente desta situação, o Kremlin tem usado o aumento dos preços da energia fornecida à Bielorrússia, numa lógica política, punindo-a por opções contrárias aos seus interesses. Quando tal sucede, Lukashenko utiliza a sua condição de país de trânsito energético para negociar com a Rússia e diminuir a influência desta (Heinrich, 2006, p. 3). Numa estratégia paralela, o líder bielorrusso tem tentado uma aproximação ao ocidente, e sobretudo à $\mathrm{UE}^{18}$, sempre que as relações com Moscovo se deterioram, salientando a sua importância geoestratégica e procurando obter vantagens negociais (Allison et al., 2005, pp. 490-492).

Em 2004, inicia-se um período de desentendimentos crescentes que haveriam de marcar o relacionamento de Lukashenko com as autoridades russas e que se repercutiram na eclosão de crises energéticas, que giravam em torno do preço a ser cobrado pelo fornecimento do gás à Bielorrússia e do controlo do gasoduto de Yamal, por onde passa $15 \%$ do gás que a

18 Mais recentemente verifica-se uma tendência de aproximação a outros atores ocidentais, com destaque para os EUA. Para uma leitura da evolução das relações entre Minsk e Washington ver Ioffe (2011). 
Rússia exporta para a Europa (Bruce, 2005, pp. 2-4). Usadas com intuito político, estas querelas evidenciam que o Kremlin está a retirar o seu apoio a Lukashenko. Desde então, o presidente bielorrusso tem procurado estreitar as suas relações com a UE como saída política para as crises com Moscovo (Jarábik e Rabagliati, 2010, p. 3). Em troca da assistência técnica e financeira necessária para superar os constrangimentos impostos pela Rússia em momentos de maior tensão, Minsk tem feito algumas cedências políticas a Bruxelas. Desta forma, demonstra que a Bielorrússia não está regionalmente isolada, o que dada a sua importância geoestratégica lhe permite ganhar alguma manobra negocial com Moscovo (Rotman e Veremeeva, 2011, pp. 80-83).

Em dezembro de 2006, na sequência de mais uma crise energética, Moscovo aumenta a influência sobre Minsk ao consolidar a sua participação no setor energético, através da aquisição, pela Gazprom, de 50\% da Beltransgaz, em troca de um período de transição nos preços de gás aplicados à Bielorrússia, que deviam atingir o preço de mercado em 2011 (Gromadzki e Konunckuk, 2007, p. 24). Uma vez que a economia bielorrussa se encontra dependente dos lucros do setor energético, esta situação implicou o agravar das condições internas e o descontentamento generalizado da população, que começa a contestar o poder autoritário de Lukashenko (Lindner, 2007, pp. 56-60).

Apesar da fragilidade política e económica, o presidente bielorrusso continuou a tomar uma série de medidas que têm hostilizado Moscovo, nomeadamente: a ameaça em cobrar compensações financeiras pela presença de bases militares no seu território; a recusa em integrar uma União Aduaneira juntamente com a Rússia e o Cazaquistão; o não reconhecimento da independência da Abcázia e da Ossétia do Sul; e o boicote à cimeira da OTSC, em 2008 (Padhol e Marples, 2011, pp. 4-7). A adoção de um discurso que apresenta a Rússia como uma ameaça para a integridade do país (Lindner, 2007, pp. 65-6), bem como a paulatina aproximação à UE e a sua participação na iniciativa Eastern Partnership ${ }^{19}$, desde maio de 2009 (Tumanov et al., 2011, pp. 130-31), acabou por deteriorar a já fragilizada relação.

19 A Parceria Oriental é uma iniciativa da UE, lançada em 2009, para fortalecer a dimensão leste no âmbito da Política Europeia de Vizinhança (Arménia, Azerbaijão, Bielorrússia, 
O resultado foi o embargo aos laticínios bielorrussos declarado por Moscovo em 2009, e uma nova crise energética em 2010 (Shapovalova e Zarembo, 2010, p. 2), que permitiram aumentar mais uma vez a participação russa no setor energético bielorrusso (Yafimava, 2010). Paralelamente, Moscovo tem apoiado movimentos da oposição em Minsk e promovido campanhas para expor a opressão e a violação dos direitos humanos perpetrados pelo regime, com o objetivo de fragilizar a posição política de Lukashenko (Frear, 2010).

Porém, a situação alterou-se após uma reunião, a 9 de dezembro de 2010, entre Dmitri Medvedev e o presidente bielorrusso, em que ambos anunciaram a abolição de taxas aduaneiras pelo petróleo importado por Minsk e a garantia de não haver um aumento dos preços do gás em 2011. Em troca, Lukashenko acordou integrar o Espaço Económico Comum com a Rússia, que entraria em vigor em janeiro de $2012 .{ }^{20}$ Mais uma vez Moscovo oferecia uma saída política que beneficiava os seus interesses regionais, ao mesmo tempo que garantia a Lukashenko a sua vitória eleitoral (Padhol e Marples, 2011, p. 7).

No entanto, o facto de as autoridades russas afirmarem que vão continuar a renegociar os preços energéticos com Minsk, ao mesmo tempo que reconhecem a sua posição estratégica e a sua indispensabilidade para a segurança da Federação Russa (Makarychev, 2008, p. 55), sugere que o problema neste relacionamento reside na sua elite política. ${ }^{21} \mathrm{O}$ apoio aos movimentos de oposição nas eleições presidenciais de 2010 demonstra

Geórgia, Moldova e Ucrânia) e garantir a segurança no continente europeu (Conselho da União Europeia, 2009). Moscovo encara esta iniciativa como um ato hostil que reforça a posição europeia no espaço pós-soviético e coloca em risco os seus interesses regionais. Por esse motivo, tem procurado explorar as suas fragilidades, ao mesmo tempo que promove modelos de integração regionais alternativos, como a CEI, a OTSC ou o Espaço Económico Comum (Popescu e Wilson, 2009).

20 O Espaço Económico Comum constitui um passo na direção de uma União Económica Eurasiática, garantindo a liberdade de circulação de bens, serviços, capitais e pessoas entre a Rússia, a Bielorrússia e o Cazaquistão, ao mesmo tempo que cria a Comissão Económica Eurasiática, o órgão de direção supranacional deste processo de integração (Cameron e Orenstein, 2012, pp. 30-31).

${ }^{21}$ Com efeito, o Kremlin continua a reconhecer a importância estratégica do país com o presidente Vladimir Putin a declarar que uma União entre a Rússia e a Bielorrússia num futuro próximo não só é possível como desejável (Voice of America, 2012). 
que Lukashenko não é indispensável para manter o país na esfera de influência russa (Lindner, 2007, p. 64). Por outro lado, Lukashenko tem visto a sua dependência face à Rússia aumentar em prol da grave situação financeira que o país enfrenta e que o forçou a aceitar um plano de resgate de 140 mil milhões de dólares em troca de importantes prerrogativas económicas, energéticas e políticas, fragilizando a sua posição perante a opinião pública da Bielorrússia e as oligarquias que beneficiam dos lucros provenientes do setor do gás (Raskolnikova, 2012). Ainda que a sua posição geoestratégica lhe tenha permitido ganhar algumas vantagens negociais com Moscovo, o presidente bielorrusso encontra-se politicamente fragilizado (Leshchenko, 2008, p. 1429). Desta forma, o futuro do seu regime permanece incerto, dependendo da sua capacidade de negociar com a Rússia e, nos vários momentos, contribuir para a satisfação dos seus interesses na região.

\section{Relações Rússia-Moldova}

Apesar da dimensão relativamente reduzida, quando comparada com a Ucrânia ou com a Bielorrússia, a Moldova ocupa um lugar de destaque na ótica geopolítica de Moscovo que a considera como parte integrante da sua esfera de influência. Neste sentido, a estratégia russa tem passado pela manutenção da neutralidade de Chisinau e, consequentemente, a prevenção da sua integração em instituições como a UE ou a OTAN (Makarychev, 2010, pp. 3-4).

A questão da Transnistria constitui um dos elementos mais importantes neste relacionamento. Após o colapso da União Soviética, o debate em torno da independência da Moldova e potencial reunificação com a Roménia, levou a comunidade na margem esquerda do rio Dniestre a reclamar estes territórios, desencadeando uma série de confrontos violentos. A intervenção do $14^{\circ}$ exército soviético estacionado na Moldova, a favor da Transnistria, evidenciou a Rússia como uma terceira parte no conflito e não como uma força apaziguadora (Donaldson e Nogee, 2005, pp. 214-15). Desde o cessar-fogo acordado em 1992 entre Chisinau e Moscovo, 
a Rússia manteve-se no terreno através de uma força de peacekeeping composta por contingentes russos, transnistrianos e moldavos, que coloca Chisinau numa desvantagem de 2 para 1 (Sanchez, 2009, p. 164).

Trata-se de um exemplo paradigmático de intervenção russa na sua vizinhança próxima para controlar este território e mantê-lo na sua esfera de influência (Tudoroiu, 2011, p. 239). Apesar de a Moldova ter protestado sucessivas vezes contra a presença de militares russos no seu território, a Rússia não só se mantém no terreno como joga um papel fulcral no conflito, apoiando política, militar e economicamente a liderança em Tiraspol (Boonstra 2007, pp. 3-4). Simultaneamente, nas negociações ao mais alto nível, Moscovo obstaculiza qualquer solução para o conflito, favorecendo a sua manutenção como cenário que melhor satisfaz os seus interesses regionais, uma vez que a preservação de um regime separatista próximo de Moscovo constitui um meio para assegurar a permanência de Chisinau na sua zona vital de segurança (Buzan e Waever, 2003, p. 418).

Desta forma, a Rússia contribui para que a Moldova se mantenha um Estado frágil, incapaz de aplicar a autoridade à totalidade do seu território, refreando as suas tentativas de integração com o ocidente, que permanece reticente em importar um conflito onde a Rússia se mantém como parte ativa (Tudoroiu, 2011, p. 139). Por outro lado, esta estratégia constitui uma forma do Kremlin exercer influência no sistema político moldavo e manter Chisinau na sua esfera de influência (Tolstrup, 2009, p. 936).

Durante a década de 1990, a Moldova tentou manter relações amistosas com a Rússia, ao mesmo tempo que tentava escapar ao seu monopólio económico e energético. A sua forte dependência externa, agravada pelo conflito na Transnistria, era vista como uma fragilidade que jogava a favor de Moscovo. Ainda assim, Chisinau tentou atenuar o poderio russo ao cooperar apenas de forma limitada em instituições como a CEI (King, 2003, pp. 75-6). Da mesma forma, tentou contrabalançar o poder da Rússia e a sua influência regional através do estreitar de relações com a UE, que se estabelecem em 1994 através do Acordo de Parceria e Cooperação, ainda que o mesmo só tenha entrado em vigor em 1998 (Korosteleva, 2010, pp. 1268-69; Partnership and Cooperation Agreement, 1998). 
Apesar do presidente Vladimir Voronin ter sido eleito, em fevereiro de 2001, numa plataforma que visava a aproximação a Moscovo, não tardou a que ele abandonasse este rumo pró-russo em prol de uma maior aproximação às instituições ocidentais. Com efeito, a integração com a UE surgia como principal eixo da política externa moldava, tendo sido definitivamente consagrada pela European Strategy of the Republic of Moldova, em 2003. Tal revela uma visão pragmática em que Chisinau procura obter vantagens económicas e políticas no relacionamento com outros parceiros (International Crisis Group, 2007, p. 78) para superar a fragilidade que advém da sua forte dependência de Moscovo. ${ }^{22}$

Por forma a evitar que Chisinau se afaste da sua esfera de influência, o Kremlin tem recorrido aos mecanismos económicos, políticos e militares de que dispõe para explorar as suas vulnerabilidades. Para além da sua presença militar na Transnístria, que constitui uma incontornável fonte de pressão e condicionamento político, a Rússia utiliza a sua posição económica para influenciar o país. É neste sentido que podemos compreender os embargos aos produtos agrícolas moldavos em 2006, que se seguiram a períodos de tensão entre Moscovo e Chisinau (Tolstrup, 2009, p. 938), bem como a crise energética que teve lugar durante o inverno de 2005-2006, como resposta ao fracasso do Memorandum Kozak, promovido unilateralmente pela Rússia como solução para o conflito da Transnístria. Proposta em 2003, esta tentativa de resolução implicava uma federalização assimétrica da Moldova, onde Tiraspol teria poder de veto em todas as questões políticas. Na prática, o objetivo era impedir a integração do país nas estruturas internacionais, ao mesmo tempo que favorecia a sua manutenção na órbita de influência russa, levando Chisinau a recusar um compromisso (Berg, 2006, p. 232).

22 Ainda que esta estratégia seja relativamente bem-sucedida, permitindo a integração de Chisinau em instituições como a Organização Mundial do Comércio (OMC) ou a Parceria para a Paz (OTAN), bem como uma aproximação à UE que lhe permite usufruir de vários programas de assistência técnica e financeira, a fragilidade económica do país e a forte presença (militar, política e económica) da Rússia no seu território permanecem sérias vulnerabilidades (Boonstra, 2011, pp. 1-5). 
Neste contexto, a Federação Russa contempla com desagrado o crescente envolvimento da UE no país, sobretudo no que concerne à resolução do conflito da Transnístria e ao estabelecimento da European Union Border Assistance Mission (EUBAM), que opera na região desde 2005, a pedido das autoridades moldavas. ${ }^{23}$ Perante este cenário, a Rússia tenderá a manter a sua presença militar e tem poucos incentivos para deixar de promover a manutenção do status quo na região, uma vez que essa missão da UE facilitará a integração da Moldova nas instituições europeias, implicando o afastamento da sua órbita de influência (Stent, 2007, p. 15).

Contudo, após a guerra entre a Rússia e a Geórgia, encarada como um exemplo do caminho que os vizinhos russos não deviam seguir, os líderes moldavos têm mostrado uma maior disponibilidade para aceitarem a mediação russa, por oposição a um período de clara aproximação ao ocidente. O considerável aparato militar russo presente em solo moldavo e o receio de que Moscovo possa reconhecer a independência da Transnístria como forma de penalizar o regime de Chisinau pelas suas opções de política externa, à semelhança do que sucedeu com a Geórgia, encontram-se no cerne desta aproximação a Moscovo (Dyomkin, 2008). É neste sentido que se devem entender as declarações favoráveis à resolução do conflito da Transnístria proferidas pelo presidente Medvedev, em 2008, e uma nova proposta de resolução do conflito avançada em julho de 2012, que passava por uma (con)federalização da Moldova onde a Transnístria tivesse poder de veto em matéria de política externa e todos os assuntos ligados à presença e legitimidade das forças militares russas na região (Rettman, 2011). Este momentum foi reforçado pela eleição de Yevgeny Shevchuk para líder do governo da região da Transnístria, que admitiu promover a livre circulação de pessoas e bens entre Chisinau e Tiraspol, aproximando as duas margens do rio Dniester e contribuindo para a resolução do conflito (Barry, 2012a).

Todavia, factores como a morte de um civil moldavo por um militar russo, declarações russas que indicam um respeito cada vez menor pela

23 EU Border Assistance Mission to Moldova and Ukraine. Disponível em: www.eubam. org. Consultado em: 29 março 2012. 
integridade territorial do país e a nomeação de Dmitry Rogozin como enviado especial para a Transnístria ${ }^{24}$ (à semelhança do que sucedeu na Abcázia e na Ossétia do Sul, duas regiões que a Rússia reconhece como independentes) vieram quebrar este padrão ${ }^{25}$ e contribuíram para um escalar de tensões entre Chisinau e Moscovo, colocando em causa qualquer solução viável para o conflito (Socor, 2012). Estes episódios, apesar de não mudarem drasticamente a situação no terreno, forçaram a tomada de medidas mais intransigentes ou pelo menos um desacelerar do processo de resolução do conflito, numa altura em que surgia pela primeira vez em muitos anos uma janela de oportunidade para uma postura mais conciliatória entre as partes envolvidas.

A enorme dependência energética de Chisinau tem sido agravada pela crescente participação russa na sua economia. Com efeito, a incapacidade da Moldova pagar a sua divida energética a Moscovo, durante os anos 1990, permitiu à Rússia controlar virtualmente toda a rede de gás na Moldova e ganhar uma participação significativa no setor elétrico (Gromadzki e Konunckuz, 2007, p. 20). Adicionalmente, tem expandido o seu investimento no setor agrícola moldavo, promovendo a sua privatização (Fokina, 2005, pp. 81-2). Assim, a Rússia tem vindo a controlar os principais setores económicos da Moldova, aumentando a dependência desta e diminuindo a sua capacidade de negociação (Gromadzki e Konunckuz, 2007, p. 26). Por outro lado, nos últimos anos a Rússia tem procurado criar condições favoráveis ao crescimento das exportações moldavas para o seu território de modo a criar benefícios para as elites económicas de Chisinau, levando a uma maior aproximação das mesmas a Moscovo e, consequentemente, ao aumento da

${ }^{24}$ Apesar desta nomeação demonstrar que a Rússia continua a ter interesses estratégicos na Moldova, o facto de Dmitry Rogozin ser uma figura favorável ao reconhecimento da independência da região da Transnístria pode ser considerada uma forma de exercer pressão sobre Chisinau e levar a uma solução para o conflito favorável às pretensões russas, uma vez que Moscovo dispõe dos meios para reconhecer a independência de Tiraspol e contribuir para a rutura definitiva da República da Moldova, à semelhança do que sucedeu na Geórgia.

25 Como resultado Chisinau reforçou os seus apelos à comunidade internacional para diminuir a presença militar russa na região da Transnístria e substituir a atual força de peacekeeping por uma missão civil internacional que leve a cabo a tarefa de reaproximar a população de ambas as margens do rio Dniester, uma opção que Moscovo e a região da Transnístria se recusam a ponderar (Rodkiewicz, 2012). 
dependência (e vulnerabilidade) económica da Moldova (Rodkiewicz, 2012). Deste modo, Moscovo ganha uma enorme influência económica e política, ao mesmo tempo que reúne as condições para manter um relacionamento assimétrico, que joga a favor da satisfação dos seus interesses.

A influência da Federação Russa no país estende-se também aos atos eleitorais, onde se tem mostrado ativa desde o início da década de 1990. Consciente do poder de Moscovo, Voronin tem sabido jogar com a situação aproximando-se da Rússia, em detrimento da UE, na véspera de importantes momentos eleitorais. Com efeito, o presidente moldavo foi eleito, em 2001, numa plataforma pró-russa, da qual se afastou posteriormente em prol de um rapprochement ao ocidente. Não obstante, não hesitaria em trocar o vetor europeu pelo apoio russo durante as eleições locais de 2003 e nas eleições parlamentares de 2009 (Korosteleva, 2010, p. 1281), evidenciando uma abordagem pragmática por parte de Chisinau que visa a satisfação dos interesses nacionais e que Moscovo sabe explorar para manter o país na sua esfera de influência.

Os resultados das eleições de 2009, que implicaram a derrota do Partido Comunista da Moldova e a vitória da Aliança para a Integração Europeia, levou a Federação Russa a intensificar a sua retórica relativamente aos perigos da aproximação à UE e a mudar a sua estratégia para o país, intensificando os contactos e iniciativas com as elites pró-ocidentais de Chisinau e think tanks que apoiam a integração europeia (Makarychev, 2010 , pp. 1-4). O objetivo é aumentar a capacidade normativa da Rússia 26 e aliá-la às estratégicas políticas, económicas e militares que tem aplicado na região, para influenciar o rumo político da Moldova e, assim, melhor cumprir os objetivos de manter o país na sua esfera de influência (Haukkala, 2008, pp. 40-42) e preservar uma forte presença militar no terreno de modo a prevenir a sua integração nas estruturas euro-atlânticas.

26 A agenda normativa no seio da política externa russa é uma questão embrionária que se encontra associada a mecanismos de soft power que complementam uma abordagem regional mais musculada. Neste plano a Rússia tem a vantagem de oferecer benefícios políticos e económicos, sem o mecanismo de condicionalidade que está associado à UE. Todavia, o sucesso do projeto de integração europeia continua a ter uma enorme atratividade na região e constitui um desafio para a estratégia de Moscovo na vizinhança partilhada (Haukkala, 2008; Makarychev, 2009). 


\section{Conclusão}

O novo cenário regional e global do pós-Guerra Fria levaram a Federação Russa a redefinir a sua orientação de política externa. Após um breve período 'romântico' de aproximação ao ocidente, os seus principais objetivos vão prender-se com a recuperação do seu estatuto de grande potência. Nesta lógica, o relacionamento com o espaço pós-soviético assume uma dimensão preponderante. Defendendo esta zona como área de interesses privilegiados, Moscovo vai procurar explorar as dependências económicas, políticas e de segurança dos seus vizinhos para perpetuar um relacionamento assimétrico e assegurar o seu controlo na região, ao mesmo tempo que impede a ingerência de poderes externos na sua zona vital de segurança.

Se nos anos 1990 a situação política interna não permitiu à Federação Russa aplicar esta estratégia em toda sua potencialidade, a eleição de Vladimir Putin, em 2000, foi acompanhada de uma política pragmática e assertiva na região. Neste sentido, a máxima passa a ser a satisfação dos interesses económicos e políticos de Moscovo, que não se coíbe de usar os mecanismos económicos, políticos e de segurança ao seu dispor para reforçar as vulnerabilidades dos países na sua periferia, mantê-los na sua esfera de influência e, por esta via, assegurar a reafirmação da Rússia como grande potência.

As dinâmicas que resultam da tentativa do Kremlin de controlar o espaço pós-soviético são particularmente visíveis na atual vizinhança partilhada com a UE - Ucrânia, Bielorrússia e Moldova - um espaço de importância estratégica incontornável, uma vez que constitui o último reduto entre a Rússia e o ocidente. Ainda que cada um destes relacionamentos tenha um grau de intensidade e dinâmica variável, todos se baseiam numa lógica assimétrica que favorece Moscovo e dificulta a atuação de outros atores regionais neste espaço, nomeadamente da UE. Com efeito, as vulnerabilidades económicas, energéticas e políticas que cada um destes países revela, aliada a uma forte presença militar na região, dá à Federação Russa uma enorme capacidade de influenciar o rumo interno e as opções de política externa destes países, ainda que de forma diferenciada e ajustada à realidade de cada um destes relacionamentos. Nesta ótica, Moscovo favorece os governos que facilitam a satisfação dos 
seus interesses regionais, e pune aqueles que tomam posições contrárias às suas diretrizes.

Ainda que a preponderância da Rússia na região seja inquestionável, é interessante verificar como também os países da sua vizinhança adotaram uma posição pragmática que os leva a jogar com a sua posição geoestratégica entre a Rússia e o ocidente, para obter prerrogativas económicas e políticas, ao mesmo tempo que evitam uma total submissão aos ditames de Moscovo. Com efeito, todos utilizam a aproximação ao ocidente, ou pelo menos a ideia de integração nas suas organizações, quando as relações com Moscovo se deterioram, da mesma forma que todas jogam com uma aproximação ao Kremlin quando daí lhes possa advir alguma vantagem.

No entanto, esta não deve ser entendida como uma dinâmica linear, uma vez que depende das condicionantes políticas que a cada momento se encontram em cima da mesa. Não obstante, a condição geoestratégica destes países, que lhes permite seguir políticas multivetorais e estratégias pragmáticas, tem efeitos limitados. Enquanto a Rússia mantiver uma forte presença militar na região, os seus sistemas políticos permitirem a ingerência russa e se mantiver a sua forte dependência económica e energética, Moscovo vai sempre ter a hipótese de condicionar os seus rumos domésticos e externos. Ainda que a aproximação à (e da) UE possa efetivamente representar um desacelerar nestas tendências, permitindo-lhes contrabalançar o poder russo, esta região continuará, muito provavelmente, a ser palco de dinâmicas de poder complexas, que exploram dependências múltiplas para perpetuar relacionamentos assimétricos que privilegiam a prossecução e satisfação dos interesses de Moscovo.

\section{Bibliografia}

ALLISON, Roy, WHITE, Stephen e LIGHT, Margot - Belarus between East and West. Journal of Communist Studies and Transition Politics. Vol. 21, N. ${ }^{\circ} 4$ (2005), p. 487-511.

BAEK, Jun Kee - Medvedev's Russia, a 'revisionist power' or an 'architect of a new world order'? The evolution of ideational factors and its cases. Korean Journal of Defense Analysis. Vol. 21, N. ${ }^{\circ} 4$ (2009), p. 455-484. 
BAEV, Pavel K. - Russia Aspires to the Status of 'Energy Superpower'. Strategic Analysis. Vol. 31, N. ${ }^{\circ} 3$ (2007), p. 447-465.

BARRY, Ellen - Shooting at Checkpoint Raises Tensions in a Disputed Region Claimed by Moldova. The New York Times, 3 janeiro 2012. [Acedido a 12 de ago. de 2012]. Disponível na Internet: http://www.nytimes.com/2012/01/04/world/europe/shooting-raises-tensionsbetween-moldova-and-russia.html?_r=0

BERG, Eiki - Pooling Sovereignty, Losing Territoriality? Making Peace in Cyprus and Moldova, Tijdschrift voor Economische en Sociale Geografie. Vol. 97, N. 3 (2006), p. 222-236.

BOONSTRA, Igor - Moldova, Transdniestria and European Democracy Policies. FRIDE Comment, 2007. [Acedido a 8 de jan. de 2012]. Disponível na Internet: www.fride.org/ download/COM_Moldav_ENG_feb07.pdf.

BOONSTRA, Igor - Moldova: an EU success strory?. FRIDE Policy Brief. N. ${ }^{\circ}$ 92, 2011. [Acedido a 27 de mar. de 2012]. Disponível na Internet: http://fride.org/publication/940/moldova:an-eu-success-story.

BRIDGE, Robert - Russia, Ukraine hammer out historic strategic partnership. $R T, 13$ julho 2012. [Acedido a 12 de ago. de 2012]. Disponível na Internet: http://rt.com/politics/ russia-ukraine-agreement-putin-yanukovich-113/.

BRUCE, Chloe - Friction or Fiction? The gas factor in Russian-Belarusian relations. Chatham House Briefing Paper. REP BP 05/01 (2005) p. 1-14.

BUZAN, Barry e WAEVER, Ole - Regions and Powers: The Structure of International Security. Cambridge: Cambridge University Press, 2003.

CAMERON, David R.; ORENSTEIN, Mitchell A. - Post-Soviet Authoritarianism: The influence of Russia in its "Near Abroad". Post-Soviet Affairs. Vol. 28, N. ${ }^{\circ} 1$ (2012), p. 1-44.

CLOSSON, Stacy - Russia's key customer: Europe. In Perovic, Jeronim; Orttung, Robert e Wenger, Andreas, eds. Russian Energy Power and Foreign Relations: Implications for Conflict and Cooperation. London: Routledge, (2009), p. 89-108.

Conselho da União Europeia - Joint Declaration of the Prague Eastern Partnership Summit, Prague, 7 May 2009. 8435/09 (Presse 78).

DENISOV, Andrey e GRIVACH, Alexei - The gains and failures of the energy superpower. Russia in Global Affairs. Vol. 6, N. ${ }^{\circ} 2$, (2008), p. 96-108.

DEYERMOND, Ruth - The state of the union: military success, economic and political failure in the Russia-Belarus Union. Europe-Asia Studies. Vol. 56, N. ${ }^{\circ} 8$ (2004), p. 1191-1205.

DIMITROVA, Antoaneta e DRAGNEVA, Rilka - Constraining external governance: interdependence with Russia and the CIS as limits to the EU's rule transfer in the Ukraine. Journal of European Public Policy. Vol. 16, N. ${ }^{\circ} 6$ (2009), p. 853-872.

DONALDSON, Robert H. e NOGEE, Joseph L. - The Foreign Policy of Russia: changing systems, enduring interests. Armonk: M. E. Sharpe, 2005.

DYOMKIN, Denis - Russia warns Moldova against 'Georgian mistake'. Reuters, 25 agosto 2008. [Acedido a 12 de ago. de 2012]. Disponível na Internet: http://www.reuters.com/ article/2008/08/25/us-russia-moldova-transdniestria-idUSLP59197620080825.

EU-Ukraine Summit, Paris, 9 setembro 2008, Joint Press Release - [Acedido a 7 de jan. de 2012]. Disponível na Internet: http://www.consilium.europa.eu/uedocs/cms_data/docs/ pressdata/en/er/102633.pdf

European Strategy of the Republic of Moldova - updated version (2007), [Acedido a 29 de mar. de 2012]. Disponível na Internet: http://www.ipp.md/libview.php?l=en\&idc=167\&id=524.

FOKINA, L. V. - Economic Cooperation between Russian Regions and Moldova. Problems of Economic Transition. Vol. 47, N. ${ }^{\circ} 12$ (2005), p. 80-86. 
FREAR, Mathew - Friends or Foes? Developments in relations between Russia and Belarus. Russian Analytical Digest. No. 87 (2010), p. 2-4.

FREIRE, Maria Raquel - A Política Externa em Transição: o caso da Federação Russa. Relações Internacionais. N. ${ }^{\circ} 23$ (2009), p. 75-89.

GROMADZKI, Grzegorz e KONONCZUK, Wojciech - Energy Game: Ukraine, Moldova and Belarus between the EU and Russia. Warsaw: Batory Foundation, 2007.

HÄRTEL, André - Ukrainian-Russian gas relations after the 2009 conflict: the current situation and future prospects. Russian Analytical Digest. No. 75 (2010), p. 2-5.

HAUKKALA, Hiski - The Russian Challenge to EU Normative Power: The Case of European Neighbourhood Policy. The International Spectator. Vol. 43, N. 2 (2008), p. 35-47.

HEINRICH, Andreas - Gazprom: a reliable partner for Europe's Energy Supply? Russian Analytical Digest. No. 1 (2006), p. 2-7.

IGUMNOVA, Lyudmila - Russia's Strategic Culture between American and European Worldviews. The Journal of Slavic Military Studies. Vol. 24, N. ${ }^{\circ} 2$ (2011), p. 253-273.

International Crisis Group - Moldova's Uncertain Future. In Hamilton, Daniel e Mangott, Gerhard (eds.) The New Eastern Europe: Ukraine, Belarus and Moldova. Washington, DC: Center for Transatlantic Relations (2007), p. 77-124.

IOFFE, Grigory - Belarus and the West: From Estrangement to Honeymoon. Journal of Communist Studies and Transition Politics. Vol. 27, N. ${ }^{\circ}$ 2, (2011), p. 217-240.

ISAKOVA, Irina - Russian Governance in the Twenty-First Century. London: Frank Cass, 2005.

JARÁBIK, Balazs e RABAGLIATI, Alastair - Assessing Democracy Assistance: Belarus. FRIDE, 2010. [Acedido a 7 de jan. de 2012]. Disponível na Internet: www.fride.org/download/ IP_WMD_Belarus_ENG_jul10.pdf.

KING, Charles - Marking time in the middle ground: Contested identities and Moldovan foreign policy. Journal of Communist Studies and Transition Politics. Vol. 19, N. ${ }^{\circ} 3$, (2003), p. 60-82.

KOROSTELEVA, Elena - Moldova's European Choice: 'Between two stools'?. Europe-Asia Studies. Vol. 62, N. ${ }^{\circ} 8$ (2010), p. 1267-1289.

LARRABEE, F. Stephen - Rethinking Russia: Russia, Ukraine and Central Europe: The return of Geopolitics. Journal of International Affairs. Vol. 63, N. ${ }^{\circ} 2$ (2012), p. 33-52.

LESHCHENKO, Natalia - The National Ideology and the Basis of the Lukashenka Regime in Belarus. Europe-Asia Studies. Vol. 60, N. ${ }^{\circ} 8$ (2008), p. 1419-1433.

LINDNER, Rainer - Neighborhood in Flux: EU-Belarus-Russia. Prospects for the European Union's Belarus Policy. In Hamilton, Daniel e Mangott, Gerhard (eds.) The New Eastern Europe: Ukraine, Belarus and Moldova. Washington, DC: Center for Transatlantic Relations (2007), p. 55-76.

LYNCH, Allen C. - The Evolution of Russian Foreign Policy in the 1990s. Journal of Communist Studies and Transition Politics. Vol. 18, N. ${ }^{\circ}$ 1, (2002), p. 161-182.

MAKARYCHEV, Andrey S. - Russia's Search for International Identity through the Sovereign Democracy Concept. The International Spectator. Vol. 43, N. ${ }^{\circ} 2$, (2008), p. 49-62.

MAKARYCHEV, Andrey S. - A Rússia, a Europa e o legado de 1989: conflitos de interpretação. Relações Internacionais. N. ${ }^{\circ} 23$ (2009), p. 53-74.

MAKARYCHEV, Andrey S. - Russia's Moldova Policy: Soft Power at the Service of Realpolitik?. PONARS Eurasia Policy Memo, No. 94 (2010).

MALYGINA, Katerina - Ukrainian-Russian Gas Relations after the 2009 Conflict: The Current Situation and Future Prospects. Russian Analytical Digest. No. 75 (2010), p. 5-9. 
MANKOFF, Jeffrey - Russian Foreign Policy. The Return of Great Power Politics. Maryland: Rowman \& Littlefield Publishers, Inc., 2009.

MARTINSEN, Kaare Dahl - The Russian Takeover of Belarus. Comparative Strategy. Vol. 21, N. ${ }^{\circ} 5$ (2002), p. 401- 416.

MOROZOVA, Natalia - Geopolitics, Eurasianism and Russian Foreign Policy. Geopolitics. Vol. 14, N. $^{\circ} 4$ (2009), p. 667-686.

OLDBERG, Ingmar - Sunset over the swamp - the independence and dependence of Belarus. European Security. Vol. 6, N. ${ }^{\circ}$ 3, p(1997), p. 110-130.

PADHOL, Uladzimir e MARPLES, David R. - The 2010 Presidential Elections in Belarus. Problems of Post-Communism. Vol. 58, N. ${ }^{\circ} 1$ (2011), p. 3-16.

PCA - Partnership and Cooperation Agreement between the European Communities and their Member States and the Republic of Moldova (1998), JO L 181/3, 24.6.1998.

POPESCU, Nicu e WILSON, Andrew - The Limits of Enlargement-Lite: European and Russian Power in the Troubled Neighbourhood. London: European Council on Foreign Relations, 2009.

RASKOLNIKOVA, Ilona - Kazakhstan, Russia and Belarus to integrate joint air defense system. Pravda, 12 de julho 2012. [Acedido a 12 de ago. de 2012]. Disponível na Internet: http:// english.pravda.ru/world/ussr/12-07-2012/121633-kazakhstan_russia_belarus_missile_defense-0/.

RETTMAN, Andrew - "Russian decision boosts Moldova's EU entry prospects", EUobserver, 30 março 2011. [Acedido a 12 de ago. de 2012]. Disponível na Internet: http://euobserver. com/foreign/32095.

RFE/RL - Russia, Ukraine Hold Inconclusive Gas Summit. Radio Free Europe/Radio Liberty, 12 de julho 2012. [Acedido a 12 de ago. de 2012]. Disponível na Internet: http://www. rferl.org/content/russia-ukraine-gas-summit/24643469.html.

RiaNovosti - Russia Calls on Ukraine to Treat Tymoshenko with Humanity. RiaNovosti, 24 de Abril 2012. [Acedido a 12 de ago. de 2012]. Disponível na Internet: http://en.rian. $\mathrm{ru} / \mathrm{russia} / 20120424 / 173019528 . \mathrm{html}$.

RODKIEWICZ, Witold - Russia's strategy towards Moldova: continuation or change?. OWS Commentary, 2012. [Acedido a 12 de ago. de 2012]. Disponível na Internet: http://www. osw.waw.pl/en/publikacje/osw-commentary/2012-04-19/russia-s-strategy-towards-moldovacontinuation-or-change.

ROTMAN, David e VEREMEEVA, Natalia - Belarus in the Context of the Neighbourhood Policy: Between the EU and Russia. Journal of Communist Studies and Transition Politics. Vol. 27, N. ${ }^{\circ} 1$ (2011), p. 73-98.

SANCHEZ, W. Alejandro - The 'Frozen' Southeast: How the Moldova-Transnistria Question has become a European Geo-Security Issue. The Journal of Slavic Military Studies. Vol. 22, N. ${ }^{\circ} 2$ (2009), p. 153-176.

SHAPOVALOVA, Natalia e ZAREMBO, Kateryna - Russia's Machiavellian support for democracy. FRIDE Policy Brief. N. ${ }^{\circ} 56$ (2010), p. 1-5.

SHERR, James - Russia's Elections and the Near Abroad. Stockholm: Institute for Security and Development Policy, 2008.

SHUMYLO-TAPIOLA, Olga - Ukraine and Russia: Another Gas War? Carnegie Endowment for International Peace, 2012. [Acedido a 12 de ago. de 2012]. Disponível na Internet: http://carnegieendowment.org/2012/02/21/ukraine-and-russia-another-gas-war/9roh.

SOCOR, Vladimir - Russia Multiplies Conditions for Conflict-Resolution in Moldova. Eurasia Daily Monitor Issue, Vol. 9, N. ${ }^{\circ} 145$ (2012). [Acedido a 12 de ago. de 2012]. Disponível na Internet: http://www.jamestown.org/programs/edm/single/?tx_ttnews\%5Btt_news\% $5 \mathrm{D}=39707 \& \mathrm{cHash}=\mathrm{ee} 4544 \mathrm{a} 08 \mathrm{bd} 1972 \mathrm{fa} 858 \mathrm{~d} 83902 \mathrm{c} 61082$. 
STENT, Angela E. - The Lands in Between: The New Eastern Europe in the Twenty-First Century. In Hamilton, Daniel e Mangott, Gerhard (eds.) The New Eastern Europe: Ukraine, Belarus and Moldova. Washington, DC: Center for Transatlantic Relations (2007), p. 1-21.

STENT, Angela E. - Restoration and Revolution in Putin's Foreign Policy. Europe-Asia Studies. Vol. 60, N. ${ }^{\circ}$ 6, (2008), p. 1089-1106.

SUSHKO, Oleksandr - The dark side of integration: Ambitions of domination in Russia's backyard. The Washington Quarterly, Vol. 27, N. ${ }^{\circ} 2$ (2004), pp. 119-131.

TOLSTRUP, Jakob - Studying a negative external actor: Russia's management of stability and instability in the 'Near Abroad'. Democratization. Vol. 16, N. 5 (2009), p. 922-944.

TRENIN, Dmitry - Russia and Ukraine. In Hamilton, Daniel; Mangott, Gerhard (eds.) The New Eastern Europe: Ukraine, Belarus and Moldova. Washington, DC: Center for Transatlantic Relations, (2007), p. 195-213.

TRENIN, Dmitry - Modernizing Russian Foreign Policy. Russian Politics and Law. Vol. 49, N. ${ }^{\circ} 6$ (2011), p. 8-37.

TSYGANKOV, Andrei P. - Russia's Foreign Policy: change and continuity in national identity. Maryland: Rowman \& Littlefield Publishers, Inc, 2006a.

TSYGANKOV, Andrei P. - If Not by Thanks, Then by Banks? The Role of Soft Power in Putin's Foreign Policy. Europe-Asia Studies. Vol. 58, N. 7 (2006), p. 1079-1099.

TUDOROIU, Theodor - Structural factors vs. regime change: Moldova's difficult quest for democracy. Democratization. Vol. 18, N. 1 (2011), p. 236-264.

TUMANOV, Sergey el al. - Russia-EU relations, or How the Russians Really View the EU. Journal of Communist Studies and Transition Politics. Vol. 27, N. 1 (2011), p. 120-141.

VAHABOV, Tamerlan - Ukraine: a challenge for U.S, EU \& OTAN regional policy. Caucasian Review of International Affairs. Vol. 4, N. 3 (2010), p. 297-305.

Voice of America - Russian PM Says Unification with Belarus Possible and Desirable. 31 julho 2012. [Acedido a 12 de ago. de 2012]. Disponível na Internet: http://www.voanews.com/content/ russian-pm-says-unification-with-belarus-possible-and-desirable--126555343/170796.html.

WEIR, Fred - Ukraine-Russia relations: Why Kiev made a dramatic U-turn back toward Moscow. The Christian Science Monitor, 7 maio 2010. [Acedido a 12 de ago. de 2012]. Disponível na Internet: http://www.csmonitor.com/World/Europe/2010/0507/UkraineRussia-relations-Why-Kiev-made-a-dramatic-U-turn-back-toward-Moscow.

WILSON, Jeanne L. - The Legacy of the Colour Revolutions for Russian Politics and Foreign Policy. Problems of Post-Communism. Vol. 57, N. ${ }^{\circ} 2$ (2010), p. 21-36.

ZAGORSKI, Andrey - Russia's neighbourhood policy. European Union Institute for Security Studies, 2012. [Acedido a 12 de ago. de 2012]. Disponível na Internet: http://www.iss. europa.eu/publications/detail/article/russias-neighbourhood-policy/. 
CAPÍTULO 3

A RÚSSIA E O CÁUCASO DO SUL: DAS RELAÇÕES NEOCOLONIAIS À REALPOLITIK NO 'ESTRANGEIRO P R Ó X I M O'

Maria Raquel Freire e Licínia Simão

\section{Introdução}

As relações entre a Rússia e o Cáucaso do Sul (Arménia, Azerbaijão e Geórgia) permanecem marcadas pela herança soviética, com profundas ligações culturais, linguísticas e políticas entre os dois espaços. Esta herança é ainda visível, quer ao nível da atuação política, quer dos discursos que a sustentam. Ou seja, Moscovo, perceciona-se como mantendo primazia na articulação dos discursos e princípios que estão na base das novas relações com os seus vizinhos, e simultaneamente arroga-se uma função reguladora das relações regionais. Esta postura, que tem sido apelidada de neocolonial, deve-se em primeira instância ao contexto histórico das relações regionais, encontrando expressão em diferentes linhas de pensamento estratégico russo nos últimos vinte anos (tal como mapeado por Tsygankov, 2003).

Na prática, a Rússia não tem contudo sido capaz de efetivar esta política neocolonial. O que está aqui em causa é a capacidade russa de projeção dos seus interesses na área, com muitos limites e num processo contínuo de negociação e concessões. Há, por isso, simultaneamente uma linha clara de afirmação russa, e de reconhecimento do seu estatuto internacional, onde a Comunidade de Estados Independentes (CEI) tem um papel central, mas que no contexto pós-Guerra Fria não se coaduna 
com uma política externa neocolonial. A abertura da Eurásia às dinâmicas globais trouxe novos atores estratégicos à região, desafiando a proeminência russa. A presença económica (principalmente na área energética) e militar norte-americana no Cáspio e na Ásia Central, a presença europeia no Cáucaso e da China na Ásia Central ilustram a necessidade russa de ajustar os seus interesses e políticas estratégicas a um novo contexto.

De facto, no período imediato pós-Guerra Fria, a presença dos interesses económicos e políticos dos Estados Unidos da América (EUA), principalmente em torno da energia do Cáspio e através do alargamento da cooperação com a Organização do Tratado do Atlântico Norte (OTAN), no âmbito da Parceria para a Paz, representou um primeiro desafio. Ao virar do século e no processo de preparação do alargamento da União Europeia (UE) a dez novos Estados membros, incluindo os Estados do Báltico, a Polónia, a Roménia e a Bulgária, com forte presença no Mar Negro e com interesses no desenvolvimento de uma política europeia para a vizinhança de leste, os interesses russos no Cáucaso do Sul foram mais uma vez afetados. Estes desenvolvimentos implicavam um envolvimento consistente da UE, em termos do seu alargamento institucional (a estes novos 10 Estados), e em termos do desenvolvimento de uma política de vizinhança inclusiva às repúblicas do espaço pós-soviético. De facto, o Mar Negro tem sido entendido como zona fundamental de influência russa nas fronteiras com a UE, e alguns dos novos Estados pós-soviéticos haviam já sinalizado vontade de integração mais formal nas instituições europeias (por exemplo, a Geórgia ou a Moldova). Desenvolvimentos que a Federação Russa vai ler como intrusivos, implicando uma aproximação e um envolvimento mais alargado da UE num espaço descrito como prioritário aos interesses russos.

Neste quadro, o capítulo argumenta que embora as relações da Rússia com o Cáucaso possam ser lidas a priori como neocoloniais ou neoimperialistas, são na realidade o resultado da política de Moscovo para a área, prosseguindo interesses em várias dimensões (política, económica, securitária), e buscando afirmação internacional. Assim, o capítulo começa por apresentar o contexto histórico-concetual da evolução das relações da Rússia com as repúblicas ex-soviéticas, mapeando a forma como estas relações são concetualizadas e operacionalizadas. A proeminência de uma 
lógica de realpolitik e pragmática traduz os princípios da política externa russa para o Cáucaso do Sul, adaptando-se às novas realidades e fazendo uso dos recursos herdados do período soviético. O texto avança depois para uma análise mais detalhada das relações russas com o Cáucaso do Sul a partir de 2000, que permite desmontar o argumento neocolonial ou neoimperial de atuação russa, mostrando a sua política como a expressão de objetivos e interesses, semelhantes aos de outros Estados soberanos.

\section{Enquadramento histórico-concetual}

A União das Repúblicas Socialistas Soviéticas (URSS) estabelecida em 1922 consistia numa união de 15 repúblicas, inspirada nos princípios marxistas-leninistas onde o poder único do Partido Comunista, expresso nas decisões do Politburo ${ }^{27}$, definia as orientações fundamentais em termos de política interna e externa. Definindo a União Soviética como um Estado socialista que representava a vontade e interesses de todos, as várias Constituições Soviéticas (1924, 1936 e 1977) assumem este pressuposto e traduzem-no numa organização política representativa dos poderes executivo, legislativo e judiciário. O poder executivo residia no Soviete Supremo que elegia o Presidium dirigido pelo representante máximo do Partido Comunista e que se encarregava de nomear o governo da União, responsável pela execução da política soviética. O poder legislativo encontrava-se no Congresso dos Deputados do Povo, que ratificava as decisões tomadas pelo executivo. Dividido em duas câmaras, o Soviete da União e o Soviete das Nacionalidades, que visava constituir-se enquanto órgão representativo das várias repúblicas, pretendia conferir expressividade prática à ideia da 'ditadura do proletariado'. No entanto, e dada a prevalência clara do Politburo na definição e gestão de políticas, este órgão acabou por funcionar intermitentemente (entre 1917 e 1936,

27 Criado em vésperas da revolução bolchevique de 1917, o Politburo que constituía o organismo central de decisão do Partido Comunista, tornou-se funcional após a realização do Congresso do Partido em 1919. 
com Estaline a retirar-lhe relevância e a suspender as suas funções, que foram absorvidas inteiramente pelo poder centralizador da estrutura do Partido Comunista, e mais tarde entre 1989 e 1991, quando a abertura e transição iniciadas por Mikhail Gorbachev procuram consubstanciar-se em estruturas mais representativas) (ver Sakwa, 1999; Service, 2003).

Este quadro institucional baseava-se num pressuposto de representatividade das várias repúblicas constituintes, como afirmado nas várias Constituições soviéticas. Teoricamente, a União traduzia uma vontade própria das várias repúblicas, que tinham individualmente os seus textos constitucionais. Contudo, a autoridade residia efetivamente no Partido Comunista e no governo central em Moscovo que definia as políticas a serem executadas localmente. Ou seja, apesar de se constituir como uma união de repúblicas iguais, na realidade, a diferenciação interna entre a Rússia e as outras repúblicas constituintes da URSS era evidente, na concentração de poder que aí residia e que se estendia depois ao restante espaço soviético. O comunismo soviético, expressando ideais de comunitarismo, traduziu formalmente uma ideia de igualdade entre as partes constituintes da União que na realidade não se verificava. A desigualdade era visível não só em termos do relacionamento entre repúblicas, com a Rússia a prevalecer, como também entre classes, com 'a luta de classes' e a 'revolução proletária' a serem conceitos que nunca se materializaram face ao poder do Partido Comunista como único órgão legítimo.

O processo de transição iniciado com as reformas de Mikhail Gorbachov e as conhecidas políticas de abertura e transparência a partir de meados da década de 1980 vão permitir a emergência de dinâmicas políticas e sociais que estiveram subjugadas a um regime de partido único que não reconhecia efetivamente a sua natureza diferenciada, e que, em várias instâncias, limitou (incluindo através de métodos repressivos) a sua manifestação. As políticas reformistas postas em marcha questionaram todo um sistema assente num conjunto de princípios alicerçados numa estrutura de organização política, social e económica, que revelava grandes fragilidades.

"A credibilidade da ideologia oficial, que nas palavras de Yakovlev, permitia manter o sistema político e económico soviético unido como 
'correntes de aço', estava rapidamente a enfraquecer-se. As novas perceções contribuíram para uma mudança de atitudes face ao regime e para 'uma mudança de valores'. Gradualmente, a legitimidade dos arranjos políticos começou a ser questionada" (Aron, 2011). De facto, o novo contexto de desagregação da União Soviética permite a emergência de nacionalismos étnicos, alguns destes com uma escalada para a violência, como no caso do Nagorno-Karabakh, por exemplo, bem como o desejo cada vez mais claro das várias repúblicas constituintes em afirmarem a sua independência. Este processo de autonomização e declaração das sucessivas independências face ao governo central da União Soviética vai decorrer, na sua maioria, de forma pacífica, mas alguma tensão vai permanecer na gestão das políticas destes novos Estados com a Federação Russa. Esta tensão será mais visível em alguns casos do que noutros. Por exemplo, no Cáucaso do Sul, a Geórgia e o Azerbaijão, prosseguindo políticas de maior autonomia, vão desafiar tentativas de maior influência russa, o que não se verifica no caso da Arménia, como analisado adiante. O momento da transição permite perceber a qualidade das relações existentes no quadro unificador da União Soviética, que eram relações de dependência e cujo processo de transição para um novo modelo é complexo.

A Rússia nunca havia antes experimentado um sistema de governo que não fosse centralizado e autoritário, seja na época imperial dos czares, seja no período de liderança comunista soviética. A tradição imperial da 'grande Rússia', retomada numa nova fórmula no quadro soviético (a URSS enquanto superpotência), deixa marcas profundas na definição dos novos realinhamentos no grande espaço da antiga União Soviética. Assumindo-se como sucessora legal e herdeira dos espaços de representação internacional da extinta União Soviética, a Federação Russa vai conter em si os ingredientes da hegemonia, da dominação e da perpetuação de influência. "A nossa diplomacia não podia retornar ao modelo pré-revolucionário de início do século XX ou continuar de forma automatizada com a política externa soviética. A Federação Russa cortou resolutamente com o legado ideológico da União Soviética enquanto proclamando o seu estatuto legal como Estado herdeiro da URSS" (Ivanov, 2001, p. 7). Num quadro diferenciado, onde o exercício de poder russo encontra limites na era 
pós-Guerra Fria, é interessante notar como o espaço pós-soviético se mantém como um espaço de interesse vital para a Rússia.

Primeiro, pela partilha de um passado histórico comum e pela localização geográfica, que tornam toda esta área um espaço de importância estratégica clara entre o ocidente e o oriente, onde a Rússia partilha traços linguísticos e culturais importantes. Segundo, pelas ligações económicas e comerciais que uniam a Rússia e estes Estados no quadro da URSS, onde uma economia planificada e centralizada determinava os modos de produção coletivizada e definia cadeias de produtividade, cuja interdependência era inegável; ${ }^{28}$ bem como pelos mercados e rotas de trânsito, onde a energia se constituiu como factor determinante nas relações. Terceiro, pelas questões de segurança na nova vizinhança da Rússia com implicações diretas na sua segurança e estabilidade. Por um lado, a instabilidade que emerge no espaço pós-soviético e que leva ao despoletar de conflitos violentos, como os casos da Transnístria, Ossétia do Sul, Abcázia e o já mencionado Nagorno-Karabakh ilustram. O envolvimento da Rússia nestes conflitos violentos, enquanto Estado parte, facilitador, mediador, e enquanto Estado disponível para implementação de medidas de consolidação de confiança num cenário pós-consensualização política de diferendos, revela o caráter ambíguo que a Federação Russa assume, refletindo a natureza dos objetivos de manutenção de influência e poder num espaço que a Rússia descreve em todos os documentos fundamentais de política externa como central. Por outro lado, acrescem às preocupações russas, as dinâmicas relacionadas com os movimentos islâmicos radicais e as redes transnacionais ligadas a práticas ilícitas e ao terrorismo, sob observação apertada de Moscovo, que os entende como ameaça à sua segurança interna, bem como à segurança mais alargada no espaço pós-soviético (ver Freire, 2012).

Estes princípios demonstram a postura pragmática que a Federação Russa vai assumir, especialmente após a aprovação da nova Constituição

28 Esta questão da planificação e centralização da produção a nível económico é fundamental dado o princípio de especialização desenvolvido e que acaba por se refletir na rápida decadência industrial pós-URSS dado não só o carácter pesado da indústria, mas as interdependências resultantes do nível de especialização, que a tornam obsoleta num quadro de autonomização da produção. 
de 1993, face à sua área de vizinhança. Revelam o entendimento do envolvimento russo nos assuntos regionais, por exemplo ao nível da delimitação de fronteiras, ou relativamente à presença de forças de manutenção da paz russas neste espaço, patente nos documentos e ações da Rússia pós-soviética. Além do mais, a Rússia procura manter-se envolvida nos processos de restruturação política e económica nestas sociedades, embora com limites claros, dado o caráter crescentemente heterogéneo que o espaço pós-soviético vai assumindo nas décadas pós-Guerra Fria.

Em termos formais, a Rússia pós-soviética adotou três documentos de referência de política externa (1993, 2000, 2008 e 2013), que numa lógica de continuidade vão atualizando os textos ao contexto, mas onde a ideia central da relevância do espaço pós-soviético se mantém sempre presente. É interessante ainda sublinhar que nos vários documentos a ideia da Rússia como grande potência é veiculada, num quadro internacional cujo princípio ordenador deverá ser multipolar. Este alinhamento é reforçado nos documentos com orientação securitária. Por exemplo, no Conceito de Segurança Nacional (2000) pode ler-se como objetivo da Federação Russa, "fortalecer a [sua] posição como grande potência e como um dos centros influentes num mundo multipolar".

De facto, desde o final da URSS até aos nossos dias, o espaço pós-soviético reajustou-se ao novo quadro relacional que se seguiu ao fim da lógica aglutinadora da União Soviética. As várias repúblicas seguiram cursos diferenciados e foram afirmando a sua independência, em lógicas de maior ou menor autonomia face a Moscovo. De um espaço artificialmente homogéneo sob o regime comunista soviético, estamos hoje perante um espaço heterogéneo, onde a Rússia não tem poder ilimitado. E este reconhecimento da parte das autoridades em Moscovo tem forçado o desenvolvimento de novas políticas, readaptadas a este novo contexto, de onde o desenvolvimento de políticas de soft power merece destaque. Esta postura enquadra-se na vontade russa de afirmação de influência nesta área, mas distanciando-se de conotações neoimperialistas ou neocoloniais. Ou seja, a política russa para este espaço não deve ser entendida no quadro de lógicas neocoloniais, onde a nostalgia de um passado agregado e o poder reforçado da república dominante de então 
se faz novamente afirmar, sem permitir alternativas aos Estados inseridos nesta área, no sentido em que a reafirmação russa neste contexto faz parte de um continuum nos princípios da sua política externa e, como referido, apresenta limitações claras.

Num alinhamento de realpolitik o Kremlin procura assegurar o seu interesse nacional em termos do que entende dever ser a sua presença neste espaço. Neste sentido, não se trata de um julgamento valorativo de ser uma 'boa' ou 'má' política, mas antes de se tratar de um curso de ação que reflete os objetivos fundamentais da política externa russa neste espaço. As relações que se foram estabelecendo, ora de maior proximidade, ora de distanciamento entre as políticas russas e as destes Estados, revelam dinâmicas de cedência e compromisso, compatibilidade e discordância, que fazem parte do relacionamento entre Estados no sistema internacional afastando deste modo um discurso neoimperialista. A Rússia procura através da sua diplomacia política ativa transmitir uma leitura de normalidade no seu relacionamento com estes Estados, desconstruindo ideias de que age promovendo uma ordem neocolonial, apesar de este ser um espaço descrito e assumido como de especial importância na sua política externa.

A guerra na Geórgia no verão de 2008 é um elemento central na análise deste debate. A Rússia aproveitou esta oportunidade para se afirmar no espaço pós-soviético perante a ingerência crescente ocidental e, acima de tudo, perante um conjunto de políticas e ações liderados pelos EUA, em particular, e considerados em Moscovo como ultrapassando uma política de cooperação estratégica, com implicações diretas para a segurança da Rússia. O projeto do escudo de defesa antimíssil, o alargamento da Aliança Atlântica ao espaço CEI e a questão do Kosovo, por exemplo, demonstram o descontentamento russo. O pós-Geórgia revela o reposicionamento dos vários atores na área, onde a Rússia parece assumir um papel de destaque na sua afirmação enquanto ator fundamental no espaço CEI. Esta leitura não tem que ser feita, como argumentado, numa lógica neocolonialista ${ }^{29}$,

${ }^{29}$ As perspetivas sobre a tendência dominante da política externa russa no período pós-soviético têm oscilado entre os que se posicionam de forma mais crítica e argumentam que a Rússia independente assume interesses neocoloniais e neoimperialistas na CEI (Ismayilov, 2011; Socor, 2003) e outros que veem a atuação russa como obedecendo a 
uma vez que novos processos estão em curso, sendo o 'recongelamento' dos conflitos na Geórgia claramente um deles. Já no caso arménio a leitura pode ser diferenciada, uma vez que a relação de dependência desta face à Rússia perpetuou-se desde a independência e tem sido reforçada através de acordos comerciais, e em particular, acordos militares. No caso do Azerbaijão, e face à interdependência que se desenvolveu, essencialmente em termos económicos, e em grande medida resultante dos recursos energéticos de que o país beneficia, a relação é mais equilibrada, com ajustes e negociação, correspondendo a um exemplo de convivência que faz parte do continuum de normalização nas políticas russas.

Deste modo, parece que podemos assumir o pós-2008 como o início do processo de aceitação russa de uma abordagem de política externa de realpolitik, que fica aquém de lógicas neoimperiais e neocoloniais, e do reconhecimento internacional da atuação da Rússia como uma potência, onde a Geórgia constitui um marco de aplicação de um conjunto de procedimentos e justificações familiares ao ocidente, incluindo a gestão de instabilidade nas suas fronteiras próximas, a proteção de minorias, e a defesa de direitos fundamentais. Basicamente, este alinhamento traduz uma reprodução russa da retórica ocidental de justificação de intervenções, como aconteceu no caso do Iraque em 2003, muito criticada por Moscovo, ou no recente caso da intervenção ocidental na Líbia. Além da retórica argumentativa russa, o reconhecimento do seu estatuto pelos seus pares a nível internacional parece claro. A Rússia entende a ordem internacional pós-2008 como uma ordem multipolar onde é um ator relevante.

Acresce ainda a ideia defendida por Anatoly Chubais (2003) que uma das prioridades russas para o século XXI é o desenvolvimento do "capitalismo liberal" e a construção de um "império liberal". De acordo com Chubais, político russo que esteve envolvido nos processos de privatização económica de inícios dos anos 1990, "o imperialismo liberal deve tornar-se a ideologia russa e a construção de um império russo a sua missão”. Parece propor-se uma política externa marcada por uma economia liberal,

interesses de realpolitik que ficam aquém de uma presença neoimperial (Wallander, 2007; Freire, 2011; Light, 2003). 
complementada com músculo militar. A proposta visa avançar para além da herança dos czares e da herança soviética e assumir uma nova Rússia, potência liberal. O programa de ação da presidência Medvedev concentrou atenção nesta dimensão, entendida como essencial à afirmação da Rússia no sistema internacional. Seguindo este alinhamento, voltamos a reforçar a ideia de que as políticas energéticas e comerciais na sua área de vizinhança espelham os princípios delineados sem constituírem necessariamente um instrumento de imposição neoimperial.

A reeleição de Putin para um novo mandato na presidência russa, apesar de alterar procedimentos, não altera a substância em termos das relações da Rússia com o Cáucaso do Sul. Significa isto que a Rússia está a regressar a um modelo de governação mais centralizado e menos liberal do que aquele que Medvedev procurava desenvolver, sem que, no entanto, esta alteração no modo de gestão e atuação política implique mudanças significativas nos alinhamentos que têm prosseguido em relação aos três países do Cáucaso do Sul. Além do mais, deve ainda ser assinalado o projeto de integração no espaço pós-soviético que Vladimir Putin tem liderado, e que pressupõe a criação de uma União Euroasiática (Putin, 2011). O objetivo é o estabelecimento de uma união à imagem da UE, enquanto processo inovador que visa a consolidação de relações com enfoque nas dimensões económica e política. Contudo, a diversidade existente nas relações da Rússia com os Estados da CEI, e em particular, com os Estados do Cáucaso do Sul, não facilita a concretização desta ideia, dada a crescente autonomia destes Estados e as políticas de diversificação de apoios e relações internacionais que têm prosseguido. Além do mais, os acordos económicos que alguns destes Estados pós-soviéticos estão a negociar com a UE no âmbito da Parceria Oriental, como no caso das áreas de comércio livre abrangentes e aprofundadas, poderão ainda constituir um entrave adicional ao projeto, ao implicar uma escolha, no sentido em que a compatibilidade dos projetos em termos de integração económica tem sido questionada (Van der Loo e Van Elsuwege, 2012). Analisamos em seguida as políticas russas para o Cáucaso do Sul para de forma mais detalhada percebermos os contornos das relações aqui sugeridos. 


\section{Revisionismo russo no Cáucaso}

Durante grande parte do período pós-soviético, a política externa russa para o Cáucaso do Sul promoveu uma abordagem de instabilidade controlada. Através do bloqueio de soluções efetivas para os conflitos congelados do espaço pós-soviético e o seu apoio aos regimes semi-autoritários da região, a Rússia garantiu a sua posição como o principal ator político e de segurança neste espaço. O principal desafio a esta posição hegemónica russa surge com a abertura da Eurásia às dinâmicas globais do pós-Guerra Fria, principalmente a sua integração nos mercados energéticos mundiais, com a conclusão do oleoduto Baku-Tbilisi-Ceyhan (BTC), em 2006, e a crescente cooperação política e institucional com os EUA e as organizações europeias, como a UE, a OSCE e o Conselho da Europa. A resposta russa a esta abertura e gradual integração destes países nas estruturas de governação ocidentais passou pela criação de instituições novas no espaço pós-soviético que evitassem a total desintegração das ligações privilegiadas entre Moscovo e os Estados do seu estrangeiro próximo. A CEI, criada a 8 de dezembro de 1991 por acordo entre a Rússia, Bielorrússia e Ucrânia, é o principal exemplo, embora no contexto do Cáucaso do Sul a adesão a estas estruturas criadas por Moscovo tenha demonstrando grande diversidade, com a Geórgia desde logo a adiar a sua inclusão na CEI (e tendo formalizado a sua saída da Comunidade após a guerra com a Rússia no verão de 2008). A reafirmação do poder russo nesta região variou substancialmente, exigindo de Moscovo estratégias mais agressivas de reafirmação regional.

As revoluções coloridas da Geórgia, em 2003, e da Ucrânia, em 2004, foram o principal ponto de viragem na estratégia russa de afirmação regional e inauguraram um período revisionista da política externa russa. Esta posição deve-se principalmente à perceção, em Moscovo, de que a manutenção do status quo da década de 1990 não era mais possível ou vantajosa, tendo em conta os inúmeros desafios à posição hegemónica russa. Numa tentativa de desenvolver o seu próprio soft power, através de uma diplomacia pública ativa e do financiamento de Organizações Não-Governamentais (ONGs), Moscovo denunciou ainda as revoluções 
coloridas como estratégias deliberadas do ocidente para colocar no poder líderes de orientação pró-ocidental, cujas agendas passaram a incluir, entre outros assuntos, a adesão à OTAN e uma colaboração mais estreita com a UE, no âmbito da sua política de vizinhança. Estas dinâmicas contribuiriam, segundo os líderes russos, para o fomento da competição regional, desvirtuando as organizações regionais enquanto fóruns de cooperação e instrumentalizando-as para alcançar os objetivos dos governos ocidentais. O discurso do presidente Putin, na Conferência de Segurança de Munique, em 2007, foi a crítica mais contundente desta abordagem ocidental à Eurásia e às consequências negativas que daí poderiam advir, caso os interesses russos não fossem tidos em conta.

"De acordo com os documentos fundadores, na esfera humanitária a OSCE visa assistir países membros na implementação de normas internacionais de direitos humanos, a pedido destes. [...] Contudo, isto não significa interferência nos assuntos internos de outros países, e em particular a imposição de um regime que determine como estes Estados devem viver e desenvolver-se. É óbvio que tal interferência não promove de modo algum o desenvolvimento democrático dos Estados. Pelo contrário, torna-os dependentes e, como consequência, política e economicamente instáveis." (Putin, 2007)

Pese embora a crítica confrontacional adotada por Moscovo, a verdade é que os interesses políticos e económicos dos EUA e de alguns países europeus começavam a ganhar terreno na Eurásia, incluindo no Cáucaso do Sul. O Azerbaijão e a Geórgia tornaram-se particularmente relevantes, devido aos projetos de exportação energética e, no caso da Geórgia, devido à orientação pró-ocidental (e profundamente anti-russa) do presidente Mikhail Saakashvili. A resposta russa a estas mudanças em curso pautou-se por uma mistura de gestos de boa vontade e medidas coercivas. Moscovo apoiou os esforços iniciais do governo de Saakashvili na gestão da crise da Ajária e mediou a saída do líder regional Aslan Abashidze, em 2004. Contudo, numa fase posterior, Moscovo impôs uma série de medidas restritivas ao comércio com a Geórgia, embargando 
alguns produtos agrícolas fundamentais à frágil economia georgiana (The Economist, 2010; Patsuria, 2010), e aumentou significativamente os preços da energia à Ucrânia (Beehner, 2010), o que acabou por criar dificuldades acrescidas aos novos governos pró-ocidentais no poder nestes dois países. Esta política pautada por alguma ambivalência reflete as alterações nas relações políticas e económicas da Rússia com estes países, demonstrando a diversidade da região e as especificidades inerentes aos vários Estados que a compõem, para além de factores externos, como o envolvimento de atores extra-regionais numa área considerada vital para Moscovo. Estas ações russas estão, no entanto, em linha com os princípios fundamentais de política externa definidos para a sua área de vizinhança, mantendo coerência no seu conteúdo, mas alternando formatos em termos da prossecução de políticas e práticas.

\section{Desconstrução do discurso neo-colonial nas relações da Rússia com a Arménia, o Azerbaijão e a Geórgia}

A análise das políticas revisionistas russas no Cáucaso, no período pós-revoluções coloridas permite entender as motivações da política externa russa bem como os instrumentos privilegiados pelo Kremlin para reforçar a sua presença estratégica na região. A necessidade de desenvolver novas abordagens que permitissem responder de forma satisfatória aos desafios emergentes na Eurásia foi refletida numa diversificação das abordagens e estratégias, em linha com a noção de um continuum de política externa. Assim, é possível encontrar exemplos de políticas mais conciliatórias e até mesmo de acomodação, bem como de políticas de maior assertividade e coação, mas que em diversas instâncias ficaram deliberadamente aquém do que poderia ser visto como uma abordagem neocolonial. Neste alinhamento, a tendência de desenvolver mecanismos de dependência que estrangulem lógicas emancipatórias e impeçam a marginalização de Moscovo, acabou por se revelar limitada, essencialmente visível no posicionamento da Rússia face a desenvolvimentos considerados contrários aos seus interesses, como exemplificado em seguida. 
Um dos exemplos mais significativos desta leitura é o alcance da intervenção russa na Geórgia, em 2008. Apesar dos debates sobre as motivações e legalidade da intervenção (ver Allison, 2008), o que parece significativo do ponto de vista do nosso argumento é a opção de Moscovo de não ocupar Tbilisi e procurar depor o regime de Saakashvili, com o qual as relações de tensão são evidentes. Tsygankov e Tarver-Wahlquist (2009) argumentam que

“(..) um olhar mais próximo à Rússia e à Geórgia desafia a noção de que a Rússia procura reestabelecer a sua hegemonia e controlo imperial no Cáucaso. As alegações de que a segurança da Rússia é posta em causa pela pequena Geórgia são também difíceis de entender, a menos que se tenha em conta o contexto mais alargado das relações entre a Rússia, a Geórgia e as nações ocidentais."

O que os autores sugerem é um entendimento das motivações de política externa que tem em conta a noção de 'honra', a par de interesses de realpolitik, num contexto mais amplo, onde as relações da Rússia com o ocidente são fundamentais. Para eles, só assim se consegue explicar o caráter limitado da intervenção russa na Geórgia, ficando aquém da ocupação ou da deposição do presidente georgiano. Este entendimento está em linha com o argumento apresentado aqui, que vê as leituras neoimperiais da política externa russa para o Cáucaso do Sul como oferecendo capacidade explicativa limitada. Mesmo o adensar do discurso e das políticas centralizadoras com o regresso de Putin à presidência na primavera de 2012, após os anos mais liberais de Medvedev, não permite consubstanciar um discurso alinhado em argumentos neocoloniais, face a um espaço diverso e heterogéneo onde a capacidade de ação russa encontra sérios limites. As acusações persistentes, no âmbito do espaço político georgiano, de que os partidos de oposição ao presidente Saakashvili e que advogam, muitos deles, uma normalização das relações com Moscovo - são agentes dos interesses russos, parece servir propósitos de desacreditação da oposição, mais do que refletir uma realidade de ingerência direta russa na vida política georgiana (de Waal, 2012b; entrevista, 2011). 
Apesar de o Kremlin ter afirmado explicitamente que não dialogará com o presidente Saakashvili e de isso constituir, naturalmente, uma pressão intensa sobre as autoridades políticas do país, o prosseguimento de relações de boa vizinhança e diálogo entre os dois Estados é fundamental para a estabilidade regional e tem, por isso, crescido como uma opção política urgente para ambos os lados. Isso tem sido visível em algumas medidas de apoio ao diálogo entre os dois vizinhos, promovidas pelo novo governo georgiano, eleito em outubro de 2012, liderado pela coligação de partidos de oposição ao presidente Saakashvili, Georgian Dream. Entre essas medidas destaca-se a criação da posição de Enviado Especial para as Relações com Moscovo, que permite a manutenção de diálogo direto entre as partes, enquanto as relações diplomáticas, cortadas depois de 2008, não forem reestabelecidas.

Outra área onde a política externa russa para o Cáucaso do Sul foi claramente influenciada pelo contexto das relações com o ocidente é a área energética. O carácter eminentemente político do desenvolvimento energético fez com que, a par dos interesses comerciais das multinacionais que passaram a atuar no Cáucaso, os seus Estados de origem fossem também envolvidos nos processos negociais. Nesse sentido, o interesse norte-americano em desenvolver alternativas à produção e escoamento de energia na região do Cáspio que não fossem dominadas pela Federação Russa, tinha um objetivo claro de reforçar a soberania dos Estados produtores e de trânsito. Este foi também o objetivo central da liderança azeri ao assinar em 1994 o chamado 'contrato do século', constituindo um consórcio internacional para exploração dos recursos minerais do Cáspio e que, em 2006, viria a ser concluído com a abertura do BTC.

A opção russa face a esta abertura aos capitais e influência ocidental na área energética foi em grande medida de acomodação. Ao passo que o processo de 'economização' da política externa russa permitiu algum nível de normalização (a integração nos mercados mundiais e o uso do chamado 'império liberal' para avançar os seus interesses políticos e estratégicos) (Wallander, 1997), os processos de acomodação foram reativos, face às políticas externas mais assertivas do Azerbaijão (Kjaernet, 2008) e ao novo contexto internacional pós-11 de setembro. Ilustrando esta 
tendência, é apenas em 2001 que a Rússia celebra um acordo bilateral com o Azerbaijão para dividir as reservas do Cáspio para exploração e, em 2003, a Rússia concorda com a celebração de um acordo tripartido com o Azerbaijão e o Cazaquistão sobre a divisão dos recursos do Mar Cáspio, removendo um obstáculo importante ao seu desenvolvimento económico (Karbuz, 2010).

Parece pois plausível afirmar que, embora Moscovo veja os recursos energéticos como um instrumento político importante na sua afirmação regional no contexto pós-soviético, a sua utilização tem sido flexível, em linha com a ideia de um continuum de política externa. Ou seja, a utilização da arma energética tem refletido um cálculo estratégico sobre os ganhos e os custos da sua utilização, numa lógica neopatrimonialista, tendo em conta o nível elevado de interdependência entre a Rússia e os seus vizinhos da CEI e tendo em conta a importância estratégica da energia na economia russa, como a comparação entre o caso ucraniano e azeri demonstra.

A presença russa na Arménia é particularmente propícia a análises neoimperialistas. As relações entre Moscovo e Ierevan, no contexto pós-soviético têm oscilado entre declarações de parcerias estratégicas e uma presença hegemónica russa. Tal como no caso da Geórgia e do Azerbaijão, a política externa russa para a Arménia refletiu também o ativismo arménio, na reformulação das relações com Moscovo, no quadro pós-independência. Ilustrando isso, uma das prioridades das autoridades arménias foi a criação de novos mercados que lhe permitissem escapar aos bloqueios impostos pela Turquia e pelo Azerbaijão, em resultado da guerra do Nagorno-Karabakh e a imprevisibilidade da rota georgiana que liga a Arménia à Rússia, face às difíceis relações entre Moscovo e Tbilisi. No âmbito da Política Europeia de Vizinhança (PEV), a Arménia tem sido um parceiro entusiasta das possibilidades económicas previstas e os níveis de trocas comerciais entre a UE e a Arménia têm crescido exponencialmente, revelando uma dimensão de diversificação que se vai afirmando cada vez mais nas políticas do país. De qualquer modo, é revelador que os resultados das eleições parlamentares de 6 de maio de 2012 tenham sido marcadamente de continuidade, apesar dos protestos da oposição de registos fraudulentos, e que as eleições presidenciais de 2013 não 
pareçam oferecer grandes alternativas políticas ao regime vigente, pelo que a manutenção do status quo parece para já permanecer inalterada.

No contexto do Cáucaso do Sul, a proposta avançada pelo presidente Putin de constituir uma União da Eurásia, tem maior ressonância junto das autoridades arménias, tendo em conta o nível de influência económica e financeira de Moscovo. Numa das visitas do presidente arménio a Moscovo, a possível inclusão da Arménia neste projeto foi discutida, aparentemente de forma favorável (Kremlin, 2012), o que levanta problemas importantes para as atuais negociações entre a Arménia e a UE, para o estabelecimento de uma área de comércio livre abrangente e aprofundada. Contudo, e apesar de alguns indicadores de diversificação, a presença russa na Arménia é fundamental para os dois atores. Para Moscovo, a Arménia representa o último aliado estratégico na região, com importantes possibilidades de influenciar as dinâmicas regionais. Para a Arménia, a Rússia e a Organização do Tratado de Segurança Coletiva (OTSC), representam a única garantia militar de apoio numa guerra contra o Azerbaijão. Face à importância histórica da Rússia como o garante militar e protetor da Arménia, num contexto que esta perceciona como hostil, as autoridades arménias têm sido incapazes de se reposicionar no contexto regional. As relações de dependência com Moscovo têm sido uma necessidade, mas não uma opção natural e incontestada. Por isso, o processo de normalização de relações com a Turquia, iniciado em 2008, representa um esforço importante de abertura de novas possibilidades de desenvolvimento (Torbakov, 2010). Para Moscovo, o principal interesse na sua presença na Arménia é garantir a permanência de um aliado na região, mas simultaneamente assegurar também que os custos dessa presença não se tornem incomportáveis. Nesse sentido os esforços de mediação do presidente Medvedev no quadro do conflito do Nagorno-Karabakh, são uma tentativa clara de garantir que as tensões não escalem para uma situação onde a Rússia tenha que se envolver militarmente num conflito de dimensões regionais.

É contudo interessante perceber algumas dinâmicas nem sempre visíveis, mas que se vão desenvolvendo e deixando marcas. Como argumenta Elkhan Nuriyev (2012), "nos últimos anos a Geórgia e o Azerbaijão procuraram organizar e consolidar as suas próprias forças armadas, com o 
apoio dos Estados Unidos e de Israel. A Arménia, o Estado mais leal à Rússia no Cáucaso, acordou recentemente pela primeira vez a realização dos primeiros exercícios militares conjuntos com os Estados Unidos, para a primavera, com o objetivo de melhorar a interoperabilidade das suas forças integradas na missão do Afeganistão”. Estas novas dinâmicas geram forças de resistência face às políticas russas limitando em grande medida a sua capacidade de atuação e influência, e sublinhando uma vez mais não só a heterogeneidade da área como a crescente autonomia e capacidade de ação/reação destes Estados. Desenvolvimentos face aos quais devemos estar atentos, uma vez que podem implicar alterações nas leituras regionais e ter impacto direto nas relações da Rússia com estes três Estados do Cáucaso do Sul.

\section{Os conflitos congelados}

Os conflitos congelados da Eurásia permanecem um dos instrumentos privilegiados da Rússia para projetar poder na região. A influência que a Rússia tem nestes processos, devido ao seu envolvimento direto nos mesmos, confere-lhe uma posição de grande relevância na procura de compromissos políticos. A questão mais controversa para todas as partes envolvidas nos conflitos da Geórgia, por exemplo, tem sido a natureza das operações de manutenção da paz nas duas regiões separatistas da Abcázia e Ossétia do Sul. Aqui, a mudança do status quo seria mais difícil e traria maiores custos para todos os envolvidos. A Rússia manteve simultaneamente as suas atividades de manutenção da paz, através do mandato da CEI, e o seu apoio militar, político e económico às regiões separatistas, na sua luta pela independência face à Geórgia (Zverev, 1996). Perante este cenário, as novas autoridades georgianas pós-revolução das rosas, em 2003, iniciaram uma campanha intensiva para internacionalizar os conflitos, forçando a revisão dos formatos existentes de mediação, o que contribuiu significativamente para o processo de 'descongelamento' destes conflitos.

A estratégia da administração Saakashvili baseou-se numa opção de aproximação às estruturas europeias, fazendo lóbi intensivo em Bruxelas, 
para que a UE incluísse a Geórgia na sua Política Europeia de Vizinhança e para que assumisse uma posição mais proeminente na gestão dos conflitos (Delcour e Duhot, 2011). Por outro lado, e face à relutância europeia em assumir novos compromissos securitários nesta região, a opção de integração na OTAN e o apoio norte-americano tornou-se fundamental (Pardo Sierra, 2011, p. 1393) para a gestão das ameaças securitárias relacionadas com a infiltração de guerrilheiros chechenos no território georgiano e outras questões transnacionais. Em todos estes contextos, o relacionamento entre a Geórgia e a Rússia ficou fortemente danificado, quer pela instabilidade que se desenvolvia na fronteira sul da Rússia, quer pela presença reforçada dos EUA nesta região.

Para a política externa russa do início da década de 2000, estes desafios, representados pelo avanço das estruturas euro-atlânticas na CEI, nomeadamente através da Parceria para a Paz, e pelo carácter anti-russo do discurso das elites georgianas, exigiram medidas mais enérgicas, em linha com a nova administração no Kremlin, liderada por Vladimir Putin. Para a Rússia, o escalar do conflito em 2008, foi simultaneamente um momento de afirmação regional e internacional, com riscos claros. A retórica que acompanhou a intervenção russa na Geórgia alinhou em duas vertentes centrais. Por um lado, a necessidade de proteção dos cidadãos russos face às políticas nacionalistas agressivas da Geórgia e por outro, uma narrativa mais ampla de oposição às dinâmicas unipolares do contexto pós-Guerra Fria, que induziram a Geórgia a acreditar que teria o apoio dos EUA e da OTAN nos seus planos reintegracionistas (Baek, 2009, p. 456). Em ambas as vertentes, os riscos para a política externa russa são significativos. Nas relações com a CEI, a regresso de uma visão da Rússia como uma potência com ambições imperialistas disposta a recorrer à força militar para reafirmar a sua posição regional foi inevitável. Isto exigiu uma campanha de diplomacia pública ativa, onde a narrativa do Kremlin se fizesse ouvir. Tal como Feklyunina (2008, p. 620) argumenta

"No seu todo, posicionar a Rússia como um país sem ambições imperiais mas com interesses legítimos nos Estados vizinhos é uma das tarefas mais difíceis da campanha de relações públicas. Por um lado, 
algumas ações de Moscovo na área pós-soviética, como as guerras comerciais com a Geórgia, não correspondem à imagem projetada. Por outro, os estereótipos centenários sobre o imperialismo russo entre as elites na 'vizinhança próxima' são reforçados cada vez que a Rússia permite qualquer oportunidade nesse sentido. Para as antigas repúblicas soviéticas e os países que faziam parte do bloco de leste, quaisquer ações russas que não lhes sejam favoráveis parecerão sempre neoimperiais."

No período pós-conflito, a lógica do Kremlin passou a ser de minimização das consequências negativas (damage control) e maximização dos benefícios possíveis, numa lógica pragmática. Perante estas tendências, a Rússia reajustou as suas prioridades e privilegiou um novo 'congelamento' do status quo, em condições que lhe garantissem maior capacidade de gerir a instabilidade nas suas fronteiras a sul e projetar poder. A intervenção militar na Geórgia, em 2008, reconfigurou o posicionamento da Rússia no Cáucaso do Sul e reajustou os equilíbrios militares e políticos na região. Depois da guerra, a Rússia reforçou a sua presença militar na Abcázia e na Ossétia do Sul e, ao reconhecer a independência destas duas regiões, aumentou o número de aliados políticos no Cáucaso, reforçando a autonomia das administrações separatistas no desenvolvimento de políticas pró-russas. Moscovo reforçou também a sua presença na Arménia, através da extensão da licença da base militar de Gyumri, até 2044 (RFE/RL, 2010). Moscovo procurou ainda garantir a sua permanência na estação de radar de Gabala, no Azerbaijão, estrategicamente importante para o controlo do Cáspio e do Médio Oriente. No entanto, as autoridades azeris, desagradadas com a decisão russa de renovar a licença da base militar arménia por um período tão extenso e pela falta de capacidade (ou vontade) russa de influenciar a Arménia no processo de paz do Nagorno-Karabakh, resolveram aumentar o preço para a renovação da licença, dos correntes 7 milhões de dólares para 300 milhões (Abbasov, 2012). De acordo com fontes russas, o valor exigido pelas autoridades azeris corresponde à construção de duas novas estações na Rússia (Ministro da Defesa Russo Anatoli Serdyukov, citado em Bridge, 2012), tendo levado à decisão de não-renovação e à retirada russa em 
finais de 2012. Podemos pois dizer que a Rússia aceitou as mudanças em curso no Cáucaso do Sul como sendo inevitáveis e procurou moldar o novo contexto regional a seu favor, embora mais uma vez encontrando limites à concretização dos seus objetivos.

Um aspeto crucial deste reposicionamento foi a tentativa de melhorar a imagem pública da Rússia entre os países da CEI, depois da guerra em 2008. Para esse efeito, a Rússia envolveu-se de forma mais ativa na resolução dos conflitos do Cáucaso do Sul e da Moldova, com o presidente Medvedev a mostrar liderança particularmente forte na mediação entre a Arménia e o Azerbaijão, relativa ao conflito de Nagorno-Karabakh. Medvedev encontrou-se pessoalmente com os presidentes dos dois países em nove ocasiões, entre 2008 e 2011, na tentativa de alcançar um acordo de paz. Moscovo aceitou também uma presença internacional reforçada no Cáucaso do Sul, nomeadamente concordando com a mediação da UE durante a guerra de 2008 e que conduziu ao acordo de paz entre a Rússia e a Geórgia, mediado em nome da UE pelo presidente francês, Nicolas Sarkozy, na altura à frente da presidência do Conselho de Ministros da União Europeia. Esta presença traduziu-se também na colocação no terreno de uma força de observadores da UE, a Missão de Monitorização da UE (EUMM, da sigla em inglês). ${ }^{30}$ Apesar destes passos importantes, a Rússia não tem observado na sua totalidade o acordo assinado, e o andamento das negociações de paz tem sido muito lento, sugerindo que Moscovo tem seguido uma estratégia de limitação do impacto negativo que a presença internacional tem nos seus interesses estratégicos e de combate a esses efeitos.

O contexto securitário no Cáucaso do Norte e as suas implicações para a segurança dos Estados do Cáucaso do Sul, em especial para a estabilização da Geórgia (RFE/RL, 2012), fazem com que o estabelecimento de boas relações entre Moscovo e Tbilisi seja fundamental. Para além disso, a realização dos jogos olímpicos de inverno de 2014, em Sochi, a poucos quilómetros de distância da região da Abcázia, tem aumentado o nível de alerta das forças de segurança russas na região. Ilustrando isso, Moscovo desenvolveu exercícios militares no Cáucaso do Norte, em setembro de 2012.

30 Informação sobre a missão pode ser encontrada em www.eumm.eu. 
Segundo Shiriyev (2012), estes exercícios visam simultaneamente preparar as forças russas para um possível cenário de conflito armado entre Israel e o Irão e para possíveis atos de sabotagem e destabilização por parte das forças georgianas em Sochi. A gestão dos conflitos armados no Cáucaso do Sul é uma questão sensível no relacionamento de Moscovo com estas ex-repúblicas, quer pela capacidade de intervenção externa que propicia a Moscovo, quer pela incerteza que cria nas relações com os pequenos vizinhos do Cáucaso. Segundo de Waal (2012a), a própria política georgiana para o Cáucaso do Norte tem-se revelado "esquizofrénica", simultaneamente reconhecendo a instabilidade no norte e usando-a para pressionar Moscovo. Esta é uma situação que cria vulnerabilidades para as autoridades russas, especialmente tendo em conta a falta de relações políticas com a administração Saakashvili e o reconhecimento das autoridades abcáses e ossetas do sul como soberanas na gestão do seu território. A Rússia adaptou-se também aos novos desenvolvimentos nas relações entre a Turquia e a Arménia, concordando com o processo de normalização de relações entre estes dois Estados. Contudo, a Rússia mantém poder de veto sobre os conflitos da Eurásia e está hoje em melhor posição para controlar a região, apesar de ter retirado as suas forças militares da Geórgia, em 2007 (Antidze, 2007).

A Rússia parece ver o papel dos mediadores do conflito do Nagorno-Karabakh como sendo limitado, na procura de uma solução duradoura para o mesmo. Nesse sentido, devem ser os presidentes da Arménia e do Azerbaijão que devem dar os passos necessários para alterar a atual situação. Apesar dos esforços do presidente Medvedev para mediar o conflito durante 2011, promovendo encontros regulares ao mais alto nível entre os dois presidentes e conseguindo que assinassem, em outubro de 2010, o primeiro documento conjunto desde o cessar-fogo, a Declaração de Astrakhan, prevendo medidas de criação de confiança em áreas humanitárias, envolvendo a troca de prisioneiros de guerra, entre outros aspetos ${ }^{31}$.

31 Site do presidente russo, Встреча с президентами Азербайджана и Армении. Reunião com os presidentes do Azerbaijão e da Arménia, 27 de outubro de 2010, Astrakhan. Disponível em http://www.kremlin.ru/news/9350. Consultado em 20 fevereiro 2012. 
Em última análise, parece claro que a permanência do status quo é mais favorável aos interesses russos de curto prazo, do que a deterioração da situação no terreno. $\mathrm{Na}$ ausência de probabilidades realistas de alcançar um acordo, pequenas medidas de consolidação de confiança parecem ser uma estratégia adequada. A Rússia tem, por isso, apoiado medidas de diplomacia cultural, que resultaram na visita de representantes da Arménia e do Nagorno-Karabakh ao Azerbaijão, em 2007, e de representantes azeris à Arménia e ao território de Nagorno-Karabakh, em 2009, incluindo neste grupo, os embaixadores da Arménia e do Azerbaijão em Moscovo (Broers, 2010). O processo de normalização de relações entre a Arménia e a Turquia acabou por não obter resultados positivos para Moscovo, tendo tido um impacto negativo no processo de paz do Nagorno-Karabakh e colocando enorme pressão nas relações entre o Azerbaijão e a Turquia, o que joga a favor dos interesses de curto prazo da Rússia.

A influência turca na Arménia e no Azerbaijão diminuiu consideravelmente, ao mesmo tempo que a Rússia conseguiu revitalizar a sua imagem como um mediador ativo nos processos de paz. Deste modo, a Rússia tem demonstrado capacidade de adaptação ao novo contexto eurasiático, através de respostas integradas, onde elementos de soft power e uma diplomacia pública ativa assumiram um papel fundamental. Este curso permite-nos entender a evolução da política externa russa para o Cáucaso do Sul num sentido de normalização das relações, com base em interesses, bem como concessões que têm estado na base da construção das relações russas na e para com a área.

\section{Conclusão}

O reposicionamento russo face aos conflitos congelados da Eurásia ilustra o processo de adaptação de Moscovo às novas realidades de uma CEI integrada nos processos de globalização. A presença de outros atores internacionais como a UE e os EUA serviu como elemento catalisador do processo de normalização da política externa russa. Pese 
embora os argumentos que veem a presença militar russa na região como uma estratégia neocolonial, a visão de Moscovo como um ator de política externa normal nos conflitos da Eurásia traz algumas vantagens. A primeira vantagem é permitir uma análise mais objetiva dos interesses securitários russos no seu estrangeiro próximo. Este argumento tem sido instrumentalizado pelas elites russas e usado como uma justificação para a ingerência nos assuntos internos dos seus vizinhos. Contudo, as preocupações russas com a instabilidade armada nas suas fronteiras e o uso dos territórios vizinhos para organização dos movimentos separatistas do Cáucaso do Norte, incluindo a penetração do Islão radical, são preocupações legítimas.

Neste sentido, uma segunda vantagem da perspetiva das relações externas normalizadas é a necessidade de cooperação na área da segurança. O reconhecimento da interdependência securitária entre a Rússia e o Cáucaso do Sul é um passo importante no desenvolvimento de relações cooperativas que sejam enquadradas numa perspetiva de normalização. Ou seja, o reconhecimento da soberania dos pequenos Estados do Cáucaso, por parte da Rússia, deveria ser materializado em acordos de segurança cooperativa, onde a resolução dos conflitos fosse uma prioridade. Nesse sentido, a proposta de um novo tratado de segurança na Europa, avançada pelo presidente Medvedev, em Berlim em 2008 (RFE/RL, 2009), poderia reconciliar estas diferentes posições. Mas dada a incapacidade de traduzir a proposta avançada e reformulada num entendimento alargado, o uso de mecanismos existentes, sejam eles a OSCE, a parceria estratégica com a UE, ou mesmo a Parceria OTAN-Rússia no quadro da Aliança Atlântica, deverão permitir o desenvolvimento de propostas securitárias englobantes que alinhem e prossigam entendimentos cooperativos de segurança, numa ótica de promoção de uma comunidade alargada de segurança num entendimento lato de Europa. Num quadro de normalização da política externa russa, estes desenvolvimentos poderiam contribuir de forma definitiva para avanços significativos nos conflitos que se arrastam no espaço pós-soviético e para limitar dinâmicas de competição que objetam à construção de uma Europa assente em pressupostos de estabilidade. 


\section{Bibliografia}

ABBASOV, Shahin - Azerbaijan: Signs Point to Russia's Departure from Gabala Radar Base. Eurasianet, 25 julho 2012. [Acedido a 27 de set. de 2012]. Disponível na Internet: http:// www.eurasianet.org/node/65706.

ALLISON, Roy - Russia resurgent? Moscow's campaign to 'coerce Georgia to peace'. International Affairs. Vol. 84, N. ${ }^{\circ} 6$ (2008), p. 1145-1171.

ANTIDZE, Margarita - Russia Closes Last Military Base in Georgia. Reuters, 13 novembro 2007. [Acedido a 26 de out. de 2011]. Disponível na Internet: http://www.reuters.com/ article/2007/11/13/us-georgia-russia-bases-idUSL1387605220071113.

ARON, Leon - Everything you think you know about the collapse of the Soviet Union is wrong. Foreign Policy, N. ${ }^{\circ} 187$ (2011), p. 64-70.

BAEK, Jun Kee - Medvedev's Russia, a 'revisionist power' or an 'architect of a new world order'? The evolution of ideational factors and its cases. Korean Journal of Defense Analysis. Vol. 21, N. ${ }^{\circ} 4$ (2009), p. 455-484.

BEEHNER, Lionel - Russia's Energy Disputes. Council on Foreign Relations, 3 fevereiro 2010. [Acedido a 9 de jan. de 2012]. Disponível na Internet: http://www.cfr.org/energy/ russias-energy-disputes/p12327.

BRIDGE, Robert - Bye-bye Gabala? Russia may quit Soviet-era radar. RT, 24 maio 2012. [Acedido a 15 de set. de 2012]. Disponível na Internet: http://rt.com/politics/gabalaradar-russia-baku-nato-095/.

BROERS, Laurence - Opening Borders, Preserving Walls: Opportunities to Support the Karabakh Peace Process. Journal of Conflict Transformation Caucasus Edition. Vol. 3, N. ${ }^{\circ}$ 1, (2010). [Acedido a 26 de out. de 2011]. Disponível na Internet: http:// caucasusedition.net/wp-content/uploads/2010/05/Laurence-Broers_Final_approved_June1-issue.pdf.

CHUBAIS, Anatoly - Missiya Rossiyi v XX veke (A Missão da Rússia no Século XX). Nezavisimaya gazeta, 1 de Outubro 2003.

Conceito de Segurança Nacional - Permanent Representation of the Russian Federation to the Council of Europe, Estrasburgo (2000).

DELCOUR, Laure e DUHOT, Hubert - Bringing South Caucasus closer to Europe: Achievements and Challenges in ENP Implementation. Natolin Research Papers. N. ${ }^{\circ} 3$ Polónia, College of Europe, (2011) .

DE WAAL, Thomas - Violence Flares on the Georgian-Russian Border. The National Interest, 7 de setembro 2012. [Acedido a 28 de set. de 2012]. Disponível na Internet: http:// nationalinterest.org/commentary/violence-flares-the-georgian-russian-borders-7441.

DE WAAL, Thomas - A Crucial Election in Geórgia. Carnegie Endowment for International Peace commentary, 11 de Setembro 2012. [Acedido a 28 de set. de 2012]. Disponível na Internet: http://carnegieendowment.org/2012/09/11/crucial-election-in-georgia/drlp..

Entrevista - entrevista das autoras com Thea Tsolukiani, membro do Partido Free Democrats, Tbilisi, 9 de maio de 2011.

Economist, The - Georgia's wine industry: What doesn't kill us makes us stronger. 21 setembro 2010. [Acedido a 9 de jan. de 2012]. Disponível na Internet: http://www. economist.com/blogs/easternapproaches/2010/09/georgias_wine_industry.

FEKLYUNINA, Valentina - Battle for Perceptions: Projecting Russia in the West. Europe-Asia Studies. Vol. 60, N. ${ }^{\circ} 4$ (2008), p. 605-629.

Foreign Policy Concept - Russian Federation. Janeiro 1993. 
Foreign Policy Concept - Russian Federation. Approved by the President of the Russian Federation V. Putin, 28 junho 2000. [Acedido a 2 de mar. de 2011]. Disponível na Internet:http://www.fas.org/nuke/guide/russia/doctrine/econcept.htm.

Foreign Policy Concept - Russian Federation. Approved by Dmitry A. Medvedev, President of the Russian Federation, 12 julho 2008. [Acedido a 30 de mar. de 2011]. Disponível na Internet:http://www.mid.ru/ns-osndoc.nsf/1e5f0de28fe $77 f d c c 32575 d 900298676 / 869$ c9d2b87ad8014c32575d9002b1c38?OpenDocument.

Foreign Policy Concept - Russian Federation. Approved by President of the Russian Federation V. Putin, 12 fevereiro 2013. [Acedido a 3 de mar. de 2013]. Disponível na Internet:http:// www.mid.ru/brp_4.nsf/0/76389FEC168189ED44257B2E0039B16D.

FREIRE, Maria Raquel - Russian Foreign Policy towards its Neighbourhood: A Complex Mosaic of Relations. In Kanet, Roger E. e Freire, Maria Raquel, Competing for Influence: The EU and Russia in Post-Soviet Eurasia. Dordrecht: Republic of Letter Publishing, 2012.

FREIRE, Maria Raquel - A Rússia de Putin - Vectores Estruturantes de Política Externa. Coimbra: Almedina, 2012.

ISMAYILOV, Elnur - How Neo-Imperial Is Russia: Neo-Imperialism in the Foreign Policy of Russia Towards Post-Soviet Countries. Saarbrücken: VDM Verlag Dr. Müller, 2011.

IVANOV, Igor - The New Russian Identity: Innovation and Continuity in Russian Foreign Policy. The Washington Quarterly, Vol. 24, N. ${ }^{\circ} 3$ (2001), p. 7-13.

KARBUZ, Sohbet - The Caspian's Unsettled Legal Framework: Energy Security Implications. Journal of Energy Security, 18 maio 2010.

KJAERNET, Heidi - Giving Moscow A Taste of its Own Medicine: Azerbaijan. ADA Biweekly. Vol. I, N. ${ }^{\circ} 10,15$ junho 2008.

Kremlin - Press statements and answers to journalists' questions following a meeting with President of Armenia Serzh Sargsyan, Moscovo, 8 agosto 2012. [Acedido a 28 de set. de 2012]. Disponível na Internet: http://eng.kremlin.ru/transcripts/4274.

LIGHT, Margot - In search of an identity: Russian foreign policy and the end of ideology. Communist Studies and Transition Politics. Vol. 19, N. 3 (2003), p. 42-59.

NURIYEV, Elkhan - Putin's plan for Russia's neighbours - a Eurasian Union", Open Democracy, 19 março 2012. [Acedido a 15 de set. de 2012]. Disponível na Internet:http://www. opendemocracy.net/od-russia/elkhan-nuriyev/putin $\% \mathrm{E} 2 \% 80 \% 99$ s-plan-for-russia\%E2\%80\%99sneighbours-eurasian-union.

PARDO SIERRA, Oscar - Shaping the Neighbourhood: the Impact of the EU on Georgia. Europe-Asia Studies. Vol. 63, N. ${ }^{\circ} 8$ (2011), p. 1377-1398.

PATSURIA, Nino - Can Georgia find the backdoor for exports into Russia? Eurasianet, 17 Maio 2010. [Acedido a 9 de jan. de 2012]. Disponível na Internet:http://www.eurasianet. org/node/61079.

PUTIN, Vladimir - Speech at the 43rd Munich Conference on Security Policy", Munique, Alemanha, 10 fevereiro 2007. [Acedido a 26 de out. de 2011]. Disponível na Internet: http://www.securityconference.de/archive/konferenzen/rede.php?menu_konferenzen= \&menu_2007=\&id=179\&.

PUTIN, Vladimir - Novyi integratsionnyi proekt dlya Evrazii - budushchee kotoroe rozhdaetsya segodnya. Izvestia, 3 outubro 2011. [Acedido a 28 de set. de 2012]. Disponível na Internet: http://www.izvestia.ru/news/502761.

RFE/RL - Russia unveils proposal for European security treaty. Radio Free Europe/Radio Liberty, 30 novembro 2009. [Acedido a 9 de jan. de 2012]. Disponível na Internet: http://www.rferl. org/content/Russia_Unveils_Proposal_For_European_Security_Treaty/1891161.html. 
RFE/RL - Deal Signed On Extending Russian Military Presence In Armenia. Radio Free Europe/Radio Liberty, 20 agosto 2010. [Acedido a 26 de out. de 2011]. Disponível na Internet: http://www.rferl.org/content/Russia_Armenia_Sign_Extended_Defense_ Pact_/2133043.html.

SAKWA, Richard - The Rise and Fall of the Soviet Union. London: Routledge, 1999.

SERVICE, Robert - A History of Modern Russia: From Nicholas II to Vladimir Putin. Cambridge, Massachusetts: Harvard University Press, 2003.

SOCOR, Vladimir - Standing Up to Putin's Imperial Ambitions. The Moscow Times, 19 setembro 2003. [Acedido a 30 de ago. de 2012]. Disponível na Internet: http://online. wsj.com/article/0,,SB106392013285091900,00.html.

TORBAKOV, Igor - Russia and Turkish-Armenian Normalization: Competing Interests in the South Caucasus. Insight Turkey. Vol. 12, N. ${ }^{\circ} 2$ (2010), p. 31-39.

TSYGANKOV, Andrei P e TARVER-WAHLQUIST, Matthew - Duelling Honors: Power, Identity and the Russia-Georgia Divide. Foreign Policy Analysis. Vol. 5, N. ${ }^{\circ} 4$ (2009), p. 307-326.

TSYGANKOV, Andrei P. - Mastering space in Eurasia: Russia's geopolitical thinking after the Soviet break-up. Communist and Post-Communist Studies. Vol. 36,N. ${ }^{\circ} 1$ (2003), p. 101-127.

VAN DER LOO, Guillaume e VAN ELSUWEGE, Peter - Ukraine's Regional Economic Integration: Stuck in the Middle between Its Neighbours? A Legal and Political Analysis. Artigo apresentado na conferência 'Exchanging Ideas on Europe 2012: Old Borders - New Frontiers', 3-5 setembro 2012, Passau, Alemanha.

WALLANDER, Celeste - The Economization, Rationalization and Normalization of Russian Foreign Policy. PONARS, Policy Memo 1, Harvard University, 1997.

WALLANDER, Celeste - Russian Transimperialism and its Implications. The Washington Quarterly. Vol. 30, N. ${ }^{\circ} 2$ (2007), p. 107-122.

ZVEREV, A. - Ethnic Conflicts in the Caucasus 1988-1994. In Coppieters, Bruno (org.) Contested Borders in the Caucasus. Brussels: Vubpress, 1996. [Acedido a 26 de out. de 2011]. Disponível na Internet:http://poli.vub.ac.be/publi/ContBorders/eng/. 
(Página deixada propositadamente em branco) 
CAPÍTULO 4

\section{A RúSSIA E A ÁSIA CENTRAL: GLOBALIZAÇÃO E COM P E T I Ç Ã O H E G E M Ó I C A}

Licínia Simão

\section{Introdução}

A presença da Federação Russa no espaço da Ásia Central, incluindo as cinco ex-repúblicas Soviéticas (Cazaquistão, Quirguistão, Tajiquistão, Turquemenistão e Uzbequistão) tem vindo a reforçar-se de forma gradual desde o fim da União Soviética (União das Repúblicas Socialistas Soviéticas, URSS). À medida que a política externa russa abandonou o ocidente como prioridade central, após o período de entusiasmo inicial, e se concentrou na afirmação de uma esfera de influência no seu 'estrangeiro próximo' (na Comunidade de Estados Independentes (CEI)), visível já, em meados da década de 1990, as relações com a Ásia Central voltaram a ser uma parte fundamental dos interesses russos. A reentrada da Rússia neste espaço geográfico coincidiu, contudo, com a abertura da Ásia Central às dinâmicas da globalização económica e geopolítica, dividindo a região entre polos distintos de atração: o ocidente, a Rússia e a China. Na área económica, a atuação das organizações internacionais de desenvolvimento como as Nações Unidas e o Banco Mundial, a par dos investimentos dos Estados Unidos da América (EUA) e das potências europeias no sector energético, foram fatores fundamentais de sustentabilidade financeira, enquanto a entrada da China nos mercados centra-asiáticos abriu importantes novas possibilidades de desenvolvimento socioeconómico. A nível 
político e de segurança, as oportunidades de cooperação com a potência global, os Estados Unidos, com a Organização do Tratado do Atlântico Norte (OTAN) e a Organização para a Segurança e Cooperação na Europa (OSCE), reforçaram a presença ocidental e deram um sinal importante de envolvimento na região. Este contexto conduziu, contudo, também ao desenvolvimento de dinâmicas competitivas entre os interesses ocidentais e a Rússia e a China, principalmente no âmbito da cooperação regional de segurança, materializadas na Organização de Cooperação de Xangai (OCX).

A política externa russa teve, pois, de lidar com esta realidade complexa à medida que definia as suas prioridades nesta região. Efetivamente, o processo de reafirmação dos interesses russos evidenciou, numa fase inicial, uma natureza reativa aos acontecimentos no terreno (por exemplo, à guerra civil no Tajiquistão ou à presença crescente das companhias energéticas ocidentais no Cáspio). Com a chegada do presidente Putin ao Kremlin, em 2000, os interesses russos na região tornam-se mais claros e a estratégia de atuação tornou-se mais determinada, em resposta a estas novas dinâmicas. O recurso à institucionalização da cooperação económica e de segurança foi uma forma, relativamente barata, de manter a região sob influência de Moscovo, por exemplo através da criação da Comunidade Económica da Eurásia (CEdE) ou do Tratado de Segurança Coletiva (TSC) ${ }^{32}$, em 1992, ao passo que o investimento nos recursos energéticos se adequou à estratégia russa de se transformar na principal potência energética da Eurásia. Num momento em que o acesso aos recursos energéticos é uma questão central para o crescimento económico internacional, o monopólio russo sobre o acesso às reservas energéticas da Ásia Central, que se manteve até 2009, foi uma peça importante na afirmação internacional russa (Kramer, 2009).

Por fim, a mais recente dinâmica a afetar os processos de globalização e competição hegemónica na Ásia Central foi a guerra global contra o terrorismo. Após os acontecimentos de 11 de setembro de 2001 nos EUA

32 O TSC é uma aliança de defesa mútua, que estabelece mecanismos de consulta e assistência militar, no caso de ataque externo a um dos seus membros (Arménia, Bielorrússia, Cazaquistão, Quirguistão, Federação Russa, Uzbequistão e Tajiquistão). Em maio de 2002, foi estabelecida a Organização do Tratado de Segurança Coletiva. 
e a consequente guerra no Afeganistão, os regimes da Ásia Central passaram a estar no centro da atenção internacional. Não só a potência global, os EUA, se apresentou sensível ao problema do terrorismo, que era desde a independência um problema grave para as sociedades da Ásia Central (incluindo o Afeganistão), como se apresentou disponível para atuar militarmente. Para a Federação Russa, este foi, porventura, o maior desafio aos seus interesses, já que, até esta altura, a Rússia mantinha o monopólio da presença militar externa na Ásia Central. Face aos processos de crescente interdependência global e à sua sobreposição às dinâmicas de competição hegemónica nesta região, a segurança da Ásia Central tornou-se objeto de disputa, mais do que de reflexão cuidada e de cooperação. Para a Federação Russa, estes foram desafios importantes para a sua política externa pós-Guerra Fria, não só por a Ásia Central ser um dos últimos redutos de influência no espaço da ex-URSS, mas também pelas dinâmicas de interdependência que regulam o atual sistema internacional e que ligam os interesses de Moscovo, com os de Pequim e de Washington.

\section{Competição hegemónica}

Alguns autores sugerem que a Rússia está destinada a permanecer um ator fundamental na Ásia Central, mesmo que não represente o destino final desta região (Garnett, Rahr e Watanabe, 2000, p. 71). A abertura da Eurásia aos processos de interdependência e competição globais representa um leque vasto de novas possibilidades para estes Estados, usado para manter a Rússia a uma distância de segurança, no que concerne a afirmação pós-independência das nacionalidades da Ásia Central e a persecução dos interesses das elites nacionais.

Entre estas possibilidades está a cooperação com os EUA e a OTAN. Logo, isto significa que qualquer processo de reafirmação hegemónica da Rússia nesta região está destinado a entrar em conflito direto com a presença e os interesses da potência hegemónica global, ou seja, os EUA. Podemos pois falar de uma hegemonia multinível na Ásia Central (Deyermond, 2009), onde se incluem a potência hegemónica global (os EUA), uma 
potência hegemónica regional em reafirmação (a Rússia), uma potência aspirante a nível sub-regional (o Uzbequistão) (Deyermond, 2009, pp. 162-164; Buzan e Waever, 2003, p. 425), bem como potências hegemónicas externas aspirantes, como a China e a Índia (Laruelle, Peyrouse, Huchet e Balci, 2010). Este cenário complexo torna os cálculos de todos os atores envolvidos muito incertos, aumentando a possibilidade de competição estratégica, em detrimento de abordagens mais cooperativas, face aos desafios que se colocam à segurança regional, tal como analisado mais à frente, neste capítulo.

O modelo da hegemonia multinível é particularmente útil para tratar as relações de poder de natureza muito complexa na região da Ásia Central, uma vez que fornece um quadro analítico para abordar, de forma relacional, os interesses dos diferentes atores presentes nesta região e como estes são constrangidos ou potenciados nas suas relações com outras potências hegemónicas neste contexto regional. Quando há coincidência de interesses entre potências hegemónicas, Deyermond (2009, p. 151) apelida esta situação de um "modelo hegemónico matrioska [onde] as potências hegemónicas nos diferentes níveis podem acomodar-se mutuamente, de forma pacífica e formar alianças, quando os seus interesses coincidirem". Esta é uma visão informada pela escola realista das Relações Internacionais, onde a cooperação é possível e desejável apenas quando isso reforçar os interesses dos atores envolvidos. A cooperação não é, pois, um objetivo em si, senão uma necessidade de curto prazo e que pode ser revogada quando o cálculo de interesses for alterado. Perante esta lógica, partilhada pela maioria dos atores estatais nesta região, a possibilidade de desenvolver e enraizar uma visão cooperativa, como resposta aos desafios regionais, parece também não ser suportada pelos parceiros externos da região.

O modelo da hegemonia multinível é também relevante para avaliar o potencial de conflito em regiões onde a competição hegemónica se desenvolve, como é o caso da Ásia Central. Este modelo concebe a hegemonia como "um conceito multifacetado, em que a hegemonia num dos níveis representa um desafio à hegemonia noutro nível, mas não a faz desaparecer" (Deyermond, 2009, p. 157). Além disso, perante a possibili- 
dade de coexistência hegemónica multinível, o potencial de conflito entre as diferentes potências hegemónicas deve ser avaliado tendo por base a natureza complexa das suas relações, onde a competição e a cooperação são possíveis em diferentes níveis. Quais são, então, as possibilidades de acomodação e cooperação ao nível sub-regional, na Ásia Central? De que forma tem a potência regional gerido o desafio colocado pela potência hegemónica global e as potências hegemónicas externas aspirantes? Poderão existir compensações de outras áreas de interação entre potências hegemónicas, com impacto no contexto regional da Ásia Central?

A interação entre a Federação Russa e os EUA tem sido, porventura, um dos factores de maior destabilização regional na Ásia Central, desde o fim da Guerra Fria. Se analisarmos a forma como ambos têm gerido as suas ambições na região, podemos verificar que a presença norte-americana tem-se pautado por uma lógica imediatista, conduzida por interesses voláteis, definidos conforme a Administração na Casa Branca e sem um plano de longo prazo de estabilização e desenvolvimento da região. Por isso, são visíveis momentos e áreas de interesse, como foi a década de 1990 e o investimento no acesso às reservas energéticas do Cáspio, sob pressão das grandes companhias energéticas norte-americanas. Depois dos acontecimentos de 11 de setembro de 2001, e face à guerra global contra o terrorismo e às operações militares no Afeganistão, a importância estratégica da Ásia Central para a potência hegemónica global aumentou exponencialmente. Hoje, a estabilização do Afeganistão e dos seus vizinhos é uma prioridade da Administração Obama, no âmbito da anunciada retirada militar do cenário afegão, em 2014. Esta política norte-americana de interesses pragmáticos de curto prazo tem sido vista pela Rússia como um desafio direto aos seus interesses e à sua posição no contexto da Ásia Central, principalmente por oferecer aos líderes regionais uma alternativa às relações com Moscovo, o que tem consolidado a competição como a principal característica nas relações regionais. No entanto, por ser um envolvimento pragmático, ditado por interesses concretos ligados principalmente ao conflito afegão, Moscovo sabe que esta presença norte-americana pode ser revista quando outros interesses mais relevantes surgirem. 
Esta situação apresenta dois problemas para a estabilização regional. Primeiro, a falta de um compromisso alargado e de longo prazo com a estabilidade e a segurança na Ásia Central, nomeadamente interligando a guerra contra as forças talibãs no Afeganistão ao combate ao tráfico de droga e à cooperação para o desenvolvimento na Ásia Central. As políticas de interesses imediatos norte-americanas têm conduzido a compromissos hesitantes com as reformas democráticas e de direitos humanos, numa região onde o autoritarismo é frequentemente recompensado. Estas são áreas que a potência hegemónica global poderia fazer valer na região, face a outras potências como a Rússia ou a China, mas que Washington vê como enfraquecendo a sua posição, ao invés de a fortalecer. Este é um entendimento que tem em linha de conta a posição das elites da Ásia Central, para quem a permanência no poder é o objetivo máximo, em detrimento de uma visão mais solidária com os povos da região, para quem as potências ocidentais representam (ainda que com crescente relutância) um imaginário de igualdade e prosperidade. Nesse sentido, a dimensão normativa da política externa dos EUA é simultaneamente um problema nas suas relações com os regimes ditatoriais da região e insuficiente para exigir reformas e mudanças estruturais.

O segundo problema resulta da sobreposição entre os esforços dos EUA e da Rússia para se (re)afirmarem como potências no contexto euroasiático, no pós-Guerra Fria, e da crescente complexidade das relações entre os dois atores ao nível global. Na década de 1990, e perante o aumento da presença norte-americana no Cáspio, a Rússia procurou reforçar a sua presença comercial na região, fazendo uso dos laços privilegiados herdados da URSS. Já sob liderança do presidente Putin, o Kremlin iniciou também um processo de reafirmação regional, incluindo uma gradual revisão das estruturas de cooperação lideradas pela Rússia e fazendo uso do seu significativo orçamento, como resposta aos desafios da guerra global contra o terrorismo e à presença militar dos EUA na Ásia Central. Finalmente, e desde os acontecimentos de Andijon, no Uzbequistão, em $2005^{33}$, a influência russa consolidou-se junto dos líderes regionais, fruto

33 A 13 de maio de 2005, um protesto juntou cerca de 10000 pessoas na cidade uzbeque de Andijon, no Vale de Fergana, em resposta ao julgamento de 23 empresários locais, 
do apoio político de Moscovo ao princípio de não ingerência nas questões internas dos Estados. Esta opção revelou-se particularmente proveitosa, tendo em conta a reação europeia e norte-americana de impor sanções ao regime de Tasquente, incluindo o fim do uso da base aérea uzbeque, de Khanabad, pelas tropas aliadas, na guerra do Afeganistão, a partir de novembro de 2005.

Esta é, pois, uma situação em que os EUA e a Rússia têm competido diretamente, embora tenham também entrado em cooperação, nomeadamente após o 'reset' de relações entre Washington e Moscovo, com as administrações Obama e Medvedev. A política de 'reset' de relações com Moscovo foi uma das primeiras iniciativas de política externa da administração Obama, com o objetivo de "reverter a "perigosa deriva" 34 em curso nas relações bilaterais entre os EUA e a Federação Russa, manifesta principalmente durante o segundo mandato do presidente George W. Bush. No âmbito desta política, as questões de armamento nuclear, cooperação com a OTAN e os esforços de guerra no Afeganistão têm sido áreas onde os dois atores têm conseguido encontrar terreno mútuo de entendimento, principalmente face aos fracos resultados da cooperação dos EUA com a potência regional em aspiração, o Uzbequistão. Em linha com o quadro de análise da hegemonia multinível, isto abre possibilidades simultâneas de cooperação, nomeadamente na estabilização do Afeganistão, e dinâmicas de competição, relativamente à presença militar e aos recursos energéticos.

A política de 'reset' não tem sido suficiente para alterar esta situação, apesar das numerosas oportunidades de cooperação com vista a uma estabilização regional e global e, hoje, encontra-se virtualmente extinta com o regresso ao Kremlin do Presidente Putin e o contexto crispado das relações EUA-Rússia face aos conflitos no Médio Oriente, em especial

acusados pelo regime de Islam Karimov de serem extremistas islâmicos ligados à organização pan-islâmica Hizb ut-Tahrir. As tropas uzbeques enviadas para o local abriram fogo, matando centenas de pessoas (os números exatos são desconhecidos).

${ }^{34}$ Informação disponível na página oficial da Casa Branca, "U.S.-Russia Relations: 'Reset' Fact Sheet", The White House, Office of the Press Secretary, 24 de junho de 2010. http:// www.whitehouse.gov/the-press-office/us-russia-relations-reset-fact-sheet. Consultado em: 14 fevereiro 2012. 
a guerra na Síria. A guerra no Afeganistão foi, naturalmente, a principal oportunidade para desenvolver esta cooperação entre os dois atores. A Rússia afirmou o seu compromisso em dar assistência aos esforços de guerra das potências ocidentais e partilha com elas um interesse genuíno em travar o islamismo radical no seu estrangeiro próximo e em limitar o impacto pernicioso que o tráfico ilícito de drogas tem na sua própria sociedade. No entanto, a Rússia vê a guerra no Afeganistão como um trunfo nas suas relações com os EUA e a OTAN (Stepanova, 2009, p. 2), aumentando a relevância estratégica de Moscovo. Perante esta instrumentalização do contexto regional de segurança nos cálculos estratégicos de poder e influência de ambos os atores, existe o risco de, nem os EUA definirem uma estratégia coerente de luta contra o tráfico de drogas e as atividades transnacionais terroristas na Ásia Central, nem a Rússia reconhecer a importância fundamental de estabilizar o Afeganistão, com vista ao controlo do tráfico de droga e dos movimentos islâmicos de cariz radical. A forma como Washington e Moscovo gerirem entre si a estabilização da Ásia Central, no contexto pós-guerra do Afeganistão, será crucial. Neste sentido, a intenção norte-americana de criar uma base militar permanente em território afegão e os receios russos de que a gestão da segurança regional seja deixada exclusivamente ao seu cuidado podem significar que, no futuro, algum nível de cooperação será possível, apesar da retórica inflamada entre as partes. Uma posição clara em Moscovo passa por aceitar envolver-se na reconstrução do Afeganistão, mas está fora de questão um envolvimento militar.

Os processos eleitorais na Rússia (eleições presidenciais em março de 2012) e nos EUA (eleições presidenciais em novembro de 2012) traduziram-se numa maior atenção às questões internas em detrimento de grandes decisões de política externa. Da nova Rússia de Putin, emergem sinais de maior contestação ao presidente e de maior fragmentação do Kremlin (Freire, 2012, p. 71) que poderão criar novas tensões nas relações com o ocidente e os EUA. Em Washington, a polarização do espectro político tem tido consequências preocupantes no que toca às relações com a Rússia. Se por um lado, o primeiro mandato de Obama procurou reconciliar “a visão grandiosa do presidente com o seu realismo inato e cuidado 
político" (Indyk, Kenneth e O'Hanlonthe, 2012), que no caso das relações com a Rússia e da interação entre os dois na Ásia Central se traduziu em ganhos de estabilidade imediata e apoio à estratégia norte-americana de retirada do Afeganistão, por outro lado, a visão de política externa apresentada pelo partido republicano durante a campanha presidencial norte-americana foi criticada como sendo "um regresso a uma ideologia neoconservadora intimidatória" (Jentleson e Kupchan, 2012). No caso concreto das relações com a Rússia, o candidato republicano prometia reverter o processo de aproximação a Moscovo, caracterizando o regime no Kremlin como corrupto e autoritário e a Rússia como o principal inimigo dos EUA. Uma caracterização que a imprensa russa denunciou ativamente (Friedman, 2012). A reeleição de Obama em novembro de 2012 confirmou que as relações dos EUA com Moscovo são centrais para resolver a guerra no Afeganistão e para a estabilização da Ásia Central.

\section{O complexo contexto de segurança da Ásia Central}

O estabelecimento e consolidação de Estados-nação soberanos na Ásia Central foram processos essencialmente pacíficos ao longo do período pós-Guerra Fria. Uma das áreas de tensão atual e de potencial conflito é a natureza arbitrária das fronteiras da região e a sua falta de delimitação. As fronteiras da Ásia Central foram desenhadas por Estaline, visando garantir que os principais grupos étnicos da União Soviética estivessem politicamente representados ao nível das repúblicas. Neste processo, largas minorias ficaram deslocadas, fora das fronteiras das novas repúblicas soviéticas, o que impediu a consolidação de identidades étnicas que pudessem vir a pôr em causa o poder central de Moscovo. Embora as fronteiras fossem aspetos meramente simbólicos dentro da União Soviética, depois de 1991 tornaram-se objeto de disputa. Um dos passos mais importantes para resolver a questão das fronteiras na região foi a decisão chinesa de procurar um acordo com o Cazaquistão, o Quirguistão e o Tajiquistão sobre a delimitação e desmilitarização da fronteira comum, de cerca de 3000 quilómetros (Xing, 2001, p. 154), no âmbito do Fórum de Xangai. Por oposição, uma 
das áreas onde a delimitação de fronteiras ainda não foi possível é o Mar Cáspio, o que representa um obstáculo ao desenvolvimento dos recursos energéticos da região (Pratt e Schofield, 1997; Janusz, 2005).

O Vale de Fergana é, de longe, o assunto mais complexo, no que toca à delimitação de fronteiras na Ásia Central. Grandes secções das fronteiras entre o Uzbequistão e o Quirguistão e entre o Uzbequistão e o Tajiquistão permanecem sob disputa. Um outro factor adicional de tensão é o facto de esta ser a zona mais fértil de toda a Ásia Central, com recursos naturais como terra arável e água a serem disputados. Embora a maior parte das disputas tenha sido gerida a nível local, entre as diferentes comunidades, existe potencial para conflito inter-estatal (Swanstrom, Cornell e Tabishalieva, 2005, p. 17). As preocupações uzbeques com o terrorismo e a luta do regime contra o Movimento Islâmico do Uzbequistão (MIU), particularmente ativo no Vale de Fergana, tornaram a gestão das fronteiras e a segurança transfronteiriça num problema regional. Ilustrando esta questão, em 1999, o Uzbequistão fechou as suas fronteiras no Vale e lançou ataques aéreos sobre o sul do Quirguistão, após duas explosões em Tasquente. Os ataques aéreos, sem autorização quirguiz, provocaram a morte da uma dezena de civis e elevaram o nível de tensão entre os dois vizinhos (Internation Crisis Group, 2002b, p. 14). A presença de enclaves uzbeques no Quirguistão e a importante minoria uzbeque no norte do Tajiquistão têm sido usadas pelo regime de Islam Karimov, para exercer pressão sobre os seus vizinhos mais pequenos e mais pobres, em disputas de água e na luta contra a ameaça islâmica radical, com vista à consolidação de uma posição hegemónica sub-regional.

As disputas fronteiriças tornam-se particularmente complexas quando se sobrepõem a ameaças de segurança não tradicionais e de natureza transnacional. Redes de crime organizado transnacional têm-se infiltrado na Ásia Central, alimentando-se do lucrativo narcotráfico do Afeganistão e minando as instituições nacionais. A maior fatia do narcotráfico vindo do Afeganistão ocorre hoje ao longo da antiga Rota da Seda, pela Ásia Central (Fenopetov, 2006), em parte devido à falta de controlos fronteiriços funcionais. O narcotráfico, tal como as preocupações com a ameaça terrorista, têm materializado e endurecido as fronteiras terrestres da 
CEI (Allison, 2001, p. 258), com impacto negativo nos processos de integração económica e de desenvolvimento social. O narcotráfico afeta também a legitimidade das instituições nacionais (Lubin, 2004, p. 364), conduzindo a situações de "captura de Estados" (Cornell, 2006), especialmente no Quirguistão e no Tajiquistão. A crise política de abril de 2010 no Quirguistão, que conduziu à queda do presidente Bakiev, lançou luz sobre o nível de cooperação da elite no poder com as redes de crime organizado ativas no sul do país e ilustrou os perigos subjacentes ao cruzamento de divisões de natureza étnica, regional e social com interesses criminosos (Marat, 2008; 2010).

O narcotráfico na Ásia Central tem contribuído também para o aumento de pandemias e consumo de drogas, afetando o frágil tecido social desta região. Os níveis de pobreza mantêm-se extremamente elevados. No período imediato após o fim da URSS, entre 1990 a 1996, a diminuição do PIB das economias da Ásia Central situou-se entre os 20 e $60 \%$, tendo os efeitos desta drástica contração económica sido geridos com recurso a elevados níveis de endividamento (Hill, 2002), mas com consequências sociais devastadoras. Apesar de nos últimos anos os países da região terem apresentado crescimento económico sustentável, o impacto da crise financeira internacional de 2008 tem sido visível, parando as taxas de crescimento impressionantes do Cazaquistão e limitando de forma drástica as remessas dos emigrantes quirguizes e tajiques na Rússia (Pomfret, 2009; Gullette, 2010).

A falta de desenvolvimento económico generalizado e sustentável na Ásia Central também reflete a distribuição desigual de recursos naturais da região, onde coexistem países ricos em recursos energéticos, como o petróleo e o gás natural (o Cazaquistão, o Turquemenistão e o Uzbequistão), e países mais pobres (Quirguistão e Tajiquistão). Estes últimos controlam os recursos hídricos da região, o que lhes dá alguma margem de manobra nas suas relações com o vizinho Uzbequistão, cuja economia é altamente dependente da produção de algodão - uma cultura com uso intensivo de água (Internation Crisis Group, 2005, pp. 2-6). Além disso, a produção de energia hidroelétrica é uma das áreas de maior investimento em ambos os países, criando uma fonte de rendimento e de orgulho nacional. A 
falta de regulamentação do uso da água e da troca de água por energia faz da gestão dos recursos hídricos um tema urgente na segurança regional, com vista a evitar a escalada de tensões (Internation Crisis Group, 2002a).

Por fim, as preocupações com o terrorismo têm sido outro assunto crucial na segurança da Ásia Central, com impacto nas dinâmicas internas e externas da região. Apesar do terrorismo islâmico radical ser uma fonte muito real de preocupação para as sociedades da Ásia Central, tem sido feito um uso instrumental do Islão pelos regimes autoritários da região. É o caso no Uzbequistão, mas também no Tajiquistão e de forma mais limitada no Quirguistão (The Economist, 2010). O 11 de setembro de 2001 e o envolvimento norte-americano na região reforçaram ainda mais esta tendência de ver qualquer movimento islâmico como uma ameaça à segurança, criminalizando os movimentos religiosos ressurgentes da Ásia Central. A Rússia também considera estes movimentos islâmicos, com ligações ao Afeganistão, como uma ameaça à sua segurança, especialmente no Cáucaso do Norte. Não é, pois, surpreendente que esta tenha sido uma das áreas de maior cooperação entre Moscovo, Washington e os regimes da Ásia Central, com implicações importantes para a estabilidade regional. Contudo, o resultado desta cooperação tem sido o reforço destes regimes autoritários e repressivos, usando a bandeira do Islão radical para restringir liberdades cívicas. Tem também conduzido a uma incapacidade crónica de lidar com as ameaças à segurança, provenientes das redes terroristas transnacionais, que operam livremente na Ásia Central, com impactos muito reais na vida das populações da região.

\section{A Ásia Central na Política Externa da Federação Russa}

\section{Da independência ao 11 de setembro}

No período imediato pós-Guerra Fria, as elites russas em Moscovo demonstraram uma clara falta de visão relativamente ao futuro das relações da Rússia com o antigo império. Alguns elementos da nomenkla- 
tura defenderam que se deveria "largar o fardo pesado do ventre mole da Ásia Central" (Solzhenitsyn, citado em Rashid, 1994, p. 39; ver também Jonson, 2001, pp. 96-97). Por outro lado, a Rússia liderou a criação da CEI, com vista a gerir um 'divórcio civilizado' das Repúblicas Soviéticas e assisti-las na sua passagem para a independência (Sakwa e Webber, 1999; Markedonov, 2010). As relações da Rússia com os novos Estados independentes da Ásia Central foram simultaneamente complicadas e facilitadas pelo legado anterior. Por um lado, a política externa da Rússia independente deu prioridade às relações com o ocidente, fruto do desejo de afirmação nacionalista russa e das políticas de abertura e aproximação ao ocidente, protagonizadas por Gorbachev (Jackson, 2003, p. 55). Isto traduziu-se numa negligência inicial das relações com o antigo império, por necessidade de concentrar recursos na gestão dos problemas internos da Federação Russa e face à perceção generalizada de que qualquer tentativa de interferir nas políticas nacionais seria vista com desconfiança pelas elites da Ásia Central. As relações com a antiga potência colonial teriam de ser temperadas pelo entusiasmo nacionalista que varreu também esta região, daí que possamos dizer que a herança colonial e o contexto interno russo favoreceram um afastamento inicial.

No entanto, e face às dificuldades trazidas pela independência, alguns dos líderes da Ásia Central expressaram a sua incerteza face ao futuro da região e face ao que significaria um afastamento da Rússia. Aliás, a região da Ásia Central foi a única a votar contra o fim da União Soviética, no referendo popular de 1991. Perante esta realidade, em dezembro de 1991, a Rússia, a Bielorrússia e a Ucrânia estabeleceram a CEI e, em 1993, as cinco repúblicas centro-asiáticas aderiram à organização, reconhecendo "uma necessidade funcional de cooperação", que visava suprimir as suas necessidades militares e económicas (Sakwa e Webber, 1999, p. 381). Por isso, a colaboração com a Rússia era simultaneamente necessária, face às limitações de facto das soberanias na Ásia Central, e indesejada, tendo em conta o período pós-independência de afirmação nacionalista na região.

Em termos securitários, a guerra civil tajique, entre 1992 e 1997, representou o principal desafio à capacidade russa de influenciar a reestruturação das relações regionais. As tropas russas, que permaneciam 
na região desde o período soviético, intervieram no conflito e Moscovo envolveu-se no processo de paz, mediando uma solução para a guerra no quadro da CEI (Akiner, 2001, pp. 45-46). Outra preocupação central de segurança nas relações da Rússia, principalmente com o Uzbequistão, prendeu-se com os movimentos islâmicos radicais ativos no Vale de Fergana. Apesar dos desacordos entre Moscovo e Tasquente sobre a forma como gerir a situação no Tajiquistão, a Rússia, o Uzbequistão, o Cazaquistão e o Quirguistão concordaram em estabelecer o TSC, em 1992, em Tasquente, consolidando a cooperação de segurança e defesa no quadro da CEI (Cutler, 2006, p. 112).

Em meados da década de 1990, as políticas da Rússia para a Ásia Central alteraram-se significativamente, rumo a um envolvimento mais forte, numa altura em que o primeiro ministro Evgeny Primakov promovia o 'Eurasianismo' como o princípio central das relações da Rússia com o seu estrangeiro próximo. Isto refletia um desejo claro de recuperar o estatuto de superpotência (Jonson, 2001, p. 97), através do reforço de uma posição hegemónica na CEI e da oportunidade de consolidar uma doutrina de interesses especiais russos na ex-URSS, tal como definido já por Ieltsin e o ministro dos negócios estrangeiros Andrei Kozyrev. O Conceito de Política Externa da Federação Russa e a Doutrina Militar de 1993 confirmaram a tentativa russa de se posicionar como o principal garante político e de segurança no espaço pós-soviético (uma potência hegemónica regional), bem como o seu direito de intervir na CEI para proteger os cidadãos russos na região (Conceito de Política Externa da Federação Russa, 1993).

Durante o segundo mandato de Ieltsin, a Rússia procurou consolidar a sua presença na CEI, num equilíbrio entre o reconhecimento formal da independência dos seus vizinhos e das suas necessidades de segurança. A Rússia viu com preocupação a expansão da presença ocidental no Cáspio e na Ásia Central e procurou contrabalançá-la, uma vez que representava uma ameaça aos seus interesses e um desafio aos seus esforços de se restabelecer como uma potência hegemónica regional. Estes desafios incluíram a construção de novos oleodutos e gasodutos fora do território russo, a expansão da OTAN e o aprofundamento 
das relações entre a Aliança Atlântica e os países da CEI, através da Parceria para a Paz (PpP), bem como a cooperação militar bilateral dos EUA com a Ásia Central (Burghart, 2007, p. 8). Não é, por isso, surpreendente que a competição com os EUA tenha aumentado nos anos anteriores ao 11 de setembro, tendo culminado com a guerra na Geórgia, em 2008.35

\section{De Putin a Medvedev}

Antes das eleições presidenciais russas de março de 2000, desenvolveu-se uma nova visão da política externa e de segurança russa. O Conceito de Política Externa da Federação Russa e a Doutrina Militar de 2000 viam claramente a limitação dos interesses russos como uma ameaça central e sublinhavam a promoção de uma ordem internacional multipolar como um princípio fundamental, que deveria guiar as relações internacionais (Jonson, 2001, p. 99). Ambos os documentos refletiram um reconhecimento tácito da validade limitada que os modelos de desenvolvimento económico e político ocidentais tinham para a Rússia e abriam caminho a divergências crescentes. A crise financeira de 1998 e a crise socioeconómica que se seguiu expôs a assistência limitada que o ocidente estava disposto a estender a Moscovo e exigiu um modelo novo, mais adequado às vantagens competitivas russas. Isto significava colocar os recursos naturais no centro da atividade económica, numa altura em que os mercados internacionais começavam a beneficiar os países exportadores de petróleo e gás natural. Politicamente, a Rússia estava também longe de alcançar os padrões democráticos que os parceiros ocidentais esperavam. No Cáucaso do Norte, a gestão que Moscovo fez das guerras

35 A breve guerra de cinco dias, que opôs as forças russas e georgianas, deflagrou após a intervenção georgiana na república separatista da Ossétia do Sul, a 5 de agosto de 2008, numa tentativa de reintegrar esta região no Estado georgiano. Em apoio às autoridades separatistas, Moscovo interveio militarmente no conflito, tendo mesmo chegado a ameaçar a capital Tbilisi e o regime do presidente Saakashvili. Para um relato detalhado do contexto e acontecimentos desta guerra ver Asmus (2010). 
na Chechénia, colocou a Rússia no centro das críticas internacionais, consolidando uma clara necessidade de um modelo de desenvolvimento político alternativo para a Rússia (Kobrinskaya, 2005, p. 78).

Estas questões facilitaram a reaproximação de Moscovo aos líderes da Ásia Central. Depois de uma década de dificuldades na consolidação da independência e de grandes desilusões com as promessas do ocidente, estes líderes procuraram envolver novamente a Rússia nas questões regionais. Com o presidente Putin, Moscovo iniciou uma abordagem, preparada mais cautelosamente, de reafirmação da sua presença na Ásia Central e no Cáspio. Isto traduziu-se na institucionalização da cooperação com cada um dos Estados na sua vizinhança, bem como no uso de bens estratégicos, como as relações energéticas e as bases militares na região, para consolidar a presença russa (Laruelle, 2007). O presidente Putin demonstrou um entendimento claro das dinâmicas regionais centro-asiáticas, bem como um compromisso forte com o princípio de não ingerência nos assuntos internos dos Estados, o que foi bem recebido pelos regimes locais. Nesse sentido, uma das primeiras decisões de Putin foi dar prioridade ao Cazaquistão, assinando um acordo de cooperação com Astana, pouco tempo depois da sua eleição (Cutler, 2007, p. 117) e avançando os planos de integração económica, que levariam à entrada em funcionamento, em 2010, de uma União Aduaneira entre a Rússia, a Bielorrússia e o Cazaquistão.

Isto deu duas vantagens a Moscovo: em primeiro lugar, aproximou um parceiro difícil e que era simultaneamente um aliado importante do ocidente na extração de recursos do Cáspio; em segundo lugar, contribuiu para a competição estratégica por domínio sub-regional entre o Cazaquistão e o Uzbequistão. Um outro exemplo deste entendimento de Putin foi o apoio político de Moscovo aos frágeis regimes autoritários da região, no período pós-revoluções coloridas da Eurásia. Esta política teve o seu apogeu com o apoio claro ao presidente uzbeque, Islam Karimov, depois dos acontecimentos de Andijon, em 2005. Além disso, Moscovo manteve um compromisso inabalável com a luta contra o terrorismo no período pós-11 de setembro (Wilhelmsen e Flikke, 2005, p. 391), o que gerou empatia nos líderes da Ásia Central. 
Em geral, as políticas de Moscovo concentraram-se em dois assuntos centrais. Primeiro, em restabelecer a cooperação institucional com a Ásia Central, quer bilateralmente, quer multilateralmente em duas áreas principais: militar e económica. Com o presidente Putin, a Rússia negociou acordos militares bilaterais com o Quirguistão, em 2003 (Eurasianet, 2002), com o Tajiquistão, em 2004 (RFE/RL, 2004a), com o Uzbequistão, em 2005 (Eurasianet, 2005), e existiam já processos de cooperação militar bem estabelecidos com o Cazaquistão. A nível multilateral, em 2002, a Rússia liderou a transformação do TSC numa organização formal, a Organização do Tratado de Segurança Coletiva (OTSC), e promoveu a CEdE como uma ferramenta central no aprofundamento dos laços económicos com a região. A adesão do Uzbequistão à OTSC e à CEdE, em 2006, foi vista como uma importante vitória de Moscovo e um passo fundamental para consolidar o seu domínio hegemónico na região (Laruelle, 2007; Trenin, 2007a, p. 99). Contudo, a adesão do regime de Tasquente a estas organizações tem de ser vista no contexto da imposição de sanções pela UE e EUA, após os eventos de Andijon. A aproximação à Rússia foi, por isso, uma decisão pragmática que visava demonstrar ao ocidente que a Rússia permanece uma alternativa ao isolamento da região, mas que é, por isso mesmo, reversível. Não só o Uzbequistão não implementou nenhuma das medidas previstas pela CEdE, como saiu da organização na mesma semana em que a UE levantou as sanções ao país (Lybman e Obydenkova, 2012, p. 12) e suspendeu a sua participação na OTSC, em junho de 2012.

Em segundo lugar, a Rússia aprofundou a sua presença económica e financeira recorrendo aos recursos energéticos e minerais da região, incluindo petróleo, gás, energia hidroelétrica e minérios (Trenin, 2007b, pp. 106-110). Moscovo mostrou-se disponível para pagar preços mais elevados para aumentar o volume de energia que compra diretamente aos países da Ásia Central, de forma a garantir o controlo da maior parte da produção e exportação energética da região. Este objetivo foi reforçado pelos laços de proximidade entre o Estado e as companhias energéticas russas, como a Lukoil e a Gazprom, cujas ações podem ser interpretadas como reforçando os objetivos políticos do Kremlin (Baev, 2004, p. 272). Por fim, a Rússia investiu também na produção hidroelétrica no 
Tajiquistão e no Quirguistão, que representa a principal fonte de rendimento dos dois países. Contudo, também nesta área os ganhos russos não têm sido consolidados. Depois de aceitar diversas formas de apoio financeiro russo, as autoridades tajiques acabaram por não permitir que a Rússia participasse no desenvolvimento da barragem hidroelétrica de Rogun. Por seu lado, quer o Cazaquistão, quer o Turquemenistão desenvolveram novos oleodutos e gasodutos, ligando-os à China e ao Irão, o que efetivamente reduz o controlo russo sobre os recursos energéticos destes países (Digol, 2012, p. 192).

À medida que a Rússia procurou reverter o declínio da sua presença na Ásia Central, os acontecimentos de 11 de setembro e a guerra global contra o terrorismo representaram um desafio para Moscovo (Antonenko, 2001). Face à decisão norte-americana de intervir militarmente no Afeganistão, a Ásia Central passou a ocupar um local central na estratégia dos EUA. A resposta imediata dos líderes da Ásia Central passou por facilitar as operações dos EUA e permitir o estabelecimento de duas bases militares norte-americanas, em Manas, no Quirguistão e em Khanabad, no sul do Uzbequistão. Esta cooperação centro-asiática pode ser, em parte, explicada pela preocupação partilhada com a ameaça islâmica proveniente do Afeganistão, mas também por um cálculo estratégico. Uma cooperação mais próxima com os EUA reforçaria a política externa multivetorial destes países e manteria os apetites hegemónicos russos sob controlo. Numa tentativa de apresentar os seus interesses na Ásia Central como sendo coincidentes com os da potência hegemónica em ascensão e a potência hegemónica sub-regional, Washington teve a preocupação de, numa fase inicial, assegurar Moscovo e os regimes da Ásia Central que a sua presença na região seria de curto prazo e limitada às necessidades operacionais da guerra no Afeganistão. Contudo, e como argumenta Baev (2004, pp. 274-5), em 2003, o presidente Putin percebeu que "a administração Bush não tinha, nem a intenção de retirar da Ásia Central, nem a capacidade para reforçar a sua presença militar ao ponto de se tornar a potência regional dominante", o que criava oportunidades para a atuação da Rússia.

A eleição do presidente Medvedev, em 2008, representou uma opção política pela continuidade das políticas desenvolvidas pelo presidente 
Putin (Freire e Simão, 2008). Isto coincidiu com um realismo crescente da Rússia no contexto internacional e com o seu desejo de reconstruir as fundações do Estado russo, em desenvolvimento nos últimos anos (Kanet, 2008, p. 8; Freire, 2009, p. 129). Medvedev apresentou uma agenda liberal de modernização, onde as relações com o ocidente eram fundamentais e que muitos no ocidente esperavam pudesse definir uma nova era nas relações com os EUA e a Europa, num potencial regresso ao espírito dos anos 1990 (Averre, 2010). Na Rússia, contudo, o sentimento predominante foi de algum ceticismo e cautela. Ilustrando isto, a Estratégia de Segurança Nacional da Federação Russa até 2020 (ESN), apresentada em maio de 2009, identifica uma ligação clara entre a capacidade de a Rússia defender a sua segurança nacional e o potencial económico do país (de Haas, 2009, p. 3; ESN, 2009). Esta ligação subentende, por isso, uma parceria de modernização com os parceiros norte-americanos e europeus, que poderá ser posta em causa face às políticas expansionistas da OTAN na Eurásia, nomeadamente a política de alargamento e a PfP, e face aos frutos limitados da política de 'reset' com os EUA. Ou seja, na medida em que a ESN liga a segurança nacional com o desenvolvimento socioeconómico da Rússia e que ambos estão profundamente dependentes da qualidade das relações de Moscovo com o ocidente, a direção que estas duas dinâmicas tomar será fundamental para a postura russa noutros cenários internacionais, como a Ásia Central, onde a cooperação com os EUA e a UE é fundamental.

O enfoque de Medvedev nas parcerias para a modernização da Rússia ditou um certo afastamento face à região, que pouco tem para oferecer nesta vertente. Por outro lado, a falta de uma resposta eficaz de Moscovo, ao pedido de ajuda do Quirguistão, para lidar com os conflitos interétnicos que abalaram o sul do país em 2010, ilustrou a falta de preparação da Rússia para exercer liderança regional. Mostrou também a ineficácia da OTSC para dar resposta a conflitos intraestatais nos seus membros. Apesar da carta fundadora da organização ter sido revista para contemplar essa possibilidade, a desconfiança que caracteriza as relações entre os seus membros deverá criar obstáculos políticos à ação atempada em casos semelhantes. 


\section{Política externa russa na Ásia Central: que futuro?}

De facto, as dinâmicas em curso aquando da chegada do presidente Medvedev ao Kremlin foram continuadas. A Rússia manteve uma política de crescente envolvimento económico e militar na Ásia Central, distribuindo ajuda financeira e investindo em sectores altamente lucrativos das economias regionais (Barry, 2009). Contudo, apesar dos esforços para reforçar uma "esfera de interesses privilegiados", a Rússia deparou-se com o facto de "não ser [hoje] mais fácil lidar com os vizinhos da Ásia Central, do que tem sido ao longo das últimas duas décadas" (Kanet, 2010, p. 93). Para além das dificuldades nas relações bilaterais e no âmbito das organizações regionais da Ásia Central, as opções políticas de Moscovo nesta região têm sido influenciadas por dinâmicas das suas próprias relações com as potências europeias e os EUA. Por exemplo, após a breve guerra na Geórgia, em 2008, e o esfriar de relações com o ocidente, Moscovo procurou apoio no âmbito da CEI e da OCX para o reconhecimento das regiões separatistas na Abcázia e da Ossétia do Sul, sem resultados.

Para as políticas externas multivetoriais dos Estados da Ásia Central, a competição por influência entre várias potências hegemónicas serve o objetivo de proteger as elites regionais de pressão unilateral. Esta competição tem favorecido o status quo, embora apresentando respostas muito limitadas para os desafios regionais. As perspetivas de que isto venha a mudar são limitadas, apesar da crescente pressão social, económica, financeira e de segurança sobre os regimes da região. Para a Rússia, salvaguardar a sua posição regional hegemónica, especialmente contra a presença militar dos EUA tem sido uma prioridade. Tal como afirma Deyermond (2009, p. 171), mesmo que exista uma coexistência pacífica na Ásia Central, a Rússia fez da preservação do seu papel hegemónico, na área de segurança na Ásia Central, uma parte fundamental da sua política. À medida que os EUA se preparam para retirar do Afeganistão, a competição estratégica tenderá a diminuir, diminuindo também o risco de conflito hegemónico entre Washington e Moscovo. Contudo, isto também colocará pressão acrescida sobre a Rússia para que responda aos desafios securitários da região e assuma o papel de garante da 
segurança regional. A capacidade política e operacional limitada da Rússia em atuar como garante da segurança regional ficou bem visível no caso dos conflitos no Quirguistão em 2010, e no Tajiquistão, em agosto de 2012, quando, após o assassinato do responsável pelo gabinete do Comité Estatal para a Segurança Nacional na província de Gorno Badakhshan, o governo de Emomalii Rahmon enviou tropas que mantiveram a região isolada, sob a justificação de lutar contra forças extremistas e desleais ao governo (The Economist, 2012; ver também a entrevista com o analista Andrei Grozin, 2012).

Em termos da competição hegemónica comercial, financeira e de soft power, esta deverá manter-se alimentada pela presença de potências aspirantes como a China e a Índia. Esta competição teve já os seus impactos na região, em pelo menos duas ocasiões. A primeira foi a capacidade da China quebrar o monopólio russo sobre a exportação de recursos energéticos da região. A inauguração do oleoduto ligando o Turquemenistão à China, a 14 de dezembro de 2009, garante, pela primeira vez, acesso chinês aos recursos do Cáspio e permite a compra direta de recursos aos Estados da região, sem mediação russa. Um outro exemplo da crescente tensão entre a Rússia e a China foi visível na crise política no Quirguistão, em 2010. A abertura ao investimento chinês nos projetos hidroelétricos do país foi um elemento adicional de tensão entre Bisqueque e Moscovo, que tinha sido o principal financiador do regime e em particular destes projetos (Simão, 2010). Em parte, este foi um factor importante na queda do regime do presidente Bakiev, em abril de 2010, facilitado pela retirada do apoio de Moscovo e pela campanha difamatória que os meios de comunicação russos veicularam contra o regime.

Tal como argumentado por Menon (2007), o alinhamento de interesses russos e chineses na Ásia Central, alimentado primordialmente pelo desejo de contrabalançar a presença norte-americana, corre um risco real de vir a desaparecer com a gradual retirada norte-americana do Afeganistão e à medida que o equilíbrio regional de poder se altera a favor da China.

"A questão central é a de saber se a convergência dará lugar à rivalidade ou se a Rússia, perante a constatação dos limites do seu poder, 
irá gradualmente acomodar a hegemonia chinesa na região, criando um processo de mudança histórica, onde Moscovo passa da aceitação da competição na sua esfera de influência, por parte de um conjunto de Estados (o que faz atualmente, mesmo que por necessidade), para a cedência da supremacia a um Estado.” (Menon, 2007, p. 12)

\section{Conclusão}

O principal argumento deste capítulo é que a crescente complexidade da competição hegemónica em curso na Ásia Central representa um risco real de instabilidade e conflito na região. Este contexto está diretamente ligado às políticas de Moscovo e às suas relações com outras potências regionais. O modelo da hegemonia multinível permite-nos conjugar os elementos de interdependência regional e global que se cruzam no espaço da Ásia Central, resultantes dos processos de globalização desta região. Efetivamente, as opções de Moscovo parecem ter seguido um padrão reativo numa primeira fase, caracterizada pela necessidade de reorganização interna e simultaneamente impelido pelas ligações provenientes do seu passado imperial nesta região contígua ao seu território. Numa segunda fase, já sob a liderança do presidente Putin, a Rússia abraçou a competição regional, mostrando alguma ambivalência entre a presença norte-americana na região, no pós-11 de setembro - da ótica de Moscovo, um mal necessário -, e a consolidação de uma esfera de interesses privilegiados numa região cada vez mais disputada. Finalmente, podemos dizer que a Rússia se encontra numa fase de consolidação da sua presença militar, económica e política na região, embora num plano de longo prazo esta consolidação deva continuar a ser desafiada, quer pelos atores regionais, quer pelas outras potências hegemónicas a atuar na região.

O contexto atual é de grande urgência em garantir que a Ásia Central não caia num ciclo vicioso de instabilidade política, criminalidade e violência que colocaria uma pressão insuportável sobre os frágeis regimes da região e as suas sociedades. As lições da história mostram-nos que a resposta das elites no poder é o reforço dos padrões autoritários, o que 
enfraqueceria ainda mais estes Estados. À medida que os EUA se preparam para retirar da região, a tendência será de maior liberdade de movimento das forças a operar na região, posicionando-se como novas ameaças. Apesar de a Rússia reclamar para si o papel de garante de segurança na região, tem sido relutante em colocar forças no terreno quando solicitada, quer no quadro dos acordos bilaterais, quer no quadro da OTSC.

Neste contexto, o papel do Uzbequistão tornar-se-á crucial para a (in) estabilidade regional, podendo contribuir para novas fontes de tensão regional. Neste momento, esta possibilidade é particularmente preocupante para o Quirguistão, devido ao contexto político vulnerável do país e a incapacidade de gerir as relações com a considerável minoria uzbeque, no sul do país, no Vale de Fergana. A saída uzbeque da OTSC representa também um desafio adicional de coordenação da ação militar e política, sob liderança russa, num cenário pós-retirada norte-americana. Com o regresso de Vladimir Putin ao Kremlin, em 2012, o sentido da política externa russa para a Ásia Central não deverá ser alterado. Se pensarmos que o mandato de Medvedev representou apenas uma quebra formal, mas não substancial, do exercício do poder por Putin, então este novo mandato permitirá continuar os processos em curso. Segundo Trenin (2012), a diversificação e modernização económica manter-se-á uma prioridade, exigindo relações estáveis com os EUA e a Europa, o que por sua vez deverá ditar uma maior cooperação no âmbito da retirada das forças norte-americanas do Afeganistão e na estabilização da Ásia Central.

Esta atenção aos aspetos económicos está também plasmada nos projetos anunciados de criar uma União Euroasiática, que deverá desenvolver-se tendo por base a União Aduaneira já existente entre a Rússia, a Bielorrússia e o Cazaquistão, com vista à criação de um mercado único, onde poderão participar os Estados interessados. Esta opção de integração económica poderá ser bastante atrativa para os governos e sociedades da Ásia Central, criando melhores acessos ao mercado russo para os produtos e, especialmente, para os trabalhadores da região. O principal problema para países como o Quirguistão, prende-se com o aumento das barreiras alfandegárias para aqueles que permanecerão fora deste mercado único, nomeadamente a China que domina o mercado quirguiz. Esta é, aliás, uma 
das prioridades de Moscovo com este projeto, mas que irá criar tensões e dificuldades para as políticas comerciais dos Estados da região. Para além disso, as divisões entre as cinco repúblicas ex-soviéticas são profundas, o que mina a visão de um espaço geográfico contíguo integrado a nível económico. Independentemente das dificuldades, os projetos económicos e a cooperação militar manter-se-ão aspetos centrais da presença russa na região e das dinâmicas de competição com outras potências regionais.

\section{Bibliografia}

AKINER, Shirin - Tajikistan: Disintegration or Reconciliation? London: The Royal Institute of International Affairs, 2001.

ALLISON, Roy - Conclusion: Central Asian Security in the Regional and International Context. In Roy Allison e Lena Jonson (eds.), Central Asian Security: The New International Context. London: Royal Institute of International Affairs (2001), p. 247-268.

ANTONENKO, Oksana - Putin's Gamble. Survival. Vol. 43, N. ${ }^{\circ} 4$ (2001), p. 49-60.

ASMUS, Ronald D. - A Little War that Shook the World: Georgia, Russia, and the Future of the West. New York: Palgrave Macmillan, 2010.

AVERRE, Derek - Triangulation or Strangulation? The US, the EU and Russia in European Security Governance. Artigo apresentado na 'UACES Annual Conference', Bruges, 6-8 setembro 2010.

BAEV, Pavel K. - Assessing Russia's Cards: Three Petty Games in Central Asia. Cambridge Review of International Affairs. Vol. 17, N. ${ }^{\circ} 2$ (2004), p. 269-283.

BARRY, Ellen - Russia's Neighbors Resist Wooing and Bullying”, The New York Times, 2 julho 2009. [Acedido a 20 de set. de 2010]. Disponível na Internet: http://www.nytimes. com/2009/07/03/world/europe/03russia.html.

BURGHART, Dan - The New Nomads? American Military Presence in Central Asia. China and Eurasia Forum Quarterly. Vol. 5, N. ${ }^{\circ} 2$ (2007), p. 5-19.

BUZAN, Barry e WAEVER, Ole - Regions and Powers: The Structure of International Security. Cambridge: Cambridge University Press, 2003.

Casa Branca - U.S.-Russia Relations: 'Reset' Fact Sheet. The White House, Office of the Press Secretary, 24 junho 2010. [Acedido a 14 de fev. de 2012]. Disponível na Internet: http:// www.whitehouse.gov/the-press-office/us-russia-relations-reset-fact-sheet.

Conceito de Política Externa da Federação Russa (1993) Reproduzido in Melville, Andrei e Shakleina, Tatiana, eds. (2005). Russian Foreign Policy in Transition: Concepts and Realities. Budapest: CEU Press, p. 27-64.

CORNELL, Svante E. - The Narcotics Threat in Greater Central Asia: From Crime-Terror Nexus to State Infiltration? China and Eurasia Forum Quarterly. Vol. 4, N. 1 (2006), p. 37-67.

CUTLER, Robert - U.S.-Russian Strategic Relations and the Structuration of Central Asia. Perspectives on Global Development and Technology. Vol. 6, N. ${ }^{\circ} 1-3$ (2007), p. 109-125.

DE HAAS, Marcel - Medvedev's Security Policy: A Provisional Assessment. Russian Analytical Digest. N. ${ }^{\circ} 62$ (2009), p. 2-5. 
DEYERMOND, Ruth - Matrioshka Hegemony? Multi-leveled Hegemonic Competition and Security in Post-Soviet Central Asia. Review of International Studies. Vol. 35, N. 1 (2009), p. 151-173.

DIGOL, Diana - Russia's foreign policy in Central Asia: From Yeltsin to Medvedev. In Maria R. Freire e Kanet, Roger E., eds., Russia and its Near Neigbbours. Basingstoke: Palgrave Macmillan (2012), p. 174-202.

Economist, The - Troubled Tajikistan: Where Cure Begets Disease. The Economist Asia View, 23 setembro 2010. [Acedido a 14 de set. de 2010]. Disponível na Internet: http://www.economist. com/blogs/asiaview/2010/09/troubled_tajikistan. Consultado em: 14 setembro 2010.

Economist, The - Violence in Tadikistan. The strongman cometh. The Economist, 28 julho 2012. [Acedido a 30 de ago. de 2012]. Disponível na Internet: http://www.economist. com/node/21559664.

ESN - Estratégia de Segurança Nacional da Federação Russa até 2020, 12 maio 2009. [Acedido a 31 de ago. de 2010]. Disponível na Internet: http://www.scrf.gov.ru/documents/99.html.

EurasiaNet - Russia to Establish Air Base in Kyrgyzstan, Deals Blow to US Strategic Interests in Central Asia, 2 dezembro 2002. [Acedido a 14 de set. de 2010]. Disponível na Internet: http://www.eurasianet.org/departments/insight/articles/eav120302.shtml.

EurasiaNet - Uzbekistan and Russia Sign Mutual Defense Pact, 14 novembro 2005. [Acedido a 14 de set. de 2010]. Disponível na Internet: http://www.eurasianet.org/departments/ insight/articles/eav111505.shtml.

FENOPETOV, Vladimir - The Drug Crime Threat to Countries Located on the 'Silk Road'. China and Eurasia Forum Quarterly. Vol. 4, N. ${ }^{\circ} 1$ (2006), p. 5-13.

FREIRE, Maria R. - Russian Policy in Central Asia: Supporting, Balancing, Coercing, or Imposing? Asian Perspective. Vol. 33, N. 2 (2009), p. 125-149.

FREIRE, Maria R. - Tempo de balanço: as presidências de Barack Obama e Dmitri Medvedev. Relações Internacionais. N. ${ }^{\circ} 34$ (2012), p. 61-72.

FREIRE, Maria R. e Licínia Simão - As eleições presidenciais na Rússia: continuidade na mudança. IPRI Occasional Paper, no. 32, março 208 - 2008. [Acedido a 26 de set. de 2010]. Disponível na Internet:http://www.ipri.pt/publicacoes/working_paper/working paper.php?idp=231.

FRIEDMAN, Uri - Russian press rips Romney and his promise of 'Republican hell'. Foreign Policy, 30 agosto 2012. [Acedido a 9 de set. de 2012]. Disponível na Internet: http:// blog.foreignpolicy.com/posts/2012/08/30/russian_press_rips_romney_and_his_promise_ of_republican_hell.

GARNETT, Sherman W., RAHR, Alexander e WATANABE, Koji - The New Central Asia: In Search of Stability. New York, Paris e Tokyo: The Trilateral Commission, 2000.

GROZIN, Andrei - Andrei Grozin: as operações na região de Badakhshan no Tajiquistão estavam preparadas desde a primavera, Entrevista ao jornal eletrónico Regnum (em russo), 2012. [Acedido a 9 de set. de 2012]. Disponível na Internet:http://www.regnum. $\mathrm{ru} /$ news/polit/1555574.html.

GULLETTE, David - Kyrgyzstan: Components of Crisis. OpenDemocracy, 28 junho 2010. [Acedido a 3 de set. de 2010]. Disponível na Internet:http://www.opendemocracy.net/ david-gullette/kyrgyzstan-components-of-crisis.

HILL, Fiona - Une stratégie incertaine: la politique des États-Unis dans le Caucase et en Asie centrale depuis 1991. Politique Étrangère. Vol. 66,N. ${ }^{\circ} 1$ (2001), p. 95-108.

HILL, Fiona - The United States and Russia in Central Asia: Uzbekistan, Tajikistan, Afghanistan, Pakistan, and Iran. Brookings, 15 agosto 2002. [Acedido a 27 de set. de 2010]. Disponível na Internet:http://www.brookings.edu/speeches/2002/0815russia_hill.aspx. 
HILL, Fiona - Central Asia and the Caucasus: The Impact of the War on Terrorism. In Adrian Karatnycky, Alexander J. Motyl e Amanda Schnetzer, eds., Nations in Transit 2003. Lanham, MD: Rowman e Littlefield (2003), p. 39-50.

Internation Crisis Group - Central Asia: Water and Conflict. International Crisis Group, Asia Report, N. ${ }^{\circ}$ 34, 30 maio (2002a).

Internation Crisis Group - Central Asia: Border Disputes and Conflict Potential. International Crisis Group, Asia Report, N. ${ }^{\circ} 33,4$ abril (2002b).

Internation Crisis Group - The Curse of Cotton: Central Asia's Destructive Monoculture. International Crisis Group, Asia Report, N. ${ }^{\circ}$ 93, 28 fevereiro 2005.

INDYK, Martin; LIEBERTHAL, Kenneth e O'HANLON, Michael - Scoring Obama's Foreign Policy. A Progressive Pragmatist Tries to Bend History", Foreign Policy, maio/junho 2012. [Acedido a 9 de set. de 2012]. Disponível na Internet: http://www.foreignaffairs. com/articles/137516/martin-indyk-kenneth-lieberthal-and-michael-e-ohanlon/scoringobamas-foreign-policy.

JACKSON, Nicole J. - Russian Foreign Policy and the CIS: Theories, Debates and Actions. New York: Routledge, 2003.

JANUSZ, Barbara - The Caspian Sea: Legal Status and Regime Problems. Russia and Eurasia Programme, Chatham House, REP bp 05/02, agosto 2005.

JENTLESON, Bruce W. e KUPCHAN, Charles A. - A Dangerous Mind. Foreign Policy, 30 agosto 2012. [Acedido a 9 de set. de 2012]. Disponível na Internet: http://www. foreignpolicy.com/articles/2012/08/30/a_dangerous_mind_mitt_romney.

JONSON, Lena - Russia and Central Asia. In Roy Allison e Jonson, Lena, eds., Central Asian Security: The New International Context. London: Royal Institute of International Affairs (2001), p. 95-126.

KANET, Roger E. - The return of Imperial Russia: Russia and its Neighbors. ACDIS Occasional Paper, setembro 2008. [Acedido a 13 de maio de 2010]. Disponível na Internet: http:// acdis.illinois.edu/assets/docs/309/TheReturnofImperialRussiaRussiaandItsNeighbors.pdf.

KANET, Roger E. - Russia and the Greater Caspian Basin: Withstanding the US Challenge. In Maria R. Freire e Kanet, Roger E. eds., Key Players and Regional Dynamics in Eurasia: The Return of the 'Great Game'. Basingstoke: Palgrave Macmillan (2010), p. 81-102.

KOBRINSKAYA, Irina - The CIS in Russian Foreign Policy: Causes and Effects. In Hanna Smith, ed., Russia and Its Foreign Policy. Saarijärvi: Kikimora Publications (2005), p. 77-92.

KRAMER, Andrew E. - New Gas Pipeline from Central Asia Feeds China. The New York Times, 14 dezembro 2009. [Acedido a 9 de jun. de 2011]. Disponível na Internet: http:// www.nytimes.com/2009/12/15/world/asia/15pipeline.html.

LARUELLE, Marléne - Asie Centrale: Le retour de la Russie. Politique Internationale, . $^{\circ}$ 115, primavera 2007. Versão eletrónica. [Acedido a 12 de set. de 2010]. Disponível na Internet: http://www. politiqueinternationale.com/revue/read2.php?id_revue=115\&id=630\&content=texte.

LARUELLE, Marlène, PEYROUSE, Sébastien, HUCHET, Jean-François e BALCI, Bayram, eds. China and India in Central Asia: A New 'Great Game'? New York: Palgrave Macmillan, 2010.

LUBIN, Nancy - Who's Watching the Watchdogs?: Drug Trafficking in Central Asia. In Dan Burghart e Sabonis-Helf, Theresa, eds., In the Tracks of Tamerlane: Central Asia's Path to the 21st Century. Washington, D.C.: National Defense University, Center For Technology and National Security Policy (2004), p. 361-376.

MARAT, Erica - The Changing Dynamics of State-Crime Relations in Kyrgyzstan. Central Asia Caucasus Institute Analyst, 20 fevereiro 2008. [Acedido a 20 de set. de 2010]. Disponível na Internet:http://www.cacianalyst.org/?q=node/4796. 
MARAT, Erica - Bakiyev, the Security Structures, and the April 7 Violence in Kyrgyzstan. Central Asia Caucasus Institute Analyst, 28 abril 2010. [Acedido a 20 de set. de 2010]. Disponível na Internet: http://www.cacianalyst.org/?q=node/5316.

MARKEDONOV, Sergei - Post-Soviet Integration: Does the CIS Work?. OpenDemocracy, oD Russia Post-Soviet World, 13 janeiro 2010. [Acedido a 31 de ago. de 2010]. Disponível na Internet: http://www.opendemocracy.net/od-russia/sergei-markedonov/post-sovietintegration-does-cis-work.

MENON, Raja - Introduction: Central Asia in the Twenty-First Century. In Eugene Rumer, Trenin; Dmitri e Zhao, Huasheng, eds. Central Asia: Views from Washington, Moscow, and Beijing. New York: M.E. Sharpe (2007), p. 3-17.

POMFRET, Richard - Central Asia and the Global Economic Crisis. EU Central Asia Monitoring (EUCAM), 7 junho 2009. [Acedido a 31 de ago. de 2010]. Disponível na Internet: http:// www.eucentralasia.eu/fileadmin/user_upload/PDF/Policy_Briefs/PB-7-eversion.pdf.

PRATT, Martin e SCHOFIELD, Clive - International Boundaries, Resources and Environmental Security in the Caspian Sea. In Blake, Gerald; Chia Lin Sien; Grundy-Warr, Carl; Pratt, Martin e Schofield, Clive, eds., International Boundaries and Environmental Security: Frameworks for Regional Cooperation. London: Kluwer Law International (1997), p. 81-104.

RASHID, Ahmed - The Resurgence of Central Asia: Islam or Nationalism? London: Zed Books, 1994.

RASHID, Ahmed - Jihad: Ascensão do Islão Militante na Ásia Central. Tradução de Freitas e Silva, Lisboa: Terramar, 2002.

RFE/RL - Tajikistan: First Permanent Russian Military Base Opened", Radio Free Europe/ Radio Liberty, 17 outubro 2004. [Acedido a 31 de ago. de 2010]. Disponível na Internet: http://www.rferl.org/content/article/1055375.html.

SAKWA, Richard e Webber, Mark - The Commonwealth of Independent States, 1991-1998: Stagnation and Survival. Europe-Asia Studies. Vol. 51, N. 3 (1999), p. 379-415.

SIMÃO, Licínia - Carta de Bisqueque: Da democracia na Ásia Central. Relações Internacionais. N. ${ }^{\circ} 26$ (2010), p. 61-66.

STEPANOVA, Ekaterina - Does Russia Want the West to Succeed in Afghanistan?. PONARS Eurasia Policy Memo, N. ${ }^{\circ}$ 61, setembro 2009.

SWANSTROM, Niklas; Cornell, Svante e Tabishalieva, Anara - A Strategic Conflict Analysis of Central Asia with a Focus on Kyrgyzstan and Tajikitan. Central Asia-Caucasus Institute \& Silk Road Studies Program, junho 2005. [Acedido a 28 de set. de 2010]. Disponível na Internet:www.silkroadstudies.org/docs/publications/2005/SIDA_CA.pdf.

TRENIN, Dmitri - Russia and Central Asia: Interests, Policies, and Prospects. In Rumer, Eugene; Trenin, Dmitri e Huasheng Zhao, Central Asia: Views from Washington, Moscow, and Beijing. New York: M.E. Sharpe (2007b), p. 75-136.

TRENIN, Dmitri - What Will Putin Do in Foreign Policy? Carnegie Endowment for International Peace, maio 2012.

WILHELMSEN, Julie e FLIKKE, Geir - Evidence of Russia's Bush Doctrine in the CIS. European Security. Vol. 14, N. ${ }^{\circ} 3$ (2005), p. 387-417.

XING, Guangchend - China and Central Asia. In Allison, Roy e Jonson, Lena, eds., Central Asian Security: The New International Context. London: Royal Institute of International Affairs (2001), p. 152-170. 
(Página deixada propositadamente em branco) 


\section{CAPITULO 5}

\section{A RÚSSIA E A ALEMANHA:}

\section{UMA RELAÇ ÃO SUI GENERIS EM MUDA NÇA}

Patrícia Daehnhardt

\section{Introdução}

A história da relação entre a Alemanha e a Rússia, as duas potências centrais do continente europeu, caracteriza-se por momentos de cooperação, rivalidade e tensão. No pós-Guerra Fria a Rússia deparou-se com o papel de crescente importância da Alemanha tornando-se esta essencial à Rússia como interlocutora privilegiada de Moscovo no palco europeu e transatlântico. A Rússia articula os seus interesses securitários e energéticos em cooperação com a Alemanha para reforçar a sua posição junto dos restantes atores políticos do quadro euro-atlântico já que é através de Berlim que a Rússia exerce influência na Europa. Por seu turno, a Alemanha é um elo de articulação entre a União Europeia (UE), os Estados Unidos (EUA) e a Rússia, na medida em que a forma como a Alemanha define a sua relação com a Rússia tem repercussões sobre como estes atores lidam com Moscovo e sobre a configuração do espaço euro-atlântico. Isto sugere uma relação sui generis, cujos contornos estão a ser redefinidos, na sequência da eleição de Vladimir Putin, em março de 2012, para um terceiro mandato presidencial e a crescente desilusão dos políticos alemães face ao percecionado afastamento da Rússia dos princípios que sustentam uma ordem interna democrática e pluralista e uma ordem securitária europeia de estabilidade e cooperação. Consequentemente, 
o papel que a Alemanha desempenha na política externa russa está a mudar, perante o risco de a Rússia perder o maior defensor dos seus interesses junto da UE.

Este capítulo analisa as relações bilaterais entre a Rússia e a Alemanha de uma perspetiva de convergência quanto à procura da redefinição das respectivas identidades internacionais no pós-Guerra Fria e da normalização das suas políticas externas, e de divergência quanto à inserção em contextos institucionais diferenciados e às posições daí decorrentes. As duas narrativas que informam as condutas da política externa da Rússia e da Alemanha são abordadas no início. De seguida são analisadas as opções estratégicas prosseguidas por Moscovo e Berlim. Num cenário pós-11 de setembro de 2001 e de novos desafios energéticos e enquadramentos geopolíticos, a análise recairá principalmente sobre as políticas bilaterais nos domínios da cooperação económica, política energética e política de segurança, três dimensões que sugerem uma dinâmica própria entre Berlim e Moscovo, com implicações para a UE e a Aliança Atlântica.

\section{Enquadramento histórico}

A história revela-nos que ambos os lados, têm, de uma maneira geral, optado pela cooperação e pela gestão de um relacionamento bilateral cooperativo mais do que conflituoso. Duas vezes, em 1871 e 1990, a Rússia tolerou as pretensões da Alemanha em unificar-se, contra adversidades e, no rescaldo da Primeira Guerra Mundial, a República de Weimar, constituída em 1919 e a União das Repúblicas Socialistas Soviéticas (URSS), criada em 1922, estabeleceram relações diplomáticas entre os dois novos regimes. Assinaram o Tratado de Rapallo, composto por acordos económicos e pela cooperação militar, à margem da conferência internacional de Genova, a primeira grande cimeira económica e financeira do pós-Guerra com o objetivo de reconstruir a economia europeia (Pipes, 1995, pp. 423-435). Daí que este tratado seja, para alguns, sinónimo do receio do 'espirito de Rapallo', reflexo da cooperação bilateral entre a Alemanha e a Rússia, feita à custa e com o desconhecimento das restantes potências europeias e euro-atlânticas. 
Durante a Guerra Fria, quando a Europa foi o palco preferencial da rivalidade bipolar entre os EUA e a URSS, e quando a Europa ocidental desenvolveu uma estreita relação de segurança com os EUA através da Aliança Atlântica, enquanto a Europa de leste estava subjugada ao controlo de Moscovo através do Pacto de Varsóvia, as relações entre a República Federal da Alemanha (RFA) e a URSS foram a exceção à regra. Em setembro de 1955, ambos os Estados iniciaram relações diplomáticas, ficando patente que apesar da inserção da República Democrática da Alemanha (RDA) na zona de influência soviética, a Alemanha ocidental era a parte alemã mais relevante para Moscovo porque se encontrava no centro geopolítico da Guerra Fria e porque, a entrada, um ano antes, da RFA na Organização do Tratado do Atlântico Norte (OTAN), tinha alterado os equilíbrios geopolíticos desfavoravelmente à União Soviética.

Esta relação bilateral foi reforçada em inícios da década de 1970 quando o chanceler Willy Brandt (SPD) definiu uma política de aproximação - a Ostpolitik (política a leste) - para a URSS e a Europa de leste, cujo destinatário principal foi a RDA. Durante o processo de negociação da unificação alemã, entre novembro de 1989 e julho de 1990, a União Soviética encontrou-se numa posição enfraquecida, incapaz não apenas de impedir a unificação, como de definir os contornos do futuro quadro de segurança europeu (Stent, 1999). De facto, o futuro estatuto da Alemanha unificada foi decidido pelo governo do chanceler Helmut Kohl (CDU) e pela administração norte-americana de George Bush, acabando a Alemanha, contra a oposição inicial de Moscovo, por ficar integrada nas estruturas políticas e militares da OTAN. A concordância de Moscovo aos termos do Tratado " $2+4$ " prendeu-se mais a circunstâncias de debilidade política interna na URSS e à perspetiva de contrapartidas económicas do que à aceitação da alteração profunda que a unificação alemã iria trazer ao futuro quadro estratégico europeu ao consubstanciar-se, nos anos seguintes, o alargamento da Aliança Atlântica até junto das fronteiras da ex-URSS. As posições assumidas pela União Soviética e pela RFA nas negociações revelaram-se assim como essenciais, mas diferenciadas na definição da ordem de segurança europeia no pós-Guerra Fria e ainda se refletem em posições assumidas mais de duas décadas depois (Daehnhardt, 2009). 
No pós-Guerra Fria a Rússia deparou-se com o papel de crescente importância da Alemanha tornando-se esta essencial à Rússia como interlocutora privilegiada de Moscovo no palco europeu e transatlântico (Stelzenmüller, 2009), exercendo Berlim influência junto dos líderes do Kremlin na definição da diplomacia multilateral russa para o espaço euro-atlântico, como ilustra a aproximação dos últimos anos entre a Polónia e a Rússia e o início de consultas trilaterais. Assim, a Rússia articula os seus interesses securitários e energéticos em cooperação com a Alemanha para reforçar a sua posição junto dos restantes atores políticos do quadro euro-atlântico: é através de Berlim que a Rússia exerce influência considerável na Europa. Por seu turno, a forma como a Alemanha define a sua relação com a Rússia tem repercussões diretas sobre como os Estados Unidos e a Europa lidam com a Rússia e sobre a configuração do espaço euro-atlântico já que é a Alemanha que em boa medida serve de elo de articulação entre ambos os lados.

A relação entre a Rússia e a Alemanha é, por isso, uma relação sui generis. Para a Rússia, a Alemanha é fundamental para projetar interesses russos no quadro europeu na definição da política externa russa face à UE, à OTAN e aos EUA; desde 1991, a relação bilateral com a Alemanha é uma das importantes linhas de continuidade proveitosa ao Kremlin, em dois domínios: primeiro, porque Berlim se definiu como o interlocutor privilegiado nas relações de Moscovo com a UE (Daehnhardt, 2013b) e os EUA, o que pode amortecer os efeitos de potenciais tensões; segundo, porque a relação lhe serve de trunfo a instrumentalizar na contínua política russa de divisão dos membros da Aliança Atlântica. Para a Alemanha, a estabilidade no continente europeu passa pela cooperação com a Rússia e a inclusão de preocupações securitárias da mesma (Chivvis e Rid, 2009), o que gerou um consenso na elite política alemã de que era necessário integrar a Rússia na ordem securitária europeia que se desenvolveu após 1991.36 Apesar da diplomacia alemã não ser conduzida em detrimento

36 A expressão integração refere-se aqui à inclusão, no sentido lato, da Rússia no desenvolvimento de um contexto de cooperação que garanta a estabilidade na Europa, e não no sentido da sua adesão jurídica à União Europeia ou à Aliança Atlântica como membro de pleno direito. 
da coesão ocidental do espaço euro-atlântico, a relação bilateral assumiu um grau de autonomia considerável, como se verificou durante a crise transatlântica de 2002-2003, quando Berlim e Moscovo, juntamente com a França, se opuseram à política dos EUA para o Iraque ou em 2008, quando a OTAN adiou as negociações de adesão da Geórgia e da Ucrânia, aproximando-se da postura alemã de não hostilização de Moscovo. Para além disso, existe uma relação de dependência mútua no que se refere ao relacionamento económico e energético: a Alemanha depende do gás natural russo enquanto que a Rússia depende dos investidores alemães para modernizar a sua economia. Esta dependência mútua é, contudo, amortecida pela pertença a quadros institucionais divergentes, o que principalmente no caso da Alemanha, condiciona a sua capacidade de atuação.

\section{A Rússia e a Alemanha no espaço Euro-Atlântico}

O fim da ordem bipolar na Europa projetou a Alemanha e a Rússia pós-soviética para campos diferentes. Importa, por isso, sublinhar as diferenças de percurso, de políticas e de opções estratégicas entre Moscovo e Berlim.

A política externa da Rússia pós-soviética no pós-Guerra Fria define-se por três fases: uma primeira, durante a década de 1990, marcada pela transição assim como pela continuidade, quando a Rússia com o presidente Boris Ieltsin entrou num período de desorientação na sua política externa e confrontou-se com um estatuto de grande potência desacreditado, de Estado humilhado e enfraquecido, com fronteiras instáveis e contestadas. $\mathrm{Na}$ definição da conduta externa isto pautou-se por uma indefinição da opção estratégica, que oscilou ora entre a ocidentalização, impulsionada pelo ministro dos negócios estrangeiros, Andrei Kozyrev, visando uma aproximação à Europa e aos Estados Unidos, até 1996, ora uma preferência por privilegiar uma política de grandes potências, a primazia dos interesses russos no antigo território soviético e uma reorientação para países fora do contexto euro-atlântico, caminho escolhido por Evgeny Primakov, como ministro dos negócios estrangeiros e posterior primeiro ministro, entre 1996 e 1999. 
A partir de 2000 iniciou-se a segunda fase, catalisada pela humilhação da década antecessora, quando o presidente Vladimir Putin veio a definir um percurso de acelerada recuperação do estatuto de poder de Moscovo, assente numa crescente auto-confiança possibilitada pelo crescimento económico. A Rússia reforçou o jogo geo-estratégico no espaço pós-soviético do seu chamado 'estrangeiro próximo' através de uma política pragmática, numa evidente procura de recuperação de influência para consolidar-se como grande potência. Aqui Moscovo atuou para recuperar a sua influência em organizações como a Comunidade de Estados Independentes (CEI), a Comunidade Económica Euroasiática, e a Organização do Tratado de Segurança Coletiva (OTSC) e para garantir o acesso a matérias primas e o controlo sobre as rotas de fornecimento energético, principalmente de gás natural para a Europa. A Ucrânia e a Geórgia assim como as cinco repúblicas da Ásia Central são peças fundamentais no jogo Rússia-UE e nas relações da Rússia com a OTAN. Se no final da Guerra Fria o percurso da URSS fora de retraimento do poder de Moscovo, de fora para dentro, perdendo influência na zona mais longínqua, passando pela Europa de leste e finalmente perdendo o poder sobre as antigas repúblicas da URSS, a partir de 2000 o percurso de recuperação de poder seguia a lógica inversa, de gradual recuperação de poder junto das capitais dos novos Estados soberanos da antiga URSS, onde Moscovo apoiava regimes simpatizantes e tentava frustrar apoios europeus à democratização nesses países, como aconteceu na Geórgia, Ucrânia ou Bielorrússia.

A terceira fase da política externa russa é recente, e prende-se com o retorno de Vladimir Putin ao poder, em março de 2012, como presidente da Federação Russa. Se este facto não contraria necessariamente um cenário de continuidade da política externa com uma trajetória de assertividade e projeção de poder na dimensão internacional (Kuchins e Zevelev, 2012) já conhecida dos primeiros dois mandatos presidenciais de Putin entre 2000 e 2008 e do mandato presidencial de Dmitry Medvedev entre 2008 e 2012, é possível sugerir que os próximos anos testarão a robustez do regime russo. O catalisador foi a realização de eleições legislativas em dezembro de 2011 e a eleição presidencial de março de 2012, ambas consideradas 
fraudulentas por observadores independentes, o que fortaleceu uma vaga de oposição interna que reivindica, de forma sistemática, um processo de democratização, numa escala que o regime dificilmente poderá ignorar ou reprimir a longo prazo (Carnaghan e Hale, 2012; Dmitriev e Treisman, 2012). Porque a política externa está inextricavelmente ligada à política interna, a fragilização lenta do regime afetará a condução da política externa russa implicando duas alternativas: primeiro, uma liderança russa fragilizada nos palcos internacionais, onde outros Estados poderão tirar proveito político em negociações internacionais e pressionar Moscovo a ter uma atitude mais cooperadora, por exemplo, em relação à Síria ou ao Irão. Segundo, e em contrapartida, os factores desestabilizadores internos poderão levar o regime a negar as alterações em curso, e assumir uma posição de demonstração de força no palco internacional, através do endurecimento da postura russa em negociações internacionais ou mesmo de uma ação militar no seu 'estrangeiro próximo', por exemplo. Ambos os casos refletiriam os efeitos das mudanças internas na definição de uma nova política externa. Apesar desta terceira fase ainda estar no seu início, é um cenário que merece ser incluído na análise das atuais relações russo-alemãs, e que sugere mudanças na relação sui generis: o possível fim do consenso alemão face ao posicionamento securitário da Rússia na Europa e, por implicação, uma margem de manobra decrescente da liderança russa face à sua capacidade de lidar com Berlim.

Neste contexto de mudança, a Rússia ainda não consolidou a recuperação do seu estatuto de grande potência. É membro permanente do Conselho de Segurança das Nações Unidas, uma potência nuclear, e a sexta maior economia mundial. No plano multilateral, integra um conjunto de instituições internacionais de cariz ocidental tendo aderido, em dezembro de 2011, à Organização Mundial do Comércio (OMC). Contudo, as características que definem uma grande potência no século XXI passam pela inclusão de outros elementos relevantes, como a taxa demográfica, a diversificação dos factores de produção de riqueza e crescimento económico, e o poder normativo (ou soft power) que a potência projeta internacionalmente. No caso da Rússia, estes últimos três factores não refletem uma evolução estável e fazem com que o seu estatuto de grande potência se encontre 
numa posição volátil: em primeiro lugar, a taxa demográfica russa tem vindo a registar um declínio contínuo desde meados da década de 1990 (Sievert, Zakharov e Klingholz, 2011). Em segundo lugar, a economia russa, para além de carecer de uma modernização efetiva e de se encontrar afetada pela corrupção, é pouco diversificada porque excessivamente centrada na indústria energética, nuclear e de armamento. Depende muito da exportação - para a União Europeia - de recursos naturais como o petróleo e o gás natural, uma situação que a crise económica global tornou mais evidente e onde elevadas variações de preços no mercado energético global podem ter consequências imprevisíveis para a economia russa. A crise financeira e económica global, desde 2008 e a volatilidade do preço do petróleo provocaram uma desaceleração do crescimento económico russo, agravada pela diminuição de investimento estrangeiro na Rússia. ${ }^{37}$ Em terceiro lugar, perante a incapacidade de o maior Estado do mundo conseguir assegurar a estabilidade nas suas fronteiras, a Rússia tem relações de vizinhança complexas porque potencialmente conflituosas e tem prosseguido uma política externa de criação de estruturas institucionais modeladas pelo exemplo ocidental, mas descredibilizada pela sua ingerência nos assuntos internos da maioria desses Estados. Por último, a Rússia tem pouco a oferecer em termos de poder normativo na política internacional: no contexto de soft power ela falha em exercer atração sobre outros Estados como potência-modelo a seguir. No agrupamento conhecido como BRICs, o Brasil, a Índia, e até a China exercem mais poder normativo sobre outros atores, para além de estes se estarem a tornar mais atrativos para investidores estrangeiros do que a Rússia. É perante este quadro de incerteza quanto ao estatuto de grande potência consolidado ao qual se junta a ausência de um quadro de inserção institucional multilateral efetivo, com riscos claros, que a Rússia tenta recuperar relações bilaterais com alguns Estados

37 Em 2012, quando a economia global estava desacelerada e a zona euro em recessão, a economia russa cresceu apenas 3,4 por cento em 2012 , abaixo dos 4,3 por cento em 2011, tendo a produção industrial caido no início de 2013, pela primeira vez desde 2009. Mais significativamente, o crescimento económico russo diminuiu para metade do nível da década até a crise de 2008. Ver "Russia Overview", The World Bank. Disponível em: http:// www.worldbank.org/en/country/russia/overview. Consultado em: 12 março 2013. 
europeus. A Alemanha, por razões históricas e geoestratégicas, surge aqui como uma parceira ideal.

Em contrapartida à posição da Rússia, no espaço euro-atlântico, o peso da Alemanha aumentou de forma mais consolidada desde o fim da Guerra Fria porque a Alemanha saiu reforçada do processo de negociação internacional para a sua unificação, em 1990, afirmando-se como potência central na nova política europeia. A fórmula encontrada que tolerava esta nova posição foi o duplo reforço e alargamento do quadro multilateral euro-atlântico: tornava-se necessário 'ancorar' a Alemanha ainda mais nas estruturas institucionais existentes e estabilizar as fronteiras nessa nova Europa para a dissuadir de seguir um caminho unilateral. Assim, os alargamentos institucionais da UE e da OTAN amorteceram simultaneamente o aumento da margem de manobra da Alemanha ao mesmo tempo que esta era ainda mais integrada nas estruturas institucionais. Na realidade, contudo, seria dentro das instituições europeias e transatlânticas através da continuidade das suas políticas multilateralistas que a Alemanha iria redefinir o seu estatuto de poder (Daehnhardt, 2009 e 2011a). E neste enquadramento em transformação, se a Rússia era considerada, por muitos, um desafio ao alargamento institucional, para a Alemanha, a Rússia definia-se como um parceiro a não hostilizar e onde a cooperação deveria ser o incentivo para atenuar a rivalidade estratégica com o ocidente.

O novo contexto europeu após o fim da Guerra Fria levantou por isso para alguns países vizinhos e aliados da Alemanha não apenas o receio de que uma Alemanha unificada e fortalecida poderia constituir-se como potência hegemónica na Europa como o de que a Alemanha pudesse voltar-se para a Rússia, ou seja, iniciar um relacionamento bilateral especial com Moscovo em detrimento das suas relações com outros Estados, principalmente os da Europa de leste, que estavam agora a libertar-se da hegemonia soviética e a 'regressar à Europa'. Estes receios, contudo, revelaram-se infundados, por um lado, porque a Alemanha não ambicionava uma posição de hegemonia que pusesse em risco a integração europeia ou a comunidade de segurança criada pela Aliança Atlântica; e por outro lado, porque apesar da especificidade do relacionamento russo-alemão, este não era prosseguido à custa do capital político euro-atlântico e 
transatlântico que a Alemanha ajudou a construir desde o fim da II Guerra Mundial. A prioridade da diplomacia alemã continuava a definir-se pela sua política europeia de inserção nas estruturas comunitárias da UE através de um multilateralismo institucionalizado, e pela sua pertença à Aliança Atlântica. Apesar das transformações que a diplomacia alemã percorreu nas últimas duas décadas (Bulmer, Jeffery e Padgett, 2010), esta dupla prioridade continua a sobrepor-se à relação entre a Alemanha e a Rússia.

A diplomacia da Alemanha assenta assim numa estratégia de inserção da Rússia no quadro securitário euro-atlântico, que tem evitado que Berlim tenha que escolher entre relações com a Rússia e uma Ostpolitik com os países do Cáucaso, alguns deles interessados a aderir às instituições ocidentais: com a Rússia, a Alemanha está antes de mais interessada em cooperar economicamente e garantir o fornecimento de energia, e logo a segurança energética; com a Ucrânia e a Geórgia, Berlim aceita a adesão longínqua de ambos à UE preferindo promover por agora a Parceria Oriental, ao mesmo tempo que reconhece que com a OTAN a lógica de adesão segue objetivos diferentes, e que afetam a relação com Moscovo, já que a Rússia se opõe ao alargamento institucional da mesma para junto das suas fronteiras.

Estes contextos diferenciados levam-nos a uma situação paradoxal: enquanto que a Rússia não se conforma com a perda de estatuto de grande potência mundial, e define as suas opções externas em função deste predicamento, a Alemanha, vinte e três anos depois da unificação, não aceitou ainda as consequências da expetativa de liderança que a desafiam quanto a uma estratégia de política externa europeia e internacional mais assertiva. Ou seja, enquanto que a Rússia prossegue uma estratégia de revisão dos contornos da ordem europeia do pós-Guerra Fria, a Alemanha é defensora do status quo sem aceitar que para manter essa ordem terá de assumir um papel de liderança. O paradoxo daí resultante é que a Rússia quer ser a grande potência europeia do espaço euro-atlântico mas não consegue, ao passo que a Alemanha exerce influência e ganhou auto-confiança mas permanece cautelosa e hesitante em afirmar-se enquanto grande potência europeia. Enquanto a primeira quer mais do que as capacidades lhe permitem, a segunda, apesar das expetativas de alguns parceiros e da 
potência económica evidente abstém-se de exercer, uma política externa mais assertiva no espaço euro-atlântico e na sua vizinhança (Daehnhardt, 2012). Esta tensão subjacente à discrepância entre capacidades e vontade política existe nas políticas externas tanto da Rússia como da Alemanha.

A acrescentar a isso, existe um conjunto de elementos idiossincráticos que condicionam a perceção que os decisores políticos transportam para a política externa, com uma diferenciação clara entre a narrativa russa e a narrativa alemã da política internacional e do papel que cada um dos países desempenha nela (Freire e Daehnhardt, 2011, pp.175-79). Para a Rússia, a conceção das relações internacionais é soberanista e vestefaliana, onde os interesses nacionais russos orientam a política externa. Partindo da premissa que a política externa é moldada pela identidade internacional de um país, a Rússia tem assumido uma identidade nacional(ista) assente numa visão tradicionalista e geopolítica que prossegue a recuperação do estatuto de poder e a criação de uma zona de influência no espaço pós-soviético (Tsygankov, 2006). O recurso ao uso da força militar (hard power) segue uma leitura russa do mesmo, quando considera interesses seus ameaçados e onde se atribui um droit de regard para intervir unilateralmente. Num plano internacional, e no seio das Nações Unidas, contudo, a Rússia reflete grande hesitação no uso conjunto da força militar, por não subscrever o princípio da ingerência nos assuntos internos (por razões humanitárias), receando que esse princípio possa vir a ser aplicado contra ela. Por outras palavras, a Rússia mantém uma perspetiva realista das relações internacionais, e rege-se por princípios que não se guiam pela tool box ocidental dos instrumentos ao dispor dos Estados, condicionados por um forte código normativo, mas define os seus objetivos e formas de os alcançar em função dos interesses da Rússia.

Em contrapartida, a conceção da Alemanha da política internacional contrasta com a perspetiva russa por basear-se numa conceção pós-soberanista da política internacional que aceita a limitação da soberania dos Estados por razões de integração multilateral ou por razões de ingerência humanitária. Constata-se a preferência pelo multilateralismo, pelo soft power e por princípios da boa governabilidade o que se repercute 
na europeização de vários setores da política alemã (Daehnhardt, 2011b e Daehnhardt, 2013a). A União Europeia afirma-se como o quadro de referência essencial, mesmo existencial para a defesa dos seus interesses e para amortecer o seu percurso de normalização da política externa condicionada por constrangimentos legais e morais que explicam a relutância da Alemanha face ao uso da força militar e que tem levado Berlim a considerá-lo apenas como último recurso, por razões humanitárias, preferencialmente com um mandato das Nações Unidas, e assumindo uma posição multilateral com os seus aliados. Por vezes esta relutância sobrepõe-se ao princípio do multilateralismo, levando Berlim a divergir da postura dos seus parceiros da Aliança Atlântica, como aconteceu em 2003, sobre a guerra no Iraque e em 2011, sobre a intervenção militar na Líbia. Isso já produziu o efeito adverso de uma convergência paradoxal de posições onde Berlim e Moscovo se posicionaram de forma semelhante, ou pela oposição a uma resolução proposta, como aconteceu com o Iraque, em 2003 ou abstendo-se, como aconteceu com a resolução sobre a Líbia, em 2011, se bem que por motivos distintos. ${ }^{38}$

O conjunto das características referidas define assim dois códigos "genéticos" diferenciados e colocam a Rússia e a Alemanha nas duas extremidades do quadro narrativo que molda a atuação externa no espaço euro-atlântico, com a Rússia crítica de uma ordem pós-moderna e desconfiada de princípios que se pretendam sobrepor à ordem soberanista. A Alemanha continua, mesmo que em menor grau do que antigamente, a ser condicionada pela memória histórica e a privilegiar, apesar da crise das dívidas soberanas que ameaçam a sobrevivência do euro, o multilateralismo e a integração europeia. Neste quadro normativo a política alemã é fundada na premissa de que a cooperação política e económica com o ocidente poderá resultar numa progressiva

38 A abstenção da Alemanha quanto à aprovação da Resolução 1973 de 17 de março de 2011 sobre a aplicação de uma zona de exclusão aérea sobre a Líbia foi duramente criticada; o que agravou a leitura da posição alemã foi o facto de a Rússia, juntamente com a China também se terem abstido, o que colocou o voto alemão numa luz ainda mais problemática, já que a abstenção alemã, em comparação com a abstençao russa e chinesa podia ser interpretada mais como um 'não' do que uma mera abstenção. 
integração da Rússia no espaço securitário euro-atlântico através da aceitação de normas e valores europeus, ao passo que a Rússia, na subscrição de uma conceção menos normativa e não recíproca, não se vê condicionada a atuar nesse sentido.

\section{A relação entre a Rússia e a Alemanha}

A relação entre a Rússia e a Alemanha caracteriza-se por consultas bilaterais anuais entre o presidente russo e o chanceler alemão e entre diferentes ministros que abordam as relações bilaterais nos domínios político, económico, energético, de segurança e cultural. A centralidade da relação económica levou à institucionalização da cooperação e desde 2000, realizam-se regularmente, geralmente duas vezes por ano, reuniões bilaterais do Grupo de Trabalho Estratégico da Economia e das Finanças onde representantes políticos e empresariais abordam questões económicas e financeiras. Estes contatos regulares ao mais alto nível revelam a posição da Alemanha como principal parceira económica da Rússia. Para além do relacionamento entre as estruturas governamentais, foi criado, em 2001, pelo presidente russo Vladimir Putin e o chanceler alemão, Gerhard Schröder, o "Diálogo de Petersburgo", um fórum de discussão que se realiza anualmente para promover o aprofundamento das relações entre as duas sociedades civis nos domínios da política, economia, educação e ciência, cultura e media. 39

39 O Diálogo de Petersburgo, que nos últimos anos se transformara num fórum ritualizado representado, por parte da Rússia, por antigos funcionários do Kremlin, mais do que representantes da sociedade civil russa, foi revitalizado, da parte alemã, em abril de 2012, quando a chanceler Merkel nomeou Andreas Schockenhoff, vice-presidente da CDU/ CSU no Bundestag e coordenador para a Rússia do seu governo para chefiar o grupo de trabalho do "Diálogo de Petersburgo". Desde então, a posição alemã tem vindo a endurecer o discurso, como aconteceu, por exemplo, na condenação do caso Pussy Riot, um grupo de música, cujos membros foram condenados, em agosto de 2012 a dois anos de prisão, detidos sob acusação de ódio religioso e hooliganismo por terem atuado, em fevereiro de 2012 numa igreja, apelando à deposição de Putin. Ver "Kreml kritisiert CDU-Politiker Schockenhoff”, Frankfurter Allgemeine Zeitung, 14 agosto 2012. Disponível em: http:// www.faz.net/aktuell/politik/ausland/prozess-gegen-pussy-riot-kreml-kritisiert-cdu-politiker-schockenhoff-11855427.html. Consultado em: 12 setembro 2012. 


\section{A relação económica}

A relação bilateral económica e energética com a Alemanha é fundamental para a Rússia que necessita dos investimentos de empresas alemãs e do mercado energético alemão (e europeu) para escoamento das suas exportações, compostas primordialmente por recursos energéticos como o gás natural e o petróleo. A Alemanha é um ator chave no contexto euro-atlântico: é a maior economia europeia, a quinta maior economia no mundo e detém um papel importante nas instituições económicas internacionais como o G8 e o G20. É, depois da China, o segundo maior país exportador no mundo e, perante as adversidades da crise na zona euro, tem conseguido manter algum crescimento económico e uma forte indústria exportadora, afirmando-se como potência geoeconómica (Kundnani, 2011). É por isso, inevitavelmente, um parceiro económico atraente para a Rússia tornando-se o seu principal parceiro comercial europeu. Por outro lado, a UE é fundamental à modernização económica russa tendo a diplomacia russa se esforçado por desenvolver uma relação dinâmica com alguns Estados membros, especialmente através de 'alianças para a modernização' bilaterais com a Alemanha, a França e a Itália. A posição chave que a Alemanha assume em Bruxelas é relevante na definição das relações entre a UE e a Rússia e nos recursos que Bruxelas está disposta a disponibilizar a Moscovo.

A relação económica russo-alemã existe desde há longa data, sendo a Rússia a quarta maior parceira comercial da Alemanha fora da UE. Por seu turno, a Alemanha foi, até 2010, o maior parceiro comercial da Rússia, tendo sido ultrapassada pela China, mas mantendo-se como o segundo parceiro a nível mundial e um importante mercado para as exportações da Rússia na UE.

O volume comercial entre os dois países aumentou significativamente entre 2000 e 2008 e voltou a aumentar em 2011, após um abrandamento em 2009 e 2010, atingindo o volume de comércio transacionado um valor máximo de 75 mil milhões de euros. ${ }^{40} \mathrm{Em} 2011$, as exportações alemãs

40 Os números que se seguem nesta secção foram consultados no Gabinete Federal de Estatística alemão (Statistische Bundesamt, Destatis), quando não assinalados de outra forma. 
para a Rússia aumentaram 30.5\%, alcançando 27 mil milhões de euros e as importações da Rússia aumentaram $27 \%$ perfazendo 25 mil milhões de euros. ${ }^{41} \mathrm{Em} \mathrm{2007}$, por exemplo, quase $70 \%$ das importações alemãs da Rússia eram produtos energéticos, tendo o petróleo e o gás natural sido os principais produtos importados no valor de 28.8 mil milhões de euros. Cerca de $15 \%$ das importações provenientes da Rússia foram metais como o ferro e o aço. Por seu turno, a Rússia depende da relação comercial com a Alemanha devido à necessidade de modernização da sua economia para a qual os investimentos alemães são indispensáveis. A Alemanha é dos países que mais investe na Rússia, tendo, em 2009, investido cerca de 13 mil milhões de euros. Apesar da crise económica e financeira, principalmente na zona euro, os dois países têm vindo a aprofundar a sua relação económica.

A Rússia ocupou, em 2011, o décimo segundo lugar dos países destinatários das exportações alemãs, no valor de 34.4 mil milhões de euros. ${ }^{42}$ Da parte das exportações russas para a Alemanha, estas ocuparam o sexto lugar, no valor de 40.5 mil milhões de euros. De acordo com o Ost-Ausschuss der Deutschen Wirtschaft (Comissão de Leste da Economia Alemã) esta situação poderia ser melhorada se existisse uma zona de livre comércio e se se procedesse à abolição, discutida desde 2003, do sistema de vistos entre os países do espaço Schengen e a Europa oriental, incluindo a Rússia. Como consta de um documento da Comissão publicado em novembro de 2011,

"A criação de um espaço económico harmonioso de Lisboa a Vladivostok é um dos grandes desafios da próxima década. Para não perder definitivamente a sua influência no palco da economia mundial face aos EUA e países asiáticos emergentes as economias europeias devem interligar-se mais com as economias fora do espaço da UE. A obrigatoriedade de vistos com muitos países vizinhos da Europa oriental é um dos maiores obstáculos ao comércio internacional. Especialmente o país exportador, a

41 "Rekordergebnis für Exporte nach Osteuropa", 2 março 2012. Disponível em: http://www. ost-ausschuss.de/rekordergebnis-f-r-exporte-nach-osteuropa. Consultado em: 12 março 2012.

42 Informação disponível em: http://www.ost-ausschuss.de/rekordergebnis-f-r-exporte-nach-osteuropa. Consultado em 12 março 2012. 
Alemanha tem um interesse fundamental em fazer progressos neste domínio." (Comissão de Leste da Economia Alemã, 2011, p. 5)

Enquanto que a Rússia é favorável à abolição dos vistos, alguns países da UE, entre os quais a própria Alemanha, colocam entraves à supressão dos mesmos por preocupações relacionadas com a segurança e o receio da imigração ilegal para o espaço comunitário. Isto revela que enquanto os setores económico e industrial alemães têm fortes interesses na intensificação da relação, exercendo pressão sobre o governo, a condução política da relação económica encontra-se condicionada por considerações políticas orientadas pela narrativa alemã acima descrita, mesmo que reúna consenso entre a elite política e económica alemã que uma crescente integração da economia russa nos mercados do espaço euro-atlântico serve para atenuar a rivalidade estratégica russa para com o ocidente.

\section{A relação energética}

A questão da segurança energética tornou-se uma das questões centrais da política externa. Para além dos benefícios económicos, os vastos recursos energéticos de que a Rússia dispõe no seu território são uma fonte de prestígio internacional que Moscovo instrumentaliza para projetar poder político no plano internacional. São, ao mesmo tempo, uma moeda de troca que os decisores russos têm utilizado para exercer pressão política e diplomática sobre Estados vizinhos e parceiros europeus, ou, em alguns casos, como instrumento para forçar uma alteração do posicionamento externo de um país vizinho, como aconteceu com a Ucrânia, em 2006 e 2009. A Rússia usa as exportações energéticas como instrumentos da sua política externa, sendo a companhia petrolífera russa Transneft um veículo de pressão sobre as exportações de petróleo, e a companhia de extração de gás natural Gazprom um veículo de pressão sobre as exportações de gás. Na vizinhança da Rússia, este tipo de pressão recai principalmente sobre a Ucrânia, a Bielorrússia e a Moldova por serem países de trânsito no fornecimento de gás russo para a UE. 
Uma componente importante do relacionamento económico bilateral entre Berlim e Moscovo é o fornecimento de energia russa à Alemanha. Mais de dois terços das importações alemãs da Rússia são recursos energéticos e quase um terço do consumo energético alemão de petróleo e gás natural é proveniente da Rússia. A Rússia é o maior fornecedor de energia da Alemanha desde a década de 1970, e continua a ser o maior fornecedor de gás natural para o mercado de gás alemão, tendo exportado, em 2007, 36\% do gás que a Alemanha importa, seguida pela Noruega e os Países Baixos que para aí exportam 26\% e 18\%, respetivamente (Bayer, 2009, p. 420). Entre 2008 e 2012, a Rússia manteve-se como a principal fornecedora de gás e petróleo para a Alemanha. ${ }^{43}$ Esta relação sugere uma maior dependência da Alemanha da Rússia, do que o inverso, já que a Alemanha importou, em 2011, 39.8\% do gás da Rússia (e 40.6\% de petróleo), representando o maior consumidor das exportações de energia da Rússia na Europa. ${ }^{44}$ No seio da UE, a Alemanha tem apoiado a entrada de companhias de energia russas no mercado europeu de energia, sublinhando que esta abertura reduziria os incentivos russos para manipular o fornecimento energético à Europa.

Perante a inexistência de uma política energética comum da UE, e de uma política europeia única para a Rússia, a Alemanha prossegue a relação energética bilateralmente. Assinou, em 2005, o projeto Nord Stream, como forma de garantir o acesso alemão ao gás natural russo e o seu transporte para a UE, assegurando que a rota de fornecimento ligasse a Rússia diretamente à Alemanha através do Mar Báltico, contornando os países bálticos e a Polónia cujas reações foram previsivelmente negativas ao projeto, o que se explica também pela perspetiva política que o então chanceler

43 Ranglisten für den Außenhandel Deutschlands nach Warenkategorien für das Jahr 2012, Außenwirtschaftsportal Bayern, Fonte: Statistische Bundesamt. (Posição dos parceiros económicos no comércio exterior da Alemanha, por categoria de produto para o ano de 2012), Disponível em: http://www.auwi-bayern.de/awp/inhalte/Laender/Warenkategorien/ kat/GP09-06/Erdö1\%20und\%20Erdgas/\#. Consultado em: 12 março 2013.

44 Discurso do Embaixador alemão em Moscovo, Ulrich Brandenburg, em 30 agosto de 2012, em Magdeburgo. Disponível em:

http://www.moskau.diplo.de/Vertretung/moskau/de/05/05-klima-energie/vortrag-botschafter-energiebeziehungen.html. Consultado em 12 setembro 2012. 
Schröder defendia, de uma aliança geopolítica e geo-económica entre as duas potências continentais euroasiáticas, integrando-as economicamente e reforçando a ligação política. Esta "parceria de modernização" faria com que a Rússia proporcionasse os recursos energéticos, enquanto que a Alemanha disponibilizava as tecnologias. $\mathrm{O}$ aumento dos laços bilaterais entre a Alemanha e a Rússia, no entanto, não é necessariamente contrário aos interesses europeus já que o gasoduto Nord Stream tem como objetivo fornecer gás natural russo à UE. Mas as implicações políticas do acordo bilateral evidenciavam a proximidade política entre Schröder e Putin e a forma como esta proximidade se traduzia em ganhos económicos, por vezes à custa dos parceiros da Alemanha.

A estratégia de Moscovo, por seu turno, é a de controlar as rotas de exportação de gás da Ásia Central para a Europa e adquirir uma influência crescente sobre o mercado energético europeu. Estes interesses estratégicos refletem-se, por exemplo, nas ações da empresa Gazprom, que pretende investir nas companhias alemãs E.ON Rubrgas ou BASF para entrar no mercado de gás alemão e assegurar uma posição importante em todo o mercado energético. Por outro lado, serve como meio de pressão sobre uma participação da Alemanha no projeto South Stream, rival do projeto Nabucco, proposto há uma década e que prevê o acesso europeu a gás natural do Cáspio e da Ásia Central através da Turquia e dos Balcãs, evitando a passagem por território russo (Westphal, 2011). O monopólio da Gazprom assim como as suas políticas de preço e falta de transparência nas políticas energéticas e de transferências económicas são igualmente motivos de preocupação do ocidente (Smith, 2010). Nesse sentido, a Alemanha tem tentado diversificar as fontes de fornecimento energético como aconteceu, por exemplo, com o Cazaquistão, o país com as quintas maiores reservas de recursos conhecidas no mundo. Em fevereiro de 2012 a chanceler Merkel recebeu Nursultan Nesarbaijev, presidente do Cazaquistão, em Berlim, tendo sido assinado um contrato comercial de exploração de recursos naturais por empresas alemãs. Por outro lado, a nova política energética alemã de 2011 de eliminação gradual da energia nuclear até 2022, requer uma nova política para a Rússia, já que as importações de gás poderão crescer significativamente e aumentar a 
dependência alemã do gás russo e os riscos associados à sua segurança económica, o que limitará a sua margem de manobra negocial.

\section{Segurança europeia e transatlântica}

A relação da Rússia com a Europa e com os Estados Unidos no quadro securitário euro-atlântico permanece, mais de duas décadas depois do fim da Guerra Fria e do fim da União Soviética, uma relação complexa e ambígua. Para alguns autores, os avanços neste domínio são tão precários, que se pode falar apenas de uma 'Paz Fria' que substituiu a 'Guerra Fria' (Sakwa, 2011; Karaganov, Teltschik e Olechowski, 2011). A complexidade prende-se mais com o contexto inerente ao espaço euro-atlântico do que ao espaço exterior a ele.

Moscovo distingue entre diferentes anéis de atuação: em primeiro lugar, o território da antiga URSS, o 'estrangeiro próximo' face ao qual a Rússia se reserva um droit de regard onde não aceita a interferência de países europeus; este espaço está longe de ser uma zona pacificada já que se caracteriza pela existência dos chamados 'conflitos congelados' da zona da Transnístria, na Moldova, do Nargorno-Karabakh, no Cáucaso do Sul, assim como as divergências entre a Rússia e a Geórgia quanto às regiões separatistas da Abcázia e da Ossétia do Sul. Estas questões destabilizam não apenas a vizinhança da Rússia mas afetam as relações entre Moscovo e o ocidente, produzindo uma competição latente pelo 'estrangeiro próximo' como lhe chama a Rússia ou a 'vizinhança europeia' como lhe chama a UE e que teve o seu auge com a guerra da Geórgia, em agosto de 2008. Esta guerra que opôs a Rússia à Geórgia numa disputa sobre a soberania da Abcázia e Ossétia do Sul, duas repúblicas secessionistas de Tbilisi provocou uma reação contida por parte da Alemanha, combinando o apoio à mediação do presidente francês Nicholas Sarkozy, enquanto líder da presidência rotativa da UE, com a não hostilização aberta de Moscovo. Poucos meses antes, na cimeira da OTAN, em Bucareste, em abril de 2008, a Alemanha e a França opuseram-se à aplicação do Membership Action Plan (MAP) da Geórgia e da Ucrânia à OTAN, ficando 
este objetivo norte-americano adiado sine die devido às preocupações franco-alemãs em não hostilizar Moscovo. ${ }^{45}$ Como o estatuto de segurança destes países e dos restantes quatro da Parceria Oriental ainda está por resolver, mantém-se a competição entre a Rússia, a UE e os EUA quanto à projeção de influência na definição do quadro de segurança inacabado do espaço euro-atlântico. É nesta zona precisamente que a leitura russa do seu 'estrangeiro próximo' entra em choque com a leitura da UE de 'vizinhança europeia' na qual a UE pretende projetar o seu modelo liberal democrático e onde, como afirmou Robert Kagan, a Rússia do século XIX choca com a União Europeia do século XXI (Kagan, 2008). Enquanto a Alemanha e a UE pretendem alargar a ordem de integração europeia vigente nas suas fronteiras, a Rússia pretende alterar esse modelo de ordem e assegurar a sua perspetiva tradicional de projeção de influência.

Em segundo lugar, o anel definido pelo quadro de segurança existente no espaço euro-atlântico mais amplo, onde a perspetiva securitária da Rússia converge seletivamente com as posições da UE e dos EUA na identificação de interesses comuns. A relação entre a OTAN e a Rússia nunca foi por isso uma relação livre de controvérsia (Kramer, 2010). A criação do Ato Fundador sobre Relações Mútuas, Cooperação e Segurança OTAN-Rússia, em 1997, institucionalizou a relação bilateral, enquanto o Conselho OTAN-Rússia, de 2002, tornou a Rússia um parceiro privilegiado da OTAN. Contudo, este formato equivalia à baixa probabilidade de a Rússia vir a tornar-se um membro da Aliança.

A prolongada ou permanente exclusão da estrutura transatlântica como membro de pleno direito tem levado Moscovo a seguir uma estratégia de, por um lado, tentar dividir os aliados e afastar os EUA da Europa e, por outro, influenciar as decisões sobre a segurança europeia de forma a incluir interesses estratégicos russos, o que tem resultado numa linha pouco definida em relação ao ocidente já que Moscovo se mostra ora cooperativo ora conflituoso com o mesmo. É principalmente em relação aos países da

45 Membership Action Plan ou 'Plano de Ação para a Adesão' (MAP) é um programa da OTAN, que prepara países que pretendam tornar-se membros da Aliança. O MAP não é contudo uma garantia de uma futura adesão à OTAN. 
Europa de leste, a antiga zona de influência da União Soviética que Moscovo tem revelado menos inibições em opor-se ao alargamento da OTAN durante a década de 1990 ou assumir posições conflituosas, realizando ataques cibernéticos contra os Estados Bálticos, aumentando as tarifas alfandegárias à Polónia, opondo-se à independência do Kosovo ou explorando tensões étnicas nos Balcãs para minar os esforços de estabilização regional da UE. Para além disso, a oposição russa ao projeto de defesa antimíssil para a Europa, defendido pelos EUA, evidencia a dificuldade de estabelecimento de um verdadeiro quadro de segurança euro-atlântico. ${ }^{46}$ Esta ambiguidade russa reflete-se também na sua doutrina militar, adotada em fevereiro de 2010, e que identificou explicitamente a OTAN e o seu alargamento para o leste europeu como representando uma ameaça militar para a Rússia. O discurso russo face aos países ocidentais sublinhava repetidamente que o aparecimento de infra-estruturas estratégicas norte-americanas na proximidade imediata das suas fronteiras será interpretado como uma ameaça à sua segurança. Nesse sentido, o relatório do grupo de peritos sobre o novo conceito estratégico da OTAN, de maio de 2010, afirmava que “a Rússia enviou sinais conflituosos quanto à sua abertura à cooperação contínua com a OTAN, e as suas propostas para uma ordem de segurança alternativa na Europa parecem desenhadas em parte para constringir as atividades da OTAN" (OTAN 2020, 2010, p. 26).

Por último, Moscovo define um terceiro anel de actuação, fora do espaço euro-atlântico, caracterizado pelas ameaças globais como o terrorismo internacional, a proliferação das armas de destruição maciça, o crime mundial

46 O projeto de defesa balística de mísseis continua a ser uma das principais divergências entre a Rússia e os EUA/OTAN. Os EUA e a OTAN pretendem construir um sistema de mísseis anti-balísticos na Europa, destinado a dissuadir potenciais ataques dirigidos do Irão à Europa ou aos EUA. A Rússia, contudo, teme que a implantação deste sistema anti-míssil na Europa seja dirigido contra os seus arsenais nucleares tornando a dissuasão nuclear russa vulnerável. Os países ocidentais e particularmente os EUA têm reservas sobre o grau de partilha de informações a que a Rússia estará disposta no desenvolvimento de um sistema de defesa anti-míssil conjunto e onde a forma de acesso ao comando de tal sistema (um único como defende Moscovo ou dois sistemas separados como defendem os membros da OTAN) permanece um ponto de discórdia. Apesar dos EUA, a Alemanha, e a OTAN terem proposto a cooperação com a Rússia neste projeto, Moscovo exige que a OTAN assine com a Rússia um tratado internacional que lhes permita controlar o sistema. A OTAN, em contrapartida, oferece apenas garantias políticas de que o sistema não visa a Rússia, em boa parte porque um tratado internacional desse tipo não seria ratificável no Senado dos EUA. 
organizado, assim como ameaças emergentes de países como o Irão e a Coreia do Norte, a incerteza securitária do Afeganistão após a retirada das forças da OTAN, em 2014, ou a instabilidade política que permanece no Médio Oriente, acentuada pela chamada Primavera Árabe. Ao contrário do que acontece nos primeiros dois anéis, aqui existe alguma convergência de interesses e cooperação securitária entre a Europa, os EUA e a Rússia, se bem que as mudanças políticas no Médio Oriente, em particular na gestão das crises da Líbia e da Síria, decorrentes da Primavera Árabe, ou a prolongada questão nuclear do Irão não têm levado a posições conjuntas. ${ }^{47}$

Pela permanência desta ambiguidade do relacionamento entre a Rússia e os restantes atores do espaço euro-atlântico, a relação bilateral com a Alemanha tornou-se ainda mais relevante no pós-Guerra Fria e produz implicações no quadro político-securitário euro-atlântico que Moscovo tenta aproveitar. Para atenuar essas divergências, a Alemanha tem seguido o princípio de que a Rússia deve ser tratada como parceira e não como adversária: será apenas através da inclusão da Rússia no quadro de segurança europeu que se consegue alcançar a estabilidade na Europa e que as grandes crises internacionais poderão ser resolvidas com Moscovo como importante parceiro na resolução de questões internacionais em zonas como o Médio Oriente ou os Balcãs. Um dos defensores mais ativos deste princípio foi o antigo ministro dos negócios estrangeiros alemão Frank-Walter Steinmeier (SPD), quando sugeriu uma nova Ostpolitik, em 2006-2007, baseada na "reaproximação através da interdependência económica" (“Annäherung durch Verflechtung”) e numa ordem de paz europeia estável, democrática e de vigência do direito nos países vizinhos da UE (Steinmeier, 2006). Isto pressupunha a participação da Rússia, servindo o reforço dos laços políticos, económicos e culturais entre a UE e a Rússia para garantir a estabilidade nas fronteiras da UE.

Da parte russa pretendia-se capitalizar esse apoio alemão. Em junho de 2008, o presidente russo Dmitri Medvedev afirmou num discurso, em

47 A Alemanha tem votado a favor das resoluções do Conselho de Segurança das Nações Unidas sobre a Síria que condenam o regime do presidente sírio Bashar al-Assad e a guerra civil em curso, enquanto a Rússia (e a China) tem repetidamente, desde outubro de 2011, vetado resoluções que prevejam a aplicação de sanções ao regime de Damasco. 
Berlim: "A importância da reconciliação russo-alemã é claramente subestimada. É tão importante para o futuro pacífico da Europa como foi, digamos, a reconciliação entre a França a e Alemanha" (Medvedev, 2008a). Nesse discurso, Medvedev falou pela primeira vez publicamente numa nova arquitectura de segurança europeia e transatlântica, de Vancouver a Vladivostok, sem ser muito específico quanto aos contornos da mesma. Sem a rejeitar, Berlim reagiu à proposta com alguma hesitação: apoiá-la decididamente levaria a críticas de desunião na Aliança Atlântica; rejeitá-la abertamente desincentivaria Moscovo a manter-se interessado no quadro de estabilização na Europa que a Alemanha considera vital.

Em finais de 2009, na primeira reunião OTAN-Rússia após a guerra com a Geórgia, Medvedev lançou uma proposta mais formal, no novo contexto da política do reset da administração norte-americana da Barack Obama que pretendia relançar as relações depois do desaire sobre a Geórgia. $\mathrm{Na}$ realidade, contudo, continuava a não existir uma convergência de interesses entre as partes que permita um avanço quanto à iniciativa russa: enquanto a Rússia pretendia uma renegociação das estruturas de segurança europeias, ou seja, uma substituição das antigas estruturas por um novo quadro securitário, cujos termos seriam primordialmente definidos por Moscovo, a UE - e a Alemanha - tentavam resolver os problemas dentro do quadro securitário existente concebendo mecanismos de resolução de conflitos dentro da UE e mantendo inalterada a importância da OTAN e da presença dos EUA na Europa (Makarychev, 2009b).

Nos meses que antecederam a Cimeira da OTAN, em Lisboa, em novembro de 2010, as iniciativas russo-alemãs multiplicaram-se, revelando mais uma vez a importância que a Alemanha assume para a Rússia como parceiro preferencial no lançamento de propostas vindas de Moscovo. Em 6 de junho de 2010 Merkel e Medvedev propuseram a criação de um Comité Político e de Segurança UE-Rússia, para uma cooperação mais estreita em questões de segurança. Este memorando de Meseberg, como ficou conhecido, sugeria a realização de reuniões a nível ministerial, entre a Alta Representante para a Política Externa e de Segurança, Catherine Ashton e o ministro dos negócios estrangeiros russo, Sergej Lavrov. Segundo o comunicado, o Comité deveria "tornar-se um fórum de troca 
de perspetivas sobre assuntos atuais de política e segurança internacional" e servir para desenvolver "linhas orientadoras quanto a operações civis e militares conjuntas no domínio da gestão de crises" (Memorando de Meseberg, 2010). Esta iniciativa bilateral apanhou os restantes membros da UE e a Comissão Europeia de surpresa, e apesar de a iniciativa não ter tido seguimento ilustrou como Berlim qualificava Moscovo como essencial na definição do quadro de segurança europeu ao passo de lançar propostas conjuntas sem conhecimento prévio dos seus parceiros europeus. Dos cinco pontos do comunicado consta uma referência específica à cooperação entre a UE e a Rússia com vista à resolução do conflito da Transnístria sugerindo atividades conjuntas "que garantam uma transição suave da situação atual até à fase final." Berlim tentou estabelecer uma ligação entre a proposta de criação do acima referido Comité Político e de Segurança UE-Rússia e a tentativa de resolução da situação nesta região separatista da Moldova porque vê o caso da Transnístria como um test case das relações de segurança entre a Alemanha e a Rússia na Europa. Contudo, para os decisores russos a resolução deste conflito é vista como contrária aos interesses russos, já que levaria a uma perda de influência russa e aceleraria a integração da República da Moldova na UE. Claramente, as divergências entre a perspetiva alemã de resolução de conflitos e a perspetiva russa quanto aos mesmos pode ser aplicada a outros conflitos de países que integram a Parceria Oriental, como o caso do Nagorno-Karabakh, entre a Arménia e o Azerbaijão, e o caso da Abcázia e da Ossétia do Sul, entre a Geórgia e a Rússia: uma resolução dos mesmos aproximaria estes países mais à UE, ao passo que a sua continuação mantem as partes na dependência da Rússia.

Ainda em 2010 várias personalidades alemãs manifestaram-se a favor de uma redefinição do relacionamento político e de segurança dos países ocidentais com a Rússia. Em 14 de janeiro de 2010, o então secretário de estado alemão dos Assuntos Europeus, Werner Hoyer (FDP), sugeriu uma nova dinâmica na política do Conselho OTAN-Rússia que incluísse uma política da porta aberta da OTAN em direção a Moscovo (Hoyer, 2010). Para Hoyer a criação de um quadro de segurança europeia duradouro dependeria da adesão da Rússia à “aliança de segurança das democracias 
ocidentais do espaço euro-atlântico" devendo a OTAN manter a sua 'Open-door policy' em relação a Moscovo.

Numa carta aberta publicada no semanário alemão Der Spiegel, em março de 2010, a antigo ministro alemão da defesa, Volker Rühe, o ex-general da Bundeswehr, Klaus Naumann, o antigo diplomata, Frank Elbe e um antigo chefe de gabinete do ministério da defesa, Ulrich Weisser sugeriram a adesão, no futuro, e segundo critérios previamente acordados, da Rússia à Aliança Atlântica argumentando que, na defesa contra ameaças externas e para responder aos desafios colocados pelas dinâmicas transformadoras da multipolaridade emergente, largamente devido às potências asiáticas, a OTAN não estava preparada. Por isso, como entidade estratégica a Aliança deveria agrupar os três centros de poder: América do Norte, Europa e Rússia. Este trio, para estes autores, tinha interesses comuns que são ameaçados pelos mesmos desafios e que exigem por isso respostas comuns (Der Spiegel, 2010).

Dois diplomatas alemães, Wolfgang Ischinger, coordenador da Conferência de Segurança de Munique e antigo embaixador da Alemanha nos EUA e Ulrich Weisser, antigo chefe de gabinete do ministério da defesa publicaram um artigo conjunto, em junho de 2010, onde afirmaram que o desafio central para a OTAN era 'getting Russia right' (Ischinger e Weisser, 2010) e onde uma diminuição da 'fricção permanente entre membros da OTAN quanto à Rússia poderia ser conseguida através de uma maior inclusão da Rússia num contexto negocial entre a OTAN, a UE e a Rússia, e a Alemanha e a Rússia, por exemplo, relativamente ao sistema de defesa anti-míssil, controlo de armamento convencional e nuclear. $\mathrm{O}$ apelo a uma comunidade de segurança euro-atlântica que reunisse estrategicamente a América do Norte, a Europa e a Rússia, sustentado por uma cooperação no projeto de defesa anti-míssil foi reiterado por Ischinger em maio de 2012 pouco antes da cimeira da OTAN em Chicago (Ischinger, 2012). Assim, a Rússia contava com o apoio de Berlim quanto às suas preocupações de segurança no sentido do reconhecimento por uma parte considerável da elite alemã do risco de marginalização das questões europeias e euro-atlânticas. Se bem que se tratou de posições individuais dentro da elite política alemã, a Alemanha era dos grandes 
Estados membros da OTAN aquele para quem uma futura, mesmo que longínqua hipótese de adesão russa à OTAN não era inconcebível.

\section{Quadros de cooperação alargados: França e Polónia}

Numa tentativa de resolver a contínua indefinição sobre os contornos da ordem europeia de segurança e um discurso russo que oscila entre a abordagem cooperativa e a hostilização do ocidente, a Alemanha tem vindo a promover dois quadros de cooperação alargados, nomeadamente com a França e com a Polónia. A primeira reunião triangular entre Berlim, Paris e Moscovo ocorreu em 1998, entre o chanceler Helmut Kohl, o presidente Jacques Chirac e o presidente Boris Ieltsin. Mas foi o encontro entre o chanceler Gerhard Schröder, o presidente Jacques Chirac e o presidente Vladimir Putin, em São Petersburgo, em abril de 2003, no auge da guerra do Iraque e quando os três líderes convergiram na crítica a Washington (e Moscovo e Paris convergiam no apoio à pretensão da Alemanha em tornar-se um membro permanente do Conselho de Segurança das Nações Unidas) que este formato ganhou maior relevância. O encontro foi seguido por reuniões triangulares anuais, com o objetivo da intensificação da cooperação económica, e onde questões de direitos humanos que integravam as agendas de Berlim e Paris acabavam por ser secundarizadas aos interesses económicos de três atores.

Mais recentemente, a Alemanha tem promovido a integração da Polónia na relação bilateral entre Berlim e Moscovo argumentando que o desentendimento entre Moscovo e Varsóvia, de meados da década de 2000 era prejudicial a progressos no relacionamento entre a UE e a Rússia. Assim, desde inícios de 2010 Varsóvia e Moscovo iniciaram um lento processo de reconciliação entre as elites políticas, tornando-se a Polónia um parceiro importante para a Rússia por várias razões para além da cooperação económica: primeiro, porque integra o grupo de Visegrado cujo foco securitário é a zona geográfica que engloba a Moldova, a Ucrânia e a Bielorrússia; segundo, porque partilha a costa marítima do Mar Báltico com os países bálticos e escandinavos, evidenciando também aqui questões 
securitárias no relacionamento com Moscovo. Aliás, a Parceria Oriental, que criou um quadro institucional próprio da UE com seis ex-repúblicas da União Soviética, em 2009, surgiu através de uma iniciativa bilateral entre a Polónia e a Suécia, com o apoio de Berlim, demonstrando a relevância da dimensão nórdica para Varsóvia. Terceiro, nos últimos anos, a Polónia provou ser o aliado da Europa central mais importante dos Estados Unidos, o que aumentou o seu poder negocial junto a Moscovo. Por último, a relação bilateral da Polónia com a Alemanha é decisiva, e o seu enquadramento no triângulo de Weimar, que, para além destes dois paises inclui a França, surge como complemento importante na diplomacia de Varsóvia.

A iniciativa de consultas trilaterais entre a Alemanha, a Rússia e a Polónia poderia produzir uma transformação qualitativa no relacionamento entre a Rússia e a UE, porque a Polónia surge como peça chave, ao legitimar uma nova dimensão de confiança e potencial reconciliação polaco-russa, por um lado, e ao retirar à relação bilateral entre Berlim e Moscovo a exclusividade que por muitos é vista como excessiva, por outro. Das tensões germano-polacas, em 2005, sobre como abordar a Rússia, ou o veto polaco sobre a renovação do Acordo da Parceria e Cooperação (APC) UE-Rússia em 2007, passou-se para uma abordagem germano-polaca face à Rússia no quadro securitário europeu. Da perspetiva da diplomacia russa, este formato é ainda visto como veículo para promover acordos regionais, principalmente a cooperação transfronteiriça, junto de Bruxelas, onde Berlim tem poder de alavancagem. O primeiro encontro do 'Diálogo Trilateral' ocorreu em Kaliningrado, em maio de 2011, e abordou questões sobre o fim dos vistos para residentes de Kaliningrado e a UE.

Em novembro de 2011, no decurso da presidência polaca da União Europeia, os ministros dos negócios estrangeiros alemão e polaco, Guido Westerwelle e Radoslav Sikorski, numa carta conjunta a Catherine Ashton, Alta Representante para a Politica Externa da UE, apelaram à UE para que adopte uma estratégia europeia para a Rússia para o aprofundamento da relação de cooperação, assumindo esta "o seu lugar apropriado numa Europa democrática de liberdade e prosperidade”. A UE deveria apoiar a modernização da economia e do sistema político e social russos, em troca 
de uma Rússia como "parceiro fiável no palco político e económico europeu" (Turkowski, 2011). Estas iniciativas sugerem o desenvolvimento de uma Ostpolitik multilateral germano-polaca, que joga a favor do aumento da influência da Alemanha ao mesmo tempo que facilita uma reconciliação russo-polaca. Mesmo assim, esta fórmula trilateral não tem até à data produzido os efeitos pretendidos. A relação entre estes três países é ainda dificultada, por um lado, pela inexistência de uma verdadeira política da UE para a Rússia, por outro, pelas divergentes prioridades que definem as atuações políticas dos três atores: a Polónia, orientada primordialmente por considerações geopolíticas no seu relacionamento com Moscovo, a Alemanha orientada primordialmente por considerações económicas e a Rússia, receosa do alargamento da OTAN para junto das suas fronteiras.

A potência ausente deste quadro de relacionamento bi e multilateral para a Rússia são os Estados Unidos. Em contrapartida à linha de continuidade que a diplomacia alemã segue em relação à Rússia, a política dos EUA para a Rússia orienta-se por um leque mais abrangedor de opções, da cooperação à confrontação política. Esta divergência subjacente às diferentes perspetivas de Berlim e de Washington face a Moscovo tem dificultado uma política americano-alemã face à Rússia (Szabo, 2010). Da mesma maneira que não existe uma política da UE para a Rússia, também não existe uma política continuamente convergente entre a Alemanha e os EUA face a Moscovo: se houvesse uma política bilateral americano-alemã para a Rússia esta teria menos margem de manobra. Da perspetiva de Washington, a ausência de um consenso estratégico europeu para a Rússia faz com que o poder negocial da Alemanha junto dos EUA aumente, já que Berlim se tornou o principal interlocutor junto de Moscovo. Ao mesmo tempo, a Alemanha é o parceiro indispensável para gerir a estabilidade do continente europeu e as relações entre a UE e a Rússia. É ainda importante no relacionamento entre a Aliança Atlântica e a Rússia, porque na sua gradual transformação de potência europeia para potência asiática, os EUA vão precisar da Alemanha para que esta assegure a estabilidade na Europa. Como afirmou Constanze Stelzenmüller, "a Alemanha é uma ponte entre a Rússia e o ocidente, e a forma como Berlim escolhe lidar com Moscovo irá marcar o tom como os 
Estados Unidos e o resto da Europa vão gerir as suas próprias relações com a Rússia" (Stelzenmüller, 2009). Por outras palavras, "não pode haver nenhuma estratégia ou política séria ocidental para a Rússia que não seja apoiada por Berlim" (Szabo, 2010). A crítica vinda de alguns analistas dos EUA é que a Alemanha põe a tónica excessivamente na cooperação, interdependência e parceria com a Rússia e que isto impede que capitalize uma abordagem conjunta Alemanha-EUA ou mesmo Europa-EUA face a Moscovo (Bergmann, 2009; Szabo, 2010).

A reeleição de Barack Obama, em novembro de 2012, não provocou uma revitalização da relação entre os EUA e a Rússia, impedida pelo fracasso da política norte-americana do reset, e o endurecimento da postura de Vladimir Putin no seu regresso ao cargo presidencial; para além disso, a deslocação estratégica dos EUA do espaço euro-atlântico para o Pacífico e a criação de uma rede de parcerias e instituições semelhantes às europeias (Clinton, 2011, p. 58) sugere uma desaceleração da relação bilateral quanto a questões europeias. Estes três factores reforçam, contudo, a importância da relação entre a Rússia e a Alemanha numa altura em que a diminuição do envolvimento norte-americano na Europa poderá levar ao aumento da tensão entre a Rússia e a Alemanha.

A defesa mútua de interesses energéticos e económicos confirma que o pragmatismo é ainda a característica que melhor define a relação bilateral entre a Rússia e a Alemanha. Mas o governo alemão e os deputados do Bundestag não esconderam a sua desilusão ao tomarem conhecimento, em setembro de 2011, da candidatura de Putin a um terceiro mandato presidencial, que interpretaram como sinal de desaceleração da modernização iniciada por Dmitri Medvedev e de recuo no gradual processo de democratização da Rússia. Isto pode representar o início do fim do consenso político quanto à Rússia com alguns autores a identificar uma crescente alienação nas relações russo-alemãs (Meister, 2012). Antigos defensores de uma maior proximidade à Rússia têm mudado de postura. O general Klaus Naumann, por exemplo, que em 2010 fora co-assinante da carta acima referida, escreveu poucos dias depois da eleição presidencial, em março de 2012, que a posição de Putin quanto à Síria mostrava 
que a Rússia tinha deixado de ser um parceiro aceitável para a OTAN. ${ }^{48}$ A chanceler Angela Merkel não manifestou, nos primeiros meses após a reeleição de Putin sinais de que pretenderia reestabelecer uma relação próxima como ela existira com Medvedev. A primeira visita de estado de Putin como novamente presidente da Rússia, para fora do 'estrangeiro próximo', foi a Berlim, em 1 de junho de 2012. Tratou-se de um encontro cordial, mas que simbolizou o esfriamento das relações bilaterais, e onde, para além das habituais conversações sobre a cooperação económica, o desacordo entre Berlim e Moscovo sobre a forma de se abordar, no Conselho de Segurança das Nações Unidas, a guerra civil na Síria, manifestou uma vez mais a oposição da liderança russa em aceitar princípios da ordem securitária subscritos por Berlim. Neste sentido, está a emergir um debate, em Berlim, sobre se a Ostpolitik alemã para a Rússia - promover a mudança através da cooperação, interdependência e parceria - produziu até hoje os resultados pretendidos no sentido de aproximar a Rússia do quadro de valores e normas ocidentais e sobre se é possível construir uma ordem securitária europeia entre atores que não partilham a mesma conceção política. A intransigência de Putin face à questão da Síria, ao defender o regime criticado pelo ocidente, a crescente crítica de Moscovo do projeto de defesa anti-míssil, a recusa de Putin em participar nas reuniões do G8 e da OTAN, nos Estados Unidos, em abril de 2012, exemplificam o mal-estar atual nas relações entre a Rússia e o ocidente. Perante um potencial retrocesso deste relacionamento, a Alemanha posiciona-se, cautelosa, numa postura de não hostilização aberta, mas de um maior distanciamento de Moscovo. As iniciativas trilaterais, com a Polónia e a França persistem, mas com menos intensidade e sem resultados concretos. A cooperação económica irá manter-se, mas é possível que o ponto alto do relacionamento da Rússia de Putin-Medvedev-Putin com a Alemanha já tenha sido ultrapassado, e que apenas com uma verdadeira transição na Rússia para um sistema democrático os dois lados se voltem a aproximar.

48 Citado em John Vinocur (2012) "Germany's 'unpolitical' new president", New York Times, 26 março. Dísponível em: http://www.nytimes.com/2012/03/27/opinion/germanys-unpolitical-new-president.html?_r=0. Consultado em: 23 abril 2012. 


\section{Conclusão}

Da perspetiva da Rússia, faz sentido continuar a privilegiar as relações com a Alemanha porque Berlim serve de ponte de ligação nas relações políticas com o ocidente que pode evitar um isolamento europeu da Rússia, para além dos óbvios interesses económicos e energéticos. Ter Berlim como o seu interlocutor preferencial no relacionamento com a UE, e, em menor grau, na relação com a OTAN e os EUA, continua a ser um trunfo da diplomacia russa que esta quererá manter. Os decisores russos sabem que não caberá à Alemanha individualmente decidir sobre a futura composição da OTAN, assim como não será Berlim a definir unilateralmente os contornos da ordem securitária euro-atlântica. Mas com a transformação da identidade internacional dos EUA, e sendo a Alemanha atualmente a única potência económica na crise das dívidas soberanas na Europa, saber que o apoio mais decisivo com que Moscovo poderá contar vem de Berlim, é uma mais valia no relacionamento da Rússia com o ocidente euro-atlântico. Nesse sentido, relacionar-se bilateralmente com a Alemanha é preferível a ter que lidar com uma posição europeia conjunta, já que em caso de divergências bilaterais os mecanismos institucionais entre Berlim e Moscovo podem amortecer potenciais desentendimentos.

Da perspetiva da Alemanha, a sua diplomacia tem conseguido equilibrar um relacionamento sui generis com a Rússia, com uma relação estreita com países da Europa central e oriental, principalmente a Polónia. A Alemanha, pelas razões apresentadas neste capítulo, é a potência europeia que tem sido melhor sucedida no desenvolvimento de uma relação próxima com a Rússia, também pelas considerações que tece sobre as sensibilidades do vizinho russo face à estabilidade da ordem europeia e transatlântica. Foi o que se verificou quando Berlim desacelerou o alargamento da OTAN à Geórgia e Ucrânia. É evidente que a dependência europeia, e especialmente alemã, do fornecimento de gás natural russo é um factor preponderante na definição da política alemã, mas a não hostilização diplomática de Moscovo orienta a diplomacia de Berlim.

Contudo, existem sinais de que a dinâmica desta relação pode estar a mudar, por parte de Berlim, e de que a falta de credenciais democráticas 
consolidadas dificultem o papel da Rússia como parceiro na construção de uma ordem securitária europeia pós-atlântica, onde os EUA terão, por opção, um papel mais reduzido. A Rússia continua a insistir na revisão da ordem europeia do pós-Guerra Fria, em ser o ator preponderante no seu "estrangeiro próximo" e em não deixar que os países ocidentais e o seu enquadramento normativo euro-atlântico imponham condicionalidade a Moscovo. Daí que a Rússia e a Alemanha deverão manter a cooperação económica e energética, mas não a qualquer custo. Para a coesão do espaço euro-atlântico, já por si desafiada pelo redireccionamento estratégico dos EUA para o Pacífico e a ascensão de potências asiáticas, isto significa mais e não menos riscos de tensão.

\section{Bibliografia}

Außenwirtschaftsportal Bayern (2013) "Ranglisten für den Außenhandel Deutschlands nach Warenkategorien für das Jahr 2012", Statistische Bundesamt. [Acedido a 12 de mar. de 2013]. Disponível na Internet: http://www.auwi-bayern.de/awp/inhalte/Laender/ Warenkategorien/kat/GP09-06/Erdöl\%20und\%20Erdgas/\#.

BAYER, Wolfgang - Das GETS-Projekt: Gaslieferungen von und nach Deutschland. Statistisches Bundesamt. N. ${ }^{\circ} 5$ (2009), p. 416-424. [Acedido a 27 de jul. de 2012]. Disponível na Internet: https://www.destatis.de/DE/Publikationen/WirtschaftStatistik/EnergieWasserversorgung/ GetsProjekt509.pdf?__blob=publicationFile.

Bergman, Max - Germany's Russia Moment. World Politics Review (2009). [Acedido a 27 de jul. de 2012]. Disponível na Internet: http://www.worldpoliticsreview.com/articles/3773/ germanys-russia-moment.

BRANDENBURG, Ulrich - Discurso do Embaixador alemão em Moscovo, em 30 agosto de 2012, em Magdeburgo. [Acedido a 12 de set. de 2012]. Disponível na Internet: http:// www.moskau.diplo.de/Vertretung/moskau/de/05/05-klima-energie/vortrag-botschafterenergiebeziehungen.html.

BULMER, Simon, JEFFERY, Charlie e PADGETT, Stephen, eds. - Rethinking Germany and Europe: Democracy and Diplomacy in a semi-sovereign state. Houndsmills, Basingstoke, Hampshire and New York: Palgrave Macmillan, 2010.

CARnaghan, Ellen, e HALE, Henry - Public Opinion Polls and Political Culture. Russian Analytical Digest, N. ${ }^{\circ} 117$ (2012). [Acedido a 24 de set. de 2012]. Disponível na Internet: http://www.css.ethz.ch/publications/pdfs/RAD-117.pdf.

CHIVVIS, Christopher e RID, Thomas - The Roots of Germany's Russian Policy. Survival. Vol. 51, N. ${ }^{\circ} 2$ (2009), p. 105-122.

CLINTON, Hillary - America's Pacific Century. Foreign Policy. N. ${ }^{\circ} 189$ (2011), p. 56-63.

DAEHNHARDT, Patricia - O fim da Guerra Fria e a Unificação Alemã. Relações Internacionais. N. ${ }^{\circ} 23$ (2009), p. 39-52. 
DAEHNhARDT, Patricia - A transformação da política europeia da Alemanha. Política Internacional e Segurança, N. ${ }^{\circ} 5$ (2011a), p. 53-75.

DAEHNHARDT, Patricia - Germany in the European Union. In Reuben Wong and Christopher Hill, eds. National and European Foreign Policy: Towards Europeanization. London: Routledge (2011b), p. 35-56.

DAEHNHARDT, Patricia - Germany's New Role in Europe: European Leadership, German Hegemony or None of Both? Artigo apresentado na conferência UACES 'Exchanging Ideas on Europe 2012: Old Borders - New Frontiers', Passau, Alemanha, 3-5 setembro 2012.

DAEHNHARDT, Patricia - Germany, the EU and a transforming domestic political arena. In M. Mannin and C. Bretherton, eds., The Europeanization of European Politics. Basingstoke: Palgrave Macmillan (2013a), p. 25-38.

DAEHNHARDT, Patricia - A implosão da URSS e a União Europeia. In Pedro Aires de Oliveira, ed., O Fim da URSS, a Nova Rússia e a crise das esquerdas, Lisboa: Colibri (2013b), p. 143-165.

DMITRIEV, Mikhail e TREISMAN, Daniel - The Other Russia: Discontent grows in the Hinterlands. Foreign Affairs. Vol. 91, N. ${ }^{\circ} 5$ (2012), p. 59-72.

Foreign Policy Concept of the Russian Federation. 12 julho 2008. [Acedido a 3 de jun. de 2011]. Disponível na Internet: http://www.mid.ru/nsosndoc.nsf/1e5f0de28fe 77 fdcc 325 75d900298676/869c9d2b87ad8014c32575d9002b1c38?OpenDocument

Frankfurter Allgemeine Zeitung, "Kreml kritisiert CDU-Politiker Schockenhoff", 14 agosto 2012. [Acedido a 12 de set. de 2012]. Disponível na Internet: http://www.faz.net/aktuell/politik/ ausland/prozess-gegen-pussy-riot-kreml-kritisiert-cdu-politiker-schockenhoff-11855427.html.

FREIRE, Maria Raquel e DAEHNHARDT, Patricia - As relações entre a Alemanha e a Rússia: Duas políticas externas em transição. Relações Internacionais. N. ${ }^{\circ} 32$ (2011), p. 171-196.

HOYER, Werner - Discurso no seminário "Strategic Seminar 3: NATO's Partnerships and Beyond", 14 janeiro 2010. [Acedido a 6 de jan. de 2012]. Disponível na Internet: http:// www.auswaertiges-amt.de/diplo/en/Infoservice/Presse/Reden/2010/100115-Hoyer-OsloNatoRus.html.

ISCHINGER, Wolfgang - Yes to Missile Defense, With Russia. The New York Times, 17 maio 2012. [Acedido a 22 de jul. de 2012]. Disponível na Internet: http://www.nytimes. com/2012/05/18/opinion/yes-to-missile-defense-with-russia.html?_r=1\&.

ISCHINGER, Wolfgang e WEISSER, Ulrich - Getting Russia Right. The New York Times, 9 junho 2010. [Acedido a 19 de nov. de 2011]. Disponível na Internet: http://www.nytimes. com/2010/06/10/opinion/10iht-edischinger.html.

KAGAN, Robert - New Europe, Old Russia. The Washington Post, 6 fevereiro 2008. [Acedido a 16 de set. de 2011]. Disponível na Internet: http://www.washingtonpost.com/wpdyn/ content/article/2008/02/05/AR2008020502879.html.

KARAGANOV, Sergei; TELTSCHIK, Horst e OLECHOWSKI, Andrzej - Hotel Europe: Guests and Permanent Partners, 29 dezembro 2011. [Acedido a 3 de jan. de 2012]. Disponível na Internet: http://eng.globalaffairs.ru/number/Hotel-Europe-Guests-and-PermanentPartners-15432.

KRAMER, David J. - Resetting U.S.-Russian Relations: It Takes Two. The Washington Quarterly. Vol. 33, N. ${ }^{\circ} 1$ (2010), p. 61-79.

KUCHINS, Andrew C. e ZEVELEV, Igor A. - Russian Foreign Policy: Continuity in Change. The Washington Quarterly. Vol. 35, N. ${ }^{\circ} 1$ (2012), p. 147-161.

KUNDNANI, Hans - Germany as a Geo-economic Power. The Washington Quarterly. Vol. $34,{ }^{\circ} 3$ (2011), p. 31-45. 
MAKARYCHEV, Andrey S - Russia and its 'New Security Architecture' in Europe: A Critical Examination of the concept. CEPS Working Document. N. ${ }^{\circ}$ 310, (2009b). [Acedido a 12 de jun. de 2011]. Disponível na Internet: http://www.ceps.be/book/russia-and-its-newsecurity-architecture-europe-critical-examination-concept.

MEDVEDEV, Discurso do presidente Dmitry Medvedev - Speech at Meeting with German Political, Parliamentary and Civic Leaders, 5 junho 2008, Berlim. [Acedido a 7 de out. de 2010]. Disponível na Internet: http://archive.kremlin.ru/eng/speeches/2008/06/05/2203_ type82912type82914type84779_202153.shtml.

Memorando de Meseberg (2010). [Acedido a 5 de jun. de 2011]. Disponível na Internet: http://www.russianmission.eu/sites/default/files/user/files/2010-06-05-mesebergmemorandum.pdf.

MEISTER, Stefan - An alienated partnership: German-Russian relations after Putin's return. The Finnish Institute of International Affairs. N. ${ }^{\circ}$ 105, 10 maio 2012. [Acedido a 12 de set. de 2012]. Disponível na Internet: www.fiia.fi/assets/publications/bp105.pdf.

NATO Bucharest Summit Declaration (2008). [Acedido a 4 de jun. de 2011]. Disponível na Internet: http://www.nato.int/cps/en/natolive/official_texts_8443.htm.

NATO 2020: Assured Security, Dynamic Engagement (2010) North Atlantic Treaty Organization. [Acedido a 4 de jun. de 2011]. Disponível na Internet: http://www.nato.int/nato_static/ assets/pdf/pdf_2010_05/20100517_100517_expertsreport.pdf.

Ost-Ausschuss der Deutschen Wirtschaft - Rekordergebnis für Exporte nach Osteuropa, 2 março 2012. [Acedido a 22 de jul. de 2012]. Disponível na Internet: http://www.ostausschuss.de/rekordergebnis-f-r-exporte-nach-osteuropa.

Ost-Ausschuss der Deutschen Wirtschaft - Wege zur Visa-Freiheit, novembro 2011, p. 5. [Acedido a 22 de jul. de 2012]. Disponível na Internet: http://www.ost-ausschuss.de/sites/default/ files/pm_pdf/Positionspapier\%20Wege\%20zur\%20Visa-Freiheit-Ost-Ausschuss_0.pdf.

PIPES, Richard - Russia under the Bolshevik Regime. London: Harper Collins, 1995.

SAKWA, Richard - Russia and Europe: Whose Society? European Integration. Vol. 33, N. 2 (2011), p. 197-214.

SIEVERT, Stephan; ZAKHAROV, Sergey e KLINGHOLZ, Reiner - The Waning World Power: The demographic future of Russia and the other Soviet successor states. Berlin Institut für Bevölkerung und Entwicklung, 2011. [Acedido a 16 de fev. de 2011]. Disponível na Internet: http://www.berlin-institut.org/fileadmin/user_upload/Russland/Russland_e_online.pdf.

SMITH, Keith - Russia-Europe Energy Relations Implications for U.S. Policy. CSIS, 2010. [Acedido a 8 de jun. de 2011]. Disponível na Internet: http://csis.org/files/publication/100218_ Smith_RussiaEuropeEnergy_Web.pdf.

Spiegel, Der - Open letter: It's Time to Invite Russia to Join NATO, 8 março 2010. [Acedido a 4 de jun. de 2011]. Disponível na Internet: http://www.spiegel.de/international/world/ open-letter-it-s-time-to-invite-russia-to-join-nato-a-682287.html.

Statistische Bundesamt, Destatis, Comunicado de imprensa no. 204, de 4 junho 2008. [Acedido a 3 de mar. de 2012]. Disponível na Internet: http://www.destatis.de/jetspeed/ portal/cms/Sites/destatis/Internet/DE/Presse/pm/2008/06/PD08__204_51.psml.

STEINMEIER, Frank-Walter - Russland, Europa und die Welt - Perspektiven der Zusammenarbeit in globalen Sicherheitsfragen. Discurso na $42^{a}$ Conferência de Segurança de Munique, 5 fevereiro 2006.

STELZENMÜLlER, Constanze - Germany's Russia Question. Foreign Affairs. Vol. 88, N. ${ }^{\circ} 2$ (2009), p. 89-100.

STENT, Angela - Russia and Germany Reborn: Unification, Soviet Collapse, and the New Europe. Princeton: Princeton University Press, 1999. 
SZABO, Stephen - Can Berlin and Washington Agree on Russia?. The Washington Quarterly. Vol. 32, N. ${ }^{\circ} 4$ (2009), p. 23-41.

TSYGANKOV, Andrei - Russia's foreign policy: change and continuity in national identity. Lanham: Rowman \& Littlefield, 2006.

TURKOWSKI, A. - The Polish-German Tandem. Carnegie Moscow Center - Carnegie Endowment for International Peace, 2011. [Acedido a 4 de jun. de 2011]. Disponível na Internet: http://carnegie.ru/publications/?fa $=46059$.

VINOCUR, John - Germany's 'unpolitical' new president. The New York Times, 26 março 2012. [Acedido a 23 de abr. de 2012]. Disponível na Internet: http://www.nytimes. com/2012/03/27/opinion/germanys-unpolitical-new-president.html?_r=0.

WESTPHAL, Kirsten - Das neue Öl? Worauf beim Gas jetzt zu achten ist. Stiftung Wissenschaft und Politik, 10 junho 2011. [Acedido a 16 de dez. de 2011]. Disponível na Internet: http://www.swp-berlin.org/de/kurz-gesagt/energiewende-und-gas.html.

World Bank (The) - Russia Overview. World Bank, 2013. [Acedido a 12 de mar. de 2013]. Disponível na Internet: http://www.worldbank.org/en/country/russia/overview. 
(Página deixada propositadamente em branco) 


\section{A PÍ T ULO 6 \\ AS RELAÇÕES ENTRE A POLÓNIA E A RÚSiA:}

$1980-2011$

Madalena Meyer Resende

\section{0-1991: O governo do Solidariedade e o fim da União Soviética}

As relações entre a Polónia e a Rússia são marcadas pelas sucessivas partilhas da Polónia dividida entre os impérios vizinhos desde finais do século XVIII, até à última partilha entre a Alemanha e a Rússia soviética em setembro de 1939, que marcou o início da II Guerra Mundial. Depois da derrota do nazismo em 1945, a Polónia foi integrada no bloco soviético com uma soberania limitada e só recuperou a sua independência quando as eleições de junho de 1989 puseram em marcha a revolução europeia que forçou a retirada soviética da Europa Central.

A questão nacional, da qual o sentimento anti-russo foi uma componente crucial, foi um dos principais motores da transição para a democracia, não só na década que precedeu as eleições de 1989, como na que se seguiu. Apesar da constante ameaça que a Rússia constituiu para a soberania e a segurança da Polónia durante o século XX, a escolha entre a aliança com a Rússia ou com a Alemanha, uma das questões aturadamente discutidas na transição para o século XX (Walicki, 1994, p. 65) e durante a Segunda República (1918-1939) (Walicki, 2000, p. 21), permaneceu indefinida. Durante o período comunista a oposição polaca no interior e no exterior do país debateu a definição das prioridades da 
política externa (Snyder, 2003, p. 225) mas a escolha pela aliança com a Alemanha e a Europa ocidental foi decidida apenas durante o primeiro governo não-comunista liderado por Tadeusz Mazowiecki.

\section{A década de oitenta}

O nascimento do movimento Solidariedade em 1980, no qual 10 milhões de pessoas se mobilizaram em oposição ao regime, marcou a primeira etapa da democratização da Polónia e determinou a história da Europa. A relevância deste movimento para as dinâmicas internas da União das Repúblicas Socialistas Soviéticas (URSS) não pode ser minimizada: a emergência de um movimento de trabalhadores sindicalizados em oposição ao regime comunista foi o sinal mais forte dos limites da dominação imperial soviética, causado pelo nacionalismo de um país etnicamente homogéneo, com uma igreja nacional capaz de veicular esse sentimento e ajudar a transferi-lo de forma organizada para a esfera da ação política. Foi um dos primeiros momentos em que a Polónia se tornou importante para os destinos da Rússia na época moderna. Para o centro soviético as "lições polacas" demonstraram que era possível derrubar pacificamente um regime comunista e que o que a "revolução auto-limitada" tinha feito na Polónia poderia repetir-se na União Soviética. A necessidade de evitar um cenário polaco esteve na origem da estratégia reformista de Gorbachov, iniciada com a perestroika e a glasnost ${ }^{49}$ depois da sua nomeação como Secretário Geral em 1985 (Malia, 1996, p. 415).

Por isso, apesar de o movimento Solidariedade ter sido ilegalizado pela lei marcial decretada pelo general Jaruselski em dezembro de 1981 sob o falso pretexto de evitar uma invasão soviética, quatro anos depois, a subida ao poder de Gorbachov levaria ao início de uma liberalização

49 Gorbachov pretendia reformar o sistema comunista com a perestroika e a glasnost de forma a permitir a sua sobrevivência. A perestroika incidiu em reformas económicas e na redução dos gastos em armamento, e a glasnost numa maior transparência no governo. 
política e económica do comunismo. Durante a perestroika Gorbachov ditou uma atitude de laisser faire em relação aos países da Europa central e oriental, o que deu azo a que o partido comunista polaco reiniciasse conversações com o que restava do movimento Solidariedade de forma a tentar resolver a crise económica e social que se agravava no fim dos anos oitenta (Lévesque, 1997, p. 74). As negociações da mesa redonda iniciadas em 1988 entre o Solidariedade e o governo comunista resultaram num acordo para a realização de eleições semi-livres, que tiveram lugar em junho de 1989 e em que as listas do Solidariedade ganharam 99\% dos votos. Gorbachov procurou o compromisso entre uma posição de não-intervencionismo, e o incentivo aos comunistas reformistas, atitude que foi condição crucial para o sucesso das transições de 1989 (Lévesque, 1997, p. 113).

A recusa de Gorbachov em intervir na Polónia depois das eleições tornaram inevitável a formação em setembro do primeiro governo não-comunista na Polónia desde o fim da Segunda Guerra Mundial, liderado pelo primeiro ministro Tadeusz Mazowiecki, um dos responsáveis políticos mais destacados do Solidariedade (Skorzynski, 2012). As primeiras medidas deste governo na política externa seguiram princípios que se tornaram fundacionais da política externa da Polónia democrática (Bingen, 1997, p. 3). Nelas se inscreveu logo a partir de 1989 uma política de reconciliação com os vizinhos, ocidentais e orientais, iniciada com o estabelecimento de tratados bilaterais de reconhecimento de fronteiras e de não-agressão, que se distinguiu pelo estabelecimento de acordos com todos os países vizinhos, de forma a reafirmar a recuperação da soberania polaca (Kuzniar, 2009, p. 29). A escolha pelo "regresso à Europa", o slogan do Solidariedade durante a campanha para as eleições de junho, foi implementado durante o governo liderado pelo Solidariedade. A nova política externa concentrou-se na reconciliação com a Alemanha e na integração na Europa ocidental (Meyer Resende, 2009, p.47).

A prioridade das relações com a Europa ocidental, anunciada em setembro de 1989 implicou uma declaração de soberania por parte da Polónia em relação à URSS. A 12 de setembro, no seu primeiro discurso no parlamento, 
o primeiro ministro Mazowiecki exortou que "as relações internacionais baseadas na soberania e na parceria são mais estáveis do que a ordem assente no domínio e na força”, e que "as relações com a União Soviética devem ser estruturadas com base no respeito pela soberania do nosso Estado, sendo nós completamente livres para formarmos a nossa própria política interna" (Skubiszewski, 1993, p. 21). Também no primeiro discurso na Assembleia Geral das Nações Unidas a 25 de setembro de 1989, o ministro dos negócios estrangeiros polaco Krzysztof Skubiszewski afirmou que, apesar da sua fragilidade geopolítica, a Polónia deveria basear a sua política externa em relação à União Soviética "nos fundamentos da soberania externa e da independência doméstica” e por isso prosseguir com a transformação da Europa de leste, nomeadamente no sentido de apoiar as possíveis aspirações de independência das Repúblicas da União Soviética. Skubiszewski e o governo polaco rejeitavam a divisão da Europa em esferas de influência. Afirmou também que "zonas de segurança não podem significar o mesmo que esferas de influência” (Skubiszewski, 1993, p. 21), reiterando que a nova Polónia rejeitava a esfera de influência da URSS no ex-bloco de leste e que se definia como um país europeu e ocidental (Kuzniar, 2009, p. 27).

Para além de redefinir a orientação política fundamental da política externa polaca, o ministro Skubiszewski foi também responsável pelas negociações da dissolução do Pacto de Varsóvia, cuja assinatura teria lugar em Praga a 1 de julho de 1991. Os soviéticos pressionaram a Polónia e outros membros do Pacto de Varsóvia para assinarem novos tratados bilaterais dando a Moscovo o direito de vetar a entrada em alianças que fossem inimigas dos interesses soviéticos, o que tanto o governo da Polónia, como os da Checoslováquia e da Hungria rejeitaram, insistindo no seu direito soberano de escolher os seus aliados (U.S. Library of Congress, s/d). No contexto destas negociações os presidentes destes três países iniciaram uma cooperação trilateral com o objetivo de restaurar a soberania, apoiar a democratização da região e integrar as estruturas euro-atlânticas. As primeiras reuniões tiveram lugar em maio de 1990 e a 15 de fevereiro de 1991 Lech Walesa, Vaclav Havel e József Antall assinaram a declaração de Visegrád que institucionalizou o grupo de Visegrád cujas 
funções eram a cooperação entre os três países ${ }^{50}$ com vista à sua integração nas instituições euro-atlânticas, e a coordenação de posições em vários setores depois da adesão à Organização do Tratado do Atlântico Norte (OTAN) e à União Europeia (UE).

A dissolução do Pacto de Varsóvia deixou pendente a questão da retirada de 58.000 tropas soviéticas da Polónia (juntamente com as dos restantes países do Pacto de Varsóvia), operação que envolveu consideráveis questões logísticas, financeiras e diplomáticas. As primeiras negociações entre Moscovo e Varsóvia começaram no outono de 1990, com a Polónia a exigir a retirada das forças soviéticas até ao final de 1991, a reparação por danos ecológicos e o pagamento da estadia das tropas em território polaco. A recusa de Moscovo em aceitar as condições polacas causou vários atritos durante as negociações mas o processo de retirada das tropas iniciou-se logo em 1990 (U.S. Library of Congress). Durante o golpe de Moscovo de agosto de 1991, em que um grupo de comunistas radicais tentaram depor Gorbachov e restaurar a ortodoxia comunista, a Polónia pressionou Moscovo para que se chegasse a um acordo sobre a retirada das tropas, o que aconteceu a 26 de outubro de 1991 (Kuzniar, 2009, p. 34). Contudo, a dissolução da União Soviética em dezembro de 1991 e a sua substituição pela Rússia como seu sucessor legal e político resultaram na interrupção do processo.

\section{1-1996: A Rússia pós-soviética e a Polónia}

Se foi a política de Gorbachov que abriu caminho à realização de eleições semi-livres em junho de 1989 na Polónia, a partir da criação do primeiro governo pós-comunista em setembro de 1989, a deposição pacífica do regime comunista na Polónia foi o primeiro passo para o fim dos regimes comunistas na Europa Central e Oriental. O "vento da liberdade" que abriu

50 Depois da separação entre a República Checa e a Eslováquia o grupo Visegrád passou a consistir de quatro membros: Polónia, Hungria, República Checa e Eslováquia e é frequentemente referido como V-4. Ver http://old.visegradgroup.eu/. 
caminho à unificação alemã acabou por chegar à Rússia e determinar o destino da União Soviética. ${ }^{51}$

Durante o golpe de Moscovo em agosto de 1991, a Polónia manteve uma postura cuidadosa: apesar de apoiar Boris Ieltsin e a democratização da Rússia, o governo polaco, receoso das consequências do desmoronar da União Soviética, manteve relações formais com as autoridades em Moscovo, mas iniciou também contatos e apoio às elites separatistas das Repúblicas da Lituânia e da Ucrânia. A seguir ao desmoronar da União Soviética em dezembro, quando novas oportunidades se abriam para a extensão dos laços com as ex-Repúblicas da URSS, a prioridade europeia ocidental da Polónia foi substanciada, no sentido em que esta determinou a sua postura em relação, por um lado, aos novos Estados da ex-URSS, principalmente aos novos Estados vizinhos independentes, a Ucrânia, a Lituânia e a Bielorrússia, mas também em relação à Rússia.

A prioridade europeia (ocidental) do ministro dos negócios estrangeiros Krzysztof Skubiszewski (1989-1993) significou o abandono das duas opções alternativas de política externa existentes para a Polónia: a primeira que advogava a federação da Polónia com a Ucrânia e que poderia agregar os Estados da Europa de leste num pólo independente da Rússia (Snyder, 2003, p. 227);52 e a segunda, que preferia uma parceria privilegiada com a Rússia. A escolha do MNE polaco Skubiszewski foi a de procurar privilegiar as relações da Polónia com a Europa ocidental em detrimento das relações com o leste. A lógica seguida por Skubiszewski era a de que a Polónia ganharia maior influência e poder se estivesse firmemente ancorada na Europa, tanto através de relações bilaterais com os principais Estados europeus, em particular com a Alemanha e a França, como pela integração em instituições euro-atlânticas (Skubiszewski, 1993). Skubiszewski defendeu esta prioridade contra os críticos que

\footnotetext{
51 Ver por exemplo Lévesque (1997) e Malia (1996).

52 Esta linha baseava-se nas ideias desenvolvidas por Jerzy Giedroyc e Juliusz Mieroszewicz na revista Kultura, e defendia que a Polónia, quando recuperasse a independência e a liberdade deveria promover a independência da Ucrânia, da Bielorrússia e da Lituânia, e restabelecer prioritariamente relações de amizade com os seus vizinhos a leste.
} 
advogavam que ao fortalecer os laços com os Estados vizinhos a leste ou a Rússia, a Polónia teria mais poder na Europa (Kuzniar, 2009, p. 30). Para Skubiszewicz e a sua equipa, a prossecução da estratégia europeia significava que a Polónia se deveria tornar, tanto nos aspetos políticos como nos económicos, num país europeu e ocidental (Skubiszewski, 1994). Isto significava reorientar fundamentalmente o seu comércio e a sua produção dos mercados do leste para os mercados ocidentais (Meyer Resende, 2009, p. 69).

A reconciliação germano-polaca, com origens na Ostpolitik da Alemanha Federal nos anos 1970, mas ganhando um novo significado depois de 1989 foi particularmente importante para a prossecução desta política. Um dos momentos críticos da reconciliação ocorreu durante as negociações para a reunificação alemã em outubro de 1990. Por exemplo, o facto de o reconhecimento das fronteiras Oder-Neisse entre os dois países ter sido ignorada pelo chanceler alemão Helmut Kohl no discurso dos dez pontos ao Bundestag em novembro de 1989 causou uma imediata reação do ministro Skubiszewski num discurso ao parlamento polaco: "o reconhecimento incondicional da fronteira ocidental da Polónia é um pré-requisito cardeal para a reconciliação polaco-alemã” (Kuzniar, 2009, p. 32). Este reconhecimento viria a acontecer com o Tratado " $2+4$ " sobre a Reunificação Alemã, a 12 de setembro de 1990 (Snyder, 2003, p. 235). Passado esse obstáculo, os dois Estados celebraram em junho de 1991 um Tratado de Amizade e Boa Vizinhança, 53 ao qual se seguiram várias iniciativas bilaterais (Bingen, 1997, p. 5). Também em 1991 se iniciou a cooperação trilateral entre a Alemanha, a França e a Polónia, denominada Triângulo de Weimar (France Diplomatie, 2006), na qual a Alemanha mostrou estar disposta a multilateralizar a relação privilegiada com a França através de reuniões anuais dos chefes de estado e governo, assim como dos ministros da defesa e dos negócios estrangeiros dos três países.

53 Traktat między Rzeczapospolita Polska a Republika Federalną Niemiec o dobrym sąsiedztwie i przyjaznej wspótpracy z 17.06.1991 r. (Tratado de Amizade e Boa Vizinhança entre a Polónia e a República Federal da Alemã) assinado a 17 de Junho de 1991 em Bona pelo primeiro ministro Polaco Jan Krzysztof Bielecki, pelo MNE Krzysztof Skubiszewski, pelo Chanceler Alemão Helmut Kohl e pelo MNE Hans-Dietrich Genscher. 
Neste período de transição, as relações da Rússia e da Polónia foram marcadas, por um lado, pela atitude pró-ocidental de Ieltsin e, por outro, pelas tensas negociações visando a retirada das tropas do antigo exército soviético da Polónia iniciadas em finais de 1990 (Kuzniar, 1991, p. 10). A pressão russa no sentido de rever os parágrafos do acordo da retirada das tropas russas foi intensa, e só o entendimento entre Lech Walesa, líder do Solidariedade e então presidente da Republica da Polónia, e Boris Ieltsin, primeiro presidente russo pós-comunista, aquando da visita a Moscovo de Walesa em março de 1992, permitiu a assinatura do acordo nesta ocasião. O acordo estipulou que a Rússia retiraria as tropas até 15 de novembro de 1992, deixando apenas 6 mil tropas para assistir a retirada das tropas da Alemanha Oriental até 1993 (U.S. Library of Congress, s/d). As últimas tropas russas deixaram a Polónia a 16 de setembro de 1993.

Outro importante acordo de cooperação ${ }^{54}$ foi assinado para substituir o Tratado de Amizade Polaco-Soviético de 1965. Durante a visita a Moscovo em 1992, Walesa anunciou o início de um novo capítulo das relações russo-polacas; em troca, Ieltsin exprimiu a esperança no entendimento mútuo e na parceria nas futuras relações entre os dois países (Spero, 2004, p. 200). Na sequência desta visita Ieltsin publicou as cláusulas secretas do Pacto Ribbentrop-Molotov entre a Alemanha Nazi e a União Soviética (de 1939), em que as duas potências acordaram em dividir a Polónia no início da Segunda Guerra Mundial e forneceu à Polónia documentos provando a culpa de Estaline na ordem de execução de 20 mil oficiais polacos na floresta de Katyn (situada na Rússia ocidental) (Reuters, 2011). O reconhecimento veio ao arrepio da posição da URSS, que tinha sustentado que o crime tinha sido cometido pelas forças nazis, posição essa que os aliados ocidentais não tinham querido contestar durante a Segunda Guerra Mundial.

Em agosto de 1993 Ieltsin visitou Varsóvia e declarou que a Rússia não se oporia à entrada da Polónia na OTAN, o que causou indignação

54 Traktat między Rzeczpospolita Polska a Federacją Rosyjska o przyjaźni i dobrosąsiedzkiej wspótpracy podpisany w Moskwie 22 maja 1992 r. (Tratado de Amizade e Boa Vizinhança entre a Polónia e a Federação Russa) assinado em Moscovo a 22 de maio de 1992 pelo Presidente Polaco Lech Wałęsa e pelo Presidente Russo Boris Ieltsin. 
nas forças armadas russas e na elite do Kremlin (Asmus, 2002, p. 147). $\mathrm{Na}$ sequência da crise de 3-5 de outubro do mesmo ano que acabou no ataque ao parlamento russo, Ieltsin e o Kremlin, pressionados pelas forças armadas russas, voltaram atrás e lançaram uma campanha contra a expansão da OTAN aos antigos satélites da União Soviética (Cohen, 1993). Note-se que a política de expansão da OTAN tinha sido iniciada pelo ministro da defesa alemão Volker Rühe em setembro de 1992 (Szabo, 2006, p. 331; Goldgeier, 1999, p. 34). Não só Rühe esteve em constante contato com Skubiszewswki, Walesa e Havel, como a principal preocupação da Alemanha era a estabilidade da Europa central e oriental, subjacente ao alargamento da OTAN (Szabo, 2006, p. 345). Sob constante pressão da Polónia55 e com o apoio da Alemanha (Szabo, 2006, p. 337), em 1995 o presidente norte-americano Bill Clinton começou a ceder em favor das exigências da Polónia relativamente à adesão pretendida à Aliança Atlântica (Asmus, 2005, p. 254). Contudo, Clinton decidiu esperar pela reeleição de Boris Ieltsin como presidente em 1996 para anunciar o início das negociações de adesão (Goldgeier, 1999, p. 160). O convite foi feito apenas em 1997 aos três Estados com fronteiras com a Alemanha: a Hungria, a Polónia e a República Checa (RFE/RL, 2004b).

\section{7-2005: A afirmação da Rússia como potência e o início de novas tensões}

Em 1997 a OTAN convidou as primeiras três democracias pós-comunistas da Europa Central e Oriental para integrar a Aliança Atlântica. Este convite coincidiu com a mudança dos princípios de política externa da Rússia iniciada pelo ministro dos negócios estrangeiros, depois primeiro ministro russo, Evgeny Primakov (Günsche). Primakov definiu os interesses da Rússia como sendo esta um polo separado do mundo ocidental e da potência hegemónica norte-americana, o que o levou ao intensificar da oposição

55 Esta pressão foi particularmente exercida durante a visita de Lech Walesa e Vaclav Havel a Washington em abril de 1993. 
à expansão da OTAN aos antigos membros do Pacto de Varsóvia (Freire e Daehnhardt, 2011, p. 178). Os dois acontecimentos simultâneos levaram à mudança decisiva da natureza das relações entre a Rússia e a Polónia. As decisões de 1997 marcaram a dupla viragem ocidental da Polónia e oriental da Rússia (a parceria estratégica com a China, iniciada por Ieltsin e continuada por Putin com o objetivo de contrabalançar a hegemonia americana). Esta mudança teve repercussões na política europeia, uma vez que a política externa dos países da Europa central, cujo principal objetivo era a integração nas estruturas euro-atlânticas, se tornou num foco de tensão entre o bloco ocidental e a Rússia.

A intervenção no Kosovo pela OTAN em março de 1999 sedimentou a nova divisão entre a Rússia e a Polónia, com a Rússia a apoiar a Sérvia, e a impedir a adoção de um mandato pelo Conselho de Segurança das Nações Unidas que legalizasse a intervenção da OTAN. A Polónia, por seu lado, apoiou e participou como novo membro da Aliança Atlântica na intervenção contra a Sérvia com o objetivo de demonstrar a sua participação como membro pleno da Aliança. A divisão entre a Rússia e a Polónia em relação à intervenção do Kosovo tornar-se-ia um prelúdio para a mais séria crise transatlântica causada pela invasão do Iraque em 2003 (Gaspar, 2004, p. 37). Também aqui a Rússia e a Polónia se encontraram em campos opostos, com a Rússia (e a França e a Alemanha) a opor-se a um possível mandato do Conselho de Segurança proposto pelos EUA. A Polónia tornou-se então um dos principais aliados dos EUA na coligação que invadiu o Iraque (Osica, 2004, p. 412).

A consolidação progressiva da orientação europeia e atlântica da Polónia neste período tornou-se a base do conflito em relação à política de asserção dos interesses nacionais da Rússia. Essa conflitualidade acentuou-se quando a Polónia assumiu uma política ativa em relação à democratização e orientação geopolítica dos seus vizinhos a leste, principalmente da Ucrânia, países que a Rússia considera parte da sua esfera de influência. Durante as revoluções na Geórgia (novembro de 2003) e na Ucrânia (dezembro de 2004), a Polónia deixou claro o seu apoio à democratização destes países, o que significou um apoio às forças pró-ocidentais dos candidatos Viktor Yushchenko e Yulia Tymoshenko na Ucrânia em 2004 e a Mikhail Saakashvili 
na revolução rosa na Geórgia. O presidente polaco Aleksander Kwasniewski teve um papel crucial como mediador entre governo e oposição durante as manifestações em Kiev na sequência das acusações de fraude eleitoral da Organização para a Segurança e Cooperação na Europa (OSCE) nas eleições presidenciais ucranianas em dezembro de 2004. Esta animosidade foi reforçada pelo apoio da administração norte-americana de George W. Bush às várias revoluções no espaço pós-soviético, assim como a promessa de adesão à OTAN, caso a consolidação democrática tivesse lugar.

\section{5-2007: A deriva nacionalista do governo Kaszynski}

A política externa polaca em relação à Rússia mudou substantivamente quando o partido Lei e Justiça (PiS) ganhou as eleições e formou governo em outubro de 2005. Durante a campanha para as eleições parlamentares e presidenciais de 2005 o partido adotou uma atitude de desafio em relações aos seus vizinhos e às suas posições quanto à integração europeia. Em meados da década de 2000 a doutrina de política externa do PiS foi dominada por uma atitude anti-russa, e amplificada pela retórica anti-comunista e anti-alemã (Meyer Resende, 2012). A Rússia respondeu à eleição do PiS e à retórica anti-russa em novembro com um embargo às importações de carne da Polónia, citando razões de saúde pública. A Polónia retorquiu com o bloqueio das negociações a uma nova parceria entre a Rússia e a UE, o Acordo de Parceria e Cooperação (APC) que era promovido principalmente pela Alemanha (Freire e Daehnhardt, 2011, p. 182). Este bloqueio manteve-se durante os dois anos do governo Kaszynski e causou também dificuldades às negociações energéticas entre a Rússia e a UE.

Depois de formar uma coligação com dois partidos eurocépticos em março de 2006 - o Auto-Defesa e a Liga das Famílias Polacas - o primeiro ministro Jaroslaw Kaszynski nomeou Anna Fotyga para ministra dos negócios estrangeiros em junho de 2006. Depois dessa nomeação a retórica anti-russa e anti-alemã ganhou o estatuto de política externa oficial, e uma notória figura pública do campo anti-alemão, Mariusz Muszynsky, foi nomeado plenipotenciário para as relações com a Alemanha. As polémicas 
entre os dois países multiplicaram-se e em julho de 2006, o presidente Kaczyński cancelou a sua participação numa cimeira do Triângulo de Weimar devido a uma polémica lançada por um artigo no jornal alemão Tageszeitung (Pankowski, 2010, p. 198). A animosidade anti-alemã foi uma clara mudança em relação à política de reconciliação entre os dois países que tinha marcado a política externa polaca desde 1989 (Bingen, 1997, p. 4).

O antagonismo entre os dois países foi mais notório na reação do governo polaco à decisão bilateral entre a Rússia e a Alemanha de construir um gasoduto que forneceria gás russo à UE através de uma ligação direta entre a Rússia e a Alemanha através do Mar Báltico (projeto Nord Stream) e que passa perto da costa polaca, em território que os polacos disputam como sendo parte do seu território nacional. A resposta do então ministro da defesa polaco, Radoslaw Sikorski, foi a de comparar o projeto Nord Stream ao Pacto Ribbentrop-Molotov, que acordou a divisão da Polónia entre as duas potências duas semanas antes da invasão da Polónia pela Alemanha em 1939 (Voice of America, 2006). O carácter bilateral do acordo foi criticado pela Polónia, nomeadamente pela falta de articulação de uma política comum da UE para a Rússia, incluindo a falta de uma estratégia energética comum.

As relações da Polónia com a Rússia neste período foram de enorme conflitualidade e provocaram um bloqueio nas relações entre a UE e a Rússia. O período do governo do PiS foi marcado pelo uso intensivo do nacionalismo introvertido e desconfiado das intenções dos seus vizinhos e que contrastava com a definição do interesse nacional polaco, tal como formulado pela elite do Solidariedade e posto em prática na política externa dos primeiros governos democráticos. Contrariamente à política de reconciliação com os seus vizinhos e de participação nas estruturas comunitárias e atlânticas, os gémeos Lech e Jaroslaw Kaszynski enfatizaram o conflito entre os interesses da nação polaca e os dos seus vizinhos e tornaram essa a base da formulação da sua política em relação à Rússia, assim como a sua política em relação à Alemanha.

A retórica nacionalista anti-russa e anti-alemã do governo de Jaroslaw Kaszynski e do presidente Lech Kaszynski provocou a deterioração das 
relações da Rússia com a UE. O apoio às revoluções na Ucrânia e na Geórgia pelos EUA e pela Polónia, e o anúncio unilateral por parte dos EUA da colocação de mísseis de interceção de longo alcance na Polónia como parte do reforço do escudo estratégico deram azo a frequentes choques entre os dois países (Rotfeld, 2010). Por seu lado, a crescente relação bilateral entre a Alemanha e a Rússia foi criticada pelos conservadores nacionalistas polacos no poder, que consideraram a Polónia como um país cercado.

\section{7-2012: O início de uma entente estratégica}

Em outubro de 2007 as eleições parlamentares na Polónia deram a vitória ao partido conservador liberal Plataforma dos Cidadãos (PO) liderado por Donald Tusk. O partido tinha anunciado durante a campanha eleitoral que iria continuar a defender os interesses nacionais polacos, mas de forma mais cooperativa. A mudança de governo significou uma alteração substantiva da política externa polaca, em particular em relação aos seus vizinhos, a Alemanha e a Rússia. A estratégia de confronto foi substituída por uma estratégia de alinhamento com a Alemanha, recebendo Tusk o apoio do ministro dos negócios estrangeiros alemão, Frank-Walter Steinmeier, que viu na nova abertura da Polónia uma oportunidade para tentar pôr em prática a sua versão de uma nova Ostpolitik (Daehnhardt, 2007, p. 39). Para os alemães a reconciliação entre a Polónia e a Rússia era uma mudança fundamental para estabelecer uma entente entre a UE e a Rússia.

Tinha ficado claro durante o período de governo nacionalista dos irmãos Kaszynski que a política hostil da Polónia em relação à Rússia era um travão às tentativas alemãs de criar esta parceria entre a UE e a Rússia. O governo de Merkel estava pois ciente de que a Polónia tinha poder de veto na relação entre a Europa e a Rússia e concluiu que a Polónia deveria fazer parte das negociações entre Berlim e Moscovo. A subida ao poder do PO foi tomada como uma oportunidade de pôr em prática uma política inclusiva e multilateral onde Varsóvia entrou na mesa das negociações 
(Daehnhardt, 2007, p. 35). Iniciou-se assim uma nova época de cooperação entre a Polónia e a Alemanha em relação à Rússia (Rotfeld, 2010). A visita a Varsóvia de Merkel foi a quarta das suas visitas inaugurais, o que demonstra a importância renovada dada à Polónia por Berlim. Em finais de 2009, aquando da constituição do novo governo alemão, MNE do governo de coligação entre Cristãos Democratas e Liberais, Guido Westerwelle, voltou a demonstrar a prioridade dada ao estabelecimento de uma parceria com a Polónia ao eleger Varsóvia como a sua primeira visita.

A nova política externa polaca deu rapidamente frutos também na relação com Moscovo, com a diplomacia russa a declarar o fim do embargo às importações de carne da Polónia e a Polónia a permitir o reinício das negociações sobre a parceria estratégica entre a Rússia e a UE que o governo anterior tinha bloqueado (Grinkevich, 2007).56 Contudo, a intervenção na Geórgia, em agosto de 2008 veio demostrar os limites da boa vontade polaca em relação à Rússia. A Polónia condenou em termos claros o apoio militar da Rússia às pretensões de separatismo da Abcázia e da Ossétia do Sul, duas repúblicas separatistas da Geórgia. $\mathrm{Na}$ altura o ministro dos negócios estrangeiros polaco Radoslaw Sikorski aproveitou para reiterar a necessidade da colocação em território polaco dos mísseis de interceção de longo alcance da OTAN afirmando que "tratados e acordos são excelentes instrumentos, mas a Polónia tem uma história de luta solitária e de abandono pelos nossos aliados" (Kulish, 2008). A condenação do governo polaco contrastou com a atitude mais contida do governo alemão em relação a Moscovo do que os outros países europeus (Freire e Daehnhardt, 2011, p. 188).

Apesar da crise da Geórgia, a mudança de vários factores conjunturais levaram à aproximação entre a Polónia e a Rússia durante 2008 e 2009. Um dos principais elementos de mudança foi a revisão da política externa americana para com a Rússia (Clinton, 2010) e a subsequente revisão

56 O reinício das negociações entre a UE e a Rússia foram, contudo, atrasadas pela oposição da Lituânia, que se recusou a dar o mandato à Comissão Europeia para iniciar as negociações devido a disputas com Moscovo. 
do objetivo da colocação na Polónia dos mísseis de interceção de longo alcance da OTAN que tinham sido previstos nos acordos de agosto de 2008 (US Department of Defense, 2010). A Polónia aproveitou a renegociação do sistema de um escudo de defesa anti-míssil da OTAN pela administração norte-americana de Barack Obama para exigir em troca a colocação de mísseis Patriot de curto alcance para a sua defesa aérea e a garantia de que os Estados Unidos da América virão em sua assistência em caso de ataque (Reuters, 2011). Moscovo argumentou que o projeto iria destruir o equilíbrio militar na Europa e avisou que a Rússia seria forçada a redirecionar os seus mísseis contra a Polónia. Iniciou também uma série de exercícios militares que foram interpretados no ocidente como intimidação aos polacos (RPC National Security Facts, 2010).

Também na Rússia se efetuaram mudanças de política em relação ao ocidente, com Moscovo a declarar uma renovação das relações com o mesmo (Trenin, 2007b, p. 4). Em vez de ignorar as críticas da Polónia em relação à invasão da Geórgia, Moscovo mostrou estar atento e recetivo às posições polacas. No contexto da revisão dos planos do escudo de defesa anti-míssil pela administração Obama teve então início um processo de consulta diplomática entre Moscovo e Varsóvia. Em setembro de 2009 o primeiro ministro Vladimir Putin foi à Polónia para a cerimónia de aniversário dos 70 anos do início da Segunda Guerra Mundial. Durante esta visita Putin iniciou conversações com o primeiro ministro Tusk, propondo a institucionalização de um diálogo entre os dois governos (Reuters, 2011). As conversações continuaram durante a visita do ministro dos negócios estrangeiros Radoslaw Sikorski a Moscovo em 2009. A implementação deste diálogo foi aceite durante uma reunião com os coordenadores do grupo russo-polaco para as questões difíceis em Smolensk a 7 de abril de 2010 (Rotfeld, 2010). A 6 de dezembro de 2010 o presidente Medvedev visitou Varsóvia, a primeira visita de um presidente russo à Polónia em oito anos (Rotfeld, 2010).

Em fevereiro de 2010 Putin convidou Tusk a visitar Katyn a propósito do septuagésimo anoversário do massacre em que cerca de 22 mil oficiais polacos foram assassinados pelas forças soviéticas. O diálogo russo-polaco sobre questões históricas entre os dois países, fomentado 
pela reaproximação da Rússia ao ocidente, resultou no reconhecimento por parte de Putin e da Duma, em novembro de 2010, da culpa de Estaline nos massacres de Katyn, perpetrados durante a Segunda Guerra Mundial (Lipman, 2010). O presidente Dmitri Medvedev declarou à imprensa polaca antes da sua visita a Varsóvia em dezembro desse ano que "Estaline e o seu governo são culpados por este crime" (Lipman, 2010). A par do diálogo político, os governos dos dois países assinaram protocolos de cooperação energética e relações comerciais, em que a Rússia se comprometeu a aumentar o fornecimento de gás até 2035 , uma questão crucial pois a Polónia importa da Rússia cerca de 65 a $70 \%$ do seu consumo anual de gás (Reuters, 2011).

A aproximação entre a Rússia e a Polónia foi o contexto do trágico acidente de aviação ocorrido em Smolensk que a 10 de abril de 2010 vitimou o presidente polaco Lech Kaczynski, a sua mulher e noventa e quatro outros membros da elite polaca quando iam a caminho das cerimónias que marcavam o septuagésimo aniversário do massacre de Katyn. Donald Tusk e Vladimir Putin tinham, dias antes, celebrado conjuntamente o mesmo aniversário, em Katyn. O debate sobre as causas da tragédia foi muito intenso, e demonstrou as dissensões internas entre o governo e o partido da oposição PiS sobre a política de reconciliação com a Rússia. O irmão gémeo do defunto presidente Lech Kaszynski, Jaroslaw Kaszynski, concorreu às eleições presidenciais de junho de 2010 e na sequência da sua derrota contra o candidato do PO, Bronislaw Komoroski, iniciou uma campanha no sentido de exigir explicações adicionais e sugerindo que o relatório sobre as causas do acidente produzido pelas autoridades russas em janeiro de 2011 era insuficiente na assunção de culpa (Kosc, 2011). Por seu lado, o governo de Tusk manteve uma atitude de sóbria aceitação da responsabilidade da força aérea polaca no acidente. Em março de 2011 o ministro dos negócios estrangeiros Sikorski defendeu os esforços do seu governo em melhorar a relação da Polónia com a Rússia, contra as insinuações do PiS, que arguia o restabelecimento das relações entre os dois países seria uma traição devido à má atuação do governo russo no esclarecimento das circunstâncias da ocorrência do desastre. 
Em maio de 2011 o alinhamento entre Berlim e Varsóvia em relação à Rússia foi institucionalizado em Kaliningrado, com o início de conversações a nível trilateral entre a Alemanha, a Rússia e a Polónia com vista ao reforço da cooperação sobre questões europeias, nomeadamente visando uma consulta das posições dos três países no contexto da relação da Rússia com a UE e a OTAN. Nas conversações em Kaliningrado foram abordados a defesa antimíssil e a questão da criação de um comité UE-Rússia de Política Externa e Segurança (Lukashevich, 2011). Este formato trilateral e o envolvimento da Polónia na relação entre a Alemanha e a Rússia, demonstra dois factos: primeiro, a importância da relevância do envolvimento da Rússia nas questões europeias, e segundo, o compromisso alemão em dar uma dimensão multilateral às suas relações com a Rússia. Para a Polónia as relações com a Rússia devem ser vistas no contexto das suas relações com a Alemanha, e a sua participação em negociações com a Rússia ao lado da Alemanha como o culminar do já longo processo de reconciliação germano-polaca, e da participação positiva num outro fórum trilateral, o Triângulo de Weimar, onde se alinha com as posições da França e da Alemanha.

No outono de 2011 a aliança entre a Polónia e a Alemanha fortaleceu-se consideravelmente, não só pela vitória do PO nas eleições parlamentares contra o nacionalismo de Jaroslaw Kaszynski (Dempsey, 2011), mas também pelo discurso proferido por Radoslaw Sikorski em Berlim a 28 de outubro de 2011 em que apelou para que a Alemanha, no contexto da crise da dívida soberana, assuma uma posição de liderança. O discurso alcançou notoriedade pela frase: "Eu receio menos o poder da Alemanha do que começo a recear a sua inatividade" (Sikorski, 2011). A 8 de novembro os ministros dos negócios estrangeiros, Radoslaw Sikorski e Guido Westerwelle escreveram uma carta conjunta à Alta Representante para a Política Externa da UE, Catherine Ashton, que recomendou a UE a melhorar a sua relação com a Rússia (Turkowski, 2011). Estes atos confirmaram a crescente coesão entre as políticas externas da Alemanha e da Polónia, crescentemente vistas como parceiras na Europa. A europeização da política externa polaca significou que a deterioração das relações entre a Rússia e os EUA durante 2012, em particular depois da recandidatura 
e vitória de Putin nas eleições presidenciais em março, não afectou significativamente as relações da Polónia com a Rússia. ${ }^{57}$

No campo multilateral a Polónia mantem uma atitude proativa em relação à necessidade de manter a Rússia em diálogo com as instituições euro-atlânticas. Numa tentativa de manter a questão da redução das armas estratégicas nucleares de curto alcance na agenda internacional, Radek Sikorski e o seu homólogo norueguês, Jonas Gahr Store escreveram uma carta conjunta sobre a oportunidade de manter o interesse da Rússia no avanço do controlo de armamento nuclear estratégico. Publicada pelo New York Times nas vésperas da Cimeira da OTAN em Chicago, a 20 de maio de 2012, a iniciativa reclamava que as negociações resultariam numa melhoria das relações entre a OTAN e a Rússia (Sikorski and Store, 2012).

Contudo, as tensões entre a Polónia e a Rússia mantêm-se. Primeiro, o apoio e a promoção polaca à parceria da Ucrânia com a OTAN, que a Rússia contesta, continuam a ser uma fonte de tensão. Perante esta oposição, a Polónia tem prosseguido a sua política de leste através da inclusão da Ucrânia na política de vizinhança da UE, à qual a Rússia é menos sensível, mas à qual, ainda assim, se opõe (Vaïsse and Kundnani, 2012 , p. 52). Segundo, depois de um breve momento de reconciliação na sequência do desastre de Smolensk, a elite polaca veio a considerar que a investigação e as explicações dadas pelos russos não tinham sido suficientes, o que tornou as relações entre os dois países mais atreitas a tensões e internamente mais controversas devido à oposição do partido PiS (Anon, 2011). No entanto, estas tensões sobre as causas do acidente não impediram o governo de Tusk de prosseguir negociações bilaterais em assuntos de interesse mútuo, como sejam a suspensão de vistos na fronteira entre o enclave russo de Kaliningrado e a Polónia.

57 As eleições legislativas de dezembro de 2011 e a reeleição de Putin na primavera de 2012 provocaram a emergência de movimentos de protesto contra a falta de democracia e liberdade na Rússia, ao que Putin respondeu com maior repressão e o regresso de uma atitude anti-ocidental, em particular quando a presença externa se relacionava com atividades pró-democráticas. As intimidações ao embaixador americano Michael McFaul, académico da democratização da Rússia e autor da política de 'reset' da administração Obama, ilustraram o fim da política americana de aproximação à Rússia (Elder, 2012a). Em setembro de 2012 a Rússia expulsou a agência americana USAID, acusando-a de atividades subversivas (Bovt, 2012). 
Um acordo entre os dois países foi assinado a 14 de dezembro de 2011 (Anon, 2012).

\section{Conclusão}

Os desenvolvimentos dos últimos três anos demonstram que a Polónia conseguiu realizar o programa inicial da sua política externa democrática, assente na reconciliação com a Alemanha e na integração europeia e ocidental como condição prévia para uma reconciliação com a Rússia. A opção fundamental pela aliança com a Alemanha e o ocidente, feita pelo primeiro governo do Solidariedade, condicionou de forma crucial a relação entre a Polónia e os seus vizinhos de leste. A elite política polaca excluiu tanto a opção de uma federação com a Ucrânia, como a de uma aliança privilegiada com a Rússia. O formato trilateral adotado em Kaliningrado em 2011 demonstra que a aliança privilegiada com a Alemanha e a integração nas instituições euro-atlânticas deram à Polónia um papel de pivot na relação da UE com a Rússia. Neste contexto a política externa do governo Kaszynski, entre 2005 e 2007, emerge como uma exceção à regra da política externa polaca pós-1989. Compreendendo que a sua situação geopolítica entre a Alemanha e a Rússia, que tantas desvantagens lhe trouxera durante os últimos dois séculos, podia, no virar do milénio, ser usada para sua vantagem, a Polónia ganhou a partir de 2007 uma posição de relevo na ordem europeia que a elite política liberal tem vindo a reforçar.

\section{Bibliografia}

AAVV - Final Report from the examination of the aviation accident no 192/2010/11 involving the Tu-154M airplane, tail number 101, which occurred on April 10th, 2010 in the area of the Smolensk North airfield. Committee for Investigation of National Aviation Accidents, 2011. [Acedido a 24 de set. de 2012]. Disponível na Internet: http://mswia.datacenterpoland.pl/FinalReportTu-154M.pdf.

AAVV - Lavrov-Sikorski agreement on local border traffic has come into force. Visa-Free Europe, 2012. [Acedido a 24 de set. de 2012]. Disponível na Internet: http://visa-freeeurope.eu/2012/07/lavrov-sikorski-agreement-on-local-border-traffic-has-come-into-force/. 
ASMUS, Ronald D. - Opening NATO's door: How the alliance remade itself for a new era. New York: Columbia University Press, 2002.

BINGEN, D. - Die Entwicklung der Deutsch-Polnischen Beziehungen seit 1991. Cologne: Bundesinstitut für ostwissenschaftliche und internationale Studien, 1997.

BOVT, G. - Whether Obama or Romney, the Reset Is Dead. The Moscow Times, 12 setembro 2012. [Acedido a 24 de set. de 2012]. Disponível na Internet: http://www.themoscowtimes. com/opinion/article/whether-obama-or-romney-the-reset-is-dead/467947.html.

CLINTON, Hillary - Remarks With Russian Foreign Minister Sergey Lavrov. US Department of State, 2010. [Acedido a 31 de jan. de 2012]. Disponível na Internet: http://www.state. gov/secretary/rm/2010/03/138531.html.

COHEN, R. - Yeltsin Opposes Expansion Of NATO in Eastern Europe. The New York Times, 2 outubro 1993. [Acedido a 25 de jan. de 2012]. Disponível na Internet: http://www. nytimes.com/1993/10/02/world/yeltsin-opposes-expansion-of-nato-in-eastern-europe.html.

DAEHNHARDT, Patricia - De Kohl a Merkel: A gradual afirmação da Alemanha como grande potência euro-atlântica. Relações Internacionais. N. ${ }^{\circ} 14$ (2007), p. 27-45.

DEMPSEY, Judy - Poland's European Union Ties May Hinge on Elections. International Herald Tribune, 7 outubro 2011. [Acedido a 24 de set. de 2012]. Disponível na Internet: http:// www.nytimes.com/2011/10/08/world/europe/polands-european-union-ties-may-hinge-onelections.html.

ELDER, Miriam - Russia's treatment of US ambassador a reflection of shaky relations. The Guardian, 5 abril 2012. [Acedido a 24 de set. de 2012]. Disponível na Internet: http:// www.guardian.co.uk/world/2012/apr/05/russia-us-ambassador-relations.

France Diplomatie - The Weimar Triangle. 2006. Disponível em: http://www.diplomatie. gouv.fr/en/country-files/poland/the-weimar-triangle/.

FREIRE, Maria Raquel e DAEHNHARDT, Patricia - As relações entre a Alemanha e a Rússia: Duas políticas externas em transição. Relações Internacionais. N. ${ }^{\circ} 32$ (2011), p. 171-196.

GASPAR, Carlos - Dois Ocidentes. Relações Internacionais. N. ${ }^{\circ} 3$ (2004), p. 37-44.

GOLDGEIER, James M. - Not whether but when: The U.S. Decision to Enlarge NATO. Washington D.C.: Brookings Institution Press, 1999.

GRINKEVICH, Vldislaw - The end of the meat war. RIA Novosti, 2007. [Acedido a 31 de jan. de 2012]. Disponível na Internet: http://en.rian.ru/analysis/20071221/93527462.html.

GÜNSCHE, Karl-Ludwig - Wie sich Rußland die Nato-Osterweiterung vorstellt. Die Welt Online, 1 abril 1997. [Acedido a 31 de jan. de 2012]. Disponível na Internet: http://www.welt.de/ print-welt/article635656/Wie-sich-Russland-die-Nato-Osterweiterung-vorstellt.html.

KOSC, W. - Smolensk tragedy report continues to complicate Russian-Polish relations. Russia Beyond the Headlines, 2011. [Acedido a 31 de jan. de 2012]. Disponível na Internet: http://rbth.ru/articles/2011/01/20/smolensk_tragedy_report_continues_to_complicate_ russian-polish_relat_12293.html.

KULISH, N. - Georgian Crisis Brings Attitude Change to a Flush Poland. The New York Times, 20 agosto 2008. [Acedido a 31 de jan. de 2012]. Disponível na Internet: http://www. nytimes.com/2008/08/21/world/europe/21 poland.html?pagewanted=print

KUZNIAR, Roman - A new Polish foreign policy. Sprawy Miedzynarodowe, 1991.

KUZNIAR, Roman - A Primavera dos Povos de 1989: A transformação dos princípios fundamentais da política externa polaca. Relações Internacionais. N. ${ }^{\circ} 23$ (2009), p. 21-37.

LÉVESQUE, Jacques - The enigma of 1989 the USSR and the liberation of Eastern Europe. Berkeley: University of California Press, 1997. [Acedido a 23 de jan. de 2012]. Disponível 
na Internet: http://search.ebscohost.com/login.aspx?direct=true \&scope=site $\& \mathrm{db}=$ nlebk\& $\mathrm{db}=$ nlabk\&AN=21260.

LIPMAN, Maria - The Third Wave of Russian De-Stalinization", Foreign Policy. 2010. [Acedido a 27 de jan. de 2012]. Disponível na Internet: https://www.carnegieendowment. org/2010/12/16/third-wave-of-russian-de-stalinization/2ft6.

LUKASHEVICH, Alexander - Briefing by Russian Foreign Ministry Spokesman Alexander Lukashevich, Russia-Germany-Poland trilateral foreign ministers' meeting in Kaliningrad. 20 maio 2011. [Acedido a 27 de ago. de 2012]. Disponível na Internet: http://www.mid.ru/bdomp/brp_4.nsf /171aab5ddf3ec3c2c32575d7004629c8/921756bb24d724dec3257897003d173c!OpenDocument.

MALIA, Martin E. - The Soviet tragedy: a history of socialism in Russia, 1917-1991. New York: Free Press, 1996.

MEYER RESENDE, Madalena - The Unintended Effects of Europe on Central and East European Party Systems: Poland and Beyond. Tallinn: Tallinn University Press, 2009.

MEYER RESENDE, Madalena - Transformando a nação: os nacionalismos dos partidos de centro-direita na Espanha e na Polónia. Análise Social. N. ${ }^{\circ} 201$ (2012), p. 741-764.

OSICA, Olaf - A Lesson in Politics: Poland and the Iraq Conflict. In B. Wizimirska, ed., Yearbook of Polish Foreign Policy 2003. Warsaw: Administrative and Maintenance Services, Ministry of Foreign Affairs of Poland, 2004.

Reuters - Factbox - Twists and turns in Polish-Russian relations. 2011. [Acedido a 24 de jan. de 2012]. Disponível na Internet: http://uk.reuters.com/article/2011/04/07/ukpoland-russia-relations-factbox-idUKTRE7363DY20110407.

RFE/RL - RFE Special Report on NATO expansion. RFE/RL Special Reports, 2004.

ROTFELD, A. - Poland and Russia: A Polish hawk turns dovish on Russia. The Economist, 2010. [Acedido a 24 de jan. de 2012]. Disponível na Internet: http://www.economist. com/blogs/easternapproaches/2010/09/poland_and_russia.

RPC National Security Facts - What Exactly Has Been 'Reset' in the Relationship With Russia? 2010. [Acedido a 24 de jan. de 2012]. Disponível na Internet: http://rpc.senate.gov/ public/?a=Files.Serve\&File_id=bb666692-2226-467f-92d1-4c0710ccf1a1

SIKORSKI, Radoslaw - Poland and the future of the European Union. Discurso do ministro dos negócios estrangeiros da Polónia em Berlim, 2011. [Acedido a 24 de set. de 2012]. Disponível na Internet: www.msz.gov.pl/files/docs/komunikaty/20111128BERLIN/ radoslaw_sikorski_poland_and_the_future_of_the_eu.pdf.

SIKORSKI, Radoslaw e STORE, J.G. - NATO, Russia and Tactical Nuclear Arms. Letter to the New York Times, 2012. [Acedido a 24 de set. de 2012]. Disponível na Internet: http:// www.nytimes.com/2012/05/15/opinion/nato-russia-and-tactical-nuclear-arms.html.

SKORZYNSKI, Jan - A revolução do Solidariedade e a crise do sistema soviético. Relações Internacionais. $\mathrm{N}^{\circ} 33$ (2012), p. 71-81.

SKUBISZEWSKI, Krzysztof - Raison d'être of the Polish Republic. Polityka Polska, 1993.

SKUBISZEWSKI, Krzysztof - We built the Polish foreign policy from scratch. Entrevista com Krzysztof Skubiszewski (com W. Beres, K. Brunetka e A. Romanowski). Tygodnyk Powszechny, 1994.

SNYDER, Timothy - The reconstruction of nations: Poland, Ukraine, Lithuania, Belarus, 1569-1999. New Haven: Yale University Press, 2003.

SPERO, Joshua B. - Bridging the European divide: middle power politics and regional security dilemmas. Lanham, MD: Rowman \& Littlefield Publishers, 2004.

SZABO, Stephen - Enlarging NATO: The German-American Design for a New Alliance. In Haftendorn, Helga; Soutou, Georges-Henry; Szabo, Stephen e Wells, Samuel, eds., The 
strategic triangle: France, Germany, and the United States in the shaping of the new Europe. Washington, D.C.; Baltimore: Woodrow Wilson Center Press; Johns Hopkins University Press, 2006. p. 327-351.

TRENIN, Dmitry - Russia redefines itself and its relations with the West. The Washington Quarterly. Vol. 30, n. ${ }^{\circ} 2$ (2007), p. 95-105.

TURKOWSKI, Andrzej - The Polish-German Tandem. Carnegie Moscow Center, Carnegie Endowment for International Peace, 2011. [Acedido a 24 de set. de 2012]. Disponível na Internet: http://carnegie.ru/publications/?fa $=46059$.

U.S. Library of Congress, Poland - Soviet Union and Russia. U.S. Library of Congress. [Acedido a 7 de fev. de 2012]. Disponível na Internet: http://countrystudies.us/poland/89.htm.

US Department of Defense - BMDR March 2010 Fact Sheet, 2010. [Acedido a 31 de jan. de 2012]. Disponível na Internet: http://www.defense.gov/bmdr/docs/BMDR\%20FACT\%20 SHEET\%20March\%202010\%20_Final_.pdf.

VAÏSSE, Justin e KUNDNANI, Hans - ECFR's Scorecard 2012. Brussels: The European Council on Foreign Relations, 2012. [Acedido a 6 de fev. de 2012]. Disponível na Internet: http:// www.ecfr.eu/scorecard/2012/extras/pdf/.

Voice of America - Polish Defense Minister's Pipeline Remark Angers Germany, 2006. [Acedido a 31 de jan. de 2012]. Disponível na Internet: http://www.voanews.com/english/ news/a-13-Polish-Defense-Minister-Pipeline-Remark-Angers-Germany.html.

WALICKI, Andrzej - Philosophy and Romantic Nationalism: the Case of Poland. Notre Dame: University of Notre Dame, 1994.

WALICKI, Andrzej - The Troubling Legacy of Roman Dmowski. East European Politics and Societies. Vol. 14, n. ${ }^{\circ} 1$ (2000), p.12-46. 


\section{CA P Í T UL O 7 \\ RÚ S S I A U N I ÃO EUROPEIA : \\ DOIS GIGANTES E UM CONTINENTE}

Sandra Dias Fernandes

Russia is an inalienable and organic part of Greater Europe and European civilization. Our citizens think of themselves as Europeans. We are by no means indifferent to developments in united Europe. (...) That is why Russia proposes moving toward the creation of a common economic and human space from the Atlantic to the Pacific Ocean - a community referred by Russian experts to as 'the Union of Europe' (Putin, 2012).

I will repeat what I said two years ago: the EU wants to be Russia's partner in its modernisation. We are indeed Strategic Partners. In many ways we are strongly interdependent. In a spirit of mutual benefit we can only win by deepening our cooperation even further (Van Rompuy, 2011).

\section{Introdução}

As relações entre a Rússia e a União Europeia (UE) são um elemento fundamental para as perspetivas de estabilidade na Europa. A forma como estes dois atores interagem tem um elevado impacto estratégico, sendo fundamental para a resolução dos desafios que se colocam à Europa. Desde o fim da Guerra Fria, a UE e a Federação Russa desenvolveram um quadro institucional único de cooperação. A partir de 1997, a sua relação foi 
organizada no âmbito do Acordo de Parceria e Cooperação (APC). A partir desse marco, evoluções significativas alargaram e aprofundaram as suas relações numa gama ampla de domínios. Para enfrentar a evolução da relação e a necessidade de melhorar a sua dimensão estratégica, uma nova metodologia de cooperação surgiu em 2003. A interação foi então reorganizada em quatro "espaços comuns" de cooperação. ${ }^{58}$ Desde 2010, ambas as partes visam desenvolver o que tem sido rotulado como uma "Parceria para a Modernização".

No entanto, apesar da aproximação vivida entre os dois maiores vizinhos europeus, o relacionamento tem sido desafiado por crescentes tensões. Desde a reeleição do Vladimir Putin em 2004 à presidência da Federação, a relação com Bruxelas tem sido marcada por dificuldades recorrentes. Foi notável o surgimento de duas características paradoxais. Por um lado, o método e os domínios de cooperação evoluiram postivamente, ao passo que, por outro lado, a qualidade da relação política deteriorou-se e os parceiros não têm sido capazes de formar uma verdadeira parceria estratégica. A guerra russo-georgiana de agosto de 2008 criou pressão adicional na já existente dificuldade de convergência política. Apesar de um diálogo abrangente e cooperativo, produzindo resultados concretos, principalmente nas áreas de economia e comércio, os resultados políticos não têm sido satisfatórios para nenhum dos parceiros. Isto é particularmente visível na demora em realizar uma parceria renovada (um novo acordo para substituir o APC, que deveria ter sido substituído em 2007).

Neste contexto paradoxal de crescente interdependência e tensões, este capítulo tem por objetivo compreender as relações que a UE e a Rússia têm vindo a desenvolver desde o fim da Guerra Fria. Procuramos abordar duas questões principais: qual é a natureza do diálogo político entre a UE e a Rússia, e qual é o potencial da relação na criação de soluções para desafios comuns. A nossa análise procura evidenciar os alcances e os obstáculos que caracterizam a relação UE-Rússia. Considerar esta questão é uma tarefa fundamental, no contexto da contínua reconstrução

58 Estes espaços são: (i) espaço económico comum, (ii) espaço comum de liberdade, segurança e justiça; (iii) espaço comum de cooperação no domínio da segurança externa, (iv) espaço comum de investigação, educação e cultura. 
da Europa, porque tem impacto na estabilidade da região. No processo de transição pós-Guerra Fria, o principal desafio tem sido a aproximação de antigos inimigos. Foram criados quadros originais de cooperação para enquadrar as relações com a Federação Russa mas esta última não está disposta a ser um país candidato à UE alargada.

A primeira parte do capítulo apresenta alguns traços principais das transformações que Bruxelas e Moscovo vivenciaram desde 1991 e que afetaram o seu relacionamento. O Kremlin teve de reposicionar a Rússia no palco europeu com uma nova identidade e um poder reduzido. A UE foi aprofundando e alargando o seu projeto de integração abarcando um número cada vez maior de países europeus, outrora aliados da antiga União das Repúblicas Socialistas Soviéticas (URSS), e delineando novas ambições no continente. A segunda parte do texto analisa o conteúdo da cooperação per se, ao descrever os alcances da relação. A terceira parte pondera os obstáculos inerentes ao diálogo russo-europeu.

\section{Uma era de transições: dois "novos" vizinhos com ambições re- novadas}

A UE e a Rússia tiveram de adaptar as suas políticas ao novo ambiente criado pelo fim de um ciclo histórico em 1991, a Guerra Fria. Os seus interesses e posicionamento internacional sofreram mudanças profundas, as quais ainda estão em curso. Esta parte do capítulo tem por objetivo expor as principais transições levadas a cabo por Moscovo e Bruxelas na medida em que tiveram impacto no seu relacionamento. Após a análise da vertente europeia da política externa russa, abordaremos a forma como a UE adaptou as suas políticas ao novo mapa europeu face ao vizinho russo.

\section{A Rússia: saindo das sombras}

A política externa russa evoluiu drasticamente desde os anos 1990, apresentando características complexas. Isso aconteceu por diferentes 
razões e teve impacto nas relações do país com terceiros, em particular na Europa. A Federação Russa é o principal Estado sucessor à URSS e teve um posicionamento atribulado na balança de poder global e regional. Vyacheslav Nikonov (2004), uma figura próxima de Putin, argumenta, em tom provocativo e eslovófilo, que "a Rússia é muito grande e muito russa". O autor refere-se à dificuldade da Federação em ser um país europeu "normal". Essa característica informa a sua política externa múltipla e desafiante, por ter tido que se adaptar a importantes mudanças internas e internacionais (Freire, 2012). O Kremlin aspirou a melhorar a sua capacidade externa de influência, e, com Putin, procurou exercer um contrapeso aos Estados Unidos da América (EUA) (Rowe and Torjesen, 2009; Borozna, 2007).

A questão de compreender a influência da Rússia em assuntos globais e europeus ganhou novo ímpeto com as duas presidências de Putin (2000-2008).59 Putin permaneceu em posição de poder após a eleição de Medvedev, em 2008, e a sua liderança marcou uma nova era para a Rússia que introduziu mudanças notáveis na relação com atores europeus, principalmente com a UE. Muitos consideram que a relação chegou a uma encruzilhada na medida em que não produziu a aproximação estratégica desejada. Na realidade, o ponto da situação no que diz respeito à aceitação das consequências do fim da Guerra Fria, durante os anos 1990 e o começo dos anos 2000, foi desafiado. Até então, a Federação Russa aceitava um status quo determinado pela sua posição mais fraca na balança de poder regional e global. Isso explica, em parte, a aproximação à UE, especialmente nas áreas económica e comercial, mas também, posteriormente, nos setores de segurança e defesa (ver abaixo). ${ }^{60}$ As relações entre a UE e a Rússia transformaram-se ao longo desse período, algo visível de forma mais marcante do lado russo.

A Rússia de Putin tornou-se uma parceira mais estável por ter gerado estabilidade interna nos níveis político e económico (Huskey, 2004, pp.

59 A terceira presidência, iniciada a 7 de maio de 2012, será analisada abaixo.

${ }^{60}$ A relação com a Organização do Tratato do Atlântico Norte (OTAN) levou à criação de um quadro institucionalizado de cooperação, baseado no Ato Fundador (1997). 
206-234; Shevtsova, 2004, pp. 141-195), apesar da exacerbação de tensões provocadas pela reafirmação internacional russa (principalmente durante o segundo mandato de Putin) e o problema da sua consolidação democrática (Sakwa, 2008, pp. 472-477). Bachkatov explica como Putin associou o poder político e económico a fim de atingir a meta de uma poderosa e respeitada Rússia (2007, pp. 137-150). Nesse período, de acordo com Nikonov, a Rússia falhou em juntar-se às instituições euro-atlânticas, e esse facto ocorreu na transição do século, quando a Rússia assumiu uma nova política e uma nova auto-identificação. Putin foi eleito nessa época, defendendo a multipolaridade, o pragmatismo e a aproximação ao ocidente (Nikonov, 2004).

Putin foi eleito em 2000 e reeleito duas vezes, em 2004 e em 2012. Foi o herdeiro direto da era Ieltsin mas tentou alterar o seu legado. Putin conseguiu transformar as incertezas da época do seu antecessor criando uma Rússia mais estável, tanto interna quanto externamente. Os resultados do período de Ieltsin podem ser resumidos nas seguintes características: uma democracia inacabada, um Estado federal desequilibrado e uma economia instável (Thumann, 2002). Zwang e Zwang sublinham a enormidade da obra que Ieltsin tinha para realizar, traduzida na implementação de uma democracia e de uma economia de mercado de modo a redefinir a identidade nacional e reencontrar um papel de grande potência no cenário internacional (2004, p. 165). Como consequência, o modelo político e económico ocidental que Ieltsin abraçou perdeu legitimidade pelas dificuldades de ajustamento que enfrentou. Esse facto levou os russos a desejar um homem forte que pudesse restaurar a "grandeza russa" (Thuman, 2002, pp. 170 e 208; Zwang and Zwang, 2004, p. 167). Quando questionado sobre a escolha de Putin como seu sucessor, Ieltsin respondeu que teve tempo de estudar o perfil de Putin e que uma das suas melhores qualidades residia no facto de não ser um maximalista, ao contrário de outros potenciais sucessores que defendiam modelos mais radicais para a transformação do país (Desai, 2006, pp. 83-84).

No compasso da abertura da Rússia para o ocidente, a Europa foi particularmente considerada (Herspring, 2003, pp. 225-256). O facto de a UE ser o maior parceiro comercial da Rússia contribui para explicar esta tendência. Por sua vez, a Rússia é o terceiro parceiro comercial mais importante da UE. 
A taxa de crescimento das exportações e importações aumentou significativamente, muito acima dos valores referentes ao comércio com os Estados Unidos da América (EUA) (Eurostat and Rosstat, 2007, pp. 198-199). De facto, existe uma forte interdependência económica e comercial entre os dois atores, mas também uma grande assimetria de desenvolvimento entre eles, que contribui de forma decisiva para o entendimento desta relação como fundamental. Putin enfatizou a importância dos esforços de aproximação com a Europa no seu discurso de 2001 no Encontro Federativo da Federação Russa, onde também sublinhou que o percurso da integração russa na Europa constitui uma das áreas-chave da sua política externa (Ivanov, 2002, p. 102). A questão do possível ingresso na UE permaneceu ambígua até ao segundo mandato de Putin, que corresponde a um novo momento de assertividade da Federação na cena europeia, como será exemplificado a seguir.

De facto, Ieltsin, em outubro de 1996, mencionara, publicamente, a possibilidade de a Rússia se tornar um Estado membro da UE. O primeiro ministro Viktor Chernomyrdin fez uma declaração similar durante uma visita a Bruxelas em junho de 1997 (Baranovsky, 2002, p. 176). Baranovsky, contudo, avalia a estratégia acima mencionada de duas maneiras distintas. Além da maior aproximação com a Europa, ele enfatiza a existência de dois posicionamentos opostos à entrada russa na UE devido às responsabilidades que emergiriam para o país (2002, pp. 33-34). Essa questão foi esclarecida durante o primeiro mandato do presidente Putin pelo primeiro ministro Kasyanov. Isso ocorreu em julho de 2001, quando o oficial destacou que a relação UE-Rússia era de linkage, e não de membership (Smith, 2002, p. 9).

A evolução do papel da Missão Permanente da Federação Russa junto da UE é um elemento adicional que aponta para a maior atenção que Moscovo tem devotado à sua relação com Bruxelas. Num curto período de tempo, correspondente ao final do primeiro mandato de Putin e ao começo do segundo, a missão cresceu cinco vezes. Isso correspondeu à expansão das competências comunitárias e a uma melhor consciência dos desenvolvimentos da UE. ${ }^{61}$ Pelos próprios padrões russos, a missão

61 Entrevista com um representante de um novo Estado membro em Bruxelas, a 13 de junho de 2007. 
tornou-se mais consistente, e alguns funcionários da UE consideram que o nível de especialização dos russos sobre o funcionamento da União é notável. Além disso, deve ser sublinhado que Moscovo prefere relações bilaterais com Estados membros em particular, de onde vai retirando dividendos, sendo certo, no entanto, que esta estratégia não é suficiente e que os russos devem lidar com a UE em questões que são decididas pelos 28 Estados membros em conjunto.

Durante o primeiro mandato de Putin, a política externa russa beneficiou do seu pragmatismo, criando laços mais fortes com o ocidente. No entanto, as habilidades pessoais de Putin reveleram os seus limites, e a aproximação começou a tornar-se mais difícil durante o seu segundo mandato. A política externa russa necessitava de iniciativas diplomáticas que poderiam ser mais construtivas e proativas quanto ao diálogo transatlântico para lograr o objetivo de contrabalançar a presença dos EUA nos quadros institucionais existentes. Exemplifica tal situação o facto de Putin procurar apoios na Europa enquanto não apoiando a intervenção norte-americana no Iraque, embora não tenha formulado críticas diretas a Washington, como o fizeram a França e a Alemanha (Coelho, 2004). Marcou posição, procurando no entanto manter o diálogo em aberto com o seu parceiro do outro lado do Atlântico. Além disso, as aptitudes de Putin no plano externo refletiam o endurecimento do seu regime, que havia começado no primeiro mandato e que continuou ao longo do segundo. Jack (2005) sintetiza as orientações da Rússia com Putin da seguinte forma:

"Putin tem feito muito para aumentar a credibilidade de seu país no exterior, provando ser um parceiro mais confiável e consistente do que Ieltsin. Ele foi ajudado pela ameaça externa do terrorismo e por uma procura crescente por fontes de energia abundantes da Rússia longe do instável Médio Oriente. Mas havia também um lado neo-imperial mais nacionalista que alertava para o facto de ele não estar simplesmente a transformar a Rússia num país ocidental." (Jack, 2005, pp. 5-6)

Sublinhamos acima que os dois primeiros mandatos do presidente Putin marcaram uma rutura com a era Ieltsin, uma vez que correspondem a 
uma dinâmica mais estável e cooperativa e a desempenhos económicos aprimorados. A posição da Federação Russa melhorou no cenário internacional e a sua política externa evoluiu em concordância. Desde então, um retorno da Rússia, devido ao grande crescimento económico e aumento de influência política que marcou a década pós-2000 até à crise financeira de 2008, tem sido observado na Europa e no mundo. Durante o período de Ieltsin, o PIB registou um crescimento positivo apenas em 1997, de 1,7\%, e em 1999 na ordem dos 6,4\%. Um desempenho negativo do PIB, uma produção industrial negativa e uma inflação enorme marcaram a década de noventa (Sakwa, 2008, p. 299; Vinhas de Souza, 2007 , p. 95). Vinhas de Souza (2007) apresenta uma análise detalhada da evolução macroeconómica russa de 1991 a 2008, nomeadamente o crescimento sustentado vivido desde 1999. O autor afirma que a Rússia se transformou num "país diferente" baseado nos efeitos das reformas económicas e estruturais e nos elevados preços da energia. No entanto, a crise global também afeta o curso de afirmação russa desde a crise financeira do verão de 1998. O ano de 2009 marcou o primeiro défice orçamental russo da década, causado nomeadamente pela descida do preço do petróleo (The Moscow Times, 2009).

A reeleição de Putin em março de 2012 deixa vislumbrar sérios desafios ao curso de reassertividade acima apresentado. Levantam-se também interrogações acerca das novas orientações da política externa russa. Certos analistas falam de um regresso "instável" e "hesitante" do líder russo (Emerson, 2012). O sinal porventura mais claro dado por Putin acerca do rumo que pretende dar à Federação russa encontra-se num artigo assinado por Putin e publicado num jornal russo, intitulado "Russia and the changing world" (Putin, 2012). O presidente russo reafirma a necessidade de uma Rússia forte para ser tratada em pé de igualdade e respeitada pelos outros países. No que concerne a Europa, Putin vislumbra a necessidade de unir esforços para enfrentar o aumento de poder da Ásia. No entanto, os eforços referidos dizem respeito sobretudo à área económica e à criação de um vasto mercado comum. Esta proposta é vista como solução para a crise da dívida soberana enfrentada pela UE. O tom do artigo é claro no sentido de afirmar a identade europeia do 
país e a vontade de cooperar com a UE para enfrentar desafios europeus e globais, sem no entanto deixar de sublinhar claramente o poder russo em também ajudar a União nos seus problemas e a necessidade de uma parceria conjunta para fazer face ao mundo global.

A Rússia tem vindo, de facto, a insistir cada vez mais na inelutabilidade da cooperação UE-Rússia para que os dois atores possam manter relevância internacional, procurando assim enaltecer a desejada igualdade que Moscovo procura no seu relacionamento com Bruxelas. Tsygankov (2012) esclarece a estratégia russa de política externa, a qual consiste em promover um mundo e uma governação multipolares através de uma aposta simultânea no relacionamento com instituições ocidentais e não ocidentais. Makarychev e Morozov (2011) explicam que a auto-perceção russa de grande potência faz com que Moscovo não se queira juntar às instituições transatlânticas mas tem, no entanto, a necessidade prática de cooperar com Bruxelas e Washington. A procura de uma parceria frutífera com a UE é, portanto, um traço duradouro dos desígnios russos num contexto mundial cada vez mais complexo.

Adicionalmente, surgiu recentemente uma dimensão interna com a qual a liderança russa renovada tem agora de lidar e cujos efeitos plenos estão, ainda, por revelar. Apesar do partido maioritário Rússia Unida e de Putin terem vencido as últimas eleições legislativas e presidenciais (2011 e 2012), surgiram movimentos de contestação internos inéditos. A crescente contestação interna ao resultado eleitoral e à reeleição de Putin contrariou a "verticalidade do poder" instaurada por Putin em 2001 e a sua figura de "czar" legítimo. Contrariando a ausência de oposição política dentro do sistema centralizador de Putin, vários grupos sociais incorparam, de forma inédita, a oposição ao regime de Putin e a vontade de participarem na vida política do país, defendendo, de acordo com um dos lemas principais das manifestações de dezembro de 2011, que Putin e o seu partido não representam os russos (Olimpieva, 2012). No âmbito das relações externas, o fim da apatia política da sociedade russa poderá trazer pressões nos campos em que Moscovo é regularmente criticado, nomeadamente o respeito pelo estado de direito e pelos direitos humanos. A título de exemplo, é notório o facto de existir, desde 2005, um 
diálogo sobre direitos humanos entre a UE e a Rússia e de ainda não ter sido possível agendar reuniões em território russo.

\section{A União Europeia: novas ambições a leste}

$\mathrm{O}$ alargamento institucional tem sido um marco fundamental nas transformações da UE no pós-Guerra Fria. Ao incluir os países da Europa central e oriental, que outrora faziam parte da antiga URSS, a União aproximou-se das fronteiras da Rússia e aumentou as suas ambições para leste. Os Conselhos Europeus de Copenhaga (1993) e Helsínquia (1999) marcaram este processo que se concretizou a 1 de maio de 2004 para oito destes países (juntamente com Chipre e Malta), passando a UE de 15 para 25 Estados membros. Em 2007, a Roménia e a Bulgária completaram o alargamento. ${ }^{62}$

Os novos Estados membros modificaram as perceções internas da UE acerca do seu papel no continente. A dicotomia entre antigos e novos membros é útil para caracterizar as diferentes visões. Isso foi particularmente visível na vontade de envolver a UE na resolução de conflitos na Europa, e na relação com a Rússia. Por um lado, alguns membros gostariam que Bruxelas se pautasse por princípios normativos, condicionando rigidamente a sua ação externa a valores comuns. Por outro lado, há Estados membros que valorizam uma postura mais realista e uma ação baseada na prossecução de interesses. Por exemplo, os três Estados Bálticos defendem uma voz unida face à Rússia e preferem lidar com o Kremlin ao nível de Bruxelas, e não bilateralmente. Países como a França, a Alemanha ou a Itália têm relações bilaterais privilegiadas com Moscovo. O exemplo porventura mais paradigmático desta dicotomia encontra-se nos assuntos energéticos. Desde 2006, acordos energéticos bilaterias foram assinados com a Federação Russa (Gazprom) para garantir fornecimentos de gás a esses países, em troca do acesso russo aos mercados nacionais. Face à ausência de uma política comum de energia, Moscovo tem vindo a usar

${ }^{62}$ Em julho de 2013, a Croácia elevou o número de Estados membros para 28. 
a sua vantagem energética, enquanto principal produtor e fornecedor, e aproveitado as divisões dentro da UE.

O quinto alargamento da UE, em maio de 2004, teve por consequência mais visível um novo mapa da Europa, tendo agora a UE uma fronteira comum com a Rússia e outros países da ex-URSS. A Rússia assumiu uma maior importância porque é o maior vizinho. Este facto explica a iniciativa política da UE, em março de 2003, intitulada Wider Europe Neighbourbood: a New Framework for Relations with our Eastern and Southern Neighbours, com o objetivo de desenvolver uma vizinhança de prosperidade e amizade. Genericamente, o objetivo desta política é partilhar os benefícios do alargamento com os Estados vizinhos, a fim de evitar a emergência de "novas linhas divisórias" no continente. Essa expressão retoma indiretamente a temática da "Europa fortaleza", i.e. a preocupação de a UE não ser um espaço fechado de estabilidade e desenvolvimento. Concretamente, Bruxelas criou, em 2004, uma Política Europeia de Vizinhança (PEV) direcionada para os países vizinhos a leste da Europa e na orla mediterrânica.

O facto de Bruxelas definir políticas especificamente delineadas para os países do antigo espaço soviético, no âmbito do seu conceito Wider Europe, permitiu a países como a Moldova, a Ucrânia ou a Geórgia desenvolver aspirações europeias e transatlânticas. No entanto, o crescente envolvimento de Bruxelas na região não é isento de tensões políticas com Moscovo. O Kremlin perceciona a Política de Vizinhança como uma iniciativa unilateral da UE, e como um desafio aos seus interesses. A relutância russa persistente em contribuir de forma positiva para a resolução dos "conflitos congelados" europeus ${ }^{63}$ enquadra-se nessa perceção. A agudização das tensões com Tbilisi levou ao deflagrar da guerra russo-georgiana de agosto de 2008. Desde então, a Rússia reconheceu, sem apoio internacional, a independência dos dois territórios separatistas da Geórgia, a Abcázia e a Ossétia do Sul. Consideramos que esta guerra sublinhou a necessidade de a UE conceber um novo modelo de relacionamento com Moscovo, nomeadamente em matéria de segurança e problemas de vizinhança.

63 A expressão refere-se aos conflitos territoriais oriundos da desintegração da antiga URSS. Existem disputas relativamente a regiões separatistas na Moldova, Geórgia, Arménia e Azerbaijão. 
No período pós-2008, a UE lançou uma nova iniciativa política com o intuito de melhorar a sua Política de Vizinhança a Leste, denominada Parceria Oriental. Esta nova política integra a PEV e foi promovida antes da crise georgiana, tendo em consideração a necessidade de desenvolver uma melhor oferta da UE, no seu flanco oriental. Esta política foi lançada oficialmente em maio de 2009, na cimeira de Praga (European Council, 2009). De forma semelhante à PEV, a Parceria Oriental visa promover a estabilidade nas fronteiras orientais externas da UE, sem oferecer garantias de adesão.

No entanto, a criação da Parceria Oriental reflete também a preocupação de alguns Estados membros em relação a Moscovo, nomeadamente no rescaldo da afirmação russa do seu poder na Geórgia em 2008. Esta intenção é visível no texto que promoveu esta iniciativa, emitido em conjunto pela Polónia e pela Suécia (Lapczynski, 2009). O texto reflete a vontade desses Estados membros de ter em consideração o desafio colocado pela Rússia aos países da vizinhança comum, para além do reconhecimento dos resultados limitados da PEV e da necessidade de a melhorar para ajudar os países parceiros na rota do desenvolvimento político, económico e social.

A criação da Parceria Oriental com seis países destaca, de facto, várias lacunas da PEV e a necessidade de abordar de forma mais consistente a transição na Arménia, Azerbaijão, Geórgia, Moldova, Ucrânia e, eventualmente, Bielorrússia. A tentativa de aprofundar a dimensão oriental da UE levanta a questão do impacto desta nova iniciativa num contexto de segurança tenso na Europa. A articulação entre a Parceria Oriental e as preocupações da UE com a Rússia é particularmente visível nas conclusões do Conselho Europeu de outubro de 2008 (Council of the European Union, 2008) porque, na sequência da guerra russo-georgiana ficou vísivel de que forma os países da Parceria Oriental constituem uma "vizinhança comum" problemática e partilhada entre a UE e a Rússia. Uma das conclusões do Conselho Europeu foi a criação de uma missão de monitorização da União na Geórgia, iniciada em outubro de 2008, o que aumentou a presença da UE na região. O maior envolvimento de Bruxelas nesta vizinhança tem, portanto, criado maiores dificuldades no relacionamento com Moscovo uma vez que se trata de uma área onde os russos têm interesses privilegiados. 


\section{O diálogo político e as áreas de cooperação entre a UE e a Rússia}

Do ponto de vista da UE, o propósito da relação com Moscovo foi, inicialmente, de evitar novas linhas divisórias na Europa, depois de ter superado as divisões bipolares da Guerra Fria. A aproximação de ex-inimigos emergiu, principalmente a partir de final dos anos noventa. Desde 1999, o relacionamento ganhou uma maior densidade estratégica. Concretamente, um quadro institucional de cooperação foi criado, composto por cinco elementos principais:

i) O Acordo de Parceria e Cooperação (APC) de 1997, que constitui a base institucional da relação UE-Rússia.

ii) Em 1999, dois documentos estratégicos foram adotados pelas duas partes (European Council, 1999; The Russian Federation, 1999).

iii) Desde 1998, ocorrem cimeiras bianuais.

iv) Órgaos de cooperação técnica, que preparam as cimeiras e implementam decisões.

v) Os programas de cooperação da UE são também instrumentos para o relacionamento criados por Bruxelas.

O APC é o alicerce para o surgimento do diálogo político, o qual é o primeiro resultado visível do acordo (Agreement on Partnership and Cooperation, 1997). Ele também substitui o anterior Tratado com a URSS de 1989, em conformidade com o artigo 112 do APC. É um acordo misto e abragente: foi concebido para gerir as relações económicas, comerciais e políticas por um período de dez anos renováveis.

O APC também permitiu dinamismo na evolução do relacionamento. O documento contém uma definição mínima do diálogo político mas a cooperação tem ido muito além daquilo que foi estipulado no APC, por vezes de forma genérica. Por exemplo, a segurança e a defesa eram apenas mencionadas geralmente através da referência ao desenvolvimento de um diálogo político que visa estabelecer novas formas de consulta e cooperação para promover a segurança internacional. Em 2000, esse dinamismo foi incorporado concretamente num documento ad hoc intitulado 
"Declaração conjunta sobre o diálogo e fortalecimento da cooperação em assuntos políticos e de segurança na Europa”, adotado em Paris. Em 1999, dois documentos estratégicos foram adotados por cada parte, acima mencionados. Hoje, ambos estão obsoletos pois foram substituídos por Planos de Ação adotados em 2005 (ver abaixo).

Quando Putin assumiu o poder em 2000 enquanto presidente, as relações UE-Rússia já beneficiavam de uma estrutura de cooperação institucionalizada e avançada em termos das áreas abrangidas. Esta relação tem evoluído desde então para uma maior maturidade, refletida no alargamento e aprofundamento da agenda de cooperação. Uma tendência definidora da relação é o facto dos objetivos económicos serem reforçados, dando assim a outras áreas uma prioridade secundária. A agenda de low politics (economia e comércio) tem sido mais desenvolvida do que a agenda de high politics (segurança e conflitos). ${ }^{64}$ Após as iniciativas tomadas nas cimeiras, a Comissão Europeia formulou o conceito de "Espaço Económico Europeu Comum”. A ideia comum de uma Europa unida economicamente, foi, assim, oficializada (Joint Statement, 2001).

$\mathrm{O}$ ano de 2003 representou um ponto de viragem no quadro da cooperação UE-Rússia, porque trouxe uma nova estrutura ad hoc de cooperação. Nesse ano, na cimeira de São Petersburgo, quatro espaços comuns foram criados (European Commission, 2003a):
1. um Espaço Económico Comum;
2. um Espaço Comum de Liberdade, Segurança e Justiça;
3. um Espaço Comum de Cooperação no domínio da Segurança Externa
4. um Espaço Comum de Investigação, Educação e Cultura.

Podemos interpretar a criação dos quatro espaços comuns como uma necessidade para enfrentar o alargamento a leste da União Europeia em 2004 (Directorate General External Relations, 2003). Em vésperas do alargamento, era necessário evitar que a Rússia se sentisse numa situação

${ }^{64}$ A secção anterior do presente capítulo contribuiu para explicar este facto uma vez que as ambições políticas externas de Bruxelas não têm colhido aceitação por parte de Moscovo. 
periférica, uma vez que não era um Estado membro nem um parceiro da política de vizinhança. Se excluirmos a responsabilidade política que está implícita para os países que pretendem ser candidatos à UE, nomeadamente através da incorporação de legislação da UE, o conceito de "quatro espaços comuns" pode ser visto como uma aproximação à UE (candidatura por proxi), porque os quatro espaços cobrem todos os campos das atividades da UE. Outra componente do quadro de cooperação institucionalizada é a referência a valores e princípios comuns contidos em todos os documentos e essenciais para uma "parceria UE-Rússia genuína” (European Council 2001, p. 13). O Conselho Europeu de Gotemburgo, em junho de 2001, definiu-os como sendo o estado de direito, a boa governação, o respeito pelos direitos humanos, incluindo os direitos das minorias, a promoção de boas relações de vizinhança, os princípios da economia de mercado e o desenvolvimento sustentável (European Commission, 2003b).

As áreas de cooperação abrangem vários setores, entre os quais: reforma da banca, contabilidade e auditoria; cultura; economia e comércio; energia; ambiente; ensino superior; direitos humanos e sociedade civil; liberdade, segurança e justiça; Kaliningrado; Cáucaso do Norte; Dimensão Nórdica; política regional; ciência e tecnologia; espaço; transporte; vistos e readmissão. Desde a adoção dos quatro espaços comuns, cinco relatórios de progresso foram aprovados publicamente pela Comissão Europeia para os anos de 2007 a 2011.65

No primeiro "espaço comum", foram criados "diálogos setoriais" de modo a concretizar a cooperação. Esses diálogos cobrem, nomeadamente, as seguintes áreas: transportes; política industrial e empresarial; diálogo regulamentar sobre os produtos industriais; espaço; sociedade da informação; agricultura, pesca, política macro-económica; serviços financeiros; energia; aquisições; meio ambiente; facilitação do comércio; direitos de propriedade intelectual; investimento; estatística; questões macroeconómicas e financeiras; cooperação inter-regional. A energia é

65 Os relatórios podem ser consultados na página internet do Serviço Europeu de Ação Externa, em http://eeas.europa.eu/russia/index_en.htm. 
um dos temas mais importantes nesta área de cooperação. Em 2000, as partes iniciaram um diálogo da energia que se materializa em três grupos temáticos: estratégias energéticas, previsões e cenários; evolução do mercado; e eficiência energética.

O segundo "espaço comum" de Liberdade, Segurança e Justiça é considerado uma área de crescente cooperação e as partes partilham o objetivo de isenção de vistos. Este domínio de cooperação visa combater o terrorismo, a migração ilegal e a criminalidade transfronteiras (que inclui o tráfico de seres humanos e drogas). Outra questão abordada nesta área de cooperação são os acordos fronteiriços. Em 2004, o alargamento da UE tem aumentado as fronteiras diretas da União com a Rússia, importando disputas fronteiriças de novos membros da UE. Concretamente, esta situação afetou os três Estados Bálticos que não tinham o reconhecimento oficial das fronteiras estabelecidas com Moscovo. O contra-terrorismo também está incluído no terceiro espaço comum de cooperação (segurança externa) mas é mais consistentemente abordado neste domínio de cooperação.

O terceiro "espaço comum" de cooperação inclui, por sua vez, a discussão de todas as questões de segurança internacional e cooperação em matéria de defesa e constitui a menos avançada das áreas de cooperação. A cooperação abrange exercícios militares virtuais, encontros entre peritos e a participação russa numa missão liderada pela UE (a missão EUFOR Chad/CAR, de 2008 a 2009). Existe também um diálogo entre Bruxelas e Moscovo na área de não-proliferação de armas de destruição em grande escala.

O quarto "espaço comum" de Investigação, Educação e Cultura, visa abranger "a cooperação entre instituições e pessoas que trabalham sobre os mesmos desafios comuns, um melhor conhecimento da história e culturas divergentes e maior contato entre as pessoas, particularmente as mais jovens" (European Commission, 2007, p. 8). Duas características principais surgem da análise dos quatro "espaços comuns" de cooperação. Em primeiro lugar, a cooperação evoluiu de forma desequilibrada em termos de atenção dedicada a cada área de cooperação. A cooperação económica e comercial tem sido favorecida em comparação com as outras áreas, não obstante o facto de elas terem também progedido. 
A cooperação comercial pode ser resumida na vontade de desenvolver uma área de livre comércio com a Rússia. Isso dependia também da adesão da Rússia à Organização Mundial do Comércio (OMC), que tem sido difícil de alcançar, e se concretizou em agosto de 2012. Em segundo lugar, todas as áreas de cooperação foram ampliadas e aprofundadas, nomeadamente após a nova metodologia de cooperação aprovada em São Petersburgo. Isto é particularmente visível no quarto espaço comum, que era quase inexistente enquanto área de cooperação antes de 2006.

O alcance da relação desde a entrada em vigor do APC em 1997 tem sido positivo em termos de criação institucional e da prática de um diálogo político. A relação é, portanto, marcada pela continuidade nas decisões tomadas e pragmatismo na prioridade dada às questões económicas. Alguma confiança política também emergiu do quadro de cooperação. A partir de 2000 o diálogo político expande-se com base na discussão de questões económicas às quais são adicionadas, de forma particular, questões de high politics na ordem do dia. Isso representou um aprofundamento e alargamento da agenda e também veio intensificar o nível de responsabilidade na relação. Neste curso de aprofundamento e alargamento da relação, tensões e dificuldades foram surgindo entre os parceiros.

\section{Dificuldades in crescendu na relação UE-Rússia}

A relação UE-Rússia revela um acervo significativo oriundo de uma relação de cooperação abrangente. A criação de canais de comunicação é certamente um dos maiores valores acrescentados da relação (diálogo político). No entanto, os problemas a enfrentar têm sido um desafio, no curto prazo, à construção desta relação sensível. Os dois atores embarcaram no processo de criação de alguma confiança política, inexistente no desfecho da Guerra Fria, tornando-se uma relação estratégica de longo prazo. No entanto, apesar dos resultados e das promessas do quadro de cooperação institucional UE-Rússia, a situação evoluiu de forma menos satisfatória para ambas as partes. O segundo mandato do presidente Putin (2004-2008) correspondeu a uma mudança na perceção da Rússia da sua 
posição em assuntos europeus, mas também a uma mudança de atitude da UE alargada em relação a Moscovo. Bruxelas tornou-se mais exigente e mais observadora dos assuntos internos russos, em particular no que concerne o funcionamento do seu regime político. Além do mais, esta atenção redobrada prendeu-se também com o processo de inclusão de novos Estados membros na UE com memórias históricas difíceis em relação à Rússia.

O resultado é uma relação difícil com mais críticas mútuas, materializada na dificuldade em negociar um período pós-APC depois de 2007. Esta situação reflete a dificuldade de avançar para uma verdadeira parceria estratégica. Ambas as partes também manifestaram grandes expetativas a nível retórico, as quais não foram concretizadas ou apenas o foram parcialmente. É particularmente visível na questão dos valores e princípios comuns inerentes a todas as referidas áreas de cooperação porque surgiram sérias dificuldades na convergência real e na adoção de normas. O exemplo mais claro desta discrepância entre Bruxelas e Moscovo tem sido as dificuldades do diálogo iniciado em 2005 sobre direitos humanos em produzir resultados concretos. Durante o contexto eleitoral russo, entre o final de 2011 e o início de 2012, as críticas ao funcionamento e regularidade dos processos também ilustraram divergências na interpretação das normas democráticas. Antes do escrutínio de dezembro de 2011, a diplomacia europeia já manifestava inquietações acerca do pluralismo na Rússia devido à dificuldade de certos partidos em registarem-se (European Union, 2011).

No final do segundo mandato de Putin como presidente da Federação Russa em 2008, um clímax foi atingido nas relações UE-Rússia. Além do reconhecimento mais ou menos entusiasta das conquistas da relação, os observadores concordaram sobre a necessidade de elevar a relação para um nível mais funcional. Como Burghardt (2008) sublinhou, um "recomeço" era necessário tendo em conta as mudanças de ambos os lados, sugerindo o fecho de um ciclo nas relações UE-Rússia e a abertura de um novo caminho para um tipo diferenciado de relacionamento. Arbatova (2008) identificou o ano de 2007 como o momento em que ambas as partes tomaram um rumo diferente. $\mathrm{O}$ ponto alto dos desentendimentos foi materializado no limbo de dois anos (2006-2008) que a relação atravessou. As partes superaram este período quando iniciaram o processo 
de negociação de um novo acordo de cooperação para substituir o APC, em julho de 2008. O objetivo do novo acordo será de cooperar com base num documento que reflita a evolução dos interesses e avanços da relação.

No entanto, uma visão pragmática sobre as relações UE-Rússia e os seus resultados permite reconhecer o acervo da cooperação em curso e desdramatizar as fases tensas da relação. A expetativa de resultados visíveis em cada cimeira não se concretizou, mas a estrutura de cooperação demonstrou duas capacidades principais. Por um lado, um diálogo aberto com Moscovo (nomeadamente sobre o conteúdo da parceria em curso) manteve-se, apesar dos contextos difíceis. Mesmo durante o período de reflexão que a UE decidiu levar a cabo, entre setembro e novembro de 2008, para tomar uma posição face ao comportamento belicista russo na Geórgia, o diálogo russo-europeu não parou. Apenas foram suspensos alguns ciclos de negociações para um novo acordo de cooperação. Por outro lado, os níveis de interação mais técnicos têm conseguido resultados setoriais, sobretudo a partir da reformulação da cooperação no âmbito dos "quatro espaços comuns" acordados em São Petersburgo em 2003. O quadro de cooperação gerou uma rotinização que explica a ausência de recuos, apesar dos períodos de abrandamento, assim como explica o alargamento e aprofundamento da agenda de cooperação.

É possível observar uma discrepância entre, por um lado, os discursos russos que não são conciliatórios e a atitude da UE que critica o funcionamento democrático da Rússia, e, por outro lado, a dimensão pragmática da relação. A relação evoluiu e alcançou resultados de cooperação em cada um dos quatro espaços comuns, sem existir no entanto um acordo sobre todos os princípios da relação. A situação criada pode, portanto, parecer paradoxal. Uma das tensões mais visíveis nas relações UE-Rússia de hoje assenta, de facto, na ausência de partilha efetiva de valores e princípios comuns, que deveriam ser a base da parceria. Para Moscovo, o método de condicionalidade da UE (o qual consiste em vincular as suas relações com terceiros à observância de valores) não contribui para a obtenção de resultados construtivos. A insistência da UE no discurso normativo é contrariada pela afirmação, por parte do Kremlin, da especificidade 
cultural da Rússia e do seu direito a uma interpretação diferente do conceito de democracia, intitulada de "democracia soberana" por Putin. Conforme acima demonstrado, o autoritarismo de Putin tem vindo a ser posto em causa por movimentos internos de contestação significativos. Estes factos recentes deixam vislumbrar a necessidade do presidente rever a sua forma de exercício do poder, o que poderá, eventualmente, ter efeitos na agenda normativa com a UE.

A relação UE-Rússia organiza-se, hoje, em torno de uma "Parceria para a Modernização". A expressão foi cunhada em 2010 e remete para objetivos de cariz essencialmente económico, apesar da União persistir com um discurso de convergência normativa. Cada uma das partes procura promover assuntos para o topo da agenda. Se para os russos a criação de uma política de isenção de vistos surge como uma das prioridades, os europeus, por seu lado, anseiam por uma melhor cooperação nos domínios comercial e energético. A entrada da Rússia para a OMC em 2012 encerra quase duas décadas de negociações e abre novas perspetivas no âmbito do primeiro "espaço comum" de cooperação com a UE, no sentido de diminuição das barreiras comerciais e da liberalização das trocas.

\section{Conclusão: da necessidade de cooperar face às transformações globais}

Ao longo dos anos noventa deu-se uma aproximação institucional, de natureza política, entre a UE e a Rússia. A qualidade e a densidade desta aproximação foram mais notórias no final dos anos 1990. Existe um quadro único e institucionalizado de cooperação entre a UE e a Rússia que tem produzido resultados específicos, principalmente em domínios económicos. A cooperação tem-se, no entanto, alargado e aprofundado para além desta área. As questões de segurança são discutidas sistematicamente desde 2000 e outros campos, como educação e assuntos internos, também foram desenvolvidos. No entanto, a relação tem enfrentado limitações na obtenção de resultados concretos de cooperação, nomeadamente na feitura 
de um novo acordo de parceria, por um lado, e por outro, no domínio da segurança não se conseguiu avançar na definição de um quadro securitário que satisfaça os objetivos - não consensuais - de Bruxelas e Moscovo.

Estas limitações advêm de um conjunto de factores. Em primeiro lugar, existe um desequilíbrio entre os quatro principais domínios de cooperação, em favor da cooperação económica, o que torna difícil criar sinergias na agenda global de cooperação. Além da consideração de resultados cooperativos desiguais nos quatro "espaços comuns", as dificuldades em encontrar soluções aumentaram durante o segundo mandato de Putin, não tendo registado progressos significativos com Medvedev. A declaração pelo respeito de valores e princípios é a referência orientadora da relação a nível retórico mas tem sido cada vez mais desafiada por falta de cumprimento. Esta evolução agudizou as tensões que criam obstáculos à obtenção de resultados de cooperação.

A solução passaria, porventura, por uma atenção mais equilibrada a cada um dos quatro "espaços comuns" de São Petersburgo. Existe um entendimento generalizado segundo o qual as dificuldades de convergência podem ser superadas, a médio ou longo prazo, desde que os contatos entre as populações sejam intensificados. Isso poderia resolver os problemas de perceção mútua, ainda marcada por desconfianças históricas e uma certa desilusão em relação ao pós-Guerra Fria. Esta é a tarefa do "espaço comum" de Investigação, Educação e Cultura. O antigo primeiro ministro Kasyanov (2008) sublinhou que os cidadãos russos precisam de ter a oportunidade de comunicar com os cidadãos da UE, a fim de promover uma aproximação nos valores para além do interesse de Bruxelas nas negociações económicas.

A cooperação tem sido, portanto, fomentada entre a UE e a Rússia, mas ainda existe controvérsia na interpretação do valor acrescentado desta cooperação no contexto da política global e como uma ferramenta para resolver questões específicas. Aqui deve ser sublinhada a existência de pontos de vista opostos sobre as relações UE-Rússia. Alguns consideram que a relação alcançou pouco no tratamento das questões europeias e globais e, pelo contrário, outros valorizam os resultados das relações UE-Rússia. O reconhecimento do alcance do quadro de cooperação, em conjunto com os obstáculos inerentes, pode contribuir para reduzir o 
paradoxo que marca a relação UE-Rússia. Desde o fim da Guerra Fria, as partes deixaram de ser inimigas na cena europeia mas ainda não alcançaram a parceria desejável.

No início do século XXI, Emerson (2001, p. 14) identificava quais seriam os desafios para as relações UE-Rússia: "como poderemos desenhar estratégias de cooperação conjunta para a UE e a Rússia nas periferias que se sobrepõem e onde a Rússia tem sido, e continua a querer ser o principal ator?". Hoje, tornou-se claro que estes dois atores diferenciados precisam de encontrar formas de cooperação mais frutíferas para partilhar um continente que lhes é comum. Para Emerson (2001, p. 18), a ideia de Gorbachov de uma "casa comum europeia" deveria ser reabilitada para que a UE e a Rússia possam viver pacificamente. No contexto atual de gestão da crise global, despoletada pela crise financeira de 2008, e face à emergência de novas potências não europeias, existem apelos para a necessidade de reforçar a relação de Bruxelas com Moscovo para manter peso no sitema internacional. Os desafios à relação colocam-se hoje para além da partilha do continente europeu e atingiram, portanto, uma dimensão mais global.

Na sequência do anúncio da sua candidatura a um terceiro mandato presidencial em setembro de 2011, Putin revelou um ambicioso projeto, uma "União Eurasiática”, que visaria integrar todos os Estados pós-soviéticos, da Bielorrússia ao Tajiquistão, nos campos político e económico (Bryanski, 2011). Embora a sua concretização ainda careça de medidas concretas, a ideia de um projeto de integração regional liderado por Moscovo levanta preocupações sobre as novas orientações da política externa russa. Uma das principais questões diz respeito à articulação entre a União e as instituições já existentes e as relações cooperativas, nomeadamente com a UE (e a China). Paralelamente, a ideia de uma "União da Europa" para enfrentar uma perda de poder a nível global também emergiu dos círculos intelectuais russos (Karaganov et al., 2010) e é retomada por Putin. Esta "União" surgiria a partir de uma cooperação mais orientada para os resultados, condição tida como necessária para tornar a UE e a Rússia os terceiros maiores atores mundiais, atrás dos EUA e da China. Nesta perspetiva, sem um esforço conjunto para esse desígnio, o poder da Rússia e da UE diminuirá para ambas. 


\section{Bibliografia}

BACHKATOV, Nina - Les interactions entre pouvoir économique et politique en Russie. In Merlin, Aude, ed., Où va la Russie?. Bruxelles: Editions de 1'Université Libre, 2007. p. 137-152.

BARANOVSKY, Vladimir - Russia's Attitudes towards the EU: Political Aspects. Programme on the Northern Dimension of the CFSP, 2002.

BOROZNA, Angela - Russian Multilateralism since 1991. Comunicação apresentada na International Studies Association Annual Convention, Chicago, 2007.

BRYANSKI, Gleb - Russia's Putin says wants to build 'Eurasian Union'. Reuters, 3 outubro 2011. [Acedido a 2 de nov. de 2011]. Disponível na Internet: http://www.reuters.com/ article/2011/10/03/us-russia-putin-eurasian-idUSTRE7926ZD20111003.

BURGHARDT, Günther - Session II: The way ahead: prospects for EU-Russia relations. Conference on EU-Russia Relations: a Trouble Strategic Partnership? Brussels: Palais d'Egmont, 27 fevereiro 2008.

Council of the European Union - Javier Solana, EU High Representative for the CFSP, confirms the withdrawal of Russian forces from the zones adjacent to South Ossetia and Abkhazia. S332/08. Bruxelas, 10 outubro 2008.

DESAI, Padma - Conversations on Russia. Reform from Ieltsin to Putin. Oxford: Oxford University Press, 2006.

Directorate General External Relations - Overview. EU-Russia Summit. Roma, 6 novembro 2003. [Acedido a 10 de jan. de 2012]. Disponível na Internet: http://europa.eu.int/comm./ external_relations/russia/summit11_03/ip03_1496.htm.

EMERSON, Michael - Some Paradigms for the Evolving Map of Europe. CEPS Working Document 164, abril 2001.

EMERSON, Michael - Putin's faltering return. CEPS ENW. N. ${ }^{\circ}$ 78, 2012.

European Commission - Comunicado de imprensa. EU-Russia Summit. São Petersburgo, 31 maio 2003a. [Acedido a 15 de ago. de 2012]. Disponível na Internet: http://europa. eu.int/comm./external_relations/russia/sum05_03/ip03_768.htm.

European Commission - Paving the Way for a New Neighbourhood Instrument. COM(2003)393 final. Brussels, 1 julho 2003b. [Acedido a 21 de jan. de 2012]. Disponível na Internet: http://ec.europa.eu/world/enp/pdf/com03_393_en.pdf.

European Commission - The European Union and Russia: Close Neighbours, Global Players, Strategic Partners, 2007. [Acedido a 21 de jan. de 2012]. Disponível na Internet: http:// ec.europa.eu/external_relations/library/publications/russia_brochure07_en.pdf.

European Council - Joint Declaration of the Prague Eastern Partnership Summit. Prague, 7 maio 2009. [Acedido a 4 de out. de 2011]. Disponível na Internet: http://europa.eu/rapid/ pressReleasesAction.do?reference $=$ PRES/09/78\&format $=$ HTML\&aged $=0 \&$ language $=\mathrm{EN} \& \mathrm{~g}$ uiLanguage $=$ en.

European Council - Conclusions of the Presidency. SN 200/101VER 1. European Council of Göteborg, 15 e 16 junho 2001. [Acedido a 4 de out. de 2011]. Disponível na Internet: http://ec.europa.eu/governance/impact/background/docs/goteborg_concl_en.pdf.

European Union - Statement by the spokesperson of High Representative Catherine Ashton on party registration in Russia. A 244/11. Bruxelas, 22 junho 2011. [Acedido a 4 de out. de 2012]. Disponível na Internet: http://www.consilium.europa.eu/uedocs/cms_data/ docs/pressdata/FR/foraff/123022.pdf.

Eurostat and Rosstat - The European Union and Russia. Statistical Comparison 1995-2005. Eurostat Statistical Books and Rosstat, 2007. 
FREIRE, Maria Raquel - A Rússia de Putin - Vectores Estruturantes de Política Externa. Coimbra: Almedina, 2012.

HUSKEY, Eugene - A Liderança Política e a Luta entre o Centro e a Periferia: As Reformas Administrativas de Putin. In Brown, Archie e Shevtsova, Lilia, eds., Gorbachev, Ieltsin $\mathcal{E}$ Putin. A Liderança Política na Transição Russa. Editora Universidade de Brasília (translation from the Carnegie Endowment for International Peace, Washington, 2001), 2004. p. 197-234.

IVANOV, Igor S. - The New Russian Diplomacy. Washington, DC: The Nixon Center and Brookings Institution Press, 2002.

JACK, Andrew - Inside Putin's Russia. London: Granta Publications, 2005.

KARAGANOV, Sergei et. al. - Towards an 'Alliance of Europe'. Analytical Report by the Russian Group of the Valdai International Discussion Club'. St. Petersberg, Kizhi-Valaam, Moscow, 31 agosto - 7 setembro 2010. [Acedido a 25 de fev. de 2011]. Disponível na Internet: http://karaganov.ru/content/images/uploaded/4b4ec04c237e760f0808556999573c53.pdf.

KASYANOV, Mikhail - Russia after the elections: what potential for common values?. Study day of the EPP-ED Group on Russia. Brussels: European Parliament, 15 maio 2008.

LAPCZYNSKI, Marcin - The European Union's Eastern Partnership: Changes and Perspectives. Caucasian Review of International Affairs. Vol. 2, n. 3 (2009), p. 143-155. [Acedido a 20 de set. de 2009]. Disponível na Internet: http://www.cria-online.org/7_3.html.

MAKARYCHEV, Andrei e MOROZOV, Viatcheslav - Multilateralism, Multipolarity, and Beyond: A Menu of Russia's Policy Strategies. Global Governance. Vol. 17, n. 3 (2011), p. 353-373.

Moscow Times, The - Kudrin dwells on budget deficit. 25 novembro 2009.

NIKONOV, Vyacheslav - Russia and European Community: politics and economics. Russian Summer Session: The Europe/Russia Relations in the new enlarged Europe. Moscow: International University of Moscow, 15-23 julho 2004.

OlimpIEVA, Evgenia - Russia's Protest Movement: A View from a Young Participant. Russian Analytical Digest. N. 108 (2012), p. 10-13.

PUTIN, Vladimir - Russia and the changing world. Artigo do prmeiro ministro Vladimir Putin, Moskovskiye Novosti, 27 fevereiro 2012. [Acedido a 28 de fev. de 2012]. Disponível na Internet: http://premier.gov.ru/eng/events/news/18252/.

ROWE, Elana Wilson e TORJESEN, Stina, eds. - The Multilateral Dimension in Russian Foreign Policy. London and New York: Routledge, 2009.

SAKWA, Richard - Russian Politics and Society (fourth edition). Oxon and New York: Routledge, 2008.

SMITH, Mark A. - Contemporary Russian Perceptions of Euro-Atlanticism. Conflict Studies Research Centre, fevereiro 2002.

SOUZA, Luís Vinhais de - A Different Country. Russia's Economic Resurgence Brussels: CEPS, 2007.

The Russian Federation - The Russian Federation Middle Term Strategy Towards the European Union (2000-2010), 1999. [Acedido a 7 de mai. de 2004]. Disponível na Internet: http:// www.delrus.ec.europa.eu/en/p_245.htm.

THUMANN, Michael - La puissance russe. Un puzzle à reconstituer? Paris: Alvik Éditions, 2002.

TSYGANKOV, Andrei P. - Russia and Global Governance in the Post-Western World. Russian Analytical Digest. N. ${ }^{\circ} 114$ (2012), p. 2-4.

VAN ROMPUY, Herman - Comentários de Herman Van Rompuy, President of the European Council, following the $28^{\text {th }}$ EU-Russia Summit. EUCO 162/11 PRESSE 500 PR PCE 121. Bruxelas, 15 dezembro 2011. [Acedido a 20 de fev. de 2012]. Disponível na Internet: http://www.consilium.europa.eu/uedocs/cms_data/docs/pressdata/en/ec/126952.pdf.

ZWANG, Annie e ZWANG, Philippe - De la Russie de Catberine II à la Russie d'aujourd'bui. 1762-début du XXIe siècle. Paris: Ellipses, 2004. 


\section{CA P ÍTULO 8 \\ WASHINGTON E MOSCOVO: \\ EM BUSCA DE UM MODUS VIVENDI}

Bernardo Pires de Lima

\section{Introdução}

Não há muitos anos, um diplomata russo estabelecido na Europa Central partilhou comigo uma pequena confidência: "o pior que pode acontecer à Rússia é deixar de ter importância para os Estados Unidos". Entre o sarcasmo e o realismo, a observação acaba por resumir com grande propriedade as relações entre estas duas grandes potências do sistema internacional contemporâneo. Se no século XIX, Tocqueville teve o brilhantismo profético de considerar que os dois países seriam chamados "por um desígnio secreto da Providência a ter um dia nas suas mãos os destinos do mundo" (Tocqueville, 2008, p. 352), não se pode dizer que no século XXI essa realidade seja tão evidente como em tempos certamente o foi.

A Guerra Fria foi um intervalo geopolítico marcante na definição das relações bilaterais, formulação das políticas externas e concetualização de estratégias militares. Hoje, a ordem internacional caminha para uma complexidade de potências e atores que tendem a diluir a concentração de poder em apenas um ou dois pólos. A Rússia e os Estados Unidos da América (EUA) têm uma concorrência geopolítica global que também molda as suas relações bilaterais. E têm uma perceção recíproca que não é indiferente à história do pós-Guerra Fria e 
que conduz a distintas avaliações da relevância que cada um tem para a política externa do outro.

Este capítulo procura perceber como evoluíram as relações entre os EUA e a Rússia nos últimos anos, sobretudo desde que Vladimir Putin se tornou presidente russo, em 2000, discutir como se encaram entre si, aferir as incompatibilidades mútuas, os pontos de contacto e os grandes desafios com que se confrontam.

\section{Do colapso soviético à guerra do Iraque}

Para os EUA, a década de 1990 foi de expansão económica, afirmação como superpotência e de otimismo quanto à prosperidade do seu modelo político. Para a Rússia, foram tempos de tal maneira atribulados que à humilhação da derrota na Guerra Fria se seguiu um período pós-traumático de colapso financeiro, quase a resultar numa guerra civil no final da década (Stürmer, 2008; Rachman, 2010; Graham, 2008). Se os EUA se tornaram a única superpotência com capacidade para influenciar o sistema internacional pós-Guerra Fria, a Rússia viveu entre o abismo e a saudade da ordem e do orgulho. É neste quadro que Vladimir Putin chega ao Kremlin e é neste contexto acelerado de triunfalismo que os EUA sofrem o maior ataque terrorista da sua história em 11 de setembro de 2001. A partir desses dois momentos o relacionamento entre ambos sofreu alterações, oscilando entre a cooperação e a desconfiança, a agressividade e o compromisso.

\section{A primeira década pós-soviética}

Os anos de Boris Ieltsin na presidência da Rússia foram marcados por uma fragilidade de Moscovo em conter uma série de iniciativas de origem norte-americana. Desde logo, pelo compromisso no alargamento da Organização do Tratado do Atlântico Norte (OTAN), que pela Declaração de Londres (6 julho 1990) sublinhava a relação entre os 
papéis político e militar da Aliança, remetendo para a história a postura defensiva e reativa da OTAN, face a ameaças à segurança dos seus membros e abraçando uma outra de carácter pró-ativo, que privilegiaria uma exportação de segurança e estabilidade para fora da sua tradicional área de ação. O ponto quatro do texto é politicamente definidor do momento entusiástico que se vivia: "A comunidade Atlântica tem de chegar aos países de leste, que foram nossos adversários na Guerra Fria, e estender-lhes a mão da amizade" (Gordon, 1997; Goldgeier, 1999). Ou seja, abria-se caminho para aquilo que ficou conhecido como a política de "porta aberta" da OTAN, uma fórmula que mantinha a atração dos futuros membros ao modelo político e económico das democracias liberais, ao mesmo tempo que não se davam à partida como garantidas as suas adesões.

Quase em simultâneo com o dominó das independências nas antigas repúblicas soviéticas, os EUA alargavam o âmbito da sua ação para lá da Europa, punindo no Médio Oriente o Iraque de Saddam Hussein após a invasão militar ao Kuwait. George Bush assistia da Casa Branca e em simultâneo à implosão de um império e à magnanimidade das ações da sua administração: defendendo a soberania de uns, ajudando a independência de outros, respeitando o centralismo das organizações internacionais (ONU, OTAN). Tudo corria bem neste início da era de otimismo norte-americana. Não era só uma certa história que tinha terminado; era uma outra que começava a ser escrita e, ao que parecia, só tinha um autor: Washington (Fukuyama, 1992; Chollet e Goldgeier, 2008).

Mas além da geografia da OTAN começar a aproximar-se das fronteiras da Rússia, a desagregação da Jugoslávia levou os EUA ao envolvimento militar na Bósnia e no Kosovo, assumindo que a segurança europeia continuava a ser um dos objetivos a preservar na sua política externa. Mas não só. A Rússia deixou sempre claro que jamais aprovaria uma intervenção militar ocidental contra a Sérvia, seu velho aliado, em sede do Conselho de Segurança. O facto de a OTAN ter usado a força à revelia de um mandato da ONU revelou mais uma vez os limites do poder de Moscovo: incapaz de influenciar os acontecimentos e de limitar o poder norte-americano. Era ainda cedo para que uma aproximação aos restantes 
europeus pudesse dividir a relação transatlântica; era demasiado tarde para isoladamente conseguir uma vitória contra Washington.

Para Moscovo, o alcance geopolítico dos avanços da OTAN esbarrava na fragilidade dos seus movimentos: sem ordem interna, crescimento económico, aparelho militar modernizado e um restabelecimento da centralidade do Kremlin no orgulho do país, a política externa russa não tinha força suficiente para travar a dinâmica do "momento unipolar" (Krauthammer, 1990).

Mas a fraqueza da ação externa de Moscovo não tornou necessariamente agressiva a sua narrativa para com o ocidente. Quando Andrei Kozyrev assume a pasta dos negócios estrangeiros começa mesmo uma estratégia de aproximação à Europa, através do pedido de adesão ao Conselho da Europa (concretizado em 1996), integrando a Parceria para a Paz na OTAN (1995) e assinando mesmo um acordo de parceria e cooperação com a União Europeia (1997). Só quando Evgeny Primakov substituiu Andrei Kozyrev (1995) é que a dimensão asiática da política externa russa conquista um outro equilíbrio face à dimensão europeia. Nesta segunda metade da década era visível a tentativa de redescobrir as linhas prioritárias da política externa russa e o seu papel na ordem unipolar. Mas era igualmente evidente que sem um apaziguamento institucional interno e a inversão do declínio económico e militar, Moscovo não podia assentar uma ação externa coerente, robusta e geradora de equilíbrios internacionais.

Depois da liberalização acelerada da economia ter falhado e dos cofres russos terem praticamente secado em 1997, não havia dinheiro para salários e pensões, o país estava paralisado, o fluxo de capitais estava em marcha para o exterior e a sociedade à beira de um conflito grave. O preço do petróleo baixara e a crise financeira asiática contribuiu para a redução da procura energética russa. A sua economia atravessava uma fase calamitosa e isso influenciava a forma de lidar com as grandes questões internacionais. No entanto, já com Vladimir Putin como primeiro ministro (1999), a luta contra o terrorismo checheno marca um novo perfil de liderança que chega à política russa pós-soviética. Putin procura dar resposta a todo este quadro interno e regional quando é indigitado no Kremlin em 2000, um ano após a adesão à OTAN dos antigos membros 
do Pacto de Varsóvia, Polónia, República Checa e Húngria. Em Moscovo, os EUA tinham agora o monopólio sobre parte da sua antiga esfera de influência, o que significava que a tolerância russa tinha atingido o limite. Era, por isso, preciso inverter o curso da história. Sobretudo a da Rússia.

Putin é eleito presidente a 26 de março de 2000 com um objetivo declarado no discurso inaugural, a 7 de maio: "por uma livre, próspera, forte, civilizada e orgulhosa Rússia" (Nicholson, 2001; New York Times, 2000). Por outras palavras, queria fortalecer internamente a Rússia para a tornar mais forte no plano internacional. Para isso precisava de inflacionar o preço do petróleo e do gás até uma quantia suportável para os países consumidores. Quando a crise financeira desabou em 1998-99, o preço do barril de crude estava em 10 dólares (Stürmer, 2008; Levgold, 2007). Ora para uma economia fortemente dependente da produção e venda de petróleo e gás, o barril a menos de 50 dólares é financeiramente desastroso. Sabendo que grande parte da Europa central e de leste está dependente do fornecimento energético russo para alimentar as suas economias e bem-estar, Moscovo tinha aqui um pilar estratégico para continuar a condicionar as relações entre Estados europeus. Putin sabia, também, que a Ucrânia era o país de acesso privilegiado das rotas energéticas abastecedoras do resto da Europa e que a Aliança Atlântica se aproximara das suas fronteiras no último alargamento. O crescimento económico russo permitia-lhe ainda renovar o seu obsoleto aparelho militar e dizer com frontalidade a Washington que os 25 milhões de pessoas etnicamente russas a viver nos países vizinhos estavam ao abrigo de uma proteção especial de Moscovo (Stürmer, 2008; Aron, 2006). O papel de Putin era, no início do século XXI, tão cristalino como o gelo da Sibéria: restituir a ordem e o orgulho nacional aos russos e recuperar o equilíbrio de poder com os EUA.

\section{O impacto do 11 de setembro}

A primeira vez que Bush e Putin se encontraram foi a 16 de junho de 2001, na capital eslovena, Liubliana. Condoleezza Rice, secretária de 
estado norte-americana, presente nessa reunião, relata nas suas memórias o comportamento dos dois presidentes (Rice, 2011, p. 62). Bush tentou que um desanuviamento pessoal pudesse servir de enquadramento às relações bilaterais. Anunciou a saída do Tratado sobre Mísseis Balísticos, mas Putin recentrou os problemas no que considerava prioritário: o terrorismo alimentado pelo caos no Paquistão e financiamento saudita. Os alertas tinham, na perspetiva da Rússia, razão de ser, confrontada que estava com os problemas das hostes caucasianas e das rotas do crime organizado na Ásia Central. Putin chegou mesmo a alertar, nessa reunião, para uma grande tragédia com origem no terrorismo islâmico. Três meses depois ela chegava a Nova Iorque e a Washington. Os EUA nunca tinham sofrido nada igual. Não só pelo número de vítimas em território nacional, mas pela interrupção da década triunfal. A "era do otimismo", como the chamou Giddeon Rachman (2010), tinha chegado ao fim. A Al-Qaeda renegava o universalismo dos valores norte-americanos, mostrava a vulnerabilidade da segurança interna da superpotência e dizia ao mundo que se a destruição foi possível em Nova Iorque e Washington, seria também possível em qualquer capital de uma grande potência. Em Moscovo, Putin já sabia o que era sofrer com o terrorismo islâmico do norte do Cáucaso e estava ciente que a geografia do terror proposta pela Al-Qaeda mais cedo ou mais tarde se voltaria a infiltrar na sua vizinhança e até nas suas metrópoles.

O 11 de setembro aproximou Washington e Moscovo. Gerou um clima de empatia política perante uma ameaça comum e Putin foi mesmo o primeiro líder mundial a expressar diretamente o seu pesar a Washington, telefonando para a Casa Branca. Bush relembra, nas suas memórias, a mensagem de Putin: "quero que saiba que nesta luta estaremos juntos" (Bush, 2010, p. 196). Dez dias depois dos ataques, o presidente russo assumia o compromisso de abrir o espaço aéreo do país à aviação militar americana e prometia exercer a influência do Kremlin junto das antigas repúblicas soviéticas da Ásia Central no auxílio às tropas que iriam para o Afeganistão. Putin chegou mesmo a disponibilizar a experiência das chefias militares russas na guerra no Afeganistão (1979-1988), na preparação dos planos militares do Pentágono (Bush, 2010, p. 196). Mas este 
ponto de convergência entre Moscovo e Washington residia sobretudo em dois vetores: nas preocupações de Putin sobre o terrorismo islâmico na vizinhança - neste sentido, ter um aliado forte na mesma luta era uma vantagem; e motivar o grande rival norte-americano para uma intervenção punitiva da Al Qaeda no Afeganistão, um cenário bem conhecido dos russos, com previsível durabilidade e enorme desgaste para Washington.

Ainda nesta fase de desanuviamento diplomático bilateral, Bush e Putin assinariam o Strategic Offensive Reduction Treaty, em maio de 2002, um acordo que prometia "amizade, parceria, confiança, abertura e previsibilidade" num horizonte até 2012 (Woodward, 2002, p. 327). Na Cimeira da OTAN em Roma (2002), os presidentes assinaram uma declaração conjunta que não só reforçava a fundação do Conselho OTAN-Rússia, como procurava marcar o início de uma "nova fundação para a relação", denominando-a de "estratégica". Isto significava que nenhuma das partes se via como inimiga da outra mas como parceiros na resolução de problemas e desafios comuns (cf. White House, 2002). Estávamos, nesta data, no pico de uma escalada rápida nas boas relações.

Ainda neste clima de boa parceria, os interesses dos EUA na energia voltaram-se para a Rússia, tendo o ministro da energia Spencer Abraham visitado Moscovo, em novembro de 2001, numa tentativa de encontrar na Rússia e no Mar Cáspio uma alternativa sólida à dependência energética do Médio Oriente. Bush e Putin também abordaram esta questão conjuntamente no encontro de maio de 2002, fazendo coincidir sinergias num grande consórcio para um oleoduto no Cáspio, entre o Cazaquistão e o porto russo de Novorossisk, incluindo no negócio as empresas americanas Chevron-Texaco, Arco, Móbil e Shell (cf. Tavernise, 2002). No início de 2003, tudo ficou congelado, quer pela tensão geopolítica entretanto gerada à volta da guerra do Iraque, como pelo proteccionismo presente na legislação russa e que acabaram por dificultar a manutenção do interesse norte-americano.

O clima de harmonia iria durar, como se percebe, pouco tempo. Washington iniciara um processo interno de discussão e planificação para o derrube de Saddam Hussein durante todo o ano de 2002, culminando na intervenção militar de março de 2003. Esta fase pode ser dividida em dois 
momentos. O primeiro, até ao discurso do presidente Bush na Assembleia Geral da ONU em setembro de 2002, quando o processo de decisão passa de uma base quase exclusivamente norte-americana para o domínio internacional, e em que a questão iraquiana passa a ser considerada por Washington como a ameaça número um à paz e segurança internacionais. A partir deste momento estava aberto o caminho das Nações Unidas e aí, em sede do Conselho de Segurança, a Rússia tinha o seu tradicional palco de intervenção decisivo. Aprovada por unanimidade, a resolução 1441 (cf. Resolução 1441), em novembro de 2002, seria na interpretação que Washington, Londres ou Madrid fariam do seu alcance punitivo, que um grupo de países se começou a constituir como opositor de qualquer uso da força no Iraque. Paris e Berlim, por razões que se prendem com um equilíbrio sistémico ambicionado pelo Eliseu e pelo calendário eleitoral alemão, conseguiram estender o eixo a Moscovo na oposição à guerra.

Em janeiro de 2003, na celebração do $40^{\circ}$ aniversário do Tratado do Eliseu, o presidente Chirac e o chanceler Schröder anunciaram uma posição conjunta de oposição à estratégia do presidente Bush. Em Washington prevalecia uma visão integrada das ameaças à segurança nacional, do terrorismo aos estados párias, da proliferação de armas de destruição maciça aos estados falhados, do "eixo do mal" à "guerra global contra o terrorismo", das coligações ad-hoc ao recurso ao uso da força unilateral. Entre Paris e Berlim ia emergindo uma conceção europeia sobretudo enquanto "potência normativa", como ficou patente na Estratégia de Segurança Europeia, uma forma de vincar o equilíbrio e o controlo das decisões norte-americanas no palco do Conselho de Segurança (Manners, 2006). A divisão transatlântica agudizou-se ainda em janeiro, com o apoio expresso de chefes de estado e de governo europeus - Carta dos Oito e Carta de Vilnius (Gordon, 2004, pp. 129-132) - à estratégia de Washington e à salvaguarda da relação transatlântica.

A posição da Rússia refletiu-se num comunicado conjunto datado de 5 de março de 2003, onde Chirac, Schröder e Putin afirmariam não aprovar nenhuma resolução da ONU "que autorizasse o uso da força", aproveitando também as altíssimas percentagens nas opiniões públicas europeias que se mostravam contrárias à guerra (Pond, 2004, p. 74). Por 
outras palavras, estas opiniões públicas que encheram as ruas das principais capitais da Europa preferiam a contenção à mudança de regime em Bagdad, mas igualmente desprezavam a forma como em Washington se exercia o poder. No plano das lideranças políticas, o quadro era um pouco distinto. A maioria dos líderes europeus via vantagens na liderança norte-americana, aceitava a sua estratégia e não estava na disposição de alienar as suas relações com Washington. As exceções francesa e alemã refletiam precisamente uma visão inversa. Não estavam preparados para aceitar a unilateralidade de Washington em decisões de guerra e paz, sobre as quais queriam continuar a ter uma palavra decisiva. No quadro particularmente sensível que se seguiu aos ataques de 11 de setembro, esta tentação musculada era não só expectável por parte dos EUA, como era inevitável uma reação equilibradora de algumas potências europeias. Paris não surpreendeu. Mas Berlim, ao invés, não hesitou em opor-se ao seu principal aliado numa questão tão essencial para Washington como sensível. Isso, sim, foi inédito (Szabo, 2004).

Do ponto de vista de Moscovo, esta oportunidade de avolumar a frente equilibradora europeia trazia-lhe duas vantagens. A primeira, manter uma linha da sua política externa que passava por dividir europeus e norte-americanos para melhor se impor na política europeia. A segunda, manifestar aos países do centro e leste da Europa que continuariam a ter uma Rússia interventiva nas grandes questões transatlânticas e que não se acomodava nem resignava aos avanços da União Europeia e da OTAN à sua antiga esfera de influência. Um ano depois da guerra do Iraque, sete países da "nova Europa" tornar-se-iam membros da Aliança Atlântica, ano em que também a União Europeia os receberia de braços abertos. Este quadro geopolítico que interligava uma decisão unilateral da superpotência, os alargamentos das instituições ocidentais, e a fragilidade do alcance do eixo alternativo composto por Paris, Berlim e Moscovo, dotou o Kremlin de um sentimento de impotência e de uma noção de cerco crescente.

O interlúdio emocional do 11 de setembro que aproximara Moscovo de Washington tinha durado um par de anos. A partir daqui tudo haveria de regressar à normalidade. 


\section{Do Iraque à guerra na Geórgia}

O primeiro mandato de Putin no Kremlin (2000-2004) foi marcado pela tentativa de restituir orgulho nacional à Rússia, reerguer a sua economia e colocar o país no núcleo duro das grandes potências com capacidade para influenciar o rumo dos acontecimentos. Evidentemente que o quadro geopolítico da unipolaridade condicionou a ação de todos os atores internacionais. Moscovo não seria nunca uma exceção, para mais tendo em conta a história que a ligou aos EUA durante toda a Guerra Fria. A variável EUA foi preponderante na formulação da política externa de Putin. Primeiro, assegurando um canal de diálogo privilegiado com a Casa Branca, que pudesse conciliar a recuperação de um estatuto de importância máxima da Rússia para a política externa norte-americana. Segundo, com o 11 de setembro, aproximando estratégias de combate ao terrorismo islâmico transnacional que tanto ameaçava Washington como Moscovo. A partir do momento em que a conciliação de posições se tornou inviável com a guerra do Iraque, Putin encontrou um caminho mais independente na relação com os EUA.

Desde que iniciou o seu segundo mandato que Putin acomodou a política externa russa às novas circunstâncias do seu poder. A recuperação económica estava acelerada, a sua política energética era cada vez mais influente numa grande parte da Europa continental, condicionando muitas das relações bilaterais, e a desconfiança com a hubris (arrogância) norte-americana subia de tom. Encontrar um espaço euro-asiático de ação - influência energética na Europa e político-militar na Ásia Central - passou a constituir a prioridade e, com os EUA atolados no Afeganistão e no Iraque, essa ascensão enquanto grande potência do sistema internacional pós-11 de setembro permitia-lhe uma maior assertividade na narrativa externa (Tsygankov, 2010; Pravda, 2005; Kuchins e Zevelev, 2012).

Numa região que havia estado sob seu absoluto domínio não há muito tempo, os anos seguintes à guerra do Iraque foram particularmente marcantes para a relação entre a Rússia e os EUA, caracterizados por um confronto surdo e indireto patente na leva de revoluções coloridas na Geórgia (2003), Ucrânia (2004/2005) e Quirguistão (2005), exasperando Moscovo e dando 
mais consistência ao argumento de cerco ocidental (promovido pelos EUA) em redor da Rússia e dos seus interesses (MacKinnon, 2007). Este movimento de alteração da influência de Moscovo na política interna destes Estados e nos seus alinhamentos internacionais também alertou o Kremlin sobre o real alcance dos objetivos da Casa Branca. Será que tinham um projeto de alteração do regime russo? Que ligações a movimentos da oposição russa estavam a ser promovidas por Washington? As palavras de Putin, mesmo sem identificar os EUA, eram muito críticas do comportamento "daqueles que querem organizar o mundo de acordo com os princípios de um mundo unipolar" (Graham, 2008, p. 3). Simultaneamente, membros da administração Bush, como o secretário de estado Colin Powell ou o vice-presidente Dick Cheney iam pondo em causa os pergaminhos da democracia russa, algo que nos últimos anos tinham deixado de lado em nome do pragmatismo.

Em 2006, Moscovo salda a dívida externa vinda ainda do tempo da União Soviética aos credores reunidos no Clube de Paris, no valor de 23 mil milhões de dólares (BBC News, 2006; New York Times, 2006), pondo fim a um sentimento de capitulação iniciado com a implosão da União Soviética e restituindo um sentido crescente de autonomia e soberania políticas. O preço do barril tinha subido praticamente cinquenta dólares desde que Putin chegara ao Kremlin até esta altura, o que enchera os cofres russos por via das poderosas e estratégicas empresas de petróleo e gás. Com uma economia altamente centrada na sua exploração e venda, uma boa parte da política externa russa era também moldada por este importante elemento. As suas relações privilegiadas na Europa tinham esta variável no topo da agenda (Alemanha, Itália), as suas tomadas de posição podiam ser punitivas de acordo com o grau de dependência que os Estados bálticos ou de leste sentiam face ao fornecimento energético, e a própria dureza na narrativa política do Kremlin acabava por sair reforçada à medida que a robustez económica se impunha. Este diálogo permanente entre energia e política externa era um caso de sucesso na presidência de Putin e a sua cada vez maior autonomia de atuação internacional trouxe alguns dissabores à vizinhança.

Em 2006/2007, ucranianos e georgianos sofreram cortes no fornecimento energético durante o inverno, percebendo o alcance das suas 
intenções em aderir à OTAN e permanecer como aliados privilegiados de Washington na região. Bush, por exemplo, leu nesta exata medida o projeto de Putin, fazendo um balanço global do sentimento da sua administração: "ele queria que a Rússia tivesse o estatuto de grande potência novamente e estava comprometido com a expansão da sua esfera de influência. Intimidava democracias nas suas fronteiras e usava a energia como arma económica [...]” (Bush, 2010, p. 433).

A Rússia de Putin traçou uma política externa típica de "pragmatismo de uma grande potência”, na expressão de Andrei Tsygankov (2010). Mas em fevereiro de 2007, na Conferência de Segurança de Munique, esse pragmatismo ganhou outro condimento: a assertividade. Não só foi profundamente crítico do "unilateralismo" norte-americano, como rejeitou quaisquer benefícios de uma ordem unipolar com a primazia de Washington. Por outras palavras, tinha chegado o momento de disputar os alicerces do pós-Guerra Fria, onde a concentração de poder numa única potência já tinha dado vários sinais de inquietude a Moscovo. A verdade é que entre 2000 e 2007, Putin conseguiu uma excelência de indicadores internos capazes de auxiliar esta postura internacional. A economia cresceu anualmente a uma média de $6.8 \%$, redimensionando seis vezes o PIB em valores brutos; o PIB per capita quadruplicou e vinte milhões de pessoas saíram da pobreza; o investimento direto estrangeiro tornou-o no país mais atrativo ao nível das grandes potências e a dinâmica económica permitiu-lhe uma maior ação empresarial nos países europeus, que perfazem metade de todo o volume de comércio externo russo (Tsygankov, 2010, pp. 173-174; Allison, 2006). Isto dava a Moscovo uma tremenda vantagem na sua política externa: influenciar as opções europeias, condicionando os seus posicionamentos económicos e políticos, continuando a projetar-se no continente como um ator divisionista. Isto revelou-se no aproveitamento desta orientação para retirar espaço de ação aos EUA na Europa.

George W. Bush olhou para a Rússia de Putin de forma cíclica. Nos seus oito discursos sobre o Estado da União, só em 2002, 2003 e 2007 se referiu à Rússia, sempre com o cuidado de não a particularizar em demasia. No primeiro, relevando os esforços conjuntos de Washington, Moscovo, Pequim e Nova Deli na erradicação da ameaça terrorista; no segundo, 
dando conta dos esforços negociais para uma solução pacífica da questão nuclear norte-coreana, agrupando Rússia, Coreia do Sul, Japão e China; no terceiro, insistindo novamente neste último ponto mas, também, na dinâmica negocial realizada pelo Quarteto para a paz do Médio Oriente, onde a Rússia está representada.

Se olharmos para os documentos estratégicos da Administração, vemos um quadro um pouco diferente. A Estratégia de Segurança Nacional de 2002 (ESN, 2002) é clara sobre o momento da relação bilateral: cooperação na luta anti-terrorista, redução de armas nucleares e controlo da proliferação de armas de destruição maciça. Coloca mesmo o patamar bilateral em "relação estratégica”, quer no confronto das ameaças, quer no alcance do apoio norte-americano à entrada da Rússia na Organização Mundial de Comércio (OMC) - uma forma de sublinhar a importância crucial de Washington para este objetivo de Moscovo -, ou na criação do Conselho OTAN-Rússia.

Na Estratégia de Segurança Nacional de março de 2006, todos os tópicos da ESN 2002 permanecem garantes do cimento da relação, ao que se junta o dossier nuclear do Irão e da Coreia do Norte, como frentes onde se torna indispensável que as partes mantenham uma posição tão aproximada como decisiva. Além disso, a Rússia aparece como um dos destinatários individuais da secção "agenda para a cooperação”, conferindo-lhe uma crescente importância em regiões de "vital interesse" para os EUA: Médio Oriente, Ásia Central, do Sul e Oriental. É visível no documento norte-americano uma crítica a Moscovo pela diminuição do seu “compromisso democrático", numa alusão ao jogo de forças da Ucrânia e Geórgia no par de anos anterior. Este mesmo diagnóstico seria reforçado na Estratégia de Defesa Nacional de junho de 2008, podendo ter "significativas implicações para a segurança dos EUA, dos aliados europeus e parceiros noutras regiões" (Estratégia de Defesa Nacional, 2008, pp. 3-4).

Esta breve análise de documentos estratégicos e dos discursos mais importantes de cada ano político no consulado de Bush, permite-nos retirar duas conclusões. A primeira é que Washington olhou para Moscovo de forma oscilante e não homogénea. Para consumo interno, a relação com Moscovo tem pouca ou nenhuma relevância do ponto de vista político. A segunda é que esta mesma relação é encarada de um ponto de 
vista realista. É estrutural na arquitetura de segurança internacional de Washington quando a Rússia traz vantagens e reforça uma certa ação externa norte-americana, ou seja, é importante no pós-11 de setembro através da ameaça terrorista comum e da proliferação nuclear que, sendo igualmente uma ameaça partilhada, gera contributos distintos em Washington e Moscovo sobre a Coreia do Norte e o Irão. É conjuntural se o comportamento russo constitui um desafio e merece uma atenção consentânea com o poder que exerce em determinados momentos, regiões e assuntos. Por outras palavras, se é um bloqueio à agenda de democratização da Administração Bush (Cáucaso do Sul, Ásia Central) e aos alargamentos eventuais da OTAN (Ucrânia, Geórgia).

Em março de 2008, Putin deu lugar a Dmitri Medvedev. Há quem diga que levou a cadeira do seu gabinete do Kremlin para os aposentos da chefia do governo. A guerra na Geórgia seria, cinco meses depois, o epílogo lógico dos oito anos deste ex-líder dos serviços secretos russos FSB à frente do Kremlin: uma imensa demonstração nacionalista de uma Rússia regressada ao tabuleiro das grandes potências.

\section{Depois da guerra na Geórgia}

Quando Dmitri Medvedev aceitou o jogo de cadeiras com Putin e assumiu a presidência, carregou um fardo simultaneamente pesado e confortável. Por um lado, precisava de lidar com o legado do antecessor sem o descaracterizar e ao mesmo tempo encontrar um estilo de liderança próprio e personalizado. Por outro, o estatuto da Rússia de Putin dava ao cargo de presidente um peso central nas relações externas, energéticas e militares. Com este quadro institucional e face aos desafios que a Rússia enfrentava, o segundo semestre de 2008 mostrou o momento de força russo, mas também a dificuldade que o início da crise financeira internacional lhe incutiu.

A intervenção na Geórgia em agosto de 2008 assenta, aos olhos do Kremlin, numa dupla legitimidade. Primeiro, responde a um ato de agressão de Tbilisi contra as forças armadas russas estacionadas na Abcázia 
e Ossétia do Sul. Segundo, esse ato de agressão atinge duas províncias independentistas da Geórgia cuja russofonia tem de ser protegida por Moscovo. Estes pontos encaixam em dois pilares da política externa russa pós-soviética, em especial do período de Putin. O primeiro pilar é a defesa das populações de etnia ou passaporte russo espalhadas em diversas zonas vizinhas, nomeadamente no Cáucaso, na Moldova e na Ucrânia. O segundo pilar é o uso da força militar em resposta a um ato considerado de agressão e que, por isso, estará de acordo com a Carta das Nações Unidas.

Claro que muito deste debate carece de maior profundidade, não apenas pelas versões contraditórias russa e georgiana que se lhe seguiram, mas para chegar à conclusão principal deste tema, não é particularmente relevante o detalhe militar e jurídico. O que Moscovo fez foi enviar a Washington três pequenos mas importantes recados: não aceitamos a interferência na política interna dos países da nossa vizinhança; atuaremos rapidamente e em força quando os nossos interesses estiverem em causa, mesmo contra um líder apoiado pelos EUA (como o presidente da Geórgia, Mikhail Saakashvili); ponderem antes de incentivarem o alargamento da OTAN à Geórgia e Ucrânia sem nos consultar. Agosto de 2008 marca o regresso da Rússia ao topo da agenda norte-americana e marca um pico na autoconfiança de Moscovo depois do fim da União Soviética.

No plano militar e geopolítico o músculo russo estava saudável e a primeira parada militar na Praça Vermelha desde 1990, a 9 de maio de 2008, tratou de mostrar o trabalho bélico. Só que no último quartel de 2008 Moscovo foi obrigado a despender 50 mil milhões de euros para defender a sua moeda, fragilizando o esforço que foi constituir a terceira maior reserva mundial de moeda estrangeira e assistindo ainda a uma fuga de capitais (Rachman, 2010, p. 295). A verdade, porém, é que o epicentro da crise estava nos EUA e era o seu modelo que parecia estar em causa. Putin e Medvedev estavam cientes das limitações da Rússia que ajudaram a reerguer, mas também conscientes que depois da crise financeira de 2008 o peso norte-americano no sistema internacional tinha sofrido outro golpe. De certa maneira, a falência do Lehman Brothers é o 11 de setembro económico da América. Dois golpes destes numa única 
década constituem um rude golpe na superpotência do pós-Guerra Fria e Moscovo estava alertada para as consequências e para a oportunidade.

As consequências residiam na globalidade da crise. A interdependência económica e financeira iria gerar uma crise de confiança no consumo, falências nas empresas, crescimento do desemprego, deslocalização de recurso humanos e capitais, falta de liquidez da banca. As potências com excedentes de capitais estavam melhor apetrechadas para lidar com a situação e tanto a China (em relação aos EUA e Europa) como a própria Rússia (veja-se o empréstimo feito à Islândia em bancarrota) mostraram resistência. Mas Moscovo não é Pequim e Putin e Medvedev têm consciência disso.

Mas os dois líderes russos sabem, igualmente, que a deslocalização do epicentro do poder económico, demográfico e eventualmente político e militar para a Ásia obriga a Rússia a manter um papel relevante no quadro das grandes potências emergentes e a equilibrar a orientação ocidental da sua política externa com uma linha de ação oriental, assumindo por completo a sua vocação euro-asiática. Criou a Organização para a Cooperação de Xangai (fundada em 1996, mas com a primeira grande cimeira em 2001), juntando-se à China e a quatro países da Ásia Central (Tajiquistão, Cazaquistão, Uzbequistão e Quirguistão) e a Organização do Tratado de Segurança Coletiva (cuja carta foi assinada em 2002), assente na cooperação militar entre Rússia, esses mesmo quatro países da Ásia Central, a Arménia e a Bielorrússia. Tem feito parte das negociações a seis sobre o problema nuclear da Coreia do Norte e percebeu que o crescimento económico chinês e indiano abriam caminho ao mercado militar: $90 \%$ das exportações de armamento russo anuais têm como destino a Índia e a China (Lieven, 2011). Em termos energéticos, a viragem é também assumida pelo Kremlin. Se o mercado europeu representa $50 \%$ da sua exportação, o mercado asiático vai passar a representar, em 2020, entre 20 a 30\%, praticamente o triplo dos dados de 2005 (Laruelle, 2008; Kuchins, 2008). Estas ambições do presente e do futuro posicionam a Rússia como um ator importante no contexto asiático, na busca de equilibrar a presença norte-americana e conter a ascensão da China. Este arco geopolítico euro-asiático dá-lhe uma capacidade de atuação invejável, mas carece de um factor imprescindível: que os rendimentos 
energéticos se mantenham elevados para manter a economia a crescer ao ritmo da China, Brasil e Índia, muscular uma política externa assertiva face aos EUA e condicionar a sua política externa na zona de vizinhança russa. Sem isto, porque a diversificação das receitas e da economia russa é uma das suas dificuldades, todo o projeto de manutenção no topo das grandes potências sai fragilizado.

\section{A estratégia do reset}

Não se pode dizer que a Rússia tenha despertado um súbito interesse na Casa Branca capaz de ser incluída no primeiro discurso do Estado da União do presidente Barack Obama, em fevereiro de 2009. Se já tinha tido pouca importância neste momento anual ao longo da presidência Bush, Obama não inverte a notoriedade de Moscovo no discurso interno norte-americano. Podia tê-lo feito, uma vez que era a primeira vez que o abordava solenemente depois da guerra na Geórgia, mas a crise financeira e o desemprego ocuparam $90 \%$ do seu discurso, sendo o restante dedicado à guerra no Afeganistão e ao compromisso de terminar responsavelmente a operação no Iraque. Enquanto candidato à nomeação Democrata e à presidência dos EUA, Obama criticou duramente a ação russa na Geórgia, promoveu apoios públicos a este aliado e sublinhou a necessidade de um papel colaborante de Moscovo na redução de arsenais nucleares enquanto objetivo da sua Administração (Obama, 2007; cf. CFR, 2008).

Mas Obama sabia que a Rússia era mais importante do que isto para uma ampla estratégia internacional norte-americana. O Afeganistão era cada vez mais a única guerra com compromisso da Administração (Obama foi desde o início contra a intervenção no Iraque) e para inverter o insucesso da missão era importante garantir duas situações: primeiro, o apoio do Congresso à surge militar, tal como fora desenvolvida em 2007 no Iraque; segundo, o apoio da Rússia na abertura de rotas de abastecimento logístico às tropas no terreno, alternativas às instáveis e inseguras vias paquistanesas, além da sua influência junto das ex-repúblicas soviéticas da Ásia Central, fundamentais no auxílio terrestre e aéreo. Sabendo que a 
frente afegã era cada vez mais complexa de explicar aos norte-americanos, pela sua duração e fundos despendidos em altura de crise, era urgente ser pragmático na obtenção de apoios regionais para melhorar o cenário de conflitualidade. Para isso a Rússia era fundamental: do ponto de vista logístico, no apoio e circulação das tropas, no fornecimento petrolífero, no auxílio que a sua aviação concedia aos EUA; do ponto de vista político, por estar ao lado do sucesso da intervenção, que também interessava garantir, quer por estancar o terrorismo islâmico na região, quer por neutralizar as rotas do narcotráfico que alimentam o terrorismo do Cáucaso e minam, como nunca anteriormente, a estabilidade da sociedade russa.

Em paralelo ao Afeganistão, Obama sabia desde que tomou posse que o bloqueio ou neutralização do programa nuclear iraniano só teria sucesso com a colaboração da Rússia no Conselho de Segurança. Obter o apoio de Moscovo para sanções financeiras ao Irão, presentes na resolução 1929 (junho 2010), e evitar a venda de armamento russo a Teerão, foi um passo significativo, embora não impeditivo da continuação da exploração nuclear do regime dos ayatolahs.

Por fim, um dos grandes temas do início da Presidência Obama, a redução das armas nucleares, carecia evidentemente da Rússia para a renovação do Strategic Arms Reduction Treaty (START), que caducara em dezembro de 2009. Medvedev e Obama assinam em abril de 2010 a renovação do START que prevê a redução em um terço da capacidade nuclear estratégica dos dois lados, mostrando que a doutrina do reset era possível mesmo com as constantes oscilações de cooperação e imprevisibilidade que marcavam a relação bilateral nas últimas duas décadas.

Para validar esta dinâmica mais profícua e distendida, uma sondagem nos EUA dava conta da melhoria da percepção russa em relação a Washington, de $44 \%$ de opiniões favoráveis em 2009, para 57\% em junho de 2010; uma sondagem na Rússia sobre o mesmo assunto ia mesmo mais longe em igual período: de 38\% para 60\% (Pew Research Center, 2010 e Levada Center, s.d.).

Em maio de 2009, é publicada a Estratégia de Segurança Nacional russa para o horizonte de 2020 (Russian National Security Strategy 2020, 2009). Neste documento, os EUA são igualmente colocados como uma "parceria 
estratégica" a valorizar, no âmbito de desafios comuns como o desarmamento, a não-proliferação de armas de destruição maciça e a cooperação anti-terrorista. No entanto, Moscovo é cristalino na forma como mede as palavras, quando foca as intenções de Washington em desenvolver um escudo anti-míssil na Europa de leste: com isso, a "possibilidade de manter a estabilidade regional e global irá diminuir substancialmente" (Russian National Security Strategy 2020, 2009). Mas a Rússia não fica por aqui e considera mesmo que a OTAN conduz uma arquitetura euro-atlântica de segurança “desadequada", criando uma "crescente ameaça” à segurança internacional. O corolário é, por isso óbvio: para Moscovo, o alargamento da OTAN e a expansão "do seu aparelho militar até às fronteiras da Rússia são inaceitáveis”.

Por outras palavras, este documento prova que a relevância dos EUA e da OTAN para a Rússia é muito superior àquela que os EUA dão à Rússia nos seus documentos estratégicos. Basta dizer que o Kremlin define como interesse nacional russo a longo prazo o estabelecimento do país como "grande potência global num mundo multipolar" (Russian National Security Strategy 2020, 2009), o que significa que o fim da unipolaridade é simultaneamente um desígnio e um interesse nacional russo.

Podemos dizer que Washington responde a este quadro na mesma moeda? Seguramente de forma bem distinta. Reparemos, por exemplo, nos termos em que Obama se refere à Rússia nos discursos do Estado da União de 2010 e 2011. No primeiro, elogiava-se a cooperação com Moscovo no objetivo da redução de arsenais nucleares (90\% possuídos pelos EUA e Rússia) e no sinal que isso enviava ao mundo no combate à proliferação. No segundo, sinalizava-se o bom momento diplomático norte-americano com o "reset" alcançado nas relações com Moscovo. Entre estes dois momentos, deu-se a Cimeira da OTAN em Lisboa (novembro de 2010), que não só originou um novo conceito estratégico para a Aliança Atlântica - o primeiro depois do 11 de setembro; o terceiro desde a queda do Muro de Berlim -, como concedeu a Medvedev uma centralidade nos trabalhos dos aliados como se deles fizesse parte. Nesta Cimeira ficaram congelados sine die os alargamentos da OTAN à Geórgia e Ucrânia, sublinhada a parceria com a Rússia na frente afegã, estipulado o enquadramento de um futuro sistema 
anti-míssil na Europa que incluísse também o contributo de Moscovo e a vontade expressa em revitalizar o Conselho OTAN-Rússia como pilar da relação (North Atlantic Council, 2010).

Para complementar esta política do reset - mais promovida por Washington do que por Moscovo -, a Estratégia de Segurança Nacional de Obama (maio 2010) ainda vem admitir com mais acutilância que existem novos centros de poder internacionais e que um deles é a Rússia. Reconhece a sua "influência", a "reemergência na arena internacional com uma voz forte" e a necessidade de fortalecer a cooperação com vista a desafios comuns: proliferação nuclear, extremismo, desenvolvimento económico, abertura comercial. Ressalva-se, porém, o apoio à "soberania e integridade territorial dos vizinhos da Rússia”, ou seja, Ucrânia e Geórgia.

No entanto, percebe-se que as perceções que cada um tem do outro são distintas, de gradações diferentes e expressas com divergentes sensibilidades. Mesmo que os desafios comuns possam mantê-las próximas por longos anos.

\section{Os desafios comuns}

O primeiro desafio diz respeito à agenda de democratização na frente oriental europeia, em particular nos países que desde 2009 fazem parte da Parceria Leste da União Europeia: Arménia, Azerbaijão, Bielorrússia, Geórgia, Moldova e Ucrânia. Esta iniciativa tem em conta duas situações. Em primeiro lugar, a necessidade de manter na órbita europeísta um conjunto de países que dificilmente terão entrada na OTAN a curto-médio prazo. Em segundo lugar, tendo em conta a emergência da estratégia norte-americana do "reset" face à Rússia, os europeus antecipam-se ao caminho pragmático da Casa Branca que parece secundarizar uma predisposição mais assertiva no apoio à democratização dessa região. Em boa verdade, esta é a crítica mais mordaz que se faz a Obama: em nome da melhoria das relações com Moscovo, retirou da narrativa a democratização dos países vizinhos e até da própria realidade russa. Por outras palavras, Obama encorajou os líderes europeus a terem uma estratégia para a Rússia sem fazer verdadeiramente parte dela (McNamara, 2012). 
Esta postura tem sido fortemente criticada internamente, sobretudo no campo republicano, que espera de um presidente uma narrativa bem mais ideológica com a Rússia do que aquela que tem sido a prática de Obama. Esta separação das águas foi particularmente nítida em dois momentos desde que o "reset" foi anunciado. O primeiro, quando se acordaram os termos do novo START, considerado pela direita norte-americana como uma descapitalização militar da América e um sinal demasiado condescendente ao sintoma de declínio do poder norte-americano. O segundo, quando Washington não aflorou sequer qualquer calendário de adesão da Ucrânia e Geórgia à OTAN, na Cimeira de Lisboa em novembro de 2010. As duas questões foram entendidas por alguns como cedências demasiado grandes a Moscovo (Heritage Foundation, 2010; The Economist, 2010; Asia Times, 2010).

No entanto, temos assistido a algumas tomadas de posição da administração Obama que parcialmente invertem algumas destas críticas. Por exemplo, aquando da última eleição para a Duma (dezembro 2011), Hillary Clinton teceu alguns comentários sobre as condições democráticas pouco claras atualmente na Rússia, exortando os seus líderes a comportamentos mais transparentes, chegando mesmo a pedir uma "investigação profunda" às suspeitas de fraude (CNN, 2011).

Mas foi já no ano de 2012 que a relação bilateral se alterou para níveis de frieza glaciares. O primeiro momento deu-se durante a campanha para as eleições presidenciais russas, em finais de fevereiro e inícios de março, protagonizada por Vladimir Putin enquanto favorito ao Kremlin. Estávamos em pleno avolumar da crise na Síria e da continuação dos planos nucleares no Irão, ambos os regimes com laços de proximidade com Moscovo. Sobre este tema vale a pena recordar a tentativa de aprovar uma resolução no Conselho de Segurança, a 4 de fevereiro, que não só expressamente condenasse a violência dos setores próximos ao presidente sírio, Bashar Al Assad, mas que traçasse um plano político que contemplasse a sua saída do poder. Esta proposta de resolução foi aprovada pelos restantes treze membros do Conselho de Segurança, deixando Moscovo e Pequim isolados na oposição (Guardian, 2012).

Como sabemos, a Rússia e a China vetaram sistematicamente resoluções no Conselho de Segurança (5 outubro 2011, 4 fevereiro 2012, 19 
julho 2012) que aplicassem sanções ao regime de Damasco, apoiando abertamente a continuidade de Assad e manifestando oposição a qualquer plano de alteração de regime ou passagem de testemunho do presidente sírio. Depois da abstenção de Moscovo e Pequim aquando da resolução que deu início à guerra na Líbia (cf. Resolução 1973), a 17 de março de 2011, a Rússia não pretendia abrir semelhante caminho à OTAN e aos EUA na Síria, onde mantinha a sua única base naval nas águas quentes do Mediterrâneo (Tartus) e com a qual alicerçava o seu cada vez mais reduzido papel no xadrez do Médio Oriente. Os campos entre as grandes potências estavam novamente clarificados. Putin foi duro na campanha eleitoral ao acusar os EUA de "engenharia política" no mundo (Reuters, 2012a). Ora, era claro para a continuidade do seu programa político que a Rússia se oporia sempre a qualquer ingerência nos seus assuntos internos e estratégicos, estivessem eles na sua zona de vizinhança ou numa região central no comércio marítimo e na exploração energética como o Médio Oriente.

Num dos momentos mais altos da sua campanha para o terceiro mandato no Kremlin e perante 130 mil apoiantes no estádio Luzhniki, em Moscovo, Putin foi claro na mensagem para o exterior: "não deixaremos que ninguém interfira nos nossos assuntos ou force a nossa vontade - nós somos uma nação vitoriosa, está nos nossos genes" (BBC News, 2012). Num comício em Tomsk, na Sibéria, iria mais longe: "às vezes tenho a impressão que os EUA não precisam de aliados, mas de vassalos" (Bloomberg, 2012). Esta narrativa de elevar Washington a tema cimeiro de campanha eleitoral, não sendo inovadora nas estratégias eleitorais de Putin, mostra como a linha de continuidade narrativa existe e como se aplica a casos concretos como, por exemplo, na gestão da guerra civil síria ou no alargamento da OTAN à Geórgia.

O segundo momento deu-se no contexto da Cimeira da OTAN em Chicago, em maio de 2012. Além de não ter tido lugar o Conselho OTAN-Rússia, exatamente no seu décimo aniversário e sendo ele um importante fórum para discutir temas comuns como a Síria, Afeganistão e sistema anti-míssil, o recém eleito presidente Putin justificou a sua ausência da Cimeira do G8, em Camp David, marcada para dois dias antes da Cimeira da OTAN, com uma preenchida agenda política interna pós-eleitoral. 
O clima de distanciamento era evidente e definia uma fase que pode vir a ser o princípio do "reset" do "reset": sinais de impaciência ocidental com Moscovo no que toca ao diálogo sobre a ameaça nuclear iraniana, violação dos direitos humanos na Síria, cortes de energia no leste europeu, Báltico e Cáucaso do Sul, cooperação para o plano de retirada faseada da OTAN no Afeganistão; e do lado russo, sinais de falta de confiança sobre as reais intenções norte-americanas com o sistema de defesa anti-míssil na Europa - acusado de não se destinar à ameaça iraniana, mas ao arsenal russo -, com a mudança de regime na Síria, os alargamentos da OTAN, o interesse de Washington nas potencialidades da Ásia Central, nomeadamente na área de interesse russo das ex-repúblicas soviéticas (The Economist, 2012). Todo este clima foi visível ao longo de 2012. Veremos se o grande exercício militar da OTAN na Letónia e na Polónia, entre 2 e 9 de novembro de 2013, intitulado "Steadfast Jazz", não acentuará estas clivagens.

O terceiro momento foi a pré-campanha eleitoral norte-americana. Não que a Rússia tenha sido central num debate fortemente marcado pela crise económica, os níveis de desemprego, a reforma da saúde ou o papel do governo federal na vida de cada um dos Estados, mas porque a campanha de Mitt Romney elegeu a Rússia como "uma força desestabilizadora do palco mundial” (Romney, 2012). Em março de 2012, chegou mesmo a considerá-la “o inimigo geopolítico número um dos EUA" (Huffington Post, 2012). Este é um dos pontos que traça uma fronteira clara entre Romney e Obama: a forma como olham para a Rússia. Para o republicano, os bloqueios de Moscovo no Conselho de Segurança, em crises como a Síria ou assuntos sensíveis como o nuclear iraniano, mostram como falhou a estratégia de flexibilidade da Administração Obama. Para lidar com a Rússia, propõe quatro grandes orientações. A primeira, rever o START negociado por Obama. A segunda, diminuir a dependência energética da Europa. A terceira, fortalecer as alianças dos EUA na Ásia Central. Por fim, apoiar a sociedade civil russa e os seus anseios por liberdade e democracia. Tendo em conta esta postura ríspida, assertiva e até de confronto estratégico, a eleição de Mitt Romney abriria um período de tensão na relação bilateral com 
consequências imprevisíveis num conjunto de temas que ambos os lados tentaram, embora com graus distintos, trabalhar. Atendendo à resposta democrata, o vice-presidente Joe Biden e a secretária de estado Hillary Clinton apressaram-se a defender o presidente, atirando Romney para os tempos da Guerra Fria e para uma inexperiência internacional que, em vez de gerar pontes e consensos, criará atrito e conflitualidade entre grandes potências (Reuters, 2012b).

No entanto, tendo em conta o trajeto de Obama face à Rússia, com os altos e baixos da sua estratégia de aproximação, olhando ainda para o facto de uma vez reeleito ter outra margem para fazer exigências no plano dos direitos humanos e no respeito pelo pluralismo interno russo, ou mesmo contornando o seu veto face a uma resolução sobre a guerra civil na Síria e que possa prever uma zona de exclusão aérea - semelhante à que deu origem à intervenção na Líbia - apoiada pelo OTAN, Liga Árabe e liderada por alguns importantes atores regionais como a Turquia, o Qatar ou a Arábia Saudita, é provável que os próximos anos venham a mostrar mais crispação bilateral do que cooperação convicta. A questão está em saber se a um "reset" se seguirá um "delete". De um ponto podemos ter a certeza: a forma como for trabalhada, neste caso pelo governo norte-americano, uma estratégia face à Rússia que desenhe a exata medida entre necessidade de cooperação bilateral e promoção da democracia na sua vizinhança, será um desafio que, para o bem ou para o mal, continuará a moldar as relações entre ambos nos próximos anos.

O segundo desafio será a China. Para Washington, Pequim já é a protagonista da grande dinâmica equilibradora da ordem internacional deste século. Demograficamente imponente, economicamente expansiva, financeiramente forte, militarmente a crescer. Apresenta um conjunto de valências nacionais que lhe garantem influência na Ásia Pacífico, a região mais apetecida na política externa norte-americana para as próximas décadas. Hillary Clinton chamou-lhe mesmo o "século americano no Pacífico" (Clinton, 2011). A grande questão em Washington é saber se o comportamento de Pequim será gerador de estabilidade ou um factor de risco para as alianças asiáticas dos EUA. Esta questão não está 
respondida e continua em aberto nos principais documentos de análise e estratégia político-militar norte-americanos. ${ }^{66}$

Na Rússia, a China é encarada com alguma ambivalência. A proximidade geográfica, a dinâmica económica, migratória e demográfica constituem um desafio tremendo para o território russo em queda abrupta de população e desertificação territorial (Eberstadt, 2011). Contudo, no plano militar, a China compra mais de 90\% do seu armamento à Rússia (Lieven, 2011). No plano das restantes trocas comerciais bilaterais (petróleo e manufaturas), só entre 2009 e 2010 cresceram praticamente 50\%, embora representem um quarto do comércio feito entre russos e europeus no mesmo período. A pertença a um grupo restrito de economias emergentes (Brasil, Rússia, Índia e China) e na Organização de Cooperação de Xangai e alguma semelhança nos procedimentos autoritários, no capitalismo de estado e na coordenação de voto no Conselho de Segurança sobre importantes questões de segurança internacional (violência na Líbia e Síria), dão aos decisores russos e chineses um largo campo de aproximação ideológica que não sentem em relação aos EUA. Assim, a forma como Moscovo e Washington lidarão com a ascensão da China ditará o grau de aproximação ou de afastamento entre ambos nas próximas décadas. Pequim tenderá a ser um dos factores determinantes no evoluir desta equação (Lieven, 2011).

O terceiro desafio será o Irão. A tensão interna em que o regime mergulhou (teocratas, presidencialistas e "movimento verde") traduz parte da complexa arquitetura de poder no Irão. A força dos Guardas da Revolução e dos grupos para-militares associados fazem do programa nuclear um risco para a segurança regional, para a credibilidade do regime de não-proliferação nuclear e para a balança de poder no Médio Oriente, onde tanto Washington como Moscovo querem continuar a pesar. A evolução das revoltas árabes (sunitas e xiitas) no Médio Oriente e Norte de África ou o futuro dos acordos de paz de Israel na região (Egipto e Jordânia) são alguns dos dilemas ainda sem resposta. E para conter uma posição

66 Incluímos neste grupo as Estratégias de Segurança Nacional (2002, 2006, 2010), as Estratégias de Defesa Nacional $(2005,2008)$ e o Annual Report to Congress: Military and Security Developments Involving the People's Republic of China 2011, do Departamento de Defesa dos EUA. 
dominante de um Irão nuclear na região, os EUA e a Rússia continuam a ser fundamentais. Seja com sanções unilaterais, seja remetendo o assunto ao Conselho de Segurança, ou ainda através de rondas negociais que façam recuar as intenções iranianas, ambos têm posições decisivas. Os norte-americanos através de uma postura condenatória, sancionatória, que zele pela manutenção das suas alianças no Médio Oriente e faça com que Teerão termine com o programa nuclear sem recurso a uma intervenção militar. Os russos, cientes da perda de influência na região, mantêm a disponibilidade em contrapor-se à vontade dos EUA e dos europeus com assento no Conselho de Segurança, de forma a condicionar as suas ações no Médio Oriente através da retaguarda mais ou menos evidente ao Irão. A verdade é que, pela via do Conselho de Segurança, o Irão é um factor de contato entre Washington e Moscovo previsível nos tempos próximos. Com ou sem capacidade nuclear para fins militares.

Por último, o terrorismo islâmico. Tanto norte-americanos como russos sabem bem os efeitos catastróficos da emergência do terrorismo jihadista. $\mathrm{Na}$ última década e meia sofreram na pele o grau de sofisticação e preparação de movimentos cuja geografia é volátil, mas identificada com uma rota que passa pelo Paquistão, Afeganistão, Cáucaso, Ásia Central, Médio Oriente, Corno de África e Europa. A guerra no Afeganistão tem sido palco da ligação entre as estratégias anti-terroristas de Washington e Moscovo e a geometria das redes terroristas tem promovido uma cooperação bilateral mais estreita do que no passado. Tendo em conta a permanência desta ameaça mesmo depois da retirada norte-americana (2014), não é crível que ambos os lados baixem o nível de alerta e colaboração. Pelo contrário, um dos denominadores comuns numa agenda bilateral continuará a ser o terrorismo islâmico.

\section{Conclusão}

Não é possível perceber a emergência de Vladimir Putin na política russa sem olhar para os anos que antecedem a sua chegada ao poder. A crise que assolou Moscovo depois do colapso da União Soviética, o processo de liberalização abrupto e a degradação financeira do final da 
década de 1990, abriram caminho a que uma figura centralizadora como Putin fizesse da Rússia o que ela é hoje: uma grande potência euro-asiática.

Também é difícil compreender como a relação entre a Rússia e os EUA evoluiu na última década sem percebermos o impacto do 11 de setembro na política externa norte-americana. Em paralelo ao declínio russo dos anos 90, os EUA viviam um momento triunfalista, hegemónico, sem rival nas diversas dimensões do poder. Os ataques terroristas em Nova Iorque e Washington tiveram o condão de abanar esta ascensão, vulnerabilizando a superpotência. Se este facto deu origem a um período de ajustamento entre grandes potências no sistema internacional, equilibrando-o, também é verdade que aproximou Moscovo de Washington, através da ameaça do terrorismo islâmico.

Mas esta aproximação não foi a regra da última década. As guerras no Afeganistão, no Iraque, na Geórgia, os alargamentos da OTAN, as revoluções no leste europeu e no Cáucaso, a proliferação nuclear à Coreia do Norte e Irão, as guerras na Líbia e Síria, ou a crise financeira, foram e continuam a ser momentos de tensão bilateral que não só mostraram diferentes visões da segurança internacional, como revelaram as perceções distintas que as duas potências têm uma da outra.

Esta é a principal conclusão das relações entre EUA e Rússia nas duas últimas décadas: os bons e os maus momentos são cíclicos, oscilantes, não trazem pré-aviso. É uma relação muito mais importante para redimensionar a Rússia do que para potenciar o estatuto dos EUA. Moscovo olha para Washington permanentemente. A Casa Branca olha para o Kremlin por necessidade e pragmatismo. É um casamento duradouro, conflitual, tenso, mas sem um divórcio à vista. Apesar de tudo, são duas potências com uma geografia e poder demasiado importantes para que alguma prescinda da outra. E este é o ponto de convergência que as atrai.

\section{Bibliografia}

ALLISON, Roy; LIGHT, Margot e WHITE, Stephen - Putin's Russia and the Enlarged Europe. London: Blackwell Publishing, 2006.

Annual Report to Congress: Military and Security Developments Involving the People's Republic of China - United States Department of Defense, 2011. 
ARON, Leon - The United States and Russia: Ideologies, Policies, and Relations. American Enterprise Institute for Public Policy Research, 2006.

Asia Times - Moscow moves to counter NATO, 14 dezembro 2010. [Acedido a 23 de mai. de 2012]. Disponível na Internet: http://www.atimes.com/atimes/Central_Asia/LL14Ag01.html.

BBC News - Russia pays off Paris Club debts, 21 agosto 2006. [Acedido a 24 de mai. de 2012]. Disponível na Internet: http://news.bbc.co.uk/2/hi/business/5271122.stm.

BBC News - Putin tells stadium rally battle is on for Russia, 23 fevereiro 2012. [Acedido a 24 de maio de 2012]. Disponível na Internet: http://www.bbc.co.uk/news/worldeurope-17136644.

Bloomberg - Putin ratchets up anti-US rhetoric as Kremlin race grows, 26 janeiro 2012. [Acedido a 12 de abr. de 2012]. Disponível na Internet: http://www.bloomberg.com/ news/2012-01-25/putin-says-u-s-seeks-vassals-not-allies-as-campaign-heats-up.html.

BUSH, George W. - Decision Points. London: Virgin Books, 2010.

CFR - The Candidates on U.S. Policy Toward Russia, Council on Foreign Relations Issue Tracker, 7 novembro 2008. [Acedido a 7 de mai. de 2012]. Disponível na Internet: http:// www.cfr.org/us-election-2008/candidates-us-policy-toward-russia/p14946.

CHOLLET, Derek and GOLDGEIER, James - America between the Wars: From 11/9 to 9/11. New York: Public Affairs, 2008.

CLINTON, Hillary - America's Pacific Century. Foreign Policy. N. 189 (2011), p. 56-63.

CNN - Clinton cites 'serious concerns' about Russian elections, 6 dezembro 2011.

EBERSTADT, Nicholas - The Dying Bear: Russia's Demographic Disaster. Foreign Affairs. Vol. 90, N. ${ }^{\circ} 6$ (2011), p. 95-108.

Economist, The - Power and Ideas, 23 novembro 2010. [Acedido a 6 de jul. de 2012]. Disponível na Internet: http://www.economist.com/blogs/democracyinamerica/2010/11/ republican_foreign_policy_and_new_start_treaty.

Economist, The - Russia and NATO: Rethink the Reset, 19 maio 2012. [Acedido a 14 de jun. de 2012]. Disponível na Internet: http://www.economist.com/node/21555580.

Estratégia de Segurança Nacional - White House, National Security Strategy. Washington D.C., setembro 2002.

Estratégia de Defesa Nacional - United States Department of Defense, National Defense Strategy. Washington D.C, março 2005.

Estratégia de Segurança Nacional - White House, National Security Strategy. Washington D.C., março 2006.

Estratégia de Defesa Nacional - United States Department of Defense, National Defense Strategy. Washington D.C, julho 2008.

Estratégia de Segurança Nacional - White House, National Security Strategy. Washington D.C., maio 2010.

FUKUYAMA, Francis - The End of History and the Last Man. New York: Free Press, 1992.

GOLDGEIER, James M. - Not Whether But When: The U.S. Decision to Enlarge NATO. Washington D.C: Brookings Institution Press, 1999.

GORDON, Philip H, ed. - NATO's Transformation: The Changing Shape of the Atlantic Alliance. Boston: Rowman \& Littlefield Publishers, 1997.

GORDON, Philip H. e SHAPIRO, Jeremy - Allies at War: America, Europe, and the Crisis Over Iraq. New York: McGraw-Hill, 2004. 
GRAHAM, Thomas - U.S.-Russia Relations: Facing Reality Pragmatically. Center for Strategic \& International Studies, julho 2008.

Guardian, The - Syria resolution vetoed by Russia and China at United Nations, 4 fevereiro 2012. [Acedido a 6 de fev. de 2012]. Disponível na Internet: http://www.theguardian. com/world/2012/feb/04/assad-obama-resign-un-resolution.

Heritage Foundation - More Reasons not to Trust Russia on START, 15 dezembro 2010.

Huffington Post - Mitt Romney: Russia is our number one geopolitical foe, 26 março 2012. [Acedido a 6 de fev. de 2012]. Disponível na Internet: http://www.huffingtonpost. com/2012/03/26/mitt-romney-russia-geopolitical-foe_n_1380801.html.

KRAUTHAMMER, Charles - The Unipolar Moment. Foreign Affairs. Vol. 70, N. ${ }^{\circ}$ (1990), p. 23-33.

KUCHINS, Andrew C. e ZEVELEV, Igor A. - Russian Foreign Policy: Continuity in Change. The Washington Quarterly. Vol. 35, N. ${ }^{\circ} 1$ (2012), p. 147-161.

LARUELLE, Marlène - Russian Eurasianism: An Ideology of Empire. Baltimore: Johns Hopkins University Press, 2008.

Levada Center (s.d.) Sondagem de opinião russa. [Acedido a 15 de jul. de 2012]. Disponível na Internet: http://www.whitehouse.gov/the-press-office/us-russia-relations-reset-fact-sheet.

LEGVOLD, Robert, ed. - Russia's Foreign Policy in the Twentieth Century and the Shadow of the Past. New York: Columbia University Press, 2007.

LIEVEN, Anatol - U.S.-Russian Relations and the Rise of China. New American Foundation, julho 2011.

MACKINNON, Mark - The New Cold War: Revolutions, Rigged Elections and Pipeline Politics in the Former Soviet Union. New York: Random House, 2007.

MANNERS, Ian - European Union 'Normative Power' and the Security Challenge. European Security. N. ${ }^{\circ} 4$ (2006), p. 235-258.

MCNAMARA, Sally - The failure of the 'Russia Reset': Next Steps for the United States and Europe. The Heritage Foundation. N. ${ }^{\circ} 2637,5$ janeiro 2012.

New York Times, The - Oil income helps Russia pay off entire debt to Paris Club Business, 21 agosto 2006. [Acedido a 4 de mai. de 2012]. Disponível na Internet: http://www. nytimes.com/2006/08/21/business/worldbusiness/21iht-debt.2553467.html?_r=0.

New York Times, The - Putin's Inaugural Address: 'We Believe in our Strength', 8 maio 2000. [Acedido a 4 de mai. de 2012]. Disponível na Internet: http://www.nytimes.com/2000/05/08/ world/putin-s-inaugural-address-we-believe-in-our-strength.html.

NICHOLSON, Martin - Putin's Russia: Slowing the Pendulum without Stopping the Clock. International Affairs. Vol. 77, N. 3 (2001), p. 867-884.

North Atlantic Council - Lisbon Summit Declaration. Lisbon, 20 novembro 2010, Parágrafo 23. [Acedido a 15 de jun. de 2012]. Disponível na Internet: http://www.NATO.int/cps/ en/NATOlive/official_texts_68828.htm.

OBAMA, Barack H. - Renewing American Leadership. Foreign Affairs. Vol. 86, N. 4 (2007), p. 2-16.

Pew Research Center - The Pew Global Attitudes Project. Pew Research Center, 17 junho 2010. [Acedido a 19 de jun. de 2012]. Disponível na Internet: http://www.pewglobal. org/files/2010/06/Pew-Global-Attitudes-Spring-2010-Report.pdf.

POND, Elizabeth - Friendly Fire: The Near-Death of the Transatlantic Alliance. Washington D.C.: Brookings Institution Press, 2004.

PRAVDA, Alex, ed. - Leading Russia: Putin in Perspective. Oxford: Oxford University Press, 2005. 
RACHMAN, Giddeon - Zero-Sum World: Power and Politics After the Crash. London: Atlantic Books, 2010.

Resolução 1441 (2002) United Nations Security Council Resolution. S/RES/1441, 8 novembro. Disponível em: http://daccessddsny.un.org/doc/UNDOC/GEN/N02/682/26/PDF/N0268226. pdf? OpenElement. Consultado em: 15 junho 2012.

Resolução 1973 - United Nations Security Council Resolution. S/RES/1973, 17 março 2011. [Acedido a 15 de jun. de 2012]. Disponível na Internet: http://daccessddsny.un.org/doc/ UNDOC/GEN/N11/268/39/PDF/N1126839.pdf?OpenElement.

Reuters - U.S-Russia ties strained during Putin political campaign, 2 março 2012a. [Acedido a 27 de jun. de 2012]. Disponível na Internet: http://www.reuters.com/article/2012/03/02/ us-russia-usa-idUSTRE82108U20120302.

Reuters - Top Obama aides hit back at Romney on Russia, 1 abril 2012b. [Acedido a 27 de jun. de 2012]. Disponível na Internet: http://www.reuters.com/article/2012/04/01/ususa-campaign-romney-russia-idUSBRE8300FK20120401.

RICE, Condoleezza - No Higher Honour: A Memoir of my Years in Washington. London: Simon \& Schuster, 2011.

ROMNEY, Mitt - Russia, 2012. [Acedido a 25 de set. de 2012]. Disponível na Internet: http:// www.mittromney.com/issues/russia.

Russian National Security Strategy 2020 - Documento aprovado por Decreto Presidencial da Federação Russa, 12 maio 2009. [Acedido a 25 de set. de 2012]. Disponível na Internet: http://rustrans.wikidot.com/russia-s-national-security-strategy-to-2020.

STÜRMER, Michael - Putin and the Rise of Russia. London: Weidenfeld \& Nicolson, 2008.

SZABO, Stephen F. - Parting Ways: The Crisis in German-American Relations. Washington D.C.: Brookings Institution Press, 2004.

TAVERNISE, Sabrina - Bush Pledges Partnership with Russians on Energy. The New York Times, 25 maio 2002. [Acedido a 12 de jun. de 2012]. Disponível na Internet: http:// www.nytimes.com/2002/05/25/business/international-business-bush-pledges-partnershipwith-russians-on-energy.html.

TOCQUEVILlE, Alexis de - Da Democracia na América. Lisboa: Relógio D’Água Editores, 2008.

TSYGANKOV, Andrei P. - Russia's Foreign Policy: Change and Continuity in National Identity. Plymouth: Rowman \& Littlefield Publishers, 2010.

White House - Office of the Press Secretary, Text of Joint Declaration. Washington DC: The White House, 24 maio 2012. [Acedido a 15 de jun. de 2012]. Disponível na Internet: www.whitehouse.gov/news/releases/2002/05/20020524-2.html.

WOODWARD, Bob - Bush at War. New York: Simon \& Schuster, 2002. 


\section{CAPÍTULO 9}

\section{RELAÇÕ ES RÚSSIA-TURQUIA：DA RIVALIDADE À PARCERIA ESTRATÉGICA}

André Barrinha

Das inúmeras guerras entre o Império Otomano e o Império Russo, aos recentes acordos energéticos entre Ancara e Moscovo, o relacionamento entre a Turquia e a Rússia foi sempre marcado por uma grande ambiguidade. Essa é uma ambiguidade derivada da inevitabilidade da proximidade geográfica, da sobreposição parcial de interesses geoestratégicos, do reconhecimento mútuo das mais valias que um relacionamento próximo oferece e, sobretudo, de uma forma de entender política externa baseada em pressupostos tendencialmente realistas. Pressupostos associados à forma de fazer política externa destes dois países, mas também ao facto de estarmos perante duas potências em ascensão na cena internacional.

A Rússia e a Turquia fazem parte de um conjunto de potências emergentes no sistema internacional, cuja ascensão tem sido alicerçada no crescimento económico e na atomização dos relacionamentos geopolíticos, sendo possível afirmar que atravessam o período mais pacífico e cooperativo da sua história (Ediger e Bagdadi, 2010, p. 223).

Pela sua crescente importância internacional e por serem os dois maiores vizinhos da União Europeia (UE) e logo, atores fulcrais no sucesso das políticas europeias relativamente à sua vizinhança tanto a sul como a leste, é fundamental perceber o estado do relacionamento entre estes dois países, bem como as eventuais tendências de evolução desse mesmo relacionamento. Como tal, este capítulo começará por fazer um breve 
resumo da evolução histórica do relacionamento, dando um claro enfoque ao período pós-Guerra Fria. A isso segue-se uma análise da relação entre estes dois países na atualidade, com destaque para as principais áreas de interação entre ambos. Na terceira e última parte, será feita uma análise crítica do mesmo onde se tentará inferir sobre os padrões de comportamento que marcam as relações entre a Rússia e a Turquia.

\section{Turquia-Rússia: da rivalidade passiva à parceria estratégica}

Atualmente separados pelas repúblicas do Cáucaso do Sul, a Turquia e a Rússia foram até ao fim da Guerra Fria países com fronteiras comuns, ambições paralelas e alianças antagónicas. O relacionamento entre estes dois atores nunca foi particularmente positivo (Warhola e Mitchell, 2006, p. 129), correspondendo a um padrão de comportamento que recua aos Impérios Otomano e Russo. Apesar de o relacionamento entre os dois Impérios recuar a 1492, ano em que o Czar Ivan III enviou uma delegação diplomática a Istambul (MFA, 2008), foi a partir de finais do século XVII que Constantinopla

e São Petesburgo "intensificaram" o seu relacionamento, neste caso, pelas piores razões. Entre 1676 e 1917, a Turquia e a Rússia foram adversários em doze guerras, o que dá uma média de uma guerra a cada vinte anos durante este período (Ediger e Bagdadi, 2010, p. 223). De entre estas, a guerra de 1768-74 teria um significado especial, pois a pesada derrota das forças otomanas significou o fim da sua hegemonia no Mar Negro e, até certo ponto, o início do declínio do Império da Sublime Porta (idem).

No entanto, boa parte do projeto hegemónico de cada uma destas potências passava pela conquista de territórios distintos: a Rússia preocupava-se com a Europa de leste, a Ásia Central e o Cáucaso. A Turquia, sobretudo com o Médio Oriente e os Balcãs, mas também com o Cáucaso, de resto o principal ponto de fricção entre as duas potências.

Se no caso russo, a revolução comunista levou à retirada do país da Primeira Guerra Mundial, no caso turco a opção pela Tríplice Entente, juntamente com a desintegração interna do Império Otomano, levaram a que a Turquia fosse reduzida a pouco mais que o planalto da Anatólia. 
Nesse sentido, toda a segunda metade do século XX, até ao fim da Guerra Fria foi ditada pelo desequilíbrio entre uma URSS Império e uma Turquia pós-Imperial sobretudo preocupada com a consolidação do seu projeto republicano, marcada pelo princípio de Mustafa Kemal 'Ataturk', "paz em casa, paz no mundo" (Kazan, 2005, p. 591).

Curiosamente, o projeto de Mustafa Kemal teria provavelmente falhado sem o apoio de Lenine, que, ao contribuir com o envio de armas e mantimentos, permitiu às forças rebeldes comandadas por Ataturk desencadear uma ofensiva contra as forças gregas estacionadas na Costa oeste do que viria a ser a Turquia. No seu discurso de vitória, Mustafa Kemal mencionava a aliança entre o "nacionalismo turco e o comunismo soviético" como estando na base da implantação da República da Turquia.

Durante a Primeira Guerra Mundial, a Rússia ocupou o leste de um Império otomano em decadência. Contudo, com a revolução soviética, o fim da Primeira Guerra Mundial e o início da rebelião liderada por Mustafa Kemal com o objetivo de expulsar as potências ocupantes da Turquia, Moscovo mudou consideravelmente a sua posição relativamente à Turquia. A Guerra de Libertação da Turquia era vista como um ato contra o imperialismo ocidental e, como tal, devia ser apoiada por Moscovo (Akçali e Perinçek, 2009, p. 553). A URSS seria a primeira grande potência a reconhecer a República da Turquia ainda durante a Guerra de Libertação (MFA, 2008). Em 1925, a Turquia e a União Soviética chegaram inclusive a assinar um pacto de não-agressão, num contexto de relacionamento positivo entre os dois países que duraria até à Segunda Guerra Mundial (Yinanç, 2010a). Seria a Segunda Guerra Mundial, em que a Turquia manteve, à semelhança de Portugal, uma neutralidade ativa, a marcar o início da deterioração das relações entre os dois países.

A Turquia, à procura do seu lugar no sistema internacional, passou a ter nos Estados Unidos (EUA) um aliado fundamental. Enquanto isso, a URSS estendia a sua zona de influência para a Europa central e de leste, o Cáucaso e a Ásia Central. A neutralidade turca durante o conflito transformar-se-ia numa clara orientação pró-ocidental, principalmente em relação aos EUA, vindo daí a resultar a adesão da Turquia à Organização do Tratado do Atlântico Norte (OTAN) em 1952 e o desenvolvimento de 
um discurso anti-soviético ${ }^{67}$, apropriado às suas novas responsabilidades no contexto bipolar internacional (Warhola e Mitchell, 2006, p. 129). A Turquia passou assim a ser o ponta-de-lança da OTAN no espaço soviético, com metade dos países com quem fazia fronteira a pertencerem ao espaço ou zona de influência soviética: Bulgária, Arménia, Geórgia e Azerbaijão.

A década de 1960 conheceu uma aproximação entre os dois países, ditada pela maior abertura do líder soviético, Nikita Kruschev, assim como pela visível insatisfação da Turquia com o comportamento do seu aliado norte-americano relativamente à questão cipriota (cf. Barrinha, 2010). Exemplo disso foi o acordo estabelecido pelos dois países em 1966 para a construção de uma fábrica de alumínio em Seydişehir, na Turquia, com tecnologia soviética (Ediger e Bagdadi, 2010, p. 229).

Seria contudo necessário esperar até à década de 1980 para que esse relacionamento voltasse a ser reatado, com a abertura política encetada pelo governo turco de Turgut Ozal. Em setembro de 1984, a Rússia e a Turquia assinariam um acordo na área do gás natural. Este acordo é ainda hoje visto como sendo um marco na viragem do relacionamento entre os dois países (Yinanç, 2010a). Ano e meio mais tarde, seria a vez de a empresa russa Gazexport e a empresa turca Botaş assinarem um acordo comercial para um período de 25 anos (Ediger e Bagdadi, 2010, p. 229).

O fim da Guerra Fria libertaria oficialmente a Rússia e a Turquia dos espartilhos geopolíticos que tinham condicionado o relacionamento entre ambos. No início de 1992, o então ministro dos negócios estrangeiros turco, Hikmet Çetin visitou Moscovo, depois de a Turquia ter reconhecido a Federação Russa pouco tempo antes. A visita seria retribuída pelo homólogo russo, Andrei Kozyrev. Em maio do mesmo ano, o primeiro ministro turco Süleyman Demirel assinaria em Moscovo o Tratado sobre os Princípios da Relação entre a República da Turquia e a Federação Russa (MFA, 2008), que serviria de base legal para o relacionamento entre os dois países. As relações durante o período Ieltsin seriam marcadas pela cooperação bilateral.

67 Durante este período, o relacionamento turco-russo piorou significativamente, atingindo pontos caricatos como o facto de os turcos passarem a chamar à salada russa, "salada americana" (Yinanç, 2010a). 
A verdade é que Moscovo continuava a percecionar a Turquia como sendo um representante dos interesses norte-americanos na região. A divergência de interesses entre os dois países relativamente a toda uma série de assuntos certamente não ajudou na mudança dessa perceção (Hill e Taspinar, 2006, p. 83). Com o fim da Guerra Fria, o Cáucaso do Sul e a Ásia Central, passaram, pelos seus laços históricos e culturais, a ser prioridades da política externa turca. Como será analisado mais adiante, a Turquia e a Rússia tinham igualmente posições diametralmente opostas relativamente aos conflitos na Bósnia, no Kosovo e na Chechénia. Por fim, o alargamento da OTAN a leste também não foi benéfico para o relacionamento entre os dois países (idem).

Contudo, rapidamente ficou claro que a Turquia não tinha a capacidade de se afirmar como um ator em todos estes cenários em simultâneo (Weitz, 2010, p. 78), o que de certa forma acalmou Moscovo e, eventualmente, contribuiu para uma aproximação (entre os dois países). Para além do mais, a crise dos mercados asiáticos no final dos anos noventa, que levou a economia russa à beira do colapso, também fez com que esta tivesse de acalmar o seu tom, por vezes agressivo, relativamente à Turquia. Se a isto juntarmos a instabilidade política na Turquia e a crise financeira de 2001, que obrigou este país a solicitar ajuda ao Fundo Monetário Internacional (FMI), temos um contexto bilateral marcado, nos anos noventa, pelo enfraquecimento dos dois países e pelo progressivo alinhamento de prioridades em matéria de política externa (idem, p. 62).

A subida ao poder do Partido da Justiça e do Desenvolvimento (AKP) na Turquia em novembro de 2002, juntamente com a ascensão e consolidação do regime de Vladimir Putin na Rússia permitiu uma rápida alteração neste panorama de fragilidade e levou à aproximação entre os dois países.

A visita de Abdullah Gül a Moscovo em fevereiro de 2004, seria a primeira visita de um ministro dos negócios estrangeiros turco à Rússia desde 1996. Essa visita seria a primeira de várias, sendo de destacar as diversas viagens de Putin 68 à Turquia e do primeiro ministro turco, Recep

68 A visita do presidente russo Vladimir Putin em janeiro de 2005, seria a primeira visita do mais alto dignatário russo à Turquia desde 1972 (MFA, 2008). 
Tayyip Erdogan à Rússia, incluindo uma visita em julho de 2005 ao retiro de verão do presidente russo, em Sochi, na costa do Mar Negro (Hill e Taspinar, 2006, p. 84). Foi numa destas visitas, a primeira de Erdogan a Moscovo, que ambos os líderes assinaram a Declaração Conjunta sobre a Intensificação da Amizade e Parceria Multidimensional entre os dois países (MFA, 2008).

Desde então, os encontros entre altos dignitários dos dois países têm-se multiplicado. Em 2009, por exemplo, teve lugar a visita do presidente Abdullah Gül e do primeiro ministro Recep Tayyip Erdogan a Moscovo e a visita de Vladimir Putin a Ancara. Nessa última, os dois países assinaram mais de vinte protocolos e acordos num claro sinal de aprofundamento e alargamento das áreas de cooperação mútua, como no turismo ou telecomunicações. Em 2010, foi ainda criado um conselho de cooperação estratégica que reúne anualmente o presidente da Rússia com o primeiro ministro turco. O objetivo deste conselho é, sobretudo, a promoção de relações económicas e comerciais entre os dois países. Nesse contexto, foi em 2011 acordada a eliminação da necessidade de vistos de entrada nos respetivos países para visitas inferiores a 30 dias.

Se pelo lado russo, este relacionamento faz parte de uma estratégia de simultânea expansão de laços económicos (e consequente afirmação enquanto potência internacional) e de contenção da influência do mundo ocidental na sua vizinhança, por parte da Turquia, esta aproximação é resultado de uma nova forma de fazer política externa promovida pelo AKP, em particular pelo ministro dos negócios estrangeiros e antigo conselheiro do primeiro ministro para os assuntos internacionais, Ahmet Davutoglu. Na opinião de Bulent Aras, "Davutoglu desenvolveu a sua política externa na base de uma nova imaginação geográfica que põe fim ao que ele apelida de 'alienação' dos países vizinhos da Turquia” (2009, p. 128), incluindo a Rússia. Com base na sua obra Profundidade Estratégia (Stratejik Derinlik) de 2001, Davutoglu definiu uma série de princípios que uma política externa turca ativa deveria ter em consideração. Na sua opinião, a Turquia devia ser capaz de tirar um maior proveito do seu contexto geográfico, dos laços culturais derivados do seu passado histórico e articular tudo isso com uma projeção económica que permitisse exponenciar um crescimento interno que levasse a Turquia a 
assumir um papel central na região e no próprio sistema internacional. Concretamente, isso obrigava a uma política de "zero problemas" com a vizinhança (Altunişik, 2009, p. 30; Davutoglu, 2010) e a uma presença ativa na mesma, marcada pela cooperação económica e não, como até então, pelas questões de segurança (Tekin, 2011, p. 30). Em termos práticos essa aproximação tem levado Ancara a ter uma posição equidistante nas frequentes confrontações entre a Rússia e o ocidente, procurando gerar consensos ao mesmo tempo que desenvolve um relacionamento com Moscovo à margem desses mesmos problemas (Aras, 2009, p. 137).

\section{O relacionamento entre duas potências em ascensão}

Energia e segurança têm, de certa forma, marcado o relacionamento entre Ancara e Moscovo nas últimas décadas. Apesar da franca melhoria no relacionamento entre ambos, a Turquia e a Rússia têm, no que diz respeito às questões centrais do seu relacionamento, posições nem sempre conciliáveis. Veremos nesta parte do capítulo, como esse relacionamento tem evoluído setorialmente, começando pelas questões energéticas.

\section{Questões energéticas}

É a energia, e tem sido a energia, a questão que mais tem unido a Rússia e a Turquia ao longo das últimas décadas. A dependência turca relativamente ao gás e ao petróleo russos tem crescido à medida que tem crescido a sua economia. Dentro deste contexto energético, há duas questões que marcam o relacionamento turco-russo: por um lado, o relacionamento económico entre os dois países, por outro, a geopolítica da questão.

Entre 1996 e 2007, o consumo energético primário da Turquia cresceu praticamente $50 \%$, numa média de cerca de $4 \%$ ao ano. De acordo com estimativas do governo de Ancara esse crescimento será, até 2020, de 6\% ao ano (Coskun e Carlson, 2010, p. 210). O relacionamento com a Rússia, assume nesse contexto um papel fundamental para a Turquia: $63 \%$ do 
gás consumido pela Turquia e $29 \%$ do seu abastecimento de petróleo são provenientes da Rússia (Ediger e Bagdadi, 2010, p. 233). Esta dependência energética resulta num significativo défice na balança comercial entre os dois países, favorável à Russia. Apesar de um volume total de trocas superior a 35 mil milhões de dólares por ano, valor esse que deverá atingir os três dígitos em 2015 (idem), só cerca de um-terço desse valor é que se destina à Turquia, sendo o restante em sentido contrário. Por exemplo, em 2008, ano em que a Rússia passou a ser o maior parceiro comercial da Turquia (Soler i Lecha, 2012, p. 3), o valor do défice comercial de Ancara relativamente a Moscovo situou-se nos 25 mil milhões de dólares (Yinanç, 2010a).

Se é verdade que para alguns autores este volume de trocas pode ser visto como correspondendo ao desenvolvimento de "uma verdadeira parceria estratégica" entre os dois países (Ediger e Bagdadi, 2010, p. 233), esta é, por enquanto, uma parceria economicamente desequilibrada. Não se pode contudo descurar a importância que a Turquia tem para a Rússia enquanto cliente privilegiada dos seus 'produtos' energéticos. Os russos vêem a Turquia como um parceiro energético de importância semelhante à Alemanha: um na Europa do sul e o outro na Europa do norte (Weitz, 2010, p. 66). Para a companhia russa Gazprom, a Turquia é inclusive vista como o seu mais importante cliente (Sergei Komlev apud Yinanç, 2010b).

Como anteriormente mencionado, a questão energética no relacionamento entre a Turquia e a Rússia não se resume ao crescimento no volume de trocas entre os dois países. Há também uma importante dimensão geoestratégica, ligada ao transporte energético e à ideia turca de se afirmar cada vez mais como uma importante plataforma energética a nível regional. É neste contexto que a política dos gasodutos e oleodutos assume uma importância central no relacionamento energético bilateral.

Em 1997, a Rússia e a Turquia assinaram o acordo de construção de um gasoduto que levaria o gás russo do porto de Novorosisk até ao porto turco de Samsun através do Mar Negro. Estava dado o passo inicial para o projeto Blue Stream, que, para além da Rússia e da Turquia, contaria com a participação ativa da Itália através da sua principal empresa energética, a Eni. 
Em 2002, a Turquia começou igualmente a desenvolver, juntamente com diversos parceiros europeus, o projeto Nabucco. A parte europeia do projeto, que ligaria o gasoduto do Cáucaso do Sul à Áustria, possibilitaria a ligação direta entre o Turquemenistão e a Europa, permitindo a diversificação energética e a redução da dependência dos países europeus relativamente à Rússia. O consórcio responsável pela sua exploração anunciou, em 2011, o adiamento do início das obras para 2013 (HDN, 6/05/2011) e não é claro que estas se venham a realizar, em parte por culpa do projeto alternativo proposto pela Rússia.

Moscovo decidiu promover o projeto South Stream, um projeto que prevê o transporte de gás da Rússia para a Bulgária através do Mar Negro e daí para a Grécia, a Itália e a Áustria. Para a Turquia, os dois projetos são compatíveis e não rivais (The Economist, 2009) e por isso, em troca da possibilidade de fazer passar os gasodutos pela sua zona económica exclusiva no Mar Negro, num acordo obtido com a Rússia em agosto de 2009 (Ulutas, 2010, p. 8), a Turquia conseguiu o apoio russo para a construção de um oleoduto do porto de Samsun no Mar do Norte para o terminal de Ceyhan no Mediterrâneo (The Economist, 2009). Esse acordo seria materializado com a visita de Erdogan a Moscovo em janeiro de 2010 (Weitz, 2010, p. 68). Ceyhan é uma peça fundamental no projeto turco de se tornar uma plataforma energética internacional. De acordo com o seu Ministro para a Energia, Taner Yildiz, a Turquia pretende em 2020 fazer passar 3 a 4\% do abastecimento global de gás e 5 a $6 \%$ do abastecimento global de petróleo pelo terminal energético de Ceyhan (Yildiz, 2010, p. 38).

Apesar do apoio russo ser fundamental, é para a Turquia importante que este apoio não se torne numa insustentável relação de dependência, pelo que o governo de Erdogan pretende limitar a 50\% o consumo de gás proveniente de um só abastecedor, uma medida claramente dirigida à Rússia (Coskun e Carlson, 2010, p. 213). O facto de estar ligado ao Azerbaijão através do gasoduto Baku-Tiblisi-Erzurum (BTE) e do oleoduto Baku-Tiblisi-Ceyhan (BTC) permite aliviar um pouco essa dependência (Tekin e Williams, 2009, p. 342). Permite igualmente elevar o valor geoestratégico da Turquia na sua relação com Moscovo: pois se é verdade que a Turquia está bastante dependente da Rússia em termos energéticos, também o é que 
a Rússia necessita da Turquia como plataforma de transporte energético. Neste contexto, a Rússia e a Turquia assinaram uma parceria estratégica em janeiro de 2010 (Ediger e Bagdadi, 2010, p. 232) que prevê o aprofundamento do relacionamento bilateral e que poderá levar, entre outras medidas, ao Blue Stream II, um projeto de criação de um gasoduto que liga a Rússia a Israel através da Turquia.

Para além do petróleo e do gás, a Turquia e a Rússia têm interesses comuns na área do nuclear. A Rússia, em virtude de negociações resultantes da venda dos seus bens energéticos à Turquia, está a construir o primeiro reator nuclear turco, em Mardin, num investimento de 20 mil milhões de dólares. Este corresponde ao maior investimento russo da atualidade no exterior (Akkan, 2012) e é um importante sinal político da aproximação estratégica entre os dois países.

A Turquia joga assim um jogo de ambivalência estratégica com a Rússia no que à energia diz respeito: por um lado pretende afirmar-se internacional e autonomamente como uma plataforma energética à escala global, por outro, sabe que isso só será possível com o apoio de Moscovo, que por sua vez tem na Turquia um dos seus principais parceiros comerciais e energéticos.

\section{Segurança e conflitos}

Relativamente às questões de segurança, há dois aspetos centrais no atual relacionamento Rússia-Turquia: a questão nuclear iraniana e a conflitualidade regional no Sudeste turco, na Chechénia, no Cáucaso do Sul e, mais recentemente, no Médio Oriente, no contexto da Primavera Árabe. Quanto à primeira questão, a convergência entre os dois países relativamente a este tema aparenta ser significativa. Apesar de partirem de pontos diferentes, no sentido em que a Rússia é uma potência nuclear, ao contrário da Turquia, que nunca desenvolveu passos nesse sentido, ambos convergem na necessidade de evitar a proliferação nuclear na sua vizinhança, em particular no Irão. A abordagem de ambos tem contudo

divergido da abordagem dos países ocidentais, uma vez que a Rússia e a Turquia têm procurado ajudar o Irão a desenvolver tecnologia nuclear 
para fins civis. O primeiro ministro turco, em oposição à posição oficial do seu país, considera 'normal' um país no contexto geopolítico do Irão pretender obter armas nucleares (Koprulu, 2009, p. 194). Erdogan chegou em 2010, juntamente com outra potência em ascensão, o Brasil, a acordo com o Irão no sentido de este abdicar da produção de urânio enriquecido. O acordo, posteriormente rejeitado pelo Conselho de Segurança das Nações Unidas (CSNU), previa a transferência de urânio pouco enriquecido (1200 kg) para a Turquia, que continuaria a ser propriedade do Irão, em troca de um reator de pesquisa.

Para a Turquia, é importante chegar a um entendimento com o Irão, sobretudo para evitar uma nova intervenção norte-americana na região e a consequente desestabilização da sua vizinhança. Para a Rússia, que por regra resiste às tentativas norte-americanas de levar a questão iraniana ao CSNU, trata-se não só de limitar a influência norte-americana no Médio Oriente, como de recuperar alguma da influência por si perdida com o fim da Guerra Fria (Hill e Taspinar, 2006, p. 82).

No que à conflitualidade armada interna e regional diz respeito, a Rússia e a Turquia têm por diversas vezes definido posições antagónicas: internamente, o conflito na Chechénia (Rússia) e no Sudeste turco contra os movimentos rebeldes curdos tem levado Ancara e Moscovo a adotar posições contrárias. Externamente, os conflitos no Cáucaso do Sul, em particular o conflito do Nagorno-Karabakh que envolve a Arménia e o Azerbaijão, o Chipre e as guerras dos Balcãs durante os anos 1990 colocaram a Rússia e a Turquia em lados opostos das barricadas. O mesmo sucedendo atualmente no conflito sírio, como veremos mais à frente.

Em termos de conflitualidade interna, a questão curda tem sido uma questão particularmente sensível no relacionamento entre os dois países. A proximidade ideológica entre o Partido dos Trabalhadores do Curdistão (PKK) e a União Soviética, levou a que Moscovo tivesse em vários momentos apoiado direta ou indiretamente a insurreição do movimento de Abdullah Ocalan em pleno território da OTAN. Três décadas depois, a Rússia recusa-se ainda a reconhecer o PKK como um movimento terrorista, algo que deixa Ancara profundamente descontente (The Economist, 2009). Por seu turno, Moscovo gostaria que Ancara apoiasse de forma mais 
ativa os seus esforços de 'normalização' da situação na Chechénia. A Rússia considera que a Turquia não tem sido assertiva o suficiente relativamente a esta questão. Episódios como o desvio de um ferry no Mar Negro por parte dos separatistas chechenos em 1996 ou o cerco, em abril de 2001, ao Swissotel em Istambul durante 12 horas igualmente por parte de um grupo checheno, têm contribuído para esta perceção por parte de Mosocovo (Gorvett, 2011). Afinidades religiosas têm feito com que as reinvidicações chechenas colham simpatia junto da população turca. Aquando da visita de Vladimir Putin a Ancara, em dezembro de 2004, uma manifestação de vários milhares de pessoas concentrou-se nas ruas da capital turca contra a presença do primeiro ministro russo na Turquia. A questão chechena estava no topo das reinvidicações (Warhola e Mitchell, 2006, p. 136). O popular imam turco Tahir Buyukkorukçu fala frequentemente no "porco russo' quando menciona a questão chechena no seu programa televisivo no canal Kon (The Economist, 2009). No seu encontro de julho de 2005, Putin e Erdogan chegaram a um aparente entendimento relativamente a estes dois conflitos internos, reiterando o seu repúdio pelo terrorismo e pelo secessionismo nos seus respetivos territórios (Hill e Taspinar, 2006, p. 84).

Para além das questões internas, o Cáucaso do Sul tem sido uma região que tem ocasionalmente gerado uma forte tensão entre a Rússia e a Turquia. Desde logo o conflito do Nagorno-Karabakh (Weitz, 2010, p. 75) que coloca, desde o final dos anos 1980 frente a frente a Arménia e o Azerbaijão, países que têm na Rússia e Turquia, respetivamente, os seus principais aliados (Terterov et al, 2010, p. 198). A clara melhoria no relacionamento entre Ancara e Ierevan nos últimos anos tem levantado a possibilidade de se estar próximo de um entendimento entre os dois países, para um possível reatamento das relações diplomáticas. Contudo, o envolvimento russo nesse processo levanta suspeitas (The Economist, 2009) de que o verdadeiro objetivo da Rússia é manter o status quo, pois só assim conseguirá manter a sua influência na região e prevenir a ascensão da influência turca (Weitz, 2010, p. 77) numa região que Moscovo considera central aos seus interesses geopolíticos (Torbakov, 2010, p. 37).

De resto, foi obedecendo a essa lógica que a Rússia invadiu parte do território da Geórgia em agosto de 2008. Durante os cinco dias que 
o conflito durou, a Turquia tentou servir de intermediária ao processo, ao mesmo tempo que se coibiu de criticar a Rússia ou de defender a Geórgia (Koprulu, 2009, p. 194). Seria contudo o presidente francês Nicolas Sarkozy a alcançar um cessar-fogo entre as partes. Perspetivando um relacionamento mais estável no longo prazo, Ancara propôs a criação de uma Plataforma de Estabilidade e Cooperação para o Cáucaso (PECC), um projeto que ainda está por se materializar. ${ }^{69}$

Contudo, e apesar da postura defensiva da Turquia, foi de certa forma inevitável que o seu relacionamento com a Rússia sofresse alguns danos causados pela sobreposição de interesses geo-estratégicos (Koprulu, 2009, p. 6). A Turquia rejeitou, numa primeira fase, a entrada de navios norte-americanos no Mar Negro, uma medida que deixou particularmente irritados os seus parceiros da OTAN. Porém, quando Ancara acabou por deixar passar três navios norte-americanos, seria a vez de o governo russo manifestar o seu descontentamento, alegando que a Turquia estava a actuar em violação da Convenção de Montreux de 1936 que regula a passagem de embarcações para o Mar Negro (Weitz, 2010, p. 81). A juntar a isso, a Rússia ficou particularmente insatisfeita por saber que a Turquia, pouco depois do fim do conflito, estava a preparar o envio de equipamento militar para a Geórgia70 (Terterov et al, 2010, p. 198).

Desde 2011, as atenções dos dois países têm-se centrado no Médio Oriente, com a Primavera Árabe no topo da agenda dos dois países. Em particular, na Síria, onde é profundo o desentendimento entre os dois países sobre a melhor política a seguir para resolver o conflito interno entre as forças do regime de Bashar al-Assad e vários movimentos de oposição. A Turquia tem tentado, desde o início da crise, alcançar uma posição comum com a Rússia, mas isso tem-se revelado impossível, em virtude dos diferentes interesses que Ancara e Moscovo têm na Síria:

69 Um aspeto interessante da proposta turca era o facto de esta não ter incluído nem ter avisado antecipadamente os seus parceiros europeus e norte-americanos (Koprulu, 2009, p. 193), facto que agradou à Rússia que viu na proposta um plano de desenvolvimento de relacionamento com a Turquia baseado num jogo de soma nula com os EUA (Torbakov, 2008, p. 26).

70 Já em 2006, a Turquia tinha oferecido 1.8 milhões de dólares em ajuda militar a Tiblisi, com quem de resto mantém um acordo de cooperação na área da defesa (Torbakov, 2008, p. 9). 
para a Rússia trata-se de garantir que a Síria continua a ser uma zona de influência e que lhe garanta a sua presença militar no Mediterrâneo através da (pequena) base naval que possui em Tartus. Para a Turquia, está em causa a instabilidade na sua vizinhança, com implicações diretas para a sua própria estabilidade interna, não só devido ao elevado número de refugiados que diariamente se desloca para a fronteira turca como pela possível criação de um enclave curdo no norte da Síria, o que faria ressuscitar em Ancara os fantasmas do irredentismo curdo. É pois natural que a questão síria seja um tema importante no topo da agenda de relacionamento bilateral entre a Turquia e a Rússia (Donat, 2012).

Contudo, e apesar das profundas divergências entre os dois países relativamente a esta questão, russos e turcos parecem decididos a não deixar que a questão síria mine o seu bom relacionamento. Numa visita de Erdogan a Moscovo em julho de 2012, o primeiro ministro turco e o presidente russo estiveram lado a lado numa conferência de imprensa o tema dominante foi a cooperação económica, tendo somente feito um breve comentário à situação de guerra civil na Síria (Today's Zaman, 2012). Para a Rússia, mais preocupante que a própria diferença de posições relativamente ao regime de Bashar al-Assad, é o facto da política turca para a Síria assinalar uma clara harmonização de posições com os seus parceiros da Aliança Atlântica, o que depois do ainda por concluir episódio da instalação de um sistema de radar anti-mísseis norte-americano na província de Malatya, no sudeste da Turquia ${ }^{71}$, deixa Moscovo particularmente alarmado sobre o grau de re-ajustamento da política externa turca com o ocidente (Bacik, 2012).

Em suma, no campo securitário, a Rússia e a Turquia jogam, uma vez mais, um jogo de ambivalência estratégica, aproximando-se no sentido de promoverem iniciativas comuns - como a participação da Rússia desde 2006 numa operação de policiamento militar no Mar Negro - que ajudem na afirmação das suas posições na região, particularmente em oposição

71 Em setembro de 2011 a Turquia chegou a acordo com os Estados Unidos para instalar um radar antimísseis no contexto do escudo de defesa antimíssil da OTAN, previsto desde a Cimeira de Lisboa, em novembro de 2010 (cf. Shanker, 2011). 
à influência dos EUA (Hill e Taspinar, 2006, p. 82), ao mesmo tempo que procuram limitar essa mesma influência de forma mútua. $O$ atual jogo geopolítico no Médio Oriente é um bom exemplo disso mesmo.

\section{Aspetos definidores do relacionamento entre Ancara e Moscovo}

O relacionamento entre a Rússia e a Turquia é marcado por um curioso paradoxo cultural no sentido em que é a diferença clara entre estes dois países que os torna tão semelhantes no seu comportamento internacional. Ancara e Moscovo privilegiam um relacionamento mútuo assente em princípios realistas, conscientes das suas mais valias e limitações. Há uma tentativa clara de explorar sinergias onde estas são uma clara mais valia, sem a necessidade de incluir discursos de proximidade ideológica ou cultural. No que concerne ao relacionamento mútuo, a Rússia e a Turquia procuram expandir as suas zonas de influência, ao mesmo tempo que privilegiam a cooperação de curto prazo em matérias de interesse mútuo, num discurso pautado pelo interesse nacional (Aras, 2009, p. 137) e esvaziado de alusões normativas. Como referem James Warhola e William Mitchell (2006, p. 138):

"Para o bem e para o mal, as relações entre a Federação Russa e a República Turca têm sido poupadas a complicações derivadas de um possível questionamento relativamente aos tipos de regime político, a alegações de abusos de direitos humanos ou a posturas político-morais de ambos os lados relativamente ao outro."

Um aspeto interessante no relacionamento entre estes dois países diz respeito à sua 'utilidade' na autonomização (no caso da Turquia) e na afirmação (no caso da Rússia) das suas políticas externas face aos EUA. Como tivemos ocasião de ver no caso dos conflitos no Cáucaso do Sul, apesar de nem sempre haver um entendimento entre Ancara e Moscovo, é claro para ambos que os EUA não devem ter uma posição predominante na região (Koprulu, 2009, p. 194). O mesmo se aplica à Ásia Central 
(cf. Warhola e Mitchell, 2006), em que os interesses russos e turcos são bastante semelhantes: combate ao terrorismo e crime organizado, e exploração de recursos energéticos (Weitz, 2010, p. 79). Em questões centrais da segurança internacional que envolvem os EUA, tanto a Turquia como a Rússia adotam, frequentes vezes, posições semelhantes: é assim relativamente à questão nuclear no Irão, foi assim relativamente ao apoio à invasão do Afeganistão e foi assim relativamente à oposição à invasão do Iraque (The Economist, 2009).

Foi possivelmente no sentido de fortalecer um eventual distanciamento de Ancara relativamente ao ocidente que a Rússia apoiou a entrada da Turquia para a Organização de Cooperação de Xangai com o estatuto de 'parceiro de diálogo' (Today's Zaman, 2011). Contudo, as boas relações entre o presidente norte-americano Barack Obama e o primeiro ministro turco Recep Tayyip Erdogan, juntamente com a aproximação estratégica no quadro da OTAN e no contexto da Primavera Árabe, têm, de certa forma, levado a um relativo 'fracasso' desta estratégia. É visível a importância estratégica atribuída pela atual administração americana às suas relações com a Turquia: no conflito sírio, a Turquia e os EUA surgem, frequentemente, lado a lado e nem o 'verão quente' turco, com milhões de pessoas nas ruas a exigir mudanças na política do governo do AKP, levou a mais do que um simples puxão de orelhas por parte de Washington.

\section{Conclusão}

Como tivemos oportunidade de observar ao longo deste capítulo, a Rússia e a Turquia têm hoje em dia um relacionamento de convergências de interesse, particularmente interesses económicos e energéticos. Este relacionamento pode ser explicado internamente pela existência de lideranças políticas fortes e estáveis - Erdogan na Turquia, Putin na Rússia - e externamente por um contexto internacional favorável à ascensão de um conjunto de potências emergentes no sistema internacional, que, particularmente após a crise financeira de 2008, adquiriram um protagonismo crescente na esfera internacional (Onis, 2011, p. 48). O tipo de 
relação entre a Rússia e a Turquia deve pois ser entendido, não somente como algo de específico a estes dois países, mas como algo que pode ser exemplificativo do padrão de relacionamento que progressivamente marca este mundo pós-americano (Zakaria, 2008): uma relação forte, desprovida de grandes princípios morais e focada sobretudo na prossecução de objetivos de natureza económica. Esta não é uma relação definida por qualquer proximidade cultural, por fortes laços de confiança (Terterov, 2010, p. 198) ou por uma grande substância política (Hill e Taspinar, 2006, p. 90); é, sobretudo, uma relação pragmática. Por isso, independentemente da maior ou menor aproximação da Turquia ao ocidente, da divergência de opiniões relativamente ao conflito sírio, ou da contradição de interesses no Cáucaso, o relacionamento entre Rússia e Turquia continuará a ser pautado pelo interesse estratégico dos dois países.

\section{Bibliografia}

AKKAN, Faruk - Turkey, Russia improve ties, eye further cooperation. Today's Zaman, 1 janeiro 2012. [Acedido a 5 de ago. de 2012]. Disponível na Internet: http://www. todayszaman.com/news-267353-turkey-russia-improve-ties-eye-further-cooperation.html.

ALTUNISIK, M. - Turkey's new activism in the Middle East. Negócios Estrangeiros. N. ${ }^{\circ} 14$ (2009), p. 29-39.

AKÇALI, Emel e PERINÇEK, Mehmet - Kemalist Eurasianism: An Emerging Geopolitical Discourse in Turkey. Geopolitics. Vol. 14 (2009), p. 550-569.

ARAS, Bulent - The Davutoglu Era in Turkish Foreign Policy. Insight Turkey. Vol. 11, N. 3 (2009), p. 127-142.

BACIK, Gokhan - Turkey and Russia in the Arab Spring: Straining Old Rifts Further?. On Turkey Series, The German Marshall Fund of the United States, 2012.

COSKUN, Bezen Balamir e CARLSON, Richard - New Energy Geopolitics: Why does Turkey Matter?. Insight Turkey. Vol. 12, N. ${ }^{\circ} 3$ (2010), p. 205-220.

DAVUTOGLU, Ahmet - Turkey's Zero-Problems Foreign Policy. Foreign Policy. 2010. [Acedido a 26 de ago. de 2012]. Disponível na Internet: http://www.foreignpolicy.com/articles/2010/05/20/ turkeys_zero_problems_foreign_policy?print=yes\&hidecomments=yes\&page=full.

DONAT, Gozde Nur - Turkey tries best to convince Russia, Iran to help solve Syrian crisis. Today's Zaman, 26 agosto 2012. [Acedido a 15 de set. de 2012]. Disponível na Internet: http://www.todayszaman.com/news-290512-turkey-tries-best-to-convince-russia-iran-tohelp-solve-syrian-crisis.html.

Economist, The - Turkey and Russia. Old Rivals, new partners, 13 agosto 2009. [Acedido a 12 de set. de 2012]. Disponível na Internet: www.economist.com/node/14216768.

EDIGER, Volkan e BAGDADI, Itir - Turkey-Russia Energy Relations: Same Old Story, New Actors. Insight Turkey. Vol. 12, N. 3 (2010), p. 221-236. 
GORVETT, Jon - Chechen Question Harms Turkish-Russian Relations. Eurasia Insight. 2002. [Acedido a 5 de jun. de 2011]. Disponível na Internet: http://www.eurasianet.org/ departments/insight/articles/eav110702a.shtml.

HILL, Fiona e TASPINAR, Omer - Turkey and Russia: Axis of the Excluded?. Survival. Vol. 48, N. $^{\circ} 1$ (2006), p. 81-92.

Hurriyet Daily News - Nabucco start delayed as North Stream moves ahead, 6 junho 2011. [Acedido a 12 de set. de 2012]. Disponível na Internet: http://www.hurriyetdailynews.com/ default.aspx?pageid=438\&n=nabucco-start-delayed-as-north-stream-moves-ahead-2011-05-06.

KAZAN, Isil - Turkey: Where Geopolitics still matters. Contemporary Security Policy. Vol. 26, N. $^{\circ} 3$ (2005), p. 588-604.

KOPRULU, Kemal - Paradigm Shift in Turkey's Foreign Policy. Brown Journal of World Affairs. Vol. XVI, N. ${ }^{\circ} 1$ (2009), p. 185-201.

Ministry of Foreign Affairs - Turkey's Political Relations with Russian Federation, 2008. [Acedido a 6 de jun. de 2011]. Disponível na Internet: http://www.mfa.gov.tr/turkey_spolitical-relations-with-russian-federation.en.mfa.

ONIS, Ziya - Multiple Faces of the 'New' Turkish Foreign Policy: Underlying Dynamics and a Critique. Insight Turkey. Vol. 13, N. ${ }^{\circ} 1$ (2011), p. 47-65.

ROBERTS, John - Turkey as a Regional Energy Hub. Insight Turkey. Vol. 12, N. 3 (2010), p. 39-48.

SHANKER, Thom - U.S. Hails Deal with Turkey on Missile Shield. The New York Times, 15 setembro 2011. [Acedido a 26 de out. de 2012]. Disponível na Internet: http://www. nytimes.com/2011/09/16/world/europe/turkey-accepts-missile-radar-for-nato-defenseagainst-iran.html?_r=0.

SOLER I LECHA, Eduard - The Conceptual Architecture of Turkish Foreign Policy: An update in light of regional turbulence. Documentos CIDOB. N. ${ }^{\circ}$ 18, 2012.

TEKIN, Ali e WILLIAMS, Paul - EU-Russian Relations and Turkey's Role as an Energy Corridor. Europe-Asia Studies. Vol. 61, N. ${ }^{\circ} 2$ (2009), p. 337-356.

TEKIN, Caner - Turkish foreign policy in the 21st century: institutional idealism revisited. Turkish Review. Vol. 1, N. ${ }^{\circ} 4$ (2011), p. 30-35.

TERTEROV, Marat; VAN POOL, John e NAGORNYY, Sergiy - Russian Geopolitical Power in the Black and Caspian Seas Region: Implications for Turkey and the World. Insight Turkey. Vol. 12, N. ${ }^{\circ} 3$ (2010), p. 191-203.

Today's Zaman - Turkey disappointed over third veto of UN draft resolution on Syria, 20 julho 2012. [Acedido a 12 de ago. de 2012]. Disponível na Internet: http://www. todayszaman.com/news-287104-turkey-disappointed-over-third-veto-of-un-draft-resolutionon-syria.html.

Today's Zaman - Turkey to become 'dialogue partner' at SCO, 4 novembro 2011. [Acedido a 14 de ago. de 2012]. Disponível na Internet: http://www.todayszaman.com/news261928-turkey-to-become-dialogue-partner-at-sco.html.

TORBAKOV, Igor - The Georgia Crisis and Russia-Turkey Relations. Washington DC: The Jamestown Foundation, 2008.

TORBAKOV, Igor - Russia and Turkish-Armenian Normalization: Competing Interests in the South Caucasus. Insight Turkey. Vol. 12, N. ${ }^{\circ} 2$ (2010), p. 31-39.

ULUTAS, Ufuk - Turkish Foreign Policy in 2009: a Year of Pro-activity. Insight Turkey. Vol. 12 , N. ${ }^{\circ} 1$ (2010), p. 1-12.

WARHOLA, James e MITCHELL, William - The Warming of Turkish-Russian Relations: Motives and Implications. Demokratizatsiya. Vol. 14, N. ${ }^{\circ} 1$ (2006), p. 127-143. 
WEITZ, Richard - Russian-Turkish Relations: Steadfast and Changing. Mediterranean Quarterly. Vol. 21, N. ${ }^{\circ} 3$ (2010), p. 62-85.

YILDIZ, Taner - Turkey's Energy Policy, Regional Role and Future Energy Vision. Insight Turkey. Vol. 12, N. ${ }^{\circ} 3$ (2010), p. 33-38.

YINANÇ, Barçin - Old rivals, new partners: Turkey and Russia's journey from Cold War to hot sun, Hurriyet Daily News, 8 agosto 2010a. [Acedido a 12 de ago. de 2012]. Disponível na Internet: http://www.hurriyetdailynews.com/default. aspx? pageid=438\&n=from-coldwar-to-hot-sun-2010-08-06.

YINANÇ, Barçin - Old rivals, new partners: Russia and Turkey, tied by energy dependence, Hurriyet Daily News, 8 setembro 2010b. [Acedido a 12 de ago. de 2012]. Disponível na Internet: http://www.hurriyetdailynews.com/default.aspx?pageid=438 $\&$ n=russia-andturkey-tied-by-energy-dependence-2010-08-09.

ZAKARIA, Fareed - The Post-American World. New York: W. W Norton \& Company Ltd, 2008. 
(Página deixada propositadamente em branco) 


\title{
CA P ÍTULO 10
}

\section{A POLÍTICA EXTERNA RUSSA EM RELAÇÃO AO} NORTE: A DIMENSÃO SETENTRIONAL E OÁTICO

\author{
Alena Vysotskaya Guedes Vieira ${ }^{72}$
}

\section{Introdução}

Esta contribuição visa analisar a política externa da Rússia em relação ao Norte, no contexto das relações entre a Rússia e o ocidente, desde o fim da Guerra Fria até à atualidade. O Norte pode ser definido de várias maneiras, mas seja qual for a definição, a Rússia sempre fará uma grande parte dele. Esta contribuição adota a definição mais ampla, incluindo no 'Norte' tanto os oito países árticos ${ }^{73}$ como também bálticos, enquanto se foca na visão russa sobre a cooperação entre a Rússia e a União Europeia (UE) no âmbito da Iniciativa da Dimensão Setentrional (Northern Dimension Initiative), bem como na política externa russa na época de ascensão do Ártico. A primeira representa uma iniciativa que visa ultrapassar a lógica da geopolítica da Guerra Fria, através da intensificação de cooperação nas várias áreas, criando assim interdependência entre a Rússia e o ocidente, que se traduziria

\footnotetext{
${ }^{72}$ Esta contribuição baseia-se na análise de bibliografia primária e secundária, bem como nas entrevistas da autora com altos oficiais da UE e da Finlândia durante a sua estadia em Helsínquia, como Visiting Researcher, no Finnish Institute of International Affairs, entre fevereiro e abril de 2008.

73 Rússia, Dinamarca, EUA, Noruega e Canada (os 'cinco' árticos costeiros) bem como a Islândia, Suécia e Finlândia. Este grupo de países é conhecido como os 'oito países árticos' (Young, 2011, p. xxiii).
} 
no aumento da segurança na região (o processo conhecido como de-securitarização). O caso do Ártico, por sua vez, parece desafiar a lógica das iniciativas como a Dimensão Setentrional, uma vez que as alterações climáticas anunciam o regresso das considerações geopolíticas no Norte e a prioridade atribuída aos assuntos de hard security em relação aos assuntos de soft security, assinalando assim a prevalência de modos de cooperação semelhantes aos que caracterizavam a região durante a Guerra Fria, introduzindo a possibilidade de uma 're-securitarização'.

Enquanto o capítulo confirma o aumento da assertividade na política externa russa, ele visa também demonstrar os limites da ação de Moscovo ao longo desta linha no Norte e especialmente no Ártico, que se estabelecem (a) no contexto mais amplo de cooperação entre a Rússia e o ocidente/UE, (b) em relação às motivações de cooperação económica entre as partes, bem como (c) em relação à contínua busca da identidade russa, tanto ao nível nacional como internacional.

\section{O pós-Guerra Fria e as implicações para o Norte}

Durante a Guerra Fria, o Norte, e especialmente o Ártico, foi um palco de contestação entre os dois blocos. Nestas áreas geográficas encontravam-se as linhas mais curtas de comunicação aérea entre as zonas mais populosas da União Soviética e os Estados Unidos da América (EUA). $\mathrm{Na}$ estratégia de dissuasão, o Norte foi o lugar ideal onde se cruzaram rotas planeadas dos bombardeiros de longo alcance e dos mísseis intercontinentais. A região foi uma das mais militarizadas e 'nuclearizadas' do mundo, como é o caso da península de Kola (Lassinantii, 2000). Como resultado, durante muito tempo foi fácil associar considerações geopolíticas ao Norte, o que deixou o seu marco na diplomacia dos atores internacionais em relação a esta região. Este marco é visível ainda hoje, tanto no facto da referida península de Kola continuar como uma região de alta concentração de armas, reatores e material nuclear (Baev, 2002, p. 10), como a atenção que Moscovo atribui às operações e ao trânsito 
dos submarinos nucleares de mísseis balísticos (Ship Submersible Ballistic Nuclear, SSBN). ${ }^{74}$

Durante décadas, a cooperação entre os países do Norte foi quase inexistente. ${ }^{75} \mathrm{O}$ impulso definitivo para a alteração do modo de cooperação internacional no Ártico foi dado pelo 'discurso de Murmansk' de Mikhail Gorbachov em outubro de 1987 (Gorbachov, 1987), que pode ser considerado o ponto de viragem na história do Norte. Este discurso incluía propostas para a cooperação entre a URSS e o ocidente, desde a definição de uma zona sem armas nucleares e redução de atividades militares, até à cooperação civil na área de desenvolvimento dos recursos naturais, bem como cooperação em áreas científicas, ambientais, e ainda a abertura da passagem marítima a norte (Northern Sea Route) aos navios estrangeiros (Atland, 2008, p. 290). O discurso de Murmansk, que foi positivamente recebido pelas lideranças dos países da região, foi seguido pelo 'processo Rovaniemmi', que resultou na instituição do Centro de Investigação de Ártico, e na organização de uma série de conferências durante a década de noventa.

O 'processo Rovaniemmi', especialmente apoiado pela Finlândia, foi acompanhado e seguido por projetos e ideias similares, apoiados pelo Canadá, EUA, Noruega e Suécia. No outono de 1993, a Noruega lançou a dupla iniciativa que visava estabelecer a cooperação tanto entre os governos como com as autoridades regionais da região de Barents. Surge, assim, o Conselho Euro-Ártico de Barents (BEAC) e a Região Euro-Ártica de Barents (BEAR), com o intuito de promover integração e cooperação entre os países para a resolução dos problemas comuns da região. No âmbito deste processo, foi ainda estabelecido, em Otava, em 1996, o Conselho do Ártico, enquanto fórum de alto nível para promover a cooperação, coordenação e interação entre os cinco países do Ártico e

\footnotetext{
74 Os submarinos russos no Norte acolhem mais de metade das 576 ogivas nucleares. Informação de acordo com as informações russas no âmbito das negociações START (2010). Disponível em http://russianforces.org.navy/, consultado em 21 fevereiro 2012.

75 Neste caso, refere-se à Rússia, Dinamarca, EUA, Noruega e Canadá (os 'cinco' árticos costeiros) bem como a Islândia, Suécia e Finlândia. Este grupo de países também é conhecido como os 'oito países árticos' (Young, 2011, p. xxiii).
} 
três países nórdicos, a Finlândia, a Suécia e a Islândia. Em setembro de 1997, os EUA lançaram a Northern European Initiative (NEI), para apoiar a construção de uma região económica e socialmente unida.

Em resultado destes desenvolvimentos, na segunda metade dos anos noventa, o Norte estava coberto por uma densa rede de iniciativas, que visavam resolver diversos problemas da região no sentido do 'espírito de Murmansk'. Apesar das variações em termos de número e da geografia dos Estados participantes, bem como das prioridades temáticas, as novas organizações apresentavam traços comuns. Em primeiro lugar, todas elas visavam estabelecer uma cooperação multilateral entre os países do Ártico, nórdicos e bálticos, integrando também a Rússia, no sentido de mitigar a tensão entre o leste e o ocidente. O objetivo destas iniciativas foi estabelecer um novo padrão nas relações entre os Estados, emancipando-se das considerações tradicionalmente associáveis a esta região. Em segundo lugar, a cooperação estava orientada para áreas não militares, com especial destaque para os problemas ambientais. Neste sentido, as novas iniciativas contribuíram para a alteração da agenda securitária do Norte, onde os assuntos de soft security assumiram um novo papel na agenda das organizações internacionais e dos Estados individuais.

Para além da reação positiva da parte da Rússia a todas estas iniciativas (Rowe, 2009, p. 143), que foi acompanhada pela redução das forças militares até ao mínimo indispensável, é importante reconhecer que o Norte não foi tratado como uma região prioritária na política externa russa. A cooperação com os parceiros no Norte representava uma dimensão regional da política de aproximação com o ocidente que as lideranças russas adotaram na primeira metade da década de noventa. Nesta política, o Norte foi considerado o 'fundamento' da nova Casa Comum Europeia que se afigurava como o tema recorrente nos discursos políticos desta época (Stålvant, 2001, p. 4). Como resultado, a política externa soviética, e posteriormente, russa em relação ao Norte na sua fase inicial foi guiada pelos mesmos princípios, motivos e razões que estavam subjacentes ao estabelecimento das novas relações com outras regiões, i.e. Ásia Pacífico e Mediterrâneo (Keskitailo, 2007, p. 195), nomeadamente a redução das tensões com o ocidente. 
Além disso, é importante reconhecer as implicações do leitmotiv da política externa russa na sua fase inicial imediatamente depois da dissolução da União Soviética, i.e. a aspiração de fortalecer a cooperação com o ocidente e juntar-se às organizações internacionais mais relevantes. No início dos anos noventa, a questão do modo de definição da agenda de cooperação do Norte não representava uma prioridade: Moscovo estava preparado para aceitar a agenda para a cooperação regional definida pelos parceiros ocidentais como um passo no caminho para a futura integração com o ocidente (Rowe, 2009, p. 146). Como resultado, a posição secundária do Norte em relação à prioridade de aproximação ao ocidente em termos gerais definiu o primeiro padrão da relação entre as partes nesta região, onde o papel da Rússia pode ser descrito como de policy-taker. Isto significava, efectivamente, que os atores ocidentais avançavam com as propostas de agenda de cooperação, enquanto a Rússia, por sua vez, raramente avançava com propostas que contestavam a agenda proposta pelos seus parceiros ocidentais.

\section{O Norte enquanto plataforma de cooperação entre a Rússia e a UE: um novo padrão de cooperação (em análise)}

Entre todas as iniciativas lançadas (no Norte) com o intuito de estabelecer novas relações entre os países do Norte, destacava-se a iniciativa de Dimensão Setentrional ${ }^{76}$ da UE (Northern Dimension Initiative). Apesar da sua distância temporal do 'discurso de Murmansk' de Mikhail Gorbachov, a iniciativa partilhava com todas as propostas lançadas anteriormente os principais objetivos, como a proteção do ambiente, atenção aos assuntos de saúde na região, o seu desenvolvimento sustentável, bem como a aspiração de criar uma interdependência positiva entre as partes que se transformasse, eventualmente, no aumento de segurança na região. A iniciativa visava reunir regularmente, à mesa de negociações,

${ }^{76}$ A tradução 'Dimensão Nórdica' não é completamente correta (vf.: Northern, não Nordic Dimension). 
a Rússia, os Estados membros da UE, e os países bálticos "para aumentar a prosperidade, fortalecer a segurança e de forma resoluta combater os perigos associados, por exemplo, à poluição ambiental, riscos nucleares e crime organizado transfronteiriço" (Comissão Europeia, 1998, p. 1).

Ao mesmo tempo, a iniciativa da Dimensão Setentrional apresentava traços que a diferenciava das outras iniciativas. Em primeiro lugar, destacava-se pela sua cobertura geográfica, englobando as regiões nórdicas, do Báltico e do Ártico, estendendo-se, ao mesmo tempo, ao noroeste da Rússia e a toda a região do Mar Báltico até às áreas árticas da Gronelândia no ocidente, e aos Urais no leste. ${ }^{77} \mathrm{Em}$ segundo lugar, a iniciativa visava incluir vários tipos de participantes, nomeadamente Estados, municípios, câmaras de comércio, universidades e cidades. Além disso, englobava os três Conselhos mais importantes da região: o Conselho dos Países Bálticos (Council of the Baltic Sea States), o Conselho Euro-Ártico de Barents (Barents Euro-Arctic Council), e o Conselho do Ártico (Arctic Council). Finalmente, a Dimensão Setentrional visava integrar atores sub-regionais, como por exemplo, o Conselho de Ministros Nórdico e Báltico (Nordic and Baltic Council of Ministers). Como resultado, a mesa de negociações numa Cimeira da Dimensão Setentrional tinha que ter a capacidade de acomodar quarenta delegações (Henriksson, 2006, p. 118).

Deste modo, a iniciativa visava funcionar como um guarda-chuva para outras organizações e iniciativas da região, com o objetivo de alinhá-las com o funcionamento dos programas da UE. Determinada a evitar a criação das novas instituições e o desvio dos fundos comunitários, a Dimensão Setentrional visava encontrar o efeito de sinergia entre os projetos e as instituições já existentes. O ponto importante foi a participação das instituições internacionais de crédito, que representavam o 'valor acrescentado' prezado pelos protagonistas da iniciativa. Deste modo, numa reunião da Dimensão Setentrional, tanto ao nível dos funcionários públicos como ao nível ministerial, estão presentes ao lado dos representantes dos

77 Uma das facetas da Dimensão Setentrional é a 'Arctic Window', que visa promover e realizar os interesses específicos da UE no Ártico e que foi especialmente apoiado pela Dinamarca. 
Estados membros da UE e da Comissão Europeia, a Rússia, a Noruega e a Islândia, e também instituições como o Banco Europeu de Investimento, o Banco Europeu de Reconstrução e Desenvolvimento, ou o Banco Nórdico de Investimento.

A adoção oficial da Dimensão Setentrional ocorreu durante a primeira presidência finlandesa do Conselho da UE, na primeira cimeira dos ministros dos negócios estrangeiros em 1999. Em junho de 2000, durante a segunda presidência portuguesa, foi adotado o primeiro Plano de Ação (2000-2003), que foi seguido pelo segundo Plano de Ação (2003-2006). Avaliando os resultados desta iniciativa desde o seu lançamento até aos dias de hoje, pode-se afirmar que a Dimensão Setentrional alcançou importantes objetivos nas áreas do ambiente, combate ao crime organizado e cooperação no âmbito de tecnologias informáticas. Entre os exemplos de sucesso desta cooperação encontravam-se a Parceria para o Ambiente (Northern Dimension Environmental Partnership), ${ }^{78}$ lançada em 2001 e com fundos previstos de mais de dois bilhões de euros, e a Parceria para Saúde Pública e Bem-Estar (Northern Dimension Partnership in Public Health and Social Well-being).

Entretanto, a maior parte dos analistas, tanto na UE como na Rússia, concordava com o facto de que os sucessos da iniciativa eram modestos, especialmente quando comparados com as suas aspirações na altura da conceção desta iniciativa em 1997. Olhando para os resultados da cooperação, tanto a Rússia como a UE não poupavam críticas ao processo. A UE criticava o facto de que a Rússia não estava em condições de apoiar financeiramente os projetos e, por esta razão, permanecia afastada da realização prática da Dimensão Setentrional. ${ }^{79}$ Também as lideranças russas não estavam satisfeitas com os resultados da iniciativa, apontando como principal desafio da Dimensão Setentrional as dificuldades de coordenação entre os vários projetos e os seus

78 O foco desta Parceria são problemas relacionados com águas residuais, resíduos sólidos, poluição atmosférica, eficiência energética e resíduos nucleares.

79 Neste ponto, a crítica dos países ocidentais participantes na Dimensão Setentrional é semelhante à crítica inicialmente avançada em relação aos participantes russos no âmbito de outras iniciativas, como o Conselho do Ártico, onde o envolvimento 'esporádico' dos oficiais impedia o desenvolvimento da iniciativa (Rowe, 2009, p. 145). 
participantes (Markushina, 2005, p. 29). Devido ao modo de funcionamento da iniciativa, que tinha a ver com o facto das propostas de cada região da Federação Russa serem enviadas diretamente para a Comissão Europeia, ultrapassando Moscovo (com o objetivo de criar o espírito de common ownership já ao nível regional), surgiram propostas, no âmbito do Primeiro Plano de Ação, de projetos muito similares, planeados para serem realizados simultaneamente lado a lado, como no caso da construção das três fábricas de pasta de papel no noroeste da Rússia (Markushina, 2005, p. 29). Apesar dos governadores de cada uma das regiões terem apoiado entusiasticamente propostas deste tipo, elas não contribuíam da melhor forma para o desenvolvimento do noroeste da Rússia. Além disso, a Dimensão Setentrional foi inicialmente interpretada em Moscovo como parte da política dos atores ocidentais direcionada para ajudar a Rússia a ultrapassar a fase mais difícil da sua transformação e facilitar a integração do país na economia mundial. Ao longo da evolução desta iniciativa, Moscovo convenceu-se de que a mesma estava formatada para realizar, em primeiro lugar, os interesses da UE, nomeadamente mitigar as consequências negativas da fronteira entre a Rússia e a UE, conhecida como a mais assimétrica de toda a Europa (Stålvant, 2001, p. 3).

Os representantes russos nem sempre concordavam com estas prioridades, preferindo destacar o desenvolvimento da indústria e infra-estrutura no território do noroeste do país. A ausência de projetos neste sentido dentro da Dimensão Setentrional levou os representantes russos a pensar que a UE iria simplesmente extrair os recursos naturais russos do noroeste do país sem oferecer nada em concreto em troca. De acordo com o vice-primeiro ministro Viktor Khristenko, a Dimensão Setentrional não poderia contribuir para o aprofundamento do padrão que tinha como o seu ponto central 'projetos isolados' orientados para as exportações das matérias-primas russas (Khristenko, 2001, p. 18), mas deveria estabelecer, de acordo com as preferências russas, "um instrumento para o desenvolvimento do noroeste do país” (Khristenko, 2001, p. 18).

Moscovo sentia-se posto à margem pela interpretação da ideia original que estava na base da Dimensão Setentrional, nomeadamente a 'interdependência positiva', desde o início apresentada como relativa 
ao aumento das relações nas várias áreas que eventualmente se traduziria no aumento de segurança na região, por parte da UE (Voronov, 2003, p. 77). Os Planos de Ação foram essencialmente concebidos pela Comissão Europeia, sem reservarem à Rússia qualquer papel consultivo. Apesar de prever consultas entre os vários participantes russos nos projetos, a decisão final foi tomada unilateralmente pela Comissão, impondo assim a sua visão da iniciativa sobre a Rússia (Haukkala, 2010, pp. 156-159). Como resultado, os representantes russos podiam aceitar ou ignorar a iniciativa, sem a poderem contudo alterar. Apesar das alterações temáticas entre o Primeiro e o Segundo Plano de Ação terem ido ao encontro de algumas críticas russas, orientadas para inclusão no âmbito da iniciativa dos assuntos de transportes e da infra-estrutura (Haukkala, 2010, p. 156), estas alterações não foram suficientes para introduzir um padrão mais simétrico de cooperação entre a Rússia e a UE no âmbito da Dimensão Setentrional.

Esta crítica russa à Dimensão Setentrional refletia a crítica das relações entre a Rússia e a UE de modo mais geral, que se fazia sentir cada vez mais desde a chegada ao poder de Vladimir Putin em 2000. Por exemplo, a Estratégia Comum da UE em relação à Rússia foi vista como uma iniciativa unilateral, que refletia os interesses domésticos da UE (Haukkala, 2010, pp. 97-99) e representava uma abordagem típica da UE, sem permitir à Rússia participar na formulação e desenvolvimento de iniciativas. A leitura das relações UE-Rússia que se fazia em Moscovo não correspondia, de modo algum, ao padrão que deveria estar na base de uma parceria. De acordo com a visão de Moscovo, a parceria deveria assentar num padrão onde cada um dos parceiros estaria preparado para fazer concessões, alterar as suas prioridades, e até modificar a sua legislação (Likhachev, 2006).

A implementação dos programas da Dimensão Setentrional previa também uma certa autonomia das regiões da Federação Russa na escolha dos projetos. Depois da mudança na presidência russa de Boris Ieltsin para Vladimir Putin, a política de Moscovo foi no sentido de não aprovar o aumento da autonomia das regiões da Federação. Como já referido, as lideranças russas justificavam esta postura com a falta de coordenação dentro da iniciativa, que criava duplicações e problemas de responsabilidade (Markushina, 2005, p. 29). Contudo, o que realmente preocupava 
Moscovo eram as tendências centrífugas nas regiões da Federação, que o Kremlin via proporcionadas pela cooperação com os parceiros ocidentais no âmbito da Dimensão Setentrional. As lideranças russas temiam que a cooperação entre os parceiros ocidentais e as regiões russas se transformasse numa divisão interna da Federação Russa, ou seja, em Moscovo cresciam dúvidas relativamente às verdadeiras intenções dos parceiros ocidentais.

Como resultado, na altura da 'crise' da Dimensão Setentrional em 2005, o maior problema para o futuro desta iniciativa prendeu-se com a posição crítica da Rússia. Esta última não estava interessada em participar numa iniciativa que considerava profundamente assimétrica, e onde a UE definia os termos e as prioridades da cooperação. A importância da visão russa sobre a iniciativa para o futuro da Dimensão Setentrional aumentou significativamente depois da entrada da Polónia e dos países bálticos para a UE em 2004. Este facto mudava a motivação principal da Dimensão Setentrional, definida como integração da Rússia no mundo democrático, fortalecendo, ao mesmo tempo, a cooperação com os países pequenos na região, especialmente os países bálticos. Depois do alargamento, desaparecia a necessidade de coordenação entre as políticas de apoio à adesão dos países bálticos e da Polónia, por um lado, e as políticas orientadas para a Rússia, por outro. A Dimensão Setentrional enfrentava assim um dilema: alterar a sua filosofia, ou perder a sua relevância para a ação externa da UE. A primeira destas duas opções estava intrinsecamente ligada ao aumento do interesse e apoio de Moscovo.

Entretanto, os diplomatas finlandeses estavam determinados em utilizar a sua segunda presidência em 2006 para reformatar a iniciativa, procurando apoios entre os participantes e promovendo-a tanto dentro como fora da UE. A partir de 2005, durante meses, o trabalho do departamento da Dimensão Setentrional do ministério dos negócios estrangeiros finlandês consistia em constantes visitas, conferências e apresentações da iniciativa fora do país. O departamento da Dimensão Setentrional acabou por ser chamado the flying unit dentro do ministério (Entrevista, 2008). A estratégia dos diplomatas finlandeses apostava na demonstração dos resultados já obtidos, como no âmbito da Parceria Ambiental, bem como 
no fortalecimento da posição dos três importantes parceiros da UE, nomeadamente a Noruega, a Islândia e a Rússia.

Como resultado do esforço da diplomacia finlandesa, a essência da nova Dimensão Setentrional foi definida de acordo com as expetativas russas: uma vez que a cooperação estava desenhada explicitamente como tendo por base um padrão simétrico, onde todos os quatro parceiros - a UE, a Noruega, a Islândia e a Rússia - mantinham participação de pleno direito e igualdade de responsabilidades. Este facto foi o que mais convenceu Moscovo a apoiar a Dimensão Setentrional no seu novo formato. A nova Dimensão Setentrional foi uma iniciativa 'com', e não 'sobre' a Rússia e com isso, Moscovo via a sua crítica reconhecida nas alterações na política da UE no sentido de criação de uma parceria. Maimo Henriksson, uma diplomata finlandesa, definiu a alteração da Dimensão de seguinte maneira: "A Dimensão Setentrional foi transformada numa política comum da UE, Rússia, Noruega e Islândia. Deste modo, a Rússia, a Noruega, e a Islândia tornaram-se parceiros iguais da UE. A Rússia alterou o seu papel de objeto para o sujeito ativo desta iniciativa" (Henriksson, 2006, p. 118).

Em Moscovo, a criação de uma iniciativa partilhada entre os parceiros iguais foi vista como um passo em frente em relação à política avançada unilateralmente pela UE, acabando, ao mesmo tempo, com a prática dos Planos de Ação com a duração de três anos. A Rússia participa na nova Dimensão Setentrional, em todas as estruturas e atividades da iniciativa. De notar é que a nova Dimensão Setentrional acabava por representar uma expressão regional dos Quatro Espaços Comuns, aprovados em maio de 2005 (Declaração Política, 2006; Documento Quadro 2006). As prioridades da nova Dimensão Setentrional refletiam este facto: incluíam a proteção civil como o assunto prioritário da 'segurança externa', enquanto a cooperação transfronteiriça, era definida como cross-cutting issue, representando "a principal mais valia da Dimensão Setentrional, continuando a assegurar que não voltem a erguer-se linhas de divisão no Norte da Europa" (Comunicado de Imprensa Conjunto sobre a IV Reunião Ministerial relativa à Dimensão Setentrional, 2005; Documento Quadro, 2006). A nova Dimensão Setentrional estabelecia uma ligação entre a cooperação transfronteiriça e o objetivo de atingir, no longo prazo, 
o livre movimento de pessoas entre a Rússia e a UE (tal como definido na Cimeira UE-Rússia em São Petersburgo em 2003). Verificava-se, mais uma vez, a aproximação das prioridades temáticas da iniciativa às prioridades de Moscovo.

Assim, a posição da Rússia em relação à iniciativa mudou de uma postura de policy-taker, para a postura de policy-maker. Além das alterações institucionais já referidas, a nova postura proativa manifestava-se no apoio financeiro para as parcerias individuais por parte da Rússia. No caso da Parceria Ambiental, a Rússia é o segundo maior financiador da iniciativa (60 milhões de euros), depois da Comissão Europeia (84 milhões). A alteração da postura de Moscovo no caso de Dimensão Setentrional reflete, mais uma vez, a alteração da postura russa em relação à UE em termos gerais, que é visível na análise comparativa dos dois documentos que regulam esta relação: o Acordo de Parceria e Cooperação e o Acordo sobre os Quatro Espaços Comuns (Vysotskaya, 2008; Haukkala 2010).

Enquanto o primeiro documento é claro sobre a aproximação da Rússia à UE como objetivo principal, tanto em termos da adoção unilateral dos valores como do acquis communautaire da UE (neste caso, a Rússia deveria "esforçar-se para tornar a sua legislação gradualmente compatível com a legislação comunitária"), o segundo documento afasta-se desta visão de cooperação (Acordo de Parceria e Cooperação, 1997). No caso dos Espaços Comuns, não só desaparece a ideia de aproximação russa às normas da UE como a principal referência para o desenvolvimento da relação, mas também a aproximação ao acquis não é definida como uma tarefa exclusivamente da Rússia. Em vez disso, o texto indica a necessidade de chegar às normas e regulações "harmonizadas e compatíveis" (Road Map for the Common Economic Space, 2006, p. 1). A definição dos termos de cooperação representa, deste modo, um assunto onde a Rússia avança com as suas críticas, alterando, efetivamente, os fundamentos da relação entre os parceiros.

Ao mesmo tempo, tanto na sua versão anterior como depois do upgrade, a Dimensão Setentrional continua a demonstrar limitações, nomeadamente relativas ao alargamento das áreas de cooperação. Por exemplo, as Parcerias da Dimensão Setentrional não incluem uma Parceria Energética, ao contrário dos planos iniciais e das tentativas dos protagonistas desta 
iniciativa nesse sentido. Este facto prende-se com várias razões, entre elas a determinação dos países bálticos e da Polónia em reduzir a sua dependência da Rússia, uma limitada margem de manobra da UE em relação aos Estados membros nesta matéria, bem como a definição de políticas em questão como os assuntos de interesse nacional ou até de segurança nacional - tanto na Rússia como na UE (Godzimirski, 2008, p. 157).

\section{A cooperação entre a Rússia e o ocidente e a ascensão geopolítica do Ártico}

Se em 2007 havia analistas e políticos que acreditavam no 'espírito de Murmansk' como o principal motivo de cooperação entre países nórdicos, esta visão veio a ser desafiada pelas mais recentes alterações no Ártico. A nova importância desta região está relacionada, em primeiro lugar, com o aumento de temperatura global, provocado pelas alterações climáticas, atividades humanas e poluição, que diminuem, por sua vez, a espessura do gelo e do solo permanentemente congelado, conhecido como permafrost (Ho, 2011, p. 35). O degelo do permafrost é, por sua vez, responsável pelas taxas recorde da diminuição do gelo no Ártico. De acordo com informações divulgadas pelo Centro de Dados sobre a Neve e o Gelo, sediado no Instituto de Investigação em Ciências Ambientais no Colorado, Estados Unidos, a velocidade da redução da calota polar do Ártico atingiu um nível recorde em agosto de 2012 (National Snow and Ice Data Center, 2012). Considerando a taxa de degelo atual, alguns cientistas como Peter Waadhams da Universidade de Cambridge prevêem o desaparecimento completo do gelo no Ártico durante o verão, já a partir de 2016 (Harrabin, 2012).

As alterações no Ártico produzem não só desafios ecológicos (libertação de metano, e aumento do nível das águas do mar), mas também outro efeito importante, nomeadamente o aumento da acessibilidade do Ártico para atividades humanas. Para além das implicações comerciais, relacionadas, por exemplo, com a possibilidade de aumentar o comércio de pesca e desenvolver turismo na região, a nova acessibilidade do Ártico 
tem implicações geopolíticas. Em primeiro lugar, surgem perspetivas da exploração do petróleo e gás natural no Ártico. De acordo com as previsões da equipa de geólogos norte-americanos liderada por Donald Gautier, o Ártico contabiliza 13\% do petróleo não descoberto e 30\% de gás natural (Gautier et al., 2012, p. 1217). O Ártico aumenta a segurança energética dos países da região que se orientam, cada vez mais, para exploração petrolífera na região. Entre os notáveis exemplos neste contexto são as medidas adotadas pela liderança dos EUA. Em janeiro de 2012, o presidente norte-americano Barack Obama abriu 75\% das reservas do petróleo e gás natural na plataforma continental dos EUA, acabando, assim, com a história de proibições e moratórias sobre a exploração petrolífera na plataforma continental que remontam aos anos oitenta.

A longo prazo, a exploração petrolífera no Ártico poderá alterar o preço do petróleo e do gás natural nos mercados internacionais, ainda que o exato efeito dependerá da procura nos mercados internacionais, e a tecnologia disponível nos Estados árticos litorais que por sua vez determina os custos de exploração. Estas previsões são ainda importantes uma vez que na medida em que os países como a Alemanha e o Japão se afastem da exploração da energia nuclear, aumentará a procura de petróleo e gás natural. De notar é que o Ártico representa uma região mais estável do que o Médio Oriente: a exploração petrolífera no Ártico pode abrir a possibilidade de contornar, a longo prazo, a Organização dos Países Exploradores de Petróleo (OPEP).

Entretanto, as oportunidades de exploração petrolífera, por um lado, e as preocupações ambientais, por outro, apresentam um dilema relativamente ao equilíbrio entre estas duas dimensões. A exploração petrolífera nas regiões polares está relacionada com sérios desafios, uma vez que nenhum dos países possui a tecnologia que permite lidar com derramamentos de petróleo no Oceano Ártico, cuja possibilidade é elevada dada a frequência de catástrofes naturais. Foram exatamente estas preocupações, relacionadas com um possível derramamento de petróleo nas condições agrestes do Ártico que levaram os representantes da organização ambiental Greenpeace a organizar protestos contra a política da Gazprom Neft Shelf, entre 24 e 28 de agosto de 2012. O objetivo específico da Greenpeace 
foi interromper o processo da preparação, por parte da empresa, da plataforma de petróleo Prilazlomnaya no Mar de Pechora - protestando assim contra os planos de perfuração de petróleo no Ártico. Entre 24 e 28 de agosto de 2012, os ativistas escalaram a plataforma e bloquearam a âncora da nave 'Anna Akhmatova' que assegurava o transporte com a plataforma. Os representantes da Greenpeace estavam especialmente preocupados com o facto dos serviços de emergência e proteção civil mais próximos se situarem em Murmansk, i.e. cerca de $1000 \mathrm{~km}$ da localização da Prilazlomaya. A Greenpeace exigia da Gazprom o cancelamento dos planos de perfuração ou, pelo menos, a definição de um um plano de contingência para um eventual derramamento.

Para além da exploração petrolífera como uma importante implicação do degelo do Ártico, existe mais um factor que deve ser tomado em consideração: a região torna-se navegável, abrindo assim a possibilidade de novas rotas de navegação e transformações importantes para o comércio global. A viagem entre os portos da Europa e os portos da China ou Japão poderá demorar até uma semana menos do que através da rota do Canal do Suez. Isto explica o interesse cada vez mais pronunciado no Ártico por parte da China, cuja economia depende em grande medida dos custos de transporte marítimo (em agosto de 2012, o quebra-gelo chinês Xuelong realizou a sua primeira viagem no Ártico). Por estes motivos, a China, tal como a UE, pretende obter estatuto de observador permanente do Conselho do Ártico, em maio de 2013.

Entretanto, a nova navegabilidade do Ártico, tal como a exploração petrolífera, apresenta custos, nomeadamente o aumento dos riscos securitários da região. O incremento do trânsito marítimo suscita a necessidade de reforçar o seu controlo, o que exige reforço da frota de quebra-gelos, investimentos nos sistemas de navegação e também uma presença militar ou policial reforçada. Esta última medida prende-se com o possível aumento do terrorismo e crime organizado. Por último, o Ártico levanta uma importante questão sobre o desenho da governação e o modo de cooperação entre os atores desta região.

Dadas as alterações no Ártico, não surpreende o facto de a região se ter tornado o centro de atenção dos poderosos atores políticos e económicos 
da região, incluindo os EUA, o Canadá, a Noruega e a Dinamarca. Ainda proporcionou o envolvimento de outros atores de fora desta região - não só a China, mas também a Índia, o Japão, a Coreia do Sul e Singapura (Young, 2011, p. xxiv). Os interesses destes países variam desde a formulação de programas de investigação até políticas concretas em relação ao Ártico. No contexto desta nova postura de muitos países, surgiu a dúvida sobre o caráter das relações entre os países interessados na região. Foi referida, várias vezes, a expressão 'corrida ao Ártico', deixando em aberto a questão se as alterações teriam a capacidade para uma potencial 're-securitarização' desta região (Atland, 2008, p. 209), ou seja, a prioridade das considerações geopolíticas nas políticas externas e nas agendas das organizações internacionais, que já foi característica desta região durante a época da Guerra Fria. Esta maior atenção prende-se com a publicação dos novos documentos por parte dos ministérios da defesa dos cinco países árticos litorais - Canadá, Dinamarca, Noruega, Estados Unidos e Rússia (Wezeman, 2012, p. 7), onde o risco de um conflito entre os participantes está explicitamente referido. Mais do que isso: três países, nomeadamente o Canadá, a Dinamarca e a Rússia, optaram pelo aumento da presença militar, bem como das capacidades militares para uso no Ártico (idem).

No que se refere aos instrumentos do Direito Internacional, o papel central cabe à Convenção Internacional do Direito do Mar, da Organização das Nações Unidas (ONU). Assinada em 1982 e ratificada em 1994, esta Convenção define a Zona Económica Exclusiva (que inclui os recursos submarinos) a ser constituída por 200 milhas náuticas (360 quilómetros), contados a partir da costa polar. Entretanto, os países podem alargar o território da exploração dos recursos naturais desde que se prove que a fronteira da plataforma continental se estende para além deste limite. Entre os países que estão a trabalhar para apresentar a respetiva proposta no sentido de redefinir os limites da sua plataforma no Ártico encontram-se a Dinamarca, o Canadá, os EUA, a Noruega, a Islândia e a Rússia. Entretanto, a legislação internacional deixa alguma margem para interpretação, o que leva à existência de algumas disputas entre os países árticos, como por exemplo, entre o Canadá e os EUA. De notar que os EUA assinaram mas não ratificaram a Convenção Internacional do Direito 
do Mar, e não podem apresentar a proposta à Comissão de Limites da Plataforma Continental.

A Rússia constitui um ator central no Ártico devido à sua extensa costa (a maior) e com as reservas mais significativas de gás e petróleo. Não surpreende por isso que a Rússia represente um dos mais ativos atores a tentar definir e influenciar a cooperação intergovernamental no Ártico. Esta política inclui tanto os traços que apontam para uma postura cooperativa como aqueles que demonstram a postura assertiva e às vezes ofensiva por parte de Moscovo.

A política da Rússia em relação ao Ártico é muitas vezes avaliada em função da expedição 'Arktika 2007'. Esta expedição ocorreu em agosto de 2007, e foi chefiada pelo vice-presidente da Duma e explorador russo Artur Chilingarov. A expedição incluía o navio de investigação 'Academik Fedorov', reforçado com o quebra-gelo nuclear 'Rossiya'. No âmbito desta expedição, dois mini-submarinos (Mir-1 e Mir-2) instalaram uma bandeira russa no leito oceânico ártico, a uma profundidade de 4200 metros, juntamente com uma cápsula de metal que continha a bandeira do partido 'Rússia Unida' (liderado naquele período por Vladimir Putin). De acordo com Chilingarov, a expedição visava demonstrar a posição russa em relação à zona conhecida como a Cordilheira de Lomovosov, que a Rússia considera fazer parte da extensão da sua plataforma continental, e que está a ser contestada pelo Canadá e Dinamarca (Ogonyok, 2010). Fora da Rússia, esta expedição suscitou uma reação crítica nos meios de comunicação social internacional, que proclamava uma 'Nova Guerra Fria'. Esta expedição suscitou uma forte crítica do governo canadiano, avançada pelo (ex)-ministro dos negócios estrangeiros Peter MacKay, que declarou que a Rússia "não podia simplesmente andar pelo mundo a colocar as suas bandeiras" (Current Digest of the Post-Soviet Press, 2007).

A expedição de Chilingarov parecia assinalar uma alteração na política russa em relação ao Ártico. O Norte foi elevado ao estatuto de região prioritária na 'Estratégia para a Segurança Nacional da Federação Russa até 2020' (Strategy, 2009). Além disso, em 18 de setembro de 2008, foi adotada uma nova estratégia para o Ártico, designada 'Fundamentos da Política da Federação Russa no Ártico até 2020' (Osnovy, 2008). Os documentos 
demonstram a aspiração em atuar como 'potência-líder do Ártico', com especial atenção para os recursos energéticos, e incluíram referências a potenciais conflitos com outros países relativamente às Zonas Económicas Exclusivas no Ártico. As prioridades da política externa russa são definidas como (a) a passagem marítima a norte, (b) as questões energéticas, (c) assuntos militares, bem como (d) o quadro legal internacional, definido pelas Nações Unidas e pela UE. Além disso, o Ártico é representado como uma futura "base estratégica de referência da Rússia para os recursos naturais" (Osnovy, 2008). Ao mesmo tempo, a nova estratégia no Ártico estipula a criação de duas brigadas militares especializadas para o Ártico, do exército russo e Serviço de Proteção de Fronteiras, com o objetivo de proteção das regiões no norte da Rússia.

Além disso, a Rússia aumentou as suas atividades militares no Ártico, tanto em termos da presença reforçada da Marinha como da Força Aérea. A Frota do Norte representa a maior frota das cinco frotas russas, com bases navais e aéreas ao longo das costas do Mar de Barents e do Mar Branco, bem como na Península de Kola. Esta frota contém submarinos nucleares com mísseis balísticos cuja atuação se tornou mais ativa desde 2004. Depois de uma década, foram retomadas as patrulhas dos submarinos nucleares debaixo do gelo ártico bem como nas outras zonas marinhas longe da costa, e a Rússia tem novamente realizado testes com mísseis no Mar Branco, Mar de Barents e no Oceano Ártico (Atland, 2011, p. 243). Os antigos submarinos foram modernizados e novos estão a ser construídos. O reforço das atividades dos submarinos aumenta, por sua vez, a necessidade de reforçar a Marinha e a Frota Aérea. Em junho de 2008, o ministério da defesa da Rússia reforçou a presença da Frota do Norte no Ártico. Entre 2006 e 2008, o número das patrulhas pelos bombardeiros ao longo da costa da Noruega aumentou sete vezes (Zysk, 2011, p. 86).

É importante referir que as alterações nas atividades da Marinha e Força Aérea russa não representaram uma postura excecional no Ártico, uma vez que outros países, como já indicado acima, também optaram por reforçar a sua postura militar. Entretanto, as medidas adotadas por Moscovo em relação ao Ártico coincidiram com um discurso mais assertivo cultivado pelas lideranças russas em relação ao ocidente a partir do 
segundo mandato presidencial de Vladimir Putin. O símbolo desta nova postura foi o discurso de Putin em Munique em fevereiro de 2007 (Putin, 2007). A aspiração de atuar enquanto grande potência que se apoiava nas suas próprias forças e recursos militares, e que não possuía interesses necessariamente compatíveis com o ocidente, foi o ponto central da sua mensagem. A política do presidente Dmitri Medvedev, a partir de 2008, continuava, em larga medida, esta linha. A ascensão económica da Rússia, que permitia o reforço das forças militares e a modernização das capacidades militares, incluindo o arsenal nuclear, parecia confirmar a linha da política externa traçada nas declarações de Vladimir Putin e Dmitri Medvedev (Zysk, 2011, p. 90).

Apesar dos traços assertivos na política externa russa que entram rapidamente nos títulos dos jornais, seria errado caracterizar a política da Rússia em relação ao Ártico como uma política sem traços cooperativos. A Rússia é membro do Conselho Euro-Ártico de Barents e do Conselho Regional de Barents, desde 1993, bem como do Conselho do Ártico desde 1996. Em 2011, durante a Sétima Reunião Ministerial do Conselho do Ártico, que teve lugar em Nuuk, capital da Gronelândia, os representantes da Rússia assinaram o primeiro documento vinculativo do Conselho, a Declaração sobre Busca e Salvamento (The Arctic Council, 2011). A Rússia desempenhou um papel crucial neste processo, como comprovado pelo artigo de Sergey Lavrov onde se demonstrava uma apreciação positiva da postura russa nesta matéria (Lavrov, 2011). Em Moscovo, foi notado que o Conselho do Ártico estava disposto a considerar assuntos definidos como de interesse nacional, como em relação à passagem marítima a norte (Skak, 2012). Desde 2010, a Frota do Norte participa nos exercícios militares conjuntos com a Noruega, organizados anualmente; 'Pomor-2012' decorreu em maio de 2012. Os exercícios da OTAN, 'Bold Monarch', em maio e junho de 2011, contaram, pela primeira vez, com a participação do primeiro submarino russo. Enquanto a Rússia defende a sua soberania no Ártico, a realização desta aspiração assenta no uso dos instrumentos do Direito Internacional. Quanto ao incidente com a implantação da bandeira, os representantes russos afirmam que esta ação de 2007 era um ato de importância científica e não política (representante 
da Embaixada Russa na Suécia, citado em Bergh e Oldberg, 2011, p. 8). De acordo com esta interpretação, a ação da expedição de Chiligarov, representava um marco na primeira tentativa realizada com sucesso para chegar às profundezas do leito do Oceano Ártico, e não é diferente das outras ações deste tipo, como, por exemplo, a implantação da bandeira norte-americana na lua (Izvestia, 2007).

Depois da ratificação da Convenção das Nações Unidas sobre o Direito do Mar em 1997, Moscovo submeteu, em 2001, a primeira proposta à Comissão de Limites da Plataforma Continental. De acordo com a proposta, o alargamento para 1,2 milhões de $\mathrm{km}^{2}$ adicionais justificava-se pelo facto de se tratar de uma continuação da plataforma siberiana. A proposta não foi aprovada por falta de provas científicas. Em agosto de 2013, a Rússia entregou uma nova proposta à Comissão de Limites da Plataforma Continental, relativa à plataforma do Mar de Ochotsk. O objetivo (oficial) de expedição de Artur Chilingarov referida acima foi, deste modo, o de obter mais informação geológica para re-submissão da proposta. De lembrar também que a Rússia assinou a Declaração de Ilulissat durante o encontro dos cinco países do Ártico (Canadá, Dinamarca, Noruega, Rússia e EUA) em maio de 2008, que reitera a importância dos instrumentos e normas do Direito Internacional para a resolução dos vários e complexos problemas do Ártico e apresenta mecanismos para resolução das disputas territoriais (The Ilulissat Declaration, 2008).

A Rússia não tentou antagonizar as disputas sobre as fronteiras nesta região (Baev, 2010, p. 20). Uma prova disto é o acordo sobre a delimitação da fronteira marítima no Mar de Barents e no Oceano Ártico entre a Rússia e a Noruega, assinado em Murmansk em 15 de setembro de 2010. O acordo foi ratificado durante a primavera de 2011 e o Tratado entrou em vigor em 7 de julho de 2011. Este acordo, que demorou 40 anos para ser assinado, sinalizou que os dois países árticos possam chegar a concluir o 'compromisso de Barents' e facilitar a cooperação na região (Kefferpütz e Bochkarev, 2010, p. 7). Além disso, a cooperação entre a Rosneft e as empresas Statoil, ENI e Exxon Mobil na exploração do petróleo no Mar de Barents e de Okhotsk indica o potencial promissor das relações entre 
a Rússia e a Noruega (Solodovnikova, 2012). ${ }^{80}$ A Rússia tem necessidade de entrar em cooperação com as empresas como a Statoil (com participação do Estado da Noruega): a Gazprom e a Rosneft, as únicas empresas que têm permissão para trabalhar no off-shore do norte, precisam dos recursos, tecnologia e experiência dos parceiros ocidentais, especialmente no que diz respeito a exploração petrolífera na plataforma continental do Ártico.

O caso da exploração da reserva de Shtokman serve como uma ilustração do facto que a exploração petrolífera impõe o imperativo de cooperação com as empresas ocidentais, que não foi inicialmente reconhecido em Moscovo. Assim, até 2008, a exploração petrolífera na plataforma continental só podia ser realizada pelas empresas registadas na Rússia, e com a comparticipação de 50\% do Estado. Após 2008, em fevereiro, foi criada a empresa Shtokman Development AG, que contava com a participação, para além da Gazprom, da empresa francesa Total e da Statoil. Nesta última, a participação do Estado da Noruega atinge 62,5\%. Três anos e meio depois, em agosto de 2012, foi anunciada a derrota deste ambicioso projeto da Gazprom. A Statoil abandonou o projeto, citando os altos custos de exploração, que acabaram por ser mais elevados do que era previsto, e tornaram o projeto pouco rentável. Além disso, a decisão da Statoil foi influenciada pela diminuição do preço do gás natural, bem como pelas tentativas da maior parte dos clientes da Gazprom de procurar fornecedores alternativos a esta empresa (Mordyshenko, 2012). Depois da sua saída de Shtokman, a Statoil demonstrou interesse na exploração de gás natural de uma outra reserva russa, juntamente com a Gazprom, nomeadamente 'Bovanenskoye', na penísula de Yamal - a maior reserva de gás natural e o maior projeto russo na área até hoje.

O caso de Shtokman demonstra que a Rússia, determinada em reforçar o seu perfil como grande potência energética, está perante um dilema. A opção de fortalecer a sua autonomia energética através da exploração petrolífera no Ártico só é exequível a longo prazo; todos os benefícios da exploração no médio e curto prazo implicam uma cooperação com as

80 A Gazprom detém 51\% da empresa, enquanto a parte da Total e da Statoil era de $25 \%$ cada. 
empresas ocidentais que possivelmente exigirá alterações na legislação nacional, por exemplo, no código dos impostos. Dado o papel central da energia para a política externa russa, esta última opção significa que os próprios fundamentos da política externa da Rússia estabeleceram limites à sua assertividade, e fazem aparecer os esforços de 'militarização' no Ártico numa outra perspetiva. Do mesmo modo, também os planos da passagem marítima do norte exigirão cooperação com empresas ocidentais, o que por sua vez suscitará a necessidade de uma clarificação do estatuto, em termos do Direito Internacional, das partes do Ártico que a Rússia considera suas.

Ao mesmo tempo, a exploração petrolífera no Ártico detém uma importância especial para Moscovo no contexto das declarações eleitorais de Vladimir Putin em 2012. Nas semanas antes da sua reeleição em março 2012, Putin laçou uma campanha onde prometia aumentar as despesas sociais (o respetivo aumento constituirá 5.1 triliões de rublos russos, ou 170 mil milhões de dólares, de acordo com o Centro de Estudos Macroeconómicos da Sberbank (Kuvshinova, 2012) e subsídios de maternidade, duplicar os salários dos médicos, polícias e professores, e triplicar as bolsas dos estudantes. Além disto, a campanha prometia o rearmamento completo do exército (onde se planeava gastar, ao longo de dez anos, 777 mil milhões de dólares) e construir habitação para os veteranos da guerra. Pelo menos uma parte dos recursos necessários viria da exploração petrolífera e do gás natural do Ártico, referidas por Vladimir Putin várias vezes como as maiores reservas comprovadas do mundo.

Finalmente, a política da Rússia em relação ao Ártico, tal como a política externa em relação ao ocidente em geral, tem que ser avaliada no contexto da procura de identidade nacional e internacional deste país. Vinte anos depois da dissolução da União Soviética, a procura da identidade nacional ainda continua. As declarações relativamente à 'conquista do Norte', que existem na memória coletiva russa, correspondem às expetativas da população russa relativamente à necessidade de uma política externa mais assertiva, que anuncia defender os interesses da Rússia enquanto a 'Grande Potência Ártica'. A conquista do Norte foi realizada durante as heróicas expedições no século XVIII e XIX, 
continuando posteriormente durante a década de 1930, nos tempos de governação de Estaline (Baev, 2010, p. 21). Os sentimentos de orgulho que acompanham estas memórias são fáceis de instrumentalizar para os objetivos políticos contemporâneos, especialmente numa altura em que a 'corrida ao Ártico' cada vez mais parece desafiar a posição prioritária da Rússia bem como a sua influência nesta região.

Medidas como a expedição de Artur Chilingarov têm como objetivo acordar estes sentimentos do eleitorado, que ao mesmo tempo vão contra a grande 'perda' russa na memória coletiva, como a venda do Alasca aos EUA em 1867. De acordo com este sentimento partilhado, para os políticos que querem o apoio do eleitorado, é mais vantajoso defender os 'interesses nacionais vitais' abstratos, do que tentar avaliar os lucros concretos da exploração nas áreas do Ártico. Estes lucros não são tão evidentes como os políticos os apresentam, se considerarmos as dificuldades do processo de exploração nas condições polares agrestes, bem como o custo e as complicações relacionadas com o transporte dos recursos em causa (Baev, 2009, p. 34). O caso da reserva extensa de Shtokman demonstra este facto. Da mesma maneira, a proteção dos 'interesses nacionais vitais' que se traduzem no aumento da atividade da Frota de Norte e da aviação de longo alcance tem por base os mesmos factores identitários, e muito menos o objetivo de confrontação com o ocidente, que não é apoiado por nenhuma estratégia com medidas concretas.

\section{Conclusão}

O Norte representa uma região especial onde os assuntos de hard security e soft security estão intimamente interligados, e onde os modos de relacionamento entre os países são muito diferentes, desde as considerações geopolíticas até à governação de novo tipo promovida pelas organizações regionais e sub-regionais. Estas últimas surgiram na década de 1990 na sequência do 'discurso de Murmansk' de Mikhail Gorbachov e tiveram como objetivo a alteração da lógica da Guerra Fria, e a integração política e económica da Rússia nas organizações e estruturas ocidentais. 
Na sua fase inicial, a política externa russa visava o Norte como uma dimensão regional de aproximação entre a Rússia e o ocidente, que representava o motivo principal da ação externa russa no início dos anos 1990. Neste sentido, a criação de uma pletora de organizações regionais foi positivamente recebida em Moscovo. Uma vez que a mera participação nas várias iniciativas, fóruns e organizações foi considerada como resultado positivo, a determinação, e muito menos a contestação da agenda destas iniciativas não foi vista como uma prioridade. A fase inicial da política externa russa, em termos da cooperação da Rússia com os seus parceiros ocidentais no Norte, pode ser descrita como policy-taker.

A análise da cooperação no âmbito da Dimensão Setentrional da UE demonstra uma alteração nos principais motivos, mensagens e linhas gerais da política externa russa. Ao longo desta iniciativa, a aspiração de integração incondicional foi substituída pela mensagem de compatibilidade dos interesses das duas partes, onde a Rússia insiste numa parceria entre iguais. O novo formato da Dimensão Setentrional comprova o facto de que a posição da Rússia em relação ao ocidente mudou de uma postura de policy-taker, para a postura de policy-maker, que se refletiu, entre outros factos, num aumento significativo do financiamento da iniciativa por parte da Rússia a partir de 2006.

As alterações na política externa russa relativamente à Dimensão Setentrional demonstram uma dinâmica que também é característica nas relações entre a Rússia e a UE. Por outro lado, existe um paralelismo entre a política externa da Rússia em relação à Dimensão Setentrional e outras organizações (sub)regionais. Tal como no caso do Conselho do Ártico, a construção de uma agenda comum é, às vezes, obstruída pelas dúvidas russas acerca das verdadeiras intenções dos parceiros (e vice versa), bem como a reticência em alargar a cooperação às áreas que a Rússia considera estratégicas. Os últimos incluem, em primeiro lugar, os assuntos de hard security, e em segundo lugar, a cooperação no âmbito de exploração energética com os parceiros ocidentais.

O caso da política externa russa em relação ao Ártico serve como confirmação do facto de que a política da Rússia em relação ao Norte não se está a formar exclusivamente como a resposta às propostas ocidentais. 
Relativamente ao seu carácter, pode-se concluir que esta política, apesar do reforço da presença militar russa, está essencialmente orientada para a cooperação com os parceiros ocidentais. O facto que mais comprova este argumento é a postura de Moscovo em relação às fronteiras marítimas da região, onde a política da Rússia assenta no uso dos instrumentos do Direito Internacional.

A contradição entre a postura assertiva da Rússia e a sua aspiração de seguir as normas do Direito Internacional explica-se pelos factores identitários na política externa russa. Na memória coletiva russa, o Norte continua a ocupar um lugar especial. As declarações que fazem ressurgir uma nova 'conquista do Norte', e afirmar os direitos russos ao Ártico, vão ao encontro das expetativas da população russa e são fáceis de instrumentalizar para garantir objetivos políticos. Tanto o aumento da presença militar no Ártico como a expedição de Artur Chilingarov, têm por base a aspiração de acordar estes sentimentos junto do eleitorado, ao contrário de propositadamente piorar as relações entre a Rússia e o ocidente.

\section{Bibliografia}

Acordo de Parceira e Cooperação entre as Comunidades Europeias e os seus EstadosMembros, por um lado, e a Federação Russa, por outro lado (1997) Jornal Oficial no. L 327 de 28/11/1997, p. 0003-0069. [Acedido a 12 de mar. de 2012]. Disponível na Internet: http://eur-lex.europa.eu/LexUriServ/LexUriServ.do?uri=CELEX:21997A1128\%2 801\%29:PT:HTML.

Arctic Council, The - Nuuk Declaration on the Occasion of the Seventh Ministerial Meeting of the Arctic Council, 2011. [Acedido a 5 de mai. de 2012]. Disponível na Internet: http://goo.gl/qhMmd.

ÅTLAND, Kristian - Mikhail Gorbachev, the Murmansk Initiative, and the Desecuritization of State Relations in the Arctic. Cooperation and Conflict. Vol. 43, n. 3 (2008), p. 289-311.

ÅTLAND, Kristian - Russia's Northern Fleet and the Oil Industry: Rivals or Partners?: Petroleum, Security, and Civil-Military Relations in the Post-Cold War European Arctic. Armed Forces E Society. Vol. 35, n. ${ }^{\circ} 2$ (2009), p. 362-384.

ÅTLAND, Kristian - Im Norden nichts Neues? Die Arktis in Russlands Sicherheitspolitik. Osteuropa. Vol. 61, n. ${ }^{\circ}$ 2-3 (2011), p. 243-256.

BAEV, Pavel - Could the Former Super-Power Turn into a Battle-Ground? Russia in 2015, ISF Info 3/02, 2002.

BAEV, Pavel - Troublemaking and Risk-Taking: The North in Russian Military Activities. In Rowe, Elana Wilson, ed., Russia and the North. Ottawa: University of Ottawa Press, 2009. p. 17-34. 
BAEV, Pavel - Russia's Arctic Policy. Geopolitics, Mercantilism and Identity-Building. The Finnish Institute of International Affairs. Briefing Paper n. ${ }^{\circ}$ 73, 17 dezembro 2010.

BERGH, Kristofer e OLDMAR, Ingmar - The New Arctic: Building Cooperation in the Face of Emerging Challenges. SIPRI Conference Report, 26 abril 2011.

Comunicado de Imprensa Conjunto sobre a IV Reunião Ministerial relativa à Dimensão Setentrional, realizada em Bruxelas, em 21 novembro 2005. [Acedido a 10 de mar. de 2012]. Disponível na Internet: http://www.consilium.europa.eu/press/press-releases/ latest-press-releases/newsroomrelated?bid=102\&grp=9423\&lang=pt\&id=.

Current Digest of the Post-Soviet Press - Cold War Goes North - Russia and West Begin Struggle for Arctic. Vol. 59, n. ${ }^{\circ} 21$ (2007).

Declaração Política sobre a Política da Dimensão Setentrional - [Political Declaration on the Northern Dimension Policy], aprovada na Cimeira da Dimensão Sententrional, Helsínquia, 24 novembro 2006. [Acedido a 10 de mar. de 2012]. Disponível na Internet: http://eeas.europa.eu/north_dim/docs/pol_dec_1106_en.pdf.

Documento Quadro da Dimensão Setentrional - [Northern Dimension Policy Framework Document], aprovada na Cimeira da Dimensão Sententrional, Helsínquia, 24 novembro 2006. [Acedido a 10 de mar. de 2012]. Disponível na Internet: eeas.europa.eu/north.../frame_pol_1106_en.pdf.

Entrevista da autora com um alto funcionário do ministério dos negócios estrangeiros da Finlândia, março 2008.

GAUTIER, Donald L. et al. - Assessment of Undiscovered Oil and Gas in the Arctic. Science. Vol. 324, n. ${ }^{\circ} 5931$ (2009), p. 1175-1179.

GODZIMIRSKI, Jakub M. - Russia's energy strategy and prospects for a Northern Dimension energy partnership. In Blakkisrud, Helge; Aalto, Pami e Smith, Hanna, eds., The New Northern Dimension of the European Neighbourhood. Brussels: Centre for European Policy Studies, 2008. p. 145-163.

GORBACHOV, Mikhail - Discurso em Murmansk. Ceremonial meeting on the occasion of the presentation of the Order of Lenin and the Gold Star Medal to the city of Murmansk, 1 outubro 1987. Moscow: Novosti Press Agency, p. 23-31. [Acedido a 21 de mar. de 2012]. Disponível na Internet: www.barentsinfo.fi/docs/Gorbachev_speech.pdf.

Guardian, The - US and Russia stir up political tensions over Arctic, 6 julho 2011. [Acedido a 21 de fev. de 2012]. Disponível na Internet: http://www.guardian.co.uk/world/2011/ jul/06/us-russia-political-tensions-arctic.

HARRABIN, Roger - Arctic Sea Ice Reaches Record Low, NASA says. BBC. Environmental Analysis, 27 agosto 2012. [Acedido a 1 de set. de 2012]. Disponível na Internet: http:// www.bbc.co.uk/news/science-environment-19393075.

HAUKKALA, Hiski - The EU-Russia Strategic Partnership. The limits of post-sovereignity in international relations. London: Routledge, 2010.

HENRIKSSON, Maimo - The New Northern Dimension Policy. Proceedings of the Fourth Northern Research Forum The Borderless North Oulu and Tornio in Finland, and Haparnada and Luleå, Sweden, 5-8 outubro 2006. [Acedido a 21 de fev. de 2012]. Disponível na Internet: http://www.nrf.is/Publications/The\%20Borderless\%20North/Borderless\%20North.html.

Ilulissat Declaration - Arctic Ocean Conference, Ilulissat, Greenland, 27-29 maio 2009. [Acedido a 21 de fev. de 2012]. Disponível na Internet: http://www.oceanlaw.org/ downloads/arctic/Ilulissat_Declaration.pdf.

Izvestia - Lavrov osadil nedovolnych rossiyskim flagom Canady i SSHA, 2007. [Acedido a 12 de mar. de 2012]. Disponível na Internet: http://www.izvestia.ru/news/405525.

KEFFERPÜTZ, Roderick - On Thin Ice? (Mis)interpreting Russian Policy in the High North. CEPS Policy Brief. N. ${ }^{\circ} 205$, fevereiro 2010. 
KEFFERPÜTZ, Roderick e BOCHKAREV, Danila - Expanding the EU's Institutional Capacities in the Arctic Region. Policy Briefing and Key Recommendations. Heinrich Boell Stiftung, EU Regional Office, 2008. [Acedido a 15 de mar. de 2012]. Disponível na Internet:www. boell.eu/web/269-258.html.

KESKITALO, Carina - International Region-Building. Development of the Arctic as an International Region. Cooperation and Conflict. Vol. 42, n. 2 (2007), p. 187-205.

KHRISTENKO, Viktor - Speech at the Northern Dimension Forum, Lappeenranta, Finland. 22 de outubro 2001. [Acedido a 21 de fev. de 2012]. Disponível na Internet: http://www. government.fi/ajankohtaista/tiedotteet/tiedote/en.jsp?oid=95842.

KONYSHEV, V. e SEGOUNIN, A. - Arktika na perekrestke geopoliticheskih interesov. Mirovaya Ekonomika e Meshdunarodyje Otnosheniya. N. 9 (2010), p. 43-53.

KUVSHINOVA, Olga - Sozialnye obeshaniya Putina (As promessas sociais de Vladimir Putin). Vedomosti, 17 fevereiro 2012. [Acedido a 19 de set. de 2012]. Disponível na Internet: http://www.vedomosti.ru/politics/news/1506398/obeschal_5_trln_rub.

LASSINANTII, Gunnar - Initiative of the Barents Region Co-operation and the Northern Dimension. Comunicação apresentada na IPRA Conference, Tampere, Finlândia. 5-9 agosto 2000 .

LAVROV, S. - Nuuk Declaration: A New Stage of Cooperation among Arctic States. 2011. [Acedido a 5 de mai. de 2012]. Disponível na Internet: http://goo.gl/sjjzL.

LIKHACHEV, Vassily - Russia and the European Union. International Affairs - Russian Journal of World Politics, Diplomacy and International Relations. Vol. 52, n. ${ }^{\circ} 2$ (2006), p. 102-114.

MARKUSHINA, Natalyia - Russkie regiony v sisteme meshdunarodych otnoshenij. Fokus na kooperazii Rossii e EC. Na primere Severnogo Izmerenia (Russia's Regions within the System of International Relations: Case-study of Russia-EU Cooperation in the Framework of the Northern Dimension (in Russian). InBev Baillet-Latour Working Paper. Leuven, fevereiro 2005.

MORDYSHENKO, Olga - Gazovyj Pusyrj (A bola de gás). Kommersant. Neft i Gas. Vol. 161, n. ${ }^{\circ}$ 4946, 30 agosto 2012. [Acedido a 19 de set. de 2012]. Disponível na Internet: http:// www.kommersant.ru/doc/2002147? isSearch=True.

National Snow and Ice Data Center - Overview of Conditions, 14 agosto 2012. [Acedido a 19 de set. de 2012]. Disponível na Internet: http://nsidc.org/arcticseaicenews/.

Ogonyok - O glavnyh pokoriteliach Arktiki, 27 outubro 2010. [Acedido a 21 de fev. de 2012]. Disponível na Internet: http://www.kommersant.ru/doc/1503124.

Osnovy gosudarstvennoi politiki Rossiyskoy Federatsii v Arktike na period do 2020 goda i dal'neishnuyu perspektivu - (The Russian Federation's main state policy in the Arctic until 2020 and beyond), 18 setembro 2008. [Acedido a 21 de fev. de 2012]. Disponível na Internet: http://www.scrf.gov.ru/documents/98.html.

PUTIN, Vladimir - Speech at the $43^{\text {rd }}$ Munich Conference on Security Policy, 10 fevereiro 2007. [Acedido a 10 de mar. de 2012]. Disponível na Internet: http://www.securityconference. de/archive/konferenzen/rede.php?menu_2007=\&menu_konferenzen=\&sprache=en\&id=179\&.

Road Map for Common Economic Space - Cimeira UE-Rússia, Moscovo. Conclusões, Anexo 1. 10 maio 2005. [Acedido a 12 de mar. de 2012]. Disponível na Internet: http://ec. europa.eu/environment/enlarg/pdf/road_map_ces.pdf,.

ROWE, Elana Wilson - Russian regional multilateralism: The case of the Arctic Council. In Rowe, Elana Wilson e Torjesen, Stina, eds., The Multilateral Dimension in Russian Foreign Policy. London: Routledge, 2009. p. 142-152.

SKAK, Mette - Denmark. In Lobjakas, Ahto e Mölder, Martin, eds., EU-Russia Watch 2012, 2012. p. 29-35. 
SOLODIVNIKOVA, Anna - Statoil vzyala kurs na Ohotskoe more (Statoil orienta-se para o Mar de Ohotsk), 2012. [Acedido a 5 de set. de 2012]. Disponível na Internet: http:// www.kommersant.ru/doc/2011751?isSearch=True.

STÅLVANT, Carl-Einar, ed. - The Northern Dimension: a Policy in Need of an Institution?. Berlin: Humboldt Universität, vol. 1, 2001. [Acedido a 21 de fev. de 2012]. Disponível na Internet: http://www2.hu-berlin.de/ostseekolleg/virtual/archive_bsn_publ_en.php.

Strategy for National Security until 2020 - (Strategiya natsionalnoy bezopasnosti Rossiizkoy Federatsii do 2020 goda). N. ${ }^{\circ}$ 537, 12 maio 2009. [Acedido a 21 de fev. de 2012]. Disponível na Internet: http://www.scrf.gov.ru.

VORONOV, Konstantin - Severnoe izmereije: zatjanuvshijsja debjut. Mirovaja Ekonomika I Meshdunarodnye Otnoshenia. N. ${ }^{\circ} 2$ (2003), p. 76-86.

VYSOTSKAYA, Alena - Russland, Belarus und die EU-Osterweiterung. Stuttgart: IbidemVerlag, 2008.

WEZEMAN, Siemon T. - Military Capabilities in the Arctic. SIPRI Background Paper, março 2012.

YOUNG, Oran - Arctic Futures: the Politics of Transformation. In Kraska, James, ed., Arctic Security in an Age of Climate Change. Cambridge: Cambridge University Press, 2011. p. xxi-xxvii.

ZYSK, Katarzyna - Military Aspects of Russia's Arctic Policy: Hard Power and Natural Ressources. In Kraska, James, ed., Arctic Security in an Age of Climate Change. Cambridge: Cambridge University Press, 2011. p. 85-107. 


\section{CA P ÍTULO 1}

\section{A QUARTA VAGA DE DEMOCRATIZAÇÃO E A SUA INFLUÊECIA NA RÚSSIA. O I N ÍCIO DA TRANSIÇ̃̃ O?}

Alberto Priego Moreno

Este capítulo analisa os acontecimentos que estão a ter lugar na Federação Russa, incluindo protestos, tumultos, desobediência pública, entre outros, fenómenos que mais não são do que uma demonstração de descontentamento da população com o regime político que o presidente Vladimir Putin lidera. ${ }^{81}$ No entanto, estes acontecimentos não são novos nem sequer especificamente russos, mas antes obedecem a um contexto internacional favorável à democratização tanto no mundo árabe como no mundo pós-soviético. Trata-se de um processo imparável que se iniciou há mais de dez anos com a saída do poder de Slobodan Milosevic na Sérvia, que teve a sua continuação nas revoluções coloridas (Geórgia, Ucrânia, Quirguistão) e que agora se alargou ao mundo árabe muçulmano. Como consequência da globalização, este 'vírus' parece ter afetado outras zonas do planeta como a Federação Russa. Por isso entendemos estar perante uma quarta vaga de democratização que teve a sua primeira fase nas revoluções coloridas e que, hoje, além de varrer os regimes autoritários do mundo árabe, ameaça demolir alguns regimes pós-comunistas como é o caso da Federação Russa.

81 A conceção teórica desenvolvida neste capítulo foi publicada em Priego (2011). 


\section{Quadro concetual}

Concetualmente podemos distinguir dois modos de conceber democracia. Alguns autores consideram a democracia como uma escala onde os sistemas políticos se situam entre um grau máximo ótimo, que poderíamos denominar de democracia perfeita e outro, no extremo oposto, nulo, ${ }^{82}$ que seria composto por regimes não democráticos essencialmente autoritários, mas também totalitários, embora estes últimos sejam bastante menos frequentes. Face a esta conceção que se poderia denominar gradual, encontramos autores que entendem a democracia como dicotómica.

Isto significa assumir a existência de uma linha que separa os regimes que cumprem uma série de características próprias da democracia daqueles que não as cumprem. No seio dos defensores desta segunda conceção, que pode ser qualificada de binária, destacam-se autores como Robert Dahl (1971), Samuel Huntington ou Juan José Linz. Para o desenvolvimento deste estudo baseamo-nos precisamente nesta segunda conceção embora não abandonemos a primeira aproximação já que a linha entre uma e outra é pouco nítida. Em qualquer caso, deve ser deixado claro que a metodologia em que este estudo assenta se insere na metodologia de trabalho desenvolvida pela transitologia (transitology).

Ao longo da história temos visto como a maior parte dos regimes não democráticos têm evoluído até sistemas democráticos através do que denominamos processos de transição. Trata-se de um processo que se inicia no século XIX e que se estende sem interrupção até aos nossos dias. Por isso, podemos afirmar que uma transição é a passagem de um regime não democrático - essencialmente autoritário, embora possa também ser totalitário - a outro regime, onde se dão condições de competência e participação adequadas para que possa ser considerado democrático. Os processos de transição democrática podem iniciar-se através de dois mecanismos distintos: liberalização e revolta-revolução.

82 Esta conceção inspira o Think-Tank Freedom House que elabora um ranking de sistemas políticos numa escala do 1 ao 7 onde 1-2 corresponde a países livres, 3-5 parcialmente livres e 6-7 não livres. Disponível em www.freedomhouse.org. 
Entendemos por liberalização as aberturas parciais de um regime não democrático que não têm por objetivo a transformação geral do mesmo nem sequer a eleição de líderes governamentais através de processos competitivos. Podemos encontrar múltiplos exemplos nos processos de transição recentes, como por exemplo a substituição de Salazar por Caetano em Portugal, a convocatória do referendo de Pinochet em finais dos anos 1980, o malogrado Tratado da União de Gorbachov ou, mais recentemente, a limitação dos mandatos presidenciais introduzida por Raul Castro, em Cuba. A liberalização pretende resolver um problema colocado ao regime quer pela população quer pela comunidade internacional. Mediante estas medidas tratar-se-ia de "despressurizar a panela de pressão" ou de acalmar o clima social. Na maior parte dos casos a liberalização não é mais do que uma forma de acabar com o descontentamento popular e, como dissemos anteriormente, vê-se reforçada pela pressão exercida desde o exterior.

Estas medidas são geralmente adotadas quando os dirigentes de regimes autoritários não são capazes de satisfazer as exigências da população e por isso se vêem obrigados a aceitar um second best ou a tomar medidas que num primeiro momento e de motu próprio nunca seriam levadas a cabo. Em várias ocasiões, o governo apenas procura assegurar a sua sobrevivência ou preparar o seu futuro num regime democrático que se delineie. Em qualquer dos casos, por vezes, a adoção deste tipo de medidas por parte do regime pode ser considerada uma debilidade do mesmo e, a médio prazo, pode mesmo propiciar o seu final.

Partindo de um enfoque sistémico relativamente às transições políticas pode-se argumentar que as populações congregam um conjunto de exigências (input) à autoridade ou governo que, se não forem atendidas em forma de respostas (output), voltam a converter-se em exigências mais radicais, dada a sua não resolução quando anteriormente formuladas. Deste modo, o regime não democrático tenderá a assumir a pressão que a comunidade internacional pode traduzir sob a forma de sanções, influência ou mesmo intervenções. Se a liberalização não solucionar os problemas associados às exigências da população, estes perdurarão no tempo, tornar-se-ão mais graves e, deste modo, encontramo-nos com o segundo caso apresentado neste texto: a revolta ou mesmo a revolução. 
O segundo modo pelo qual se pode iniciar uma transição é o dueto revolta-revolução. Face à ausência de liberalização e quando a pressão exercida pela população é tão grande que possa forçar um governo a demitir-se, e inclusive em algumas ocasiões levar à falência do próprio sistema político, neste caso estamos perante o segundo cenário que designamos de revolta-revolução. Sem dúvida, é necessário diferenciar revolta e revolução. Enquanto a revolução se prende com qualquer alteração que tenha como principal objetivo a derrocada da autoridade, o conceito de revolução - na linha de Hanna Arendt - inclui dois elementos próprios que o diferenciam do conceito de revolta: a procura de uma nova ordem e desejo de liberdade (Arendt, 2004, pp.50-57).

Nem a mudança via liberalização nem a opção revolta-revolução garantem que a mudança política iniciada conduza a uma democracia. De facto, em algumas ocasiões, uma revolta - que não tem por objeto levar à derrocada do poder, mas apenas chamar a atenção para a situação difícil em que se encontra a população - converte-se em processo revolucionário e posteriormente dá lugar à democracia. ${ }^{83}$ Este poderia ser precisamente o caso português. Sem dúvida, noutras ocasiões as revoltas não levaram a nada de concreto ou transformaram o regime num outro tipo de regime como aconteceu no caso do Irão de Khomeini. Este conceito, conhecido como backsliding, não será, no entanto, objeto de análise neste capítulo (Hague e Harrop, 2010, p. 92).

Em suma, podemos afirmar que a transição democrática é o passo para avançar de um regime não democrático para um regime democrático. O processo pode iniciar-se por um processo de liberalização e quando este não se produz, pode acabar por despoletar uma revolta ou revolução que pode levar ao colapso do sistema. Nesta situação, estaríamos também no caminho para uma transição ou, no caso de este não triunfar, estaríamos em vias de transformá-lo noutro regime autoritário com características muito diferentes.

83 No caso dos Estados Unidos da América em 1776 com a Revolta do Chá em Boston que posteriormente deu lugar à Revolução Americana e a um sistema democrático como o norteamericano. 
No caso de liberalizações, estas podem levar a processos de transição que por vezes se prolongam no tempo. Quando isto ocorre, a ausência de perspetiva histórica leva alguns autores a afirmar que as ditaduras se convertem em "ditamacias" ou "democraduras". ${ }^{84}$ Sem dúvida, os partidários de conceções mais dicotómicas da democracia acreditam que a democratização - tal como afirmou Barrington Moore - é um processo vinculado à modernização a que tendem todos os Estados quando incrementam o seu nível de desenvolvimento. Por isso, não devemos falar de "ditamacias" ou "democraduras", mas antes de regimes democráticos ou autoritários. ${ }^{85}$ Este seria o caso da Rússia nos dias de hoje onde, apesar de ter alcançado um nível de desenvolvimento assinalável, a sua população procura cobrir necessidades numa altura em que o governo carece de outras vias que não sejam a eficácia económica para legitimar a falta de democracia e a ausência de respeito pelos direitos humanos.

Neste ponto a aplicação da teoria das "vagas de democratização" de Samuel Huntington faz sentido. Por "vaga de democratização", Huntington entende "um conjunto de transições de um regime não democrático para outro democrático que ocorre em determinado período de tempo e que supera significativamente as transições em direção oposta durante este mesmo período" (Huntington, 1994, p. 26). No entanto, não se trata de uma teoria que serve para explicar a situação que vivemos hoje tanto no mundo árabe como no espaço pós-soviético. Sem dúvida, é necessário clarificar dois pontos. Em primeiro lugar, nem todos os processos de transição se enquadram dentro das vagas de democratização já que em algumas ocasiões encontramos processos alheados destes processos internacionais. Em segundo lugar, deve ser assinalado que a cada uma das vagas se segue uma contra-vaga que tem um efeito contrário. Ou seja, há uma imposição das forças que procuram alterar regimes

${ }^{84}$ Este é o caso dos autores que têm uma perspetiva continuista da democracia, que significa um todo difuso que vai desde os Estados não democráticos aos democráticos com diferentes graus.

85 Para as categorias de regime autoritário e não autoritário ver Linz (2000). 
democráticos por autoritários. ${ }^{86}$ Samuel Huntington afirma que no seu todo se produziram um total de três grandes vagas de democratização às que adicionamos uma quarta que não foi contemplada pelo autor. Entre 2003 e 2011, esta vaga atravessou países como a Geórgia, a Ucrânia, o Líbano, o Irão (fracassada), o Azerbaijão (fracassada), o Egito, a Tunísia, Myanmar, entre outros, e como contra-vaga pós-2011 temos o caso do Paraguai.

A teoria de Samuel Huntington termina nos anos noventa com o colapso do império soviético. Não obstante, a esta terceira vaga, que se centrou sobre todo o sul e leste da Europa, seguiu-se uma contra-vaga de regimes autoritários centrados sobre toda a América Latina e em menor escala na Ásia. Assim, chegamos ao ponto onde centraremos a nossa hipótese de trabalho: a existência de uma quarta vaga ${ }^{87}$ de democratização que estamos hoje a viver e que afeta um grande número de Estados, como é o caso da Rússia (Priego, 2008).

\section{A transição na Federação Russa}

A Federação Russa faz parte de um contexto regional - espaço pós-soviético - que é antes de mais uma região distinta do ponto de vista político. Na zona que compunha a União Soviética encontramos diferentes tipos de sistemas políticos como democracias mais ou menos consolidadas, ${ }^{88}$ Estados em transição, ${ }^{89}$ e regimes de sultanato. ${ }^{90}$ Ainda se podem referir casos como o Turquemenistão, que chegam a tocar a linha do totalitarismo. ${ }^{91}$ Neste contexto produziram-se movimentos sociais

86 Estas contra-vagas têm forças que atuam para alcançar os seus objetivos. Na primeira vaga encontramos os 100.000 filhos de São Luís, na segunda vaga as forças soviéticas que aplicavam a Doutrina Brejnev e nesta quarta vaga as foças do Conselho de Cooperação do Golfo que atuaram para repor a ordem no Bahrein.

87 A tese da quarta vaga de democratização é partilhada por vários autores, dos que se destacam McFaul (2002); Gershman (2011); Grand (2012).

88 Como democracias consolidadas podemos incluir os três Estados Bálticos que são membros da OTAN e da UE.

89 Tanto a Geórgia como a Ucrânia são Estados em transição.

90 Exemplos claros são o Uzbequistão e o Cazaquistão, sendo que não são os únicos.

91 Este seria o caso do Turquemenistão com Turkmenbashi. 
tendentes à democratização que poderiam ser enquadrados dentro do que denominamos quarta vaga de democratização. Exemplos claros são a revolução rosa na Geórgia, laranja na Ucrânia, ou mesmo a revolução das tulipas no Quirguistão. Todos estes processos tiveram impacto na Federação Russa que desde meados da década atual vive um clima em que as exigências dos cidadãos não obtêm resposta adequada da parte das autoridades.

Podemos, com efeito, referir duas fases relativamente aos protestos na Rússia. A primeira (2002-2004) caracteriza-se por distúrbios que podem ser classificados como revoltas, cujo objetivo não é a mudança de regime, mas antes a transformação do mesmo, já que as reivindicações não desafiam o sistema. Face às exigências da população, o regime respondeu com a sua legitimidade baseada no crescimento económico e na segurança. Contudo, a deterioração progressiva desta fonte de legitimidade assente no incremento de insegurança visível na extensão dos atentados de Moscovo e sobretudo na deterioração económica na Rússia, levou a população a radicalizar as suas petições e a alterar as suas posições face ao respeito que nutre pelo regime. Agora, a população russa não pede uma mudança no sistema, mas antes a mudança de sistema (Dmitriev e Danielt, 2012, p. 61).

Esta segunda fase de protestos começa em dezembro de 2011. Agora os manifestantes pedem a democratização da Rússia rejeitando todas as estruturas estabelecidas em 1991. Por isso, podemos afirmar sem receio de equívoco que a Rússia está num processo de transição que se enquadra na quarta vaga de democratização. Com a Rússia em transição é necessário clarificar o tipo de regime de que partimos, o tipo de transição em que estamos, e o tipo de democracia que se alcançaria em caso de esta alteração se concretizar.

\section{O regime político na Federação Russa}

Não há dúvida que a Rússia é um regime não democrático tal como o mostram os principais think tanks que se dedicam ao estudo da democracia. Por exemplo, se olharmos para os estudos da Freedom House damos conta que a Rússia está muito longe de ser uma democracia: entre 2002 e 2006 
foi classificada como 'parcialmente livre' e desde 2006 até 2012 retrocedeu para a classificação de 'não livre'. Outros estudos, como os do Polity IV'2 ou Democracy Index ${ }^{93}$ fazem valorizações similares do regime político russo, não deixando dúvidas quanto à real falta de pluralismo político e da sua natureza autoritária. Devemos destacar a tendência cada vez mais autoritária do regime russo que está refletida nos estudos do semanário The Economist. Em 2011, a Rússia desceu até ao número 117 posicionando-se já próxima de outros regimes autoritários. O Polity IV qualifica o regime russo atual de "close anocracy", o que significa que o pluralismo e a competitividade são muito limitados e a tendência é para que o autoritarismo aumente.

Parece claro que os regimes não democráticos são muitos e devemos por isso concretizar que tipo de regime é o da Rússia nos dias de hoje. A Federação Russa pode definir-se, seguindo J. J. Linz, como um regime autoritário pós-totalitário com elementos de regime de sultanato ${ }^{94}$. Os regimes de sultanato apresentam três características particulares que os tornam únicos: primeiro, uma conceção patrimonial do Estado, assente no conceito weberiano de "sistema político patrimonial", onde as esferas públicas e privadas se confundem. Um exemplo claro deste fenómeno é a empresa Gazprom cujo conselho de administração é liderado por políticos como o anterior primeiro ministro Viktor Zubkov ou o anterior presidente, Dmitri Medvedev. Segundo, um grupo pessoal que assenta o poder na família ou num grupo particular com sucessão dinástica ou designação indireta. No caso da Rússia alguns autores assinalam o denominado "clã de São Petersburgo" do presidente Putin onde encontramos nomes como Georgy Poltavchenko, ${ }^{95}$ Sergei Sobyanin, ${ }^{96}$ ou o próprio Medvedev.

92 Disponível em http://www.systemicpeace.org/polity/Russia2010.pdf.

93 O Democracy Index do Economist Intelligence Unit qualifica o regime russo de híbrido ou mais especificamente como "managed democracy", ver http://graphics.eiu.com/ PDF/Democracy_Index_2010_web.pdf.

94 Classificação obtida em Montero e Milley (2009).

95 Georgy Poltavchenko esteve vinculado ao KGB e foi nomeado por Medvedev governador de São Petersburgo (Okorokova, 2012).

96 Presidente da câmara de Moscovo e homem da confiança de Putin que já foi governador da região de Tyumen. A sua atuação nas manifestações de dezembro de 2011 e de março de 2012 foi muito criticada. Ver Zagorodnov (2010). 
Geralmente trata-se de figuras vinculadas ao aparelho de segurança do antigo regime que são recompensadas com cargos envolvendo grande poder económico para evitar que atuem contra o sistema. Este traço é mais próprio dos regimes pós-totalitários do que dos regimes de sultanato, daí a introdução de algumas características deste tipo de regimes não democráticos (Linz e Stepan, 1996, p. 45). Por último, a utilização pessoal e personalista do Estado, não havendo distinção entre o Estado e a esfera individual uma vez que as estruturas do Estado são utilizadas para benefício do grupo dominante. No regime russo atual criticam-se muito as privatizações levadas a cabo na década de noventa, donde surgiram os denominados oligarcas.

Podemos definir três características principais em termos genéricos como traços fundamentais do regime russo atual. No entanto, existem outros aspetos mais concretos e mesmo menos claros que devem ser assinalados para uma clara definição do tipo de regime que temos hoje na Rússia. Refiro-me ao pluralismo, ideologia, mobilização e liderança. Quanto ao pluralismo, este é permitido a nível económico e social, embora de forma limitada e sempre submetido ao poder do grupo dominante. Exemplos incluem o caso Yukos ou a perseguição e condenação do grupo Pussy Riot ou de alguns líderes da oposição, como Gary Kasparov. No que concerne a ideologia, esta é gerida de forma pragmática, estando ao serviço do governante. Apesar de ter sido usado o nacionalismo e o sentimento antiocidental para mobilizar, também houve períodos de cooperação com o ocidente. Em todo o caso, neste tipo de regimes, e o caso da Rússia não é exceção, há um uso dos símbolos partidários para legitimar o próprio regime e os seus dirigentes. Relativamente à mobilização, apesar de se registar um nível baixo de mobilização na Rússia, esta tem sido instrumentalizada em vários momentos. De facto, quando se produziram episódios de mobilização, quase sempre, estes estiveram ao serviço dos interesses do regime, como por exemplo as manifestações que tiveram lugar a 12 de março em Moscovo, coincidindo com as eleições presidenciais (BBC, 2012).

O factor liderança prende-se com o grande poder detido pelo líder do regime, que recruta os seus subordinados dentro de um círculo da sua confiança. Inclusivamente, o partido político está ao serviço do líder, como 
no caso do partido "Rússia Unida". Não se tolera a emergência de outro líder incluindo dentro do próprio grupo e a lealdade baseia-se no receio de punições e no pressuposto de obtenção de benesses. Neste aspeto, o regime russo atual está mais próximo do regime pós-totalitário do que do regime de sultanato. Legitimidade, o último elemento aqui identificado, prende-se com a melhoria do nível de vida dos russos, cuja referência não seria tanto a União Soviética, mas antes os primeiros anos de independência da Rússia; a questão da segurança dos cidadãos especialmente face à ameaça do terrorismo checheno; e por fim, um elemento que permanece relativamente inalterado que é o poder externo da Rússia como grande potência. Destes três elementos, só o último permanece ativo uma vez que hoje a crise económica e a violência chechena subtraíram legitimidade ao regime do presidente Putin.

Como temos vindo a sublinhar, podemos falar de duas fases nos protestos russos em que o regime atual perdeu legitimidade, o que por sua vez abre a porta à transição na Rússia para o que seria a terceira fase, na qual nos encontramos na atualidade. A primeira fase corresponde à perda de legitimidade em termos de segurança. A tragédia do Teatro Dubrozka em 2002, e sobretudo o sequestro na Escola Número 2 de Beslan (Ossétia do Norte) em 2004 marcou um duro golpe contra o presidente Putin assim como uma radicalização das posições do círculo próximo do Kremlin onde ganharam força políticos como Rogozyn (Priego, 2002). Contudo, não se pode afirmar que estes protestos sociais destabilizaram o regime autoritário russo uma vez que o clima internacional da "guerra contra o terrorismo" permitiu a Putin implementar medidas duras que minaram o caminho da Rússia para a democracia (Priego, 2004). As classes populares com uma cultura política menos desenvolvida aplaudiram estas medidas duras contra os terroristas e começaram a converter-se na "audiência de Putin".97 Mais tarde, nas vezes em que se repetiram atentados terroristas protagonizados por chechenos, parte da população exigiu “a mão dura do presidente Putin” (Priego, 2010).

A segunda fase prende-se com a perda de legitimidade económica. Um dos problemas que a Rússia tem de enfrentar é económico. Até 2007

97 Para uma perspetiva mais ampla do conflito na Chechénia ver Priego (2000). 
a Rússia apresentou números impressionantes de crescimento, muito vinculados aos preços dos hidrocarbonetos. Assim, a descida dos preços dos hidrocarbonetos entre 2008 e 2009 vinculada, entre outros factores, ao surgimento de outras energias alternativas, supõe uma ameaça para a economia russa e, também, contra a legitimidade do próprio regime. A este problema temos que somar a falta de confiança dos investidores que tem provocado a intensificação da fuga de capitais (Satter, 2012).

Conhecendo esta realidade, em meados da década, o governo de Putin decidiu levar a cabo uma série de medidas muito impopulares como elevar as taxas de importação de bens estrangeiros, especialmente veículos ou a monetarização das pensões. O objetivo foi evitar que os problemas económicos pudessem afetar a legitimidade do regime. Contudo, longe de solucionar o problema, o governo enfrentou contestação nas ruas. Segundo alguns políticos da oposição organizaram-se manifestações que envolveram cerca de 300 mil pessoas em cidades como Vladivostok, bem como se registaram os mais baixos níveis de popularidade de Putin. De facto, estes acontecimentos provocaram uma mudança de atitude do governo russo que desde esse momento adotou uma política mais paternalista para com as classes menos favorecidas. Esta levou a um aumento dos gastos sociais limitando os recursos do Estado para implementar os projetos reformistas de Medvedev que pretendiam assegurar um crescimento sustentável necessário para a legitimidade política do regime.

Assim, o regime de Putin encontra-se numa situação de grande complexidade. Perdida a legitimidade gerada pela segurança, deve confiar-se na economia. Por um lado, é necessária uma grande quantidade de recursos a curto prazo para legitimar as políticas sociais que a apoiam, especialmente junto da população mais vulnerável, o que por sua vez obriga a confiar numa economia pouco diversificada assente nos hidrocarbonetos. Esta determinação converte a Rússia numa economia vulnerável pela volatilidade dos preços internacionais da energia. Por outro lado, a necessidade de gastar boa parte dos rendimentos obtidos com a energia em políticas sociais que geram legitimidade política, impede que se apliquem recursos financeiros noutras ações de diversificação da economia e de garantia de um crescimento económico sustentável. Este foi o caso 
do projeto Skolkovo, um Silicon Valley nas imediações de Moscovo que teve de ser cancelado por falta de recursos. Assim, podemos afirmar que perdida a legitimidade relativa à segurança e às dimensões económica e social, o regime russo está destinado a uma transição política que se viu acelerada pelas eleições de 2011.

\section{O início da transição na Rússia: a terceira fase}

Poderíamos fixar as eleições parlamentares de dezembro de 2011 como um ponto de inflexão que marca o início da transição russa. As exigências da população que vinham pressionando o governo foram-se radicalizando face à falta de resposta adequada. Ao mesmo tempo a legitimidade de que gozava o regime com base na economia e na segurança foi-se desvanecendo e assim chegamos às eleições parlamentares de dezembro de 2011 onde a situação mudou radicalmente. Por um lado, a população passou pela primeira vez desde a independência da Rússia a questionar o sistema político. Por outro lado, as exigências mudaram drasticamente passando do pedido de reformas dentro do sistema para a exigência de um novo sistema. O regime político exigido pela oposição é o de uma democracia, o que permite afirmar que na Rússia a transição está em curso, tratando-se de um processo revolucionário, já que cumpre os requisitos identificados por Hannah Arendt como necessários: a procura de algo novo e a sua âncora na exigência de liberdade.

Esta terceira fase inicia-se em setembro de 2011 quando Vladimir Putin é nomeado candidato à presidência em vez de Medvedev (Barry, 2012d). Os cidadãos russos, apesar da política repressiva em áreas como os meios de comunicação social ou o pluralismo político, consideravam que a única opção de mudança para a Rússia passava por um segundo mandato de Medvedev. A alteração de candidato supôs uma descida brusca das expetativas que levou a que os russos passassem a assumir a mudança de sistema ou revolução em lugar de alterações no próprio sistema. Neste sentido, devemo-nos apoiar na teoria de J. Davies para explicar a mudança de mentalidade dos cidadãos russos. Segundo Davies, 
os cidadãos optam pela revolução quando se produz um distanciamento face à realidade, minando as expetativas. Enquanto o diferencial entre realidade e expetativas era visível, a opção desejada pela população era proceder a alterações dentro do regime que solucionariam as disfunções existentes. Além do mais, a situação de segurança e pacificação do Cáucaso do Norte e o bom encaminhamento da economia permitiu crescimento e consequentemente um clima de maior estabilidade. Contudo, a nomeação de Putin como candidato às presidenciais abriu uma caixa de pandora cuja primeira crise chegou em dezembro de 2011, com as eleições parlamentares.

\section{As eleições parlamentares de 2011 e as presidenciais de 2012}

As eleições parlamentares e presidenciais merecem atenção. Tanto as eleições parlamentares de dezembro de 2011 como as presidenciais de março de 2012 foram duramente criticadas pela comunidade internacional e pela própria oposição russa. Como dados mais significativos podemos referir a afluência às urnas na Chechénia que alcançou 99.5\%, número que se torna alvo de suspeição. As eleições de dezembro de 2011 não anteciparam a saída de Putin do poder, mas o fim do monopólio político do seu grupo. Ainda assim, com grandes irregularidades o partido "Rússia Unida" obteve uma importante vitória que, no entanto, não lhe garantiu maioria absoluta na Duma.

Quadro 1: Resultados das eleições parlamentares russas de dezembro de 2011

\begin{tabular}{|l|l|}
\hline Partido Político & Percentagem de votos obtidos \\
\hline Rússia Unida & $49.3 \%$ \\
\hline Partido Comunista Russo & $19.2 \%$ \\
\hline Rússia Justa & 13.2 \\
\hline Democratas Liberais & 11.7 \\
\hline Yabloko & 3.4 \\
\hline Patriotas da Rússia & 1.0 \\
\hline Causa Justa & 0.6 \\
\hline
\end{tabular}

Fonte: RIA NOVOSTI, dezembro 2011 
A pressão internacional e a reprovação interna levaram a grandes manifestações que tiveram o seu ponto culminante no dia 24 de dezembro. As concentrações populares não se reduziram a Moscovo ou São Petersburgo, mas estenderam-se desde o Báltico até Vladivostok. A oposição conseguiu consensualizar um manifesto assinado por personalidades tão diferentes como Mikhail Gorbachov ou o cantor de rap Noize NC, que continha os seguintes cinco pontos:

a) Liberdade dos prisioneiros políticos;

b) Cancelamento dos comícios;

c) Demissão de Vladimir Surkov, concretizada a 27 de dezembro de 2011;

d) Participação da oposição e nova legislação sobre partidos políticos;

e) Democracia livre e comícios transparentes.

Note-se que os últimos pontos comprovam a mudança de atitude da população que já não se conforma com mudanças formais, mas que anseia por uma verdadeira mudança que pode mesmo ser considerada revolucionária. As alterações introduzidas pelo governo, como a demissão de Surkov e a abertura de um processo de investigação não serviram para satisfazer a população que exige uma verdadeira alteração com as características que assinalamos como próprias de uma revolução.

As eleições presidenciais de março não foram muito diferentes embora seja certo que as manifestações não tiveram tanto êxito dada a aprendizagem das autoridades face à má experiência de dezembro de 2011. A polícia russa deteve mais de 100 mil pessoas, muitas delas que se haviam juntado numa manifestação autorizada pelo próprio Kremlin. Entre os detidos encontravam-se membros importantes da oposição, como Alexei Navalni, Serguei Udalzov ou Iliá Iashin. Após a publicação dos resultados, onde se anunciava que Putin tinha obtido $63.81 \%$ dos votos e que por isso não seria necessária uma segunda volta, o vencedor apresentou-se em tom desafiante perante 100 mil seguidores, afirmando que nada nem ninguém se podem impor à Rússia, e que o povo russo sabe distinguir a linha da renovação da linha da destruição, demonstrando os fundamentos da política que tem marcado a sua presidência (Putin, 2012). 
Perante todos estes problemas que assinalamos o regime foi solucionando a situação genericamente com mais dureza e ausência de liberalização, o que foi radicalizando as exigências da população. Ao mesmo tempo, e ainda que seja certo que a oposição esteja desunida, esta foi somando não apenas importantes apoios de diferentes setores da população, bem como importantes figuras da sociedade russa. Contudo, há um elemento fundamental que tem feito variar a situação que nos faz pensar que o processo de transição se acelerou: um contexto internacional mais favorável à democratização. Como analisado ao longo deste capítulo, encontramo-nos na quarta vaga de democratização e isso está a limitar a Rússia nas suas reações. Se bem que é certo que as revoluções coloridas contavam com partidários e detratores nas chancelarias ocidentais, as denominadas revoluções árabes levantaram mais intrepidez que receios. É precisamente neste contexto que devemos enquadrar os protestos nas ruas russas, não apenas como um ataque contra o próprio regime, mas também contra a sua projeção no exterior, já que uma boa parte dos seus aliados internacionais como Khadafi ou Al Assad sofreram ou estão a sofrer situações de extrema gravidade. Além do mais, uma vez que Putin perdeu as duas fontes principais de legitimidade - segurança interna e crescimento económico - apenas resta a manutenção da Rússia como potência global e este ponto também se vê ameaçado pelas mudanças nos equilíbrios de poder provocados pelas revoluções árabes.

Outro aspeto decisivo é a mudança fundamental de atitude da oposição. A aposta na revolução face à revolta permite-nos afirmar que enquanto até dezembro de 2011 a opção era a revolta, ou seja, proceder a alterações no regime, hoje a postura é favorável à revolução já que não se pede uma renovação do regime, mas antes um novo sistema político.

Podemos afirmar que mesmo que não triunfe, o movimento de oposição a Putin cumpre os requisitos que assinalamos como necessários para poder falar de revolução. Por um lado, procura-se algo novo, um novo tipo de organização que nada tenha a ver com a anterior. Neste caso parece que as pretensões dos manifestantes não são outras que a democracia liberal ou legalista, usando a terminologia de David Held (2007). Por outro lado, o movimento seria conduzido pela vontade de liberdade que inspiraria os 
membros da oposição. O exemplo mais claro destes desejos de liberdade é incarnado pelos membros do grupo Pussy Riot que se converteram num ícone tanto nacional como internacional deste movimento.

Podemos assim afirmar que a Rússia se encontra num processo de transição político com características revolucionárias e que tem por objetivo a democratização do país. A opção de Putin volta a ser a repressão face à liberalização desde que regressou ao Kremlin, visível no aumento da repressão tal como demonstra a sua posição relativamente à Síria, a imposição de multas aos manifestantes (Barry, 2012b) e a sentença no caso Pussy Riot, que analisamos em seguida.

\section{O caso Pussy Riot}

Um dos acontecimentos que tem ensombrado este mandato do presidente Vladimir Putin é o denominado caso Pussy Riot. A 21 de fevereiro de 2012, três elementos do grupo punk Pussy Riot - Nadezhda Tolokonnikova, Yekaterina Samutsevich e Maria Alyokhina - irromperam pela Catedral de Cristo Salvador. Depois de se curvarem no altar e se benzerem, começaram a interpretar uma canção em que pediam à Virgem Maria (Theotokos) que livrasse o povo russo de Putin. Fizeram também referências ao Patriarca Ortodoxo Russo - Cirilo I - afirmando que este acreditava mais em Putin do que em Deus. De facto, Cirilo I expressou em algumas ocasiões o seu apoio ao atual presidente russo (Stephen, 2012).

No início de março estas três cantoras foram detidas, acusadas de vandalismo e ódio religioso, ainda que só em junho tenham sido formalizadas as acusações, violando todas as garantias processuais, como por exemplo a prisão preventiva, que em julho se estendeu por mais seis meses. De facto, as principais organizações defensoras dos direitos humanos, como a Amnistia Internacional ${ }^{98}$ e a Human Rights Watch ${ }^{99}$,

98 Disponível em http://www.amnesty.org/fr/node/33367.

99 Disponível em http://www.hrw.org/news/2012/08/17/russia-band-members-conviction-blow-free-expression. 
criticaram duramente as autoridades russas na gestão do caso Pussy Riot. Os advogados dos membros do grupo qualificaram a situação como pior que na época soviética (Elder, 2012b), tendo inclusivamente afirmado que as suas clientes haviam sofrido torturas na prisão (ver Oates, 2007).

Após o julgamento, que recordou eventos passados como o julgamento do caso Yukos, estes três elementos do grupo foram condenados a dois anos de prisão (The Guardian, 2012). Após a sentença, a Rússia foi alvo de uma torrente de críticas, procedentes de ministérios dos negócios estrangeiros e da sociedade civil, através das redes sociais como Facebook, Tuenti ou Twitter. Como vem sendo habitual, o Foreign Office britânico (The Guardian, 2012) foi um dos mais duros para com o Kremlin, ainda que a Secretária de Estado norte americana e a Alta Representante da União Europeia para os assuntos internacionais também tenham pronunciado críticas importantes.

Esta questão deve ser interpretada dentro da lógica de um país que se encontra embebido numa transição política. O grupo de música adiciona um pouco mais à falta de legitimidade do grupo de Vladimir Putin e do próprio sistema política russo. As Pussy Riot não fizeram mais do que exaltar as exigências de democracia da população, conhecendo a debilidade do governo Putin-Medvedev, que adicionalmente se encontra limitado não só pela pressão dos seus cidadãos mas, e acima de tudo, pela comunidade internacional que observa as ações da Federação Russa perante a oposição em geral, e perante os membros do grupo Pussy Riot, em particular. De facto, importantes figuras da oposição como Navalny ou Kasparov têm demonstrado abertamente o seu apoio às Pussy Riot.

Mas para além do caso Pussy Riot, os membros do grupo estão a converter-se num símbolo, a nível nacional e internacional. Para alguns, as Pussy Riot são a nova versão dos sete ativistas que se manifestaram na Praça Vermelha contra a invasão da Checoslováquia em 1968. Para outros, as suas atuações em Lobnoye Mesto têm semelhanças com as manifestações da Praça Tahir no Egito. De qualquer modo, colocaram o governo de Putin perante as opções de liberalização ou repressão, tendo este claramente optado pela segunda, deteriorando muito a sua imagem internacional e favorecendo a transição. 


\section{Conclusão}

A Rússia encontra-se num processo de transição para a democracia. Depois da independência, o processo não culminou com uma democratização do país. Ao invés, foi criado um sistema autoritário, entre o regime de sultanato e o pós-totalitarismo. Ainda que tenham existido alternâncias no que se refere aos líderes do regime, estas não variaram muito. Ieltsin, Putin, Medvedev e mais uma vez Putin, foram os chefes de Estado da Rússia, embora acima deles esteja subjacente uma estrutura proveniente da era soviética que é quem governa verdadeiramente o país.

As primeiras perguntas chegaram no início do século XXI, porém a existência de uma dupla legitimidade - económica e de segurança -, juntamente com a falta de uma cultura política adequada, impediu que pudesse ser iniciado um processo de transição. Contudo, os atentados terroristas e a crise económica acabaram com a legitimidade de um regime que passou de precisar de reformas para necessitar de uma mudança mais profunda. A população russa tornou explícita esta necessidade nas eleições legislativas de 2011, e pouco depois nas presidenciais de 2012. As poucas expetativas de mudança que poderiam ter sido representadas com Medvedev, ficaram sem efeito com a nomeação de Putin como candidato ao Kremlin em setembro de 2009. Este facto provocou a revolta da população, que passou a pedir a substituição do sistema autoritário por um democrático. Hoje Medvedev passou para um segundo plano e as suas políticas mais ou menos liberais e de abertura são só uma recordação (Barry, 2012d).

Trata-se de um processo revolucionário visto que cumpre os requisitos que Hanna Arendt estabelece como necessários para se falar de revolução. Deve ser algo novo e deve ser guiado por desejos de liberdade. No entanto, isto não significa que este processo revolucionário acabe em democracia, visto que as transições são processos incertos. A comunidade internacional mostrou o seu apoio à oposição, com o caso Pussy Riot, o que provocou críticas contra o governo de Putin e a sua ingerência no sistema judicial russo.

Hoje podemos afirmar que a Rússia está em transição, no entanto isso não implica que no dia de amanhã será uma democracia. Se, no final, a Rússia se democratizar, um dos aspetos que mais seria afetado seria a sua 
política externa que, sem dúvida, seria menos agressiva, tanto no 'estrangeiro próximo' como nas suas relações com o ocidente. Em primeiro lugar, lidemos com a sua zona de influência. Sem perder a influência que Moscovo tem sobre as ex-repúblicas soviéticas, parece que a Rússia se vai converter num pólo de democratização e num exemplo para o resto dos Estados da região. Provavelmente teriam que ser reconfigurados os acordos regionais, como a Organização do Tratado de Segurança Coletiva, que estão baseados num sistema de quase dominação russa. Moscovo perderia a capacidade de influência sobre os governantes, muitos deles provenientes da época soviética, e a única referência não-democrática seria a China.

Por outro lado, a sua atuação no seio do Conselho de Segurança seria distinta, já que sendo democrática e estando comprometida com os direitos humanos, ver-se-ia obrigada a mudar as suas linhas orientadoras na política externa, até agora centradas no apoio a Estados autoritários, como o Irão, Venezuela ou Síria. A confrontação recorrente e retórica com a Aliança Atlântica deixaria de existir e entraríamos numa fase de cooperação com a organização. Algumas conjeturas têm sido vislumbradas em momentos anteriores, como nos anos em que Kozyrev foi ministro dos negócios estrangeiros, com Boris Ieltsin. A União Europeia seria outro dos pontos que mais seriam favorecidos na agenda, já que a sua relação seria baseada num tratamento entre iguais e as relações UE-Rússia perderiam um elemento recorrente de fricção. Inclusivamente, poderia solicitar a sua entrada nestas organizações internacionais, embora tivesse que ser apurado o cumprimento dos critérios geográficos.

Tal como defendem os idealistas, as democracias não fazem a guerra e o mundo é mais estável quanto mais democracias houver. Assim sendo, a democratização da Rússia implicaria muito provavelmente a concretização última do final da Guerra Fria.

\section{Bibliografia}

ALVAREZ VELEZ, Maria Isabel - Las Cortes de Cádiz y la Constitución de 1812: La primera revolución liberal española? Madrid: Ed. Cortes Generales, 2012.

ARENDT, Hannah - Sobre la Revolución. Madrid: Alianza Editorial, 2004. 
AZHGIKhiNA, Nadezhda - The Struggle for Press Freedom in Russia: Reflections of a Russian Journalist. Europe-Asia Studies. Vol. 59, n. ${ }^{\circ} 8$ (2007), p. 1245-1262.

BARRY, Ellen - Waiting in wings, the next President Putin, The New York Times, 28 setembro 2011a.

BARRY, Ellen - Architect of Russia's Political System under Putin is Reassigned, The New York Times, 27 dezembro 2011b.

BARRY, Ellen - Russia Lawmakers take steps to impose step fines on demonstrators, The New York Times, 5 junho 2012c.

BARRY, Ellen - Putin's Russia hits the clear button on the Medvedev Era, The New York Times, 20 setembro $2012 \mathrm{~d}$.

CLARK, William A. - The presidential transition in Russia. Electoral Studies. Vol. 28 , n. ${ }^{\circ} 2$ (2008), p. 342-345.

DAHL, Robert - Polyarchy: Participation and Opposition. New Haven, Yale University Press, 1971.

DMITRIEV M., e TREISMAN, Danielt - The Other Russia. Discontent Grows in the Hinterlands. Foreign Affairs. Vol. 91, n. ${ }^{\circ} 5$ (2012), p. 59-72.

ELDER, Miriam - Pussy riot trial worse than Soviet Era, The Guardian, 3 agosto 2012b.

El Mundo - Putin, 5 março 2012.

ENGLUD, Will - Putin Web launch ignores Russian protests, The Washington Post, 12 janeiro 2012.

ENNIS, Stephen - Russian Church leader under fire after backing Putin, BBC, 10 abril 2012. [Acedido a 14 de jan. de 2013]. Disponível na Internet: http://www.bbc.co.uk/news/ world-europe-17667782.

GERSHMAN, Carl - The Fourth Wave. Where the Middle East revolts fit in the history, The New Republic, 14 março 2011.

GOLOSOV, Grigorii - Russia's Regional Legislative Elections, 2003-2007: Authoritarianism Incorporated. Europe-Asia Studies. Vol. 63, n. ${ }^{\circ} 3$ (2011), p. 397-414.

GOODE, Paul - The puzzle of Putin's gubernatorial appointment. Europe-Asia Studies. Vol. 59, n. ${ }^{\circ} 3$ (2007), p. 365-399.

GRAND, Stephen - Starting in Egypt: The Fourth Wave of Democratization?. Brookings, 10 fevereiro 2012. [Acedido a 4 de set. de 2012]. Disponível na Internet: http://www. brookings.edu/research/opinions/2011/02/10-egypt-democracy-grand.

HAGUE, Rod and HARROP, Martin - Comparative Government and Politics. Basingstoke: Palgrave, 2010.

HANSON, Philip; NIXEY, James; SHEVTSOVA, Lilia e WOOD, Andrew - Putin Again. Implication for Russia and the West. A Chatham House Report, Chatham House-RIIA, 2012.

HELD, David - Modelos de Democracia. Madrid: Alianza Editorial, 2007.

HENDERSON, Jane - The Constitution of the Russian Federation. A Contextual analysis. Oxford and Portland, Oregon: Hart Publishing, 2011.

HUNTINGTON, Samuel - La Tercera Ola. La democratización a finales del Siglo XX. Barcelona: Editorial Paidós, 1994.

KUDESHKINA, Olga - Reforming the Courts. The EU-Russia Centre Review. N. ${ }^{\circ}$ 19, outubro 2011.

LINZ, Juan - Totalitarian and Authoritarian regimes. Boulder and London: Lynne Rienner, 2000 . 
LINZ, Juan e STEPAN, Alfred - Problems of Democratic Transition and Consolidation. Southern Europe, South America and Post-communist Europe. Baltimore: John Hopkins University Press, 1996.

MCFAUL, Michael - The Fourth Wave of Democracy and Dictatorship: Noncooperative Transitions in the Postcommunist World. World Politics. Vol. 54, n. 2 (2002), p. 212-244.

MONAGHAN, A.C - The End of the Putin Era?. Carnegie Endowment for International Peace, julho 2012.

MONTERO, J.R. e MILLEY, T. - Sistemas totalitarios y regímenes autoritarios. Obras completas de Juan J. Linz, vol. 3. Madrid: Centro de Estudios Constitucionales y Políticos, 2009.

OATES, Sarah - The Neo-Soviet Model of the Media. Europe-Asia Studies. Vol. 59, n. ${ }^{\circ} 8$ (2007), p. 1279-1297.

OKOROKOVA, Lidia - New Man in Saint Petersburg, The Moscow News, 25 agosto 2012. [Acedido a 1 de set. de 2012]. Disponível na Internet: http://themoscownews.com/ russia/20110825/188961522.html.

PRIEGO, Alberto - La evolución del conflicto en Chechenia. UNISCI Papers. N. ${ }^{\circ} 20$ (2000).

PRIEGO, Alberto - Chechenia: Conflicto en la Rusia Post-Soviética, El Mundo, 27 outubro 2001.

PRIEGO, Alberto - Beslán: un punto de inflexión en la lucha contra el terrorismo checheno. UNISCI Discussion Papers. N. ${ }^{\circ} 6$ (2004).

PRIEGO, Alberto - Osetia del Sur: la cúspide del desencuentro entre EE.UU. y Rusia. ARI 108/2008, 17 setembro 2008.

PRIEGO, Alberto - Fantasmas chechenos en el Kremlin, El País, 6 abril 2010.

PRIEGO, Alberto - La primavera árabe: una cuarta ola de democratización?. UNISCI Discussion Papers. N. ${ }^{\circ} 26$ (2011). [Acedido a 1 de set. de 2012]. Disponível na Internet: http:// redalyc. uaemex.mx/redalyc/pdf/767/76718800004.pdf.

PRIEGO, Alberto - De la Primavera Árabe a la Primavera Rusa?. Razón y Fe, fevereiro 2012.

RUTLAND, Peter - Russia as an Energy Superpower. New Political Economy. Vol. 13, n. 2 (2008), p. 203-210.

SATTER, David - Russia's Looming Crisis. Foreign Policy Research Institute, março 2012.

SHARP, Gene - From Dictatorship to Democracy. London: Serpent Tail, 2012.

SHERLOCK, Thomas - Confronting the Stalisnist Past: the Politics of Memory in Russia. The Washington Quarterly. Vol. 34, n. 2 (2011), p. 93-109.

SNETKOV, Aglaya - The Image of the terrorist Threat in the Official Russian Press: the Moscow Theatre Crisis (2002) and the Beslan Hostage Crisis (2004). Europe-Asia Studies. Vol. 59, n. ${ }^{\circ} 8$ (2007), p. 1349-1365.

YAKOIEVA, Yana - Managing Russian Business through the Criminal Code. The EU-Russia Centre Review. N. ${ }^{\circ} 19$ (2011), p. 9-13.

ZAGORODNOV, Artem - Focus on Moscow's new mayor Sergei Sobyanin. The Telegraph, 28 outubro 2010.

ZIKIGAYEVA, Aigerim - What does the Arab Spring Mean for Russia, Central Asia and the Caucasus?. Center for Strategic and International Studies, setembro 2011 
(Página deixada propositadamente em branco) 


\section{CONCLUSÃ O}

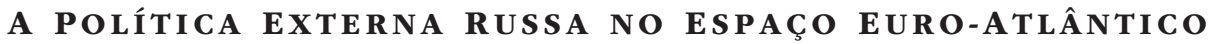

Maria Raquel Freire e Patrícia Daehnhardt

Desde o fim da União Soviética, a Rússia tem vindo a afirmar-se no sistema internacional como um ator relevante, através de uma política externa ativa, pragmática e comprometida com um conjunto de princípios coerentes com o objetivo de projeção internacional. Estes princípios incluem não só uma ordem interna coesa, assente em crescimento económico e estabilidade social, mas também uma plataforma multivetorial de gestão de interesses e compromissos nas áreas prioritárias da sua política externa: espaço CEI, relações com o ocidente e a leste (em particular com a China), relações com países do Magrebe e Médio Oriente, e ainda o seu posicionamento no Ártico. Na evolução da sua política externa, Moscovo tem demonstrado coerência nos pressupostos, apesar de na forma de implementação, esta ter variado de acordo com as lideranças. No período pós-Guerra Fria, Ieltsin marca a presidência russa por uma atuação algo inconstante, que apenas no seu segundo mandato assume um rumo mais claro, com o desenho da política externa multivetorial que servirá de base às políticas desenvolvidas por Vladimir Putin.

Os dois primeiros mandatos de Putin na presidência russa consolidam esta tendência de acomodação de perspetivas diferenciadas numa política descrita como pragmática, e que procura responder às diferentes dimensões que lhe estão implícitas, assumindo em tempos diferenciados posturas de maior ou menor cooperação, de acordo com as próprias dinâmicas no sistema internacional. Putin marca, no entanto, a sua atuação 
por assumir uma postura assertiva face a desenvolvimentos contrários aos interesses russos, que ficam muito claros nas relações mais difíceis com os EUA ou a UE, por exemplo, como analisado neste volume. Além do mais, o pragmatismo assertivo de Putin permite-lhe aumentar a capacidade russa de influência e interferência no espaço CEI, descrito como área de interesse vital para Moscovo. Mas como analisado aprofundadamente em vários capítulos dedicados à análise das relações da Rússia com os países desta área, descritos como crescentemente marcando o espaço pós-soviético como heterogéneo, Moscovo encontra aqui limites sérios à sua livre atuação. A crescente autonomia e independência face ao Kremlin de vários regimes nesta área, seja no Cáucaso do Sul, como, por exemplo, o Azerbaijão, seja na Ásia Central, como o Uzbequistão, o Cazaquistão ou o Turquemenistão, e mesmo nas repúblicas mais próximas da Europa, como o caso volátil da Ucrânia, demonstram claramente a dificuldade que a Rússia tem encontrado em prosseguir políticas unificadoras na área. O mais recente projeto de formação de uma Comunidade Euroasiática inclusiva de interesses partilhados ao nível político e económico, tendo em vista um processo formal de integração regional, pressupõe o interesse russo de reafirmação neste espaço, embora este seja um projeto que tem também encontrado entraves e que precisa ainda de maior substância e clarificação de procedimentos para que possa efetivamente tornar-se factor de atração para alguns destes Estados. Um desenvolvimento a acompanhar nos próximos anos.

Nas suas relações a ocidente, em particular com os EUA, a UE e a OTAN, os estudos desenvolvidos apontam para dificuldades nos relacionamentos bi e multilaterais, com o confronto de perspetivas a minar possibilidades de colaboração. O desenvolvimento de projetos como o escudo de defesa anti-míssil é apenas um exemplo, a par de políticas em competição que se cruzam em áreas estratégicas fundamentais, como, por exemplo, a Ásia Central ou o Ártico, onde a questão dos recursos energéticos fósseis assume relevância acrescida. De sublinhar que ao longo do volume se torna claro como o papel dos EUA é determinante no posicionamento russo no espaço euro-atlântico. De forma mais direta ou indireta, os EUA são um ator incontornável cujo peso e influência se fazem sentir quer 
através da sua diplomacia no espaço pós-soviético, quer através da sua influência em fóruns multilaterais, como é o caso da OTAN.

Relativamente à UE, a história desta parceria estratégica é pouco linear, pautada por momentos de maior proximidade até situações de grande tensão. Da "Casa Comum Europeia" à incapacidade de renegociação do Acordo fundador desta relação bilateral, a história deste relacionamento tem sido marcada por competição e rivalidade, não só motivada por factores endógenos à própria relação, mas também pelo contexto internacional mais lato onde os contatos se desenvolvem. A triangulação com os EUA ou a presença alargada da UE em áreas como o Cáucaso do Sul, constituem aqui exemplo, como analisado neste volume. Além do mais, a análise das relações da Rússia com a Polónia, um antigo Estado na esfera de influência soviética, e na atual orla leste da UE, é da maior relevância para a compreensão das dinâmicas associadas aos novos relacionamentos pós-Guerra Fria e pós-alargamento da União às fronteiras da Rússia. Uma demonstração clara de como a gestão de interesses partilhados é muitas vezes complexa, permitindo que o passado histórico e o peso desse legado marquem profundamente políticas e práticas nos dias de hoje. A fricção que tem marcado este relacionamento, apesar de uma diminuição nas tensões entre a Rússia e a Polónia neste último ano, é demonstrativa não só disto mesmo, como também da forma como a acomodação no seio de um organismo multilateral pode funcionar como catalisadora de maior cooperação - assim tem acontecido desde que a Polónia assumiu que através da UE pode servir de ponto de ligação preferencial à Rússia. Apesar deste entendimento, a Alemanha é claramente o país com ligações mais fortes à Rússia e cuja relação se mantém mais estável no tempo num registo de boa vizinhança. A inclusão destes dois capítulos, trabalhando dois Estados membros da UE tão diferentes nas suas articulações e políticas para com a Rússia, ajuda na compreensão das dinâmicas assimétricas que se vão registando quer nas relações bilaterais da Rússia com Estados membros da UE, quer nas próprias relações UE-Rússia. E desconstroem qualquer ideia apriorística relativamente a relações facilitadas ou fáceis, uma vez que a densidade implícita a estes relacionamentos, muito bem estudada nestes capítulos, demonstra o quão difícil é gerir uma relação 
com várias dimensões e com implicações também elas diversas e de aplicação a diferentes níveis.

Olhando para além do espaço UE, propriamente dito, a Turquia surge como um ator incontornável no espaço euro-atlântico, que não integra a UE, mas é membro de pleno direito da OTAN, e cuja emergência como potência regional nesta área não pode ser descurada. As relações com a Rússia, e a intensificação das mesmas são demonstrativas desta mesma relevância e da diferença que este ator tem no desenho das relações neste espaço pela proximidade à Rússia e aos EUA, em particular. Quanto ao Ártico, surge neste volume como uma área de confluência de interesses aliados à exploração de recursos energéticos e de navegabilidade, constituindo um ponto focal crescentemente importante para vários atores pertencentes ao espaço euro-atlântico, ora sugerindo sinergias, ora revelando rivalidades nem sempre fáceis de gerir. A Rússia tem procurado encontrar aqui um espaço igualitário nos principais fóruns de decisão de modo a assegurar que os seus interesses sejam tidos em linha de conta.

Um olhar pelos vários capítulos deste volume remete-nos para uma Rússia que se pretende assumir como um ator relevante e incontornável no espaço euro-atlântico. Pela sua localização, pelas suas capacidades e recursos e pelas suas relações políticas e de segurança, a Rússia é, de facto, um ator com influência e cuja presença se faz notar. Parece ainda claro, e comum aos vários capítulos, o entendimento de que o regresso de Vladimir Putin ao poder para um terceiro mandato veio travar o desenvolvimento económico de orientação mais liberal e de abertura política que o seu antecessor Dmitri Medvedev havia inaugurado, e que havia permitido uma maior margem de diálogo e proximidade com os seus parceiros no espaço euro-atlântico. A política do reset com os EUA após anos de grande frieza nas relações, e a maior proximidade da UE no desenvolvimento de várias ações conjuntas, em particular após a guerra na Geórgia em 2008, parecem, no entanto, políticas pertencentes ao passado e já desajustadas de um contexto de maior assertividade nas políticas russas. Putin recentralizou poderes, diminuiu abertura para o diálogo e assumiu uma postura de maior assertividade face aos seus parceiros tradicionais, considerando que a abertura iniciada estava a minar o poder 
de influência e interferência russo em assuntos vitais. O posicionamento da Rússia face aos acontecimentos relacionados com a Primavera Árabe, e o caso da Síria em particular, é exemplo. Se esta vaga de mudança que atravessou o mundo árabe chegará também à Federação Russa é uma questão analisada também neste volume. As convulsões populares a que se tem assistido na Rússia nos tempos mais recentes face às mudanças fundamentais na forma de fazer política parecem apontar para descontentamento social e menor apoio à presidência. Contudo, daqui a uma revolução social que implique alteração no regime, vários desenvolvimentos são necessários e as implicações dos mesmos seriam certamente irreversíveis, sendo para já apenas parte de um cenário de transformação democrática - um projeto já tentado e falhado, por exemplo logo após o final da Guerra Fria e da desagregação do bloco soviético.

Deste modo, a Rússia surge como ator estratégico unitário que por opção ou por fraqueza prefere prescindir de um sistema de alianças permanente. Contudo, o futuro da Rússia e o seu lugar dentro do espaço euro-atlântico permanece incerto. A vizinhança europeia da UE permanece um desafio: o antigo espaço soviético demonstra um misto de cooperação com a UE e um declínio na democracia e vigência do direito em alguns Estados, como a Ucrânia. O conceito de "vizinhança partilhada" é mesmo desconsiderado na Rússia por implicar "partilha” de uma área que considera como de atuação preferencial - o espaço CEI - que apenas se encontra geograficamente na orla europeia.

A Rússia confronta uma série de problemas que a tornam apenas parcialmente atrativa aos seus parceiros: primeiro, o crescimento da economia russa tem sido feito essencialmente através da exportação de matérias primas mais do que através de uma modernização sustentada e multisetorial. A hiper-dependência do setor energético confere fragilidade às bases de sustentação económica russas. A Rússia terá que modernizar as instituições políticas e económicas e fazer reformas importantes se pretender evitar uma estagnação económica e uma prolongada crise política. Segundo, a liderança política insiste na manutenção de uma centralização política de contornos democráticos limitados, reforçada pelo regresso de Vladimir Putin à presidência em 2012. Este alinhamento não permite abertura 
quer para o desenvolvimento de relações mais flexíveis com os atores no espaço euro-atlântico, quer internamente no diálogo entre diferentes fações políticas. Terceiro, na sua política externa, na pretensão de recuperar um estatuto de grandeza perdido, terá que certificar-se que detém o capital político, económico e militar para se projetar como potência líder, a começar pela zona próxima das suas fronteiras. Aqui decorre uma competição por influência entre a Rússia, os EUA e a UE. A posição russa resume-se a uma preocupação constante pela manutenção do status quo, num sentido unitário, centralizador e de perpetuação de influência em áreas de interesse estratégico.

Como referem vários autores do volume, e atestando este posicionamento de Moscovo, a probabilidade dos "conflitos congelados" serem resolvidos a curto prazo permanece incerta enquanto a Rússia demonstrar pouca recetividade em solucioná-los e preferir manter a sua influência em detrimento do acréscimo da influência de outros atores na região. A manutenção do status quo é, da perspetiva de Moscovo, preferível à emergência da UE ou da Turquia como atores eficazes na região com capacidades não apenas para resolver os conflitos como, no caso da UE em particular, de iniciar um processo de democratização contrário ao interesse estratégico russo.

Contudo, a Rússia poderá reforçar o seu papel nesta região. Por parte dos Estados Unidos, está em curso uma redefinição da sua identidade internacional como potência primordialmente virada para a região do Pacífico. O propósito de construção de novas redes de parcerias e instituições na Ásia, como a antiga secretária de estado norte-americana, Hillary Clinton definiu em 2011 (Clinton, 2011), inevitavelmente está a redirecionar as atenções dos EUA para a Ásia. Por seu turno, a UE está a braços com a crise das dívidas soberanas e a crise financeira e económica generalizada, estando ainda, desde inícios de 2011, a orientar-se nas suas preocupações de segurança para a parte sul da União, na sequência da Primavera Árabe e das incertezas securitárias que se estão a desenvolver na região do Mediterrâneo Sul e do Médio Oriente. A Rússia poderá assim aproveitar esta 'janela de oportunidade' para aumentar o seu perímetro de influência sobre o que qualifica de 'estrangeiro próximo'. Não é de descurar a possibilidade de Moscovo vir a reforçar relações de 
cooperação com os países do espaço pós-soviético. A proposta de Vladimir Putin, em dezembro de 2011, de criação de uma União Euroasiática, como referido, moldada a partir dos contornos da União Europeia, desafia-a - com os mesmos instrumentos de cooperação - onde Moscovo pode ir ao encontro de uma nova postura no relacionamento com os países da CEI, no reforço de instrumentos institucionais como forma de aumentar a influência russa na vizinhança oriental da UE.

As opções de política externa da Rússia têm, em última instância, a ver com a evolução da política doméstica do país. A liderança em Moscovo terá de decidir como proceder face às muito necessárias reformas políticas e institucionais que garantam a estabilidade interna, o crescimento económico e a modernização do país. A continuidade às políticas de modernização iniciadas por Medvedev seria, neste contexto, fundamental. No campo externo, terá de decidir se pretende manter-se como potência estratégica unitária - ou se a criação ou eventual inserção numa aliança multilateral the seria mais benéfica, definida para além dos procedimentos centralizadores e de controlo que têm pautado a sua presença neste fóruns internacionais, prevendo desde logo uma constituição mais alargada em termos de membros, bem como uma matriz de funcionamento mais liberal e inclusiva. Em qualquer dos casos, trata-se de opções que envolvem custos avultados para as políticas russas, implicando alterações fundamentais num curso que tem sido genericamente entendido como de afirmação num quadro pós-URSS, daí que é provável a Rússia opte por continuar a exercer uma política externa pragmática de cariz assertivo dentro do espaço euro-atlântico, onde o seu poder e influência, mesmo que desafiados, são reconhecidos. 
(Página deixada propositadamente em branco) 


\section{B I B L I O G R A F I A}

AAVV (2011) "Final Report from the examination of the aviation accident no 192/2010/11 involving the Tu-154M airplane, tail number 101, which occurred on April 10th, 2010 in the area of the Smolensk North airfield", Committee for Investigation of National Aviation Accidents, 10 abril. Disponível em: http://www.skybrary.aero/bookshelf/books/1557.pdf.

AAVV (2012) "Lavrov-Sikorski agreement on local border traffic has come into force", Visa-Free Europe. Disponível em: http://visa-free-europe.eu/2012/07/lavrov-sikorski-agreement-on-local-border-traffic-has-come-into-force/.

Abbasov, Shahin (2012) "Azerbaijan: Signs Point to Russia's Departure from Gabala Radar Base”, Eurasianet, 25 julho. Disponível em: http://www.eurasianet.org/node/65706.

Acordo de Parceira e Cooperação entre as Comunidades Europeias e os seus Estados-Membros, por um lado, e a Federação Russa, por outro lado (1997) Jornal Oficial $\mathrm{n}^{\circ}$ L 327 de 28/11/1997 p. 0003-0069. Disponível em: http://eur-lex.europa.eu/LexUriServ/ LexUriServ.do?uri=CELEX:21997A1128\%2801\%29:PT:HTML.

Akkan, Faruk (2012) “Turkey, Rússia improve ties, eye further cooperation”, Today's Zaman, 1 janeiro.

Akçali, Emel e Mehmet Perinçek (2009) 'Kemalist Eurasianism: An Emerging Geopolitical Discourse in Turkey', Geopolitics, vol. 14, pp. 550-569.

Akiner, Shirin (2001) Tajikistan: Disintegration or Reconciliation? London: The Royal Institute of International Affairs.

Allison, Roy (2001) "Conclusion: Central Asian Security in the Regional and International Context", in Roy Allison e Lena Jonson, eds., Central Asian Security: The New International Context. London: Royal Institute of International Affairs, pp. 247-268.

Allison, Roy; White, Stephen e Light, Margot (2005) "Belarus between East and West", Journal of Communist Studies and Transition Politics, vol. 21, no. 4, pp. 487-511.

Allison, Roy (2008) "Russia resurgent? Moscow's campaign to 'coerce Georgia to peace'", International Affairs, vol. 84, no. 6, pp. 1145-1171.

Allison, Roy; Light, Margot e White, Stephen (2006) Putin's Russia and the Enlarged Europe. London: Blackwell Publishing.

Altunisik, M. (2009) "Turkey's new activism in the Middle East", Negócios Estrangeiros, no. 14, pp. 29-39.

Alvarez Velez, Maria Isabel (2012) Las Cortes de Cádiz y la Constitución de 1812: La primera revolución liberal española? Madrid: Cortes Generales.

Antidze, Margarita (2007) "Russia Closes Last Military Base in Georgia", Reuters, 13 novembro. Disponível em: http://www.reuters.com/article/2007/11/13/us-georgia-russia-bases-idUSL1387605220071113 
Antonenko, Oksana (2001) "Putin's Gamble”, Survival, vol. 43, no. 4, pp. 49-60.

Antonenko, Oksana (2009) "Mr. Obama goes to Moscow", Survival, vol. 51, no. 5, pp. 227-231 .

Annual Report to Congress: Military and Security Developments Involving the People's Republic of China (2011), United States Department of Defense. Disponível em: http:// www.defense.gov/pubs/pdfs/2011_cmpr_final.pdf

Aras, Bulent (2009) “The Davutoglu Era in Turkish Foreign Policy”, Insight Turkey, vol. 11, no. 3, pp. 127-142.

Arendt, Hannah (2004) Sobre la Revolución. Madrid: Alianza Editorial.

Aron, Leon (2006) “The United States and Russia: Ideologies, Policies, and Relations", American Enterprise Institute for Public Policy Research.

Aron, Leon (2011) "Everything you think you know about the collapse of the Soviet Union is wrong", Foreign Policy, no. 187, pp. 64-70.

Arctic Council, The (2011) "Nuuk Declaration on the Occasion of the Seventh Ministerial Meeting of the Arctic Council”. Disponível em: http://goo.gl/qhMmd.

Ashton, Catherine (2012a) "Statement by EU High Representative Catherine Ashton in the European Parliament on the political use of justice in Russia”, Strasbourg, 11 setembro, A 403/12. Disponível em: http://www.consilium.europa.eu/uedocs/cms_Data/docs/ pressdata/EN/foraff/132370.pdf.

Ashton, Catherine (2012b) "Statement by High Representative Catherine Ashton on the wave of violent attacks against diplomatic missions”, Brussels, 14 setembro, A 410/12. Disponível em: http://www.consilium.europa.eu/uedocs/cms_Data/docs/pressdata/EN/ foraff/132457.pdf

Asia Times (2010) "Moscow moves to counter NATO”, 14 dezembro.

Asmus, Ronald D. (2002) Opening NATO's door: How the alliance remade itself for a new era. New York: Columbia University Press.

Asmus, Ronald D. (2010) A Little War that Shook the World: Georgia, Russia, and the Future of the West. New York: Palgrave Macmillan.

Åtland, Kristian (2008) "Mikhail Gorbachev, the Murmansk Initiative, and the Desecuritization of State Relations in the Arctic", Cooperation and Conflict, vol. 43, no. 3, pp. 289-311.

Åtland, Kristian (2009) "Russia's Northern Fleet and the Oil Industry: Rivals or Partners?: Petroleum, Security, and Civil-Military Relations in the Post-Cold War European Arctic", Armed Forces \& Society, vol. 35, no. 2, pp. 362-384.

Åtland, Kristian (2011) "Im Norden nichts Neues? Die Arktis in Russlands Sicherheitspolitik", Osteuropa, vol. 61, no. 2-3, pp. 243-256.

Averre, Derek (2010) "Triangulation or Strangulation? The US, the EU and Russia in European Security Governance”, artigo apresentado na UACES Annual Conference, Bruges, 6-8 setembro.

Azhgikhina, Nadezhda (1997) "The Struggle for Press Freedom in Russia: Reflections of a Russian Journalist”, Europe Asia Studies, vol. 59, no. 8, pp. 1349-1365.

Bachkatov, Nina (2007) "Les interactions entre pouvoir économique et politique en Russie", em Merlin, Aude, ed., Où va la Russie? Bruxelles: Editions de l'Université Libre, pp. 137-152.

Bacik, Gokhan (2012) "Turkey and Russia in the Arab Spring: Straining Old Rifts Further?", On Turkey Series, The German Marshall Fund of the United States. 
Baek, Jun Kee (2009) "Medvedev's Russia, a 'revisionist power' or an 'architect of a new world order'? The evolution of ideational factors and its cases", Korean Journal of Defense Analysis, vol. 21, no. 4, pp. 455-484.

Baek, Jun Kee (2009) "Medvedev's Russia, a 'revisionist power' or an 'architect of a new world order'? The evolution of ideational factors and its cases", Korean Journal of Defense Analysis, vol. 21, no. 4, pp. 455-484.

Baev, Pavel (2002) "Could the Former Super-Power Turn into a Battle-Ground? Russia in 2015", ISF Info 3/02.

Baev, Pavel (2004) "Assessing Russia's Cards: Three Petty Games in Central Asia", Cambridge Review of International Affairs, vol. 17, no. 2, pp. 269-283.

Baev, Pavel (2007) "Russia Aspires to the Status of 'Energy Superpower'", Strategic Analysis, vol. 31, no. 3, pp. 447-465.

Baev, Pavel (2009) "Troublemaking and Risk-Taking: The North in Russian Military Activities", in Rowe, Elana Wilson, ed., Russia and the North. Ottawa: University of Ottawa Press, pp. 17-34.

Baev, Pavel (2010) "Russia's Arctic Policy. Geopolitics, Mercantilism and Identity-Building", The Finnish Institute of International Affairs, Briefing Paper no. 73, 17 dezembro.

Baranovsky, Vladimir (2002) Russia's Attitudes Towards the EU: Political Aspects. Programme on the Northern Dimension of the CFSP.

Barry, Ellen (2009) "Russia's Neighbors Resist Wooing and Bullying", The New York Times, 2 julho. Disponível em: http://www.nytimes.com/2009/07/03/world/europe/03russia.html.

Barry, Ellen (2011a) "Waiting in wings, the next President Putin", The New York Times, 28 setembro.

Barry, Ellen (2011b) "Architect of Russia's Political System under Putin is Reassigned", The New York Times, 27 dezembro.

Barry, Ellen (2012a) "Shooting at Checkpoint Raises Tensions in a Disputed Region Claimed by Moldova”, The New York Times, 3 janeiro. Disponível em: http://www.nytimes.com/2012/01/04/ world/europe/shooting-raises-tensions-between-moldova-and-russia.html?_r=0.

Barry, Ellen (2012b) "Leaving the Presidency in Russia, Medvedev Fights for Relevance", The New York Times, 3 maio. Disponível em: http://www.nytimes.com/2012/05/04/world/ europe/leaving-presidency-russias-medvedev-fights-for-relevance.html?_r=0.

Barry, Ellen (2012c) "Russia Lawmakers take steps to impose step fines on demonstrators", The New York Times, 5 junho.

Barry, Ellen (2012d) "Putin's Russia hits the clear button on the Medvedev Era", The New York Times, 20 setembro.

Bayer, Wolfgang (2009) "Das GETS-Projekt: Gaslieferungen von und nach Deutschland", Statistisches Bundesamt, no. 5, pp. 416-424. Disponível em: https://www.destatis.de/ DE/Publikationen/WirtschaftStatistik/EnergieWasserversorgung/GetsProjekt509.pdf? blob=publicationFile.

BBC News (2006) "Russia pays off Paris Club debts", 21 agosto.

BBC News (2012) "Putin tells stadium rally battle is on for Russia", 23 fevereiro.

Beehner, Lionel (2010) "Russia's Energy Disputes", Council on Foreign Relations, 3 fevereiro. Disponível em: http://www.cfr.org/energy/russias-energy-disputes/p12327.

Berg, Eiki (2006) "Pooling Sovereignty, Losing Territoriality? Making Peace in Cyprus and Moldova”, Tijdschrift voor Economische en Sociale Geografie, vol. 97, no. 3, pp. 222-236.

Bergman, Max (2009) "Germany's Russia Moment", World Politics Review. Disponívl em: http://www.worldpoliticsreview.com/articles/3773/germanys-russia-moment. 
Bergh, Kristofer e Oldmar, Ingmar (2011) The New Arctic: Building Cooperation in the Face of Emerging Challenges. SIPRI Conference Report, 26 abril.

Bingen, D. (1997) Die Entwicklung der Deutsch-Polnischen Beziebungen seit 1991. Koln: Bundesinstitut für ostwissenschaftliche und internationale Studien.

Blank, Stephen (2008) "The Shanghai Cooperation Organization and the Georgian Crisis", China Brief, vol. 8, no. 17. Disponível em: http://www.jamestown.org/single/?no_ cache $=1 \&$ tx_ttnews\%5Btt_news $\% 5 \mathrm{D}=5134$.

Bloomberg (2012) "Putin ratchets up anti-US rhetoric as Kremlin race grows", 26 janeiro.

Boonstra, Igor (2007) "Moldova, Transdniestria and European Democracy Policies", FRIDE Comment. Disponível em: www.fride.org/download/COM_Moldav_ENG_feb07.pdf.

Boonstra, Igor (2011) "Moldova: an EU success strory?", FRIDE Policy Brief, no. 92. Disponível em: http://fride.org/publication/940/moldova:-an-eu-success-story.

Borozna, Angela (2007) "Russian Multilateralism since 1991", Paper presented at the International Studies Association Annual Convention, Chicago.

Bovt, G. (2012) "Whether Obama or Romney, the Reset Is Dead", The Moscow Times. Disponível em: http://www.themoscowtimes.com/opinion/article/whether-obama-or-romney-the-reset-is-dead/467947.html.

Bridge, Robert (2012) "Russia, Ukraine hammer out historic strategic partnership", RT, 13 julho. Disponível em: http://rt.com/politics/russia-ukraine-agreement-putin-yanukovich-113/.

Bridge, Robert (2012) "Bye-bye Gabala? Russia may quit Soviet-era radar", $R T, 24$ maio. Disponível em: http://rt.com/politics/gabala-radar-russia-baku-nato-095/.

Broers, Laurence (2010) "Opening Borders, Preserving Walls: Opportunities to Support the Karabakh Peace Process”, Journal of Conflict Transformation Caucasus Edition, vol. 3 , no. 1, junho. Disponível em: http://caucasusedition.net/wp-content/uploads/2010/05/ Laurence-Broers_Final_approved_June-1-issue.pdf.

Brooks, Stephen G. e William C. Wohlforth (2002) "American primacy in perspective", Foreign Affairs, vol. 81, no. 4, pp. 20-33.

Bruce, Chloe (2005) "Friction or Fiction? The gas factor in Russian-Belarusian relations", Chatham House Briefing Paper, REP BP 05/01, pp. 1-14.

Bryanski, Gleb (2011) "Russia's Putin says wants to build 'Eurasian Union'”. Reuters 3 outubro. Disponível em: http://www.reuters.com/article/2011/10/03/us-russia-putin-eurasian-idUSTRE7926ZD20111003.

Bulmer, Simon, Jeffery, Charlie e Padgett, Stephen (eds.) (2010) Rethinking Germany and Europe: Democracy and Diplomacy in a semi-sovereign state. Houndsmills, Basingstoke, Hampshire and New York: Palgrave Macmillan.

Burghart, Dan (2007) "The New Nomads? American Military Presence in Central Asia”, China and Eurasia Forum Quarterly, vol. 5, no. 2, pp. 5-19.

Burghardt, Günther (2008) Session II: The way ahead: prospects for EU-Russia relations. Conference on EU-Russia Relations: a Trouble Strategic Partnership? Brussels: Palais d'Egmont, 27 fevereiro.

Bush, George W. (2010) Decision Points. London: Virgin Books.

Buzan, Barry e Waever, Ole (2003) Regions and Powers: The Structure of International Security. Cambridge: Cambridge University Press.

Cameron, David R.; Orenstein, Mitchell A. (2012) "Post-Soviet Authoritarianism: The influence of Russia in its "Near Abroad", Post-Soviet Affairs, vol. 28, no. 1, pp. 1-44. 
Carnaghan, Ellen, e Hale, Henry (2012) "Public Opinion Polls and Political Culture", Russian Analytical Digest, no. 117. Disponível em: http://www.css.ethz.ch/publications/pdfs/RAD-117.pdf.

Casa Branca (2010) “U.S.-Russia Relations: 'Reset' Fact Sheet”, The White House, Office of the Press Secretary, 24 junho. Disponível em: http://www.whitehouse.gov/the-press-office/us-russia-relations-reset-fact-sheet.

CFR (2008) The Candidates on U.S. Policy Toward Russia, Council on Foreign Relations Issue Tracker, 7 novembro. Disponível em http://www.cfr.org/us-election-2008/candidates-us-policy-toward-russia/p14946.

China Elections and Governance (2007) "China, Russia sign joint communiqué, pledging to broaden strategic co-op", China Elections and Governance, 7 novembro. Disponível em: http://en.chinaelections.org/newsinfo.asp?newsid=12598.

Chivvis, Christopher e Rid, Thomas (2009) “The Roots of Germany's Russian Policy”, Survival, vol. 51, no. 2, pp. 105-122.

Chollet, Derek e Goldgeier, James (2008) America Between the Wars: From 11/9 to 9/11. New York: Public Affairs.

Chubais, Anatoly (2003) Missiya Rossiyi v XX veke (A Missão da Rússia no Século XX). Nezavisimaya gazeta, 1 outubro.

CIS (s.d.) Commonwealth of Independent States official webpage, disponível em: http:// www.cisstat.com/eng/cis.htm

Clark, William (2008) "The presidential transition in Russia", Electoral Studies, março vol. 28, no. 2, pp. 342-345.

Clinton, Hillary (2010) Remarks With Russian Foreign Minister Sergey Lavrov. Disponível em: http://www.state.gov/secretary/rm/2010/03/138531.htm.

Clinton, Hillary (2011) "America's Pacific Century”, Foreign Policy, no. 189, pp. 56-63.

Closson, Stacy (2008) "Russia's key customer: Europe", in Perovic, Jeronim, Orrtung, Robert e Wenger, Andreas, eds., Russian Energy Power and Foreign Relations: Implications for Conflict and Cooperation. London: Routledge, pp. 89-108.

CNN (2011) "Clinton cites 'serious concerns' about Russian elections”, 6 dezembro.

Cohen, R. (1993) "Yeltsin Opposes Expansion of NATO in Eastern Europe", The New York Times. Disponível em: http://www.nytimes.com/1993/10/02/world/yeltsin-opposes-expansion-of-nato-in-eastern-europe.html.

Comunicado de Imprensa Conjunto sobre a IV Reunião Ministerial relativa à Dimensão Setentrional, realizada em Bruxelas, em 21 novembro 2005. Disponível em: http://www. consilium.europa.eu/press/press-releases/latest-press-releases/newsroomrelated?bid=1 $02 \&$ grp $=9423 \&$ lang=pt\&id.

Conceito de Política Externa da Federação Russa (1993) Reproduzido in Melville, Andrei e Shakleina, Tatiana, eds. (2005). Russian Foreign Policy in Transition: Concepts and Realities. Budapest: CEU Press, pp. 27-64.

Conceito de Segurança Nacional (2000) Permanent Representation of the Russian Federation to the Council of Europe, Estrasburgo.

Conselho da União Europeia (2009) Joint Declaration of the Prague Eastern Partnership Summit, Prague, 8435/09 (Presse 78), 7 maio.

Cornell, Svante E. (2006) "The Narcotics Threat in Greater Central Asia: From Crime-Terror Nexus to State Infiltration?", China and Eurasia Forum Quarterly, vol. 4, no. 1, pp. 37-67.

Constitution of the Russian Federation (1993) The Constitution of the Russian Federation, Adopted at the December 12, 1993 referendum. Disponível em: http://www.mid.ru/ 
ns-osndoc.nsf/1e5f0de28fe77fdcc32575d900298676/d0bd6a5ba542c949c32575dd00400 9ee? OpenDocument.

Coskun, Bezen Balamir e Carlson, Richard (2010) "New Energy Geopolitics: Why does Turkey Matter?", Insight Turkey, vol. 12, no. 3, pp. 205-220.

Council of the European Union (2008) Javier Solana, EU High Representative for the CFSP, confirms the withdrawal of Russian forces from the zones adjacent to South Ossetia and Abkhazia. S332/08. Bruxelas, 10 outubro.

Current Digest of the Post-Soviet Press (2007) "Cold War Goes North - Russia and West Begin Struggle for Arctic", vol. 59, no. 21, agosto.

Cutler, Robert (2007) "U.S.-Russian Strategic Relations and the Structuration of Central Asia", Perspectives on Global Development and Technology, vol. 6, no. 1-3, pp. 109-125.

Daehnhardt, Patricia (2007) "De Kohl a Merkel: a gradual afirmação da Alemanha como grande potência euro-atlântica“, Relações Internacionais, no. 14, pp. 27-45.

Daehnhardt, Patricia (2009) "O fim da Guerra Fria e a Unificação Alemã", Relações Internacionais, Lisboa: IPRI, no. 23, pp. 39-52.

Daehnhardt, Patricia (2011a) "A transformação da política europeia da Alemanha”, Política Internacional e Segurança, no. 5, pp. 53-75.

Daehnhardt, Patricia (2011b) "Germany in the European Union", in Reuben Wong and Christopher Hill, eds., National and European Foreign Policy: Towards Europeanization. London: Routledge, pp. 35-56.

Daehnhardt, Patricia (2012) "Germany's New Role in Europe: European Leadership, German Hegemony or None of Both?", artigo apresentado na conferência UACES 'Exchanging Ideas on Europe: Old Borders - New Frontiers', Passau, Alemanha, 3-5 setembro.

Daehnhardt, Patricia (2013a) "Germany, the EU and a transforming domestic political arena", in M. Mannin and C. Bretherton, eds., The Europeanization of European Politics. Basingstoke: Palgrave Macmillan, pp. 25-38.

Daehnhardt, Patricia (2013b) "A implosão da URSS e a União Europeia”, in Pedro Aires de Oliveira, ed., O Fim da URSS e a Nova Rússia (no prelo).

Dahl, Robert (1971) Polyarchy: Participation and Opposition. New Haven: Yale University Press.

Davutoglu, Ahmet (2010) “Turkey's Zero-Problems Foreign Policy”, Foreign Policy. Disponível em: http://www.foreignpolicy.com/articles/2010/05/20/turkeys_zero_problems_foreign_ policy?print=yes\&hidecomments=yes\&page $=$ full.

De Gucht, Karel (2012) "Karel De Gucht European Commissioner for Trade Seizing the Opportunity: EU-Russia Relations beyond the WTO Seminar on EU-Russia Trade and Economic Relations, Helsinki, Finland 7 September 2012", SPEECH/12/590, 7 setembro. Disponível em: http://europa.eu/rapid/pressReleasesAction.do?reference=SPEECH/12/59 $0 \&$ format $=$ HTML\&aged $=0 \&$ language $=\mathrm{EN} \&$ guiLanguage $=\mathrm{en}$.

Declaração de Dushanbe (2008) "Dushanbe Declaration of Heads of SCO Member States". Disponível em: http://en.sco2009.ru/docs/documents/index.html.

Declaração Política sobre a Política da Dimensão Setentrional. [Political Declaration on the Northern Dimension Policy], aprovada na Cimeira da Dimensão Sententrional, Helsínquia, 24 novembro 2006. Disponível em: http://eeas.europa.eu/north_dim/docs/pol_dec_1106_en.pdf.

Denisov, Andrey e Grivach, Alexei (2008) "The gains and failures of the energy superpower", Russia in Global Affairs, vol. 6, no. 2, pp. 96-108.

de Haas, Marcel (2009) "Medvedev's Security Policy: A Provisional Assessment", Russian Analytical Digest, no. 62, junho, pp. 2-5. 
Delcour, Laure e Duhot, Hubert (2011) "Bringing South Caucasus closer to Europe: Achievements and Challenges in ENP Implementation", Natolin Research Papers no. 3, Polónia, College of Europe.

Dempsey, J. (2011) "Poland's European Union Ties May Hinge on Elections", International Herald Tribune. Disponível em: http://www.nytimes.com/2011/10/08/world/europe/ polands-european-union-ties-may-hinge-on-elections.html.

Desai, Padma (2006) Conversations on Russia. Reform from Ieltsin to Putin. Oxford: Oxford University Press.

Deutsch, Karl (1957) Political community and the North Atlantic area. Princeton: Princeton University Press.

Deyermond, Ruth (2004) "The state of the union: military success, economic and political failure in the Russia-Belarus Union", Europe-Asia Studies, vol. 56, no. 8, pp. 1191-1205.

Deyermond, Ruth (2009) "Matrioshka Hegemony? Multi-leveled Hegemonic Competition and Security in Post-Soviet Central Asia", Review of International Studies, vol. 35, no. 1, pp. 151-173.

De Waal, Thomas (2012a) "Violence Flares on the Georgian-Russian Border", The National Interest, 7 setembro. Disponível em: http://nationalinterest.org/commentary/violence-flares-the-georgian-russian-borders-7441.

De Waal, Thomas (2012b) "A Crucial Election in Georgia", Carnegie Endowment for International Peace commentary, 11 setembro. Disponível em: http://carnegieendowment. org/2012/09/11/crucial-election-in-georgia/drlp.

Digol, Diana (2012) "Russia's foreign policy in Central Asia: From Yeltsin to Medvedev" in Maria R. Freire e Kanet, Roger E., eds., Russia and its Near Neighbours. Basingstoke: Palgrave Macmillan, pp. 174-202.

Dimitrova, Antoaneta; Dragneva, Rilka (2009) "Constraining external governance: interdependence with Russia and the CIS as limits to the EU's rule transfer in the Ukraine", Journal of European Public Policy, vol. 16, no. 6, pp. 853-872.

Dmitriev, Mikhail e Treisman, Daniel (2012) "The Other Russia: Discontent grows in the Hinterlands", Foreign Affairs, vol. 91, no. 5, pp. 59-72.

Directorate General External Relations (2003) "Overview. EU-Russia Summit", Roma, 6 novembro. Disponível em: http://europa.eu.int/comm./external_relations/russia/ summit11_03/ip03_1496.htm.

Documento Quadro da Dimensão Setentrional [Northern Dimension Policy Framework Document], aprovada na Cimeira da Dimensão Sententrional, Helsínquia, 24 novembro 2006. Disponível em: eeas.europa.eu/north.../frame_pol_1106_en.pdf.

Donaldson, Robert H. e Nogee, Joseph L. (2005) The Foreign Policy of Russia: changing systems, enduring interests. Armonk: M. E. Sharpe.

Donat, Gozde Nur (2012) "Turkey tries best to convince Russia, Iran to help solve Syrian crisis", Today's Zaman, 26 agosto.

Dyomkin, Denis (2008) "Russia warns Moldova against 'Georgian mistake", Reuters, 25 agosto. Disponível em: http://www.reuters.com/article/2008/08/25/us-russia-moldova-transdniestria-idUSLP59197620080825.

Eberstadt, Nicholas (2011) "The Dying Bear: Russia's Demographic Disaster", Foreign Affairs, vol. 90 , no. 6 , pp. 95-108.

Ediger, Volkan e Bagdadi, Itir (2010) "Turkey-Russia Energy Relations: Same Old Story, New Actors", Insight Turkey, vol. 12, no. 3, pp. 221-236.

Economist, The (2009) "Turkey and Russia. Old Rivals, new partners", 13 agosto. 
Economist, The (2010a) "Georgia's wine industry: What doesn't kill us makes us stronger", 21 setembro. Disponível em: http://www.economist.com/blogs/easternapproaches/2010/09/ georgias_wine_industry.

Economist, The (2010b) "Troubled Tajikistan: Where Cure Begets Disease", The Economist Asia View, 23 setembro. Disponível em: http://www.economist.com/blogs/asiaview/2010/09/ troubled_tajikistan.

Economist, The (2010c) "Power and Ideas", 23 novembro.

Economist, The (2012a) "Russia and NATO: Rethink the Reset", 19 maio.

Economist, The (2012b) "The strongman cometh", The Economist, 28 julho.

Elder, Miriam (2012a) "Russia's treatment of US ambassador a reflection of shaky relations", The Guardian, 5 abril. Disponível em: http://www.guardian.co.uk/world/2012/apr/05/ russia-us-ambassador-relations.

Elder, Miriam (2012b) "Pussy riot trial worse than Soviet Era", The Guardian, 3 agosto.

El Mundo (2012) "Putin", 5 março.

Emerson, Michael (2001) "Some Paradigms for the Evolving Map of Europe", CEPS Working Document 164 , abril.

Emerson, Michael (2012) "Putin's faltering return”, CEPS ENW, no. 78.

Englud, Will (2012) "Putin Web launch ignores Russian protests", The Washington Post, 12 janeiro. Disponível em: xxx. Consultado em: xxx.

Ennis, Stephen (2012) "Russian Church leader under fire after backing Putin", BBC, 10 abril. Disponível em: http://www.bbc.co.uk/news/world-europe-17667782.

Entrevista (2008) de Alena Vysotskaya Guedes Vieira com um alto funcionário do ministério dos negócios estrangeiros da Finlândia.

Entrevista (2011) de Maria R. Freire e Licínia Simão com Thea Tsolukiani, membro do Partido Free Democrats, Tbilisi, 9 maio.

ESN (2009) "Estratégia de Segurança Nacional da Federação Russa até 2020", 12 maio. Disponível em: http://www.scrf.gov.ru/documents/99.html.

Estratégia de Segurança Nacional (2002). White House, National Security Strategy, Washington D.C., setembro.

Estratégia de Defesa Nacional (2005) United States Department of Defense, National Defense Strategy, Washington D.C, março.

Estratégia de Segurança Nacional (2006) White House, National Security Strategy, Washington D.C., março.

Estratégia de Defesa Nacional (2008). United States Department of Defense, National Defense Strategy, Washington D.C, julho.

Estratégia de Segurança Nacional (2010). White House, National Security Strategy, Washington D.C., maio.

EU-Ukraine Summit (2008) Paris, 9 setembro, Joint Press Release. Disponível em: http:// www.consilium.europa.eu/uedocs/cms_data/docs/pressdata/en/er/102633.pdf.

EurasiaNet (2002) "Russia to Establish Air Base in Kyrgyzstan, Deals Blow to US Strategic Interests in Central Asia", 2 dezembro. Disponível em: http://www.eurasianet.org/ departments/insight/articles/eav120302.shtml.

EurasiaNet (2005) "Uzbekistan and Russia Sign Mutual Defense Pact", 14 novembro. Disponível em: http://www.eurasianet.org/departments/insight/articles/eav111505.shtml. 
European Commission (2003a) Comunicado de imprensa. EU-Russia Summit. São Petersburgo, 31 maio. Disponível em: http://europa.eu.int/comm./external_relations/russia/sum05_03/ip03_768.htm.

European Commission (2003b) "Paving the Way for a New Neighbourhood Instrument", $\operatorname{COM(2003)393~final,~Bruxelas,~} 1$ julho. Disponível em: http://ec.europa.eu/world/enp/ pdf/com03_393_en.pdf.

European Commission (2007) "The European Union and Russia: Close Neighbours, Global Players, Strategic Partners". Disponível em:

http://ec.europa.eu/external_relations/library/publications/russia_brochure07_en.pdf.

European Council (2009) Joint Declaration of the Prague Eastern Partnership Summit. Prague, 7 maio. Disponível em: http://europa.eu/rapid/pressReleasesAction.do?reference=PRES/ 09/78\&format $=$ HTML\&aged $=0 \&$ language $=E N \&$ guiLanguage $=e n$.

European Council (2001) Conclusions of the Presidency. European Council of Göteborg, SN 200/101VER 1, 15 e 16 junho. Disponível em: http://ec.europa.eu/governance/impact/ background/docs/goteborg_concl_en.pdf.

European Strategy of the Republic of Moldova - updated version (2007). Disponível em: http://www.ipp.md/libview.php?l=en\&idc=167\&id=524.

European Union (2011) Statement by the spokesperson of High Representative Catherine Ashton on party registration in Russia. Bruxelas, 22 junho, A 244/11. Disponível em: http://www.consilium.europa.eu/uedocs/cms_data/docs/pressdata/FR/foraff/123022.pdf.

Eurostat and Rosstat (2007) The European Union and Russia. Statistical Comparison 1995-2005. Eurostat, Statistical Books and Rosstat.

Feklyunina Valentina (2008) "Battle for Perceptions: Projecting Russia in the West", Europe-Asia Studies, vol. 60, no. 4, pp. 605-629.

Fenopetov, Vladimir (2006) "The Drug Crime Threat to Countries Located on the 'Silk Road", China and Eurasia Forum Quarterly, vol. 4, no. 1, pp. 5-13.

Fokina, L. V. (2005) "Economic Cooperation Between Russian Regions and Moldova", Problems of Economic Transition, vol. 47, no. 12, pp. 80-86.

Foreign Policy Concept (1993) Russian Federation. Janeiro.

Foreign Policy Concept (2000) Russian Federation. Approved by the President of the Russian Federation V. Putin, 28 junho. Disponível em: http://www.fas.org/nuke/guide/russia/ doctrine/econcept.htm.

Foreign Policy Concept (2008) Russian Federation. Approved by Dmitry A. Medvedev, President of the Russian Federation, 12 julho. Disponível em: http://www.mid.ru/ns-osndoc.nsf/1e5f0de28fe77fdcc32575d900298676/869c9d2b87ad8014c32575d9002b1c3 8 ? OpenDocument.

France Diplomatie (2006) The Weimar Triangle. Disponível em: http://www.diplomatie. gouv.fr/en/country-files/poland/the-weimar-triangle/.

Frear, Mathew (2010) "Friends or Foes? Developments in relations between Russia and Belarus", Russian Analytical Digest, no. 87, pp. 2-4.

Freire, Maria Raquel (2009) "Russian Politics toward Central Asia: Supporting, Balancing, Coercing or Imposing?", Asian Perspective, vol. 33, no. 2, pp. 125-149.

Freire, Maria Raquel (2009) "A Política Externa em Transição: o caso da Federação Russa", Relações Internacionais, no. 23, pp. 75-89.

Freire, Maria Raquel (2011) "USSR/Russian Federation Major Power Status Inconsistencies", in Volgy, Thomas; Corbetta, Renato; Grant, Keith e Baird, Ryan, eds., Major Powers and the Quest for Status in International Politics: Global and Regional Perspectives. Basingstoke: Palgrave Macmillan. 
Freire, Maria Raquel (2012a) "Russia's Energy Policies in Eurasia: Empowerment or Entrapment?", in Kanet, Roger E. e Freire, Maria Raquel, eds., Russia and Its Near Neighbours: Identity, Interests and Foreign Policy. Basingstoke: Palgrave Macmillan.

Freire, Maria Raquel (2012b) "Russian Foreign Policy towards its Neighbourhood: A Complex Mosaic of Relations", in Kanet, Roger E. e Freire, Maria Raquel, eds., Competing for Influence: The EU and Russia in Post-Soviet Eurasia. Dordrecht: Republic of Letters Publishing.

Freire, Maria Raquel (2012c) A Russia de Putin: Vectores Estruturantes de Política Externa. Coimbra: Almedina.

Freire, Maria Raquel (2012d) "Tempo de balanço: as presidências de Barack Obama e Dmitri Medvedev", Relações Internacionais no. 34, junho, pp. 61-72.

Freire, Maria Raquel e Simão, Licínia (2008) "As eleições presidenciais na Rússia: continuidade na mudança”, IPRI Occasional Paper, no. 32. Disponível em: http://www.ipri.pt/ publicacoes/working_paper/working_paper.php?idp=231.

Freire, Maria Raquel e Mendes, Carmen Amado (2009) "Realpolitik Dynamics and Image Construction in the Russia-China Relationship: Forging a Strategic Partnership?", Journal of Current Chinese Affairs, no. 2, pp. 27-52.

Freire, Maria Raquel e Daehnhardt, Patricia (2011) "As relações entre a Alemanha e a Rússia: duas políticas externas em transição", Relações Internacionais, $\mathrm{n}^{\circ} 32$, dezembro, pp. 171-196.

Friedman, Uri (2012) "Russian press rips Romney and his promise of 'Republican hell'", Foreign Policy, 30 agosto. Disponível em: http://blog.foreignpolicy.com/posts/2012/08/30/ russian_press_rips_romney_and_his_promise_of_republican_hell.

Fukuyama, Francis (1992) The End of History and the Last Man. New York: Free Press.

Gaddis, John Lewis (2006) The Cold War: A New History. London: Penguin Books.

Garnett, Sherman W., Alexander Rhar e Koji Watanabe (2000) The New Central Asia: In Search of Stability. New York, Paris e Tokyo: The Trilateral Commission.

Gaspar, Carlos (2004) "Dois Ocidentes”, Relações Internacionais, no. 3, pp. 37-44.

Gaspar, Carlos (2004) "A Russia e a segurança europeia", Nação e Defesa, dezembro. Disponível em: http://www.ipri.pt/investigadores/artigo.php?idi=3\&ida=103.

Gautier, Donald L. et al. (2009) "Assessment of Undiscovered Oil and Gas in the Arctic", Science, vol. 324, no. 5931, pp. 1175-1179.

Gershman, Carl (2011) "The Fourth Wave.Where the Middle East revolts fit in the history", The New Republic, 14 março.

Godzimirski, Jakub M. (2008) "Russia's energy strategy and prospects for a Northern Dimension energy partnership", in Blakkisrud, Helge; Aalto, Pami e Smith, Hanna, eds., The New Northern Dimension of the European Neighbourbood. Brussels: Centre for European Policy Studies, pp. 145-163.

Goldgeier, J.M. (1999) Not whether but when: The U.S. decision to enlarge NATO. Washington (D.C.): Brookings Institution Press.

Golosov, Grigorii (2011) "Russia's Regional Legislative Elections, 2003-2007: Authoritarianism Incorporated", Europe Asia Studies, vol. 63, no. 3, maio.

Goode, Paul (2007) “The puzzle of Putin's gubernatorial appointment”, Europe-Asia Studies, vol. 59 , no. 3 , pp. 365-399.

Gorbachov, Mikhail (1987) Discurso em Murmansk. Ceremonial meeting on the occasion of the presentation of the Order of Lenin and the Gold Star Medal to the city of 
Murmansk, 1 outubro. Moscow: Novosti Press Agency, pp. 23-31. Disponível em: www. barentsinfo.fi/docs/Gorbachev_speech.pdf.

Gordon, Philip H, ed. (1997) NATO's Transformation: The Changing Shape of the Atlantic Alliance. Boston: Rowman \& Littlefield Publishers.

Gordon, Philip H, e Shapiro, Jeremy (2004) Allies at War: America, Europe, and the Crisis Over Iraq. New York: McGraw-Hill.

Gorvett, Jon (2002) "Chechen Question Harms Turkish-Russian Relations", Eurasia Insight. Disponível em: http://www.eurasianet.org/departments/insight/articles/eav110702a.shtml.

Graham, Thomas (2008) "U.S.-Russia Relations: Facing Reality Pragmatically", Center for Strategic \& International Studies, julho.

Grand, Stephen (2012) "Starting in Egypt: The Fourth Wave of Democratization?" Brookings, 10 fevereiro. Disponível em: http://www.brookings.edu/research/opinions/2011/02/10-egypt-democracy-grand.

Grinkevich, Vladislav (2007) "The end of the meat war" RIA Novosti. Disponível em: http:// en.rian.ru/analysis/20071221/93527462.html.

Gromadzki, Grzegorz; Kononczuk, Wojciech (2007) Energy Game: Ukraine, Moldova and Belarus between the EU and Russia. Warsaw: Batory Foundation.

Grozin, Andrei (2012) "Andrei Grozin: as operações na região de Badakhshan no Tajiquistão estavam preparadas desde a primavera", Entrevista ao jornal electrónico Regnum (em russo). Disponível em: http://www.regnum.ru/news/polit/1555574.html.

Guardian, The (2011) "US and Russia stir up political tensions over Arctic", 6 julho. Disponível em: http://www.guardian.co.uk/world/2011/jul/06/us-russia-political-tensions-arctic. Consultado em:

Guardian, The (2012) "Syria resolution vetoed by Russia and China at United Nations", 4 fevereiro. Disponivel em: http://www.theguardian.com/world/2012/feb/04/assad-obama-resign-un-resolution. Consultado em: 6 fevereiro 2012.

Günsche, Karl-Ludwig (1997) "Wie sich Rußland die Nato-Osterweiterung vorstellt", Die Welt Online. Disponível em: http://www.welt.de/print-welt/article635656/Wie-sich-Russland-die-Nato-Osterweiterung-vorstellt.html.

Gullette, David (2010) "Kyrgyzstan: Components of Crisis", OpenDemocracy, 28 junho. Disponível em: http://www.opendemocracy.net/david-gullette/kyrgyzstan-components-of-crisis.

Hague, Rod and Harrop, Martin (2010) Comparative Government and Politics. Basingstoke: Palgrave.

Hanson, Philip; Nixey, James; Shevtsova, Lilia e Wood, Andrew (2012) "Putin Again. Implication for Russia and the West", A Chatham House Report, Chatham House-RIIA.

Harrabin, Roger (2012) "Arctic Sea Ice Reaches Record Low, NASA says", BBC Environmental Analysis, 27 agosto. Disponível em: http://www.bbc.co.uk/news/science-environment-19393075.

Härtel, André (2010) "Ukrainian-Russian gas relations after the 2009 conflict: the current situation and future prospects", Russian Analytical Digest, no. 75, pp. 2-5.

Haukkala, Hiski (2008) "The Russian Challenge to EU Normative Power: The Case of European Neighbourhood Policy", The International Spectator, vol. 43, no. 2, pp. 35-47.

Haukkala, Hiski (2010) The EU-Russia Strategic Partnership. The limits of post-sovereignity in international relations. London: Routledge.

Heinrich, Andreas (2006) "Gazprom: a reliable partner for Europe's Energy Supply?", Russian Analytical Digest, no. 1, pp. 2-7.

Held, David (2007) Modelos de Democracia. Madrid: Alianza Editorial. 
Heritage Foundation (2010) "More Reasons not to Trust Russia on START", 15 dezembro.

Henderson, Jane (2011) The Constitution of the Russian Federation. A Contextual analysis. Oxford and Portland, Oregon: Hart Publishing.

Henriksson, Maimo (2006) "The New Northern Dimension Policy". Proceedings of the Fourth Northern Research Forum The Borderless North Oulu and Tornio in Finland, and Haparnada and Luleå, Sweden, 5-8 outubro. Disponível em: http://www.nrf.is/Publications/ The $\% 20$ Borderless $\% 20$ North/Borderless\%20North.html.

Hill, Fiona (2001) "Une stratégie incertaine: la politique des États-Unis dans le Caucase et en Asie centrale depuis 1991”, Politique Étrangère, vol. 66, no. 1, pp. 95-108.

Hill, Fiona (2002) "The United States and Russia in Central Asia: Uzbekistan, Tajikistan, Afghanistan, Pakistan, and Iran”, Brookings, 15 agosto. Disponível em: http://www. brookings.edu/speeches/2002/0815russia_hill.aspx.

Hill, Fiona (2003) "Central Asia and the Caucasus: The Impact of the War on Terrorism", in Karatnycky, Adrian; Motyl, Alexander J. e Schnetzer, Amanda, eds., Nations in Transit 2003. Lanham, MD: Rowman e Littlefield, pp. 39-50.

Hill, Fiona e Omer Taspinar (2006) "Turkey and Russia: Axis of the Excluded?", Survival, vol. 48 , no. 1 , pp. 81-92.

Hoyer, Werner (2010) discurso no seminário "Strategic Seminar 3: NATO's Partnerships and Beyond”, 14 janeiro. Disponível em: http://www.auswaertiges-amt.de/diplo/en/Infoservice/ Presse/Reden/2010/100115-Hoyer-Oslo- NatoRus.html.

Huffington Post (2012) "Mitt Romney: Russia is our number one geopolitical foe”, 26 março.

Huntington, Samuel (1994) La Tercera Ola. La democratización a finales del Siglo XX. Barcelona: Editorial Paidós.

Hurriyet Daily News (2011) "Nabucco start delayed as North Stream moves ahead”, 5 junho.

Huskey, Eugene (2004) "A Liderança Política e a Luta entre o Centro e a Periferia: As Reformas Administrativas de Putin", em Brown, Archie e Shevtsova, Lilia, eds. Gorbachev, Ieltsin E Putin. A Liderança Política na Transição Russa, pp. 197-234. Editora Universidade de Brasília (translation from the CarnegieEndowment for International Peace, Washington D.C., 2001).

Ikenberry, G. John (2001) After Victory: Institutions, Strategic Restraint and the Rebuilding of Order after Major Wars. Princeton: Princeton University Press.

International Crisis Group (2002a) Central Asia: Water and Conflict, International Crisis Group, Asia Report, no. 34, 30 maio.

International Crisis Group (2002b) Central Asia: Border Disputes and Conflict Potential, International Crisis Group, Asia Report, no. 33, 4 abril.

International Crisis Group (2005) The Curse of Cotton: Central Asia's Destructive Monoculture, International Crisis Group, Asia Report, no. 93, 28 fevereiro.

International Crisis Group (2007) "Moldova's Uncertain Future", in Hamilton, Daniel; Mangott, Gerhard, eds. The New Eastern Europe: Ukraine, Belarus and Moldova. Washington, DC: Center for Transatlantic Relations, pp. 77-124.

Igumnova, Lyudmila (2011) "Russia's Strategic Culture Between American and European Worldviews”, The Journal of Slavic Military Studies, vol. 24, no. 2, pp. 253-273.

Ilulissat Declaration (2009) Arctic Ocean Conference, Ilulissat, Greenland, 27-29 maio. Disponível em: http://www.oceanlaw.org/downloads/arctic/Ilulissat_Declaration.pdf.

Indyk, Martin; Lieberthal, Kenneth; e O'Hanlon, Michael E. (2012) "Scoring Obama's Foreign Policy. A Progressive Pragmatist Tries to Bend History”, Foreign Policy, maio/junho. Disponível em: http://www.foreignaffairs.com/articles/137516/martin-indyk-kenneth-lieberthal-and-michael-e-ohanlon/scoring-obamas-foreign-policy. 
Ioffe, Grigory (2011) "Belarus and the West: From Estrangement to Honeymoon", Journal of Communist Studies and Transition Politics, vol. 27, no. 2, pp. 217-240.

Isakova, Irina (2005) Russian Governance in the Twenty-First Century. London: Frank Cass.

Ischinger, Wolfgang (2012) "Yes to Missile Defense, With Russia", The New York Times, 17 maio.

Ischinger, Wolfgang e Weisser, Ulrich (2010) "Getting Russia Right", The New York Times. Disponível em: http://www.nytimes.com/2010/06/10/opinion/10iht-edischinger.html.

Ismayilov, Elnur (2011) How Neo-Imperial Is Russia. Saarbrücken: VDM Verlag Dr. Müller.

Ivanov, Igor S. (2001) "The New Russian Identity: Innovation and Continuity in Russian Foreign Policy", The Washington Quarterly, vol. 24, no. 3, pp. 7-13.

Ivanov, Igor S. (2002) The New Russian Diplomacy. Washington, DC: The Nixon Centre and Brookings Institution.

Izvestia (2007) Lavrov osadil nedovolnych rossiyskim flagom Canady i SSHA. Disponível em: http://www.izvestia.ru/news/405525.

Jack, Andrew (2005) Inside Putin's Russia. London: Granta Publications.

Jackson, Nicole J. (2003) Russian Foreign Policy and the CIS: Theories, Debates and Actions. New York: Routledge.

Janusz, Barbara (2005) "The Caspian Sea: Legal Status and Regime Problems", Russia and Eurasia Programme, Chatham House, REP bp 05/02.

Jarábik, Balazs; Rabagliati, Alastair (2010) “Assessing Democracy Assistance: Belarus”, FRIDE. Disponível em: www.fride.org/download/IP_WMD_Belarus_ENG_jul10.pdf.

Jentleson, Bruce W. e Kupchan, Charles A. (2012) "A Dangerous Mind", Foreign Policy, 30 agosto. Disponível em: http://www.foreignpolicy.com/articles/2012/08/30/a_dangerous_ mind_mitt_romney.

Joint Statement (2009) "Joint Statement by President Barack Obama and President Dmitry A. Medvedev of Russia", Administration of Barack H. Obama, Compilation of Presidential Documents, 1 abril, DCPD Nr: DCPD200900208.

Jonson, Lena (2001) "Russia and Central Asia", in Roy Allison e Jonson, Lena, eds., Central Asian Security: The New International Context. London: Royal Institute of International Affairs, pp. 95-126.

Kagan, Robert (2008) "Robert Kagan, 'New Europe, Old Russia”, The Washington Post, 6 fevereiro. Disponivel em: http://www.washingtonpost.com/wpdyn/content/article/2008/02/05/ AR2008020502879.html.

Kanet, Roger E. (2008) "The return of Imperial Russia: Russia and its Neighbors", ACDIS Occasional Paper, setembro. Disponível em: http://acdis.illinois.edu/assets/docs/309/ TheReturnofImperialRussiaRussiaandItsNeighbors.pdf.

Kanet, Roger E. (2010) "Russia and the Greater Caspian Basin: Withstanding the US Challenge", in Maria R Freire e Kanet, Roger E., eds., Key Players and Regional Dynamics in Eurasia: The Return of the 'Great Game'. Basingstoke: Palgrave Macmillan, pp. 81-102.

Karaganov, Sergei et. al. (2010) "Towards an 'Alliance of Europe'. Analytical Report by the Russian Group of the Valdai International Discussion Club", St. Petersberg, Kizhi-Valaam, Moscow, 31 agosto - 7 setembro. Disponível em: http://karaganov.ru/content/images/ uploaded/4b4ec04c237e760f0808556999573c53.pdf.

Karaganov, Sergei; Teltschik, Horst e Olechowski, Andrzej (2011) "Hotel Europe: Guests and Permanent Partners", 29 dezembro. Disponível em: http://eng.globalaffairs.ru/ number/Hotel-Europe-Guests-and-Permanent-Partners-15432. 
Karbuz, Sohbet (2010) “The Caspian's Unsettled Legal Framework: Energy Security Implications", Journal of Energy Security, 18 maio.

Kasyanov, Mikhail (2008) "Russia after the elections: what potential for common values?", Study day of the EPP-ED Group on Russia. Brussels: European Parliament, 15 maio.

Kazan, Isil (2005) "Turkey: Where Geopolitics still matters", Contemporary Security Policy, vol. 26 , no. 3, pp. 588-604.

Kefferpütz, Roderick (2010) "On Thin Ice? (Mis)interpreting Russian Policy in the High North”, CEPS Policy Brief no. 205, fevereiro.

Kefferpütz, Roderick e Bochkarev, Danila (2008) "Expanding the EU's Institutional Capacities in the Arctic Region. Policy Briefing and Key Recommendations", Heinrich Boell Stiftung, EU Regional Office. Disponível em: www.boell.eu/web/269-258.html.

Kennedy, Paul (1989) The Rise and Fall of the Great Powers: Economic Change and Military Conflict From 1500 to 2000. New York: Vintage Books.

Keskitalo, Carina (2007) "International Region-Building. Development of the Arctic as an International Region”, Cooperation and Conflict, vol. 42, no. 2, pp. 187-205.

Khristenko, Viktor (2001) Speech at the Northern Dimension Forum, Lappeenranta, Finland, 22 outubro. Disponível em: http://www.government.fi/ajankohtaista/tiedotteet/ tiedote/en.jsp?oid=95842.

King, Charles (2003) "Marking time in the middle ground: Contested identities and Moldovan foreign policy", Journal of Communist Studies and Transition Politics, vol. 19, no. 3, pp. 60-82.

Kjærnet, Heidi (2008) "Giving Moscow A Taste of its Own Medicine: Azerbaijan", ADA Biweekly, vol. I, no. 10, 15 junho.

Kobrinskaya, Irina (2005) "The CIS in Russian Foreign Policy: Causes and Effects", in Hanna Smith, ed., Russia and Its Foreign Policy. Saarijärvi: Kikimora Publications, pp. 77-92.

Konyshev, V., Segounin. A. (2010) "Arktika na perekrestke geopoliticheskih interesov", Mirovaya Ekonomika e Meshdunarodyje Otnosheniya, no. 9, pp. 43-53.

Koprulu, Kemal (2009) "Paradigm Shift in Turkey's Foreign Policy", Brown Journal of World Affairs, vol. XVI, no. 1, pp. 185-201.

Kosc, W. (2011) Smolensk tragedy report continues to complicate Russian-Polish relations. Russia Beyond the Headlines. Disponível em: http://rbth.ru/articles/2011/01/20/ smolensk_tragedy_report_continues_to_complicate_russian-polish_relat_12293.html.

Korosteleva, Elena (2010) "Moldova's European Choice: 'Between two stools'?", Europe-Asia Studies, vol. 62, no. 8, pp. 1267-1289.

Kramer, Andrew E. (2009) "New Gas Pipeline from Central Asia Feeds China", The New York Times, dezembro 14. Disponível em: http://www.nytimes.com/2009/12/15/world/ asia/15pipeline.html.

Kramer, David J. (2010) "Resetting U.S.-Russian Relations: It Takes Two", The Washington Quarterly, vol. 33, no. 1, pp. 61-79.

Krauthammer, Charles (1990) “The Unipolar Moment”, Foreign Affairs, vol. 70, no. 1, pp. 23-33.

Kremlin (2012) Press statements and answers to journalists' questions following a meeting with President of Armenia Serzh Sargsyan, Moscovo, 8 agosto. Disponível em: http:// eng.kremlin.ru/transcripts/4274.

Kuchins, Andrew C. e Zevelev, Igor A. (2012) "Russian Foreign Policy: Continuity in Change", The Washington Quarterly, vol. 35, no. 1, pp. 147-161.

Kudeshkina, Olga (2011) "Reforming the Courts", The EU-Russia Centre Review, outubro, no. 19. 
Kulish, N. (2008) "Georgian Crisis Brings Attitude Change to a Flush Poland", The New York Times. Disponível em: http://www.nytimes.com/2008/08/21/world/europe/21 poland. html?pagewante. $d=$ print.

Kundnani, Hans (2011) "Germany as a Geo-economic Power", The Washington Quarterly, vol. 34 , no. 3 , pp. 31-45.

Kuvshinova, Olga (2012) "Sozialnye obeshaniya Putina" (As promessas sociais de Vladimir Putin). Vedomosti, 17 fevereiro. Disponível em: http://www.vedomosti.ru/politics/ news/1506398/obeschal_5_trln_rub.

Kuzniar, Roman (1991) A new Polish foreign policy. Sprawy Miedzynarodowe.

Kuzniar, Roman (2009) "A Primavera dos Povos de 1989: A transformação dos princípios fundamentais da política externa polaca”, Relações Internacionais, no. 23, pp. 21-37.

Larrabee, F. Stephen (2012) "Rethinking Russia: Russia, Ukraine and Central Europe: The return of Geopolitics”, Journal of International Affairs, vol. 63, no. 2, pp. 33-52.

Laruelle, Marlene (2007) "Asie Centrale: Le retour de la Russie", Politique Internationale, no. 115, primavera. Disponível em: http://www.politiqueinternationale.com/revue/read2. php?id_revue $=115 \&$ id $=630 \&$ content $=$ texte.

Laruelle, Marlene (2008) Russian Eurasianism: An Ideology of Empire. Baltimore: Johns Hopkins University Press.

Laruelle, Marlene; Sébastien Peyrouse; Jean-François Huchet e Bayram Balci, eds., (2010) China and India in Central Asia: A New 'Great Game'? New York: Palgrave Macmillan.

Lassinatti, Gunnar (2000) "Initiative of the Barents Region Co-operation and the Northern Dimension", Paper presented to the IPRA Conference, 5-9 agosto, Tampere, Finlândia.

Lavrov, S. (2011) "Nuuk Declaration: A New Stage of Cooperation among Arctic States", Disponível em: http://goo.gl/sjjzL.

Legvold, Robert (2007) Russian Foreign Policy in the Twenty-First Century and the Shadow of the Past. Columbia: Columbia University Press.

Leshchenko, Natalia (2008) "The National Ideology and the Basis of the Lukashenka Regime in Belarus", Europe-Asia Studies, vol. 60, no. 8, pp. 1419-1433.

Levada Center (s.d.) Sondagem de opinião russa. Disponível em: http://www.whitehouse. gov/the-press-office/us-russia-relations-reset-fact-sheet. Lévesque, J. (1997) The enigma of 1989 the USSR and the liberation of Eastern Europe, Berkeley: University of California Press. Disponível em: http://search.ebscohost.com/login. aspx?direct=true\&scope=site $\&$ $\mathrm{db}=$ nlebk $\& \mathrm{db}=$ nlabk $\& \mathrm{AN}=21260$.

Levgold, Robert, ed. (2007) Russia's Foreign Policy in the Twentieth Century and the Shadow of the Past. New York: Columbia University Press.

Lieven, Anatol (2011) "U.S.-Russian Relations and the Rise of China", New American Foundation, julho.

Light, Margot (2003) "In search of an identity: Russian foreign policy and the end of ideology", Communist Studies and Transition Politics, vol. 19, no. 3, pp. 42-59.

Light, Margot; White, Stephen e Lowenhardt, John (2000) "A wider Europe: the view from Moscow and Kyiv", International Affairs, vol. 76, no. 1, pp. 77-88.

Likhachev, Vassily (2006) "Russia and the European Union", International Affairs- Russian Journal of World Politics, Diplomacy and International Relations, vol. 52, no. 2 pp. 102-114.

Lindner, Rainer (2007) "Neighborhood in Flux: EU-Belarus-Russia. Prospects for the European Union's Belarus Policy”, in Hamilton, Daniel; Mangott, Gerhard, eds., The New Eastern Europe: Ukraine, Belarus and Moldova. Washington, DC: Center for Transatlantic Relations, pp. 55-76.

Linz, Juan (2000) Totalitarian and Authoritarian regimes. Boulder and London: Lynne Rienner. 
Linz, Juan e Stepan, Alfred (1996) Problems of Democratic Transition and Consolidation. Southern Europe, South America and Post-communist Europe. Baltimore: John Hopkins University Press.

Lipman, M. (2010) "The Third Wave of Russian De-Stalinization", Foreign Policy. Disponível em: https://www.carnegieendowment.org/2010/12/16/third-wave-of-russian-de-stalinization/2ft6.

Lo, Bobo (2008) Axis of Convenience. Washington D.C.: Brookings Institution Press.

Lubin, Nancy (2004) "Who's Watching the Watchdogs?: Drug Trafficking in Central Asia", in Burghart, Dan e Sabonis-Helf, Theresa, eds., In the Tracks of Tamerlane: Central Asia's Path to the 21st Century. Washington, D.C.: National Defense University, Center For Technology and National Security Policy, pp. 361-376.

Lukashevich, A. (2011) Briefing by Russian Foreign Ministry Spokesman Alexander Lukashevich, Russia-Germany-Poland trilateral foreign ministers' meeting in Kaliningrad, 20 maio. Disponível em: http://www.mid.ru/bdomp/brp_4.nsf/171aab5ddf3ec3c2c3257 5d7004629c8/921756bb24d724dec3257897003d173c!OpenDocument.

Lynch, Allen C. (2002) “The Evolution of Russian Foreign Policy in the 1990's”, Journal of Communist Studies and Transition Politics, vol. 18, no. 1, pp. 161-182.

MacKinnon, Mark (2007) The New Cold War: Revolutions, Rigged Elections and Pipeline Politics in the Former Soviet Union. New York: Random House.

Makarychev, Andrey S. (2008) "Russia's Search for International Identity Through the Sovereign Democracy Concept”, The International Spectator, vol. 43, no. 2, pp. 49-62.

Makarychev, Andrey S. (2009a) "A Rússia, a Europa e o legado de 1989: conflitos de interpretação", Relações Internacionais, no. 23, pp. 53-74.

Makarychev, Andrey S. (2009b) "Russia and its 'New Security Architecture' in Europe: A Critical Examination of the concept", CEPS Working Document, no. 310. Disponivel em: http://www.ceps.eu/book/russia-and-its-new-security-architecture-europe-critical-examination-concept.

Makarychev, Andrey S. (2010) "Russia's Moldova Policy: Soft Power at the Service of Realpolitik?”, PONARS Eurasia Policy Memo, no. 94.

Makarychev, Andrei and Morozov, Viatcheslav (2011) "Multilateralism, Multipolarity, and Beyond: A Menu of Russia's Policy Strategies”, Global Governance, vol. 17, no. 3, pp. 353-373.

Malia, M.E. (1996) The Soviet tragedy: a history of socialism in Russia, 1917-1991. New York: Free Press.

Malygina, Katerina (2010) "Ukrainian-Russian Gas Relations After the 2009 Conflict: The Current Situation and Future Prospects", Russian Analytical Digest, no. 75, pp. 5-9.

Manners, Ian (2006) "European Union 'Normative Power' and the Security Challenge", European Security, no. 4, pp. 235-258.

Mankoff, Jeffrey (2009) Russian Foreign Policy. The Return of Great Power Politics. Maryland: Rowman \& Littlefield Publishers, Inc.

Marat, Erica (2008) "The Changing Dynamics of State-Crime Relations in Kyrgyzstan", Central Asia Caucasus Institute Analyst, 20 fevereiro. Disponível em: http://www.cacianalyst. org/?q=node/4796.

Marat, Erica (2010) "Bakiyev, the Security Structures, and the April 7 Violence in Kyrgyzstan", Central Asia Caucasus Institute Analyst, 28 abril. Disponível em: http://www.cacianalyst. org/?q=node $/ 5316$. 
Markedonov, Sergei (2010) "Post-Soviet Integration: Does the CIS Work?", OpenDemocracy, oD Russia Post-Soviet World, 13 janeiro. Disponível em: http://www.opendemocracy. net/od-russia/sergei-markedonov/post-soviet-integration-does-cis-work.

Markushina, Natalyia (2005) "Russkie regiony v sisteme meshdunarodych otnoshenij. Fokus na kooperazii Rossii e EC. Na primere Severnogo Izmerenia" (Russia's Regions within the System of International Relations: Case-study of Russia-EU Cooperation in the Framework of the Northern Dimension (in Russian). InBev Baillet-Latour Working Paper, Leuven, fevereiro.

Martinsen, Kaare Dahl (2002) "The Russian Takeover of Belarus", Comparative Strategy, vol. 21 , no. 5 , pp. $401-416$.

McFaul, Michael (2002) "The Fourth Wave of Democracy and Dictatorship: Noncooperative Transitions in the Postcommunist World", World Politics, vol. 54, no. 2, pp. 212-244.

McNamara, Sally (2012) "The failure of the 'Russia Reset': Next Steps for the United States and Europe", The Heritage Foundation, no. 2637, 5 janeiro.

Medvedev, Dmitry (2008a). Discurso do presidente Dmitry Medvedev, "Speech at Meeting with German Political, Parliamentary and Civic Leaders", 5 junho, Berlim. Disponível em: http:// archive.kremlin.ru/eng/speeches/2008/06/05/2203_type82912type82914type84779_202153. shtml.

Medvedev, Dmitry (2008b) Speech at the Meeting with Russian Ambassadors and Permanent Representatives to International Organisations. Statements on Major Issues, Russian Foreign Ministry, Moscovo, 15 julho. Disponível em: http://www.norway.mid.ru/old/ news_fp/news_fp_81_eng.html.

Meister, Stefan (2012) "An alienated partnership: German-Russian relations after Putin's return", The Finnish Institute of International Affairs, paper 105, 10 maio. Disponivel em: www.fiia.fi/assets/publications/bp105.pdf.

Memorando de Meseberg (2010). Disponível em: http://www.russianmission.eu/sites/default/ files/user/files/2010-06-05-meseberg-memorandum.pdf.

Menon, Raja (2007) "Introduction: Central Asia in the Twenty-First Century", in Rumer, Eugene; Trenin, Dmitri e Zhao, Huasheng, eds., Central Asia: Views from Washington, Moscow, and Beijing. New York: M.E. Sharpe, pp. 3-17.

Meyer Resende, Madalena (2009) The Unintended Effects of Europe on Central and East European Party Systems: Poland and Beyond. Tallinn: Tallinn University Press.

Meyer Resende, Madalena, (2012) "Transformando a nação: os nacionalismos dos partidos de centro-direita na Espanha e na Polónia”, Análise Social, 201.

Ministry of Foreign Affairs (2008) "Turkey's Political Relations With Russian Federation". Disponível em: http://www.mfa.gov.tr/turkey_s-political-relations-with-russian-federation.en.mfa.

Monaghan, A.C. (2012) "The End of the Putin Era?", Carnegie Endowment for International Peace, julho.

Montero, J.R. e Milley, T. (2009) Sistemas totalitarios y regímenes autoritarios. Obras completas de Juan J. Linz, vol. 3. Madrid: Centro de Estudios Constitucionales y Políticos.

Mordyshenko, Olga (2012) "Gazovyj Pusyrj” (A bola de gás). Kommersant, Neft i Gas, vol. 161, no. 4946, 30 agosto. Disponível em: http://www.kommersant.ru/doc/2002147?isSearch=True.

Morozova, Natalia (2009) "Geopolitics, Eurasianism and Russian Foreign Policy", Geopolitics, vol. 14 , no. 4, pp. 667-686.

Moscow Times, The (2009) "Kudrin dwells on budget deficit", 25 novembro.

National Snow and Ice Data Center (2012) "Overview of Conditions", 14 agosto. Disponível em: http://nsidc.org/arcticseaicenews/. 
NATO Bucharest Summit Declaration (2008). Disponível em: http://www.nato.int/cps/en/ natolive/official_texts_8443.htm.

NATO 2020: Assured Security, Dynamic Engagement (2010) North Atlantic Treaty Organization. Disponível em: http://www.nato.int/nato_static/assets/pdf/pdf_2010_05/20100517_100517_ expertsreport.pdf.

Neumann, Iver (1995) Russia and the Idea of Europe: Identity and International Relations. London: Routledge.

Neumann, Iver (2006) "European Identity and its changing Others", Norwegian Institute of International Affairs, no. 710. Disponível em: http://english.nupi.no/content/download/613/13779/ version/8/file/710.pdf.

New York Times, The (2000) "Putin's Inaugural Address: "We Believe in our Strength", 8 maio.

New York Times, The (2006) "Oil income helps Russia pay off entire debt to Paris Club Business", 21 agosto.

Nicholson, Martin (2001) "Putin's Russia: Slowing the Pendulum Without Stopping the Clock", International Affairs, vol. 77, no. 3, pp. 867-884.

Nikonov, Vyacheslav (2004) "Russia and European Community: politics and economics", Russian Summer Session "The Europe/Russia Relations in the new enlarged Europe". Moscow: International University of Moscow, 15-23 julho.

North Atlantic Council (2010) Lisbon Summit Declaration, Lisboa, 20 novembro, Parágrafo 23. Disponível em: http://www.nato.int/cps/en/natolive/official_texts_68828.htm.

Nuriyev, Elkhan (2012) "Putin's plan for Russia's neighbours - a Eurasian Union", Open Democracy, 19 março. Disponível em: http://www.opendemocracy.net/od-russia/elkhan-nuriyev/putin\%E2\%80\%99s-plan-for-russia\%E2\%80\%99s-neighbours-eurasian-union.

Oates, Sarah (2007) "The Neo-Soviet Model of the Media", Europe-Asia Studies, vol. 59, no. 8, pp. 1279-1297.

Obama, Barack H. (2007) "Renewing American Leadership", Foreign Affairs, vol. 86, no. 4, pp. 2-16.

Ogonyok (2010) “O glavnyh pokoriteliach Arktiki”, 27 outubro. Disponível em http://www. kommersant.ru/doc/1503124

Okorokova, Lidia (2012) "New Man in Saint Petersburg", The Moscow News, 25 de agosto. Disponível em: http://themoscownews.com/russia/20110825/188961522.html.

Oldberg, Ingmar (1997) "Sunset over the swamp - the independence and dependence of Belarus”, European Security, vol. 6, no. 3, pp. 110-130.

Olimpieva, Evgenia (2012) "Russia's Protest Movement: A View from a Young Participant", Russian Analytical Digest, no. 108, pp. 10-13.

Onis, Ziya (2011) "Multiple Faces of the "New" Turkish Foreign Policy: Underlying Dynamics and a Critique", Insight Turkey, vol. 13, no. 1, pp. 47-65.

Osica, Olaf (2004) "A Lesson in Politics: Poland and the Iraq Conflict". Em B. Wizimirska, ed. Yearbook of Polish Foreign Policy 2003. Warsaw: Administrative and Maintenance Services, Ministry of Foreign Affairs of Poland.

"Osnovy gosudarstvennoi politiki Rossiyskoy Federatsii v Arktike na period do 2020 goda i dal'neishnuyu perspektivu" (2008) (The Russian Federation's main state policy in the Arctic until 2020 and beyond), 18 setembro. Disponível em: http://www.scrf.gov.ru/ documents/98.html.

Ost-Ausschuss der Deutschen Wirtschaft, "Rekordergebnis für Exporte nach Osteuropa", 2 março. Disponível em: http://www.ost-ausschuss.de/rekordergebnis-f-r-exporte-nach-osteuropa. 
Ost-Ausschuss der Deutschen Wirtschaft, "Wege zur Visa-Freiheit", novembro 2011, p. 5. Disponível em: http://www.ost-ausschuss.de/sites/default/files/pm_pdf/Positionspapier\%20 Wege\%20zur\%20Visa-Freiheit-Ost-Ausschuss_0.pdf.

Padhol, Uladzimir e Marples, David R. (2011) "The 2010 Presidential Elections in Belarus", Problems of Post-Communism, vol. 58, no. 1, pp. 3-16.

Pardo Sierra, Oscar (2011) "Shaping the Neighbourhood: the Impact of the EU on Georgia", Europe-Asia Studies, vol. 63, no. 8, pp. 1377-1398.

Patsuria, Nino (2010) "Can Georgia find the backdoor for exports into Russia?", Eurasianet, 17 maio. Disponível em: http://www.eurasianet.org/node/61079.

PCA (1997) Agreement on Partnership and Cooperation establishing a partnership between the European Communities and their Member States, of the one part, and the Russian Federation, of the other part.

PCA (1998) Partnership and Cooperation Agreement between the European Communities and their Member States and the Republic of Moldova (1998), JO L 181/3, 24 junho. Disponível em: http://ec.europa.eu/external_relations/ceeca/pca/index.htm.

Pew Research Center (2010) "The Pew Global Attitudes Project", Pew Research Center, 17 junho. Disponível em: http://www.pewglobal.org/files/2010/06/Pew-Global-Attitudes-Spring-2010-Report.pdf.

Pipes, Richard (1995) Russia under the Bolshevik Regime. London: Harper Collins.

Pomfret, Richard (2009) "Central Asia and the Global Economic Crisis", EU Central Asia Monitoring (EUCAM), 7 junho. Disponível em: http://www.eucentralasia.eu/fileadmin/ user_upload/PDF/Policy_Briefs/PB-7-eversion.pdf.

Pond, Elizabeth (2004) Friendly Fire: The Near-Death of the Transatlantic Alliance. Washington D.C.: Brookings Institution Press.

Popescu, Nicu; Wilson, Andrew (2009) The Limits of Enlargement-Lite: European and Russian Power in the Troubled Neighbourhood. London: European Council on Foreign Relations.

Pratt, Martin e Schofield, Clive (1997) "International Boundaries, Resources and Environmental Security in the Caspian Sea", in Blake, Gerald; Chia Lin Sien, C. Grundy-Warr; Platt, Martin e Schofield, Clive, eds., International Boundaries and Environmental Security: Frameworks for Regional Cooperation. London: Kluwer Law International, pp. 81-104.

Pravda, Alex, ed. (2005) Leading Russia: Putin in Perspective. Oxford: Oxford University Press. Priego, Alberto (2000) "La evolución del conflicto en Chechenia", UNISCI Papers 20, Madrid. Priego, Alberto (2001) "Chechenia: Conflicto en la Rusia Post-Soviética”, El Mundo, 27 outubro.

Priego, Alberto (2004) "Beslán: un punto de inflexión en la lucha contra el terrorismo checheno" UNISCI Discussion Papers, no. 6.

Priego, Alberto (2008) "Osetia del Sur: la cúspide del desencuentro entre EE.UU. y Rusia", ARI 108/2008, 17 setembro.

Priego, Alberto (2010) "Fantasmas chechenos en el Kremlin", El País, 6 abril.

Priego, Alberto (2011) "La primavera árabe: una cuarta ola de democratización?", UNISCI Discussion Papers, no. 26, maio. Disponível em: http://redalyc. uaemex.mx/redalyc/ pdf/767/76718800004.pdf.

Priego, Alberto (2012) "De la Primavera Árabe a la Primavera Rusa?", Razón y Fe, fevereiro.

Prizel, Ilya (1998) National Identity and Foreign Policy: Nationalism and Leadership in Poland, Russia and Ukraine. Cambridge: Cambridge University Press.

Putin, Vladimir (2006) "Written Interview given by President Vladimir Putin to Chinese News Agency Xinhua”, Russian Presidency, 20 março. Disponível em: http://www. kremlin.ru/eng/text/speeches/2006/03/20/1117_type82916_103264.shtml. 
Putin, Vladimir (2007) "Speech at the 43rd Munich Conference on Security Policy". Discurso na Conferência de Segurança de Munique, Alemanha, 10 fevereiro. Disponível em: http:// www.securityconference.de/archive/konferenzen/rede.php?menu_konferenzen=\&menu_ $2007=\& i d=179 \&$.

Putin, Vladimir (2011) "Novyi integratsionnyi proekt dlya Evrazii - budushchee kotoroe rozhdaetsya segodnya”, Izvestia, 3 outubro. Disponível em: http://www.izvestia.ru/ news/502761.

Putin, Vladimir (2012) "Russia and the changing world". Artigo do primeiro ministro Vladimir Putin, Moskovskiye Novosti, 27 fevereiro. Disponível em: http://premier.gov.ru/eng/ events/news/18252/.

Rachman, Giddeon (2010) Zero-Sum World: Power and Politics After the Crash. London: Atlantic Books.

Rashid, Ahmed (1994) The Resurgence of Central Asia: Islam or Nationalism?. London: Zed Books.

Rashid, Ahmed (2002) Jihad: Ascensão do Islão Militante na Ásia Central. Tradução de Freitas e Silva, Lisboa: Terramar.

Raskolnikova, Ilona (2012) "Kazakhstan, Russia and Belarus to integrate joint air defense system”, Pravda, 12 julho. Disponível em: http://english.pravda.ru/world/ussr/12-07-2012/121633-kazakhstan_russia_belarus_missile_defense-0/.

Resolução 1441 (2002) United Nations Security Council Resolution, S/RES/1441, 8 novembro. Disponível em:

http://daccessddsny.un.org/doc/UNDOC/GEN/N02/682/26/PDF/N0268226.pdf?OpenElement.

Resolução 1973 (2011) United Nations Security Council Resolution, S/RES/1973, 17 março. Disponível em:

http://daccessddsny.un.org/doc/UNDOC/GEN/N11/268/39/PDF/N1126839.pdf?OpenElement.

Rettman, Andrew (2011) "Russian decision boosts Moldova's EU entry prospects", EUobserver, 30 março. Disponível em: http://euobserver.com/foreign/32095.

Reuters (2011) "Factbox - Twists and turns in Polish-Russian relations", Reuters. Disponível em: http://uk.reuters.com/article/2011/04/07/uk-poland-russia-relations-factbox-idUKTRE7363DY20110407.

Reuters (2012a) "U.S-Russia ties strained during Putin political campaign", 2 março.

Reuters (2012b) "Top Obama aides hit back at Romney on Russia”, 1 abril.

RFE/RL (2004a) "Tajikistan: First Permanent Russian Military Base Opened", Radio Free Europe/Radio Liberty, 17 outubro. Disponível em: http://www.rferl.org/content/ article/1055375.html.

RFE/RL (2004b) RFE Special Report on NATO expansion. RFE/RL Special Reports.

RFE/RL (2009) "Russia unveils proposal for European security treaty", 30 novembro. Disponível em: http://www.rferl.org/content/Russia_Unveils_Proposal_For_European_ Security_Treaty/1891161.html.

RFE/RL (2010) "Deal Signed On Extending Russian Military Presence In Armenia", Radio Free Europe/Radio Liberty, 20 agosto. Disponível em: http://www.rferl.org/content/ Russia_Armenia_Sign_Extended_Defense_Pact_/2133043.html.

RFE/RL (2012a) "Russia, Ukraine Hold Inconclusive Gas Summit", Radio Free Europe/Radio Liberty, 12 julho. Disponível em: http://www.rferl.org/content/russia-ukraine-gas-summit/24643469.html.

RFE/RL (2012b) "Russia Shut Downs USAID Activities", 19 setembro. Disponível em: http:// www.rferl.org/content/moscow-shuts-down-usaid-activities-in-russia/24712579.html. 
RiaNovosti (2012) "Russia Calls on Ukraine to Treat Tymoshenko with Humanity", RiaNovosti, 24 abril. Disponível em: http://en.rian.ru/russia/20120424/173019528.html.

Rice, Condoleezza (2011) No Higher Honour: A Memoir of my Years in Washington. London: Simon \& Schuster.

Road Map for Common Economic Space (2005) Cimeira UE-Rússia, Moscovo, 10 maio, Conclusões, Anexo 1. Disponível em: http://ec.europa.eu/environment/enlarg/pdf/ road_map_ces.pdf.

Roberts, John (2010) "Turkey as a Regional Energy Hub”, Insight Turkey, vol. 12, no. 3, pp. 39-48.

Rodkiewicz, Witold (2012) "Russia's strategy towards Moldova: continuation or change?", OWS Commentary. Disponível em: http://www.osw.waw.pl/en/publikacje/osw-commentary/2012-04-19/russia-s-strategy-towards-moldova-continuation-or-change.

Romney, Mitt (2012) "Russia”. Disponível em: http://www.mittromney.com/issues/russia.

Rotfeld, A. (2010) "Poland and Russia: A Polish hawk turns dovish on Russia", The Economist. Disponível em: http://www.economist.com/blogs/easternapproaches/2010/09/poland_and_russia.

Rotman, David e Veremeeva, Natalia (2011) "Belarus in the Context of the Neighbourhood Policy: Between the EU and Russia", Journal of Communist Studies and Transition Politics, vol. 27, no. 1, pp. 73-98.

Rowe, Elana Wilson (2009) "Russian regional multilateralism: The case of the Arctic Council", in Rowe, Elana Wilson e Torjesen, Stina, eds., The Multilateral Dimension in Russian Foreign Policy. London: Routledge, pp. 142-152.

Rowe, Elana Wilson e Torjesen, Stina, eds., (2009) The Multilateral Dimension in Russian Foreign Policy. London and New York: Routledge.

RPC National Security Facts (2010) "What Exactly Has Been 'Reset' in the Relationship With Russia?”. Disponível em: http://rpc.senate.gov/public/?a=Files.Serve\&File_id=bb666692-2226-467f-92d1-4c0710ccf1a1.

Russian National Security Strategy 2020 (2009) Documento aprovado por Decreto Presidencial da Federação Russa, 12 maio. Disponível em: http://rustrans.wikidot.com/russia-s-national-security-strategy-to-2020.

Rutland, Peter (2008) "Russia as an Energy Superpower", New Political Economy, vol. 13, no. 2, pp. 203-210.

Ryabkov, Sergei (2010) "An Interview with Sergey Ryabkov", Journal of International Affairs, vol. 63 , no. 2 , pp. 207-216.

Sakwa, Richard (1999) The Rise and Fall of the Soviet Union. London: Routledge.

Sakwa, Richard (2011) "Russia and Europe: Whose Society?", European Integration, vol. 33, no. 2, pp. 197-214.

Sakwa, Richard (2008) Russian Politics and Society (fourth edition). Oxon and New York: Routledge.

Sakwa, Richard e Webber, Mark (1999) "The Commonwealth of Independent States, 1991-1998: Stagnation and Survival”, Europe-Asia Studies, vol. 51, no. 3, pp. 379-415.

Sanchez, W. Alejandro (2009) "The 'Frozen' Southeast: How the Moldova-Transnistria Question has become a European Geo-Security Issue”, The Journal of Slavic Military Studies, vol. 22, no. 2, pp. 153-176.

Sarotte, Mary-Elise (2009) 1989: The Struggle to create Post-Cold War Europe. Princeton and Oxford: Princeton University Press.

Satter, David (2012) "Russia's Looming Crisis", Foreign Policy Research Institute, março. 
Service, Robert (2003) A History of Modern Russia: From Nicholas II to Vladimir Putin. Cambridge, Massachusetts: Harvard University Press.

Shanker, Thom (2011) "U.S. Hails Deal With Turkey on Missile Shield", The New York Times, 15 setembro.

Shapovalova, Natalia e Zarembo, Kateryna (2010) "Russia's Machiavellian support for democracy", FRIDE policy brief, no. 56, pp. 1-5.

Sharp, Gene (2012) From Dictatorship to Democracy. London: Serpent Tail.

Sherlock, Thomas (2011) "Confronting the Stalisnist Past: the Politics of Memory in Russia", The Washington Quaterly, vol. 34, no. 2, pp. 93-109.

Sherr, James (2008) Russia's Elections and the Near Abroad. Estocolmo: Institute for Security and Development Policy.

Shevtsova, Lilia (2007) Russia lost in translation: The Yeltsin and Putin Legacies. Washington D.C.: Carnegie Endowment for International Peace.

Shumylo-Tapiola, Olga (2012) "Ukraine and Russia: Another Gas War?", Carnegie Endowment for International Peace. Disponível em: http://carnegieendowment.org/2012/02/21/ ukraine-and-russia-another-gas-war/9roh.

Sievert, Stephan; Zakharov, Sergey e Klingholz, Reiner (2011) "The Waning World Power: The demographic future of Russia and the other Soviet successor states", Berlin Institut für Bevölkerung und Entwicklung. Disponível em: http://www.berlin-institut.org/ fileadmin/user_upload/Russland/Russland_e_online.pdf.

Sikorski, Radislaw (2011) "Poland and the future of the European Union", Speech of the Foreign Minister of Poland in Berlin. Disponível em: www.msz.gov.pl/files/docs/ komunikaty/20111128BERLIN/radoslaw_sikorski_poland_and_the_future_of_the_eu.pdf.

Sikorski, Radislaw \& Store, J.G. (2012) "NATO, Russia and Tactical Nuclear Arms letter to the NYTimes", The New York Times. Disponível em: http://www.nytimes.com/2012/05/15/ opinion/nato-russia-and-tactical-nuclear-arms.html.

Simão, Licínia (2010) "Carta de Bisqueque: Da democracia na Ásia Central”, Relações Internacionais, no. 26, junho, pp. 61-66.

Skak, Mette (2012) "Denmark", in Lobjakas, Ahto e Mölder, Martin, eds., EU-Russia Watch 2012, pp. 29-35.

Skorzynski, J. (2012) "A revolução do Solidariedade e a crise do sistema soviético", Relações Internacionais, no. 33, pp. 71-81.

Skubiszewski, Krzysztof (1993) "Raison d'être of the Polish Republic", Polityka Polska.

Skubiszewski, Krzysztof (1994) "We built the Polish foreign policy from scratch". Entrevista com Krzysztof Skubiszewski (com W. Beres, K. Brunetka e A. Romanowski). Tygodnyk Powszechny.

Smith, Keith, (2010) "Russia-Europe Energy Relations Implications for U.S. Policy", CSIS. Disponível em: http://csis.org/files/publication/100218_Smith_RussiaEuropeEnergy_Web.pdf.

Smith, Mark A. (2002) "Contemporary Russian Perceptions of Euro-Atlanticism", Conflict Studies Research Centre, fevereiro.

Snetkov, Aglaya (2007) "The Image of the terrorist Threat in the Official Russian Press: the Moscow Theatre Crisis (2002) and the Beslan Hostage Crisis (2004)" Europe Asia Studies, vol. 59 , no. 8 , pp. 1349-1365.

Snyder, T. (2003) The reconstruction of nations: Poland, Ukraine, Lithuania, Belarus, 1569-1999. New Haven: Yale University Press.

Socor, Vladimir (2003) "Standing Up to Putin's Imperial Ambitions", The Moscow Times, 25 setembro. 
Socor, Vladimir (2012) "Russia Multiplies Conditions for Conflict-Resolution in Moldova", Eurasia Daily Monitor Issue, vol. 9, no. 145. Disponível em: http://www.jamestown.org/programs/ edm/single/?tx_ttnews\%5Btt_news\%5D=39707\&cHash=ee4544a08bd1972fa858d83902c61082.

Soler i Lecha, Eduard (2012) "The Conceptual Architecture of Turkish Foreign Policy: An update in light of regional turbulence", Documentos CIDOB, no. 18.

Solodivnikova, Anna (2012) "Statoil vzyala kurs na Ohotskoe more" (Statoil orienta-se para o Mar de Ohotsk). Disponível em: http://www.kommersant.ru/doc/2011751?isSearch=True.

Souza, Luís Vinhais de (2008) "Foreign Investment in Russia", ECFIN Country Focus 1, 5 janeiro. Disponível em: http://ec.europa.eu/economy_finance/publications/publication10969_en.pdf.

Spero, J.B. (2004) Bridging the European divide: middle power politics and regional security dilemas. Lanham, MD: Rowman \& Littlefield Publishers.

Spiegel, Der (2010) "Open letter: It's Time to Invite Russia to Join NATO", 8 março. Disponível em: http://www.spiegel.de/international/world/open-letter-it-s-time-to-invite-russia-to-join-nato-a-682287.html.

Stålvant, Carl-Einar, ed. (2001) “The Northern Dimension: a Policy in Need of an Institution?", vol. 1. Berlin: Humboldt Universität. Disponível em: http://www2.hu-berlin.de/ ostseekolleg/virtual/archive_bsn_publ_en.php.

Statistische Bundesamt (2008) Destatis, Comunicado de imprensa no. 204, 4 junho. Disponível em: http://www.destatis.de/jetspeed/portal/cms/Sites/destatis/Internet/DE/Presse/ pm/2008/06/PD08__204_51.psml.

Steinmeier, Frank-Walter (2006) "Russland, Europa und die Welt - Perspektiven der Zusammenarbeit in globalen Sicherheitsfragen”, discurso na $42^{\circ}$ Conferência de Segurança de Munique.

Stepanova, Ekaterina (2009) "Does Russia Want the West to Succeed in Afghanistan?", PONARS Eurasia Policy Memo, no. 61, setembro.

Stelzenmüller, Constanze (2009) "Germany's Russia Question", Foreign Affairs, vol. 88, no. 2, pp. 89-100.

Stent, Angela (1999) Russia and Germany Reborn: Unification, Soviet Collapse, and the New Europe. Princeton: Princeton University Press.

Stent, Angela E. (2007) "The Lands in Between: The New Eastern Europe in the Twenty-First Century", in Hamilton, Daniel e Mangott, Gerhard, eds., The New Eastern Europe: Ukraine, Belarus and Moldova. Washington, D.C.: Center for Transatlantic Relations, pp. 1-21.

Stent, Angela E. (2008) "Restoration and Revolution in Putin's Foreign Policy", Europe-Asia Studies, vol. 60, no. 6, pp. 1089-1106.

Strategy for National Security until 2020 (2009) (Strategiya natsionalnoy bezopasnosti Rossiizkoy Federatsii do 2020 goda), no. 537, 12 maio. Disponível em: http://www.scrf.gov.ru.

Stürmer, Michael (2008) Putin and the Rise of Russia. London: Weidenfeld \& Nicolson.

Survey of Russian Federation Foreign Policy (2007) Ministry of Foreign Affairs of the Russian Federation, Department of Information and Press. Disponível em: http://www.mid.ru/ brp_4.nsf/e78a48070f128a7b43256999005bcbb3/89a30b3a6b65b4f2c32572d700292f74? OpenDocument.

Sushko, Oleksandr (2004) "The dark side of integration: Ambitions of domination in Russia's backyard", The Washington Quarterly, vol. 27, no. 2, pp. 119-131.

Swanstrom, Niklas; Cornell, Svante e Tabishalieva, Anara (2005) "A Strategic Conflict Analysis of Central Asia with a Focus on Kyrgyzstan and Tajikitan", Central Asia-Caucasus Institute \& Silk Road Studies Program, junho. Disponível em: www.silkroadstudies.org/docs/ publications/2005/SIDA_CA.pdf. 
Szabo, Stephen F. (2004) Parting Ways: The Crisis in German-American Relations. Washington D.C.: Brookings Institution Press.

Szabo, Stephen (2006) "Enlarging NATO: The German-American Design for a New Alliance", in Haftendorn, Helga; Soutou, Georges-Henri; Szabo, Stephen e Wells, Samuel F., eds., The strategic triangle: France, Germany, and the United States in the shaping of the new Europe. Washington, D.C.; Baltimore: Woodrow Wilson Center Press; Johns Hopkins University Press, pp. 327-351.

Szabo, Stephen (2009) "Can Berlin and Washington Agree on Russia?", The Washington Quarterly, vol. 32, no. 4, pp. 23-41.

Tavernise, Sabrina (2002) "Bush Pledges Partnership with Russians on Energy", The New York Times, 25 maio.

Tekin, Ali e Williams, Paul (2009) "EU-Russian Relations and Turkey's Role as an Energy Corridor", Europe-Asia Studies, vol. 61, no. 2, pp. 337-356.

Tekin, Caner (2011) "Turkish foreign policy in the 21st century: institutional idealism revisited", Turkish Review, vol. 1, no. 4, pp. 30-35.

Terterov, Marat; Van Pool, John e Nagornyy, Sergiy (2010) "Russian Geopolitical Power in the Black and Caspian Seas Region: Implications for Turkey and the World", Insight Turkey, vol. 12, no. 3, pp. 191-203.

The Russian Federation (1999) The Russian Federation Middle Term Strategy Towards the European Union (2000-2010). Disponível em: http://www.delrus.ec.europa.eu/en/p_245.htm.

Thorun, Christian (2009) Explaining Change in Russian Foreign Policy: The Role of Ideas in post-Soviet Russia's Conduct towards the West. Basingstoke: Palgrave Macmillan.

Tocqueville, Alexis de (2008) Da Democracia na América. Lisboa: Relógio D’Água Editores.

Today's Zaman (2011) “Turkey to become 'dialogue partner' at SCO”, 4 novembro.

Today's Zaman (2012) "Turkey disappointed over third veto of UN draft resolution on Syria", 20 julho.

Tolstrup, Jakob (2009) "Studying a negative external actor: Russia's management of stability and instability in the "Near Abroad'", Democratization, vol. 16, no. 5, pp. 922-944.

Trenin, Dmitri (2002) The End of Eurasia: Russia on the Border between Geopolitics and Globalization. Washington D.C.: Carnegie Endowment for International Peace.

Trenin, Dmitri (2007a) "Russia redefines itself and its relations with the West", The Washington Quarterly, vol. 30, no. 2, pp. 95-105.

Trenin, Dmitri (2007b) "Russia and Central Asia: Interests, Policies, and Prospects", in Rumer, Eugene; Trenin, Dmitri e Zhao, Huasheng, eds., Central Asia: Views from Washington, Moscow, and Beijing. New York: M.E. Sharpe, pp. 75-136.

Trenin, Dmitri (2007c) "Russia and Ukraine", in Hamilton, Daniel; Mangott, Gerhard, eds., The New Eastern Europe: Ukraine, Belarus and Moldova. Washington, D.C.: Center for Transatlantic Relations, pp. 195-213.

Trenin, Dmitri (2011) "Modernizing Russian Foreign Policy", Russian Politics and Law, vol. 49, no. 6, pp. 8-37.

Trenin, Dmitri (2012) "What Will Putin Do in Foreign Policy?", Carnegie Endowment for International Peace, maio.

Treaty of Good-Neighborliness (2001) Treaty of Good-Neighborliness and Friendly Cooperation between the People's Republic of China and the Russian Federation, 24 julho. Disponível em: http://www.fmprc.gov.cn/eng/wjdt/2649/t15771.htm.

Tsygankov, Andrei P. (2003) “Mastering space in Eurasia: Russia's geopolitical thinking after the Soviet break-up”, Communist and Post-Communist Studies, vol. 36, no. 1, março, pp. 101-127. 
Tsygankov, Andrei P. (2006a) Russia's Foreign Policy: change and continuity in national identity. Maryland: Rowman \& Littlefield Publishers, Inc.

Tsygankov, Andrei P. (2006b) "If Not by Thanks, Then by Banks? The Role of Soft Power in Putin's Foreign Policy", Europe-Asia Studies, vol. 58, no. 7, pp. 1079-1099.

Tsygankov, Andrei P. (2010) Russia's Foreign Policy: Change and Continuity in National Identity. Plymouth: Rowman \& Littlefield Publishers.

Tsygankov, Andrei P e Tarver-Wahlquist, Matthew (2009) "Duelling Honors: Power, Identity and the Russia-Georgia Divide”, Foreign Policy Analysis, vol. 5, no. 4, outubro, pp. 307-326.

Tudoroiu, Theodor (2011) "Structural factors vs. regime change: Moldova's difficult quest for democracy”, Democratization, vol. 18, no. 1, pp. 236-264.

Tumanov, Sergey el al. (2011) "Russia-EU relations, or How the Russians Really View the EU”, Journal of Communist Studies and Transition Politics, vol. 27, no. 1, pp. 120-141.

Turkowski, A. (2011) "The Polish-German Tandem", Carnegie Moscow Center - Carnegie Endowment for International Peace. Disponivel em: http://carnegie.ru/publications/?fa=46059.

Ulutas, Ufuk (2010) "Turkish Foreign Policy in 2009: a Year of Pro-activity", Insight Turkey, vol. 12, no. 1, pp. 1-12.

U.S. Library of Congress, Poland - Soviet Union and Russia. Disponível em: http:// countrystudies.us/poland/89.htm.

U.S. Department of Defense (2010) BMDR Fact Sheet, março. Disponível em: http://www. defense.gov/bmdr/docs/BMDR\%20FACT\%20SHEET\%20March\%202010\%20_Final_.pdf.

Vahabov, Tamerlan (2010) "Ukraine: a challenge for U.S, EU \& OTAN regional policy", Caucasian Review of International Affairs, vol. 4, no. 3, pp. 297-305.

Vaïsse, Justin e Kundnani, Hans (2012) ECFR's Scorecard 2012, Brussels: The European Council on Foreign Relations. Disponível em: http://www.ecfr.eu/scorecard/2012/extras/pdf/.

Van der Loo, Guillaume e Van Elsuwege, Peter (2012) "Ukraine's Regional Economic Integration: Stuck in the Middle between Its Neighbours? A Legal and Political Analysis", artigo apresentado na conferência UACES 'Exchanging Ideas on Europe: Old Borders - New Frontiers', Passau, Alemanha, 3-5 de setembro.

Voice of America (2012) "Russian PM Says Unification with Belarus Possible and Desirable", 31 julho. Disponível em: http://www.voanews.com/content/russian-pm-says-unification-with-belarus-possible-and-desirable--126555343/170796.html.

Voice of America (2006) "Polish Defense Minister's Pipeline Remark Angers Germany". Disponível em: http://www.voanews.com/english/news/a-13-Polish-Defense-Minister -Pipeline-Remark-Angers-Germany.html.

Vysotskaya, Alena (2008) Russland, Belarus und die EU-Osterweiterung. Stuttgart: Ibidem-Verlag.

Walicki, A. (1994) Philosophy and Romantic Nationalism: the Case of Poland. Notre Dame: University of Notre Dame.

Walicki, A. (2000) "The Troubling Legacy of Roman Dmowski", East European Politics and Societies, vol. 14 , no. 1 , pp. 12-46.

Wallander, Celeste (1997) "The Economization, Rationalization and Normalization of Russian Foreign Policy," PONARS, Policy Memo 1, Harvard University.

Wallander, Celeste (2007) "Russian Transimperialism and its Implications", The Washington Quarterly, vol. 30, no. 2, pp. 107-122.

Warhola, James e Mitchell, William (2006) "The Warming of Turkish-Russian Relations: Motives and Implications", Demokratizatsiya, vol. 14, no. 1, pp. 127-143.

Weir, Fred (2010) "Ukraine-Russia relations: Why Kiev made a dramatic U-turn back toward Moscow", The Christian Science Monitor, 7 maio. Disponível em: http://www.csmonitor. 
com/World/Europe/2010/0507/Ukraine-Russia-relations-Why-Kiev-made-a-dramatic-U-turn-back-toward-Moscow.

Weitz, Richard (2010) "Russian-Turkish Relations: Steadfast and Changing", Mediterranean Quarterly, vol. 21, no. 3, pp. 62-85.

Westphal, Kirsten (2011) "Das neue Öl? Worauf beim Gas jetzt zu achten ist", 10 junho. Disponível em: http://www.swp-berlin.org/de/kurz-gesagt/energiewende-und-gas.html.

Wezeman, Siemon T. (2012) "Military Capabilities in the Arctic", SIPRI Background Paper, março.

White House (2002) Office of the Press Secretary, Text of Joint Declaration, The White House, 24 maio. Disponível em: www.whitehouse.gov/news/releases/2002/05/20020524-2.html.

Wilhelmsen, Julie e Geir Flikke (2005) "Evidence of Russia's Bush Doctrine in the CIS", European Security, vol. 14, no. 3, pp. 387-417.

Wilson, Jeanne L. (2010) "The Legacy of the Colour Revolutions for Russian Politics and Foreign Policy", Problems of Post-Communism, vol. 57, no. 2, pp. 21-36.

Wohlforth, William (1999) "The stability of a unipolar world", International Security, vol. 24, no. 1, pp. 5-41.

Woodward, Bob (2002) Bush at War. New York: Simon \& Schuster.

Xing, Guangchend (2001) "China and Central Asia", in Alliso, Roy e Jonson, Lena, eds., Central Asian Security: The New International Context. London: Royal Institute of International Affairs, pp. 152-170.

Xinhuanet (2012) "Russia-China relations at 'unprecedented high': Russian FM", 3 junho. Disponível em: http://news.xinhuanet.com/english/china/2012-06/03/c_131628116.htm.

Yakoieva, Yana (2011) "Managing Russian Business through the Criminal Code", The EU-Russia Centre Review, no. 19, pp. 9-13. Disponível em: http://www.eu-russiacentre.org/ wp-content/uploads/2008/10/EURC_review_XIX_ENG.pdf.

Yildiz, Taner (2010) “Turkey's Energy Policy, Regional Role and Future Energy Vision”, Insight Turkey, vol. 12, no. 3, pp. 33-38.

Yinanç, Barçin (2010a) "Old rivals, new partners: Turkey and Russia's journey from Cold War to hot sun", Hurriyet Daily News, 8 agosto.

Yinanç, Barçin (2010b) "Old rivals, new partners: Russia and Turkey, tied by energy dependence", Hurriyet Daily News, 8 setembro.

Young, Oran (2011) "Arctic Futures: the Politics of Transformation", in Kraska, James (ed.), Arctic Security in an Age of Climate Change. Cambridge: Cambridge University Press, pp. xxi-xxvii.

Zagorodnov, Artem (2010) "Focus on Moscow's new mayor Sergei Sobyanin" The Telegraph, 28 outubro.

Zagorski, Andrey (2012) "Russia's neighbourhood policy", European Union Institute for Security Studies. Disponível em: http://www.iss.europa.eu/publications/detail/article/ russias-neighbourhood-policy/.

Zakaria, Fareed (2008) The Post-American World. New York: W. W Norton \& Company Ltd.

Zikigayeva, Aigerim (2011) "What does the Arab Spring Mean for Russia, Central Asia and the Caucasus?", CSIS, setembro.

Zverev, A. (1996) "Ethnic Conflicts in the Caucasus 1988-1994", in Coppieters, Bruno, ed., Contested Borders in the Caucasus. Brussels: Vubpress. Disponível em: http://poli.vub. ac.be/publi/ContBorders/eng/.

Zysk, Katarzyna (2011) "Military Aspects of Russia's Arctic Policy: Hard Power and Natural Ressources", in Kraska, James (ed.), Arctic Security in an Age of Climate Change. Cambridge: Cambridge University Press, pp. 85-107. 


\section{NOTAS BIOGRÁ F I CAS}

Alberto Priego estudou Ciência Política na Universidade Complutense onde se doutorou em 2006. É docente de Ciência Política e Relações Internacionais da Faculdade de Direito da Universidade Pontificia Comillas desde 2010 dirigindo atualmente o Departamento de Relações Internacionais. As suas áreas de investigação são a diplomacia, transições políticas e espaço pós-soviético. Entre as suas publicações destacam-se "El Servicio Diplomático Norteamericano | El Foreign Service", Instituto Franklin, Universidad de Alcalá (2011), "The Atlantic Alliance in Eurasia. A different player?" in Maria Raquel Freire e Roger Kanet (org.), Key Players and Regional Dynamics in Eurasia: The Return of the 'Great Game' (Palgrave, 2010), "El Servicio Europeo de Acción Exterior (SEAE): un paso adelante para la UE y una revolución para la diplomacia”, Real Instituto Elcano (Madrid, 2011) e "Pakistan: between Central and South RSC", Central Asia and the Caucasus Review, vol 6, no. 54, dezembro 2008.

Alena Vysotskaya Guedes Vieira é doutorada em Ciência Política pela Universidade de Erlangen-Nuremberga (Alemanha). É professora na Universidade do Minho, bolseira pós-Doutoramento da Fundação Ciência e Tecnologia, e investigadora do Núcleo em Ciência Política e Relações Internacionais (NICPRI/UMinho). Os seus interesses de investigação incluem a governação externa da União Europeia, segurança e cooperação no espaço pós-soviético, e a política externa da Rússia. As suas publicações

mais recentes incluem: "Beyond continuity: Analysis of the effects of the first Trio Presidency on Policy Coherence for Development", European Integration Online Papers, vol. 16 (2012) (com Sabina Kajnc Lange) e 
"Europäische Union, Russland, und Belarus" (União Europeia, Rússia e Bielorrússia), Ibidem-Verlag, 2008.

André Barrinha é professor de Política e Relações Internacionais na Canterbury Christ Church University, no Reino Unido e Investigador do Centro de Estudos Sociais da Universidade de Coimbra. É doutorado nessa mesma área pela Universidade de Kent, Reino Unido. Esteve entre 2004 e 2006 ligado ao Instituto de Estudos Estratégicos e Internacionais, em Lisboa. Os seus principais interesses de investigação centram-se nas áreas dos Estudos Críticos de Segurança, Segurança Europeia, Política Externa da Turquia e Teoria das Relações Internacionais. Entre outras publicações editou em 2008, com a Fundação Friedrich Ebert, a obra Towards a Global Dimension: EU's Conflict Management in the Neighborbood and Beyond.

Bernardo Pires de Lima é investigador do Instituto Português de Relações Internacionais da Universidade Nova de Lisboa, onde está a terminar o doutoramento sobre os EUA e a transformação da NATO depois da Guerra Fria. É visiting fellow no Center for Transatlantic Relations, SAIS, na Universidade Johns Hopkins em Washington DC, e colunista de política internacional do Diário de Notícias. Foi comentador residente da Rádio Renascença, TVI 24 e colunista do jornal i. Tem publicado em revistas académicas como Relações Internacionais, Nação e Defesa ou European Foreign Affairs Review e colaborado com a imprensa nacional e estrangeira. É autor dos livros Blair, a Moral e o Poder (Guerra \& Paz, 2008) e A Cimeira das Lajes: Portugal, Espanha e a Guerra do Iraque (Tinta-da-China, 2013).

Carlos Gaspar é professor de Estudos Políticos da Universidade Nova de Lisboa. É membro da Direção e Investigador do Instituto Português de Relações Internacionais (IPRI-UNL). Das suas publicações recentes constam "NATO's Strategic Concept", in Volodymyr Dubovyk e Luis Nuno Rodrigues (org.), Perceptions of NATO (2011), “Grã-Bretanha” in Maria Raquel Freire (coord.), Politica Externa: As Relações Internacionais em Mudança, Imprensa da Universidade de Coimbra (2011) e "O Conceito Estratégico da Aliança Atlântica”, Nação e Defesa, no. 126, 2010. 
Licínia Simão é professora auxiliar de Relações Internacionais na Faculdade de Economia da Universidade de Coimbra e investigadora do Centro de Estudos Sociais. Desde 2007 ocupou diferentes posições como investigadora e docente convidada em instituições como o Centre for European Policy Studies (CEPS), em Bruxelas, a Academia da OSCE, no Quirguistão, a Universidade da Beira Interior e o Centre for European Studies da Universidade de Carleton, no Canadá. Os seus interesses académicos incluem Políticas Externas e Estudos de Segurança, com enfoque na Política Externa Europeia e no Espaço Pós-Soviético (Cáucaso e Ásia Central), tendo diversas publicações em livros editados e artigos científicos sobre estas temáticas.

Madalena Meyer Resende é investigadora do IPRI-UNL e professora auxiliar convidada no Departamento de Estudos Políticos da Faculdade de Ciências Sociais e Humanas da Universidade Nova de Lisboa. É doutorada em Ciência Política pelo Departamento de Governo da London School of Economics (2005). Lecionou no Colégio da Europa de Natolin em Varsóvia (1998-1999) e foi Gulbenkian Research Fellow no Center for European Policy Studies em Bruxelas (2005-2006). A sua área de investigação é a Política Europeia Comparada com principal foco na Europa Central e Oriental. É autora de The Unintended Effects of Europe on Central and Eastern European Party Systems: Poland and Beyond na Tallinn University Press (2009) e "Implementing the Treaty of Lisbon: The Portuguese Parliament as an actor in the European legislative arena" (com Maria Teresa Paulo) in Nuno Severiano Teixeira e António Costa Pinto (org.), The Europeanization of Portugal, Columbia University Press (2012).

Maria Raquel Freire é professora auxiliar com agregação de Relações Internacionais da Faculdade de Economia da Universidade de Coimbra e investigadora do Centro de Estudos Sociais. Os seus interesses de investigação centram-se nos estudos para a paz, política externa, segurança internacional, Rússia e espaço pós-Soviético. Tem publicados nestas áreas vários capítulos em livros e artigos em revistas científicas. É autora, entre outros, de Conflict and Security in the Former Soviet Union: The Role of 
the OSCE, Ashgate, 2003; organizadora de Politica Externa: As Relações Internacionais em Mudança, Imprensa da Universidade de Coimbra, 2011; autora de A Rússia de Putin: Vectores Estruturantes de Politica Externa, Almedina, 2011; co-organizadora de Competing for Influence: The EU and Russia in Post-Soviet Eurasia e de Russia and European Security, com Roger E. Kanet, Republic of Letters (2 vols.) 2012, bem como de Russia and Its Near Neighbours: Identity, Interests and Foreign Policy, também com Roger E. Kanet, Palgrave, 2012.

Patrícia Daehnhardt é doutorada em Relações Internacionais pela London School of Economics and Political Science, Reino Unido. É professora auxiliar de Relações Internacionais da Faculdade de Ciências Humanas e Sociais da Universidade Lusíada de Lisboa. É investigadora do Instituto Português de Relações Internacionais (IPRI - UNL) e membro do Conselho Científico. É membro da Direção da Secção de Relações Internacionais da Associação Portuguesa de Ciência Política. Entre as suas publicações recentes contam "Germany, the EU and a transforming domestic political arena", in Charlotte Bretherton and Michael L. Mannin (org.), The Europeanization of European Politics (Palgrave Macmillan, 2013), "Germany in the European Union", in Reuben Wong and Christopher Hill (org.), National and European Foreign Policies: towards Europeanization?, (Routledge, 2011) e "As relações entre a Alemanha e a Rússia: duas políticas externas em transição" (com Maria Raquel Freire), Relações Internacionais, no. 32, dezembro 2011.

Sandra Dias Fernandes é licenciada em Relações Internacionais (1999), Mestre em Estudos Europeus (2005) pela Universidade do Minho e doutorada pelo Institut d'Etudes Politiques de Paris (Sciences Po). É professora na Universidade do Minho onde leciona no domínio da Ciência Política e das Relações Internacionais. Atualmente é Diretora da Licenciatura e do Mestrado em Relações Internacionais. As suas publicações recentes incluem: "The EU institutional balance: assessment of its impact on the relationship with Russia" in T. Cierco (coord.), The European Union Neighbourbood: Ten Years into the New Millennium (Ashgate, 2013); "The European Union and the Medvedev Proposal: A Breakthrough or an Empty Shell?" in Roger 
Kanet and Maria Raquel Freire (org.), Russian and European Security (Republic of Letters Publishing, 2012); Multilateralism and EU-Russian relations: The praxis of a competitive cooperation (ANRT, 2012).

Vanda Amaro Dias é doutoranda em Relações Internacionais: Política Internacional e Resolução de Conflitos na Universidade de Coimbra e bolseira Marie Curie na Universidade de Graz, Áustria. É mestre em Ciência Política e Relações Internacionais, com especialização em Estudos Europeus, pela Universidade Nova de Lisboa e licenciada em Ciência Política e Relações Internacionais, pela mesma instituição. Os seus principais interesses de investigação incluem a política externa da União Europeia, Rússia e espaço pós-soviético. Entre outros, publicou recentemente o artigo "The EU and Russia: Competing Discourses, Practices and Interests in the Shared Neighbourhood" na revista Perspectives on European Politics and Society. 
(Página deixada propositadamente em branco) 


\section{N D E X}

11 de setembro de 2001 25, 45, 114, 117, $124,142,224,363$

\section{Abraham, Spencer 229}

Abcázia 50, 63, 71, 77, 90, 102, 104, 105, 132, 159, 164, 190, 209, 236

Acordo de Parceria e Cooperação (APC) 7 , $24,42,46,74,187,200,211,226,284$

Afeganistão $14,47,102,117,118,121,122$, $124,130,132,133,135,162,228,229$, 232, 240, 244, 245, 248, 268

Guerra no Afeganistão, 115, 119, 120, 239, 249

Al Assad, Bashar, 243, 315

Albânia 14

Alemanha, (Republica Federal) 9, 20, 23, 24, $110,111,141-145,149-173,177-179,182-$ $-190,193,195,196,205,208,233,260$, $286,325,334,338,348,354,357,360$

Diálogo de Petersburgo 153

(No) quadro euro-atlântico 141, 144

Ostpolitik 143, 150, 162, 168, 170, 183, 189

Política energética 142, 157, 158,

República Democrática da Alemanha (RDA), Guerra Fria 143

República Federal da Alemanha (RFA), Guerra Fria 143, 183

República de Weimar 142,

Triangulo de Weimar 167, 183, 188, 193, 196, 338

Aliança Atlântica,

ver Organização do Tratado do Atlântico Norte
Al Qaeda 228, 229

Antall, József 180

Arménia 22, 37, 41, 44, 62, 63, 71, 85, 89, 97, 100, 102, 104-107, 114, 164, 209, 210, $238,242,256,263,264$

Ártico 15, 20, 25, 26, 273-276, 278, 279, 285$-297,323,324,326$

Ashton, Catherine 45, 53, 163, 167, 193, 221, $330,331,337$

Ásia Central 22, 23, 40, 46, 58, 62, 86, 113, 114-118, 120-135, 139, 146, 158, 228, 232, $235,236,238,239,245,248,254,255$, $257,267,324,348,351,359$

E guerra contra o terrorismo 114

Competição hegemónica 113-116, 133, 134

Crime organizado 122, 123, 228,

Federação Russa e Estados Unidos na 46, 113

Hegemonia multinível 115, 116, 119, 134

Disputas fronteiriças 122

Recursos naturais 158

Ásia Pacífico 51, 246, 276

Astana, acordo de cooperação com 128

Atambayev, Almazbek 38

Azerbaijão 22, 38, 41, 44, 62, 63, 71, 85, 93, 96, 97, 99-101, 104-107, 164, 209, 210, $242,256,261,263,264,306,324$

Bakiev, presidente 123, 133

Báltico 314

Estados do 37, 86, 
Mar 157, 166, 188, 278

Bielorrússia 13, 22, 37, 41, 44, 57, 58, 61-64, 69-73, 79, 95, 114, 125, 128, 135, 146, 156, $166,182,210,220,238,242,358,363$

Políticas energéticas, país trânsito 61,70 , 90, 156

Bósnia 225, 257

Brandt, Willy 143

BRICS 148

Bulgária 14, 86, 208, 256, 261

Bush, George 143, 225

Bush, George W. 46, 119, 130, 187, 227-230, 233-236, 239

Cáspio 86, 99, 104, 114, 117, 118, 122, 126, $128,133,158,229$

Cáucaso do Sul 22, 44, 85-87, 89, 94-96, 98, 99, 101, 102, 104-108, 159, 236, 245, 254, $257,261-264,267,324,325$

Chechénia 19, 51, 128, 257, 262-264, 310, 313

Cheney, Dick 233

Chernomyrdin, Viktor 204

Chilingarov, Artur 289, 292, 295, 297

China, Republica Popular da 16, 19, 30, 33, $36,38,46,49-51,61,86,113,114,116$, $118,130,133,135,148,152,154,162$, 186, 220, 235, 238, 239, 243, 246, 247 $287,288,319,323$

Chipre 208, 263

Chirac, Jacques 166, 230

Cimeira UE-Ucrânia 67

Clinton, Bill 185

Clinton, Hillary 243, 246, 328

Comissão Económica Eurasiática 72

Comissão Presidencial Bilateral Estados Unidos-Rússia 47

"comunidade de segurança" 12

Comunidade de Estados Independentes (CEI) $17,33,36,85,113,146$

Comunidade Económica da Eurásia (CEdE) 114

Comunidades Económicas Europeias 12
Conferência sobre Segurança de Munique em 2007 (Munich Security Conference) $34,45,46,96,234,291$

'conflitos congelados' 95, 102, 107, 159, 209, 241,328

Convenção de Montreux 265

Convenção Internacional do Direito do Mar 288, 292

Coreia do Norte 14, 162, 235, 236, 238, 249

Crimeia 64, 66, 67

Crise financeira internacional 123, 236

Crise financeira de 1998127

Crise financeira de 2008 220, 237, 268

Croácia 14, 208

Demirel, Süleyman 256

Democratização, 31, 146, 147, 169, 178, 180, 186, 194, 242, 301, 305-307, 315, 316, 319,328

Rússia e a, 147, 169

Transição para 178

Vagas de 301, 305-307, 315

Diálogo transatlântico 205

Dimensão nórdica 213, 277

Dimensão Setentrional 273, 274, 277-284, 296, 298, 334-336

Duma (parlamento russo) 26, 192, 243, 289, 313

Dushanbe, Declaração de 50

Elbe, Frank 165

Energia 37, 70, 86, 90, 97, 100, 123, 124, 129, $150,157,158,205,206,208,213,214$, 229, 233, 234, 245, 259, 261, 262, 286, 294, 311

No Cáspio 86, 99

Políticas energéticas 233, 294

E segurança 150, 259

Erdogan, Recep Tayyip 258, 261, 263, 264, 266, 268

Eslovénia 14

Eslováquia 181 
Espaço Económico Comum 43, 61, 70, 72, 200, 212

Espaço euro-atlântico 11-13, 15, 16, 20, 21, 23, 25-27, 141, 144, 145, 149-153, 156, 159-162, 165, 169, 172, 323, 324, 326-329

Espaço pós-soviético 17, 21, 34, 36, 38, 39, $41,42,44,46,57-63,66,69,70,72,79$, $86,90-92,94,95,108,126,146,151,187$, $305,306,324,325,329$

Estados Unidos da América 20, 30, 86, 113, 191, 202, 204, 223, 274, 304

Estratégia de Defesa Nacional, 2008235

Estratégia de Segurança Nacional, 2002235

Estratégia de Segurança Nacional, 2006235

Estratégia de Segurança Nacional, 2010242

Política de 'reset' com a Rússia 26, 27, 47, 119, 163, 169, 194, 239, 240-243, 245, 246, 326

Potência hegemónica global 115, 117, 118

Projeto de defesa antimíssil 14, 34, 47, 161

Estaline 88, 121, 184, 192, 295

Estónia 14

'estrangeiro próximo' 17, 18, 22, 39, 85, 113, $126,146,147,159,160,170,319,328$

Eurásia 17, 39, 86, 95-97, 101, 102, 106-108, $114,115,128,131$

Europa ocidental 10, 12, 19, 143, 178, 179, 182

Federação Russa, (ver Rússia)

Fórum de Xangai 121

Fotyga, Anna 187

Fundo Monetário Internacional 257

G8 27, 154, 170, 244

G20 154

Gás natural 61, 123, 127, 145, 146, 148, 154$-158,171,256,286,293,294$

gasoduto Baku-Tiblisi-Erzurum (BTE) 261

Gazprom 61, 67, 68, 71, 82, 129, 156, 158, 208, 260, 286, 287, 293, 308, 340,

Geórgia 13, 14, 17, 22, 24, 35, 36, 38, 39, 41, $44-47,50,53,60,63,66,72,76,77,85$,
86, 89, 92, 93, 95-98, 100-106, 127, 132, $145,146,150,159,163,164,171,186$, 187, 189, 190, 191, 209, 217, 232, 235-237, 239, 241-244, 249, 256, 264, 265, 301, 306, 307, 326

Adesão à OTAN 60, 145, 171, 234, 237, 242, 244

Guerra na Geórgia 17, 35, 39, 44, 50, 92, 105, 127, 132, 159, 200, 232, 236, 239, 326

Missão de monitorização da UE 105

Revolução das rosas 38, 102, 187, 307

Gorbachov, Mikhail 18, 31, 32, 88, 178, 179, $181,220,275,277,295,303,314$

Grupo de Visegrado 166

Gül, Abdullah 257, 258

Guerra Fria 9, 11-13, 15, 19, 20, 21, 24, 30, $33,42,46,47,143,159,201,211,223-$ $-225,232,273,274,288,289,295$

Guerra Fria, fim da 9, 11, 13, 15, 20, 22, $23,25,26,29,57,117,146,149,159$, $200,202,220,246,254-257,263,273$, 319,327

Muro de Berlim 11, 241

pós-Guerra Fria 12, 21, 23, 59, 79, 85, $86,90,91,95,103,115,118,121,124$, 141-145, 150, 162, 172, 199, 201, 208, 219, 224, 234, 238, 254, 274, 323, 325

guerra global contra o terrorismo 114, 117, $118,130,230$

Hard power 18, 151

Hard security 274, 295, 296

Havel, Vaclav 180, 185

Hoyer, Werner 164

Hungria 14, 180, 181, 185, 227

Identidade 12, 15, 49, 151, 171, 201, 203, $274,294,328$

Ieltsin, Boris 19, 21, 31-34, 39, 126, 145, 166, 182, 184-186, 203-206, 224, 256, 281, 318, 319,323

Ikenberry, G. John 13

Índia 19, 33, 116, 133, 148, 238, 239, 247, 288 
Integração europeia 11, 24, 78, 149, 152, 160, 187, 195

Interesse nacional 16, 17, 33, 188, 241, 267, 285, 291

Irão 14, 26, 37, 106, 130, 147, 161, 162, 235, 236, 240, 243, 247-249, 262, 263, 268, 304, 306, 319

Iraque, 14, 20, 34, 46, 93, 145, 152, 166, 186, 205, 224, 225, 229-232, 239, 249, 268, 358

Guerra do 20, 166, 224, 229, 231, 232

Ischinger, Wolfgang 165

Islamismo radical 120

Ivanov, Igor 33, 89, 204

Kaczyński, Jaroslaw 192

Kaczyński, Lech 188, 192

Kaliningrado 26, 69, 167, 193-195

Karimov, Islam 119, 122, 128

Karkiv, acordos de 67

Kemal, Mustafa 255

Khanabad, base aérea uzbeque 119, 130

Khristenko, Viktor 280

Kiev 64-68, 187

Kohl, Helmut 143, 166, 183

Kola, península de 274, 290

Kosovo 14, 34, 46, 92, 161, 186, 225, 257

Kozyrev, Andrei 19, 32, 126, 145, 226, 256, 319

Kremlin 15, 20, 35, 57, 58, 61-66, 68-72, 74, 75, 79, 80, 92, 97, 99, 101, 103, 104, 114, 118-121, 129, 132, 135, 144, 153, 185, 201, 202, 208, 209, 217, 224, 226, 228, 231-233, 236, 238, 241, 243, 244, 249, 282, 310, 314, 316-318, 324

Kruschev, Nikita 256

Kuchma, Leonid 65

Kwasniewski, Aleksander 187

Lavrov, Sergej 163, 291

Letónia 14, 245

Líbia 14, 18, 44, 93, 152, 162, 244, 246, 247, 249
Liga Árabe 246

Lituânia 14, 182, 190

Lukashenko, Aleksandr 69-73

Lukoil 129

Maastricht, Tratado de 11

MacKay, Peter 289

Malta 208

Manas, base militar no Quirguistão 130

Mar Barents 290, 292

Mar Branco 290

Mar Cáspio 100, 122, 229

Mar Negro 86, 254, 258, 260, 261, 264-266

Marxista-leninista 12, 29, 87

Mazowiecki, Tadeusz 178-180

McFaul, Michael 194

Médio Oriente 15, 23, 33, 104, 119, 162, 205, $225,229,235,244,247,248,254,262$, 263, 265, 267, 286, 323, 328

Medvedev, Dmitri 21, 26, 35, 36, 40, 45, 53, $60,66,72,76,94,98,101,105,106,108$, $119,127,130-132,135,146,162,163$, 169, 170, 191, 192, 202, 219, 236-238, 240, 241, 291, 308, 311, 312, 317, 318, 326,329

Memorando de Meseberg 163, 164

Merkel, Ângela 153, 158, 163, 170, 189, 190

Moldova 22, 41, 44, 57, 58, 61-64, 69, 72-79, $86,105,156,159,164,166,209,210,237$, 242

Políticas energéticas 61,77

Multilateralismo 150-152

Multipolaridade 19, 50, 165

Murmansk, 275-277, 285, 287, 292, 295 Discurso de 275-277, 285, 295

Muszynsky, Mariusz 187

Nabucco 158, 261

Nargorno-Karabakh 89-91, 101, 104-7, 164, 263-4

Naumann, Klaus 165, 169 
Nesarbaijev, Nursultan 158

Nord Stream 157-8, 188,

Northern European Initiative (NEI) 276

Noruega 157, 273, 275, 279, 283, 288, 290-3

Obama, Barack 26-7, 47, 117, 119-121, 163, 169, 191, 194, 239-43, 245-6, 268, 286

Organização das Nações Unidas (ONU) 225, 230,288

Conselho de Segurança 14, 20, 29, 46, $147,162,166,170,186,225,230,240$, $243,245,247-8,263,319$

Organização dos Países Exploradores de Petróleo (OPEP) 286

Organização para a Segurança e Cooperação na Europa (OSCE) 95-6, 108, 114, 187

Organização do Tratado de Segurança Coletiva (OTSC) 62, 71-2, 101, 129, 131, 135, 146

Organização do Tratado do Atlântico Norte (OTAN) 11, 13-5, 18, 26-7, 32, 39, 45, 48, $58,60,62,65,67,73,75,86,96,103$, 114-5, 119-120, 126, 131, 143-6, 149-150, 159-171, 181, 184-7, 190-91, 193-4, 202, 224-6, 229, 231, 234, 236-7, 241-6, 249, 255-7, 263, 265-6, 268, 291, 306, 324-6

Ato Fundador sobre Relações Mútuas, Cooperação e Segurança OTAN-Rússia, 1997160

Cimeira de Roma, 2002229

Cimeira de Bucareste, 2008 45, 159

Cimeira de Lisboa, 2010 26-7, 48, 163, 241, 243, 266

Cimeira de Chicago, 2012 27, 165, 194, 244

Declaração de Londres, 1990224

Membership Action Plan 159-60

Parceria para a Paz 32, 75, 86, 103, 127, 226

Política de alargamento 11, 13-5, 39, 44-5, $60,86,92,131,143,149-50,161,168,171$, $185,224,227,237,241,244,257-8$

Ossétia do Sul 50, 63, 71, 77, 90, 102, 104, $127,132,159,164,190,209,237,310$

Ozal, Turgut 256

Pacto de Varsóvia 18, 143, 180-1, 186, 227
Paquistão 228, 248

'Paz Fria'159

Petróleo 72, 123, 127, 129, 148, 154-7, 206, 226-7, 233, 247, 259-62, 286-7, 289, 292

Polónia 9, 14, 20, 23-4, 46, 86, 144, 157, 161, $166-8,170,-71,177-195,210,227,245$, $282,285,325$

Solidariedade 177-9, 184, 188, 195

Primakov, Evgeny 19, 33, 42, 126, 145, 185, 226

Primavera Árabe 9, 14-5, 162, 262, 265, 268, 327-8

Putin, Vladimir 16-7, 21, 26-7, 33-6; 40-41, 45$-6,48-50,52-3,59-60,67-8,72,79,94,96$, $98,101,103,114,118-20,127-131,134-5$, $141,146,153,158,166,169-170,186,191-$ -2, 194, 199-200, 202-7, 212, 215-6, 218-20, 224, 226-230, 232-4, 236-8, 243-4, 248-9, 257-8, 264, 268, 281, 289, 291, 294, 301, 308, 310-18, 323-4, 326-7, 329

Quarteto para a Paz do Médio Oriente 235

Quirguistão 14, 23, 38, 41, 46, 62-3, 113-4, 121-4, 126, 129-31, 133, 135, 232, 238, 301,307

Revolução, 2005 38, 307

Rahmon, Emomalii 133

República Checa 14, 46, 181, 185, 227

Rice, Condoleezza 227

Romney, Mitt 245-6

Rühe, Volker 165, 185

Rússia

Conceito de Política Externa, 1993 59, 126

Conceito de Política Externa, 2000127

Conceito de Política Externa, 200840

'democracia inacabada' 203

Doutrina Militar, 1993126

Doutrina Militar, 2000127

Doutrina Militar, 2010161

Estratégia de Segurança Nacional até 2020 (ESN) 131 
Glasnost 178

Katyn, acontecimentos de 184, 191-2

Perestroika 178-9

Política de modernização 21, 32, 35-6, $131,135,148,154-5,169,291,327,329$

Política de 'reset' com EUA 26-7, 47, 119 , $131,163,169,194,239-46,326$

Potência hegemónica regional 116, 126

Saakashvili, Mikhail 96, 98-9, 102, 106, 127, 186, 237

Schröder, Gerhard 153, 158, 166, 230

Segurança energética 14, 23, 150, 156, 286

Shtokman 293, 295

Sikorski, Radoslav 167, 188, 190-94

Síria 14, 18, 27, 44, 46, 48, 120, 147, 162, 169-70, 243-7, 249, 265-6, 316, 319, 327 Porto de Tartus 244, 266

Skubiszewski, Krzysztof 180, 182-3

Soft power 78, 91, 95, 107, 133, 147-8, 151

Soft security 274, 276, 295

South Stream 158, 261

Statoil 292-3

Steinmeier, Frank-Walter 162, 189

Store, Jonas Gahr 194

Strategic Arms Reduction Treaty (START) 47, $240,243,245,275$

Strategic Offensive Reduction Treaty (SORT) 229

Tajiquistão 23, 41, 62-3, 113-4, 121-24, 126, 129-30, 133, 220, 238

Guerra civil no 114

Transneft 156

Transnistria 14, 63, 73-7, 90, 159, 164

Tratado “2+4" 143, 183

Tratado do Eliseu 230

Tratado de Segurança Coletiva 114

Triângulo de Weimar 142, 167, 183, 188, 193

Turquemenistão 41, 62, 113, 123, 130, 133, $261,306,324$
Turquia 9, 15, 17, 20, 25, 100-101, 106-7, 158, 246, 253-69, 326, 328

Tusk, Donald 189. 191-2, 194

Tymoshenko, Yulia 186

Ucrânia 13-4, 22, 37-38, 41, 44-6, 57-8, 60-68, 70, 72-3, 79, 95, 97, 125, 145-6, 150, 156, 159, 166, 171, 182, 186, 189, 194-5, 209-10, 227, 232, 235-7, 241-3, 301, 306-7, 324, 327

Adesão à OTAN 45, 60, 67-8, 73, 145-6, 159, 171, 186, 194, 209, 227, 236-7, 241-3

Políticas energéticas, país trânsito 61, 64, 66-8, 97, 150, 156, 232

Revolução, 2004 14, 38, 46, 66, 95, 189, 301, 306-7

União Aduaneira Rússia, Bielorrússia, Cazaquistão 68, 71, 128, 135

União Euroasiática 41, 94, 135, 329

União Europeia

Conselho Europeu de Copenhaga, 1993208

Conselho Europeu de Helsínquia, 1999208

Conselho Europeu de Gotemburgo, 2001213

Estratégia de Segurança Europeia 230

Política Europeia de Vizinhança 44, 100, 209-10

Política de Vizinhança a Leste | Parceria Oriental 71, 94, 150, 160, 164, 167, 210

'potência normativa' 230

Região Euro-Ártica de Barents (BEAR) 275

Relações com Rússia 13-5, 17, 20-24, 42$-6,57-8,64-5,68,71,79-80,86,94,101$, 105, 129, 142, 144, 149, 154-68, 188-90, 193-5, 199-220, 273-4, 277-85, 296, 325

Acordo da Parceria e Cooperação (APC) 24, 42-4, 167, 187, 200, 211, 215, 217

Comité Político e de Segurança UE-Rússia 163-4

Iniciativa da Dimensão Setentrional 273, 278

Parceria para a Modernização 24, 200, 218

Quatro Espaços Comuns 24, 43, 212-3, 217, 283-4

Wider Europe 209 
Uzbequistão 41, 62, 113-4, 116, 118-9, 122-4, 126, 128-30, 135, 238, 324

Andijon, acontecimentos de 118

Movimento Islâmico do Uzbequistão (MIU) 122, 126

Walesa, Lech 180, 184-5

Weisser, Ulrich 165

Westerwelle, Guido 167, 190, 193

Yanukovitch, Viktor 38, 65, 67

Yildiz, Taner 261

Yushchenko, Viktor 66, 186 
